UNIVERSIDADE DE SÃO PAULO

FACULDADE DE ECONOMIA, ADMINISTRAÇÃO E CONTABILIDADE DEPARTAMENTO DE ECONOMIA

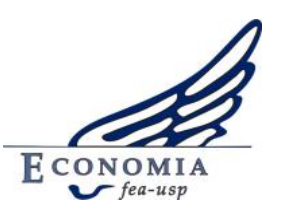

\title{
Os 50 Tons de Preto da OGX: Reconstrução do Histórico, Reflexões \& Aprendizados Possíveis
}

\section{Eduardo Franco Luzio}



UNIVERSIDADE DE SÃO PAULO

FACULDADE DE ECONOMIA, ADMINISTRAÇÃO E CONTABILIDADE

DEPARTAMENTO DE ECONOMIA

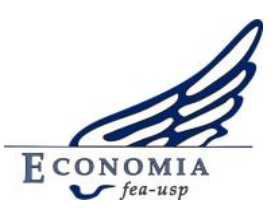

\section{Os 50 Tons de Preto da OGX: Reconstrução do Histórico, Reflexões \& Aprendizados Possíveis}

\section{Eduardo Franco Luzio}

Professor Doutor, № USP 126397

TESE DE LIVRE-DocÊNCIA APRESENTADA AO DEPARTAMENTO DE ECONOMIA DA FACULDADE DE ECONOMIA, AdMINISTRAÇÃo E CONTABILIDAdE DA UNIVERSIDADE DE SÃo PAULO (FEA/USP)

São Paulo 



\section{Sumário}

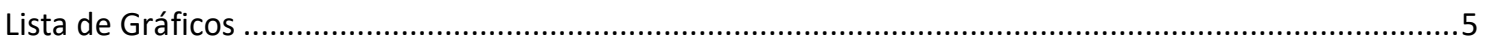

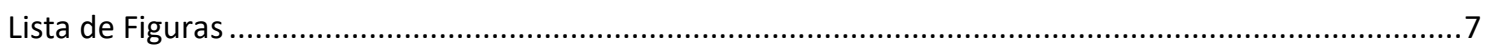

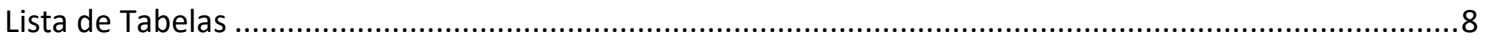

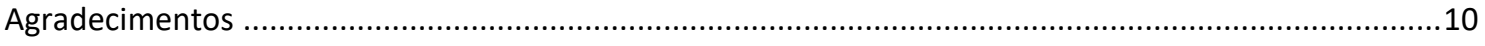

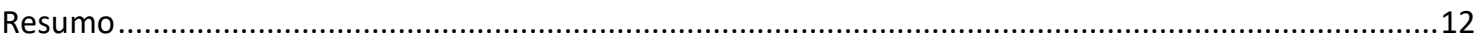

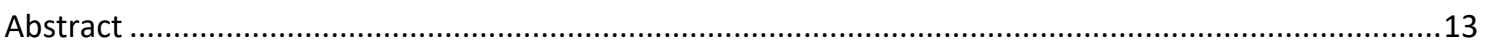

Lista de Abreviaturas e Conversões de Unidades.........................................................................14

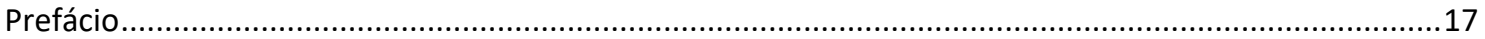

Parte 1 - Considerações Preliminares e Descrição dos Fenômenos ......................................................20

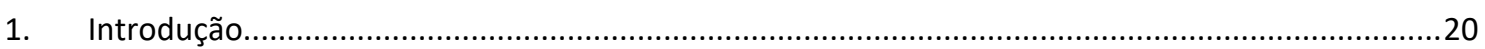

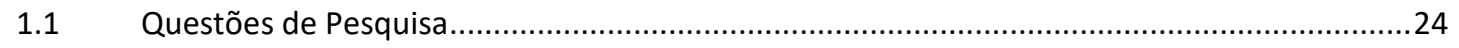

1.2 Cronologia de Principais Eventos e da Agenda de Catalisadores .......................................33

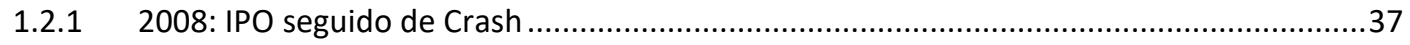

1.2.2 2009: Início da Campanha Exploratória e as Primeiras Descobertas ..................................38

1.2.3 2010: Ampliação da Agenda de Catalisadores, Farm-Out e Sinergias com OSX..................40

1.2.4 2011: Atrasos e Financiamentos.....................................................................................43

1.2.5 2012: Performance Operacional e Substituição de Executivos ........................................45

1.2.6 2013: Últimas Tentativas de Reconstrução da Agenda de Catalisadores..........................49

1.3 Três Possíveis Conjecturas e uma Escolha......................................................................53

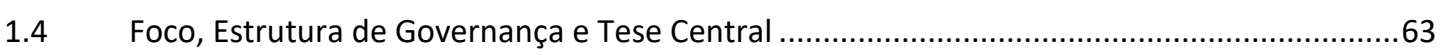

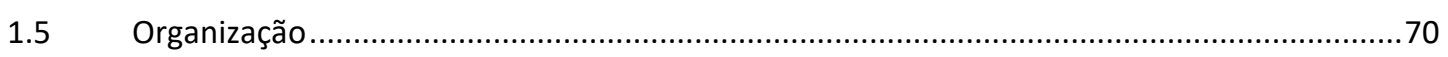

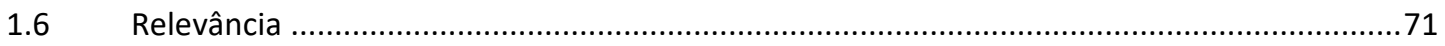

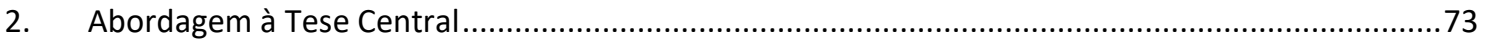

2.1 Quatro Conceitos de Valor Econômico Financeiro da OGX ..............................................74

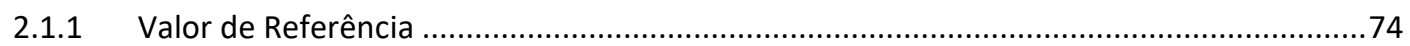

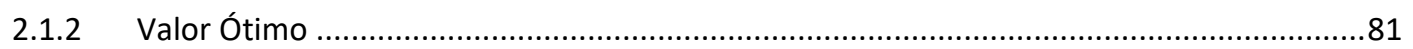

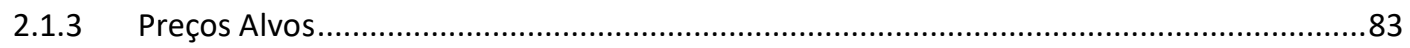

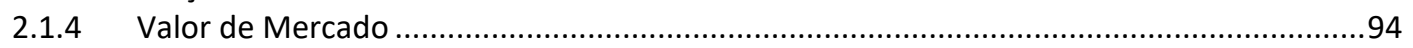

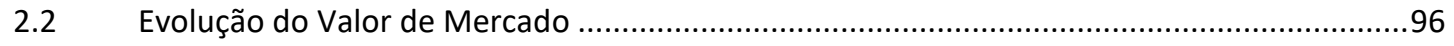

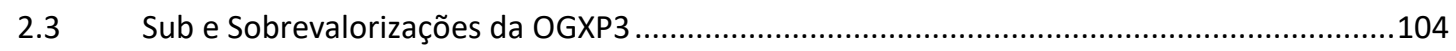

2.4 Sentimentos do Mercado e Possíveis Implicações ................................................................107

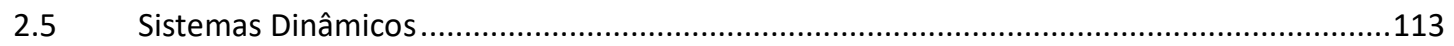

3. Evolução do Guidance, Sentimento de Mercado e Reação dos Analistas ...................................116

2008: IPO, Início da Cobertura e Primeira Correção Depreciativa ......................................117

2009: Início da Campanha e Construção do Guidance Otimista ..........................................126

2010: Farm-out, OSX e o Desgaste do Guidance .............................................................139

2011: “Ano da Virada"... da Credibilidade.....................................................................158

2012: Start-up Operacional e Substituição de Executivos...................................................181

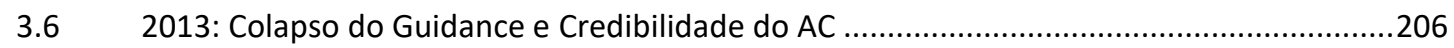


Parte 2 - Processos, Atrasos e suas Repercussões......

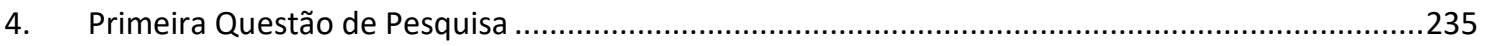

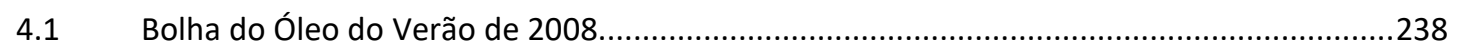

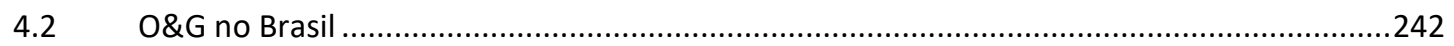

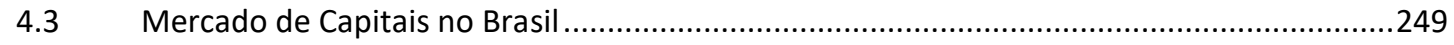

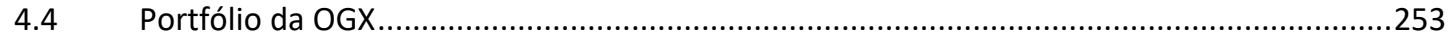

4.5 Reputação do AC e Sinergias com Partes Relacionadas ......................................................257

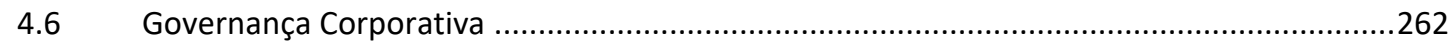

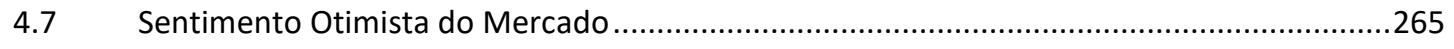

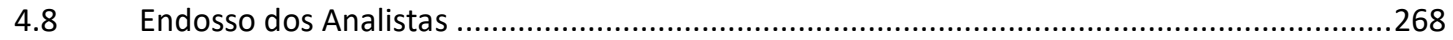

4.9 Externalidade da Avaliação e Monitoramento de Investidores e Financiadores ..................272

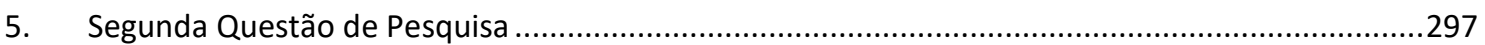

5.1 Heroína Organizacional e Campanha Exploratória.............................................................302

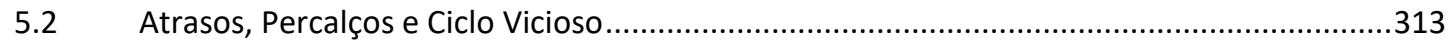

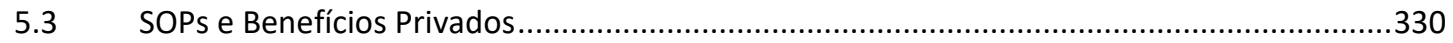

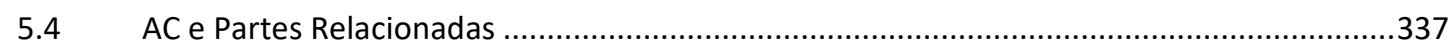

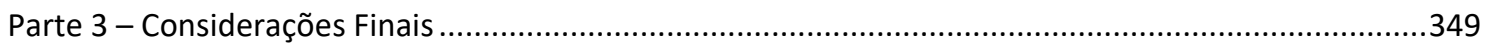

6. Terceira Questão de Pesquisa: Possíveis Lições.......................................................................349

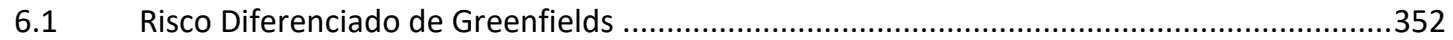

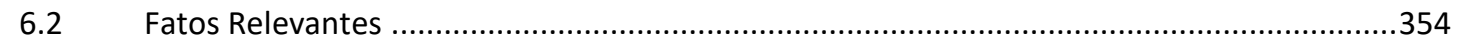

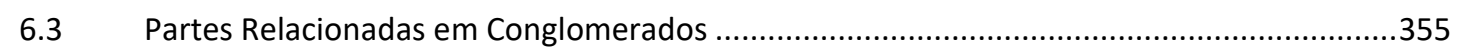

6.4 Atuação de auditores em Conglomerados .......................................................................356

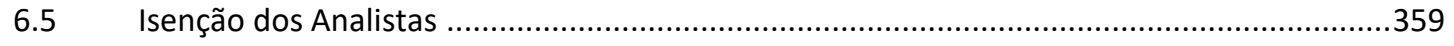

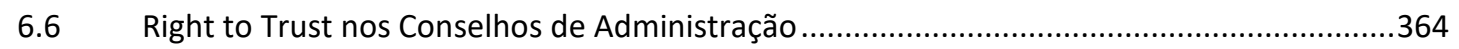

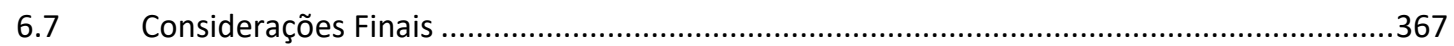

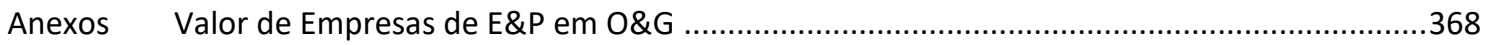

A.1 Elementos Básicos de O\&G e do Processo de E\&P ..........................................................369

A.2 Avaliação Econômico Financeira de Empresas de Exploração de O\&G ...............................380

A.3 Capitalização de Mercado de Empresas de O\&G: Evidências da Literatura Empírica.............383 


\section{Lista de Gráficos}

GRÁFICO 1 - EVOLUÇÃO do VALOR DE MERCADO (EM R\$ MILHÕES, EXCLUINDO DISPONIBILIDADES) .............................31

GRÁFICO 2 - EVOLUÇÃO DA PARTICIPAÇÃO DA OGXP3 NO IBOV (EM \%) DE 2010 A 2013.....................................67

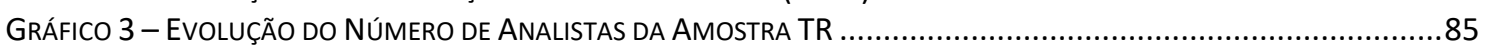

GRÁFICO 4 - EVOLUÇÃO DA MEDIANA DO PA DA AMOSTRA TR EM RELAÇÃO AO VALOR DE OGXP3 ..............................88

GRÁFICO 5 - EVOLUÇÃo dOS PREÇOS AlVO ENTRE 28/7/08 A 30/10/13: AMOSTRA TR .........................................89

GRÁFICO 6 - COMPARAÇÃo ENTRE AS MEdIANAS dos PAS DA AMOSTRA TR E DA AMOSTRA PRÓPRIA ...........................91

GRÁFICO 7 - COMPOSIÇÃO DO FLOATING DA OGXP3 POR TIPO DE INVESTIDOR ..................................................93

GRÁFICO 8 - EVOLUÇÃO DA OGXP3 (R\$̦/AÇÃO, AJUSTADOS PARA O SPLIT) ENTRE 12/06/2008 E 31/10/2013 ............96

GRÁFICO 9 - EVOLUÇÃO DA OGXP3, IBOV E BRENT ENTRE 12/6 E 6/11/2008 (IPO = 100)..................................98

GRÁFICO 10 - EVOLUÇÃO DA OGXP3, IBOV E BRENT ENTRE 6/11/2008 E 4/11/2010 (VALE = 100) ........................99

GRÁFICO 11 - EVOLUÇÃO DA OGXP3, IBOV E BRENT ENTRE 4/11/2010 E 8/08/2011 (PICO = 100) $\ldots . . . . . . . . . . . . . . . . .100$

GRÁFICO 12 - EVOLUÇÃo DA OGXP3, IBOV E BRENT ENTRE 08/08/2011 E 23/02/2012 (VALE (2011) = 100).......101

GRÁFICO 13 - EVOLUÇÃo DA OGXP3, IBOV E BRENT ENTRE 23/02/2012 E 31/10/2013 (PICO (2012) = 100) ........102

GRÁFICO 14 - CLASSIFICAÇÃo dA EVOLUÇÃo DA OGXP3 EM CINCO PERÍOdOS: 12/6/2008 A 30/10/2013 (R\$̧/AÇÃo PÓS SPLIT) 103

GRÁFICO 15 - EV VERSUS VPL DO CENÁRIOS MÉDIOS D\&M: INDÍCIOS DE SOBREVALORIZAÇÃO DA OGXP3 ..................105

GRÁFICO 16 - EV VERSUS VPL DO CENÁRIOS MÉDIOS D\&M: INDÍCIOS DE SUBVALORIZAÇÃO DA OGXP3 .....................106

GRÁFICO 17 - EVOLUÇÃo DO S\&P OGPE 600, S\&P OGPE 1500, OGXP3 E BRENT EM 2008 (12/06/2008 = 100).117

GRÁFICO 18 - EVOLUÇÃO DA OGXP3 EM 2008 (EM R\$ NOMINAIS POR AÇÃO, PÓS SPLIT) .....................................118

GRÁFICO 19 - EVOLUÇÃO DA OGXP3, BRENT E IBOV EM 2008 (BASE $100=12 / 6 / 2008$ [IPO]) ...........................119

GRÁFICO 20 - EVOLUÇÃO DO EV/2C DA OGX EM 2008 (EM US\$/BOE) ......................................................119

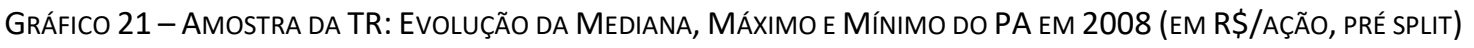

GRÁFICO 22 - EVOLUÇÃO DA OGXP3 EM 2009 (EM R\$ NOMINAIS POR AÇÃO, PÓS SPLIT) .....................................126 GRÁFICO 23 - EVOLUÇÃO DO S\&P OGPE 600, S\&P OGPE 1500, OGXP3 E BRENT EM 2009 (12/06/2008 = 100).127 GRÁFICO 24 - EVOLUÇÃO DA OGXP3, BRENT E IBOV EM 2009 (BASE $100=6 / 11 / 2008$ ) .................................128

GRÁFICO 25 - EVOLUÇÃO DO EV/2C DA OGX EM 2009 (EM US\$/BOE) .......................................................129

Gráfico 26 - Amostra da TR: EVolução da MEdianA, MÁximo e MínIMO do PA EM 2009 (EM R\$ุ/AÇÃo) ..........138

GRÁFICO 27 - EVOLUÇÃo Do S\&P OGPE 600, S\&P OGPE 1500, OGXP3 E BRENT EM 2010 (12/06/2008 = 100).139

GRÁFICO 28 - EVOLUÇÃO DA OGXP3 EM 2010 (EM R\$ NOMINAIS POR AÇÃO, PRÉ SPLIT) .........................................141

GRÁFICO 29 - EVOLUÇÃO DA OGXP3, IBOV E BRENT EM 2010 (BASE IPO = 100) ............................................141

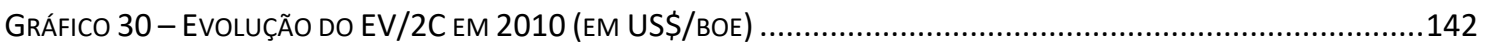

GRÁFICO 31 - EVOLUÇÃo dA OGXP3, DO PA MÁxIMO, MínIMO E MEDIANO DA AMOSTRA TR EM 2010 ..................157

GRÁFICO 32 - EVOLUÇÃO DO S\&P OGPE 600, S\&P OGPE 1500, OGXP3 E BRENT EM 2011 (12/06/2008 = 100).159

GRÁFICO 33 - EVOLUÇÃO DA OGXP3 EM 2011 (EM R\$ NOMINAIS POR AÇÃO, PRÉ SPLIT) .....................................160

GRÁFICO 34 - EVOLUÇÃO DA OGXP3, BRENT E IBOVESPA EM 2011 (BASE $100=12 / 6 / 2008$ [IPO]) .....................160

GRÁFICO 35 - EVOLUÇÃO DO ENTERPRISE VALUE (EV 2C) EM 2011 (EM US\$/BOE) ..............................................161

GRÁFICO 36 - EVOLUÇÃO dO VALOR DE MERCADO DO OGXPBZ18 AO LONGO DE 2011 ......................................162

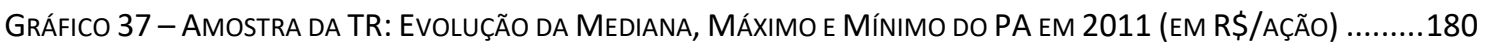

GRÁFICO 38 - EVOLUÇÃO DA OGXP3 EM 2012, EM R\$ NOMINAIS, PÓS-SPLIT ..................................................182

GRÁFICO 39 - EVOLUÇÃo DO S\&P OGPE 600, S\&P OGPE 1500, OGXP3 E BRENT EM $2012(12 / 06 / 2008=100) .183$

GRÁFICO 40 - EVOLUÇÃO DA OGXP3, BRENT E IBOV EM 2012 (BASE $100=$ 12/6/2008 [IPO]) ..........................183

GRÁFICO 41 - EVOLUÇÃO DO EV/2C DA OGX EM 2012 (EM US\$/BOE) ............................................................184

GRÁFICO 42 - EVOLUÇÃO DO VALOR DE MERCADO DO OGXPBZ 2018 EM 2012 .................................................185

GRÁFICO 43 - EVOLUÇÃO DO VALOR DE MERCADO DO OGXPBZ 2022 EM 2012 ...............................................185

GRÁfICO 44 - AMOSTRA dA TR: EVOLUÇão dA MEdIANA, MÁxIMO E MínIMO do PA EM 2012 (EM R\$̣/AÇÃo PRÉ-SPLIT)

GRÁFICO 45 - EVOLUÇ̃̃O DA OGXP3 EM 2013 (EM R\$ NOMINAIS POR AÇÃO, PÓS SPLIT)

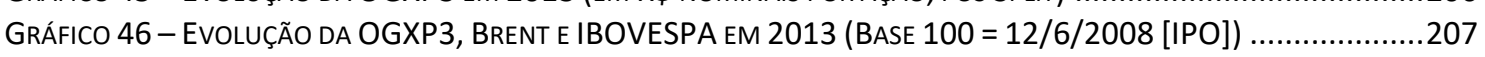

GRÁFICO 47 - EVOLUÇÃO DO EV/2C EM 2013 (EM US\$\$/BOE) ....................................................................207

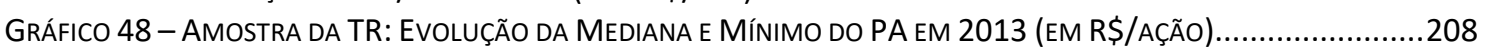

GRÁFICO 49 - EVOLUÇÃO DO VALOR DO OGXPBZ18 E OGXPBZ22 EM 2013 (VALOR DE FACE = 100) ....................218

GRÁFICO 50 - PREÇO DO PETRÓlEo BRUTO - BRENT (FOB) - US\$\$BARRIL DE 4/01/2000 A 12/06/2008 ................238

GRÁFICO 51 - EVOLUÇÃO DO S\&P OGPE 600 E 1500 02/01/2000 A 12/06/2008........................................239 
GRÁFICO 52 - NúMERO de IPOS CONCLUÍdOS DE EMPRESAS DE O\&G E E\&P NO MUNDO ENTRE JANEIRO 2000 E JUNHO 2008

GRÁFICO 53 - VALOR DOS IPOS CONCLUÍdOS DE EMPRESAS DE O\&G E E\&P NO MUNDO ENTRE JANEIRO 2000 E JUNHO 2008 (EM US\$ MILHÕES)

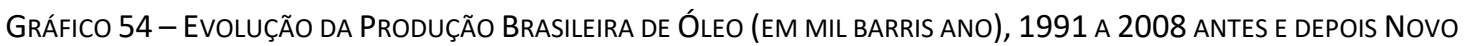
MARCO REgULATÓRIO

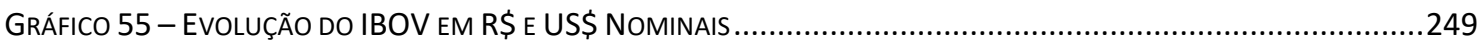

GRÁFICO 56 - EVOLUÇÃO DO VMD NA BOVESPA EM MILHÕES DE R\$ E US\$ NOMINAIS.......................................250

GRÁFICO 57 - EVOLUÇÃO DO VMD NA BOVESPA POR TIPO DE INVESTIDOR .......................................................250

GRÁFICO 58 - EVOLUÇÃO DA MMX3 E IBOV $(21 / 7 / 2006$ = 100) ENTRE O IPO DA MMX (21/07/2006) E DA OGX $(12 / 6 / 2008)$

GRÁFICO 59 - EVOLUÇÃO DA MPX3 E IBOV $(21 / 7 / 2006$ = 100) ENTRE O IPO DA MPX (13/12/2006) E DA OGX $(12 / 6 / 2008)$...

Gráfico 60 - Evolução do VALOR de MERCAdo ENTRE 2/01/2009 e 15/04/2011.........................................266

GRÁFICO 61 -S\&P OGEP 600 E 1500, BRENT E OGXP3 DE 2/01/2009 A 15/04/2011 .................................266

GRÁFICO 62 - EV VERSUS VPL DO CENÁRIOS MÉDIOS D\&M: INDÍCIOS DE SOBREVALORIZAÇÃO DA OGXP3 ..................267

GRÁfICO 63 - AMOSTRA TR: EVOLUÇão dA RAZÃO DA MEDIANA DOS PAS PELO VALOR DA OGXP3 NA BOVESPA .......268 GRÁFICO 64 - RALLY MERCADO (6/11/2008 A (15/10/2010) VERSUS RALLY DOS ANALISTAS AMOSTRA TR

(28/12/2009 A 21/6/2012) VERSUS SOBREVALORIZAÇÃO (17/8/2010 A 15/4/2011) .................................269

GRÁFICO 65 - OGXP3 X CENÁRIOS MÉDIOS D\&M (COM DÍVIDA LÍQUIDA) X PA MEDIANA (R\$̧/AÇÃO) .......................270

GRÁFICO 66 - OGXP3, CENÁRIOS MÉdIOS D\&M (COM DíVIDA LíQUIDA), PA HIGH, LOW E MEDIANA (R\$̧/AÇÃo).......271

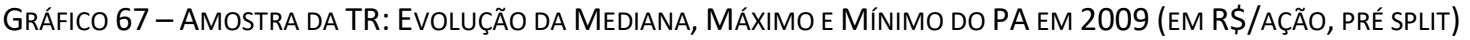

Gráfico 68 - EVoluÇão dA OGXP3, do PA MÁximo, MínIMo e Mediano dA AMOSTRA TR EM 2010 (EM R\$̧/AÇão,

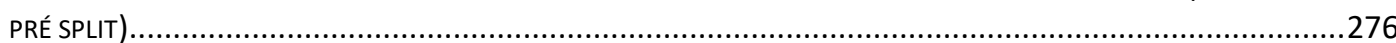

GRÁfICO 69 - AMOSTRA dA TR: EVOlução dA MEdIANA, MÁxIMO E MínIMO do PA EM 2011 (EM R\$̣/AÇÃO, PRÉ SPLIT)

281

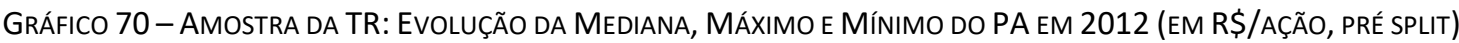

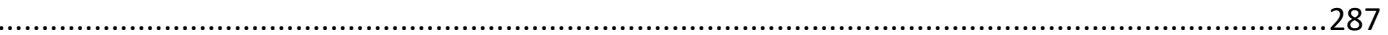

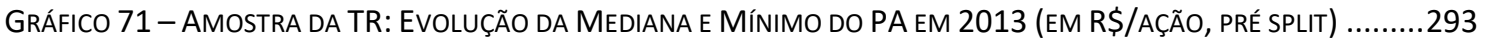

GRÁfico 72 - Volume de DAY-TRAde dA OGXP3 E PETR4 como PeRCENTUAL DO VMD ENTRE 2012 E 2013 .........299

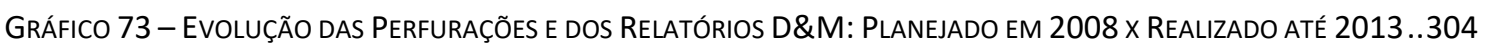
GRÁFICO 74 - EVOLUÇÃO DOS INVESTIMENTOS NA CAMPANHA DE E\&P (EM R\$ MILHÕES NOMINAIS): 3T2008 A 1T2013

GRÁFICO 75 - EVolUÇÃo do VALOR DE MERCAdo E EVENTOS IMPORTANTES NO GUIDANCE EM 2010........................316

GRÁFICO 76 - EVOLUÇÃO dO VALOR DE MERCADO E EVENTOS IMPORTANTES NO GUIDANCE EM 2011........................322

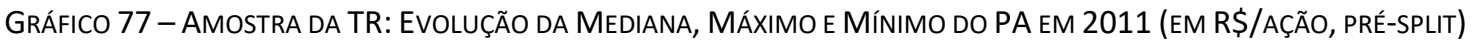

GRÁFICO 78 - EVOLUÇÃo do VALOR DE MERCADO E EVENTOS IMPORTANTES NO GUIDANCE EM 2012 ........................3325

GRÁFICO 79 - EVOLUÇÃO dO VALOR DE MERCADO E EVENTOS IMPORTANTES NO GUIDANCE EM 2013.........................328

GRÁFICO 80 - EVOLUÇÃO DA OGXP3 EM 2009 (R\$̦ NOMINAIS POR AÇÃO, PRÉ-SPLIT) ............................................333

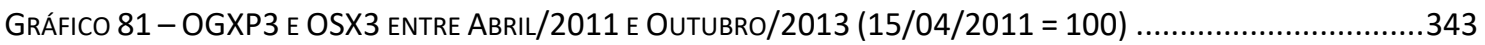

GRÁFICO 82 - EVOLUÇÃO DA OGXP3 E DA MEDIANA DO PA DA AMOSTRA TR ....................................................360 


\section{Lista de Figuras}

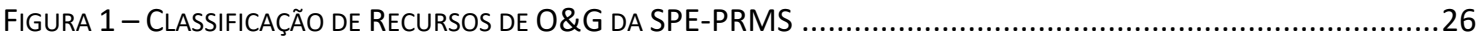

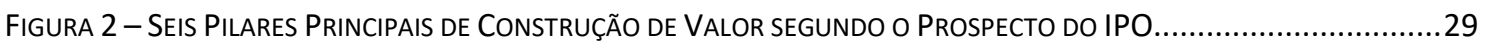

FIGURA 3 - STAKEHOLDERS DIRETA E/OU INDIRETAMENTE RELACIONADOS AO GUIDANCE E A TESE DE INVESTIMENTOS.......61

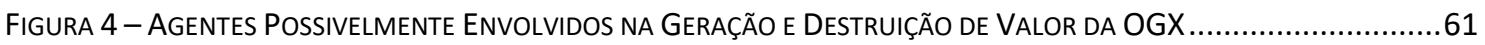

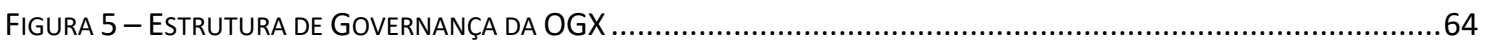

FiguRA 6 - Possível RELAÇÃo entre OS VALORES DE REFERÊNCIA, OS PAS E O VALOR ÓTIMO.....................................92

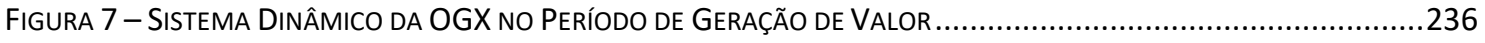

FIGURA 8 - SISTEMA DINÂMICO DA OGX NO PERÍOdo DE DESTRUIÇÃO DE VALOR ...............................................298

FIGURA 9 - FLUXO DE ATIVIDADES DA FASE DE EXPLORAÇÃO EM POÇOS OFFSHORE.................................................370

FIGURA 10 - REPRESENTAÇÃO GRÁFICA DO SISTEMA DE CLASSIFICAÇÕES DA SPE-PRMS .........................................372

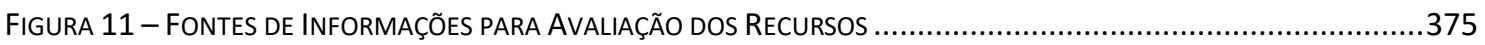

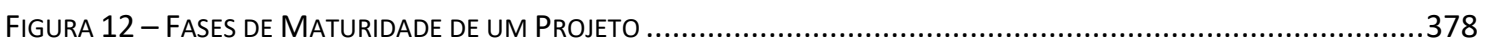




\section{Lista de Tabelas}

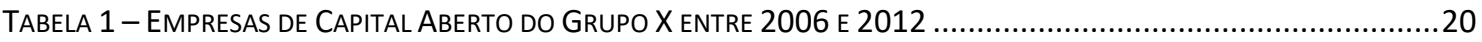

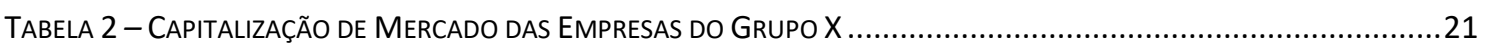

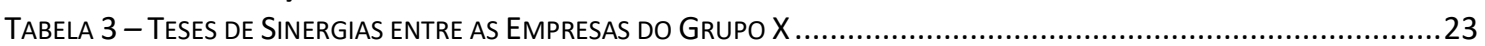

TABELA 4 - PoRTFÓlIO de BLOCOS DA OGX NO IPO: RPL EM BBOE, E PROBABILIDAdE DE SUCESSO ECONÔMICO (“PSE”) 25

TABELA 5 - ProjeÇão dA PROdUÇÃo de Óleo APRESENTAdA No IPO (EM MILHÕES DE BARRIS POR ANO) ......................28

TABELA 6 - COMPOSIÇÃO DO SALDO DEVEDOR DA OGX E SUBSIDIÁRIAS EM 07/01/2014 ......................................32

TABELA 7 - AgENDA DE CATALISAdORES FundAMENTALISTAS MonitORAdOS PELOS ANALISTAS DA OGX .....................34

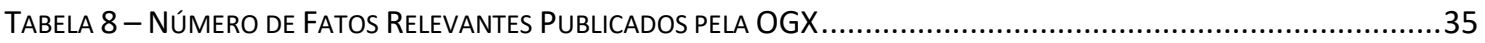

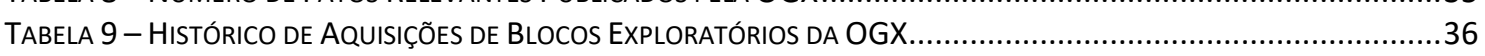

TABELA 10 - ALGUNS INDICADORES DA CAMPANHA EXPLORATÓRIA: PLANEJADOS X REALIZADOS....................................54

TABELA 11 - PROJEÇÃo dA PROdUÇÃo ANUAL DA OGX APRESENTADA NO IPO (EM MBOE) .......................................57

TABela 12 - CAMPANha Exploratória: Números de Poços Pioneiros e de AVAliação (PIONEer Wells and

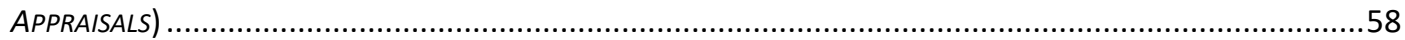

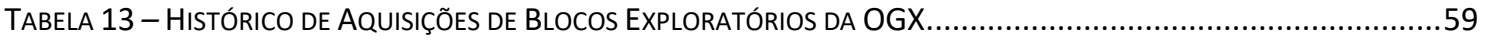

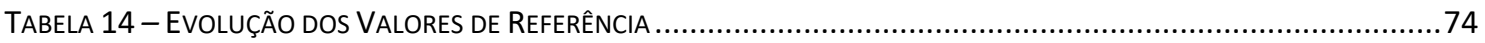

TABELA 15 - CONCEITOS DE NÍVEIS DE INCERTEZA NO SISTEMA DE CLASSIFICAÇÃO DE RECURSOS....................................76

TABELA 16 - ESTIMATIVA DO VPL DOS RECURSOS DA OGX ESTIMADOS PELA D\&M (US\$ MILHÕES) ..............................78

TABELA 17 - QuANTIDADE DE RELATÓRIOS DE ANALISTAS DAS AÇÕES DA OGX DA AMOSTRA PRÓPRIA ..........................90

TABELA 18 - REPRESENTATIVIDADE DA AMOSTRA PRÓPRIA (\% TRADING TOTAL DA BOVESPA) .................................90

TABELA 19 - CINCO MAIS UM PERÍOdOS DA EVOLUÇÃO DA OGXP3 (R\$̧/AÇÃO PÓS SPLIT) ........................................97

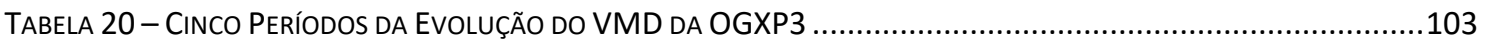

TABELA 21 - ESTIMATIVAS DO 1 D\&M, EV E OUTROS INDICADORES (US\$ BILHÕES) .............................................104

TABELA 22 - PAS NO INÍCIO DE COBERTURA (28/7/2008, AJUSTADOS PARA O SPLIT) E RESPECTIVO MÚLTIPLO DE VALOR

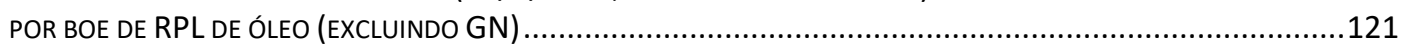

TABELA 23 - MúltipLOS DE EMPRESAS SiMILARES UtILIZAdAS PELO MS PARA COMPARAR COM A OGX ......................132

TABELA 24 - RESUMO DOS RELATÓRIOS D\&M (EM BBOE DE HIDROCARBONETOS) ...............................................135

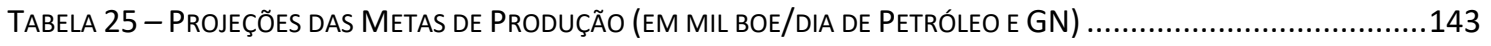

TABELA 26 - INDICADORES dOS PRINCIPAIS BlOCOS ARREMATAdOS NO LEILÃO DA 9a ROdAdA PELA OGX....................148

TABELA 27 - NúMERo de Poços Perfurados (PIONEIROS E APPRAISALS) ...........................................................156

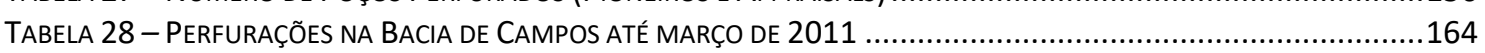

TABELA 29 - RESUMO DOS TRÊS RELATÓRIOS DE AVALIAÇÃO DA D\&M ..........................................................166

TABELA 30 - UMA INTERPRETAÇÃO dOS RECURSOS TOTAIS EM CAMPOS BASEADA NO RELATÓRIO DE ABRIL DE 2011 DA

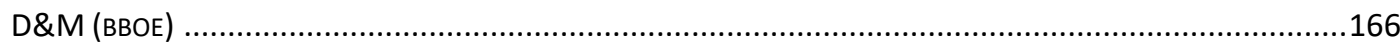

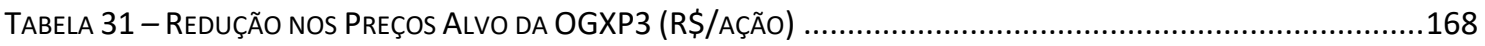

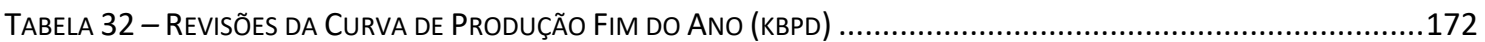

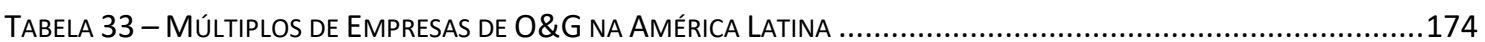

TABELA 34 - O QUE FOI CONSIDERADO NO RELATÓRIO DA D\&M DE ABRIL/2011 ...............................................174

TABELA 35 - RESUltAdOS DOS PoçOS PERFURAdOS EM CAMPOS DESDE O FIM DE 2010 .......................................175

TABELA 36 - TESTES DE PRODUÇÃO EM PoÇOS HORIZONTAIS DA OGX ............................................................175

TABela 37 - AJuste na Estimativa dos ReCURSOS Prospectivos na opINIÃo do MS (EM MBOE).........................177

TABela 38 - AJuste na Estimativa dos ReCURSOS Delineados E CONTINGENTES DAS ACUMULAÇÕES de CAMPOS NA

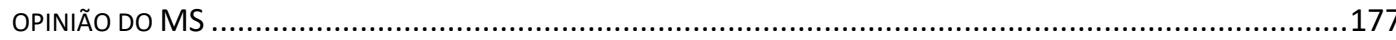

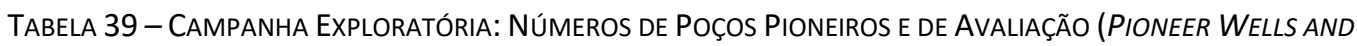

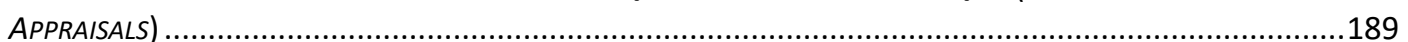

TABELA 40 - CURVA DE PRODUÇÃo dA OGX X HISTÓRICO de REVISÕES DE ALGUNS ANALISTAS ..................................197

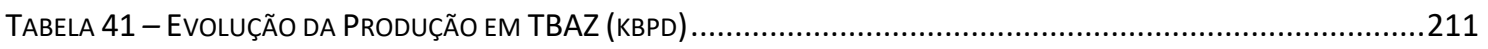

TABELA 42 - FLUXOS DOS TRÊS PoçOS DE TBAZ ENTRE FEV.2012 E JAN.2013 ...................................................216

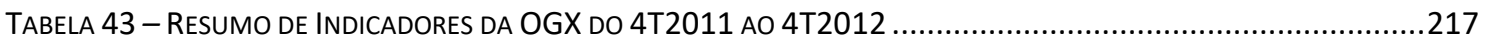

TABELA 44 - HISTÓRICO DE LEILÕES DE CONCESSÃO (RODADAS) DA ANP: INDICADORES SELETOS DA 1a A 9a RODADAS ..246

TABela 45 - TAXAÇÃo SOBRe ReCeItAS de Produção de Petróleo Pelo Mundo ..................................................247

TABELA 46 - IPO E FOLLOW-ONS NA BOVESPA ENTRE 2004 A 2008, EXCLUINDO OGX.........................................251

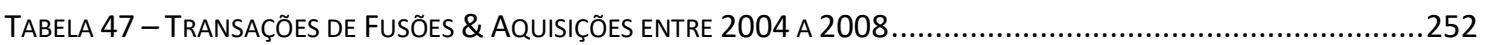

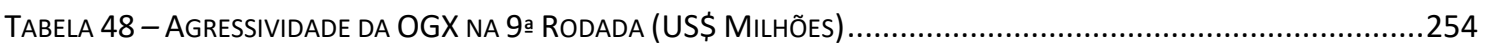


TABela 49 - Proximidade dos Blocos da OGX com outros Blocos de Concorrentes com Reservas ProvadAs E

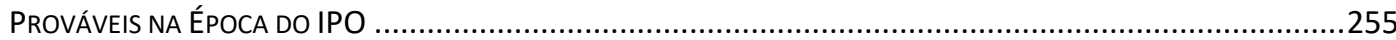

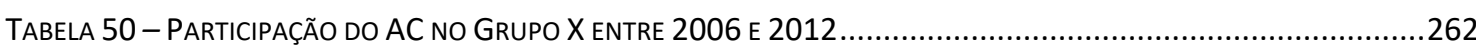

TABELA 51 - CARgos EXERCIDOS PELO AC NAS EMPRESAS DE CAPITAL ABERTO do GruPo X ..................................263

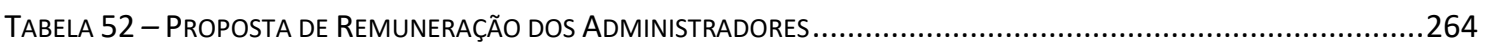

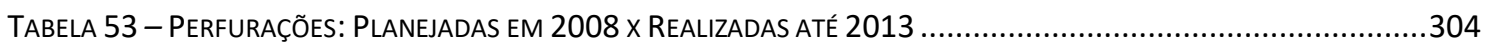

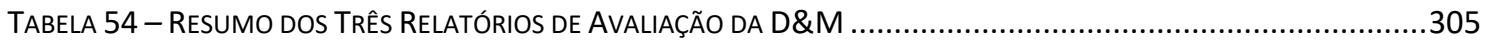

TABELA 55 - EVolUÇÃO do VALoR de REFERÊNCIA POR BBOE 2C NOS RELATÓRIOS D\&M.......................................306

TABELA 56 - PROCESSO de REFORÇO X PROCESSO de BALANCEAMENTO: DISPONIBILIDAdES, INVESTIMENTOS E ABANDONOS

TABELA 57 - HISTÓRICO DE AQUISIÇÕES DE BLOCOS EXPLORATÓRIOS E ANÚNCIOS DE DESCOBERTAS E SEUS DESFECHOS.. 311

TABELA 58 - PROPORÇÃO DE CADA ELEMENTO NA REMUNERAÇÃO TOTAL..........................................................331

TABELA 59 - VENDA DE AÇÕES PELO DRI E DEX EM 2009 (INSTRUÇÃO CVM 358) ................................................333

TABELA 60 - VENDA DE AÇÕES PELO DRI, DEX E DJUR EM 2011 (INSTRUÇÃo CVM 358) ....................................334

TABela 61 - Venda de Ações de Pessoas Relacionadas entre 2009 e 2013 (InStrução CVM 358) eM R\$ Milhões

TABELA 62 - EXECUTIVOS QUe PARTICIPAVAM No CA DO GRUPOX X 339

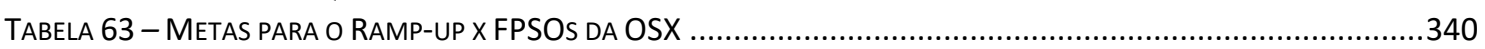

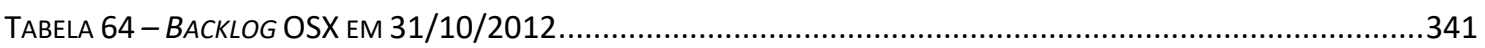

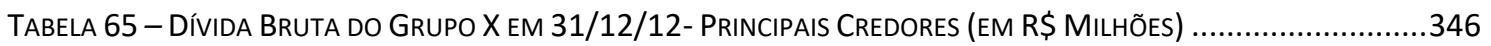

TABELA 66 - AuditoRES INDEPENDENTES DAS EMPRESAS DE CAPITAL ABERTO do GRUPO X: 2006 A 2016 ................357

TABELA 67 - FREQUÊNCIA DE ATUALIZAÇÕES PoSITIVAS No PAS DURANTE O RALLY .............................................361

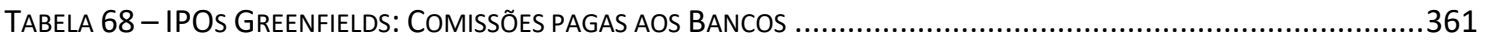

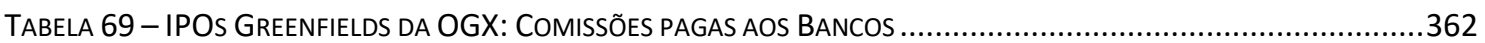

TABELA 70 - HONORÁRIOS POR ASSESSORIA (ADVISORY) DOS BANCOS DE INVESTIMENTOS ENVOLVIDOS NA EMISSÃO DOS

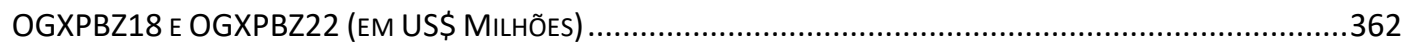

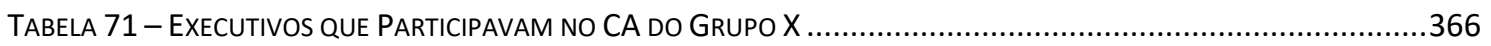

TABELA 72 - ACUMUlo de CARGOS NA PRESIDÊNCIA doS CA E PRESIDÊNCIA DA MESMA EMPRESA .............................366

TABELA 73 - CONCEITOS DE NÍVEIS DE INCERTEZA NO SISTEMA DE CLASSIFICAÇÃo DE RECURSOS.................................374 



\section{Agradecimentos}

A elaboração do presente estudo não foi apenas uma oportunidade de aprendizagem, mas também proporcionou reencontros com ex-colegas do Unibanco, da FEA-USP, da Gero Consultoria e ex-alunos. Dentre os ex-colegas, agradeço muito a Jorge Simino Junior, Marcio Guedes Pereira Junior, Cleomar Parisi e Glenn Mallet. Dentre os excolegas de FEA, destaco Rodrigo Azevedo, Marcelo Cavalheiro, e sua esposa Simone. Foi Rodrigo que me apresentou André Lion, que por sua vez me mostrou os primeiros relatórios de pesquisa sobre a OGX.

Dentre os ex-alunos que demonstraram interesse e me apoiaram na pesquisa, agradeço a André de Souza Lima (Constelation), David Birmann, Gabriel Sacardo, João Roberto Mesquita e Ricardo José Placa Oscar.

Dentre os entrevistados para a pesquisa, agradeço tempo e os insights de Newton Duarte e Ricardo Lamenza Alzogoray (Siemens), Gustavo Borges (FIESP), Mauro Rodrigues da Cunha (AMEC - Associação de Investidores no Mercado de Capitais).

O apoio da FIPE, nas pessoas de Carlos Antonio Luque e Maria Helena G.P. Zockun, foi fundamental para viabilizar a coleta e organização de dados, executado pela estagiária Nathalia Barros. Ainda na coleta de dados, um agradecimento especial aos colegas da B3: Armando Schroder, Carla Bomfim de Aquino, Christianne Bariquelli, Duílio Alves Paiva, e Édipo Ferreira.

Agradeço também os comentários e a oportunidade de discutir o caso OGX com o professor Shane Greenstein da Harvard Business School e o professor Peter Senge do MIT.

Luana Alves Viera, da Bibliotecária Telles do Insper, foi de enorme ajuda e apoio na coleta de informações. Sua perseverança e comprometimento foram de um profissionalismo raro, extraordinário.

O capricho na forma e detalhes da cuidadosa edição de Helena Ciorra foi excepcional e inestimável. Muito obrigado, Lelê.

Presto também meus agradecimentos ao professor Armênio, infelizmente falecido em 2018. Em 2017, logo no começo de minhas pesquisas sobre a OGX, eu almoçava com Armênio quando ele me alertou: "não dá para falar de OGX sem falar das outras empresas X". Seu alerta foi providencial.

Agradeço o carinho da minha família e amigos cujo apoio foi revigorante. Minha mãe, Ana Maria Franco e seu marido, Adalberto Valle, minha irmã, Patrícia Luzio e seu companheiro Paulo S. de Oliveira Neves. Dentre os amigos, um abraço especial ao bom humor de Gus Valentim, à Fernando Pinotti (Shell) e sua companheira Silvia R. S. Moreira.

Meus agradecimentos também à Sandra Letícia Berta por me ajudar a manter o eixo e o foco. Chico, Lola e Chokito, meus fiéis companheiros nos fins de semana de exílio. 
Agradeço muito o companheirismo, o amor, a paciência e os contrapontos de minha esposa, Juliana. Em outubro de 2019, completamos 10 anos de casados. Uma tese de livre docência é uma prova cruel para um casamento que a Ju suportou com muita resiliência. Esta tese é dedicada à Ju e ao nosso filho de quatro anos, Fernando Forte. 


\section{Resumo}

Em junho de 2008, a combinação entre altos preços do petróleo e descobertas no présal com uma tese de investimentos atraente proporcionou o maior IPO de uma empresa pré-operacional da história da BOVESPA ( $\mathrm{R} \$$ 6,7 bilhões). Com renomados executivos, membros do conselho de administração e acionista controlador, a campanha exploratória da OGX começou com muitas e significativas descobertas de hidrocarbonetos. Em outubro de 2010, ainda pré-operacional, a OGX mais que dobrou seu valor de mercado quando chegou a $\mathrm{R} \$ 75,2$ bilhões. A estratégia de financiamento, que captou $\mathrm{R} \$ 15,6$ bilhões em equity e quasi-equity, atraiu grandes investidores institucionais e gestores de recursos. Entretanto, momentos de sub e sobrevalorização da OGXP3 combinada com SOPs generosos e vestings de curto prazo geraram comportamentos disfuncionais dos executivos que viriam a comprometer a viabilidade da Empresa. Mas a análise da OGX não comporta conclusões ingênuas e maniqueístas. Há indícios que estes comportamentos foram corroborados pela ação, ou no mínimo complacência, de gatekeepers internos (acionista controlador e conselho de administração) e externos (analistas de sell-side, auditores e a CVM). Dentre estes comportamentos disfuncionais destaca-se a "Heroína Organizacional" e sua consequente assimetria informacional, que pode ter afetado direta e indiretamente outras empresas da EBX, cujas dívidas somavam $\mathrm{R} \$ 24,9$ bilhões (31/12/2012). As duas manifestações externas da Heroína Organizacional, inter-relacionadas, foram: a intensa campanha exploratória que consumiu $\mathrm{R} \$ 13,8$ bilhões em investimentos, perfurou 115 poços em 51 prospectos em 5 bacias; e o guidance otimista que incluiu a publicação de 110 Fatos Relevantes, quase todos otimistas, revisões nas estimativas de volumes recuperáveis de 4,8 para 10,9 bboe e aquisição de 29 novos blocos. Mas atrasos, percalços e "eventos de reputação" comprometeram a credibilidade dos executivos, acionista controlador e o valor da OGXP3. Em agosto de 2013, a produção média era de $10,7 \mathrm{kbpd}$ contra a meta de $165,0 \mathrm{kbpd}$. Em outubro de 2013, a OGX solicitou sua Recuperação Judicial ("RJ") com R\$ 13,3 bilhões em dívidas com bondholders e fornecedores, dentre eles, a OSX. Dez dias depois foi a vez da OSX solicitar a RJ, com dívidas de $R \$$ 4,1 bilhões. Por fim, o estudo identifica possíveis aprendizados e temas de pesquisas futuras que podem agregar na viabilidade de captações para financiar projetos greenfield em infraestrutura no Brasil.

Palavras-chave: governança corporativa, óleo e gás, pré-sal, de-risking, IPO, greenfield, Project Finance, valuation, heroína organizacional, principal-agente, sobrevalorização, unsecured note, conglomerados, noise traders, day trade, detracking risk, analistas sellside, ANP, fatos relevantes, right-to-trust, SOP, Recuperação Judicial, OGX, OSX, Eike Batista, farm-in, farm-out.

JEL: M52, L71, L51, L26, K22, G14, G18, G32, G34, G41, G17 


\begin{abstract}
In June 2008, the combination of high oil prices and pre-salt discoveries with an attractive investment thesis provided the largest IPO of a greenfield company in BOVESPA's history (R\$ 6.7 billion). With reputed executives, board of directors and controlling shareholder, OGX's exploratory campaign began with many significant hydrocarbon discoveries. In October 2010, still pre-operational, OGX more than doubled its market value to $\mathrm{R} \$ \mathbf{7 5 . 2}$ billion. The financing strategy, which raised $\mathrm{R} \$ 15.6$ billion in equity and quasi-equity, attracted large institutional investors, equity and debt funds. However, OGXP3 under and overvalue moments combined with generous SOPs and short-term vestings generated dysfunctional executives' behaviors that would compromise the Company's feasibility. But the OGX analysis does not admit naive and Manichaean conclusions. There are indications that these behaviors were corroborated by the action, or at least complacency, of internal gatekeepers (controlling shareholder and board of directors) and external (sell-side analysts, auditors and the CVM). Among these dysfunctional behaviors stands out the "Organizational Heroine" and its consequent informational asymmetry, which may have directly and indirectly affected other EBX companies, whose debts added to R\$ 24.9 billion (12/31/2012). The two external manifestations of the Organizational Heroine, interrelated, were: the intense exploratory campaign that consumed $\mathrm{R} \$ 13.8$ billion in investments, drilled 115 wells in 51 prospects in 5 basins; and the optimistic guidance, which included the publishing of 110 Material Facts, almost all optimistic, revisions in recoverable volume estimates from 4.8 to 10.9 bboe and the acquisition of 29 new blocks. But delays, setbacks, and "reputation events" have compromised the credibility of executives, the controlling shareholder, and the value of OGXP3. In August 2013, average production was $10.7 \mathrm{kbpd}$ versus the target of $165.0 \mathrm{kbpd}$. In October 2013, OGX requested bankruptcy protection with $\mathrm{R} \$ 13.3$ billion in debts with bondholders and suppliers, OSX among them. Ten days later it was OSX's turn to request Judicial Recovery, with debts of R\$ 4.1 billion. Finally, the study identifies possible lessons and future research topics that may contribute to raise funds to finance greenfield infrastructure projects in Brazil.
\end{abstract}

Keywords: corporate governance, oil \& gas, pre-salt, de-risking, IPO, greenfield, Project Finance, valuation, organizational heroin, principal-agent, overvaluation, unsecured note, conglomerates, noise traders, day trade, de-tracking risk, sell-side analysts, material facts, right-to-trust, SOP, bankruptcy, OGX, OSX, Eike Batista, farm-in, farmout. 


\section{Lista de Abreviaturas e Conversões de Unidades}

\begin{tabular}{|c|c|}
\hline Acrônimo & Termo sem Abreviações \\
\hline $1 \mathrm{Pe} 1 \mathrm{C}$ & $\begin{array}{l}\text { 1P refere-se à reservas provadas com } 90 \% \text { de chance que a quantidade } \\
\text { efetiva seja superior à estimada e } 10 \% \text { de chance de ser inferior, de } \\
\text { acordo com a definição do API. }\end{array}$ \\
\hline $2 \mathrm{P}$ e $2 \mathrm{C}$ & $\begin{array}{l}2 \mathrm{P} \text { refere-se à reservas provadas com } 50 \% \text { de chance que a quantidade } \\
\text { efetiva seja superior à estimada e } 50 \% \text { de chance de ser inferior. }\end{array}$ \\
\hline $3 P$ e $3 C$ & $\begin{array}{l}3 \text { P refere-se à reservas provadas com } 10 \% \text { de chance que a quantidade } \\
\text { efetiva seja superior à estimada e } 90 \% \text { de chance de ser inferior. }\end{array}$ \\
\hline $10^{3} \mathrm{ft}^{3}$ & mil pés cúbicos (GN) \\
\hline AA & Anglo American \\
\hline$A C$ & Acionista Controlador \\
\hline AGE & Assembleia Geral Extraordinária \\
\hline AGO & Assembleia Geral Ordinária \\
\hline ANP & Agência Nacional de Petróleo \\
\hline API & American Petroleum Institute \\
\hline bboe & bilhão de barris de óleo equivalentes \\
\hline bbpd & bilhão de barris de óleo por dia \\
\hline boe & $\begin{array}{l}\text { barris de óleo equivalentes. Fator de conversão: } 5.615 \text { pés cúbicos de } \\
\text { GN = } 1 \text { boe }\end{array}$ \\
\hline boed & barris de óleo equivalentes diários \\
\hline CAMF & Centennial Asset Mining Fund LLC \\
\hline $\mathrm{CHB}$ & Crowe Horwath Bendoraytes \\
\hline CM & Comunicado ao Mercado \\
\hline CNPE & Conselho Nacional de Política Energética \\
\hline COAD & Conselho de Administração \\
\hline CS & Credit Suisse \\
\hline DB & Deutsche Bank \\
\hline DEX & Diretor de Exploração \\
\hline DJUR & Diretor Jurídico \\
\hline D\&M & DeGolyer \& MacNaughton \\
\hline DRI & Diretor de Relações com Investidores \\
\hline E\&P & Exploração \& Produção \\
\hline EBITDA & $\begin{array}{l}\text { Earnings Before Interest, Taxes, Depreciation, Depletion and } \\
\text { Amortization }\end{array}$ \\
\hline EBITDAX & $\begin{array}{l}\text { Earnings Before Interest, Taxes, Depreciation, Depletion, Amortization } \\
\text { and Exploration Expenses }\end{array}$ \\
\hline ESP & Electric Submersible Pumps \\
\hline EUR & Estimativa de Recuperação Final \\
\hline EV & Enterprise Value \\
\hline EWMA & Exponentially Weigthed Moving Average \\
\hline FDC & Fluxo Descontado de Caixa \\
\hline FMM & Fundo da Marinha Mercante \\
\hline
\end{tabular}




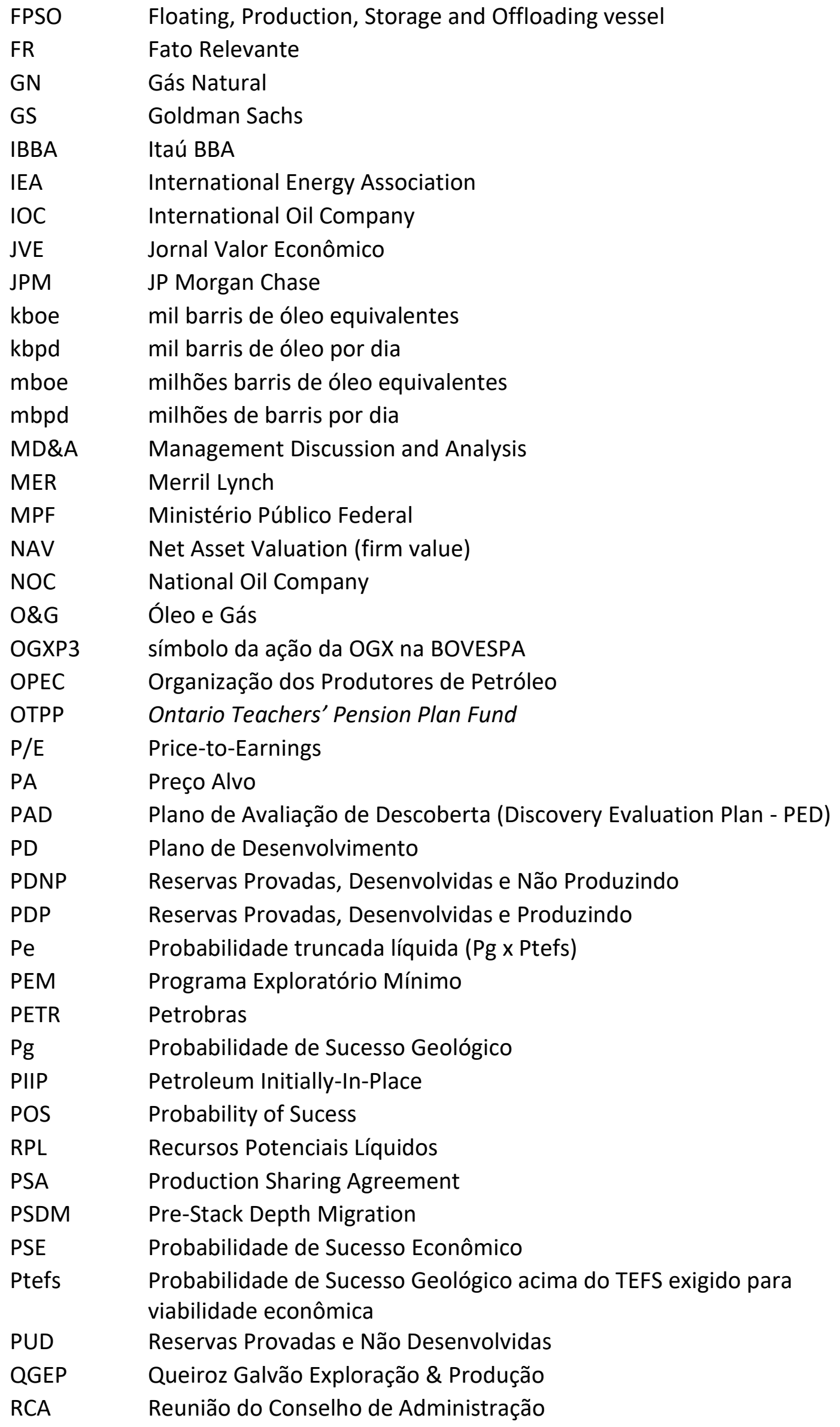




$\begin{array}{ll}\text { SAN } & \text { Santander } \\ \text { SEO } & \text { Seasoned Equity Offer } \\ \text { SOP } & \text { Stock Option Plan } \\ \text { SPA } & \text { Sistema de Produção Antecipada } \\ \text { SPE } & \text { Society of Petroleum Engineers } \\ \text { SPE-PRMS } & \text { Petroleum Resources Management Systems elaborado pela SPE } \\ \text { SPT } & \text { Special Participation Tax } \\ \text { TACC } & \text { Taxa Anual de Crescimento Composto } \\ \text { Tcf } & \text { Tera Cubic Feet (5,615 cf = 1 boe) } \\ \text { TEFS } & \text { Threshold Economic Field Size } \\ \text { TLD } & \text { Teste de Longa Duração } \\ \text { TLWP } & \text { Tension Leg Wellhead Platform } \\ \text { TMA } & \text { Taxa Mínima de Atratividade } \\ \text { UBS } & \text { Union Banks Switerzland } \\ \text { US\$ } & \text { Dólares Norte-Americanos } \\ \text { UTG } & \text { Unidade de Tratamento de Gás Natural } \\ \text { VOGIP } & \text { Volume of Gas in Place (volume de gás in situ) } \\ \text { VOOIP } & \text { Volume of Oil in Place (volume de óleo in situ) } \\ \text { WACC } & \text { Custo Médio Ponderado do Capital } \\ \text { WHP } & \text { Well Head Platform } \\ \text { WTI } & \text { West Texas Intermediate } \\ & \end{array}$



"Há algo em todos nós que ama montar um quebracabeças, que ama ver a imagem do todo emergir".

SENGE, 2006, p. 68.

Em 2009, fui convidado a ministrar a disciplina Mercado de Capitais na FGV-SP. Em certo ponto do curso, organizei a sala em grupos e os instrui a escolher uma transação real de Mercado de Capitais para analisar e apresentar em sala. Um grupo de alunos talentosos escolheu o IPO da OGX. Fiquei impressionado com a análise deles, em especial com um trecho do Prospecto que descrevia o risco do acionista controlador. O Prospecto alertava que o AC poderia tomar decisões que fossem contra o interesse dos minoritários. Eu nunca tinha visto uma cláusula como aquela: a fragilidade da governança corporativa estava declarada explicitamente no IPO. Quando veio a crise da OGX em 2012 não fiquei surpreso.

Trabalho como consultor e ministro aulas de Project Finance desde 2005, e as empresas do Grupo X sempre me fascinaram pela aparente facilidade com que conseguiram tanto capital de risco para financiar projetos greenfield. Se captar financiamentos já é difícil em Project Finance, imagine só capital de risco de investidores minoritários.

Utilizo fatos estilizados sobre o Grupo X em várias disciplinas e cursos que ministro em cursos executivos na FIPE, FEA-USP e Insper para ilustrar outros temas como: liderança, governança corporativa, avaliação de empresas, Project Finance, etc...

O setor de petróleo em si, também sempre cativou meu interesse. Lendo os livros de YERGIN [2009, 2011], fico com a nítida impressão que a história dos séculos XX e XXI poderia ser facilmente interpretada através da evolução do setor de petróleo. No curso de Organização Industrial que ministro na graduação da FEA-USP, dedico uma aula à evolução dos carteis do setor de petróleo.

Em junho de 2017, em conversas com colegas, veio a sugestão de fazer a tese de livre docência sobre um estudo de caso. Como venho trabalhando com estudos de caso desde minha tese de doutorado como instrumento de pesquisa e pedagógico, a sugestão me pareceu natural e oportuna. A escolha da OGX surgiu segundos depois. Naquele momento, não sabia ao certo o que iria encontrar, mas pressentia que eu estava diante de uma mina, ou melhor, de um iceberg de temas econômicos.

Poucas semanas depois da escolha da OGX, uma coincidência: em agosto de 2017, o Centro de História da Ciência da USP ofereceu o curso "História Global do Petróleo", organizado pelo Prof. Gildo Magalhães dos Santos Filho e ministrado pelo Prof. Nuno Luís Madureira do Instituto Universitário de Lisboa (ISCTE-IUL). Para mim coincidências são excelentes sinais de que iniciava uma jornada promissora. 
Começou aí o processo de investigação. Em agosto, me debrucei sobre os DFPs da OGX, reli o livro de GASPAR [2014] e comecei a entrevistar os primeiros executivos do mercado que tiveram alguma interação com a OGX. Dentre eles, haviam fornecedores, analistas de buy e sell-side, profissionais de bancos de investimentos, executivos ligados ao setor de Óleo \& Gás ("O\&G") e outros. Não demorou muito para descobrir que embora a OGX fosse o pilar do Grupo X, "a galinha de ovos de ouro", seria preciso analisar também, mesmo que superficialmente, outras empresas relacionadas: $M M X$, MPX, LLX, CCX e OSX. E a lista foi aumentando ao incluir Petrobras, HRT, QGEP, Petra Energia e algumas empresas estrangeiras, como a Chevron, Conoco Philips, dentre outras.

Essa análise se mostrou complexa, porém frutífera. Desde 1995 tenho dedicado boa parte de minha atividade profissional à avaliação de empresas e projetos de investimento. Iniciei esta trajetória como muitos, com foco quantitativo, partindo da análise dos demonstrativos contábeis históricos quando estes estavam disponíveis. 0 tempo me mostrou que avaliar uma empresa ou um projeto é um exercício muito mais amplo do que a projeção do fluxo de caixa. Trata-se também de avaliar estratégias competitivas e, em particular, a qualidade da gestão da empresa (ou projeto) que irá implementar tais estratégias. O caso OGX me mostrou a importância de uma outra força potencialmente destruidora de valor: a governança corporativa, ou seja, os mecanismos de incentivos e controles internos e externos à OGX.

Na primeira entrevista que fiz com um analista de buy-side de um hedge fund, tive acesso a relatórios de analistas de sell-side. Estes relatórios foram fontes valiosas de informações, pois descreviam como parte do mercado foi construindo, e posteriormente, descontruindo, sua percepção de valor sobre a OGX. Percebi então que a OGX nos convoca a refletir não apenas sobre metodologias de avaliação, gestão e governança corporativa, mas também relação com investidores, vieses cognitivos e comportamentais, ética empresarial, regulação do mercado de capitais, legislação da Recuperação Judicial, dentre outros.

Uma pergunta que muitos leigos frequentemente indagam é se Eike Fuhrken Batista ("Acionista Controlador" ou "AC") foi um habilidoso manipulador ou um empreendedor legítimo. O AC teria sido um Midas dissimulado ou um Ícaro bem-intencionado? Se foi um empreendedor legítimo, o "mercado" teria interpretado inadequadamente o potencial e riscos de seus projetos, depreciando-os prematuramente? Ou ainda, a visão de curto prazo dos investidores brasileiros teria comprometido o futuro da OGX? Por que as respostas a essas questões importariam hoje?

Para evitar vieses maniqueístas na minha análise, deixei por último, a leitura das peças jurídicas dos oito processos que o AC, seus executivos e membros do Conselho de Administração sofreram. Aí o quebra-cabeças se tornou ainda mais interessante e inusitado com as evidências de vendas de ações por parte de alguns executivos importantes da OGX.

Durante uma aula, eu abordei o tema OGX e um aluno me perguntou: "quem mais perdeu?" Respondi: além dos credores, alguns investidores e o próprio AC, quem mais perdeu fomos todos nós. Nós brasileiros e as futuras gerações. Temos um país rico em 
recursos minerais e naturais, com uma carência enorme de investimentos em infraestrutura, e capital de longo prazo é precondição para viabilizá-los. As repercussões do caso OGX, logo seguido pelo da Petrobras (outubro de 2014), na percepção de riscos dos investidores institucionais estrangeiros não podem ser minimizados.

Apesar de sua relevância, o presente estudo não pretende exaurir todos os temas que o caso OGX suscita. Há muito o que se pesquisar e aprofundar. Acredito que a tese é um começo, uma tentativa de delinear o problema que é prolífico em temas. 


\title{
Parte 1 - Considerações Preliminares e Descrição dos Fenômenos
}

\section{Introdução}

\author{
"Meu trabalho é ler o jornal de amanhã" \\ AC, citado em GASPAR, 2014, p. 86. \\ “(...) [A] loucura, objeto dos meus estudos, era até \\ agora uma ilha perdida no oceano da razão; começo \\ a suspeitar que é um continente".
}

ASSIS, M., O Alienista, p. 34.

Para alguns executivos do mercado financeiro entrevistados por nós, o AC foi um empreendedor ousado e visionário que construiu um impressionante conglomerado de seis greenfields de capital aberto ("Grupo X"), mas que perdeu o foco e cometeu graves erros de implementação em seus projetos ${ }^{1}$.

A construção do Grupo X impressiona não apenas pelo número de empresas abertas e pelo volume das captações (dívida e capital), mas também pela sua diversidade, complexidade operacional e o curto espaço de tempo com que foram criadas.

Tabela 1 - Empresas de Capital Aberto do Grupo X entre 2006 e 2012

\begin{tabular}{|c|c|c|}
\hline Empresa & Atividade & Comentários \\
\hline MMX & Minério ferro & IPO em 20/06/2006 (R\$ 1,02 bilhões) $^{1}$ \\
\hline MPX & Termoeletricidade & IPO em 12/12/2007 (R\$ 1,92 bilhões) $^{1}$ \\
\hline OGX & E\&P de O\&G & IPO em 12/06/2008 (R\$ 6,71 bilhões) $^{1}$ \\
\hline LLX & Logística portuária & Cisão da MMX em 28/07/2008 (R\$ 1,88 bilhões) \\
\hline OSX & Construção naval & IPO em 2010 em 18/03/2010 (R\$ 2,45 bilhões) ${ }^{1}$ \\
\hline CCX & Mineração carvão na Colômbia & Cisão da MPX em 25/5/2012 (R\$ 0,73 bilhões) ${ }^{2}$ \\
\hline
\end{tabular}

(1) Captação no IPO. Não considera captações de financiamentos e aportes de capital até 2012.

(2) Capitalização de mercado da LLX em 30/6/2008 e CCX em 30/6/2012. Fonte: Capital IQ.

O AC teria sido um habilidoso vendedor com um senso de timing de mercado primoroso. Para aproveitar o momento histórico, o AC foi capaz de: construir teses de investimento atraentes em momento oportuno, quando do superciclo de commodities, da alta

${ }^{1} \mathrm{O}$ Grupo X, como denominado aqui, se refere ao conjunto empresas de capital aberto na BOVESPA criadas a partir de 2006 com o IPO da MMX. Entretanto, essa é uma definição arbitrária, pois os empreendimentos do AC no Brasil e no exterior datam de muito antes de 2006, além de outras empresas de capital fechado. 
liquidez internacional e das perspectivas favoráveis ao Brasil; compor equipes com executivos experientes e renomados em seus setores de atuação; construir alianças com pessoas públicas com poder de decisão; se alinhar com bancos de investimentos e comerciais para conduzir significativas transações no mercado de capitais nacional e internacional; negociar transações de M\&A e parcerias operacionais com sócios estratégicos de renome internacional.

Considerando apenas as empresas de capital aberto, no ápice, o Grupo $\mathrm{X}$ chegou a valer R\$ 98,12 bilhões em 2010, ou US\$ 58,37 bilhões², em capitalização de mercado. Na época, a OGX Petróleo e Gás Participações S.A. ("OGX" ou "Empresa") valia R\$ 74,99 bilhões, correspondendo a $76 \%$ do valor do Grupo X, anos antes de produzir seu primeiro barril de óleo. No auge (outubro de 2010), quando sua capitalização de mercado chegou a $\mathrm{R} \$ 75,0$ bilhões, a OGX, ainda pré-operacional, só valia menos do que a Ambev, PETR e Vale ${ }^{3}$.

Mas, em 2012, a decepção com a produção do seu primeiro poço, Turbarão Azul ("TBAZ"), catalisou a queda irreversível das suas ações ("OGXP3"). A queda da OGXP3 contaminou todas as outras empresas do Grupo X, que no total chegou a valer $\mathrm{R} \$ 1,3$ bilhões (US\$ 449,3 milhões) ${ }^{4}$, ou seja, cerca de 1,5\% do valor na máxima.

Tabela 2 - Capitalização de Mercado das Empresas do Grupo X

\begin{tabular}{|l|c|c|c|c|c|c|c|c||}
\hline \multirow{2}{*}{ Empresa } & \multicolumn{2}{|c|}{$\begin{array}{c}\text { IPO OGX } \\
(12 / 06 / 2010)\end{array}$} & \multicolumn{2}{c|}{$\begin{array}{c}\text { Máximo } \\
(04 / 11 / 2010)\end{array}$} & \multicolumn{2}{c|}{$\begin{array}{c}\text { Mínimo } \\
(03 / 04 / 2015)\end{array}$} & $\begin{array}{c}\text { Pós Reestruturação } \\
(06 / 10 / 2017)\end{array}$ \\
\cline { 2 - 10 } & R\$ Milhões & $\%$ & R\$ Milhões & $\%$ & R\$ Milhões & $\%$ & R\$ Milhões & $\%$ \\
\hline OGX & $35.714,50$ & $60 \%$ & $74.993,94$ & $76 \%$ & 226,52 & $17 \%$ & 125,56 & $1,5 \%$ \\
\hline CCX & - & - & - & $0 \%$ & 69,75 & $5 \%$ & 18,03 & $0,2 \%$ \\
\hline MMX & $17.392,66$ & $29 \%$ & $6.389,87$ & $7 \%$ & 102,19 & $8 \%$ & 22,19 & $0,3 \%$ \\
\hline OSX & - & - & $6.223,22$ & $6 \%$ & 56,26 & $4 \%$ & 34,35 & $0,4 \%$ \\
\hline MPX & $6.762,69$ & $11 \%$ & $3.936,76$ & $4 \%$ & 168,02 & $12 \%$ & $3.934,23$ & $47,9 \%$ \\
\hline LLX & - & - & $6.580,97$ & $7 \%$ & 722,14 & $54 \%$ & $4.079,78$ & $49,7 \%$ \\
\hline Total (R\$ Milhões) & $59.869,85$ & $100 \%$ & $98.124,76$ & $100 \%$ & $1.344,89$ & $100 \%$ & $8.214,13$ & $100,0 \%$ \\
\hline$\%$ Total Máx. R\$ & $61 \%$ & & $100 \%$ & - & $1,4 \%$ & - & $8,4 \%$ & - \\
\hline Total US\$ Milhões & $36.523,82$ & & $58.369,37$ & - & 449,34 & - & $2.595,47$ & - \\
\hline \% Total Máx. US\$ & $63 \%$ & & $100 \%$ & - & $0,8 \%$ & - & $4,4 \%$ & - \\
\hline \hline
\end{tabular}

Fonte: Economática.

Para outros executivos do mercado financeiro entrevistados, o AC vendeu uma narrativa ao mercado que criou uma bolha especulativa que faria inveja às tulipas holandesas, cujo fim não poderia ser outro se não a óbvia e esperada derrocada. A OGX era ao

\footnotetext{
2 PTAX de R\$ 1,6811.

${ }^{3}$ Disponível em: https://www.valor.com.br/u/3202056

${ }^{4}$ PTAX de R\$2,993.
} 
mesmo tempo a empresa de maior risco e a mais valiosa de todas as empresas abertas do AC. Como mais valiosa, a OGX se tornou pivô do valor do Grupo X por suas relações objetivas e subjetivas com as Partes Relacionadas. Relações objetivas incluíam, por exemplo, as encomendas de equipamentos para a OSX. A OGX era sócia da MPX na UTE Parnaíba. Além disso, o AC, teria concedido avais em empréstimos às empresas do Grupo X lastreados em suas ações da OGX. Relações subjetivas referem-se à percepção dos investidores, financiadores e fornecedores quanto à capacidade do AC em implementar seus projetos

Quando a "bolha OGX" estourou, todo o restante do Grupo X entrou em crise, apesar de possuírem riscos diferenciados. Esta é a primeira constatação inusitada: como um grupo tão diversificado tinha em seu alicerce de valor uma empresa com risco tão elevado?

Hoje, parte das empresas de capital aberto do Grupo $X$ sobrevivem com valores diminutos frente ao seu pico histórico, incluindo a OGX, agora Dommo Energia S.A.. Apenas duas empresas abertas, a MPX (atual Eneva) e a LLX (atual Prumo), já com outros sócios majoritários, possuem capitalizações de mercado significativas, somando $R \$ 8,4$ bilhões (US\$ 2,7 bilhões), representando $98 \%$ do valor que restava do Grupo X ${ }^{5}$. A CCX foi vendida para mineradores turcos, a Yildirim, e a OSX ao Cerberus, fundo de private equity norte americano ${ }^{6}$. O Porto Sudeste da MMX para minério de ferro foi vendido para a trading holandesa de comodities, a Trafigura, e ao Mubadala, fundo soberano de Abu Dhabi?.

O portfólio de projetos do Grupo X, entre 2006 a 2013, possuía pelo menos quatro características em comum. Primeiro, eram todos projetos tipo greenfield de grandes dimensões, elevada complexidade operacional e longos ciclos de implementação ${ }^{8}$. Segundo, todos os projetos estavam sujeitos, direta ou indiretamente, aos enormes riscos geológicos na exploração de recursos minerários: O\&G, minério de ferro, carvão e seus subprodutos. Terceiro, a expertise dos principais executivos, dos membros dos Conselhos de Administração, e do próprio AC, era considerada como vantagem competitiva na gestão destes projetos e na captura de opções de crescimento. Quarto, suas teses de investimento incluíam sinergias operacionais e financeiras entre outras empresas do Grupo X, que conjuntamente formariam um sistema virtuoso de geração de valor aos investidores por dominar vários elos da cadeia de valor de exploração e processamento de recursos naturais (OGX, MMX, CCX, MPX) e sua logística (LLX), incluindo a produção de certos equipamentos (OSX) que atenderia as exigências de nacionalização.

\footnotetext{
${ }^{5}$ PTAX de R\$ 3,1642.

${ }^{6}$ The great X-it., in: The Economist, 2014, Vol. 410 (8875), p. 57.

${ }^{7}$ Bustista, in: The Economist, 2013, Vol. 409 (8860), p. 68-68.

${ }^{8}$ A rigor, no IPO, a MMX já havia iniciado suas operações em dezembro de 2005, em uma de suas minas.
} 
Tabela 3 - Teses de Sinergias entre as Empresas do Grupo X

\begin{tabular}{||l|l|l||}
\hline & & \multicolumn{1}{c|}{ Tese de sinergias } \\
\hline OGX & OSX & OSX proveria navios, plataformas e serviços \\
\hline OGX & MPX & OGX proveria GN para térmicas da MPX \\
\hline CCX & MPX & CCX proveria carvão para térmicas da MPX \\
\hline LLX & OGX & LLX proveria infraestrutura de portos para OGX \\
\hline LLX & MMX & $\begin{array}{l}\text { LLX proveria infraestrutura de portos para MMX, que por sua vez } \\
\text { forneceria o minério de ferro para siderúrgica no Porto de Açu }\end{array}$ \\
\hline MMX & OGX & MMX proveria expertise em commodity trading para OGX \\
\hline LLX & MPX & UTE $^{10}$ no Porto de Açu proveria energia para os empreendimentos \\
\hline
\end{tabular}

Fonte: Elaborado pelo autor com base no Prospecto (OGX 2008a) nos Relatórios da Administração dos DFPs.

\begin{abstract}
Grupo EBX captura as muitas sinergias existentes entre os seus negócios. $O$ minério de ferro da MMX será transportado para o Superporto Sudeste, de onde será exportado para todo o mundo. As chapas de aço produzidas pelas siderúrgicas instaladas no complexo industrial do superporto da LLX serão utilizadas pela OSX na produção de equipamentos offshore, afretados para a OGX para a sua produção de óleo e gás. O carvão das minas da CCX na Colômbia será transportado até as termelétricas da MPX localizadas ao longo da costa brasileira e no superporto da LLX, e a energia gerada será fornecida para as indústrias localizadas no complexo industrial. O gás natural produzido pela OGX pode suprir as térmicas da MPX localizadas no complexo industrial do superporto da $L L X$. O superporto da LLX poderá servir de base terrestre para a produção de óleo e gás da OGX. A MPX vai fornecer energia para a principal unidade operacional da MMX em Minas Gerais ${ }^{11}$.
\end{abstract}

Se os prazos de maturação dos greenfields foram mais longos do que se previa inicialmente, pode ter faltado dinheiro e confiança dos investidores e financiadores. Neste portfólio, a decepção do projeto mais importante comprometeria todos os outros. Como tal, a evolução da OGX, entre junho de 2008 a outubro de 2013, é o principal foco do presente estudo.

\footnotetext{
${ }^{9}$ Segundo GASPAR [2014, p. 64], o pai do AC, Eliezer Batista dizia que "uma mina nada mais é do que um empreendimento logístico." Podemos expandir essa assertiva para o petróleo também.

10 Usina Termo Elétrica (“UTE”).

${ }^{11}$ Fonte: https://pt.wikipedia.org/wiki/Grupo_EBX, acesso em 18/9/2017.
} 


\subsection{Questões de Pesquisa}

A história da OGX foi um extraordinário caso de Project Finance ${ }^{12}$. Em junho de 2008, a Empresa protagonizou o maior IPO do Brasil até então, quando captou R\$ 6,71 bilhões (US\$ 4,09 bilhões). Na época, a Empresa tinha apenas 29 funcionários e ainda nem sequer havia perfurado seu primeiro poço exploratório. Na época do IPO, a proposição de valor aos investidores ("Tese de Investimento") era constituída por "Seis Pilares"13.

O primeiro pilar era o portfólio de concessões para exploração e desenvolvimento de O\&G de 21 blocos $^{14}$ adquiridos na 9a Rodada da ANP em 27/11/2007 por R\$1,48 bilhões (US\$ 806,54 milhões, ou US\$ 0,167/boe) em Bônus de Assinaturas ("BAs"). No início de 2008, a OGX adquiriu (ou no jargão de O\&G, farm-in) 50\% de um outro bloco pertencente à dinamarquesa Maesrk Oil \& Gas ("MAESRK"), o BM-S-2915.

A renomada DeGolyer \& MacNaughton ("D\&M") ${ }^{16}$ estimou que o portfólio de 22 blocos poderia conter 4,835 bilhões de barris de óleo equivalentes ("bboe") de Recursos Potenciais Líquidos ("RPL") de óleo e gás natural ("GN"). Se confirmadas, as dimensões do portfólio permitiriam gerar economias de escala a partir de "melhores condições de negociação para a aquisição ou locação de equipamentos no longo prazo". Localizados em águas rasas, o portfólio se beneficiaria de uma "maior disponibilidade de equipamentos" ${ }^{17}$.

12 Project Finance entendido como: "Captação de recursos para financiar um projeto de investimento de capital economicamente separável, no qual os provedores de recursos veem o fluxo de caixa vindo do projeto como fonte primária de recursos para atender ao serviço de seus empréstimos e fornecer o retorno sobre seu capital investido." [FINNERTY, 1996, p. 2].

13 Prospecto OGX, 2008, p. 20-24.

${ }^{14}$ Bloco é uma pequena parte de uma bacia sedimentar, com limites definidos pela ANP. Trata-se de um prisma vertical de profundidade indeterminada, com superfície poligonal definida pelas coordenadas geográficas de seus vértices [PETROBRAS, 2010].

${ }^{15}$ A MAERSK era sócia da OGX na exploração em dois blocos na bacia de Campos (BM-C-37 e BM-C-38). A MAERSK começou a investir em E\&P no Brasil em 2001 quando participou da $3^{\text {a }}$ Rodada e adquiriu o BM-S-15. A MAERSK participou de outras rodadas e adquiriu o BM-S-29 na $4^{\text {a }}$ Rodada (2/9/2002). Segundo DA SILVA [2013], a descoberta no prospecto de Abacate pela MAERSK em 2009 causou o interesse da OGX pelo BM-S-29.

${ }^{16}$ Com 70 anos de experiência, a D\&M era a mesma certificadora da Petrobras.

17 Prospecto OGX, 2008, p. 155. 
Tabela 4 - Portfólio de Blocos da OGX no IPO: RPL em bboe, e Probabilidade de Sucesso Econômico ("PSE")

\begin{tabular}{|l|c|c|c|c|c|c|c|c|c|c||}
\hline \hline Bacias & $\begin{array}{c}\text { PSE } \\
\text { Óleo }\end{array}$ & $\begin{array}{c}\text { RPL } \\
\text { Óleo }\end{array}$ & $\begin{array}{c}\mathbf{\%} \\
\text { Óleo }\end{array}$ & $\begin{array}{c}\text { PSE } \\
\text { GN }\end{array}$ & $\begin{array}{c}\text { RPL } \\
\text { GN }\end{array}$ & $\begin{array}{c}\text { RPL } \\
\text { GN }\end{array}$ & $\begin{array}{c}\text { RPL } \\
\text { Total }\end{array}$ & $\begin{array}{c}\mathbf{\%} \\
\text { Total }\end{array}$ & $\begin{array}{c}\text { Área } \\
\left.\mathbf{( k m}^{2}\right)\end{array}$ & $\begin{array}{c}\% \\
\text { Total }\end{array}$ \\
\hline Campos & $33 \%$ & 2,562 & $71,6 \%$ & - & - & $0,0 \%$ & 2,562 & $53,0 \%$ & 1.177 & $17,2 \%$ \\
\hline Santos & $23 \%$ & 0,395 & $11,1 \%$ & $26 \%$ & 1,174 & $93,3 \%$ & 1,569 & $32,5 \%$ & 1.076 & $15,7 \%$ \\
\hline ES & $18 \%$ & 0,187 & $5,2 \%$ & $20 \%$ & 0,083 & $6,6 \%$ & 0,270 & $5,6 \%$ & 3.620 & $\mathbf{5 3 , 0 \%}$ \\
\hline PA-MA & $\mathbf{2 0} \%$ & 0,434 & $12,1 \%$ & - & 0,000 & $0,0 \%$ & 0,434 & $9,0 \%$ & 960 & $14,0 \%$ \\
\hline Total & $\mathbf{2 7 \%}$ & $\mathbf{3 , 5 7 8}$ & $\mathbf{1 0 0 , 0 \%}$ & $\mathbf{2 5 \%}$ & $\mathbf{1 , 2 5 7}$ & $\mathbf{1 0 0 , 0 \%}$ & $\mathbf{4 , 8 3 5}$ & $\mathbf{1 0 0 , 0 \%}$ & $\mathbf{6 . 8 3 3}$ & $\mathbf{1 0 0 , 0 \%}$ \\
\hline \%Total & & $\mathbf{7 4 , 0 \%}$ & & & $\mathbf{2 6 , 0 \%}$ & & $\mathbf{1 0 0 , 0 \%}$ & & & \\
\hline
\end{tabular}

Fonte: OGX, p. 16-19, 113.

A maior aposta da OGX era em Campos, que concentrava $71,6 \%$ do RPL de óleo. Santos aglutinava o maior potencial de GN (93,3\% do RPL de GN), onde a falta de infraestrutura implicava em monetização altamente incerta. A Empresa havia também arrematado extensos campos nas bacias do Espirito Santo ("ES") e do Pará-Maranhão ("PA-MA"), mas com baixo RPL. Embora pouco explorada, na bacia do ES foi descoberto o campo de Golfinho, com óleo leve em águas profundas. Após a descoberta de Golfinho, outras 23 perfurações haviam sido feitas, das quais 21 foram bem-sucedidas. Em 2008, a bacia do ES era a segunda maior região produtora do país ${ }^{18}$.

Entretanto, segundo a SPE-PRMS (Society of Petroleum Engineers, Petroleum Resources Management Systems), "Recursos Prospectivos" é a categoria de potencial geológico cuja viabilidade econômico financeira possui o mais elevado grau de incerteza na exploração em O\&G. São recursos ainda não descobertos formalmente, estimados sem nenhuma perfuração no local. Sua possível existência é deduzida a partir da proximidade dos blocos com outros em estágios mais avançados de exploração ou produção. Estimar Recursos Prospectivos é, "no melhor dos casos, uma tarefa subjetiva"19.

\footnotetext{
18 LEITE, CANHEU \& CUSTODIO, 2008a, p. 34.

${ }^{19}$ KOVARSKY \& MENDES, 2011o, p. 2.
} 
Figura 1 - Classificação de Recursos de O\&G da SPE-PRMS

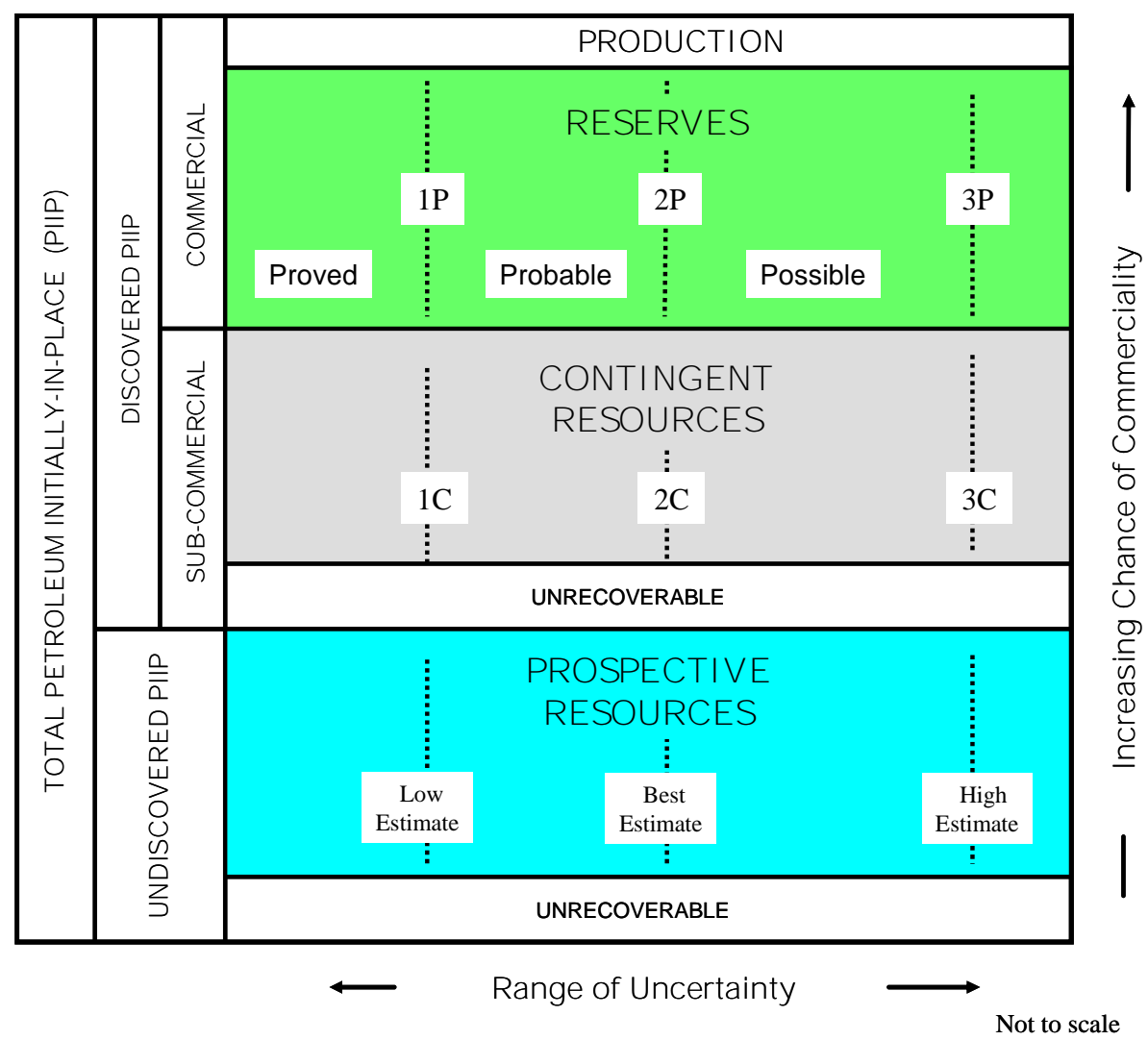

Fonte: SPE-PRMS, 2008, p. 2

A percepção da qualidade e viabilidade do portfólio da OGX foi reforçada pelo segundo pilar da Tese de Investimentos: a experiência da sua equipe técnica ("Executivos"), exfuncionários da Petrobras ("PETR"). Liderados por Paulo Mendonça, ex-Gerente de Exploração da PETR, que viria a ser conhecido como "Dr. Oil", a equipe seria capaz de avaliar o potencial não só do portfólio, mas também de outros prospectos no Brasil e no exterior que, no futuro, poderiam ser adquiridos ${ }^{20}$.

Embora o Prospecto não o definiu explicitamente como um "pilar" da Tese de Investimentos, o Conselho de Administração da OGX (“COAD”) era composto por executivos de renome com passagens pelo governo federal, grandes empresas privadas e estatais (incluindo a PETR) e bancos de investimentos ${ }^{21}$.

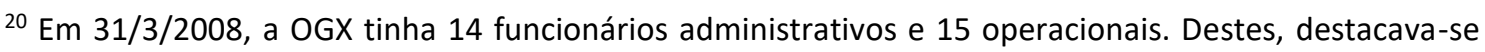
além de Paulo Mendonça (Diretor de E\&P), Edmundo Marques (que chefiara na PETR as pesquisas no pré-sal de Santos), Marcelo Torres (Diretor Administrativo Financeiro) e o CEO, Rodolfo Landim (expresidente da BR Distribuidora). Posteriormente, a OGX teria cerca de 50 ex-funcionários da PETR, ganhando de $\mathrm{R} \$ 40$ mil a $R \$ 150$ mil por mês, sendo que o presidente da PETR na época ganhava R\$ 50 mil mês [GASPAR, 2014, p. 120].

${ }^{21}$ Dentre eles destacavam-se: Eliezer Batista (ex-Ministro de Minas e Energia, ex-Secretário de Assuntos Estratégicos no Brasil, ex-CEO da CVRD); Francisco Gros (primeiro superintendente-geral da CVM, expresidente da PETR, BNDES, BACEN, Morgan Stanley no Brasil); Pedro Malan (Ministro da Fazenda de 1995 a 2002, curador do International Accounting Standard Committee Foundation - IASC); Rodolfo 
O terceiro pilar era o próprio AC. Ao contrário dos Executivos, sua experiência relevante não era na geologia do $O \& G$, mas sim na sua rede de relacionamentos empresariais, políticos e no mercado de capitais, capacidade de empreender e criar valor para si e seus sócios. Experiência essa evidenciada por dois IPOs relevantes e recentes: MMX (com captação de US\$ 0,51 bilhão em junho de 2006) e MPX (US\$ 1,2 bilhão em dezembro de 2007). Adicionalmente, entre junho de 2006 e janeiro de 2008, o AC alienou partes da MMX em três ocasiões diferentes, sendo a maior delas (o Complexo Minas-Rio) para a Anglo American ("AA") por $\mathrm{R} \$$ 6,72 bilhões.

O AC também havia criado outras empresas do Grupo $X$ que poderiam gerar sinergias estratégicas com a OGX. Em tese, a complementariedade entre OGX e MPX era de particular importância, uma vez que $26 \%$ do RPL da OGX seria de GN. Como $100 \%$ da rede de gasodutos no Brasil pertenciam à PETR, que até então não havia permitido acesso livre a terceiros para monetizar seu RPL de GN, a OGX teria de construir seus próprios gasodutos que alimentariam UTEs da MPX.

No tema governança corporativa, a OGX declarava possuir "práticas diferenciadas" 22. 0 alinhamento de interesses entre o AC, COAD e Executivos (coletivamente denominados "Gestores") teria sido reforçado por dois milionários planos de opções de ações (Stock Option Plan ou "SOP"), um concedido pela OGX ("SOP OGX") e outro com ações do próprio AC ("SOP AC").

Na época do IPO, a Empresa estimou que os valores do SOP OGX, SOP AC e a remuneração anual dos Executivos e COAD somariam $\mathrm{R} \$ 1,74$ bilhão, que poderiam ser realizados, dependendo do valor da OGXP3, em 5 anos. Nesta simulação, 85,4\% da remuneração dos Executivos e 90,0\% do COAD seria composta pelo SOP AC. O SOP AC seria interpretado como uma indicação adicional do comprometimento do AC com o sucesso da OGX ${ }^{23}$.

A combinação entre Gestores capacitados e o potencial fluxo de caixa que seria gerado pelo portfólio de concessões sustentaria os outros dois pilares da Tese de Investimento: capacidade de crescer e capturar oportunidades no "vasto potencial" ainda não explorado do O\&G do Brasil, estimado na época entre 70 a 100 bboe; e a capacidade para executar o ambicioso plano de negócios da OGX.

O plano de negócios começaria com a campanha exploratória de Campos no 2S09, "que representa uma área de menor risco exploratório e com importantes volumes potenciais". Em sequência, a OGX pretendia "perfurar poços na promissora bacia de Santos" 24 .

Landim (ex-CEO da BR Distribuidora); Rodolpho Tourinho (ex-Senador (DEM-BA), ex-Ministro de Minas e Energia, ex-Presidente dos Conselhos de Administração da PETR, BR Distribuidora e Eletrobrás); e Rodolpho Riechert (que na época era o responsável pelo banco de investimentos do UBS Pactual).

22 Prospecto OGX, 2008, p. 211.

23 LEITE, CANHEU \& SOBREIRA, 2008, p. 5 e 16.

${ }^{24}$ Prospecto OGX, 2008, p. 155. 
Tabela 5 - Projeção da Produção de Óleo Apresentada no IPO (em milhões de barris por ano)

\begin{tabular}{|l|c|c|c|c|c|c|c|c|c|c|c||}
\hline Bacias & $\mathbf{2 0 1 1}$ & $\mathbf{2 0 1 2}$ & $\mathbf{2 0 1 3}$ & $\mathbf{2 0 1 4}$ & $\mathbf{2 0 1 5}$ & $\mathbf{2 0 1 6}$ & $\mathbf{2 0 1 7}$ & $\mathbf{2 0 1 8}$ & $\mathbf{2 0 1 9}$ & Total & \%Total \\
\hline Campos & $\mathbf{2}$ & 14 & 18 & 53 & 181 & 284 & 401 & 475 & 511 & 1.939 & $55,0 \%$ \\
\hline Santos & - & - & - & 27 & 36 & 131 & 125 & 173 & 180 & 672 & $19,1 \%$ \\
\hline ES & - & - & - & - & - & 54 & 72 & 110 & 146 & 382 & $10,8 \%$ \\
\hline PA-MA & - & - & - & - & 54 & $\mathbf{7 4}$ & 110 & 146 & 146 & 530 & $15,0 \%$ \\
\hline Subtotal Óleo & $\mathbf{2}$ & $\mathbf{1 4}$ & $\mathbf{1 8}$ & $\mathbf{8 0}$ & $\mathbf{2 7 1}$ & $\mathbf{5 4 3}$ & $\mathbf{7 0 8}$ & $\mathbf{9 0 4}$ & $\mathbf{9 8 3}$ & $\mathbf{3 . 5 2 3}$ & \\
\hline \%Total & $\mathbf{0 , 1 \%}$ & $\mathbf{0 , 4 \%}$ & $\mathbf{0 , 5} \%$ & $\mathbf{2 , 3 \%}$ & $\mathbf{7 , 7 \%}$ & $15,4 \%$ & $20,1 \%$ & $\mathbf{2 5 , 7 \%}$ & $\mathbf{2 7 , 9 \%}$ & $100,0 \%$ & \\
\hline Produção (kbpd) & $\mathbf{5}$ & $\mathbf{3 8}$ & $\mathbf{4 9}$ & $\mathbf{2 1 9}$ & $\mathbf{7 4 2}$ & $\mathbf{1 . 4 8 8}$ & $\mathbf{1 . 9 4 0}$ & $\mathbf{2 . 4 7 7}$ & $\mathbf{2 . 6 9 3}$ & & \\
\hline
\end{tabular}

Fonte: Prospecto, p. 19. (*) Produção média diária foi calculada com base em 365 dias de produção por ano.

Para se ter uma dimensão da agressividade do plano de negócios, a OGX estimava produzir 0,74 milhão de barris de óleo por dia ("mbpd") em 2015, menos de sete anos após o IPO. A PETR, com seu longo histórico, somente em 2007 atingiu o marco de 0,57 mbpd em suas plataformas marítimas. Ou seja, a OGX estimava produzir em sete anos mais do que a PETR levou 54 anos para fazer ${ }^{25}$. O plano de negócios também indicava 0 otimismo da Empresa em relação ao potencial de óleo em Santos e no PA-MA, que responderiam por 19,1\% e 15,0\%, respectivamente, da produção total até 2019 .

O sexto pilar da Tese de Investimentos era a capacidade de construir alianças estratégicas. Antes do IPO, a OGX já demonstrava sua capacidade de desenvolver "parcerias de alto valor agregado" tanto no front financeiro quanto no operacional. A participação na 9a Rodada foi viabilizada financeiramente por um private placement de US\$ 1,3 bilhão ( $R \$ 2,35$ bilhões) com investidores estrangeiros qualificados, com destaque para o Ontario Teachers' Pension Fund ("OTPP") ${ }^{26}$. Na 9a Rodada, dos 21 blocos arrematados, sete (dois em Campos [BM-C-37 e BM-C-38] e cinco no ES) foram adquiridos em sociedade com dois operadores internacionais com expertise em exploração de O\&G em águas profundas: a MAERSK e a franco-britânica Perenco Petróleo e Gás do Brasil Ltda. (“PERENCO”)

\footnotetext{
25 PETR foi fundada em 3 de outubro de 1953.

${ }^{26} \mathrm{Na}$ época do IPO, o OTPP possuía ativos líquidos de US\$ 100 bilhões, 271 mil beneficiários, professores da Província de Ontario, tanto na ativa quanto aposentados.
} 


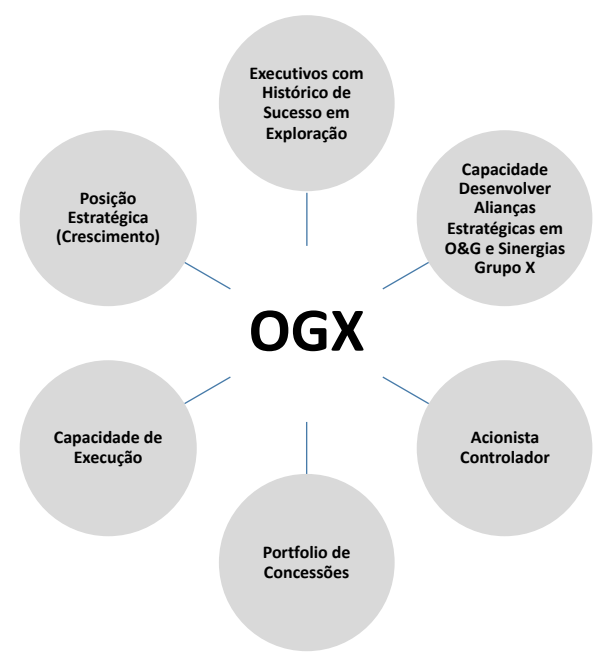

Ao viabilizar o IPO, investidores qualificados endossaram a Tese de Investimentos. No IPO, a capitalização de mercado da OGX na BOVESPA ("Valor de Mercado") equivalia a $\mathrm{R} \$ 28,48$ bilhões (US\$17,36 bilhões, 12/6/2008)27. Pouco mais de dois anos após o IPO, ainda em estágio pré-operacional, o Valor de Mercado mais que dobrou: $\mathrm{R} \$ 75,22$ bilhões (US\$ 69,82 bilhões, 15/10/2010).

Após o IPO e até 2013, a OGX implementou complexos e dispendiosos processos para reduzir a elevada incerteza inerente aos seus Recursos Prospectivos: testes sísmicos, perfurações de poços pioneiros e de avaliação, e, posteriormente, os Testes de Longa Duração ("TLDs"). Estes processos forneceriam indícios e evidências sobre o potencial de produção dos reservatórios que permitiriam, ou não, a redução da incerteza, ou no jargão de O\&G, o de-risking do portfólio: reclassificar Recursos Prospectivos para categorias de menor incerteza, como "Recursos Contingentes" e "Reservas". Ainda dentro de cada categoria, havia graus de incerteza distintos ${ }^{28}$. O de-risking é um processo longo, caro e muito incerto. Mas, uma vez completado com sucesso, inicia-se a fase de produção, que possui relativamente muito menos riscos, mas é muito mais cara.

Estudos empíricos internacionais indicam que o valor das ações de empresas de O\&G é sensível a revisões no volume de Reservas (por exemplo, SCHOLTENS \& WAGENAAR [2011]). Entretanto, estes estudos consideraram o volume de Reservas e não de Recursos Prospectivos. Nos Estados Unidos, a Security \& Exchange Commission ("SEC") sequer permite que as empresas de O\&G divulguem o volume de Recursos Prospectivos aos investidores devido ao seu alto grau de incerteza.

\footnotetext{
${ }^{27}$ Excluindo disponibilidades. O Valor de Mercado é uma extrapolação do preço de fechamento da ação da OGX na BOVESPA, em um determinado dia, aplicado ao total de ações do capital social da Empresa. ${ }^{28} \mathrm{O}$ Anexo A descreve as diversas categorias de Reservas.
} 
Como uma empresa de exploração de O\&G pré-operacional no Brasil, não havia precedentes para avaliar a OGX com parâmetros de mercado ${ }^{29}$. O elevado grau de incerteza do RPL e o complexo processo de de-risking do portfólio levaram investidores, financiadores e analistas de ações a depender, pelo menos em parte, das orientações ("guidance") dos Executivos para interpretar novas informações coletadas na intensa campanha exploratória.

Com o transcorrer do tempo, a Tese de Investimentos foi sendo ampliada e atualizada pelo guidance durante a implementação da campanha exploratória que começou em 2009. A ampliação e atualização da Tese de Investimento contou com vários elementos que incluíam: documentos oficiais da Empresa (atas das AGEs, Fatos Relevantes ["FRs"] e Comunicados ao Mercado ["CMs"] sobre o de-risking do portfólio, ramp-up da produção, Relatórios da D\&M, Demonstrações Financeiras Padronizadas ["DFPs"], Relatórios CVM 358, dentre outros); anúncios de intensões de venda de participações societárias em blocos (que no jargão de O\&G são denominados de farm-outs ${ }^{30}$ ); investimentos em opções de crescimento (por exemplo, as concessões na Colômbia, o farm-in na bacia da Parnaíba e a participação na 11a Rodada da ANP); sinergias com outras empresas do Grupo X (primeiro com a MPX, e posteriormente com a OSX e LLX); captações de financiamentos; e, posteriormente, o possível suporte financeiro do AC à Empresa. Estes elementos da Tese de Investimentos criaram uma agenda de catalisadores ("Agenda de Catalisadores") que seria monitorada por analistas de ações, investidores e financiadores.

Apesar da volatilidade do Valor de Mercado, a crença de investidores e financiadores na Tese de Investimentos, aparentemente, se sustentou por anos. Em junho de $2011 \mathrm{e}$ março de 2012, anos após o IPO, a Empresa captou um total de R\$ 6,75 bilhões (US\$ 4,50 bilhões) em dois financiamentos de longo prazo e sem garantias (Unsecured Notes).

Ou seja, no total, em menos de cinco anos (de novembro de 2007 a março de 2012), a OGX captou o equivalente a R\$15,63 bilhões (US\$ 9,01 bilhões) ${ }^{31}$ praticamente em fase pré-operacional. O histórico operacional da Empresa se circunscrevia unicamente à

${ }^{29}$ MCGANN \& KOYA [2008], por exemplo, citam três empresas "representativas" estrangeiras. Todas elas já em fase de exploração quando executaram seus IPOs e com volumes prospectivos estimados muito inferiores aos da OGX: Bowleven (IPO em dezembro/2004, captação de f 17,2 milhões), Synenco (IPO em novembro/2005, captação de C\$275,6 milhões) e Deer Creek (IPO em julho/2004, captação de C\$ 160,6 milhões).

${ }^{30}$ Farm-in/Farm-out: processo de aquisição ou venda parcial ou total dos direitos de concessão detidos por uma empresa. Em uma mesma negociação, a empresa que está adquirindo os direitos de concessão está em processo de farm-in e a empresa que está vendendo os direitos de concessão está em processo de farm-out [Glossário OGX].

No caso de um farm-in onde a empresa adquirente compra uma participação inferior a $100 \%$ do bloco, ou seja, ela se torna parte de um consórcio com outras empresas, há uma variedade de arranjos contratuais que definem as obrigações e direitos entre os sócios. Como explicam HOWARD \& HARP [2009], um acordo do tipo "working interest" pode prever que as partes compartilhem despesas, investimentos e lucros do E\&P. Neste tipo de acordo podem haver sócios não operadores e o operador. O sócio operador tem o controle das operações de E\&P e, como tal, tem o direito de cobrar taxas de overhead padronizadas (conhecidas como COPAS) dos sócios não operadores.

31 Inclui o private placement de novembro de 2007: R\$2,35 bilhões (US\$1,30 bilhão). 
experiência dos Executivos, à reputação de membros do COAD e ao empreendedorismo do AC, endossados pela D\&M e pelos auditores independentes da OGX.

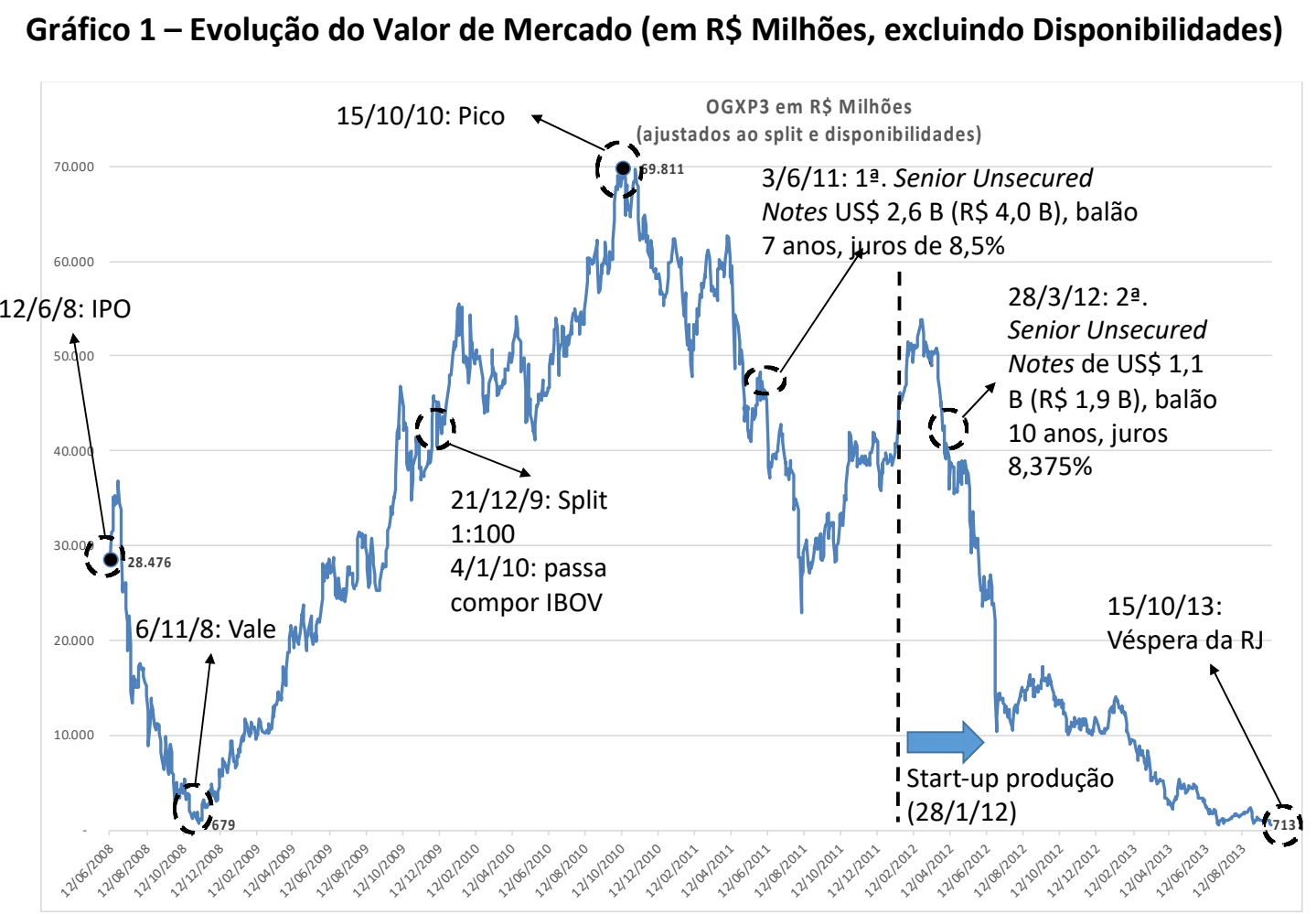

Em uma primeira leitura, a estratégia de financiamento da OGX, composta pelo IPO e pelas Unsecured Notes, parecia ser consistente com estágio pré-operacional de uma empresa de O\&G em fase exploratória: para viabilizar investimentos com elevadas incertezas, recomenda-se a captação de capital de risco e quase risco (quasi-equity). OGX tornou-se um caso emblemático e pouco comum de Project Finance.

Entretanto, se a OGX foi bem-sucedida quantitativamente e qualitativamente em sua estratégia de financiamentos, infelizmente o mesmo não ocorreu com a implementação de sua estratégia operacional. Em 1 de julho de 2013, após acumular resultados negativos com TBAZ e com limitada liquidez de caixa, o AC admitiu "fracasso na tentativa de salvar a OGX", após gastar R\$ 13,80 bilhões (US\$ 5,30 bilhões) na campanha exploratória "mais cara de uma empresa privada no Brasil"32. A notícia causou um efeito "dominó" que destruiu o que restava da capitalização de mercado de boa parte das empresas do Grupo X. Em 30 de outubro de 2013, a OGX, por "imperiosa necessidade", formalizou sua situação ao ajuizar pedido de Recuperação Judicial ("RJ") com R\$ 13,32 bilhões em dívidas.

32 Disponível em: https://www.valor.com.br/empresas/3181632/eike-admite-fracasso-na-tentativa-desalvar-ogx. 
Tabela 6 - Composição do Saldo Devedor da OGX e Subsidiárias em 07/01/2014

\begin{tabular}{||l|r|r||}
\hline Credores & R\$ Milhões & \% \\
\hline Bondholders & 8.946 & $67,2 \%$ \\
\hline Leasing OSX & 3.519 & $26,4 \%$ \\
\hline Fornecedores & 852 & $6,4 \%$ \\
\hline Total & $\mathbf{1 3 . 3 1 7}$ & $\mathbf{1 0 0 , 0 \%}$ \\
\hline
\end{tabular}

Fonte: LatinFinance Advisory \& Research, "Análise de Viabilidade Econômico-Financeira da Óleo e Gás S.A. em Recuperação Judicial”, 31/01/2014.

Na época, a RJ da OGX foi considerada o maior default da história corporativa da América Latina pela Moody's $\mathrm{s}^{33}$. A perda dos bondholders chegou a 89,6\% para o Note 2018 e 75,6\% para o Note 2022, segundo a Bloomberg. Dentre os financiadores credores havia o Deutsche Bank, Bradesco, PIMCO e BlackRock.

Além da OSX, os fornecedores credores da OGX incluíam as principais empresas de serviços de petróleo (Oil Service Companies, ou "OSC") como a Halliburton, GE Oil \& Gas, Baker Hugues Oil Field, Diamond Offshore e Schlumberger. Os sócios da OGX em blocos em águas profundas, a MAERSK e a PERENCO, também integravam a lista de credores.

As perdas também afetaram outras empresas do Grupo X. Estima-se que o Grupo X, exceto a OGX, tenha acumulado US\$ 4,5 bilhões em financiamentos indiretos (repasses) do BNDES $^{34}$.

No plano de negócios publicado no IPO, a OGX estimava produzir 18,00 milhões de barris de óleo no ano de 2013. Em seis anos de operação, de fevereiro de 2012 até março de 2018, quando a Empresa encerrou a RJ, a OGX produziu um total de 20,25 milhões de barris de óleo. Ou seja, em 6 anos de operação, a Empresa conseguiu alcançar a meta para 2013. No total, o volume total produzido equivale a $0,24 \%$ do óleo que outrora se estimou que a OGX possuiria. Atualmente, o Valor de Mercado é de $\mathrm{R} \$ 0,10$ bilhão (US\$ 0,03 bilhão, 01/08/2018), ou seja, 0,34\% daquele do IPO.

Esta breve descrição da evolução histórica da OGX suscita três questões de pesquisa. 0 que, em um primeiro momento, pode ter gerado tanto Valor de Mercado? O que, posteriormente, pode ter destruído tanto Valor de Mercado? O que podemos aprender com o estudo do caso OGX que possa contribuir para o Project Finance de greenfields no Brasil? O presente estudo se propõe a investigar indícios de possíveis respostas para estas três questões de pesquisa ("Questões de Pesquisa"). Analisar sistemas complexos é um enorme desafio, muitas vezes não factível, e o Grupo X não é exceção.

33 Disponível em: http://beforeitsnews.com/gold-and-precious-metals/2013/10/batista-fails-to-saveogx-repudiates-debt-2545352.html

${ }^{34}$ Bankruptcy Nears for Batista. Glazer, E., Magalhães, L., Lyons, J., Winterstein, P.. Wall Street Journal Eastern Edition, 2013, Vol. 262 (100), p. B1. 


\subsection{Cronologia de Principais Eventos e da Agenda de Catalisadores}

Ao longo da evolução da OGX, os Analistas, em seus Relatórios de Análise, identificaram eventos catalisadores (triggers), ou marcos (milestones), que constituíram a Agenda de Catalisadores, que endossaram, ou refutaram, os Seis Pilares da Tese de Investimento da OGX e, consequentemente, seu Valor de Mercado. Agenda de Catalisadores era monitorada e dependendo de sua materialização poderia, ou não, motivar a valorização da OGXP3. Demorou meses, por vezes anos, até que um componente da Agenda de Catalisadores fosse confirmado como verdadeiro ou não. Ao longo do tempo, alguns destes catalisadores poderiam perder relevância devido ao surgimento de outros catalisadores com importância considerada superior. A cronologia descrita nesta seção resume a construção e evolução da Agenda de Catalisadores até o seu colapso em outubro de 2013.

Os catalisadores eram de dois tipos: fundamentalistas (que afetam as premissas de projeção do fluxo de caixa e custo de capital da Empresa) e de mercado (taxa de câmbio, preço do Brent, o valor transacionado da OGXP3 e sua comparação com empresas "similares" no Brasil e exterior). A tabela 7 ilustra alguns exemplos de catalisadores fundamentalistas que surgiram na evolução da OGX que podem ser classificados de "operacionais" e "financeiros". 
Tabela 7 - Agenda de Catalisadores Fundamentalistas Monitorados pelos Analistas da OGX

\begin{tabular}{|c|c|c|}
\hline $\begin{array}{l}\text { Pilares da Tese } \\
\text { de Investimentos }\end{array}$ & Catalisadores Operacionais & Catalisadores Financeiros \\
\hline $\begin{array}{l}\text { Qualidade do } \\
\text { Portfólio }\end{array}$ & $\begin{array}{l}\text { Perfuração de poços } \\
\text { Descobertas de hidrocarbonetos } \\
\text { Relatórios de avaliação D\&M (de- } \\
\text { risking) } \\
\text { Devolução de blocos concedidos à } \\
\text { ANP ou Declaração de } \\
\text { Comercialidade de blocos } \\
\text { Valores pagos em farm-ins (ex. BM- } \\
\text { S-29), farm-out no portfólio } \\
\text { Desempenho de poços próximos (da } \\
\text { OGX ou terceiros) para read-across }\end{array}$ & $\begin{array}{l}\text { Farm-out de campos de terceiros, } \\
\text { próximos ao da OGX (múltiplos de } \\
\text { EV/boe) } \\
\text { Posição de caixa para sustentar o } \\
\text { E\&P }\end{array}$ \\
\hline $\begin{array}{l}\text { Crescimento } \\
\text { do Portfólio }\end{array}$ & $\begin{array}{l}\text { Novas rodadas da ANP e licitações } \\
\text { internacionais } \\
\text { Farm-in, farm-out } \\
\text { Alterações marco regulatório }\end{array}$ & $\begin{array}{l}\text { Posição de caixa para sustentar o } \\
\text { E\&P }\end{array}$ \\
\hline $\begin{array}{l}\text { Execução do } \\
\text { Plano de } \\
\text { Negócios }\end{array}$ & $\begin{array}{l}\text { Obtenção de licenças ambientais }{ }^{35} \\
\text { Disponibilidade de equipamentos } \\
\text { Volume de produção O\&G } \\
\text { CCVO\&G (preços e volumes) } \\
\text { Indicadores de custos de extração } \\
\text { (lifting), investimentos necessários } \\
\text { Declaração de Comercialidade }\end{array}$ & $\begin{array}{l}\text { Captação de financiamentos } \\
\text { Geração de fluxo de caixa } \\
\text { Posição de caixa } \\
\text { Dívida líquida e covenants } \\
\text { Baixas de ativos e impairment }\end{array}$ \\
\hline $\begin{array}{l}\text { Alianças } \\
\text { Estratégicas }\end{array}$ & $\begin{array}{l}\text { Farm-in, farm-out com IOCs } \\
\text { Sinergias com Grupo X }\end{array}$ & $\begin{array}{l}\text { Farm-in, farm-out de concorrentes } \\
\text { da OGX que poderiam indicar o } \\
\text { interesse de IOCs pela OGX }\end{array}$ \\
\hline $\begin{array}{l}\text { Governança } \\
\text { Corporativa }\end{array}$ & $\begin{array}{l}\text { Alterações nos quadros de } \\
\text { Executivos (contratações, } \\
\text { demissões, realocações) e COAD }\end{array}$ & $\begin{array}{l}\text { Exercícios de opções por parte dos } \\
\text { Gestores (CVM 358) }\end{array}$ \\
\hline$A C$ & $\begin{array}{l}\text { Avanços ou revezes em Partes } \\
\text { Relacionadas que poderiam afetar a } \\
\text { viabilidade de sinergias operacionais } \\
\text { e financeiras com a OGX } \\
\text { Declarações sobre a Tese de } \\
\text { Investimentos }\end{array}$ & $\begin{array}{l}\text { Aportes de capital e/ou promessas } \\
\text { de aportes (Put) } \\
\text { Compra e venda de ações }\end{array}$ \\
\hline
\end{tabular}

A evolução dos catalisadores fundamentalistas foi monitorada por analistas, investidores e financiadores através de várias fontes de informações direta ou

${ }^{35}$ A Resolução 23 do CONAMA (7/12/1994) definiu o procedimento de licenciamento ambiental para a E\&P de O\&G, que possui cinco estágios que requerem licenças específicas: (i) licença de operação de atividades sísmicas; (ii) licença prévia de perfuração; (iii) licença prévia de pesquisa de produção; (iv) licença de instalação; e (v) licença de operação. As licenças (i) a (iii) devem ser obtidas previamente à fase de pesquisa da atividade. A licença de instalação autoriza a construção das instalações de produção e escoamento. A licença de operação autoriza o início e a manutenção das atividades operacionais e devem ser renovadas periodicamente. Adiante, veremos que no caso da OGX, a obtenção de licenças na bacia do PA-MA foi tão difícil que levou a Empresa a devolver os blocos concedidos à ANP. 
indiretamente relacionadas à OGX. Dentre as informações indiretas, que afetavam diretamente a avaliação por múltiplos, destacavam-se as transações de M\&A (farm-in e farm-out) com empresas concorrentes e descobertas de O\&G próximas aos blocos da Empresa.

Dentre as informações diretamente relacionadas à Empresa destacavam-se seus DFPs, relatórios da $D \& M$, reguladores (ex. Declaração de Comercialidade ${ }^{36}$ e devolução de blocos), FRs, CMs, teleconferências, reuniões presenciais e entrevistas dos Executivos e AC.

No caso da OGX, dada as significativas assimetrias de informações advindas da complexidade dos ativos e do processo de E\&P, o guidance dos Executivos era crucial para elucidar o significado dos novos dados geológicos. Auditores independentes e consultores externos também foram cruciais para confirmar ou fragilizar a credibilidade do guidance.

Na sucinta cronologia descrita a seguir foram incluídos também informações sobre a evolução da OGXP3, alguns indicadores financeiros da Empresa (disponibilidades e endividamento) e preço do Brent em momentos de destaque. O objetivo da cronologia é ser descritivo e não analítico. Como fornecedor de equipamentos críticos para OGX, foram incluídos também alguns indicadores financeiros da OSX (disponibilidades e endividamento) e da evolução da OSXB3. A análise dos fatos pertinentes à OGX e OSX é elaborada nos capítulos 3, 4 e 5.

Somente entre 2008 e 2011, a Empresa divulgou 77 FRs, todos eles positivos. Os FRs incluíam descobertas de hidrocarbonetos, novas estimativas de volumes recuperáveis e da qualidade do óleo, aquisições de novos prospectos no Brasil e exterior, contratação de equipamentos para viabilizar a E\&P, revisões (para cima) de estimativas sobre o ramp-up da produção.

Tabela 8 - Número de Fatos Relevantes Publicados pela OGX

\begin{tabular}{|c|c|c|c|c|c|c|c|c||}
\hline \multirow{3}{*}{ Ano } & \multicolumn{4}{|c|}{ Fatos Relevantes } & \multicolumn{2}{c|}{ Positivos } & \multicolumn{2}{c|}{ Negativos } \\
\cline { 2 - 9 } & \multicolumn{4}{|c|}{ Total } & \multicolumn{2}{c||}{} \\
\cline { 2 - 9 } & Qtd & $\%$ & Acum. & $\%$ & Qtd & \% Ano & Qtd & $\%$ Total \\
\hline $\mathbf{2 0 0 8}$ & 6 & $5,5 \%$ & 6 & $5,5 \%$ & 6 & $100 \%$ & 0 & $0 \%$ \\
\hline $\mathbf{2 0 0 9}$ & 16 & $14,5 \%$ & 22 & $20,0 \%$ & 16 & $100 \%$ & 0 & $0 \%$ \\
\hline $\mathbf{2 0 1 0}$ & 37 & $33,6 \%$ & 59 & $53,6 \%$ & 37 & $100 \%$ & 0 & $0 \%$ \\
\hline $\mathbf{2 0 1 1}$ & 18 & $16,4 \%$ & 77 & $70,0 \%$ & 18 & $100 \%$ & 0 & $0 \%$ \\
\hline $\mathbf{2 0 1 2}$ & 16 & $14,5 \%$ & 93 & $84,5 \%$ & 13 & $81 \%$ & 3 & $19 \%$ \\
\hline $\mathbf{2 0 1 3}$ & 17 & $15,5 \%$ & 110 & $100,0 \%$ & 6 & $35 \%$ & 11 & $65 \%$ \\
\hline
\end{tabular}

Fonte:

http://ri.ogpar.com.br/conteudo_pt.asp?tipo=50328\&id=0\&idioma $=0 \&$ conta $=28 \&$ submenu=0\&img=0\& ano=2012. A classificação de "positivos" e "negativos" é do autor.

\footnotetext{
${ }^{36}$ Na Declaração de Comercialidade, a empresa torna público o desenvolvimento do campo com suas principais premissas, incluindo o volume recuperável.
} 
Com o passar do tempo, o número de FRs foi diminuindo. Em 2012, quando a Empresa começou o TLD de seu primeiro de três poços em TBAZ, os investidores e financiadores aguardavam ansiosos por atualizações sobre as taxas de extração de óleo (medidos em mil barris por dia, ou "kbpd"). À medida que estes fluxos foram se tornando instáveis, as atualizações divulgadas pelos Executivos foram ficando menos frequentes até 0 ponto que a ANP passou a ser a principal fonte.

Além dos anúncios de descobertas e revisões do RPL, ao longo de 2009 a 2013, a Agenda de Catalisadores cresceu em número de diversidade geográfica através da aquisição de 29 outros blocos marítimos e terrestres no Brasil e na Colômbia.

Tabela 9 - Histórico de Aquisições de Blocos Exploratórios da OGX

\begin{tabular}{|c|c|c|c|}
\hline $\begin{array}{c}\text { Data } \\
\text { Aquisição }\end{array}$ & $\begin{array}{l}\text { Número } \\
\text { Blocos }\end{array}$ & Bacias & Comentários \\
\hline $27 / 11 / 07$ & 21 & Campos, Santos, ES, PA-MA & 9ạ Rodada ANP \\
\hline $1 T 2008$ & 1 & Santos (BM-S-29) & Farm-in 50\% Maersk \\
\hline $8 / 05 / 09$ & & Santos (BM-S-29) & Farm-in de $15 \%$ adicionais \\
\hline $9 / 11 / 10$ & & Santos (BM-S-29) & Comprou os restantes 35\% da Maersk \\
\hline 24/09/09 & 7 & $\begin{array}{c}\text { Parnaíba (blocos terrestres com } \\
\text { potencial para GN) }\end{array}$ & $\begin{array}{l}\text { 33,33\% OGX, 33,33\% MPX, 33,33\% } \\
\text { Petra Energia } \\
\end{array}$ \\
\hline $22 / 06 / 10$ & 5 & Cesar Rancheira (Colômbia) & \\
\hline $20 / 03 / 12$ & 2 & Campos (BM-C-37, BM-C-38) & $\begin{array}{c}\text { Aumentou de } 50 \% \text { para } 70 \% \text { sua } \\
\text { participação (30\% Maersk) }\end{array}$ \\
\hline $26 / 11 / 12$ & 2 & $\begin{array}{l}\text { Santos (bloco BS-4, com dois } \\
\text { campos: Atlanta e Oliveira) }\end{array}$ & $\begin{array}{c}\text { Comprou 40\% da PETR (30\% QGEP, } \\
\text { 30\% Barra Energia) }\end{array}$ \\
\hline $\begin{array}{c}14 \mathrm{e} \\
15 / 05 / 13\end{array}$ & 13 & $\begin{array}{l}\text { Paranaíba, Barreirinhas, CE, } \\
\text { Potiguar e Foz do Amazonas }\end{array}$ & $\begin{array}{c}\text { 11a Rodada ANP por } 13 \text { blocos, por R\$ } \\
376 \text { milhões (US\$ } 188 \text { milhões) em BA } \\
\text { e R\$ } 698 \text { milhões (US\$ } 349 \text { milhões) } \\
\text { em PEM. }\end{array}$ \\
\hline Total & 51 & & \\
\hline
\end{tabular}

Cada nova descoberta de hidrocarbonetos, cada farm-in e farm-out se tornavam projetos cuja implantação deveria ser atualizada pelos Executivos e monitorada por gatekeepers internos e externos, como foi o caso dos emblemáticos prospectos BM-S29 e Vesúvio. Cabe destacar que mesmo com a mudança do CEO e do Diretor de Exploração da OGX em 28 de junho de 2012, a Agenda de Catalisadores e os significativos investimentos continuaram a crescer e se diversificar geograficamente. 


\section{Cronologia Sucinta da Agenda de Catalisadores e Eventos Importantes}

\subsubsection{8: IPO seguido de Crash}

Alguns Indicadores Financeiros e da OGXP3 (12/06/08 a 31/12/08)

\begin{tabular}{|l|c|c|}
\hline OGXP3 & Unidade & Valor \\
\hline Valor Início Período & $\mathrm{R} \$$ ação & 11,31 \\
\hline Valor Máximo no Período & $\mathrm{R} \$ /$ ação & 13,64 \\
\hline Valor Mínimo no Período & $\mathrm{R} \$$ ação & 2,54 \\
\hline Valor Final do Período & $\mathrm{R} \$$ ação & 5,26 \\
\hline Variação no ano & $\%$ & $-53,3 \%$ \\
\hline OGX & & \\
\hline Disponibilidades Início Período $\left(^{*}\right)$ & $\mathrm{R} \$$ milhões & $7.238,7$ \\
\hline Disponibilidades Final Período $\left(^{*}\right)$ & $\mathrm{R} \$$ milhões & $7.601,2$ \\
\hline Variação Disponibilidades & $\mathrm{R} \$$ milhões & $+362,5$ \\
\hline Dívida Bruta Início Período (**) & $\mathrm{R} \$$ milhões & - \\
\hline Dívida Bruta Fim Período $\left(^{* *}\right)$ & $\mathrm{R} \$$ milhões & - \\
\hline
\end{tabular}

(*) Fonte: DFP OGX; $(* *)$ Fonte: Capital IQ.

\section{Eventos 2008}

25/06. Após uma expressiva alta de $20,6 \%$ em duas semanas (de $\mathrm{R} \$ 11,31$ no IPO para $\mathrm{R} \$ 13,64)$, a OGXP3 inicia uma longa e significativa desvalorização.

08/07. OGX contrata sua primeira unidade flutuante da Queiroz Galvão.

15/07. Implosão da "bolha do óleo do verão de 2008". Em um mês (entre 14/07 e 14/08), o Brent caiu 21,5\% (de US\$142,43 para US\$111,82 por barril).

28/07. Analistas iniciam a cobertura da Empresa, quando a OGXP3 valia $\mathrm{R} \$ 6,95$, uma desvalorização de 38,5\% em relação ao IPO (R\$ 11,31).

15/09. Quebra da Lehman Brothers. OGXP3 se desvaloriza 14,7\% em um único pregão (de $\mathrm{R} \$ 5,39$ para $\mathrm{R} \$ 4,60$ ).

06/11. Em cerca de cinco meses, a OGXP3 valia $R \$ 2,54$, equivalente a $22,5 \%$ de seu valor no IPO. No dia seguinte, a OGXP3 começaria um longo período de valorização até chegar ao seu pico histórico de valor em 15/10/2010 (R\$ 23,27). 


\subsubsection{9: Início da Campanha Exploratória e as Primeiras Descobertas}

\section{Alguns Indicadores Financeiros e da OGXP3 (02/01/09 a 30/12/09)}

\begin{tabular}{|c|c|c|}
\hline OGXP3 & Unidade & Valor \\
\hline Valor Início Período & $\mathrm{R} \$$ /ação & 5,10 \\
\hline Valor Máximo no Período & $\mathrm{R} \$$ /ação & 17,10 \\
\hline Valor Mínimo no Período & $\mathrm{R} \$$ /ação & 4,37 \\
\hline Valor Final do Período & $\mathrm{R} \$$ /ação & 17,10 \\
\hline Variação no ano & $\%$ & $+235,3 \%$ \\
\hline \multicolumn{3}{|l|}{ OGX } \\
\hline Disponibilidades Início Período $\left({ }^{*}\right)$ & $\mathrm{R} \$$ milhões & $7.601,2$ \\
\hline Disponibilidades Final Período $\left({ }^{*}\right)$ & $\mathrm{R} \$$ milhões & $7.337,9$ \\
\hline Variação Disponibilidades & $\mathrm{R} \$$ milhões & $+263,3$ \\
\hline Dívida Bruta Início Período (**) & $\mathrm{R} \$$ milhões & - \\
\hline Dívida Bruta Fim Período (**) & R\$ milhões & - \\
\hline
\end{tabular}

$\left(^{*}\right)$ Fonte: DFP OGX; $\left({ }^{* *}\right)$ Fonte: Capital IQ.

\section{Eventos 2009}

26/03. Testes sísmicos indicavam 1,0 bboe nos blocos da bacia do ES e não 0,27 bboe como fora estimado pelo 10 D\&M.

04/05. OGXP3 passa a compor o IBrX-50 e o IBrX-100.

Maio. Repsol descobre hidrocarbonetos nas águas rasas de Santos (Panoramix), próximo ao BM-S-29. Confiante em seu potencial, a OGX aumentou sua participação societária de $50 \%$ para $65 \%$ no BM-S-29.

14/05. Empresa acelera a campanha de exploração com a contratação de 7 sondas, uma a mais do que o planejado.

Agosto. Início da campanha exploratória em Campos e Santos. Começam as perfurações no BM-S-29 (17/8).

24/09. OGX adquire $70 \%$ da Petra Energia, proprietária de 7 blocos terrestres na bacia do Parnaíba (interior do Maranhão) com grande potencial de GN. Constituição da OGX Maranhão $(66,7 \%$ OGX e 33,3\% MPX) com o objetivo de viabilizar a UTE Parnaíba (1,0 $\mathrm{GW})$, abastecida com $\mathrm{GN}$ próprio.

2/10. Em menos de 2 meses após o início das perfurações, a OGX anunciou a descoberta de hidrocarbonetos no BM-S-29.

7 a 14/10. Descoberta de hidrocarbonetos em Vesúvio, cujo reservatório poderia conter de 0,5 a 1,5 bboe. Vesúvio poderia haver $39 \%$ do óleo estimado no IPO para Campos. Começaram as perfurações nos prospectos de Pipeline e Waimea. 
09/11. Publicação do segundo Relatório de Avaliação (“2요 $\& M$ ”), que elevou as estimativas do portfólio em 38\%: de 4,8 bboe do 10 D\&M para 6,7 bboe. Destes recursos, $95 \%$ se localizariam em blocos de águas rasas com duas implicações positivas: custos menores de E\&P, além de maior disponibilidade de equipamentos.

12 e 16/11. Descoberta de hidrocarbonetos em Pipeline que poderia conter entre 0,4 e 0,5 bboe recuperável.

07 a 10/12. Parte dos Executivos (Diretor de Exploração e o Diretor de Relações com Investidores) vendeu R\$31,33 milhões em ações da OGX. Dados da CVM 358 revelaram a movimentação ao público, mas não identificavam seus autores, que só vieram a ser conhecidos anos depois através de processos judiciais.

18 a 22/12. Descoberta em Waimea, a apenas 5 quilômetros de Pipeline. Em 22/12, anunciou que as perfurações estavam finalizadas em Pipeline e revisou as estimativas iniciais para 1,0 a 2,0 bboe recuperável.

21/12. Empresa desdobra suas ações (split) na proporção de 1 para 100, aumentando a liquidez da OGXP3.

22/12. Fim das perfurações em Pipeline com estimativas confirmadas para 1,0 a 2,0 bboe. Vesúvio e Pipeline somados poderiam conter 1,5 a 3,5 bboe. Especulava-se que a OGX poderia acelerar o desenvolvimento destas descobertas através de acordos de farm-out. De fato, IOCs pareciam estar ávidas por farm-outs no Brasil.

28/12. Descoberta de hidrocarbonetos em Waimea que poderia conter de 0,5 a 0,9 bboe, contra 0,15 bboe previstos no 20 D\&M. Devido sua proximidade, Waimea e Pipeline poderiam estar conectados geologicamente, o que geraria sinergias na produção. Juntas, Waimea e Pipeline poderiam ter entre 1,5 e 2,9 bboe, o que aumentaria o RPL para 7,0 a 8,0 bboe.

30/12. Ao todo, ao longo de 2009, a Empresa perfurou 6 poços (4 em Campos e 2 em Santos) com $100 \%$ de taxa de sucesso. 


\subsubsection{0: Ampliação da Agenda de Catalisadores, Farm-Out e Sinergias com OSX}

Alguns Indicadores Financeiros e da OGXP3 e OSXB3 (04/01/10 a 30/12/10)

\begin{tabular}{|c|c|c|}
\hline OGXP3 & Unidade & Valor \\
\hline Valor Início Período & $\mathrm{R} \$$ /ação & 17,67 \\
\hline Valor Máximo no Período & $\mathrm{R} \$$ /ação & 23,27 \\
\hline Valor Mínimo no Período & R\$̦/ação & 14,72 \\
\hline Valor Final do Período & $\mathrm{R} \$$ /ação & 20,00 \\
\hline Variação no ano & $\%$ & $+13,2 \%$ \\
\hline \multicolumn{3}{|l|}{ OGX } \\
\hline Disponibilidades Início Período $\left({ }^{*}\right)$ & $\mathrm{R} \$$ milhões & $7.337,9$ \\
\hline Disponibilidades Final Período $\left({ }^{*}\right)$ & $\mathrm{R} \$$ milhões & $4.788,2$ \\
\hline Variação Disponibilidades & $\mathrm{R} \$$ milhões & $-1.549,7$ \\
\hline Dívida Bruta Início Período $\left({ }^{* *}\right)$ & $\mathrm{R} \$$ milhões & - \\
\hline Dívida Bruta Fim Período ${ }^{* *}$ ) & $\mathrm{R} \$$ milhões & - \\
\hline \multicolumn{3}{|l|}{ OSXB3 } \\
\hline Valor Início Período & $\mathrm{R} \$$ /ação & $3.200(19 / 3)$ \\
\hline Valor Máximo no Período & $\mathrm{R} \$$ /ação & 3.200 \\
\hline Valor Mínimo no Período & $\mathrm{R} \$$ /ação & 1.671 \\
\hline Valor Final do Período & $\mathrm{R} \$$ /ação & 1.932 \\
\hline Variação no ano & $\%$ & $-39,6 \%$ \\
\hline \multicolumn{3}{|l|}{ OSX $(* *)$} \\
\hline Disponibilidades Início Período & $\mathrm{R} \$$ milhões & $2.350,4$ \\
\hline Disponibilidades Final Período & $\mathrm{R} \$$ milhões & $2.237,6$ \\
\hline Variação Disponibilidades & R\$ milhões & $-112,8$ \\
\hline Dívida Bruta Início Período & $\mathrm{R} \$$ milhões & $728,1(0,0 \% \mathrm{LP})$ \\
\hline Dívida Bruta Fim Período & $\mathrm{R} \$$ milhões & 799,2 (61,9\% LP) \\
\hline
\end{tabular}

(*) Fonte: DFP OGX; $\left({ }^{* *}\right)$ Fonte: Capital IQ.

\section{Eventos 2010}

11/01. Descoberta de hidrocarbonetos em Kilawea próximo a Vesúvio. A OGX poderia rever seu plano de E\&P: as descobertas de Vesúvio ou Pipeline seriam certificadas como Reservas em 1S2010 com o first oil em 2S2011.

22/01. Em menos de um mês do início da perfuração (26/12/09), outra descoberta de hidrocarbonetos: Krakatoa.

27/01. Empresa aumentou metas de produção e antecipou o first oil para o início de 2011 (20 kboed contra 5 kboed previstos anteriormente) em Waimea. O ramp-up aumentou 83\%, de 398 para 730 kboepd em 2015. A OGX divulgou intenção de adquirir equipamentos da recém-criada OSX, em parceria com a Hyundai.

01/02. Em menos de um mês após sua descoberta (11/01), a OGX estimou que o reservatório de Kilawea poderia conter entre 0,1 e 0,2 bboe. 
2/03. OGX anunciou que completou a perfuração do BM-S-29, sem estimativa de volume.

5 e 12/03. Descoberta de hidrocarbonetos em Etna indicava uma possível conexão geológica com Waimea e Pipeline, formando um triângulo, com possíveis sinergias na produção e no compartilhamento de infraestrutura.

24/03. Descoberta de hidrocarbonetos em Fuji com características semelhantes ao triangulo Etna-Waimea-Pipeline.

12/04. Descoberta de hidrocarbonetos em poço horizontal reforçou a expectativa que o volume estimado para Vesúvio poderia estar mais próximo de 1,5 bboe.

14 e 15/04. Em entrevista à XPTV, o AC afirmou a descoberta de uma nova província petrolífera, em águas rasas, ao Sul de Campos, com o equivalente a US\$ 1,0 trilhão em "reservas". A produção começaria em 1T2011. Anunciou também que negociava a venda de $20 \%$ das ações da OGX para fazer uma "megamonetização".

13/05. OGX confirmou que Pipeline-Etna correspondiam a um mesmo reservatório que poderia conter de 1,4 a 2,6 bboe, e que Waimea-Fuji correspondiam a outro reservatório com 0,6 a 1,1 bboe.

23/06. OGX adquiriu 5 blocos terrestres na Colômbia $\left(12.580 \mathrm{~km}^{2}\right)$, por US\$ 125 milhões (R\$ 223,9 milhões), a serem explorados entre 2011 e 2013.

28/06 e 15/07. Descoberta de hidrocarbonetos em Pero. Os resultados foram tão positivos que a Empresa tornou a exploração na área uma prioridade.

16/07. Anúncio do primeiro poço seco em uma campanha com $100 \%$ de taxa de sucesso até então: o Niterói.

12/08. Em teleconferência, os Executivos reiteraram os planos de iniciar a produção em 1S2011. O AC informou que aguardava propostas para o farm-out para 18/10.

16/08 a 24/11. Empresa identificou grande potencial petrolífero de Parnaíba: 20 novos prospectos com 15 trilhões de pés cúbicos ("Tcf”) de GN.

22/09. Em conferência em Nova lorque, Executivos e o $A C$ foram questionados sobre 0 farm-out e a capacidade da OSX em servir a OGX.

27/09. Descoberta de óleo leve em Inga, ao Nordeste de Campos, dentro da área objeto do farm-out.

30/09. Descoberta de óleo leve em Aracaju, nas águas rasas de Santos.

1/10. Sinopec comprou 40\% dos negócios da Repsol na América Latina por US\$ 7,1 bilhões. 
4/11. Esperada para outubro, os Executivos, agora, estimavam que o farm-out seria concluído no 1T2011.

11/11 a 21/12. Após um $3 T 2010$ com 8 descobertas, não havia notícias sobre estimativas para Waimea, cujo início de produção (20 kbpd) foi adiado do 1T para o 2T2011.

12/11. OGX comprou o restante da participação da MAERSK (35\%) no BM-S-29, um dos primeiros blocos perfurados na campanha da OGX.

8/12. Descoberta de hidrocarbonetos em Waikiki reforçou o potencial do Nordeste de Campos (com estimativas anteriores de 2,6 a 5,5 bboe), que poderia ser tão prolífero quanto o Sudeste. Até aquele momento, a OGX havia perfurado 18 poços em Campos, "todos com identificação de hidrocarbonetos, confirmando a taxa de sucesso de $100 \%$ nesta bacia".

22/12. Congresso aprovou a Lei de Partilha da Produção, o que poderia vir a ser positivo para a OGX pois a ANP retomaria os leilões. 


\subsubsection{1: Atrasos e Financiamentos}

Alguns Indicadores Financeiros e da OGXP3 e OSXB3 (03/01/11 a 29/12/11)

\begin{tabular}{|c|c|c|}
\hline OGXP3 & Unidade & Valor \\
\hline Valor Início Período & R\$̧/ação & 20,03 \\
\hline Valor Máximo no Período & $\mathrm{R} \$$ /ação & 20,75 \\
\hline Valor Mínimo no Período & $\mathrm{R} \$$ /ação & 9,20 \\
\hline Valor Final do Período & $\mathrm{R} \$ / a c ̧ a ̃ o$ & 13,62 \\
\hline Variação no ano & $\%$ & $-32,0 \%$ \\
\hline \multicolumn{3}{|l|}{ OGX } \\
\hline Disponibilidades Início Período (*) & $\mathrm{R} \$$ milhões & $4.788,2$ \\
\hline Disponibilidades Final Período $(*)$ & $\mathrm{R} \$$ milhões & $5,419,7$ \\
\hline Variação Disponibilidades & $\mathrm{R} \$$ milhões & $+631,58$ \\
\hline Dívida Bruta Início Período $(* *)$ & $\mathrm{R} \$$ milhões & - \\
\hline Dívida Bruta Fim Período $\left.{ }^{* *}\right)$ & R\$ milhões & $4.772,4(99,5 \%$ LP) \\
\hline \multicolumn{3}{|l|}{ OSXB3 } \\
\hline Valor Início Período & $\mathrm{R} \$$ /ação & $1.980,0$ \\
\hline Valor Máximo no Período & R\$̦/ação & $2.128,0$ \\
\hline Valor Mínimo no Período & RŞ/ação & $1.100,0$ \\
\hline Valor Final do Período & $\mathrm{R} \$$ /ação & $1.150,0$ \\
\hline Variação no ano & $\%$ & $-41,9 \%$ \\
\hline \multicolumn{3}{|l|}{ OSX $(* *)$} \\
\hline Disponibilidades Início Período & $\mathrm{R} \$$ milhões & $2.237,6$ \\
\hline Disponibilidades Final Período & $\mathrm{R} \$$ milhões & $1.034,1$ \\
\hline Variação Disponibilidades & $\mathrm{R} \$$ milhões & $-1.203,5$ \\
\hline Dívida Bruta Início Período & $\mathrm{R} \$$ milhões & 818,1 (61,9\% LP) \\
\hline Dívida Bruta Fim Período & $\mathrm{R} \$$ milhões & $1.158,7(90,2 \%$ LP) \\
\hline
\end{tabular}

(*) Fonte: DFP OGX; $\left({ }^{* *}\right)$ Fonte: Capital IQ.

\section{Eventos 2011}

9/02. Em teleconferência, o $A C$ anunciou que recebeu várias propostas para o farm-out, mas ainda não havia concluído a transação. Explicou que a capitalização da PETR e as incertezas geradas pela eleição presidencial afetaram o farm-out.

O primeiro poço de produção em Waimea gerou o "impressionante" fluxo de 40 kbpd/poço de óleo leve: "um marco na história da Companhia". A expectativa era manter a média de $20 \mathrm{kbpd}$, devido a limitações dos equipamentos.

28/03. Em teleconferência, a OGX relatou que planejava o início da produção em Waimea para o 3 T11 com $20 \mathrm{kbpd}$.

15/04. Finalmente, após o fechamento do mercado, o 3 D\&M se tornou público.

9/05. Em teleconferência, os Executivos anunciaram a intenção de participar da 11ạ Rodada em setembro e os planos para captar financiamentos para prosseguir com a E\&P. 
6/06. Primeira captação de Senior Unsecured Notes de US\$2,563 bilhões, ou $\mathrm{R} \$ 4,808$ bilhões, com vencimento bullet em 1/6/2018 (sete anos).

27/07. A PETR divulgou seu novo plano estratégico para 2011-15 que incluía farm-outs.

10/08. Executivos divulgaram mais e melhores informações sobre os resultados das perfurações (Waimea, Waikiki, Pipeline, Illimanu, Fuji e Tambora) e os preparativos para o primeiro óleo (Waimea). A Empresa também declarou otimismo em relação às campanhas exploratórias nas bacias do ES e PA-MA, que deveriam começar em breve.

Setembro. No início do mês, a OGX obteve a Licença Ambiental Prévia ("LAP") para Waimea e a expectativa era obter a Licença Ambiental de Instalação ("LAI") e a Licença Ambiental de Operação (“LAO") em até 60 dias, que permitiria o início do TLD. O FPSO (OSX-1) deveria chegar ao Brasil no fim de setembro.

Início Outubro. AC anuncia que não perseguiria mais o farm-out no curto prazo.

6/10. Empresa assinou o contrato de venda dos primeiros 1,2 milhões de barris do TLD de Waimea para a Shell, equivalentes a 80 dias de produção.

Fim do Ano. Em 2011, a Empresa perfurou 47 poços com uma taxa de sucesso média superior a 90\%. Waikiki, onde se localizaria Tubarão Martelo ("TBMT") deveria iniciar a produção em 2013. Em seu último CM do ano (14/12/2011), a OGX anunciou que a produção de Waimea começaria em 23/01/2012. Entre 2009 e 2011, a OGX havia perfurado 64 poços contra os 44 planejados. Ao longo de 2011, a Empresa publicou 17 FRs, a grande maioria com notícias positivas. 


\subsubsection{2: Performance Operacional e Substituição de Executivos}

Alguns Indicadores Financeiros e da OGXP3 e OSXB3 (02/01/12 a 28/12/12)

\begin{tabular}{|c|c|c|}
\hline OGXP3 & Unidade & Valor \\
\hline Valor Início Período & R\$̧/ação & 13,75 \\
\hline Valor Máximo no Período & $\mathrm{R} \$$ /ação & 18,21 \\
\hline Valor Mínimo no Período & $\mathrm{R} \$$ /ação & 4,25 \\
\hline Valor Final do Período & $\mathrm{R} \$ / a c ̧ a ̃ o$ & 4,38 \\
\hline Variação no ano & $\%$ & $-68,1 \%$ \\
\hline \multicolumn{3}{|l|}{ OGX } \\
\hline Disponibilidades Início Período $\left({ }^{*}\right)$ & $\mathrm{R} \$$ milhões & $5,419,7$ \\
\hline Disponibilidades Final Período $(*)$ & $\mathrm{R} \$$ milhões & $3.381,3$ \\
\hline Variação Disponibilidades & $\mathrm{R} \$$ milhões & $-2.038,4$ \\
\hline Dívida Bruta Início Período (**) & $\mathrm{R} \$$ milhões & $4.772,4(99,5 \%$ LP) \\
\hline Dívida Bruta Fim Período ${ }^{* *}$ ) & R\$ milhões & $8.044,7$ (98,9\% LP) \\
\hline \multicolumn{3}{|l|}{ OSXB3 } \\
\hline Valor Início Período & $\mathrm{R} \$$ /ação & $1.159,0$ \\
\hline Valor Máximo no Período & R\$̦/ação & $1.720,0$ \\
\hline Valor Mínimo no Período & RŞ/ação & 879,0 \\
\hline Valor Final do Período & $\mathrm{R} \$$ /ação & $1.065,0$ \\
\hline Variação no ano & $\%$ & $-8,1 \%$ \\
\hline \multicolumn{3}{|l|}{ OSX } \\
\hline Disponibilidades Início Período $(* *)$ & $\mathrm{R} \$$ milhões & $1.034,1$ \\
\hline Disponibilidades Final Período & $\mathrm{R} \$$ milhões & $1.684,1$ \\
\hline Variação Disponibilidades & $\mathrm{R} \$$ milhões & $+650,0$ \\
\hline Dívida Bruta Início Período & $\mathrm{R} \$$ milhões & $1.158,7(90,2 \%$ LP) \\
\hline Dívida Bruta Fim Período & $\mathrm{R} \$$ milhões & $5.445,6(61,2 \%$ LP) \\
\hline
\end{tabular}

(*) Fonte: DFP OGX; $\left({ }^{* *}\right)$ Fonte: Capital IQ.

\section{Eventos 2012}

6/01. O primeiro poço perfurado na bacia do ES resultou seco.

13/01. OGX Maranhão captou R\$ 600 milhões para financiar o desenvolvimento de Gavião Real e Gavião Azul (incluindo a UTE).

16/01. Descoberta de hidrocarbonetos no prospecto de Fortaleza em Santos, cujo reservatório poderia conter 2,0 a 4,0 bboe.

28/01. Início da produção de Waimea (TBAZ), que inicialmente era esperado para outubro de 2011.

30/01. Primeiro óleo do TBAZ: a OGX se tornou operacional dois anos após as descobertas. 
1/02. Duas semanas depois da descoberta em Fortaleza, a Empresa confirmou a presença de óleo de boa qualidade em reservatórios pré-sal em Santos.

Fevereiro. Ao longo do mês, a taxa do fluxo de TBAZ foi, na média, 11,6 kbpd, no limite inferior do intervalo originalmente estimado entre 10-20 kbpd. A média, então, foi revisada para 10-13 kbpd por poço. A OGX insistia que terminaria $2012 \mathrm{com}$ uma produção média de $40-50 \mathrm{kbpd}$ com quatro poços. Executivos reiteraram a meta de produzir $150 \mathrm{kbpd}$ em 2013, com Waikiki (TBMT), onde se esperava uma taxa de fluxo maior do que TBAZ.

20/03. OGX aumentou sua participação de 50\% para 70\% nos blocos BM-C-37 e BM-C38 devido "ao excelente potencial das águas rasas" de Campos. Devido à proximidade geográfica, o aumento na participação societária poderia acelerar o desenvolvimento de Pipeline (com volume estimado entre 1,0 e 2,0 bboe) e Carambola. A OGX considerava que a região poderia ser uma nova "província".

23/03. Divulgação dos resultados do 4T11: prejuízo contábil R\$ 321 milhões, incluindo despesas com o primeiro write off da OGX.

28/03. Conclusão da segunda emissão de Unsecured Notes: captação de US\$1,063 bilhão, por 10 anos, com vencimento bullet em abril de 2022. Entrega da primeira carga de 600 mil barris do TBAZ (US\$ 145 milhões em receitas) para a Shell.

4/04. OGX anunciou que novas captações poderiam envolver o BNDES e Project Finance, como fora feito na Parnaíba.

Em conferência no Rio de Janeiro, os Executivos anunciaram que a Declaração de Comercialidade do TBAZ. O segundo poço de TBAZ seria conectado também até o final do mês. O terceiro poço seria conectado em agosto.

A produtividade do primeiro poço do TBAZ deveria melhorar da média de 11 para 18 kbpd com mudança na bomba do poço. Metas de produção para 2013/15 foram reiteradas. Para cumprir 2015 (730 kbpd), estimava-se que a Empresa precisaria de 8 FPSOs, dos quais apenas 5 já haviam sido encomendadas à OSX. A D\&M emitiria um novo relatório em 1S2013, que incluiria descobertas no pré-sal dos blocos adquiridos da MAERSK (BM-C-37 e BM-C-38). Com base neste relatório, a Empresa consideraria rever seu plano de negócio.

Além dos 1,2 milhão de barris já vendidos para a Shell, a OGX teria vendido outros 0,4 a 0,5 milhão de barris por um preço mais alto (porém não divulgado).

Campanhas exploratórias em ES, PA-MA e Colômbia avançavam. Dos cinco blocos no PAMA, os Executivos consideravam que dois teriam alto potencial. OGX participaria da 11a Rodada, no $2 \mathrm{~S} 12$.

12/04. Descoberta de óleo leve em Fortaleza.

25/04. OGX declarou a comercialidade do TBMT com 285 mboe. 
14/05. OGX declarou a comercialidade do TBAZ com 110 mboe recuperáveis. A Empresa também revelou que o fluxo em TBAZ em março foi de 10,4 kbpd, contra 11,6 kbpd em fevereiro.

15/05. Em conferência em Nova lorque, os investidores pediram informações sobre Vesúvio, que em 2009 era um dos focos da Empresa onde estimou haver entre 0,5 e 1,5 bboe. Os Executivos explicaram que outras descobertas ganharam prioridade e que, por se tratar de uma região vulcânica, "a geração de imagens era relativamente difícil"

29/05. Em entrevista à Reuters, O CEO da OGX divulgou que a taxa do fluxo de TBAZ foi de $8,5 \mathrm{kbpd} /$ poço, na média dois poços, portanto abaixo dos 10 a $13 \mathrm{kbpd}$ anunciados no final de março. O Executivo explicou que esta média de 8,5 se referia "a um dia em específico", portanto não deveria ser extrapolada para o mês. Também confirmou que a produção de 40 a 50 kbpd não seria alcançada em 2T2013, uma vez que o terceiro poço seria conectado no $2 \mathrm{~S} 12$ e o quarto poço em $1 \mathrm{~T} 2013$.

13/06. Descoberta de óleo no pré-sal de Campos, no prospecto de Honolulu.

26/06. Os Executivos relataram, que após o término de cinco meses de TLD, a vazão ideal seria de $5 \mathrm{kbpd}$ por poço (sem injeção de água) para os dois primeiros poços (OGX-26HP e OGX-68HP), bem abaixo dos $20 \mathrm{kbpd}$ anunciado pela OGX em setembro de 2011. OGXP3 sofreu significativa desvalorização.

28/06. Substituição do CEO por Luiz Carneiro, que foi Diretor Presidente da OSX de 2009 a 2011 e membro do COAD entre 2010/11. Paulo Mendonça foi realocado para o COAD.

16/07. Polvo (da BP), outro poço carbonato albiano próximo ao TBMT e com estrutura geológica semelhante à de TBAZ, também apresentou baixas taxas de 1,2 kbpd/poço. Injeção de água não melhoraria o fluxo e poderia danificar o reservatório.

15/08. Em uma teleconferência, os novos Executivos revelaram que o quarto poço perfurado em Inga provou ser seco. A notícia foi negativa, uma vez que a perfuração em local próximo à área considerada como Recurso Contingente no 3은. Inga ficava ao sul de TBMT (com comercialidade declarada de 285 mboe).

2/10. Os novos Executivos anunciaram que a OGX venderia a sua próxima carga de óleo para empresa asiática com um desconto de US\$ 4,5/barril. Anunciou também que reconheceria a perda contábil no BM-S-29 (US\$ 100 milhões) e o retornaria a ANP.

24/10. Quando OGXP3 chegou a R\$ 4,66, o $A C$ outorgou à OGX uma put ao preço de exercício de $\mathrm{R} \$ 6,30$ e limite máximo de US\$ 1,0 bilhão. A put poderia ser exercida a qualquer momento até 30 de abril de 2014.

8/11. No anúncio dos resultados do 3T12, não houve notícias sobre as perfurações em Fortaleza. Mas houve notícias sobre as perfurações no BM-C-37/38, cuja concessão venceria em março de 2013: entre 0,861 e 1,196 bboe em cinco prospectos, que poderiam demandar 4 FPSOs. No 3T12, a OGX reconheceu R\$ 294,0 milhões em perdas em poços secos (dos quais $\mathrm{R} \$ 213,0$ milhões se referiam ao BM-S-29). 
26/11. OGX adquiriu 40\% de participação no bloco BS-4 pertencente à PETR por R\$ 575 milhões (US\$ 270 milhões). O BS-4 era formado por dois campos pós-sal em águas profundas: Atlanta e Oliveira, com óleo pesado de $14^{\circ}$ a $16^{\circ} \mathrm{API}$.

Fim Novembro. "Primeiro gás" em Gavião Real. UTE Parnaíba I seria comissionada em janeiro de 2013

12/12. Empresa anunciou sua intenção de promover o farm-out de TBMT. 


\subsubsection{3: Últimas Tentativas de Reconstrução da Agenda de Catalisadores}

Alguns Indicadores Financeiros e da OGXP3 e OSXB3 (02/01/13 a 31/10/13)

\begin{tabular}{|c|c|c|}
\hline OGXP3 & Unidade & Valor \\
\hline Valor Início Período & $\mathrm{R} \$$ /ação & 4,76 \\
\hline Valor Máximo no Período & $\mathrm{R} \$$ /ação & 5,36 \\
\hline Valor Mínimo no Período & $\mathrm{R} \$$ /ação & 0,13 \\
\hline Valor Final do Período & $\mathrm{R} \$ / a c ̧ a ̃ o$ & 0,13 \\
\hline Variação no ano & $\%$ & $-97,3 \%$ \\
\hline \multicolumn{3}{|l|}{ OGX } \\
\hline Disponibilidades Início Período $\left({ }^{*}\right)$ & $\mathrm{R} \$$ milhões & $3.381,3$ \\
\hline Disponibilidades Final Período $(*)$ & $\mathrm{R} \$$ milhões & $188,7(30 / 9)$ \\
\hline Variação Disponibilidades & $\mathrm{R} \$$ milhões & $-3.192,6$ \\
\hline Dívida Bruta Início Período (**) & $\mathrm{R} \$$ milhões & $8.044,7(98,9 \%$ LP) \\
\hline Dívida Bruta Fim Período ${ }^{* *}$ ) & R\$ milhões & $8.919,2(0,0 \%$ LP) \\
\hline \multicolumn{3}{|l|}{ OSXB3 } \\
\hline Valor Início Período & $\mathrm{R} \$$ /ação & $1.025,0$ \\
\hline Valor Máximo no Período & R\$̦/ação & $1.025,0$ \\
\hline Valor Mínimo no Período & RŞ/ação & 45,0 \\
\hline Valor Final do Período & $\mathrm{R} \$$ /ação & 45,0 \\
\hline Variação no ano & $\%$ & $-95,6 \%$ \\
\hline \multicolumn{3}{|l|}{ OSX } \\
\hline Disponibilidades Início Período $(* *)$ & $\mathrm{R} \$$ milhões & 1684,1 \\
\hline Disponibilidades Final Período & $\mathrm{R} \$$ milhões & 195,5 \\
\hline Variação Disponibilidades & $\mathrm{R} \$$ milhões & $-1.488,6$ \\
\hline Dívida Bruta Início Período & $\mathrm{R} \$$ milhões & $5.445,6(61,2 \%$ LP) \\
\hline Dívida Bruta Fim Período & $\mathrm{R} \$$ milhões & $4.809,4(67,2 \%$ LP) \\
\hline
\end{tabular}

(*) Fonte: DFP OGX; $\left({ }^{* *}\right)$ Fonte: Capital IQ.

\section{Eventos 2013}

4/01. Após um atraso de um mês, a OGX conectou o terceiro poço em TBAZ. A expectativa era que este poço produzisse mais do que a média de $5 \mathrm{kbpd}$ dos outros dois primeiros. A confirmação do fluxo deveria levar duas semanas.

Início Janeiro. Dois anos depois de estimar seu potencial em 0,5 a 1,5 bboe, a Empresa considerou Vesúvio como baixa prioridade no portfólio, pois contém petróleo pesado em uma estrutura fragmentada. Outras áreas menos conhecidas, incluindo as prospectivas não-perfuradas dos BM-C-37/38, agora, teriam prioridade sobre Vesúvio.

31/01. Poço seco em Cozumel (BM-C-37), onde se estimou haver entre 209 a 270 mboe. Descoberta de hidrocarbonetos em Tulum e Viedna. Produção do terceiro poço do TBAZ ficou na média de $5 \mathrm{kbpd}$ (a expectativa era de $7 \mathrm{kbpd}$ ). Em janeiro, a produção média em TBAZ foi de 4,9 kbpd/poço, mas a Empresa não disponibilizou os detalhes.

3/03. OGX ainda não havia divulgado os resultados do 4T12 e sua posição de caixa. 
6/03. EBX e o BTG, um dos principais acionistas da Sete Brasil, assinaram um contratado de "cooperação estratégica de negócios". Não havia detalhes sobre o acordo: além de assessoria financeira, notícias veiculadas nos jornais mencionavam linhas de crédito, mas sem divulgar valores e alocações ao Grupo X.

11/03. OGX divulgou os resultados decepcionantes da produção do terceiro poço de TBAZ (estimada em 1,6 kbpd em fevereiro) e seu efeito negativo sobre a produção dos dois primeiros poços.

13/03. OGX anunciou a devolução de um dos seus quatro blocos de Santos, o BM-S-57, onde se localizava a acumulação de Fortaleza. A Empresa declarou também a comercialidade de três campos: Tubarão Tigre ("TBTI"), Tubarão Gato ("TBGA") e Tubarão Areia ("TBAR"). Próximo da data de expiração de suas concessões, a OGX pleiteou PADs para apenas seis acumulações em Campos e três em Santos.

14/03. A ANP divulgou dados sobre a produção dos três poços de TBAZ para janeiro, que mostrou que os problemas não eram com o terceiro poço, mas os dois primeiros, cujas produções declinaram.

26/03. OGX anunciou que, após três meses de produção, o terceiro poço de TBAZ ainda não havia se estabilizado.

4/04. Devido à baixa posição de caixa, a S\&P rebaixou a nota de crédito da OGX de $B$ para B-, apenas três níveis acima da nota de default.

12/04. ANP divulgou que a produção média em fevereiro dos dois primeiros poços do TBAZ, os mais antigos em serviço, foi de $4,247 \mathrm{kbpd}, 17 \%$ abaixo do pico de 5,129 em agosto de 2012.

6/05. Artigo na mídia relatou que o farm-out de TBMT com a malaia Petronas estava prestes a ser concluído: US\$ 850 milhões por $40 \%$ de participação (US\$ 7,5/boe). 0 pagamento, em caixa, estaria condicionado à confirmação da performance do campo, que poderia ocorrer em meados de 2014.

7/05. Produção de TBAZ em abril caiu ainda mais, de 8,3 (março) para $1,8 \mathrm{kbpd}$, por reflexos dos problemas técnicos com equipamentos.

8/05. Assinado o acordo de farm-out do TBMT com a Petronas, porém os termos dos pagamentos não foram revelados. Adicionalmente, a Petronas teria assinado com o AC um contrato de opção de compra de $5 \%$ da OGX por R\$ 6,30/ação, o mesmo preço de exercício da put. A call teria validade até abril de 2015.

10/05. Em teleconferência, Executivos divulgaram detalhes do farm-out: US\$ 250 milhões a serem pagos no 4T13; US\$ 500 milhões quando do primeiro óleo (1T14); e US\$ 100 milhões em função de metas da produtividade do campo (US\$ 50 milhões ao atingir a produção média de $40 \mathrm{kbpd}$, mais US\$ 25 milhões para $50 \mathrm{kbpd}$, mais US\$ 25 milhões para $60 \mathrm{kbpd}$, respectivamente). 
OGX anunciou também os resultados do 1T13, que incluíam: vendas de 1,2 mboe; $R \$ 1,2$ bilhão em baixas de ativos (poços subcomerciais, dos quais $R \$ 952$ milhões referiam-se aos blocos devolvidos para a ANP); EBITDA negativo de $R \$ 1$ 1,1 bilhão; $R \$ 2,3$ bilhões em disponibilidades (US\$ 1,1 bilhão).

A OGX também confirmou a viabilidade comercial de TBTI, TBAR e TBGA.

14 e 15/05. OGX arrematou 13 blocos na 11a Rodada, por R\$ 376 milhões (US\$ 188 milhões) em BA e R\$ 698 milhões (US\$ 349 milhões) em PEM. Dos 13 blocos arrematados, 4 estavam na bacia do Paranaíba, 3 em Barreirinhas, 3 no Ceará, 2 na Potiguar e 1 na Foz do Amazonas.

11/06. Na divulgação da CVM 358 de maio, soube-se que o AC havia vendido o equivalente a $\mathrm{R} \$ 70,5$ milhões da OGXP3, reduzindo sua participação de $62,6 \%$ para $60,5 \%$.

21/06. Resignação dos três membros independentes do COAD, Rodolpho Tourinho, Elen Gracie e Pedro Malan. Eles eram incumbidos de decidir sobre a validade do momento para exercício da put contra o AC.

1/07. OGX anunciou seu Plano de Negócios que incluía: (1) o pagamento imediato de US\$ 449 milhões à OSX para cobrir os custos de equipamentos encomendados, porém ainda não entregues (FPSO OSX-3 e o WHP-2); (2) não haveria novos investimentos nos três poços de TBAZ que deveriam parar de produzir até o fim do ano, porém o contrato de aluguel da FPSO OSX-1 continuaria a ser honrado (US\$ 263 mil por dia); (3) o desenvolvimento de TMTB seguiria o planejamento, mas os termos do contrato de aluguel da FPSO OSX-3 e WHP-2 seriam ajustados. O primeiro óleo era esperado para dezembro de 2013, o que implicaria no pagamento de US\$ 500 milhões da Petronas à OGX; (4) o desenvolvimento de TBTI, TBAR e TBGA seria cancelado e suas concessões devolvidas à ANP, pois os campos eram intensamente fragmentados; (5) em decorrência do estudo que apontou a falta de viabilidade econômica de TBTI, TBAR e TBGA, a encomenda da FPSOs OSX-4 e OSX-5, WHP-3/4 à OSX seria suspensa. Em um único pregão, a OGXP3 caiu 29,1\%, (de $R \$ 0,79$ para 0,56).

8/08. Novos dados sobre TBAZ desapontaram mais uma vez. Outro problema técnico praticamente impediu a produção em julho que ficou na média em 0,9 kbpd.

10/08. ANP divulgou a produção média do primeiro poço (OGX-26HP) em junho: 2,368 contra 4,665 kbpd em maio (11,037 kbpd em fevereiro). Em contraste, a produção média do segundo poço (OGX-68HP) aumentou em junho: 6,461 contra 4,065 kbpd em maio.

15/08. Anúncio dos resultados do $2 T 13$ : um prejuízo de $R \$ 4,7$ bilhões, incluindo impairment de R\$3,665 bilhões (referentes aos TBTI, TBAR e TBGA), R\$ 490,7 milhões em baixas de ativos (poços subcomerciais) e R\$ 956,8 milhões em perdas devido a cancelamentos de contratos com a OSX. O prejuízo só não foi maior pois houve um ganho de capital de $\mathrm{R} \$ 1,035$ bilhão referente ao farm-out para Petronas. O EBITDA foi negativo em $R \$ 4,1$ bilhões. O saldo das disponibilidades em 30/6 era de apenas $R \$ 721$ milhões, insuficientes para as obrigações previstas no 3T13, considerando que a OSX-1 
não produziria nada pelos próximos dois meses. $O$ auditor independente afirmava que a continuidade da OGX dependia de aporte de recursos do AC. A Empresa contratou o Blackstone Group como assessor financeiro na avaliação de sua estrutura de capital, o que indicava que a reestruturação da dívida era iminente.

27/08. OGX anunciou que devolveria à ANP 9 dos 13 blocos adquiridos na 11a Rodada em maio. A OGX justificou a devolução para evitar nova exposição ao risco exploratório em blocos onde não possuía parceiros. De fato, dos quatro blocos restantes, com BA de $\mathrm{R} \$ 96,0$ milhões, três eram em parceria com outras empresas.

Notícias na mídia (JVE) relatavam que os pagamentos do farm-out com a Petronas estariam sujeitos à reestruturação do passivo da Empresa. Como o primeiro pagamento de US\$ 250 milhões era a única fonte de recursos novos previstos no curto prazo, a Empresa precisaria exercer a put.

6/09. OGX exerceu a put contra o AC. Entretanto, do US\$1,0 bilhão a ser aportado, apenas $10 \%$ seriam desembolsados imediatamente.

9/09. AC anunciou que contestaria o aporte de US\$ 100 milhões na câmara de arbitragem.

1/10. OGX deixou de pagar US\$ 44,1 milhões em juros do OGXPBZ de 2022.

3/10. OGX divulgou um relatório da D\&M para TMAT que aumentou as dúvidas quanto à sua viabilidade: 87,9 mboe de reservas $2 \mathrm{P}, 108,5$ mboe de reservas $3 \mathrm{P}$ e zero mboe para reservas $1 \mathrm{P}$.

Outubro. Durante as negociações, a OGX teria proposto a conversão de um total de US\$ 2,73 bilhões em dívidas, incluindo US\$ 1,566 bilhão dos bonds e US\$ 1,64 bilhão das obrigações com fornecedores.

30/10. Com a recusa dos bondholders à adesão do plano de restruturação, e a recusa do AC em honrar a put, o inevitável aconteceu. Com US\$ 5,1 bilhões em dívidas (US\$ 3,7 bilhões do bonds mais US\$2,6 bilhões com a OSX) e apenas R\$ 180 milhões no caixa (31/9/13), a Empresa ajuizou o pedido de RJ (que foi deferido em 21/11/2013). Em seguida, a OGXP3 foi excluída de 10 diferentes índices incluindo o IBrX, a partir de 1/11. A RJ permitia que a Petronas abortasse o farm-out, que assim o fez.

No 3T2013, a produção média em TBAZ foi de apenas 3,9 kbpd por poço. No 4T13, não houve produção no TBAZ. 


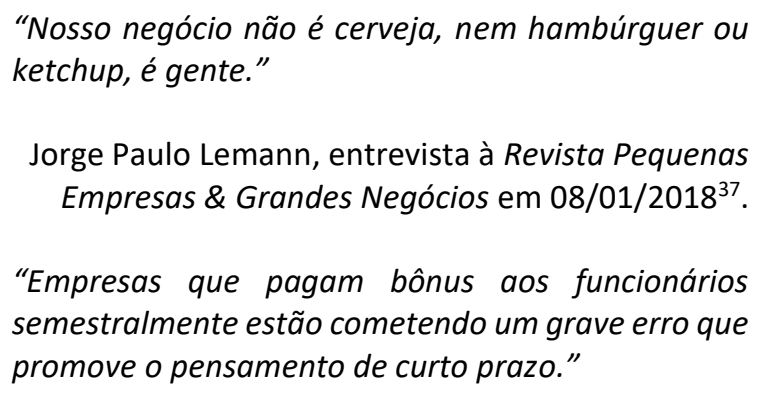

Jorge Paulo Lemann, entrevista à InfoMoney em $03 / 08 / 2018^{38}$.

Possíveis respostas às três Questões de Pesquisa possuem um eixo em comum: a Tese de Investimento foi um engodo ou era realmente factível, mas faltou capital para terminar sua implantação? Sobre a Tese de Investimento há, ao menos, três conjecturas.

Em uma primeira conjectura, os Gestores teriam sido bem-sucedidos em vender ao mercado uma "empresa de PPT". A Tese de Investimentos teria sido uma "fantasia" que foi deliberadamente superavaliada por anos até os Executivos e AC esgotarem sua credibilidade. O verdadeiro valor da OGX teria sido essencialmente especulativo e como tal, próximo a zero quando ajustado ao risco. Nesta conjectura, a Tese de Investimentos teria sido um engodo, caso os Gestores tivessem conhecimento prévio e agido de má fé ao promovê-la e defendê-la aos investidores, financiadores e fornecedores ("Primeira Conjectura"). Os Gestores teriam manipulado o mercado visando enriquecimento próprio e indevido, ferindo os artigos 27-C, 27-D da Lei 6.385/1976 (alterada pela Lei $10.303 / 01$ ), artigo VI da Lei 1.521/51 ("Crimes contra a economia popular"), e artigos I e II da Instrução CVM n. 8 (8/10/1979). Os investidores, financiadores e fornecedores teriam sido vítimas de uma trama extremamente bem elaborada capaz de ludibriar competentes analistas de crédito, analistas de buy e sell-side por anos. Essa conjectura teria repercussões muito negativas para a credibilidade dos mercados de capitais no Brasil.

Numa segunda conjectura, antagônica à Primeira Conjectura, os Gestores teriam agido de boa fé, envidaram seus melhores esforços técnicos e financeiros, mas a OGX teria tido muita "falta de sorte" ao investir em blocos que, apesar de ser bem localizados, tinham baixo potencial ou eram economicamente inviáveis dada a tecnologia disponível de E\&P e as condições de mercado de O\&G na época ("Segunda Conjectura"). Afinal, a Empresa perfurou 115 poços, mais que o dobro dos 51 planejados, e investiu $R \$ 13,80$ bilhões (US\$ 5,20 bilhões até o 3T2013) equivalentes a 1.620\% do Programa Mínimo Exploratório ("PEM"). O foco em Campos, onde a OGX perfurou 61 poços ante aos 27

37 Disponível em: https://revistapegn.globo.com/Empreendedorismo/noticia/2018/01/jorge-paulolemann-nosso-negocio-nao-e-cerveja-nem-hamburguer-ou-ketchup-e-gente.html.

38 Disponível em: https://www.infomoney.com.br/carreira/gestao-e-lideranca/noticia/7545469/jorgepaulo-lemann-revela-maior-erro-que-cometeu-como-gestor 
planejados, também parecia uma escolha sensata, uma vez que era em Campos que se concentrava a expertise dos principais Executivos.

Tabela 10 - Alguns Indicadores da Campanha Exploratória: Planejados x Realizados

\begin{tabular}{|l|c|c|c|c|c|c|c|c|c|c||}
\hline & \multicolumn{4}{|c|}{ Poços Perfurados } & \multicolumn{3}{c|}{ PEM } & \multicolumn{3}{c|}{ Gastos \& Despesas com E\&P } \\
\hline \multicolumn{1}{|c|}{ Bacias } & $\begin{array}{c}\text { Plano } \\
\text { IPO }\end{array}$ & $\begin{array}{c}\text { \% } \\
\text { Plano }\end{array}$ & Real. & $\begin{array}{c}\text { \% } \\
\text { Real }\end{array}$ & $\begin{array}{c}\text { Previsão } \\
\text { (R\$ M) }\end{array}$ & \%PEM & $\begin{array}{c}\text { Inv. } \\
\text { (R\$ M) }\end{array}$ & $\begin{array}{c}\text { \% } \\
\text { Inv. }\end{array}$ & $\begin{array}{c}\text { \% } \\
\text { PEM }\end{array}$ & $\begin{array}{c}\text { Inv./ } \\
\text { Poço }\end{array}$ \\
\hline Campos & 27 & $52,9 \%$ & 61 & $53,0 \%$ & 284,4 & $33,4 \%$ & $8.517,1$ & $61,7 \%$ & $\mathbf{2 9 9 5 , 0 \%}$ & 139,6 \\
\hline Santos & 14 & $27,5 \%$ & 16 & $13,9 \%$ & 48,2 & $5,7 \%$ & $3.164,2$ & $22,9 \%$ & $6564,1 \%$ & 197,8 \\
\hline Parnaíba & - & $0,0 \%$ & 24 & $20,9 \%$ & 166,2 & $19,5 \%$ & $1.148,4$ & $8,3 \%$ & $691,1 \%$ & 47,9 \\
\hline ES & 6 & $11,8 \%$ & 5 & $4,3 \%$ & 53,4 & $6,3 \%$ & 364,7 & $2,6 \%$ & $682,7 \%$ & 72,9 \\
\hline PA-MA & 4 & $7,8 \%$ & 5 & $4,3 \%$ & 78,6 & $9,2 \%$ & 564,6 & $4,1 \%$ & $718,3 \%$ & 112,9 \\
\hline Colômbia & - & - & - & - & 221,0 & $25,9 \%$ & 39,1 & $0,3 \%$ & $17,7 \%$ & - \\
\hline Total & $\mathbf{5 1}$ & $\mathbf{1 0 0 , 0 \%}$ & $\mathbf{1 1 5}$ & $\mathbf{1 0 0 , 0 \%}$ & $\mathbf{8 5 1 , 7}$ & $\mathbf{1 0 0 , 0 \%}$ & $\mathbf{1 3 . 7 9 8 , 0}$ & $\mathbf{1 0 0 , 0 \%}$ & $\mathbf{1 6 2 0 , 0 \%}$ & $\mathbf{1 2 0 , 0}$ \\
\hline
\end{tabular}

A Segunda Conjectura é aparentemente suportada pela intensidade da campanha exploratória e seus resultados ex-post. Afinal, apesar do diminuto volume, a OGX descobriu e produziu O\&G. Um dos Especialistas em O\&G entrevistado explicou que os blocos adquiridos na 9a Rodada estavam localizados onde, posteriormente, se caracterizou como "franjas" do pré-sal, com óleo pesado e disperso. Portanto, haveria óleo em alguns blocos da OGX, porém dentre outras possíveis decisões operacionais erradas, a Empresa teria usado a tecnologia inapropriada para explorar seus blocos. Como bem resumiu outro executivo entrevistado: "ter [petróleo] e tirar [extrair] são duas coisas bem diferentes".

Pode-se argumentar ainda que, devido à extensão e diversidade geográfica do portfólio, o caixa da OGX terminou antes da campanha exploratória pudesse ser concluída. Nesta Segunda Conjectura, a OGX não necessariamente comprometeria a credibilidade dos mercados de capitais no Brasil. A Empresa teria sido essencialmente um projeto de alto risco que infelizmente não deu certo. Os investidores, financiadores e fornecedores deveriam estar cientes dos riscos a que estavam expostos: "perdas fazem parte do jogo". Neste sentido, os efeitos nefastos aos mercados de capitais no Brasil poderiam ser limitados em relação à Primeira Conjectura.

A Segunda Conjectura foi essencialmente o argumento empregado pela Empresa na sua solicitação da RJ:

(...) [D]e 2010 a 2012, o grupo [OGX] mobilizou um conjunto de dez sondas de perfuração, operando em paralelo, o que possibilitou uma campanha exploratória em larga escala. Como produto dessa campanha, foi possivel investigar áreas que não vinham sendo priorizadas no País, gerando como subproduto um importante acervo de informações geológicas para a gestão do setor pela Agência Nacional do Petróleo - ANP, que reconhece os relevantes serviços 
prestados pelo grupo OGX. Desde sua criação, a OGX investiu mais de $R \$ 10$ bilhões em suas atividades no Brasil, valor que a torna a empresa privada que mais investiu no seu segmento (...). [p. 3, parágrafo 7]

[O] fato de que muitos poços não ofereceram a quantidade de petróleo necessária a torna-los produtivos repercutiu, negativamente, na receita do grupo [OGX] e, por consequência, na sua capacidade de honrar nos termos originariamente contratados, as obrigações financeiras assumidas (...). [p. 4, parágrafo 11]

[A]s suplicantes [OGX e suas subsidiárias] são pioneiras no desenvolvimento dos negócios a que se dedicam, graças à tenacidade empresarial, ao descortino, às iniciativas inovadoras que o Sr. Eike Batista, sempre aclamado pelo seu êxito, corajosamente tomou. Hoje em dia, se lhe imputam insucesso decorrentes fatos geológicos, pelos quais, nem de longe, é responsável. [p. 5, parágrafo 14]

Não obstante os prejuízos recentemente sofridos pelas impetrantes [OGX e suas subsidiárias], que as levam a postular a tutela da lei especifica [RJ], a existência de ativos de alto vulto, acumulados em companhias formadas por profissionais de reconhecida competência, indicam a conviç̧ão de que as impetrantes se recuperarão $e$ retomarão os caminhos do êxito, no melhor interesse de todos os que gravitam ao redor delas. [p. 5, parágrafo 15]. [Pedido de Recuperação Judicial da OGX, GRERJ n. 01426931504-79, 30/10/2013 ${ }^{39}$ ].

Em sua defesa, Pedro Malan, renomado membro do COAD entre 2008 e 2013, processado por alguns investidores minoritários por omissão e negligência, resumiu a essência da Segunda Conjectura:

[A]s dificuldades em que se encontra a OGX, como se vê, tem uma causa específica, insuperável, que nada tem a ver com a alegada omissão ou negligência do réu, em relação a qual ele nada poderia fazer para evitar: a inexistência de petróleo de extração economicamente viável em alguns dos principais poços da OGX - só evidenciada durante a fase de desenvolvimento e produção destes, ao contrário do que sugeriram os dados colhidos na custosa fase de exploração, que exigiu elevado endividamento da Companhia. Foi essa, como é de conhecimento público, a causa necessária e determinante para a OGX ter entrado em crise financeira. [Contestação P. Malan, p. 69, parágrafo 240].

O AC, que no auge teve sua fortuna estimada em US\$ 34 bilhões ${ }^{40}$, também defendeu publicamente a Segunda Conjectura e suas perdas pessoais:

[E]IKE BATISTA - que, por ser acionista controlador, provavelmente foi quem mais ganhou e quem mais perdeu dinheiro na OGX - explica,

\footnotetext{
${ }^{39}$ Disponível em:

http://ri.ogpar.com.br/conteudo_pt.asp?tipo=50327\&id=0\&idioma=0\&conta=28\&submenu=0\&img= $0 \&$ ano $=2013$. Acesso em 6/7/2018.

${ }^{40}$ Bustista, The Economist, 2013, vol. 409 (8860), p. 68.
} 
com clareza, a questão, em carta aberta publicada em jornais de grande circulação: '(...) Tive ofertas para vender fatias expressivas ou mesmo o controle da OGX a partir de um valuation de US\$ 30 bilhões. Há dois anos, coloquei mais US\$ 1 bilhão do meu bolso na companhia. Eu perdi e venho perdendo bilhões de dólares com a OGX. Alguém que deseja iludir o próximo faz isso a um custo de bilhões de dólares? Se eu quisesse, poderia ter realizado uma venda programada de US\$100 milhões por semestre ao longo de 5 anos. Eu teria embolsado US\$ 5 bilhões e ainda assim permaneceria no controle da OGX. Mas não o fiz. Quem mais perdeu com a derrocada no valor da OGX foi um acionista: Eike Batista. Ninguém perdeu tanto quanto eu, e é justo que assim seja. Eu investi em um negócio de risco. É injusto e inaceitável, por outro lado, ouvir que induzi deliberadamente alguém a acreditar num sonho ou numa fantasia. Quem mais acreditou na OGX fui eu. Continuo acreditando e por isso estamos, nestes últimos meses, reinventando a companhia. Não desistirei deste desafio. [Contestação P. Malan, p. 72, parágrafo $248^{41}$ ].

Entretanto, a Segunda Conjectura convoca uma outra reflexão: por que a OGX implementou uma campanha exploratória tão extensa e em tão pouco tempo? A Empresa perfurou mais que o dobro de poços que havia planejado no quinquênio $2008 / 13$ e investiu 16 vezes mais do que havia se comprometido com a ANP.

As projeções iniciais para a produção de petróleo indicavam que a prioridade seria Campos e seus Blocos Seletos. Santos seria a segunda bacia mais importante em óleo, porém lá a ênfase era em E\&P de GN, apesar das elevadas incertezas quanto à disponibilidade de infraestrutura de escoamento. Então, por que Empresa investiu tanto em Santos (R\$ 3,16 bilhões, ou R\$ 198 milhões por poço, em média), onde a D\&M havia estimado baixo RPL de óleo (11,1\% do total)? Mesmo o bloco BM-S-59, que custou à Empresa o maior BA da 9a Rodada, só começou a ser explorado em 2012. Por que não focou seus esforços em Campos ( $R \$$ 8,52 bilhões, ou $\mathrm{R} \$ 139$ milhões por poço) onde a expertise dos Executivos e a maior parte do RPL de óleo ( $71,6 \%$ do total) se concentrava?

41 Trecho do artigo do AC ao JVE, 19/7/13: "Se pudesse voltar atrás, não recorreria ao mercado". Disponível em: https://www.valor.com.br/empresas/3203332/se-pudesse-voltar-atras-naorecorreria-ao-mercado. Acesso em 12/12/18. 
Tabela 11 - Projeção da Produção Anual da OGX Apresentada no IPO (em mboe)

\begin{tabular}{|c|c|c|c|c|c|c|c|c|c|c|c|c|}
\hline & 2011 & 2012 & 2013 & 2014 & 2015 & 2016 & 2017 & 2018 & 2019 & Total & \%ST & \%Total \\
\hline Campos & 2 & 14 & 18 & 53 & 181 & 284 & 401 & 475 & 511 & 1.939 & $55,0 \%$ & $39,8 \%$ \\
\hline Santos & - & - & - & 27 & 36 & 131 & 125 & 173 & 180 & 672 & $19,1 \%$ & $13,8 \%$ \\
\hline ES & - & - & - & - & - & 54 & 72 & 110 & 146 & 382 & $10,8 \%$ & $7,8 \%$ \\
\hline PA-MA & - & - & - & - & 54 & 74 & 110 & 146 & 146 & 530 & $15,0 \%$ & $10,9 \%$ \\
\hline Subtotal Óleo & 2 & 14 & 18 & 80 & 271 & 543 & 708 & 904 & 983 & 3.523 & $100,0 \%$ & $72,3 \%$ \\
\hline \%Total & $0,1 \%$ & $0,4 \%$ & $0,5 \%$ & $2,3 \%$ & $7,7 \%$ & $15,4 \%$ & $20,1 \%$ & $25,7 \%$ & $27,9 \%$ & $100,0 \%$ & & \\
\hline Produção (kbpd) & 5 & 38 & 49 & 219 & 742 & 1.488 & 1.940 & 2.477 & 2.693 & & & \\
\hline Santos & - & - & - & 94 & 173 & 193 & 212 & 232 & 251 & 1.156 & $85,5 \%$ & $23,7 \%$ \\
\hline ES & - & - & - & - & - & 18 & 51 & 64 & 64 & 196 & $14,5 \%$ & $4,0 \%$ \\
\hline \multirow[t]{2}{*}{ Subtotal GN } & - & - & - & 94 & 173 & 211 & 263 & 296 & 315 & 1.352 & $100,0 \%$ & $27,7 \%$ \\
\hline & $0,0 \%$ & $0,0 \%$ & $0,0 \%$ & $6,9 \%$ & $12,8 \%$ & $15,6 \%$ & $19,4 \%$ & $21,9 \%$ & $23,3 \%$ & $100,0 \%$ & & \\
\hline Campos & 2 & 14 & 18 & 53 & 181 & 284 & 401 & 475 & 511 & 1.939 & $39,8 \%$ & \\
\hline Santos & - & - & - & 121 & 209 & 324 & 337 & 405 & 431 & 1.828 & $37,5 \%$ & \\
\hline ES & - & - & - & - & - & 72 & 123 & 174 & 210 & 578 & $11,9 \%$ & \\
\hline PA-MA & - & - & - & - & 54 & 74 & 110 & 146 & 146 & 530 & $10,9 \%$ & \\
\hline Total & 2 & 14 & 18 & 174 & 444 & 754 & 971 & 1.200 & 1.298 & 4.875 & $100,0 \%$ & \\
\hline \%Total & $0,0 \%$ & $0,3 \%$ & $0,4 \%$ & $3,6 \%$ & $9,1 \%$ & $15,5 \%$ & $19,9 \%$ & $24,6 \%$ & $26,6 \%$ & $100,0 \%$ & & \\
\hline
\end{tabular}

Fonte: Prospecto, p. 19. (*) Produção média diária foi calculada com base em 365 dias de produção por ano.

Adicionalmente, por que pulverizar esforços e capital ( $R \$ 2,08$ bilhões) em bacias mais desconhecidas (ES, PA-MA) e com baixo RPL de óleo? Por que investir no E\&P de GN na Parnaíba ( $R \$ 1,15$ bilhão), que apesar de bem-sucedida, agregava pouco valor presente líquido à OGX? De fato, alguns analistas de sell-side ("Analistas") não consideraram o valor do GN na OGX. 
Tabela 12 - Campanha Exploratória: Números de Poços Pioneiros e de Avaliação (Pioneer Wells and Appraisals)

\begin{tabular}{|l|c|c|c|c|c|c|c|}
\hline & $\mathbf{2 0 0 9}$ & $\mathbf{2 0 1 0}$ & $\mathbf{2 0 1 1}$ & $\mathbf{2 0 1 2}$ & $\mathbf{2 0 1 3}$ & Total & $\mathbf{\%}$ \\
\hline Campos & 4 & 18 & 31 & 6 & 2 & 61 & $53,0 \%$ \\
\hline Santos & 2 & 6 & 3 & 4 & 1 & 16 & $13,9 \%$ \\
\hline Parnaíba & & 2 & 8 & 6 & 8 & 24 & $20,9 \%$ \\
\hline ES & & & 2 & 1 & 2 & 5 & $4,3 \%$ \\
\hline PA-MA & & & & 2 & 3 & 5 & $4,3 \%$ \\
\hline Colômbia & & & & 1 & 3 & 4 & $3,5 \%$ \\
\hline Total Realizado & $\mathbf{6}$ & $\mathbf{2 6}$ & $\mathbf{4 4}$ & $\mathbf{2 0}$ & $\mathbf{1 9}$ & $\mathbf{1 1 5}$ & $\mathbf{1 0 0 , 0 \%}$ \\
\hline Planejado 2008 & $\mathbf{6}$ & $\mathbf{1 9}$ & $\mathbf{1 9}$ & $\mathbf{7}$ & - & $\mathbf{5 1}$ & $\mathbf{1 0 0 , 0 \%}$ \\
\hline Campos & 4 & 11 & 10 & 2 & - & 27 & $52,9 \%$ \\
\hline Santos & 2 & 8 & 4 & - & - & 14 & $27,5 \%$ \\
\hline Parnaíba & - & - & - & - & - & - & $0,0 \%$ \\
\hline ES & - & - & 3 & 3 & - & 6 & $11,8 \%$ \\
\hline PA-MA & - & - & 2 & 2 & - & 4 & $7,8 \%$ \\
\hline
\end{tabular}

Fontes: Planejamento 2008: Prospecto IPO. Realizados 2009 a 2011: SEQUEIRA \& FONSECA, 2012a, p. 10. Projeções 2012 e 2013: KOVARSKY \& MENDES [2012g].

Por fim, aparentemente houve dispersão geográfica da campanha exploratória do portfólio do IPO. Além do esforço financeiro e de recursos humanos, a dispersão geográfica poderia limitar potenciais ganhos de sinergia no uso de equipamentos e infraestruturas de exploração, desenvolvimento e produção ${ }^{42}$. Ao longo de 2009 a 2013, a OGX investiu em novas frentes através da aquisição de concessões de outros 29 blocos marítimos e terrestres no Brasil e na Colômbia.

42 No prospecto do follow-on da PETR [p. 28], na seção "Nossas Vantagens Competitivas", lê-se: "de aproximadamente $90,0 \%$ das nossas reservas provadas de petróleo e 53,0\% das nossas reservas provadas de gás natural em 2009 estarem localizadas nos campos de produção da Bacia de Campos, o que nos permite concentrar geograficamente a infraestrutura necessária para dar suporte às nossas atividades e, dessa forma, reduzir os nossos custos com exploração, desenvolvimento e produção". 
Tabela 13 - Histórico de Aquisições de Blocos Exploratórios da OGX

\begin{tabular}{|c|c|c|c|}
\hline $\begin{array}{c}\text { Data } \\
\text { Aquisição }\end{array}$ & $\begin{array}{l}\text { Número } \\
\text { Blocos }\end{array}$ & Bacias & Comentários \\
\hline $27 / 11 / 07$ & 21 & Campos, Santos, ES, PA-MA & $\begin{array}{l}\text { 9a Rodada ANP por } R \$ 1,568 \text { bilhão } \\
\text { em BA, uma média de } R \$ 243,7 \\
\mathrm{mil} / \mathrm{km}^{2} \text {. }\end{array}$ \\
\hline $1 T 2008$ & 1 & Santos (BM-S-29) & $\begin{array}{l}\text { Farm-in 50\% Maersk (sem valor } \\
\text { informado). }\end{array}$ \\
\hline $8 / 05 / 09$ & & Santos (BM-S-29) & $\begin{array}{l}\text { Farm-in de } 15 \% \text { adicionais (sem valor } \\
\text { informado). }\end{array}$ \\
\hline $9 / 11 / 10$ & & Santos (BM-S-29) & $\begin{array}{l}\text { Comprou o restante } 35 \% \text { da Maersk } \\
\text { (sem valor informado). }\end{array}$ \\
\hline $24 / 09 / 09$ & 7 & $\begin{array}{l}\text { Parnaíba (blocos terrestres com } \\
\text { potencial para GN) }\end{array}$ & $\begin{array}{l}33,33 \% \text { OGX, 33,33\% MPX, 33,33\% } \\
\text { Petra Energia }\end{array}$ \\
\hline $22 / 06 / 10$ & 5 & Cesar Rancheira (Colômbia) & $\begin{array}{l}\text { Concessão onerosa de US\$ } 125 \\
\text { milhões (R\$ } 223,9 \text { milhões, média de } \\
\left.\mathrm{R} \$ 17,8 \mathrm{mil} / \mathrm{km}^{2}\right) \text {. }\end{array}$ \\
\hline $20 / 03 / 12$ & 2 & Campos (BM-C-37, BM-C-38) & $\begin{array}{l}\text { Aumentou de } 50 \% \text { para } 70 \% \text { sua } \\
\text { participação ( } 30 \% \text { Maersk), sem valor } \\
\text { informado. }\end{array}$ \\
\hline $26 / 11 / 12$ & 2 & $\begin{array}{l}\text { Santos (bloco BS-4, com dois } \\
\text { campos: Atlanta e Oliveira) }\end{array}$ & $\begin{array}{l}\text { Comprou } 40 \% \text { da PETR (30\% QGEP, } \\
30 \% \text { Barra Energia) por R\$ } 575 \\
\text { milhões (US\$ } 270 \text { milhões) }\end{array}$ \\
\hline $\begin{array}{c}14 \mathrm{e} \\
15 / 05 / 13\end{array}$ & 13 & $\begin{array}{l}\text { Paranaíba, Barreirinhas, CE, } \\
\text { Potiguar e Foz do Amazonas }\end{array}$ & $\begin{array}{l}\text { 11' Rodada ANP por R\$ } 376 \text { milhões } \\
\text { (US\$ } 188 \text { milhões) em BA e R\$ } 698 \\
\text { milhões (US\$ } 349 \text { milhões) em PEM. }\end{array}$ \\
\hline Total & 51 & & \\
\hline
\end{tabular}

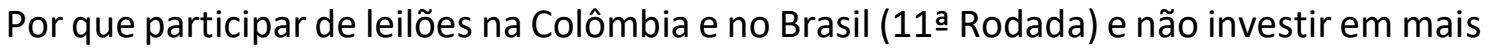
farm-ins com outras operadoras em blocos com a exploração mais avançada? Ou seja, os Gestores poderiam ter preservado Valor de Mercado se a gestão da campanha exploratória tivesse sido mais conservadora como inicialmente planejado? A RJ poderia ter sido evitada se a campanha tivesse sido mais focada e seletiva em Campos onde a PSE era a maior (33\%) e onde dois poços já iniciavam produção (TBAZ e Tubarão Martelo ("TBMT")? Enfim, uma gestão mais focada, conservadora, menos dispersa poderia ser contra intuitiva para a personalidade arrojada (ou temerosa do fracasso) do AC e pelo menos parte dos Executivos, mas poderia ter viabilizado uma campanha mais longa e talvez mais eficaz.

A maneira e intensidade da implementação da campanha exploratória sugere uma terceira conjectura com potenciais implicações analíticas e regulatórias mais relevantes para a credibilidade dos mercados de capitais no Brasil e a financiabilidade de futuros projetos greenfield. Os Executivos teriam envidado significativos esforços técnicos e financeiros, mas dada a estrutura de incentivos, objetiva e subjetiva, em que estavam inseridos, não teriam atuado de maneira ótima na gestão e supervisão da campanha exploratória. 
Os Executivos, com endosso tácito e/ou explícito do AC e do COAD, construíram uma ampla Agenda de Catalisadores para sustentar um guidance otimista por anos, que buscava sobrevalorizar a Tese de Investimentos, mas que posteriormente comprometeu a credibilidade de uma possível mudança na gestão, como defendida na solicitação da RJ. Os Executivos e o AC teriam adotado a arriscada conduta do "tudo ou nada", como caracterizado por GASPAR [2014].

Entretanto, se os Executivos promoveram um guidance otimista com repercussões operacionais e financeiras nefastas, os "gatekeepers" internos (AC, COAD) e externos (analistas de buy e sell-side, analistas de crédito, agências de risco, auditores independentes, appraisers, bancos de investimentos e reguladores) por sua vez, podem não ter cerceado tal comportamento e até atuado de forma a complementá-lo. Gatekeepers, de maneira intencional ou não, podem ter falhado em alertar investidores e financiadores que a Tese de Investimentos, a eficácia da gestão e da governança corporativa da OGX estavam comprometidas.

Do lado da demanda final pelo guidance, os investidores, financiadores e fornecedores, nacionais e estrangeiros, também expostos aos seus próprios incentivos, podem também ter contribuído para reforçar a atuação dos Executivos. Parte dos investidores pode ter lucrado com o guidance otimista, implementando estratégias de momentum trade $^{43}$ e/ou day trade com uso de informações privilegiadas ou falsas. Outros investidores na OGXP3, financiadores e fornecedores podem ter agido passivamente ao não executar suas análises com a necessária diligência. Dentre estes, podem ter havido aqueles que confiaram no poder de análise e monitoramento dos grandes bancos e fundos de investimentos envolvidos com a OGX e outras empresas do Grupo X. Todos estes grupos de pessoas físicas e jurídicas envolvidos direta e/ou indiretamente com a evolução da Tese de Investimentos, com a oferta e demanda pelo guidance e sua interpretação denominaremos doravante de "Stakeholders".

43 “Estratégias de momento baseiam-se na premissa que ações que performaram bem no passado irão continuar a performar bem em período de curto a médio prazo. De forma contrária, ações que tiveram um desempenho inferior manterão sua tendência" [TEMPLE, 2018, p. 11]. 
Figura 3 - Stakeholders Direta e/ou Indiretamente Relacionados ao Guidance e a Tese de Investimentos

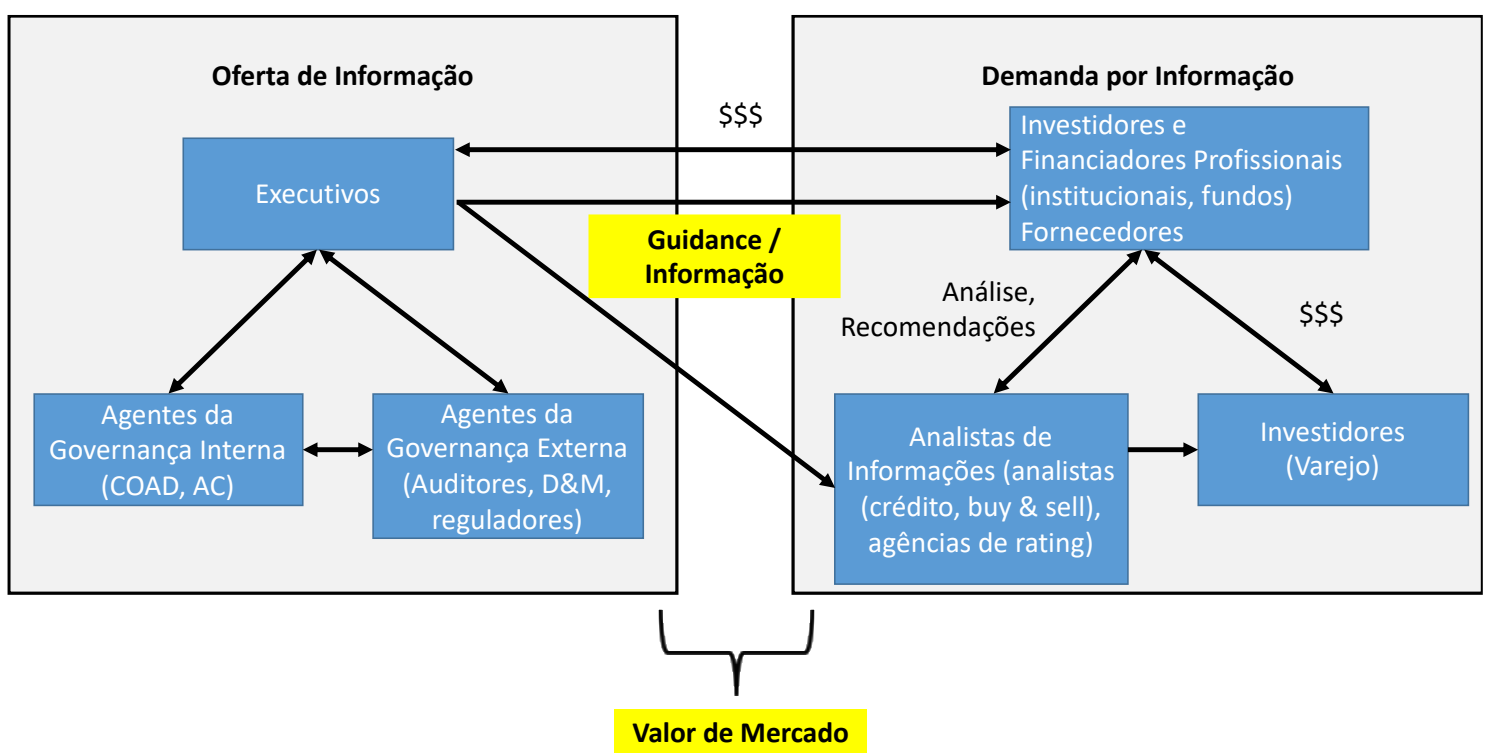

Fonte: adaptado de HEALY \& PALEPU [2003, p. 13]

Vale destacar que o escopo de agentes econômicos envolvidos direta ou indiretamente na geração de valor da OGX é muito mais amplo do que os Stakeholders. Essa ampla gama de agentes ilustra a complexidade dos desafios que a presente pesquisa encontrou e a necessidade de limitar seu escopo sob pena de nunca completá-la.

Figura 4 - Agentes Possivelmente Envolvidos na Geração e Destruição de Valor da OGX

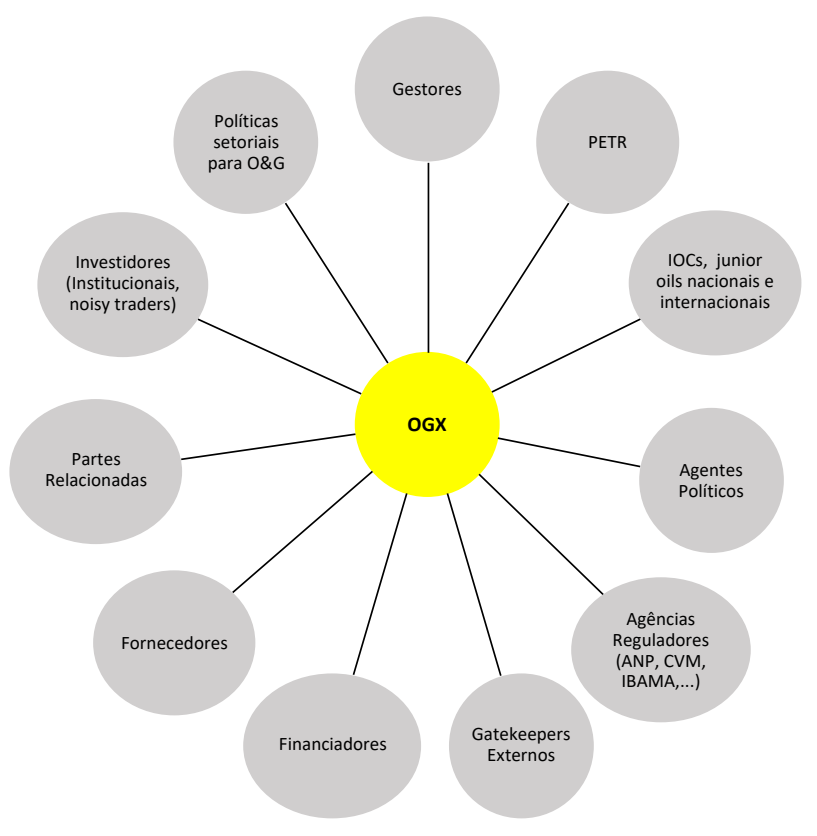


Em suma, nesta outra conjuntura, a combinação entre os sistemas de incentivos nos quais os Stakeholders, ofertantes e demandantes de informações estavam inseridos, e a evolução do Valor de Mercado, formaram dinâmicas que promoveram, ou pelo menos não cercearam, a gestão ineficaz da OGX ("Terceira Conjuntura"). Trata-se de uma conjectura muito mais complexa, porém não maniqueísta, ou até ingênua, do que as outras duas.

$\mathrm{Na}$ Terceira Conjectura, muitos Stakeholders perderam e outros ganharam. Em particular, dentre os perdedores podem ter havido investidores e financiadores com horizonte de mais longo prazo e maior tolerância ao risco exploratório ("Investidores de Longo Prazo"). As perdas dos Investidores de Longo Prazo geradas por falhas nas governanças, podem ter gerado externalidades negativas que limitariam a capacidade de novos greenfields em captar recursos. Esta Terceira Conjectura é objeto deste estudo e a base de investigação para possíveis respostas às Questões de Pesquisa. 
"[N]o dia em que achar que as minhas companhias estão com preços inflados na bolsa, eu mesmo enfio o dedo nessa bolha".

AC em entrevista ao Valor Investe em setembro de $2010^{44}$.

Dado o amplo espectro de Stakeholders envolvidos e a disponibilidade de informações públicas, a presente pesquisa sobre a Terceira Conjuntura foca na atuação de um subgrupo de Stakeholders: Executivos, AC e Analistas. Portanto, a pretendida comprovação da Terceira Conjectura é limitada.

A tese central a ser investigada no presente estudo é que um dos principais vetores de geração e destruição de valor da OGX foram os incentivos e as circunstâncias em que os Executivos, AC e Analistas estavam inseridos.

A CVM [2002, p. 2] define governança corporativa como:

(...) o conjunto de práticas que tem por finalidade otimizar o desempenho de uma companhia ao proteger todas as partes interessadas, tais como investidores, empregados e credores, facilitando o acesso ao capital. A análise das práticas de governança corporativa aplicada ao mercado de capitais envolve, principalmente: transparência, equidade de tratamento dos acionistas e prestação de contas (...) Quando investidores financiam companhias, eles sujeitamse ao risco de apropriação indevida, por parte de acionistas controladores ou de administradores da companhia, de parcela do lucro do seu investimento. [grifo nosso].

A "apropriação indevida" que a CVM se refere faz parte do risco moral da relação Principal-Agente. Neste sentido, Governança corporativa é constituída por incentivos punitivos e motivacionais que moldam os comportamentos dos agentes nela inseridos: executivos, membros do Conselho de Administração, acionistas majoritários e minoritários. Os comportamentos destes agentes são sintomas da estrutura de governança. Estes comportamentos produzem ações, reações, eventos.

A estrutura de governança, que definia e limitava incentivos aos Executivos e AC, era composta por quatro elementos dispostos em camadas do macro para o micro ("Estrutura de Governança"). Primeiro, na camada superior, o arcabouço legal e regulatório no Brasil e outras jurisprudências em que a OGX operava. O arcabouço legal brasileiro inclui o mercado de capitais, Novo Mercado, o código civil, o setor de O\&G,

44 RAGAZZI, A.P. "Prejuízo com ações do grupo EBX estava embutido no risco", Jornal Valor Econômico, Disponível em: https://www.valor.com.br/empresas/3199170/prejuizo-com-acoes-do-grupo-ebxestava-embutido-no-risco. Acesso em 11/12/18. 
meio ambiente, etc. Em segundo, as participações societárias majoritárias do AC tanto na OGX quanto em Partes Relacionadas que teriam relações comerciais e societárias entre si. Soma-se à estas relações o fato do AC ter avalisado empréstimos e ter aportado capital nestas empresas. Terceiro, a estrutura de gatekeepers internos e externos: COAD; auditores (KPMG, E\&Y, dentre outros e avaliadores (D\&M); Analistas. Cabe destacar que a composição dos Conselhos de Administração das empresas do Grupo X, onde executivos da OGX foram conselheiros de Partes Relacionadas e vice-versa. Por fim, os SOP OGX e o SOP AC.

Figura 5 - Estrutura de Governança da OGX

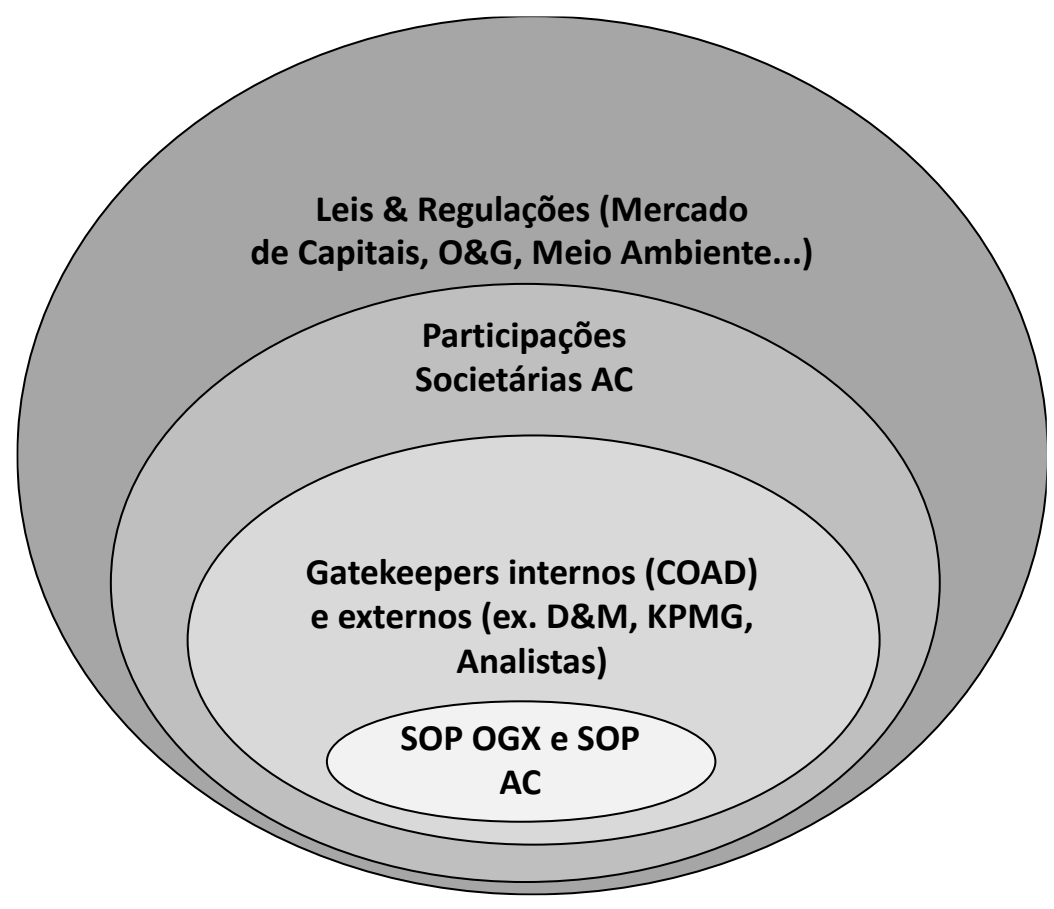

A princípio, a Estrutura de Governança tinha potencial para ser virtuosa. A participação societária significativa do AC e sua atuação operacional, como principal, nos Conselhos de Administração e, por vezes, até em cargos executivos, poderia reduzir assimetrias de informação com seus agentes, os executivos. Adicionalmente, a atuação do AC e seus principais executivos nos Conselhos de Administração poderia propiciar a identificação de sinergias estratégicas, operacionais e financeiras entre Partes Relacionadas. Os SOPs baseados em opções de compra de ações de empresas de capital aberto, a princípio, também poderiam ser poderosos elementos de alinhamentos entre principal e agentes. A elevada liquidez da OGXP3 poderia sinalizar rapidamente aos Gestores as percepções dos investidores minoritários sobre a eficácia da implementação operacional e financeira da campanha exploratória.

Entretanto, esta complexa Estrutura de Governança operou em circunstâncias extraordinárias que produziram efeitos nefastos no médio prazo. Estas circunstâncias incluíram momentos de sobre e subavaliação da OGXP3, que podem ter gerado um 
fenômeno o qual JENSEN [2005] denominou de "heroína organizacional e gerencial" ("Heroína Organizacional").

Perplexo com as bolhas das ações de empresas de internet, tecnologia e telecomunicações do final da década de $1990^{45}$, e os inúmeros escândalos corporativos do início do século ${ }^{46}$, que geraram bilhões de dólares de prejuízos, JENSEN [2005] analisou o ciclo vicioso que pode se criar quando as ações de uma empresa se tornam sobrevalorizadas ${ }^{47}$ :

[P]or definição, uma ação sobrevalorizada significa que a empresa não poderá entregar, exceto por pura sorte, a performance que justificaria seu valor [JENSEN, 2005, p. 5].

Vários autores ${ }^{48}$ entendiam que os mercados financeiros, capital e financiamentos, como potenciais forças que diminuiriam os custos de agência. Entretanto, os significativos custos de agência materializados em escândalos corporativos indicam que quando as ações estão sobrevalorizadas, os mercados financeiros podem atuar exacerbando o conflito entre principal e agente. Os mercados financeiros, junto com gestores de recursos (otimistas e por vezes, iludidos), podem viabilizar e exacerbar condutas destruidoras de valor. Gatekeepers, como executivos das empresas investidas, Conselho de Administração, analistas de ações, auditores, bancos de investimentos, bancos comerciais e escritórios de advocacia contribuiriam para manipulações e desinformações que alimentaram as sobrevalorizações.

Um vetor importante no círculo vicioso e perverso da supervalorização é a remuneração por metas. Na remuneração por metas, os executivos e outras partes envolvidas, incluindo gatekeepers, não são remunerados pelo o que fazem em si, mas pelo que fazem em relação a uma meta. Gerentes são penalizados se não atingem suas metas operacionais. CEOs e CFOs são penalizados se não atingem as projeções operacionais e financeiras divulgadas aos analistas. Então se cria incentivos em manipular as metas e as estratégias para atingi-las, "jogando com o sistema" ("gaming the system").

Geralmente, a única maneira que os executivos têm para atingir ou superar suas metas ano após ano é manipular os números ("cook the numbers") e ocultar as incertezas inerentes aos negócios da empresa. A "gestão dos lucros" ("earnings management") se espalhou pelo mundo corporativo podendo até ter se tornado uma rotina ${ }^{49}$. Essa manipulação não pode ser feita sem comprometer o valor da empresa, pois além de mentir ao principal e aos outros gatekeepers, os executivos podem estar tomando

\footnotetext{
${ }^{45}$ MILLER, WELLER \& ZHANG [2002] relatam que o S\&P 500 aumentou 360\% em relação ao vale observado no crash de 1987 (330 pontos em agosto de 1987) para 1.500 em agosto de 2000, para depois cair para 1.100 pontos em agosto de 2001.

${ }^{46}$ Enron, Xerox, Worldcom, Global Crossing, Vodafone, Nortel, HealthSouth, Lucent, Tyco, Royal Dutch Shell, Consumer Associates e outros.

47 Embora não seja objeto do presente estudo investigar suas causas, é importante notar que as sobrevalorizações do final da década de 1990 e início do século XXI, seguidas de derrocadas, não são eventos inéditos. Segundo JENSEN [2005], a sociedade parece sobrevalorizar o novo e assim o fez com as ferrovias, automóveis, telefones, canais e etc...

${ }^{48}$ Entre eles, JENSEN \& MECKLING [1976].

${ }^{49}$ GRAHAM, HARVEY \& RAJGOPAL [2005, 2006]; GLATER [2005].
} 
decisões operacionais que não seriam as melhores para a empresa no longo prazo. Mentiras geram outras mentiras e assim avançam. O reconhecimento de receitas futuras antecipadas e despesas futuras postergadas em algum momento precisaram ser reconhecidas e ajustadas. A destruição de valor no médio longo prazo se dará de várias maneiras, incluindo a destruição da reputação da empresa e seus executivos.

Ao estudar os casos da Enron e das empresas de internet durante a "bolha da internet/tecnologia/telecomunicações" no fim dos anos 90 e início do século XXI, JENSEN [2005], notou que nos primeiros estágios de um ciclo de sobrevalorização, executivos e conselheiros estão recebendo sinais distorcidos de mercado. JENSEN associou a força destes sinais à heroína. No começo, o CEO, CFO podem se sentir muito bem. Tornam-se celebridades e os investidores os adoram, seus SOPs estão se valorizando e o mercado de capitais demonstra estar à sua disposição. Entretanto, como todo drogadito sabe: o custo do vício só aumenta com o tempo e o final não é feliz.

A questão central é que se a ação está sobrevalorizada, exceto por pura sorte, não é possível sustenta-la. Os executivos começam a perceber que se não satisfizerem as expectativas do mercado, o mercado será impiedoso. Então, os executivos começam a agir visando resultados de curto prazo, mesmo em detrimento da sustentabilidade da empresa no longo prazo. Por exemplo, os executivos podem captar recursos no mercado de capitais para fazer aquisições e/ou investimentos arriscados, porém com alto retorno potencial, mas que oferecem ao mercado a percepção que a empresa está crescendo e os resultados virão com o tempo. Aumentam gastos internos, distorcem práticas contábeis até chegar ao extremo de promover fraudes contábeis. JENSEN [2005] denominou esta dinâmica de "fator medo" ("fear fator"), embora alguns autores ${ }^{50}$ denominaram de "otimismo gerencial" ("managerial optimism").

Os executivos agem desta maneira destrutiva, postergando o inevitável encontro com a realidade, na esperança que até este dia chegar, ou alguma solução surgirá (sorte pura), ou estes executivos já podem ter deixado a empresa e liquidado seu SOP. No contexto de ações sobrevalorizadas, sistemas de remuneração variável para os executivos, tipo SOP, funciona como "jogar gasolina na fogueira".

A trágica ironia do ciclo de ações sobrevalorizadas é que, na realidade, parece não ser factível aos executivos agirem de outra maneira. Ou será que algum CEO relatará ao Conselho de Administração que acredita não ser possível crescer com rentabilidade para justificar o valor das ações? O Conselho de Administração pode muito bem responder substituindo-o por outro profissional que afirme ser capaz de atingir as metas. Se a sobrevalorização atinge também outros concorrentes ou empresas relacionadas, como ocorreu na bolha da internet/tecnologia/telecomunicações, a posição do CEO é ainda mais difícil.

JENSEN [2005] alerta que os custos de agência gerados por ações sobrevalorizadas também se observam em projetos greenfield, viabilizados em momentos de alta liquidez nos mercados de capitais. Este pode ter sido o caso da OGX, que pode ter sido ainda agravado pelo fato de a OGXP3 ter entrado na composição do índice BOVESPA ("IBOV")

${ }^{50}$ HEATON [2002]; EFENDI, SRIVASTAVA \& SWANSON [2004]. 
ao fim de 2009. Para gestores de fundos de ações que utilizavam o IBOV como parâmetro de performance, mesmo não acreditando nos fundamentos da Empresa, tinham de comprar a OGXP3 para evitar o detracking risk. Em 24/11/2011, por exemplo, a OGXP3 chegou a responder por 6,56\% do IBOV.

Gráfico 2 - Evolução da Participação da OGXP3 no IBOV (em \%) de 2010 a 2013

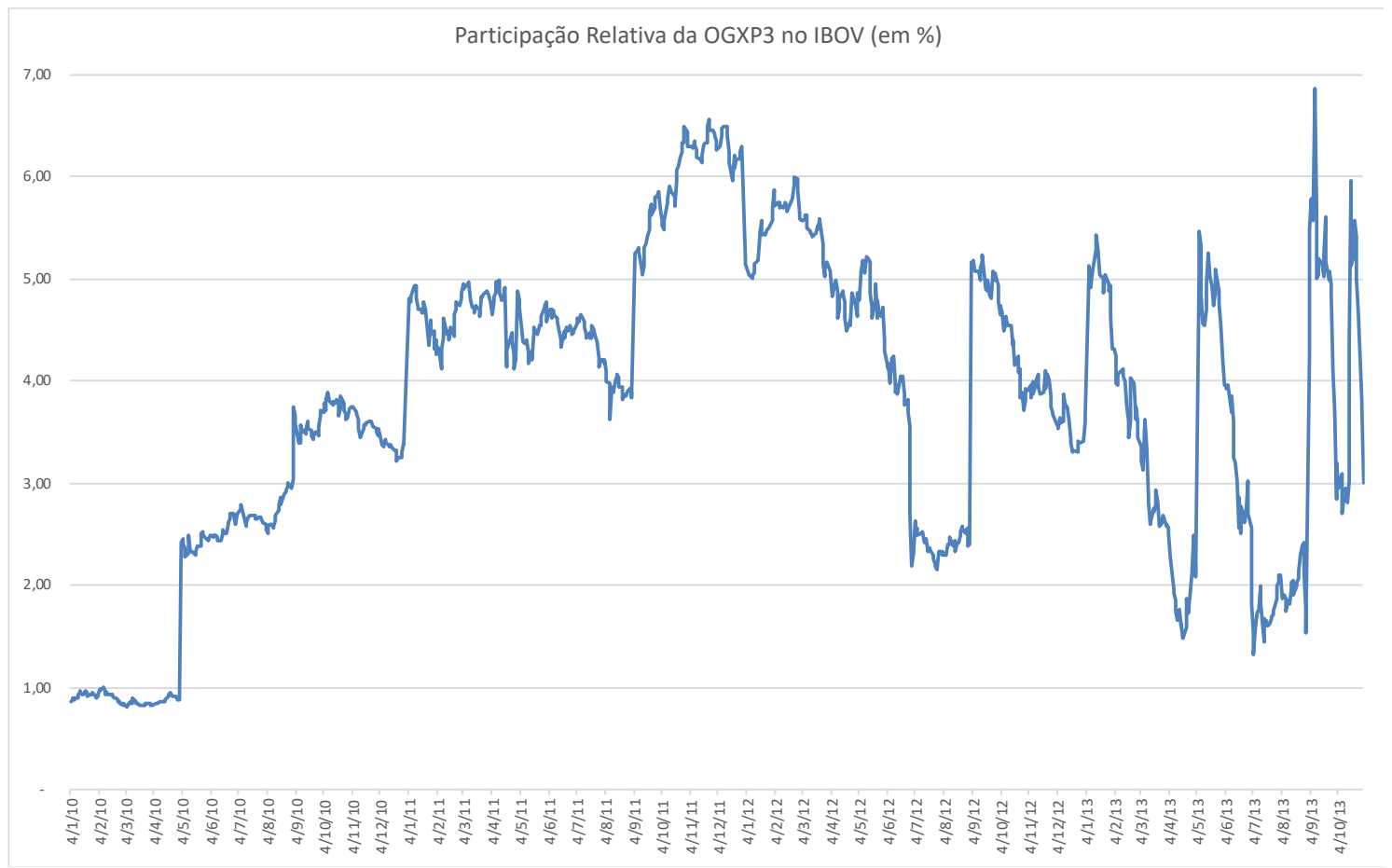

Em suma, sobrevalorizações, combinadas com incentivos por metas, podem levar executivos, capturados pela Heroína Organizacional, tomar decisões destruidoras de valor ("Condutas de Valor"): manipular as metas e as estratégias para atingi-las; ocultar as incertezas inerentes aos negócios da empresa; tomar decisões operacionais que visam o curto prazo em detrimento do longo prazo; postergar despesas futuras (por exemplo, write-offs); captar recursos no mercado de capitais para fazer aquisições e/ou investimentos arriscados, porém com alto retorno potencial, mas que oferecem ao mercado a percepção que a empresa está crescendo e os resultados virão com o tempo; aumentar gastos internos.

Em outra classificação, TIROLE [2006] identifica como comportamentos próprios de estruturas disfuncionais de governança: investimentos ineficazes e/ou extravagantes; 
esforços insuficientes na gestão operacional, financeira e de riscos, controles, custos; entrincheiramento ${ }^{51}$; self-dealing legais e ilegais ${ }^{52}$. São todas Condutas de Valor.

Outra característica das Condutas de valor é que em um primeiro momento elas são eficazes em valorizar o valor da empresa no mercado. Os investidores acreditam nas informações e interpretações dos executivos. Mas esta eficácia é temporária. A destruição de valor no médio longo prazo se dará de várias maneiras, incluindo a destruição da reputação da empresa e seus executivos.

Uma das manifestações públicas destas Condutas de Valor é o guidance otimista e seus efeitos internos e externos à empresa. É interessante destacar a ambivalência do guidance otimista: em análise superficial, pode ser interpretado como arrojo, autoconfiança, mas há também o medo (fear factor) de falhar e ser desacreditado.

Gatekeepers internos e externos à empresa, como conselhos de administração, acionistas controladores, auditores, consultores, agências de rating, analistas de investimentos, bancos, que também ganham com a sobrevalorização e perdem com a subvalorização, também podem reforçar as manipulações dos executivos se não agirem com diligência e isenção, corroborando com a Conduta de Valor dos executivos.

Portanto, na pesquisa sobre a Terceira Conjuntura, a tese central do presente estudo é que há indícios que um dos principais vetores de geração e destruição de valor da OGX foram os efeitos da Heroína Organizacional: a Estrutura de Governança, em momentos de sobre e subavaliações da OGXP3, sobre o guidance, construído pelos Executivos, com endosso tácito ou explícito do AC. Para sustentar o guidance otimista, os Executivos implementaram Condutas de Valor ao construir uma ampla Agenda de Catalisadores de uma intensa, dispersa campanha exploratória e, como tal, de elevado risco, com implicações de curto e médio prazo para a liquidez e credibilidade da Empresa. Há indícios também que parte dos Analistas, por sua vez, atuando direta ou indiretamente como interlocutores entre os investidores e os Executivos endossaram, ou não se contrapuseram, o guidance otimista por anos. Indícios da ocorrência da Heroína Organizacional e seus efeitos sobre as Condutas de Valor de Executivos, AC e Analistas formam a tese central do presente estudo ("Tese Central").

Durante o processo de pesquisa, o presente estudo identificou indícios sobre as possíveis motivações de outros Stakeholders. São eles: agentes de governança interna (COAD) e externa (auditores independentes e bancos de investimento). Estas evidências são abordadas, porém superficialmente, devido à disponibilidade de informações e/ou tempo para investiga-las com a devida profundidade.

51 Estratégias de entrincheiramento incluem: investimentos em produtos ou tecnologias que os executivos dominam e, portanto, aumentam o valor de sua retenção; manipulações contábeis ou do valor de mercado para superestimar sua performance.

52 Self-dealings podem ser legais, como por exemplo, benefícios excessivos (jatos executivos, obras de arte, despesas extravagantes com jantares e entretenimento...); escolha de amigos, familiares e/ou seguidores (salas de eco) para posições executivas, ou ainda, isolamento executivos com posições divergentes; contratação de fornecedores caros por amizade ou reciprocidade pessoal. Mas também há self-dealing ilegais que podem incluir o uso de informação privilegiada, venda de ativos abaixo do valor de mercado para empresas relacionadas indiretamente aos executivos, roubos. 
Também devido à falta de informações, o presente estudo não abordará com a devida profundidade a atuações de outros Stakeholders: fornecedores, agências de rating, analistas de crédito e de buy-side. Em relação aos investidores e financiadores, o presente estudo também enfrenta limitações consideráveis. Não há informações públicas disponíveis sobre os tipos de investidores envolvidos (institucionais, hedge funds, gestores de fundos, indivíduos, etc.) e suas estratégias. Mesmo a análise da atuação dos reguladores (CVM, ANP, SEC, dentre outros) também é limitada e merece estudos dedicados. 


\subsection{Organização}

Dentre as possíveis abordagens para investigar a Tese Central, seus efeitos sobre o Valor de Mercado e responder às Questões de Pesquisa, o presente estudo tem como ponto de partida a análise da evolução da Tese de Investimentos e do guidance. A abordagem coleta evidências e indícios das Condutas de Valor que sustentam a tese da ocorrência da Terceira Conjectura.

O capítulo 2 descreve a abordagem, conceitos, indicadores e dados utilizados para investigar a Tese Central e responder às duas primeiras Questões de Pesquisa. O capítulo também apresenta uma possível classificação histórica para a evolução do Valor de Mercado entre o IPO (junho/2008) e o pedido de RJ (outubro/2013) em seis subperíodos. Esta classificação é usada para identificar possíveis reflexos do guidance no Valor de Mercado e vice-versa. O capítulo 2 apresenta também as premissas que indicam que houve momentos de sub e sobrevalorização da OGXP3, suas possíveis causas e consequências para o guidance e a implantação da campanha de E\&P e a reação (quantitativa) dos Analistas.

O capítulo 3 descreve, em ordem cronológica ao longo dos seis subperíodos, a evolução da Tese de Investimentos, Agenda de Catalisadores, Valor de Mercado e a interpretação e reação de alguns Analistas sobre o guidance dos Executivos e AC. A cronologia busca capturar parte do zeitgeist e fornece indícios sobre a dinâmica da Heroína Organizacional e as Condutas de Valor que em um primeiro momento contribuíram para a apreciação do Valor de Mercado, mas posteriormente o comprometeu.

Com base nos indícios coletados no capítulo precedente, os capítulos 4 e 5 buscam responder à Primeira e Segunda Questão de Pesquisa, respectivamente. As repostas às duas primeiras Questões de Pesquisa produzem elementos que podem contribuir para responder a terceira Questão de Pesquisa.

O capítulo 5 investiga com maiores detalhes os indícios de ineficácia da Estrutura de Governança que podem ter comprometido a geração do Valor Ótimo ao não impor limites à gestão operacional, financeira e comprometer relação de confiança entre Gestores e os investidores. Estes indícios se referem a Condutas de Valor e conflitos de interesse de três Stakeholders cruciais: Executivos; o AC, incluindo as relações com Partes Relacionadas; e o COAD. A análise da evolução dos possíveis conflitos de interesse dos Executivos, AC e COAD é complementada com informações e depoimentos coletadas por jornalistas do JVE, Wall Street Journal, The Economist, Financial Times. Utilizamos também os autos dos processos contra os Executivos, COAD e AC.

O capítulo 6 dedica-se a considerações finais e busca identificar elementos que possam responder a terceira Questão de Pesquisa. A terceira Questão de Pesquisa merece estudos muito mais aprofundados do que o presente estudo oferece, por isso podem compor temas para futuras pesquisas.

O Anexo descreve conceitos e metodologias básicas para se estimar o valor de empresas de O\&G. O Anexo também descreve algumas evidências empíricas sobre a relevância destes conceitos para explicar o valor de mercado de empresas de O\&G. 
Qual é a relevância das Questões de Pesquisa? Podemos identificar quatro aspectos que justificariam a relevância do presente estudo: (1) crescente participação da indústria de petróleo na economia brasileira; (2) necessidade de financiamento a investimentos em infraestrutura e greenfields; (3) políticas de fomento à indústria de equipamentos de O\&G e seus efeitos; (4) regulação e desenvolvimento da indústria de GN no país.

Na época do IPO da OGX, em 2008, a bacia de Campos concentrava praticamente toda a produção de O\&G do país, enquanto o potencial de Santos era uma incógnita. Hoje, o petróleo no pré-sal de Santos é uma realidade com participação significativa na produção de O\&G. Em 2017, o Brasil produziu uma média de 2,62 mbpd, sendo 49\% em Campos e 45\% em Santos. Entre 2010/17, a produção de óleo em Campos decresceu 4,9\% ao ano, em média, enquanto em Santos cresceu 50,8\% ao ano. Da média de 2,62 mbpd de óleo de $2017,49 \%$ (1,29 mbpd) veio do pré-sal, sendo $87 \%$ de Santos e $13 \%$ de Campos.

Financiar projetos de E\&P de O\&G no pré-sal brasileiro representa significativa oportunidade para o país, já refletida nos resultados das últimas rodadas de licitações da ANP. Apenas nos seis leilões dos últimos onze meses (entre outubro de 2017 e setembro de 2018), 18 empresas investiram $R \$ 27,96$ bilhões na aquisição de 105 blocos exploratórios, sobretudo nas bacias de Santos e Campos ${ }^{53}$. Em contraste, nas quatorze Rodadas de licitações que a ANP conduziu entre junho de 1999 e setembro de 2017, o total de Bônus de Assinatura ("BA") somou R\$ 12,39 bilhões.

Dentre os investidores dos últimos seis leilões destacam-se a: Exxon ( $R \$$ 8,71 bilhões), PETR (R\$ 6,22 bilhões), Shell (R\$ 2,81 bilhões), Equinor (Statoil, com R\$ 2,38 bilhões), Qatar Oil (R\$ 2,24 bilhões), Chevron (R\$ 1,90 bilhão), British Petroleum (R\$ 1,47 bilhão), Petrogal (R\$ 1,08 bilhão). Excluindo a PETR, os investidores nacionais tiveram participação tímida: Queiroz Galvão E\&P (“QGEP") com R\$ 35 milhões, e Imetame com $\mathrm{R} \$ 3$ milhões. Ou seja, exceto pela PETR, aparentemente, empresas brasileiras de O\&G de menor porte não conseguiram participar da nova onda de investimentos no pré-sal, possivelmente devido às dificuldades de captar recursos financeiros.

Além das junior oils nacionais, haverá também demanda por investimentos em infraestrutura logística e portuária relacionada a E\&P de O\&G. O recente edital do jornal Valor Econômico ${ }^{54}$ resume o desafio de viabilizar investimentos em infraestrutura no Brasil:

O Brasil, nona maior economia do mundo, está em 73 lugar em infraestrutura em ranking de 137 países elaborado pelo Fórum Econômico Mundial. Fica atrás de países vizinhos como o Chile, e

\footnotetext{
53 O total de investimentos se refere aos bônus de assinaturas ("BA") pagos nas 14a e 15a Rodadas de concessões e 2aㅡ, 3aㅡ, 4a e $5 \underline{a}$ - Rodadas de partilha do pré-sal [RAMALHO et al., 2018].

54 “Destravar a infraestrutura é vital para a retomada", p. A12, 25/09/2018.
} 
Uruguai e de alguns de seus principais parceiros comerciais, como a China.

(...) Nos primeiros 12 anos deste século, a média anual de investimento em infraestrutura ficou em $2,14 \%$ do PIB, segundo a consultoria Inter.B. (...) Em 2017, ficou em 1,69\% (...) Os valores deveriam ser muito maiores. Calcula-se que seria necessário investir o equivalente a 2,38\% do PIB apenas para compensar a depreciação dos ativos $e$ manter a qualidade dos serviços. Já para modernizar a infraestrutura do país, o percentual deveria atingir $4,15 \%$ do PIB ao ano, ao longo de duas décadas, estima o IPEA.

(...) O investimento brasileiro em infraestrutura estagnou. Um dos principais motivos é a velha dependência das fontes públicas de recursos. O setor público chegou a responder por 55,8\% do capital injetado na infraestrutura em 2009 e, recuou, desde então, encolhendo para cerca de um terço.

Há relatos de parte envolvida no IPO da Ômega Energia em 2017 que houve dificuldades em precificar os projetos greenfield. O portfólio da Ômega de ativos de geração de energia renovável era composto de ativos já geradores de caixa (brownfields) e greenfields. Entretanto, segundo estes relatos, os investidores aceitaram precificar apenas os ativos brownfields, e levaram os projetos greenfield de graça, como prêmio de risco adicional. A parte envolvida no IPO associou a dificuldade em precificação dos projetos greenfield com o efeito na reputação gerado pela OGX.

Portanto, as possíveis respostas às Questões de Pesquisa podem vir a contribuir para a captação de recursos financeiros para viabilizar não apenas empresas de E\&P de O\&G, mas também para outros recursos minerários, infraestrutura e greenfields em geral no Brasil. 


\section{Abordagem à Tese Central}

Este capítulo apresenta conceitos, metodologias e a base de dados utilizados para defender a Tese Central. A primeira seção (2.1) apresenta e discute quatro conceitos de valor econômico financeiro da OGX: Valor de Referência; os PAs; Valor Ótimo; e Valor de Mercado. Estes quatro conceitos de valor possuem virtudes e limitações, mas a articulação destes produz indícios que sustentam a Tese Central, bem como suas repercussões para responder as Questões de Pesquisa.

A segunda seção (2.2) apresenta uma possível classificação da evolução do Valor de Mercado no período que antecede o IPO, em junho de 2008, até a requisição da RJ, em outubro de 2013. São seis subperíodos utilizando conceitos de Análise Técnica. Esta divisão permite articular os PAs, Valor de Mercado os possíveis efeitos da Agenda de Catalisadores (de-risking do portfólio [incluindo reclassificações de recursos e o rampup da produção], opções de crescimento, captações de recursos [financiamentos e capital de risco]) e de vetores críticos de valor (gestão do caixa, credibilidade dos Executivos e AC, preço do petróleo e custo de capital).

Com base nos Valores de Referência e Valor de Mercado, a terceira seção (2.3), identifica os períodos onde há indícios que a OGXP3 foi sobre e subavaliada. Por fim, a seção (2.4) aborda o tema Sentimento de Mercado e suas possíveis repercussões para a evolução da percepção de valor da OGX. Sentimento de Mercado é um tema tão importante quanto complexo e o presente estudo o aborda de maneira superficial.

Por fim, a seção (2.5) descreve suscintamente os principais conceitos de sistemas dinâmicos, que podem contribuir para compreender as dinâmicas de geração e destruição de valor da OGX. 


\subsection{Quatro Conceitos de Valor Econômico Financeiro da OGX}

\subsubsection{Valor de Referência}

Dentre os gatekeepers envolvidos com a OGX, a D\&M ocupava papel central na sustentação ou fragilização da Tese de Investimentos. Com décadas de experiência na avaliação de riscos geológicos de prospectos no Brasil e no exterior e uma reputação a zelar, a D\&M teria vantagens competitivas para estimar o Valor Ótimo da OGX.

No complexo de de-risking do portfólio da OGX, a D\&M elaborou três appraisal reports, ou relatórios de avaliação ("Relatórios de Avaliação"): março de 2008 ("10 D\&M", utilizado no IPO), setembro de 2009 (“2으M") e abril de 2011 (“3으 D\&M"). Estes Relatórios de Avaliação foram temas cruciais na evolução da Tese de Investimentos e objeto de intensas discussões entre os Executivos, investidores e Analistas.

Nos Relatórios de Avaliação, a D\&M estimou o volume recuperável de O\&G do portfólio da OGX e os classificou em categorias com decrescentes graus de incerteza e viabilidade comercial, descrito em detalhes no Anexo. Estes relatórios, além de estimar o volume de O\&G recuperável do portfólio de concessões e classifica-los em categorias de prováveis sucesso, quantificava também seu valor presente líquido utilizando parâmetros médios da indústria de O\&G ("Valor de Referência").

Tabela 14 - Evolução dos Valores de Referência

\begin{tabular}{|l|r|c|c|c|}
\hline Relatórios & Publicação & $\begin{array}{c}\text { VPL médio } \\
\text { (US\$ Milhões) }\end{array}$ & $\begin{array}{c}\text { RPL } \\
\text { (bboe) }\end{array}$ & $\begin{array}{c}\text { \% 1 } \\
\text { D\&M }\end{array}$ \\
\hline 10 D\&M & junho/08 & 23.367 & 4,835 & $100,00 \%$ \\
\hline 20 D\&M & novembro/09 & 33.271 & 6,884 & $142,39 \%$ \\
\hline 3o D\&M & abril/11 & 52.198 & 10,800 & $223,38 \%$ \\
\hline
\end{tabular}

Ao longo dos três Relatórios de Avaliação, além da magnitude dos recursos ${ }^{55}$, a composição do portfólio da OGX se alterou. Vale destacar que dada a intensidade da campanha exploratória, os Executivos e AC frequentemente consideravam que o Valor de Referência do último relatório da D\&M estaria desatualizado ao desconsiderar novas informações coletadas desde sua publicação.

A categoria mais incerta, Recursos Prospectivos ("untapped resources", ou ainda, "recursos potenciais") são identificados através de testes sísmicos, porém ainda não

55 O termo "recursos" se refere a todas as quantidades de petróleo na crosta da Terra, descobertas e não descobertas (recuperáveis e não recuperáveis). Inclui todos os tipos de petróleo convencional e não convencional. Areia betuminosa, gás de xisto são exemplos de petróleo não convencional, que pode ser extraído com o uso de tecnologias diferenciadas. 
foram submetidas à perfuração. Essa definição implica que não há certeza que alguma parte dos recursos prospectivos seja descoberta e, se a for, não há certeza que sua produção seja viável economicamente. Os Recursos Contingentes, por sua vez, são quantidades de petróleo, de acumulações conhecidas, que podem ser potencialmente recuperáveis, entretanto ainda não são consideradas maduras o suficiente para desenvolvimento comercial devido a uma ou mais contingências, em uma determinada data. Recursos Contingentes podem incluir projetos que ainda não têm mercado, ou que requerem uma tecnologia ainda em desenvolvimento, ou ainda que a avaliação ainda não é suficiente para estimar a viabilidade comercial.

Já as Reservas são quantidades de petróleo que podem ser comercialmente recuperáveis dentro de certas premissas técnicas e comerciais, em uma determinada data. A proximidade dos prospectos com outras reservas já comprovadas é um diferencial, pois permite o read-across. Portanto, como descrito a seguir, em muitos momentos durante a campanha exploratória da OGX, as descobertas de Recursos Prospectivos e confirmações de Reservas de outras empresas de E\&P, próximas aos prospectos da Empresa, criaram expectativas sobre o seu Valor Ótimo.

Como descrito adiante, uma das grandes fontes de discussões sobre as estimativas de valor da OGX foi o significado das classificações utilizadas pela Empresa, pela D\&M e por outras referências (peers) utilizadas pelos Analistas. Por questões regulatórias, no Brasil, Recursos Contingentes podem ser interpretados como estimativas das reservas. $O$ conceito de "reserva" requer a "Declaração de Comercialidade", que por sua vez marca o fim do período de exploração e o início do período contratual da concessão de produção. Por isso, as empresas, geralmente, adiam a Declaração de Comercialidade até o momento que a produção efetivamente começará. Por vezes, quando o período de concessão está por terminar, empresas podem antecipar a Declaração de Comercialidade para não perder a possibilidade de desenvolver da área. Entretanto, após a entrega da Declaração de Comercialidade, a empresa tem prazos para apresentar e implementar o Plano de Desenvolvimento (“PD").

Para os Recursos Contingentes serem classificados como Reservas é preciso ter uma alta confiança na capacidade do reservatório produzir comercialmente, consubstanciada por testes de formação ou pela produção efetiva. Sem novas informações técnicas, não deve haver mudanças na distribuição e categorização dos recursos recuperáveis.

O tempo para iniciar o desenvolvimento de um projeto varia de acordo com seu escopo e com as circunstâncias. Apesar de recomendar benchmark de 5 anos, o SPE-PRMS reconhece que o período pode ser mais longo, se o produtor tiver esta opção. Nestes casos, o produtor pode aguardar condições de mercado mais favoráveis ou critérios estratégicos para iniciar o desenvolvimento do projeto. Entretanto, o SPE-PRMS recomenda que, nestes casos, as justificativas para a classificação das reservas sejam claramente documentadas.

Em suma, o fator decisivo para a classificação entre "recursos prospectivos", "recursos contingentes" e "reservas" é o nível de incerteza, calculado com base em análises qualitativas, mas que podem ser associados com os conceitos probabilísticos de P90, 
P50 e P1056. As classificações de incerteza utilizam simulações de Monte Carlo considerando funções de distribuição de probabilidades para vários aspectos físicos químicos (porosidade, saturação do óleo, taxas de recuperação, densidade do fluído, etc.) e econômicos (preço do petróleo, custo de extração, etc).

Tabela 15 - Conceitos de Níveis de Incerteza no Sistema de Classificação de Recursos

\begin{tabular}{|c|c|c|}
\hline Recursos Prospectivos & Recursos Contingentes & Reservas \\
\hline Baixo (P90) & $1 \mathrm{C}(\mathrm{P} 90)$ & 1P (P90) - Provada \\
\hline Melhor (P50) & 2C (P50) & 2P (P50) - Provável \\
\hline Alto (P10) & 3C (P10) & 3P (P10) - Possível \\
\hline
\end{tabular}

Fonte: KOVARSKY \& MENDES [2011a].

A SPE recomenda que a incerteza das estimativas dos recursos recuperáveis seja divulgada em intervalos de possíveis resultados. Caso seja necessário um único resultado, então recomenda-se o uso da "melhor" estimativa (P50) ${ }^{57}$. Entretanto, segundo a SPE, para considerar um recurso prospectivo como reserva, deve haver uma probabilidade de $\mathbf{9 0 \%}$ que a reserva é maior ou igual ao seu volume estimado.

Além de classificar os recursos do portfólio da OGX, a D\&M também estimou seu valor presente líquido com base em parâmetros técnicos e na metodologia do Net Asset Value ("NAV") utilizados na indústria internacional de $O \& G$ e aceitos por agências regulatórias, como a SEC ${ }^{58}$. Em geral, as estimativas de volumes recuperáveis nestes relatórios podem ser usadas para: (i) fins contábeis e exigências das agências reguladoras dos mercados de capitais; (ii) bancos e outras fontes de financiamento; (iii) transações de M\&A.

A SPE-PRMS recomenda ainda que os relatórios de avaliação descrevam suas premissas comerciais de forma clara. A avaliação da viabilidade comercial dos recursos pode ser baseada em preços e custos históricos de desenvolvimento, recuperação e produção da própria empresa nos projetos ou parâmetros de empresas comparáveis, na ausência de histórico.

56 P90, por exemplo, significa que há, pelo menos, $90 \%$ de probabilidade que a quantidade de óleo efetivamente recuperada seja igual ou maior do que a menor estimativa.

57 SPE-PRMS, 2008, p. 14.

${ }^{58}$ As três diferenças básicas entre o NAV e o FDC são:

(a) no NAV, o volume de reservas existentes não aumenta, portanto não há investimentos adicionais no futuro para desenvolver o portfólio atual.

(b) Enquanto o FDC considera os fluxos de caixa da empresa (ativos e passivos operacionais), no NAV são apenas considerados os fluxos dos ativos, que consideram investimentos, despesas de desenvolvimento e produção, e impostos. Portanto, o valor presente das despesas gerais e administrativas é subtraído posteriormente do VPL dos fluxos dos ativos.

(c) Enquanto o FDC assume que a empresa tem vida útil indeterminada, no NAV a vida útil é limitada à exaustão das reservas. Não se assume novos investimentos para adquirir outras reservas. Após as reservas atingirem um ápice, assume-se uma TACC negativa para a produção. 
Quando a empresa em avaliação possui histórico operacional, como era o caso da OGX, a SPE recomenda que as projeções devam ter como base variações em relação às médias históricas dos últimos 12 meses de preços e custos. São considerados também os tributos, pagamentos de royalties e outras deduções. A vida útil da reserva pode ser projetada de acordo com o prazo contratual de propriedade, ou "qualquer outra estimativa razoável"59. A taxa de desconto utilizada deve refletir o WACC ou a TMA do projeto. As projeções devem ser em moeda constante e cenários econômicos alternativos devem ser considerados.

As avaliações da D\&M, como outras consultorias especializadas em avaliar e classificar volumes recuperáveis de O\&G, tinham suas limitações. Primeiro, a D\&M conduz seus trabalhos com base nas informações disponibilizadas pelos seus próprios clientes. Entretanto, nos Estados Unidos, por exemplo, o Pension Protection Act de 2006 define multas para os avaliadores que aceitarem informações de seus clientes sem uma adequada auditoria (due diligence). Portanto, os usuários dos Relatórios de Avaliação podiam supor que as informações geológicas, químicas e geofísicas disponibilizadas pela OGX e avalizadas pela D\&M eram de qualidade.

A segunda limitação dos Relatórios de Avaliação é que, dada a diversidade de técnicas exploratórias, o volume classificado em uma determinada categoria, por exemplo, "reservas $2 \mathrm{P}^{\prime}$, para uma empresa de $0 \& \mathrm{G}$ pode não ser diretamente comparável à mesma classificação de outras empresas. Esta limitação fragiliza a análise por múltiplos de mercado.

Uma terceira limitação dos Relatórios de Avaliação são as premissas para as projeções de preços do petróleo e o custo de oportunidade do capital. É prática nos Relatórios de Avaliação utilizar a taxa real de $10 \%$ (conhecido como "SEC $10^{\text {") }}{ }^{60}$ como premissa para o custo de oportunidade do capital, independente das idiossincrasias de cada empresa e do regime regulatório em que está inserida. A projeção de preços do petróleo é mantida constante ao longo de toda a projeção em um patamar ("price deck"), apesar das conhecidas flutuações dos preços no mercado internacional.

Em seus três relatórios, a D\&M publicou estimativas do NAV do portfólio da OGX em três cenários probabilísticos P90, P50, P10. Também publicou a média aritmética destes cenários, que por sua vez é muito próxima do P50.

\footnotetext{
59 SPE-PRMS, 2008, p. 14.

${ }^{60}$ A taxa de desconto de $10 \%$ se tornou uma referência da indústria internacional de O\&G. A SPE não requer que a avaliação dos recursos inclua o financiamento do projeto (project finance). Ou seja, a taxa de $10 \%$ equivale ao WACC, porém com $100 \%$ de capital acionário.
} 
Tabela 16 - Estimativa do VPL dos Recursos da OGX estimados pela D\&M (US\$ milhões)

\begin{tabular}{|l|c|c|c|c|c|}
\hline \hline Relatórios & Média & P10 & P90 & P50 & $\%$ \\
\hline 1ㅇ D\&M (Mar. 2008) & 23.367 & 27.638 & 19.521 & 23.142 & $100,0 \%$ \\
\hline 20 D\&M (Nov. 2009) & 33.271 & 39.352 & 27.795 & 32.951 & $142,4 \%$ \\
\hline 3으\&\&M (Abr. 2010) & 52.198 & 61.739 & 43.607 & 51.696 & $223,4 \%$ \\
\hline
\end{tabular}

Nota: para estimar o NAV, a D\&M usou uma taxa de desconto de $10 \%$ em moeda constante.

Segundo a SPE-PRMS [2008, p. 14], geralmente, um projeto de O\&G pode ser considerado economicamente viável se tiver um VPL positivo usando "melhores estimativas" (P50) de "volumes recuperáveis". A SEC recomenda o uso de P90 em Reservas Provadas para definir o termo "certeza razoável" (reasonable certainty) (SEC, 2010, p. 27). Portanto, por ambos os critérios da SPE (P50) e SEC (P90), a OGX não teria valor algum, pois não possuía Reservas stritu senso.

Entretanto, em junho de 2008, apesar de não possuir Reservas ou Recursos Contingentes, OGX protagonizou o maior IPO do Brasil na época. Aparentemente, no IPO, os investidores consideraram o NAV de Recursos Prospectivos do 10 D\&M na sua demanda pela a OGXP3.

A aposta no NAV da D\&M foi além do IPO. Geralmente, financiamentos externos exigem que a avaliação utilize somente volumes em reservas provadas. Na época que a OGX emitiu duas Notes (em junho de 2011 e março de 2012) somando US\$ 3,7 bilhões, o 30 D\&M (data base de dezembro 2012) estimava que a Empresa teria 3,0 bboe (3C ou P10) em Recursos Contingentes e somente 0,7 bboe em 2C (P50) e 0,1 bboe em 1C (P90). Ou seja, aparentemente, os financiadores, sem garantias, apostavam na capacidade da OGX em transformar recursos contingentes em Reservas Provadas.

Desde o final da década de 1970, a SEC obrigava a divulgação de Reservas Provadas (1P) aos investidores das empresas de O\&G listadas nos EUA. Porém, entre 2008/10, possivelmente por causa da "revolução" do gás de xisto, a SEC e o FASB atualizaram as regras permitindo a divulgação, facultativa, de Reservas Prováveis $(2 \mathrm{P})^{61}$, compatíveis com as classificações da SPE (permaneceu a obrigação de divulgar Reservas Provadas [1P]). Apesar desta atualização, MISUND \& OSMUNDSEN [2017] constataram que poucas empresas de O\&G dos EUA divulgam suas Reservas Prováveis, o que pode subestimar sistematicamente o potencial de crescimento destas empresas.

No Canadá, as empresas de O\&G são obrigadas a divulgar suas Reservas Provadas e Não Provadas e podem divulgar também Recursos Contingentes, o que permite a análise do impacto dos diferentes tipos de reservas no valor de mercado das empresas ${ }^{62}$. Segundo os autores, há poucos estudos que focam na importância das outras classificações de reservas, porém há evidências circunstanciais que demonstram sua importância. Citam, por exemplo, em 2004, quando a Royal Dutch Shell reclassificou 28\% de suas reservas

${ }^{61}$ Cf. Financial Accounting Standards Board [1982, 2009, 2010] e Securities and Exchange Commission. [1978, 1979, 1981, 2008].

${ }^{62}$ Cf. Canadian Securities Administrators [2002a, 2002b]. 
de O\&G de provadas para prováveis, suas ações se depreciaram significativamente. Essa reclassificação também ilustrou a incerteza inerente ao conceito de reservas provadas.

No Brasil, na época do IPO da OGX, o artigo 15 da Instrução CVM n. 400 (29/12/2003) ${ }^{63}$ previa que a aprovação de uma oferta de ações no mercado aberto não requereria "qualquer garantia quanto ao conteúdo da informação, à situação econômica ou financeira do ofertante ou da emissora ou à sua administração, à viabilidade da oferta ou à qualidade dos valores mobiliários ofertados". O artigo 32 requeria "Estudo de Viabilidade" caso a "emissora exerça a sua atividade há menos de dois anos" (inciso II) ou "a fixação do preço da oferta baseie-se, de modo preponderante, nas perspectivas de rentabilidade futura" (inciso III), e foi o que a OGX fez ao incluir o 1을 (base março 2008) no Prospecto do seu IPO. Os artigos 38 e 56 definiam que as informações contidas no Prospecto fossem verdadeiras e que tanto a Emissora, no caso a OGX, quanto a Instituição Líder do IPO, no caso o UBS Pactual, eram responsáveis pela veracidade das mesmas, incluindo o Estudo de Viabilidade.

O Prospecto deveria conter uma seção denominada "Fatores de Risco" que deve expor os riscos relacionados à emissão, o setor da economia em que a empresa atua, acionistas e aspectos macroeconômicos. De fato, no PROSPECTO DA OGX [2008] lê-se:

$O$ investimento nas nossas Ações envolve um alto grau de risco. $O$ investidor pode perder parte do seu investimento ou o seu investimento integral devido a qualquer um dos riscos descritos neste Prospecto, incluindo, entre outros fatores, a nossa falta de histórico operacional e as incertezas que cercam o nosso desempenho futuro, as incertezas substanciais sobre a nossa capacidade de ter os recursos necessários às nossas operações, a nossa incapacidade de obter as licenças necessárias ou celebrar parcerias estratégicas, caso deixemos de atingir os resultados e as previsões descritas neste Prospecto, a nossa incapacidade de desenvolver os Recursos Potenciais ou de atingir as probabilidades esperadas de sucesso, especialmente caso a nossa prospecção futura não resulte em descobertas e, mesmo que nós consigamos realizar descobertas com sucesso, não há certeza de que as mesmas sejam comercialmente viáveis, e caso deixemos de gerar ou obter capital de giro adicional suficiente no futuro [p. 25, grifo nosso].

(...) O Estudo de Viabilidade anexo ao presente Prospecto não compreende todas as informações que possam ser importantes para uma decisão de investimento. Em vista de tais incertezas, os investidores não devem se basear nestas projeções para tomar a sua decisão de investimento, devendo analisar cuidadosamente as informações incluídas neste Prospecto, inclusive as nossas demonstrações financeiras notas explicativas relacionadas [p. 63, grifo nosso].

As estimativas de Recursos Potenciais apresentadas neste Prospecto foram elaboradas em conformidade com o Sistema de Administração de Recursos Petroliferos (Petroleum Resources Management System -

${ }^{63}$ A instrução CVM 400 posteriormente foi alterada pela Instrução CVM 482, 5/04/2010. 
PRMS) aprovado em março de 2007 pela Sociedade de Engenheiros do Petróleo, pelo Conselho Mundial de Petróleo e pela Associação Americana de Geólogos do Petróleo. Tendo em vista a incerteza da possibilidade de comercialização e a falta de sondagem suficiente, as estimativas de Recursos Potenciais não podem ser classificadas como e nem são fornecidas para comparação de possíveis recursos ou reservas [p. 64, grifo nosso].

O Estudo de Viabilidade anexo a este Prospecto foi preparado com base na legislação brasileira e não segue as regulamentações de quaisquer outras bolsas de valores [p. 67, grifo nosso].

Nem a KPMG nem qualquer outro auditor independente, nem os Coordenadores da Oferta ou os Agentes de Colocação Internacional, compilaram, examinaram ou executaram quaisquer procedimentos com respeito às informações financeiras projetadas usadas para preparar o Estudo de Viabilidade, nem expressaram sua opinião ou qualquer outra forma da declaração sobre tais informações ou a possibilidade de realizarem, e não assumem nenhuma responsabilidade por, e negam qualquer associação, com estas informações financeiras projetadas [p. 67, grifo nosso].

Ou seja, o PROSPECTO deixou claro a incerteza em relação ao conceito de Recurso Prospectivo e a isenção da reponsabilidade da KPMG e coordenadores do IPO sobre a veracidade e exatidão do Estudo de Viabilidade.

Dada a reputação da D\&M e a assimetria de informação sobre o risco geológico, os Valores de Referência eram parâmetros importantes para a Tese de Investimento. Eram parâmetros que investidores e financiadores consideravam para deduzir se o Valor de Mercado poderia estar sub ou sobrevalorizado. 


\subsubsection{Valor Ótimo}

Na essência, governança corporativa é constituída por sistema de incentivos punitivos e motivacionais. Sistemas de incentivos são constituídos por contratos explícitos e/ou implícitos. A base de muitos sistemas de incentivos, tanto da demanda quanto da oferta de informações, é o valor do ativo subjacente. No caso das empresas de capital aberto, proxy do valor do ativo subjacente é observável nos preços de suas ações em bolsa. Entretanto, estes preços podem ou não refletir o real valor do ativo subjacente.

No caso do AC, Executivos e membros do COAD com SOP, e investidores minoritários, o Valor de Mercado era observável diariamente, sem custo, através das cotações da OGXP3, transacionada tanto no Brasil quanto nos Estados Unidos (ADRs). Quantos aos financiadores, que adquiriram os Notes com vencimentos em 2018 e 2022, os preços de curto prazo eram observáveis diariamente, através das cotações da OGXPBZ18 e OGXPBZ22, respectivamente.

Entretanto, por fatores exógenos e endógenos, os valores correntes da OGXP3, OGXPBZ18 e OGXPBZ22 nos mercados abertos podem destoar do valor de longo prazo destes títulos. Ou seja, o Valor de Mercado pode ter sido diferente do "valor ótimo" da OGX. Valor ótimo aqui definido "como o valor da empresa com uma hipotética equipe de administração ótima" ("Valor Ótimo") ${ }^{64}$. Por definição, o Valor Ótimo não era observável, mas era objeto de estimativas por boa parte dos Stakeholders. O Valor Ótimo menos o valor de mercado das dívidas onerosas da OGX, que até a RJ se restringiam à OGXPBZ18 e OGXPBZ22, resultava no Valor Ótimo do Equity ("VOE”).

A princípio, a "hipotética equipe de administração ótima" do Valor Ótimo era formada pelos Gestores, mas em abril de 2010 surgiu outra possibilidade: a venda de parte da OGX (o chamado "farm-out") para um investidor estratégico, que poderia ser uma International Oil Company ("IOC") ou até mesmo para a PETR. A expectativa de uma possível diferença positiva entre o VOE e o Valor de Mercado geraria um prêmio ("Prêmio de Controle"). Tal investidor estratégico poderia superar os Executivos na capacidade de incrementar o VOE ao agregar expertises na gestão financeira e operacional, explorar sinergias, capturar ganhos de escala e aumentar o poder de barganha com fornecedores.

A possibilidade de um Prêmio de Controle positivo incentivaria investidores minoritários a comprar a OGXP3, uma vez que o tag along previsto no Novo Mercado permitiria a captura deste valor pelos minoritários. Em abril de 2010, quando se tornou pública a negociação do farm-out de $20 \%$ das ações da OGX para IOCs, o volume de negociações triplicou de $\mathrm{R} \$ 244$ milhões para $\mathrm{R} \$ 734$ milhões por dia ${ }^{65}$. Além da possibilidade de um prêmio de controle, havia também a especulação de distribuição de dividendos.

Tanto na Primeira e Segunda Conjectura, o Valor Ótimo ex-ante seria nulo, uma vez que não haveria valor no portfólio da Empresa, mesmo sob uma nova gestão potencialmente

\footnotetext{
64 DAMODARAN, 2012, p. 316.

65 GASPAR, 2014, p. 246-249.
} 
mais eficiente que os Gestores. A diferença é que na Primeira Conjectura, os Gestores, ex-ante, percebiam o Valor Ótimo como nulo.

Na Segunda Conjectura, a percepção de que o Valor Ótimo poderia ser nulo seria construída ao longo da campanha exploratória. Até chegar a esta conclusão, os Gestores podem ter genuinamente investido em novas opções de crescimento acreditando não só que a Tese de Investimentos era factível, mas com a percepção de que o VOE poderia ser muito superior ao Valor de Mercado.

$\mathrm{Na}$ Terceira Conjectura, os Gestores poderiam perceber, ao longo da campanha exploratória, o VOE como inferior ao Valor de Mercado, mas pelos incentivos a que estavam expostos, insistiam em manter e até ampliar a Tese de Investimentos na esperança que novos fatos, como por exemplo novas descobertas e/ou farm-outs, viessem a melhorar e atualizar sua percepção quanto ao Valor Ótimo. O fear factor pode ter levado o AC e os Executivos a insistirem e intensificarem a campanha que, se bemsucedida, não apenas recuperaria sua credibilidade, mas também o lastro do AC para garantir os financiamentos das Partes Relacionadas.

Por fim, é importante também distinguir as duas formas em que o Valor de Mercado é utilizado no presente estudo. O Valor de Mercado, que inclui o valor das disponibilidades e exclui o valor da dívida, é comparado diretamente aos PAs, discutido na próxima seção. Mas, quando a comparação for entre o Valor de Mercado e o Valor de Referência, é preciso utilizar o conceito de Valor da Empresa ("EV"), que por sua vez inclui o valor contábil da dívida líquida.

Como o valor das disponibilidades era publicado trimestralmente, para estimar seus valores diários, foi deduzida uma relação linear decrescente entre os saldos no início e fim de cada trimestre. O valor contábil dos financiamentos da OGX intra-trimestre não precisaram ser estimados, uma vez que suas amortizações estavam programadas para pagamentos integrais quando do vencimento dos títulos (bullet em 2018 e 2022). 


\subsubsection{Preços Alvos}

Um subgrupo particular dos analistas que apoiavam ou não decisões de investimentos e financiamentos para a OGX era formado pelos Analistas. Os Analistas buscavam estimar o Valor Ótimo em vários cenários descritos em relatórios técnicos privados ("Relatórios"). A média dos cenários resultava no PA. Comparando o PA com o Valor de Mercado, os Analistas faziam a seus clientes recomendações de investimento ou desinvestimento.

Em teoria, os Analistas são considerados gatekeepers. Em suas análises e recomendações, a CMV exige que os Analistas atuem com diligência, objetividade, boa fé e independência, ou seja, sem conflitos de interesse em relação às instituições a quem estão vinculados ${ }^{66}, 67,68$.

A literatura empírica internacional produziu evidências que investidores institucionais e investidores individuais (retail investors) usam Relatórios no processo decisório de investir em ações (MADAN et al. [2003] apud GROYSBERG et al [2011]). Empresas de capital aberto utilizam os Relatórios para vender seus títulos mobiliários (por exemplo,

${ }^{66}$ Artigos 40 e 9o da Instrução CVM 388 de 30/4/2003:

"Art. 4o $O$ analista deve agir com observância dos princípios de probidade e boa fé, empregando todo cuidado e diligência que despenderia na análise de títulos e valores mobiliários para seus próprios negócios, respondendo por quaisquer infrações ou irregularidades que venham a ser cometidas sob sua gestão".

"Art. go É vedado às instituições integrantes do sistema de distribuição a que os analistas de valores mobiliários porventura estejam vinculados, bem como às companhias objeto de sua análise, exercer qualquer influência na elaboração de recomendações sobre a aplicação de recursos para investimento, de modo a reduzir ou retirar-lhe sua independência na emissão de recomendações sobre aplicação de recursos para investimento."

67 Instrução CVM 483 de 6/7/2010, artigo 18, parágrafo 1, descreve exemplos de conflitos de interesses criados por relações entre o analista (incluindo não apenas a pessoa física do analista, mas também a pessoa jurídica autorizada pela CVM como consultor de valores mobiliários) e o emissor do título:

I - Tenham participações societárias relevantes no emissor objeto do relatório de análise (...);

II - Tenham interesses financeiros e comerciais relevantes em relação ao emissor ou aos valores mobiliários objeto do relatório de análise;

III - Estejam envolvidas na aquisição, alienação ou intermediação dos valores mobiliários objeto do relatório de análise; e

IV - Recebam remuneração por serviços prestados para o emissor objeto do relatório de análise ou pessoas a ele ligadas.

${ }^{68} \mathrm{O}$ artigo 20 do código de ética da APIMEC [2011] exige que o Analista siga os seguintes princípios:

1. Honestidade, Integridade e Equidade - O Analista deve observar os mais elevados padrões de honestidade, integridade e equidade de forma a manter a confiança do investidor em sua profissão;

II. Prudência e diligência - O Analista deve conduzir suas atividades com cuidado, diligência e prudência compatíveis com as expectativas do investidor e de seu empregador, dando a ambos o conforto em relação à qualidade do trabalho;

III. Independência e objetividade - As análises devem sempre refletir o melhor juízo do autor, nunca sendo influenciadas por pressões ou benefícios a que este possa estar sujeito.

IV. Competência profissional - O Analista deve sempre procurar manter e aperfeiçoar sua competência técnica, seu conhecimento dos instrumentos, instituições e normas que regem o mercado e das informações pertinentes ao exercício de sua profissão.

V. Cumprimento das leis e normas - O Analista deve cumprir todas as normas e leis a que esteja sujeito. 
em um IPO, uma oferta subsequente) e aumentar a liquidez de suas ações ${ }^{69}$. Os Analistas dos bancos mais proeminentes têm a capacidade de afetar os preços das ações ${ }^{70}$, seu volume transacionado ${ }^{71}$ e transações de finanças corporativas ${ }^{72}$.

Em julho de 2008, Analistas de grandes bancos e corretoras nacionais e internacionais iniciaram uma intensa cobertura do Valor de Mercado, marcada por frequentes revisões nos PAs. A OGX foi a primeira e-company de capital aberto no Brasil ${ }^{73}$, muito diferente da PETR, que é uma empresa de O\&G integrada, pois possui o upstream, midstream (oleodutos, gasodutos e comercialização) e downstream (refinarias e petroquímicos). Dadas as singularidades da OGX, nomeadamente uma empresa pré-operacional, $100 \%$ exploratória e com um portfólio integralmente composto por Recursos Prospectivos, e sua história entre 2007 e 2013, os Analistas buscaram informações sobre o de-risking e apoio técnico para interpretá-las no guidance.

Os Analistas construíram suas projeções com base em informações públicas padronizadas sobre a Empresa, incluindo os Relatórios de Avaliação da D\&M, teleconferências e reuniões presenciais com Executivos. Por vezes, utilizavam informações privadas oriundas da contratação de geólogos especializados. Os Analistas também consideravam informações públicas sobre a performance dos concorrentes nacionais (QGEP, HRT e PETR), empresas similares internacionais, bem como transações de $M \& A$ envolvendo empresas de O\&G no Brasil, frequentes entre 2009/13.

Os Analistas geralmente utilizam metodologias consagradas para estimar o Valor Ótimo, como o FDC e o NAV, e a análise relativa, também conhecida como análise de múltiplos. Os múltiplos mais usados eram o EV pelo volume de RPL em $2 \mathrm{C}$ barris ("EV/ $2 C^{\prime}$ "), durante a fase pré-operacional, e pelo EBITDA ("EV/EBITDA"), na fase operacional. Em geral, na indústria de O\&G, os Analistas utilizavam EV/boe de Reservas e/ou Recursos Contingentes, que no caso da OGX só se tornaram disponíveis no 3으\&M.

Pela OGX ter sido uma empresa pré-operacional e 100\% exploratória (e-company) até março 2012, os Analistas enfrentaram cinco particularidades nas estimativas dos PAs. Primeiro, à rigor, como não era possível usar o EV/EBITDA, utilizou-se o EV/2C que possuía poucos benchmarks internacionais, uma vez que as junior oils listada geralmente já eram operacionais. Os Analistas da MER, por exemplo, ajustavam os múltiplos EV/2C da OGX aplicando um desconto de $45 \%$ em múltiplos de empresas "similares" com reservas $3 \mathrm{P}^{74}$.

Frequentemente, os Analistas consideraram as implicações de possíveis transações de M\&A (múltiplos de farm-out) de blocos próximos àqueles da OGX como indicadores de

${ }^{69} \mathrm{Cf}$ KRIGMAN et al. [2001]

70 Por exemplo, STICKEL [1995], WOMACK [1996].

${ }^{71}$ Por exemplo, IRVINE [2000, 2004], JUERGENS AND LINDSEY [2009].

72 Por exemplo, KRIGMAN, SHAW, AND WOMACK [2001].

${ }^{73}$ A HRT e a QGEP executaram seus IPOs em 25 de outubro de 2010 e fevereiro de 2011, respectivamente. A HRT Participações em Petróleo (hoje, PetroRio S.A.), uma greenfield formada por ex-funcionários da PETR, captou R\$ 2,624 B em no seu IPO junto a investidores qualificados, com 2,1 bboe em Recursos Prospectivos, nas bacias dos Solimões, AM, e na Namíbia, segundo a D\&M. O líder no IPO foi o CS, junto com Citi e GS.

${ }^{74}$ MCGANN \& KOYA, 2008a, p. 6. 
de-risking e possibilidades de capitalização. Foi o caso da entrevista que o AC concedeu, em 15/04/2010, divulgando a intenção de vender parte da OGX (farm-out) para uma IOC, que por meses foi objeto de intensa expectativa por partes dos Analistas.

Segundo, a eficácia da metodologia do FDC ou NAV era discutível para um portfólio com tantas incertezas e longos prazos de maturação.

As reservas não desenvolvidas (isto é, reservas não desenvolvidas e não
comprovadas) podem ser difíceis de avaliar usando a abordagem de FDC,
particularmente em áreas onde pouco desenvolvimento ocorreu e onde não
se sabe muito sobre reservas e potencial de produção. Como a área não
desenvolvida ainda precisa ser 'de-risked', a falta de informações
necessárias para identificar os parâmetros do FDC pode tornar a análise
altamente especulativa [KOC, ROSS \& SZCZPANSKI, 2015, p. 27, grifo nosso].

Terceiro, dadas as duas primeiras particularidades, a reputação e o guidance dos Executivos, incluindo os Valores de Referência, foram muito importantes na construção da percepção de valor dos Analistas. A interpretação dos anúncios de várias descobertas e seus efeitos sobre o portfólio, novas aquisições e farm-ins (por exemplo, BM-S-9, blocos na Colômbia, na 9a e 11ạ Rodadas), e a ocorrência de poços secos foram exemplos da dificuldade dos Analistas em distinguirem entre componentes transitórios e permanentes de efeitos inesperados nos lucros futuros.

Além disso, uma quarta particularidade era a atenção do mercado, da mídia nacional e internacional dedicada à OGX, ao $A C$ e seus outros empreendimentos. A evolução do número de Analistas da Thompson Reuters ("Amostra TR") cobrindo a OGX mais que triplicou em dois anos, especialmente a partir do rally de novembro de 2008 a outubro de 2010.

Gráfico 3 - Evolução do Número de Analistas da Amostra TR

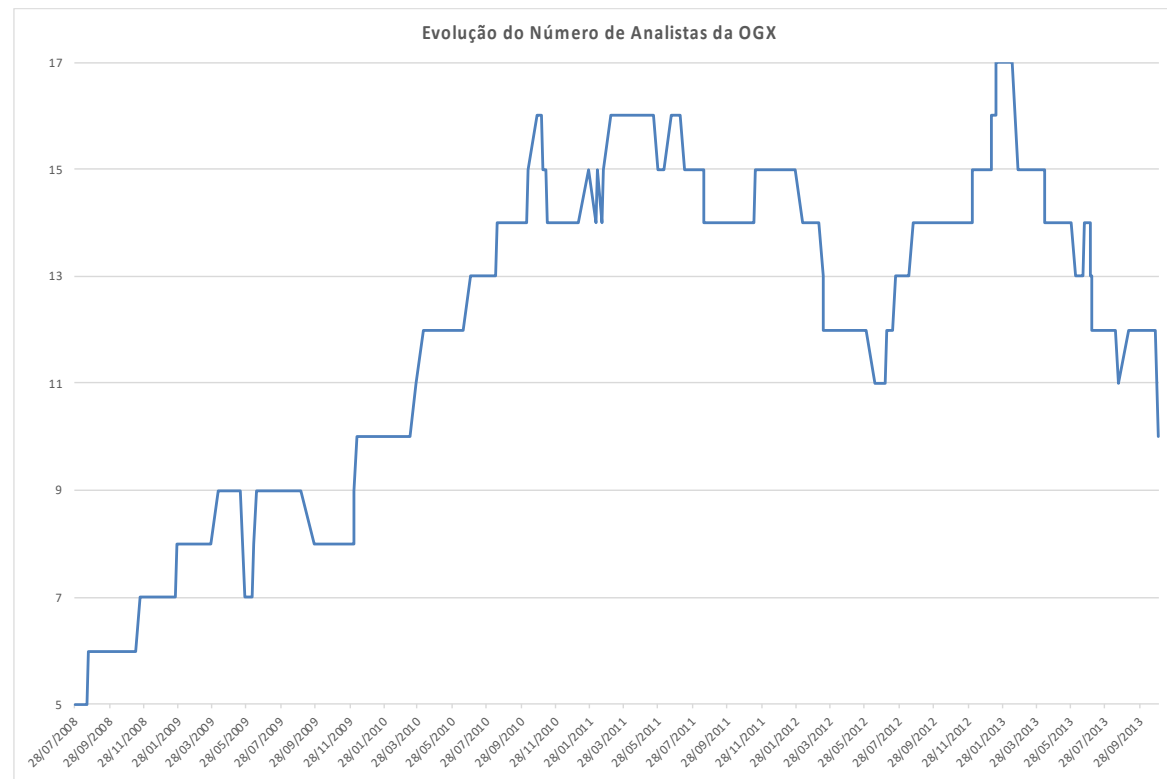

Fonte: Thompson Reuters. 
A literatura internacional coletou evidências de que CEOs com elevada autoconfiança, que tendem a superestimar sua habilidade de gerar valor, afetam indiretamente os participantes do mercado, em especial os Analistas. Os gestores das empresas alvo de análise são importante fonte de informação para os Analistas. A elevada autoconfiança dos gestores pode se manifestar de duas maneiras: excessivo otimismo sobre a futura performance da empresa (sobre-estimativa [overestimation]) e excessiva certeza sobre o grau de precisão de suas informações privadas (sobre-precisão [overprecision]) $)^{75}$.

O otimismo e a elevada autoconfiança do AC acompanharam a evolução de seus empreendimentos e sua exposição na mídia ${ }^{76}$. O otimismo dos Executivos, especialmente até junho de 2012, também merece destaque. Quantos Analistas ousariam contradizer o otimismo do AC e dos Executivos?

Uma quinta particularidade foi o potencial conflito de interesses entre os Analistas e outros executivos dos bancos de investimentos e bancos múltiplos em que trabalhavam. O AC e o Grupo X conduziam muitas transações no mercado de capitais com vários bancos. Não deve ter sido fácil para Analistas pessimistas sustentarem suas recomendações e PAs quando o consenso era mais otimista, como ocorreu, por exemplo, durante longos períodos de valorização da OGXP3.

A literatura internacional coletou evidências de que os Analistas tendem a ser otimistas ${ }^{77}$, por questões relacionadas a incentivos (por exemplo, conflitos de interesse em underwriting $)^{78}$ e comportamentais ${ }^{79}$. As projeções de Analistas de bancos de investimentos que atuaram como underwritters no IPO (affiliated analysts) tendem a ser mais otimistas ${ }^{80}$. Analistas geram maiores comissões de corretagem, emitindo recomendações otimistas e projeções de lucro mais otimistas, sugerindo que os Analistas têm mais incentivo para viesar recomendações ${ }^{81}$.

Seguir o consenso seria uma estratégia de autopreservação de parte dos Analistas ${ }^{82}$. Quanto maior a incerteza sobre o futuro da empresa sob análise, maior a probabilidade de herding entre os Analistas. Portanto, quanto maior a incerteza, menor poderia ser a dispersão entre as projeções e recomendações dos Analistas. Ou ainda, se altas dispersões indicam que não houve herding e os Analistas (e investidores) discordam sobre o futuro da empresa, o que também poderia estar positivamente relacionado com

\footnotetext{
${ }^{75}$ Cf. DANIEL et al. [1998] e MOORE et al. [1999].

${ }^{76} \mathrm{O}$ otimismo e a elevada autoconfiança do AC pode ser evidenciado pelo fato de não ter vendido suas ações na OGX até fevereiro de 2013. Já o mesmo não pode ser dito com relação ao Diretor de Exploração, Diretor de Relações com Investidores e Diretor Jurídico, como foi evidenciado em processo movido pela CVM por uso de informações privilegiada.

77 BUTLER \& LANG [1991].

${ }^{78}$ Cf. DUGAR \& NATHAN [1995]; LIN \& MCNICHOLS [1998]; MICHAELY \& WOMACK [1999].

${ }^{79}$ Cf. FRIESEN \& WELLER [2006].

${ }^{80}$ Cf. DUGAR \& NATHAN [1995]; MICHAELY \& WOMACK [1999]; HONG \& KUBIK [2003].

${ }^{81}$ Cf. IRVINE [2004].

82 Cf. TRUEMAN [1994], GRAHAM [1999], WELCH [2000].
} 
o volume transacionado (quanto mais os investidores discordam, maiores são as oportunidades de transação) ${ }^{83}$.

Por outro lado, Analistas com elevada reputação ("all-star analysts") reduzem suas recomendações antes e com maior ênfase do que os outros ${ }^{84}$. Estes Analistas ganham significantemente mais do que os outros não estrelados ${ }^{85}$. Revisões dos Analistas mais pontuais (timeliness leaders) geram reações do mercado mais significativas ${ }^{86}$. As reações do mercado são maiores também às revisões que divergem do consenso e/ou de Analistas que são mais audazes (bold analysts) do que seus pares ${ }^{87}$.

Há evidências que os Analistas também consideram fatores não econômicos em suas recomendações e PA, incluindo o "sentimento" (investors sentiment ou market sentiment) dos investidores ou do mercado, que podem ser positivos (bullinsh) ou negativos (bearish) ("Sentimento do Mercado") que é discutido com maiores detalhes na seção 2.4. Alguns autores ${ }^{88}$ encontraram evidências da relação entre Sentimento do Mercado em alta e recomendações mais favoráveis dos Analistas. Os efeitos dos sentimentos dos investidores na eficácia dos Analistas em traduzir suas projeções em recomendações é conhecido como "translational effectiveness" 89 ou efetividade transacional.

Em suma, possivelmente por uma combinação de fatores, como a influência do otimismo dos Executivos e AC, herding, conflitos de interesse organizacionais e a efetividade transacional com a elevada incerteza da viabilidade do portfólio da OGX, a mediana dos PA dos Analistas da Amostra TR ficou acima do preço de mercado da

83 Há evidências também que o volume transacionado pode aumentar, mesmo sem alterações nas dispersões, particularmente antes da divulgação de resultados. Esse fenômeno é conhecido por "belief jumbling", quando os Analistas trocam informações e percepções que podem acarretar em futuras revisões em suas projeções e recomendações. Exemplo: BARRON [1995].

${ }^{84}$ CLARKE et al. [2006].

85 GROYSBERG, HEALY, MABER [2011] resumem que devido à falta de informações sobre a compensação financeira dos Analistas, as pesquisas até então se baseavam mais em conjecturas plausíveis do que evidências sistemáticas. Em abordagem diferenciada, os autores consideraram informações sobre a compensação financeira de 609 Analistas-ano (uma média de 33,8 Analistas por ano) de proeminentes bancos de investimentos entre 1988 a 2005, os All-Star Analysts da renomada revista de buy-side, a Institutional Investor ("II"), e/ou pelo Wall Street Journal (WSJ). Os All-Star Analysts da II ganhavam $61 \%$ a mais do que a média dos outros Analistas. Os autores não encontraram relação entre a precisão das projeções de longo prazo com a compensação dos Analistas, entretanto encontraram evidências de relação entre erros extremos nas projeções e a probabilidade de demissão do Analista. Como era esperado, os autores encontram relação entre a compensação dos Analistas e suas contribuições para transações de bancos de investimentos, especificamente underwriting.

Pesquisas anteriores indicavam que os All-Star Analysts contribuíam para receitas de corretagem e atração de clientes para as atividades de bancos de investimentos. Entretanto, as evidências encontradas por GROYSBERG, HEALY, MABER [2011] indicam que os bancos preferem associar a compensação dos Analistas com os votos dos clientes, que indiretamente podem levar a receitas de corretagem e atração de clientes para o banco de investimentos.

${ }^{86}$ Cf. COOPER, DAY, \& LEWIS [2001].

${ }^{87}$ GLEASON \& LEE [2003]; MOZES [2003]; CLEMENT \& TSE [2005].

${ }^{88}$ Cf. BAGNOLI, CLEMENT, CRAWLEY \& WATTS [2009].

${ }^{89}$ Cf. KE \& YU [2009]. 
OGXP3 por longos períodos, indicando o otimismo destes especialistas em O\&G sobre o valor da OGX ${ }^{90}$.

\section{Gráfico 4 - Evolução da Mediana do PA da Amostra TR em relação ao Valor de OGXP3}

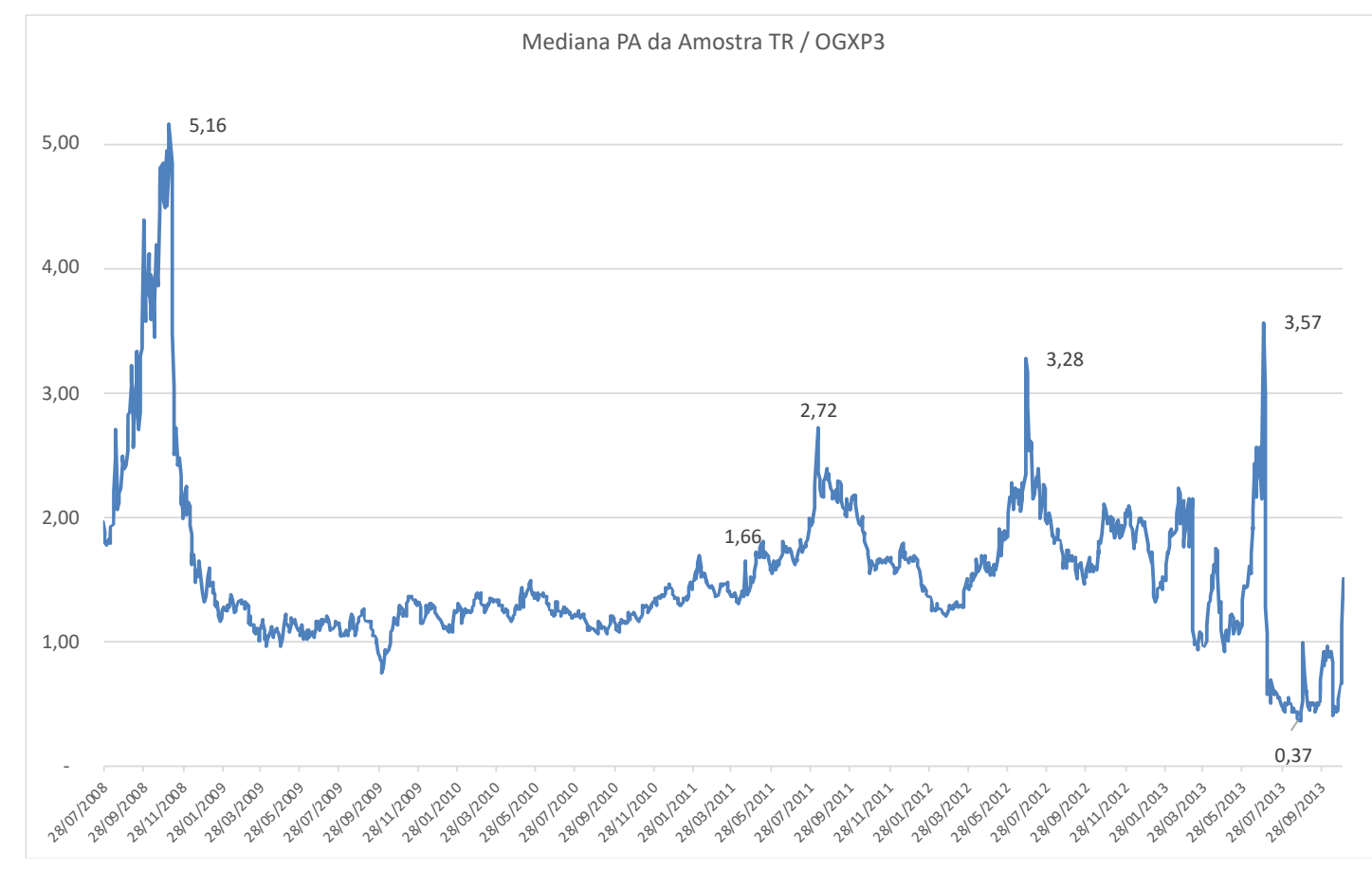

Em certos períodos, mesmo os Analistas mais pessimistas sustentaram PAs acima do Valor de Mercado.

90 DAMODARAN [2007, p. 1-2] pondera que raramente uma avaliação parte do zero. Ou seja, frequentemente, as opiniões sobre o valor de uma empresa começam a ser formadas antes mesmo da construção do modelo de avaliação. As fontes de viés podem incluir: a escolha da empresa a ser avaliada (que nos casos da OGX e do AC eram marcadas pela intensa cobertura da mídia); as fontes de informações utilizadas; fatores institucionais (exemplo: Analistas tendem a emitir mais recomendações de Compra do que de Venda); estrutura de incentivos. Além disso, o próprio resultado da avaliação, que se for muito diferente daqueles de outros Analistas e/ou do preço corrente da ação em bolsa, pode inibir sua divulgação ou suscitar ajustes por parte de Analistas menos experientes. 


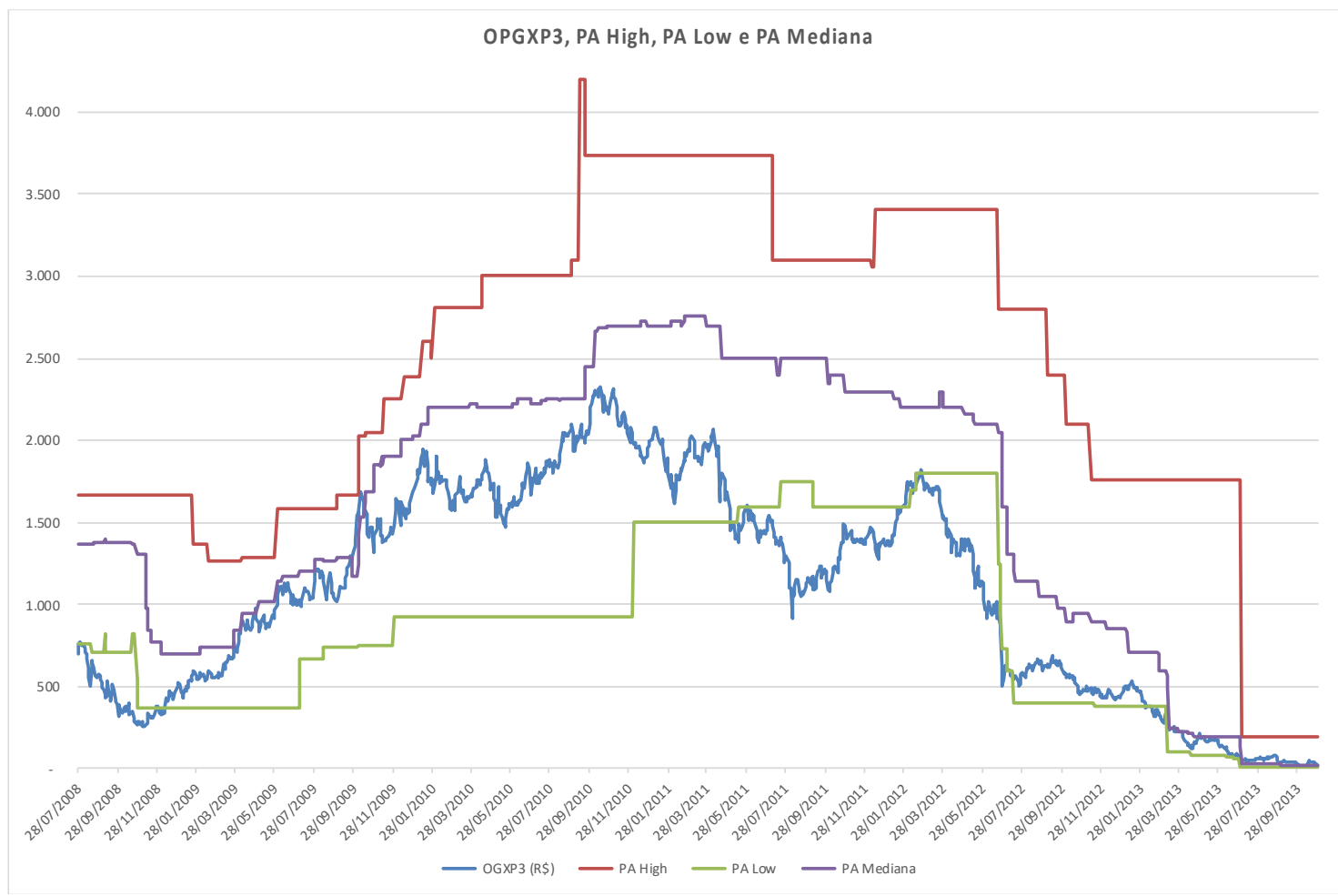

Os Analistas, como outras partes envolvidas na possível sobrevalorização da OGXP3, enfrentaram conflitos de interesse. Por um lado, têm incentivos a serem otimistas e assim promover transações de bancos de investimentos e receitas de corretagem. Por outro lado, têm uma reputação a zelar diante de seus clientes e deveres fiduciários perante o órgão regulador (no caso, a CVM).

Como especialistas em O\&G e em avaliação de empresas, os Analistas, em tese, têm capacidade de processar informações superior a parte dos investidores. Em setores de alta complexidade, como é o caso de O\&G, além de informações públicas padronizadas ou não, os Analistas baseiam parte de seus estudos na orientação (guidance) dos Executivos. Portanto, as interações entre Analistas, Executivos e, no caso da OGX, o AC, constituem material rico para a compreensão da formação de expectativas entre os investidores, o Sentimento de Mercado.

Para reconstituir a história da Tese de Investimentos, a construção da Agenda de Catalisadores e os impactos diretos do guidance no Valor de Mercado, utilizamos uma amostra com cerca de 393 relatórios de Analistas de nove bancos nacionais e estrangeiros (doravante denominada de "Amostra Própria"): BTG Pactual ("BTG"); Bradesco (“BBD"); Credit Suisse (“CS"); Deutsche Bank ("DB"); Goldman Sachs ("GS"); Itaú BBA (“IBBA"); Merril Lynch (“MER"); Morgan Stanley (“MS"); Santander ("SAN"). 
Tabela 17 - Quantidade de Relatórios de Analistas das Ações da OGX da Amostra Própria

\begin{tabular}{|l|c|c|c|c|c|c|c|c|}
\hline \hline & $\mathbf{2 0 0 8}$ & $\mathbf{2 0 0 9}$ & $\mathbf{2 0 1 0}$ & $\mathbf{2 0 1 1}$ & $\mathbf{2 0 1 2}$ & $\mathbf{2 0 1 3}$ & Total & $\mathbf{\%}$ \\
\hline BTG & 0 & 0 & 1 & 3 & 3 & 0 & 7 & $1,8 \%$ \\
\hline BBD & 5 & 0 & 0 & 0 & 1 & 0 & 6 & $1,5 \%$ \\
\hline CS & 8 & 28 & 6 & 2 & 0 & 13 & 57 & $14,5 \%$ \\
\hline DB & 0 & 0 & 8 & 10 & 13 & 22 & 53 & $13,5 \%$ \\
\hline GS & 0 & 0 & 0 & 0 & 3 & 9 & 12 & $3,1 \%$ \\
\hline IBBA & 4 & 29 & 45 & 21 & 29 & 18 & 146 & $37,2 \%$ \\
\hline MER & 1 & 0 & 0 & 0 & 0 & 5 & 6 & $1,5 \%$ \\
\hline MS & 1 & 9 & 9 & 5 & 1 & 15 & 40 & $10,2 \%$ \\
\hline SAN & 0 & 0 & 7 & 12 & 28 & 19 & 66 & $16,8 \%$ \\
\hline Total & $\mathbf{1 9}$ & $\mathbf{6 6}$ & $\mathbf{7 6}$ & $\mathbf{5 3}$ & $\mathbf{7 8}$ & $\mathbf{1 0 1}$ & $\mathbf{3 9 3}$ & $\mathbf{1 0 0 , 0 \%}$ \\
\hline $\mathbf{\%}$ & $\mathbf{4 , 8 \%}$ & $\mathbf{1 6 , 8 \%}$ & $\mathbf{1 9 , 3 \%}$ & $\mathbf{1 3 , 5 \%}$ & $\mathbf{1 9 , 8 \%}$ & $\mathbf{2 5 , 7 \%}$ & $\mathbf{1 0 0 , 0 \%}$ & \\
\hline \hline
\end{tabular}

Os relatórios dos Analistas da Amostra Própria incluem "relatórios de início de cobertura", "updates" e análises setoriais que incluem não apenas a OGX, mas também outras empresas do setor de O\&G no Brasil e, por vezes, na América Latina (coletivamente denominados de "Relatórios"). Não podemos afirmar que a Amostra Própria contém séries completas dos relatórios de cada banco. Há também casos, como o do MS, onde, ao longo da cobertura, houve troca de Analistas.

Dos 393 relatórios analisados, 92\% pertencem a cinco dos nove bancos: CS, DB, IBBA, MS e SAN. Segundo a B3, as corretoras destes cinco bancos responderam por cerca de $25 \%$ do volume transacionado no mercado à vista da BOVESPA entre 2S2008 e os primeiros 10 meses de 2013.

Tabela 18 - Representatividade da Amostra Própria (\% Trading total da BOVESPA)

\begin{tabular}{|l|c|c|c|c|c|c|}
\hline & $\mathbf{2 S 2 0 0 8}$ & $\mathbf{2 0 0 9}$ & $\mathbf{2 0 1 0}$ & $\mathbf{2 0 1 1}$ & $\mathbf{2 0 1 2}$ & $\mathbf{1 0 m 2 0 1 3}$ \\
\hline DB & $1,30 \%$ & $1,56 \%$ & $1,49 \%$ & $1,95 \%$ & $2,39 \%$ & $1,34 \%$ \\
\hline CS & $8,84 \%$ & $7,50 \%$ & $6,88 \%$ & $9,26 \%$ & $9,68 \%$ & $11,57 \%$ \\
\hline IBBA & $3,78 \%$ & $5,66 \%$ & $5,57 \%$ & $5,78 \%$ & $5,19 \%$ & $5,39 \%$ \\
\hline SAN & $2,15 \%$ & $2,69 \%$ & $2,30 \%$ & $2,54 \%$ & $2,50 \%$ & $1,95 \%$ \\
\hline MS & $7,57 \%$ & $5,38 \%$ & $5,57 \%$ & $7,21 \%$ & $8,07 \%$ & $7,45 \%$ \\
\hline Total (\% Bovespa) & $\mathbf{2 3 , 6 4 \%}$ & $\mathbf{2 2 , 7 9 \%}$ & $\mathbf{2 1 , 8 1 \%}$ & $\mathbf{2 6 , 7 4 \%}$ & $\mathbf{2 7 , 8 3 \%}$ & $\mathbf{2 7 , 7 0 \%}$ \\
\hline
\end{tabular}

Obs.: inclui todos os CNPJs. Fonte: B3.

Ao comparar a evolução das medianas dos PAs da Amostra TR e da Amostra Própria do presente estudo, nota-se grande proximidade ao longo do período, com um viés mais conservador nesta última. 


\section{Gráfico 6 - Comparação entre as Medianas dos PAs da Amostra TR e da Amostra Própria}

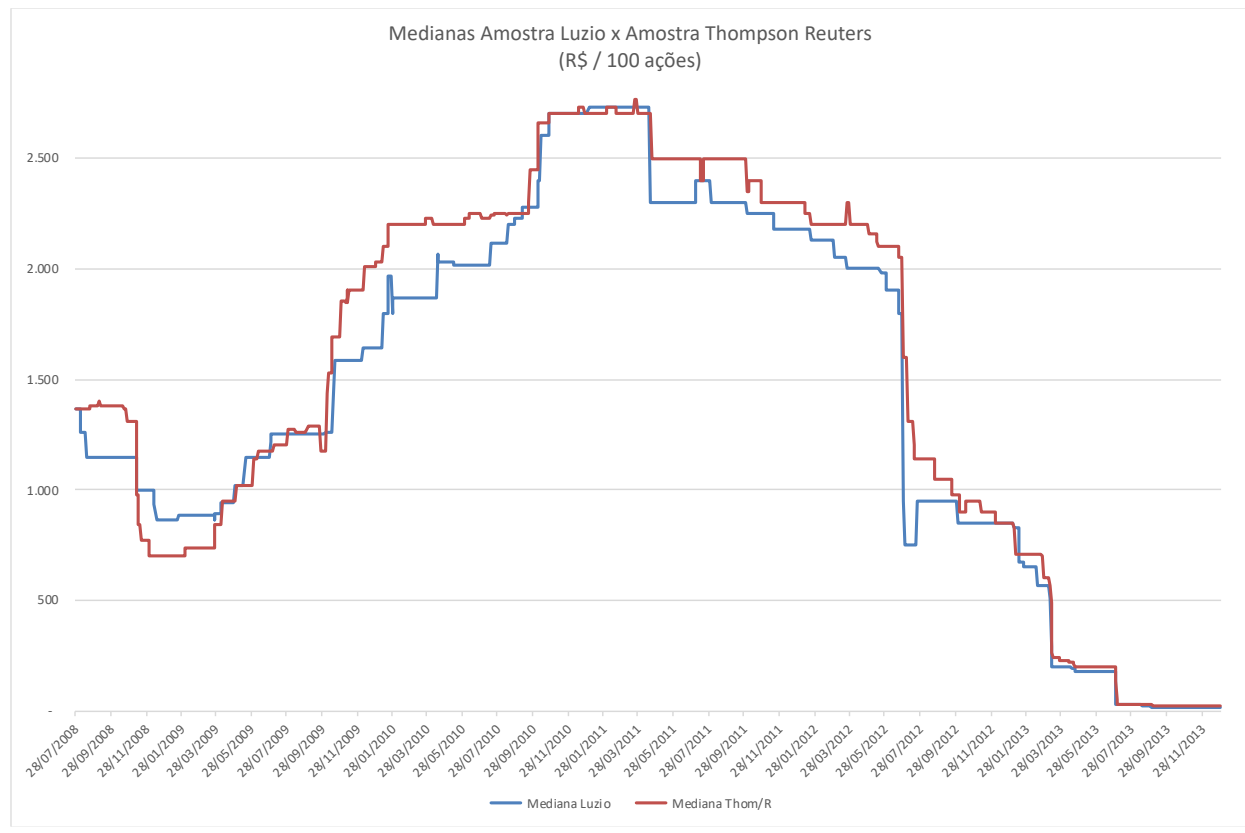

Dados os incentivos que a D\&M e os Analistas estavam expostos, é possível considerar que dentre os três conceitos de valor descritos, o Valor de Referência era, relativamente, o mais conservador. Os PAs tendiam a ser mais otimistas, quer seja por influência do otimismo do AC, dos Executivos e do Sentimento de Mercado, quer seja por conflitos de interesse com os Bls. E o Valor Ótimo estaria entre estes dois conceitos. 
Figura 6 - Possível Relação entre os Valores de Referência, os PAs e o Valor Ótimo

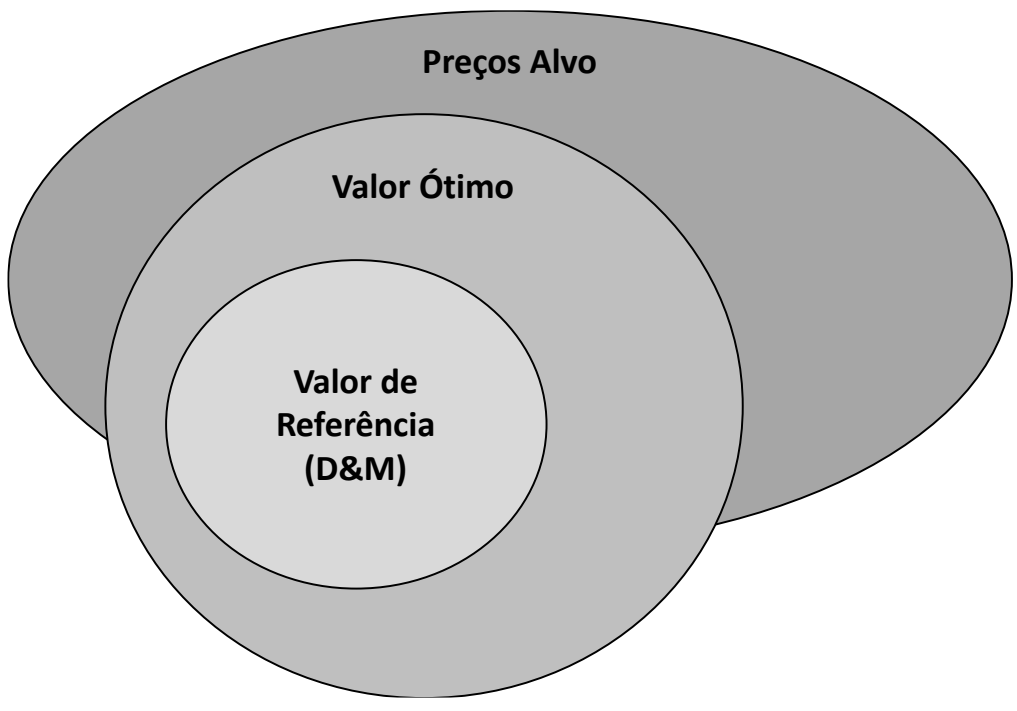

Analistas Otimistas

Analistas mais

Conservadores?

Dada estas ponderações, qual a possível contribuição da análise da evolução dos PAs e das reações dos Analistas ao guidance? A análise dos PAs e, principalmente, das justificativas dos Analistas sobre seus níveis pode "dar voz" ao mercado, que se manifesta de maneira lacônica através dos preços da OGXP3. Ao contestar ou ao endossar o guidance, a Tese de Investimento, os Analistas oferecem interpretações sobre erros e acertos dos Executivos e AC, com base em informações públicas e privadas. Apesar do viés do avaliador, estas interpretações oferecem subsídios para responder às três Questões de Pesquisa.

A análise dos relatórios dos Analistas da Amostra Própria e da Amostra TR pode ajudar a entender o impacto do guidance otimista sobre o ponto de vista do sell-side da OGXP3, que pela maior parte do tempo, defendiam que a OGXP3 estava subavaliada. No entanto, a capitalização de mercado da OGX é resultante do encontro entre as expectativas do sell-side com as do buy-side. Do buy-side há poucas informações diretas disponíveis.

A evolução da composição do floating da OGXP3 indica que a partir de fevereiro de 2012, a participação de investidores estrangeiros, que antes dominavam, começou a declinar drasticamente e a participação de pessoas físicas nacionais aumentou. 
Gráfico 7 - Composição do Floating da OGXP3 por Tipo de Investidor

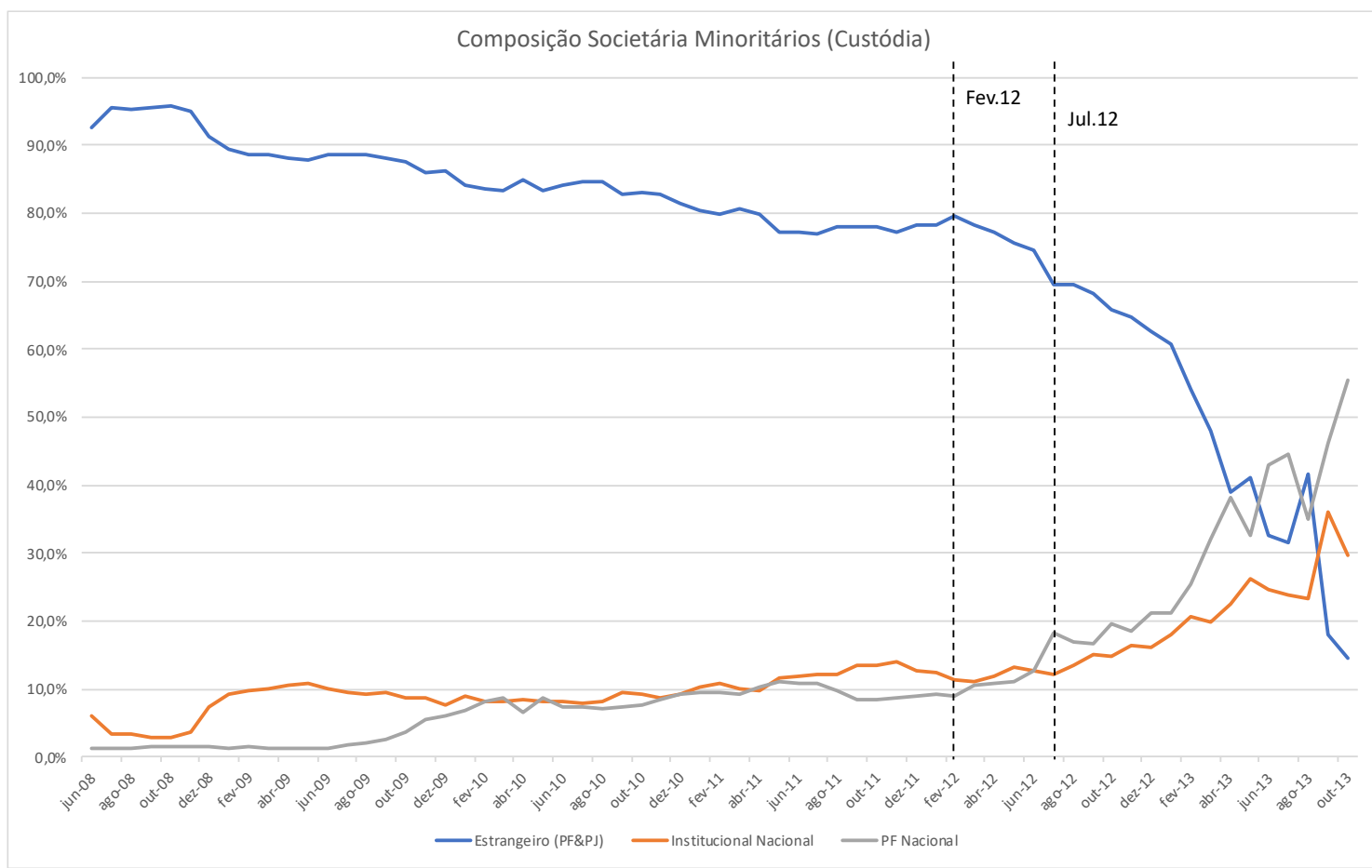

Fonte: B3.

Nas atas das AGEs, há indícios que muitos investidores sofisticados com visão de longo prazo mantiveram seu interesse na OGX por um bom tempo (até o fim de 2012). Através da análise de alguns indicadores de volatilidade ${ }^{91}$, encontramos indícios também de condições propícias aos noise traders, cuja atuação pode desestimular investidores racionais de longo prazo (DE LONG et al. [1987]), criando um círculo vicioso e potencialmente depreciativo. Até o momento da conclusão deste estudo, a OGX, a B3 não divulgou dados mais detalhados sobre a evolução das participações societárias dos vários tipos de investidores

91 Volatilidade "MaxMin" [PARKINSON, 1980] e o Alisamento Exponencial (Exponentially Weigthed Moving Average, ou "EWMA"). 


\subsubsection{Valor de Mercado}

O Valor de Referência e os PAs enquanto proxies para o Valor Ótimo têm virtudes e limitações. Os Valores de Referência foram estimados a partir de informações geológicas, químicas e geofísicas coletadas pela OGX e premissas e conceitos utilizados pela indústria de $O \& G$ internacional. Por exemplo, é prática nos Relatórios de Avaliação, utilizar a taxa real de $10 \%$ como premissa para o custo de oportunidade do capital, independente das idiossincrasias de cada empresa e do regime regulatório em que está inserida. O patamar de preços do petróleo ("price deck") é mantido constante ao longo de toda a projeção, apesar de suas conhecidas flutuações. Apesar desta e de outras limitações, como analisado no capítulo 3, o Valor de Referência foi parâmetro crucial no guidance e na Tese de Investimento e, como tal, crítico para a construção da percepção de valor da OGX por parte dos investidores e financiadores.

Os PAs e as premissas e projeções que os justificavam eram baseadas na percepção dos Analistas sobre a credibilidade e eficácia dos Gestores ${ }^{92}$. Como tal, os PAs representavam leituras críticas do Valor de Referência endereçadas aos clientes dos Analistas: os investidores racionais e com elevado potencial de compra. Parte destes investidores, considerando o potencial otimismo dos Analistas, não apenas liam seus Relatórios de Pesquisa, mas também os questionavam.

O que todos os Stakeholders observavam de maneira mais tangível, diária e sem custo era o Valor de Mercado. Entretanto, o conceito de Valor de Mercado não é menos controverso do que os outros três conceitos utilizados neste estudo.

Por várias razões, incluindo choques exógenos e realocações de portfólio, o Valor de Mercado poderia não refletir o do Valor Ótimo e/ou o Valor de Referência. Os Analistas tentavam diferenciar os fundamentos da OGX de fatores não idiossincráticos que afetaram seu Valor de Mercado. A tarefa era complexa. Dentre os fatores não idiossincráticos havia também os possíveis efeitos dos noise traders ${ }^{93}$, herding e do momentum trading de especuladores racionais sobre o valor da OGXP3.

Quando a OGXP3 passou a compor o IBOV em dezembro de 2009 surgiu outro fator não idiossincrático: o detracking risk. SHLEIFER [1986] e HARRIS \& GUREL [1986] ${ }^{94}$ demonstraram que a inclusão de uma ação no S\&P 500, e a consequente demanda por ações de fundos de índices (detracking risk), tem um impacto substancial nos preços da ação, embora não haja nenhuma implicação para os fundamentos de seu valor.

Contudo, apesar das controvérsias, não se pode menosprezar o valor informativo do Valor de Mercado de uma ação com a liquidez da OGXP3. O Valor de Mercado representava a média das perspectivas de valor de milhares de investidores sofisticados

\footnotetext{
92 Eficácia dos Gestores entendida aqui como a capacidade dos mesmos em gerenciar riscos e monetizar o portfólio de exploração dado as restrições orçamentarias da Empresa.

93 DE LONG et al. [1987], mostram que, mesmo com crenças errôneas, os noise traders podem afetar preços e capturar ganhos mais elevados do que investidores racionais. Estes elevados retornos podem ocorrer pelo aumento do risco gerado pela presença do noise traders.

${ }^{94}$ Cf. também LEE, SHLEIFER \& THALER [1991]; SHLEIFER \& SUMMERS [1990].
} 
e não sofisticados, especuladores racionais e noisy traders sobre o valor da OGX. O Valor de Mercado, portanto, poderia ser interpretado como uma leitura crítica as duas outras proxies, o Valor de Referência e os PAs. Adicionalmente, o Valor de Mercado era a base do SOP OGX e do SOP AC, com implicações para a gestão da Empresa.

Em suma, o Valor Ótimo pode ser estimado através de três proxies disponíveis: o Valor de Mercado, Valores de Referência e os PAs. Os Valores de Referências foram importantes alicerces da Tese de Investimento, enquanto os PAs podem ser considerados como interpretações dos Analistas sobre o quão factível era a Tese de Investimento e a eficácia dos Gestores na execução da campanha exploratória da OGX, ou seja, o Valor Ótimo.

Para compreender a estrutura de incentivos e investigar suas possíveis repercussões para as Questões de Pesquisa na Terceira Conjectura, o ponto de partida será a análise da evolução das três proxies para o Valor Ótimo entre junho de 2008 a outubro de 2013, analisada nos capítulos 3, 4 e 5 . 
"Eventos passados, presentes e mesmo eventos futuros descontados refletem-se no preço de mercado, mas muitas vezes não mostram relação aparente com as variações de preço... Causas artificiais também intervêm: a Bolsa reage a si mesma, e a flutuação atual é uma função, não apenas das flutuações anteriores, mas também do estado atual. A determinação dessas flutuações depende de um número infinito de fatores; é, portanto, impossível aspirar a previsões matemáticas das mesmas ... [A] dinâmica da Bolsa nunca será uma ciência exata".

BACHELIER, L., Theory of Speculation. Paris: Gauthier-Villars, 1900. apud BERNSTEIN, 2005, p. 19.

Dada sua importância para as Dinâmicas de Valor e a Tese Central, a frequência e acessibilidade de sua atualização, é importante analisar a evolução do Valor de Mercado entre o IPO e 31/10/2013, quando da RJ. A evolução da OGXP3 indica uma sequência de acentuadas desvalorizações e valorizações que se alternaram, em parte correlacionadas ao de-risking do portfólio, preço do petróleo tipo Brent, IBOV, volume transacionado, dentre outras. Embora não seja objeto de análises econométricas que poderiam elucidar as principais variáveis explicativas da evolução da OGXP3, o presente estudo se propõe a identificar elementos e eventos no guidance que podem estar relacionados às variações na OGXP3 para investigar sua relevância e implicações.

Gráfico 8 - Evolução da OGXP3 (R\$̧/ação, ajustados para o split) entre 12/06/2008 e $31 / 10 / 2013$

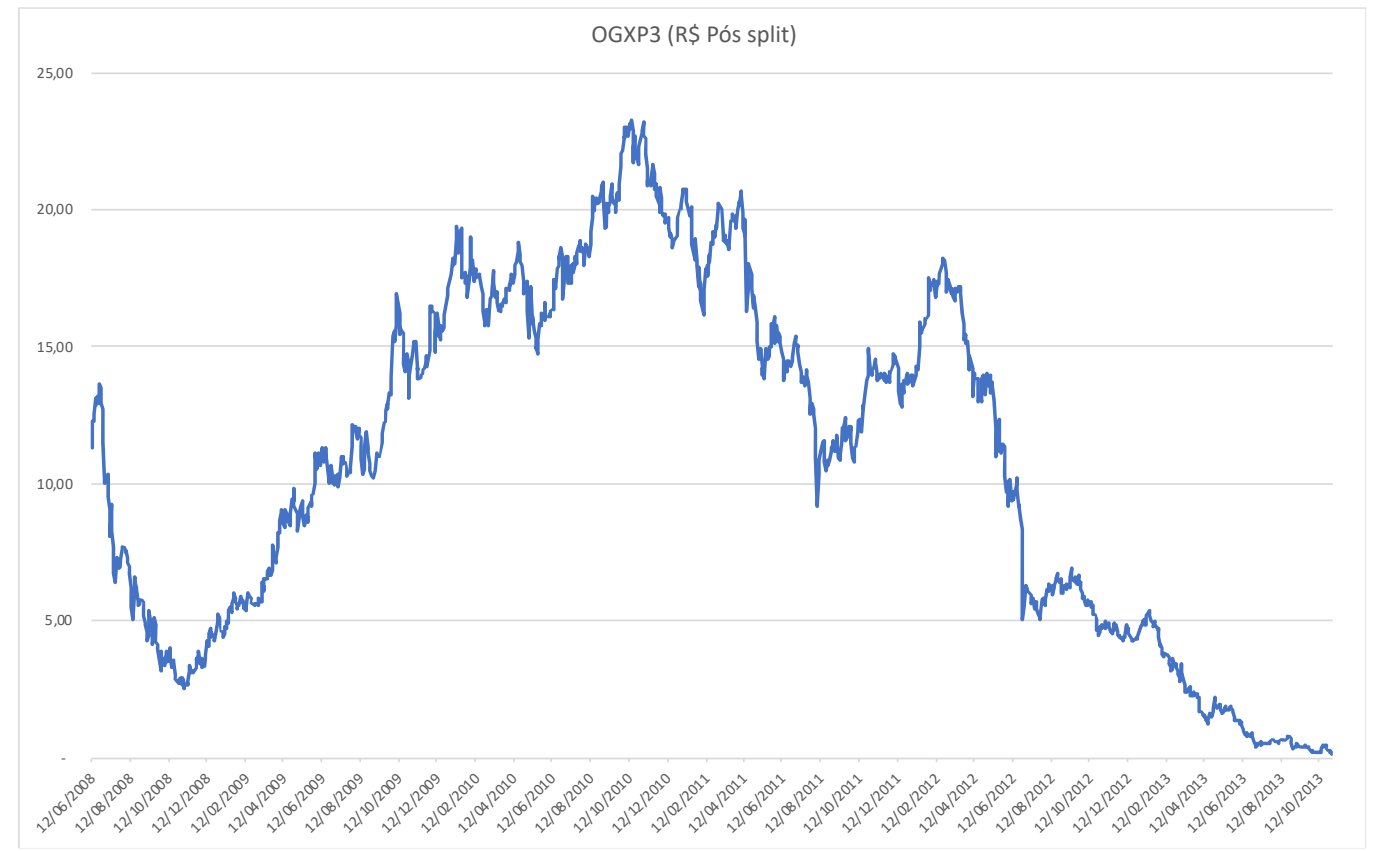


Os vetores endógenos incluem a percepção do risco geológico (incialmente com anúncios de descobertas de hidrocarbonetos, seguidos de estimativas de qualidade e quantidade de óleo no reservatório, e, posteriormente, os TLDs), captura de opções de crescimento (via farm-in e leilões de concessões), disponibilidade de equipamentos de E\&P, a capacidade de atrair novos recursos financeiros (via emissões de dívida e farmout) e a gestão do caixa da Empresa. Estes vetores endógenos compunham a Tese de Investimento.

Possivelmente, além dos vetores supramencionados, houve também o impacto de movimentos especulativos, realocações de portfólios (como, por exemplo, IPOs de outras junior oils e o follow-on da PETR) e outros vetores exógenos e não relacionados à OGX, ao setor de O\&G nacional e internacional.

Para começar a análise da evolução da OGXP3, com base em conceitos da análise técnica ${ }^{95}$, é possível identificar ao menos cinco períodos ao longo de junho de 2008 a outubro de 2013. São períodos com tendências apreciativas e depreciativas, pontos de inflexão, que refletem o Sentimento de Mercado. Soma-se a estes cinco períodos um anterior, um sexto período: os precedentes ao IPO.

Tabela 19 - Cinco mais Um Períodos da Evolução da OGXP3 (R\$̦/ação pós split)

\begin{tabular}{|l|l|c|c|c|c||}
\hline Datas de Início e Fim & \multicolumn{1}{|c|}{ Períodos } & $\begin{array}{c}\text { Número } \\
\text { Pregões }\end{array}$ & $\begin{array}{c}\text { OGXP3 } \\
\text { Início }\end{array}$ & $\begin{array}{c}\text { OGXP3 } \\
\text { Fim }\end{array}$ & \multicolumn{1}{|c||}{$\begin{array}{c}\text { Var. } \\
\%\end{array}$} \\
\hline 2006 a 25/06/08 & Antecedentes e IPO & 9 & 11,31 & 13,64 & $20,6 \%$ \\
\hline 25/06/08 a 06/11/08 & 1 a Correção Depreciativa & 102 & 13,64 & 2,54 & $-81,4 \%$ \\
\hline 06/11/08 a 04/11/10 & Primária Apreciativa (Rally) & 480 & 2,54 & 23,20 & $813,1 \%$ \\
\hline 04/11/10 a 08/08/11 & 2 a Correção Depreciativa & 179 & 23,27 & 9,20 & $-60,3 \%$ \\
\hline 08/08/11 a 23/02/12 & Correção Apreciativa & 128 & 9,20 & 18,21 & $97,9 \%$ \\
\hline 23/02/12 a 31/10/13 & Primária Depreciativa & 405 & 18,21 & 0,13 & $-99,3 \%$ \\
\hline
\end{tabular}

Fonte: Thompson Reuters para o VMD e preços da OGXP3.

Cabe enfatizar que as escolhas das datas que definem estes subperíodos não tiveram associação com um único evento corporativo. As expectativas, positivas ou negativas, foram construídas gradualmente, podendo incluir certos dias com significativas flutuações no valor da OGXP3 que foram associados a eventos corporativos específicos.

Antecedentes ao IPO a 25/6/08 (2006 a 25/6/08). Como descrito no capítulo 3, uma série de precedentes envolvendo a MMX em particular, o preço do Brent e as perspectivas do pré-sal brasileiro, viabilizaram o maior IPO da OGX. Entretanto, após uma alta de 20,6\% em 9 pregões (de $R \$ 11,31$ em 12/6/08 para $R \$ 13,64$ em 25/6/08,

\footnotetext{
95 Na definição de EDWARDS \& MAGEE [1992, p. 4], análise técnica "refere-se ao estudo da ação própria do mercado em contraposição ao estudo do ativo que o mercado transaciona".
} 
quando a Empresa chegou a valer 5,5x seu patrimônio líquido ${ }^{96}$ ), a OGXP3 inaugurou desvalorizações consecutivas que perduraram por quatro meses. Neste período, a OGXP3 se valorizou em 20,6\%, enquanto o IBOV se depreciou 2,2\% e o Brent (em $\mathrm{R} \$ /$ barril) perdeu $3,4 \%$.

Primeira Correção Depreciativa (de 25/06/08 a 06/11/08). A OGPX3 começou uma trajetória de queda a partir de 25/6, antes da implosão da "bolha do óleo do verão de 2008" (15/7) e da quebra da Lehman Brothers (15/9). Até 6/11, a OGXP3 havia se desvalorizado em $77,5 \%$, enquanto que o IBOV perdeu $46,0 \%$ e o Brent, em $\mathrm{R} \$$ /barril, perdeu $42,6 \%$.

Ou seja, em relação ao IBOV e ao Brent, após a euforia do IPO, a OGXP3 experenciou um significativo undershooting, que pode, ao menos em parte, ter sido amplificado pelo aumento da aversão ao risco após a crise de setembro de 2008. A aversão ao risco pode ter penalizado desproporcionalmente mais empresas greenfield, como a OGX. A trajetória de desvalorização da OGXP3 só se reverteria após $6 / 11$, quando atingiu um vale com $\mathrm{R} \$ 2,54$ equivalente a $22,5 \%$ do valor do IPO.

Gráfico 9 - Evolução da OGXP3, IBOV e Brent entre 12/6 e 6/11/2008 (IPO = 100)

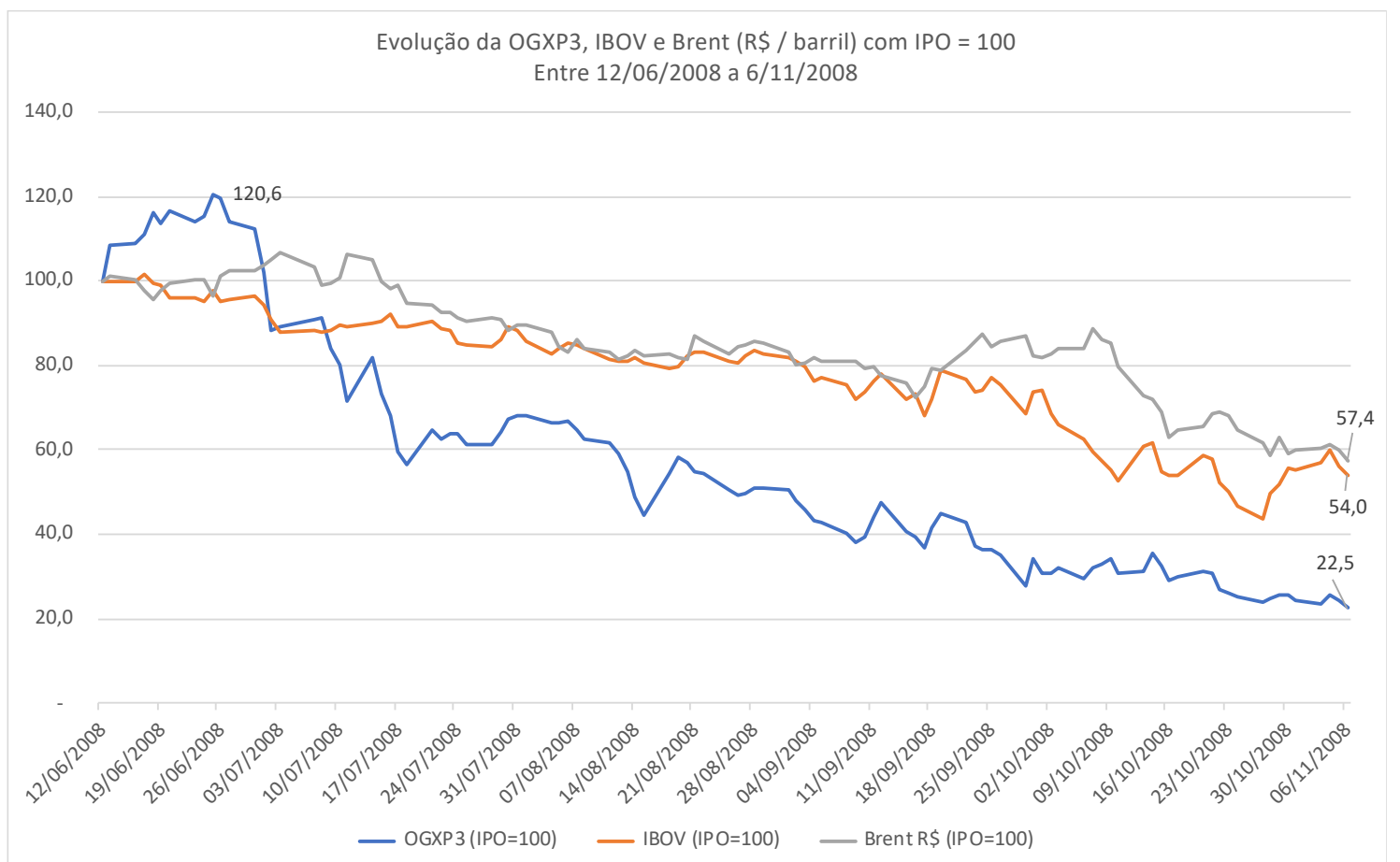

Primária Apreciativa (de 06/11/08 a 4/11/10). Em quase dois anos após seu primeiro vale histórico (R\$ 2,54 em 6/11/08), a OGXP3 praticamente se multiplicou por 9x, acumulando uma valorização de $816,1 \%$, quando chegou ao seu pico histórico de $\mathrm{R} \$$ ${ }^{96}$ Em $25 / 6 / 08$, quando a OGXP3 alcançou seu primeiro pico com $\mathrm{R} \$ 13,64$ por ação, equivalente a uma
capitalização de $\mathrm{R} \$ 44,08$ bilhões e um patrimônio líquido de cerca de $\mathrm{R} \$ 8,00$ bilhões. 
23,27 (15/10/10). O valor no pico correspondia a $205,7 \%$ do valor do IPO. O Valor de Mercado chegou a R\$ 75,2 bilhões, equivalente a 7,9x seu valor patrimonial. Devido a sua longa extensão (480 pregões) e sua significativa valorização, podemos considerar este período como uma "tendência primária" (ou major), de acordo com a Teoria de Dow $^{97}$ ("Rally").

No mesmo período, a OGXP3 se valorizou $(816,1 \%)$ muito mais do que a IBOV (que se valorizou em $97,6 \%$ ) e que o Brent $(9,8 \%)$, o que, a princípio, poderia sugerir um overshooting. Como descrito no capítulo 3, neste período, o 2을 9/11/2009, indicava que a OGX poderia ter $42,4 \%$ mais RPL (em bboe) do que havia previsto no IPO. A Empresa também publicou vários FRs com descobertas de hidrocarbonetos em Campos no mesmo período. Em abril de 2010, o AC divulgou ao mercado que estava negociando uma grande operação de farm-out com "várias" IOCs que poderia injetar bilhões de dólares na campanha exploratória, além de prover uma confirmação externa (IOC) que o portfólio prospectivo da OGX realmente tinha potencial para se transformar em Reservas. Os investidores estavam confiantes na Empresa e no guidance.

Gráfico 10 - Evolução da OGXP3, IBOV e Brent entre 6/11/2008 e 4/11/2010 (Vale = 100)

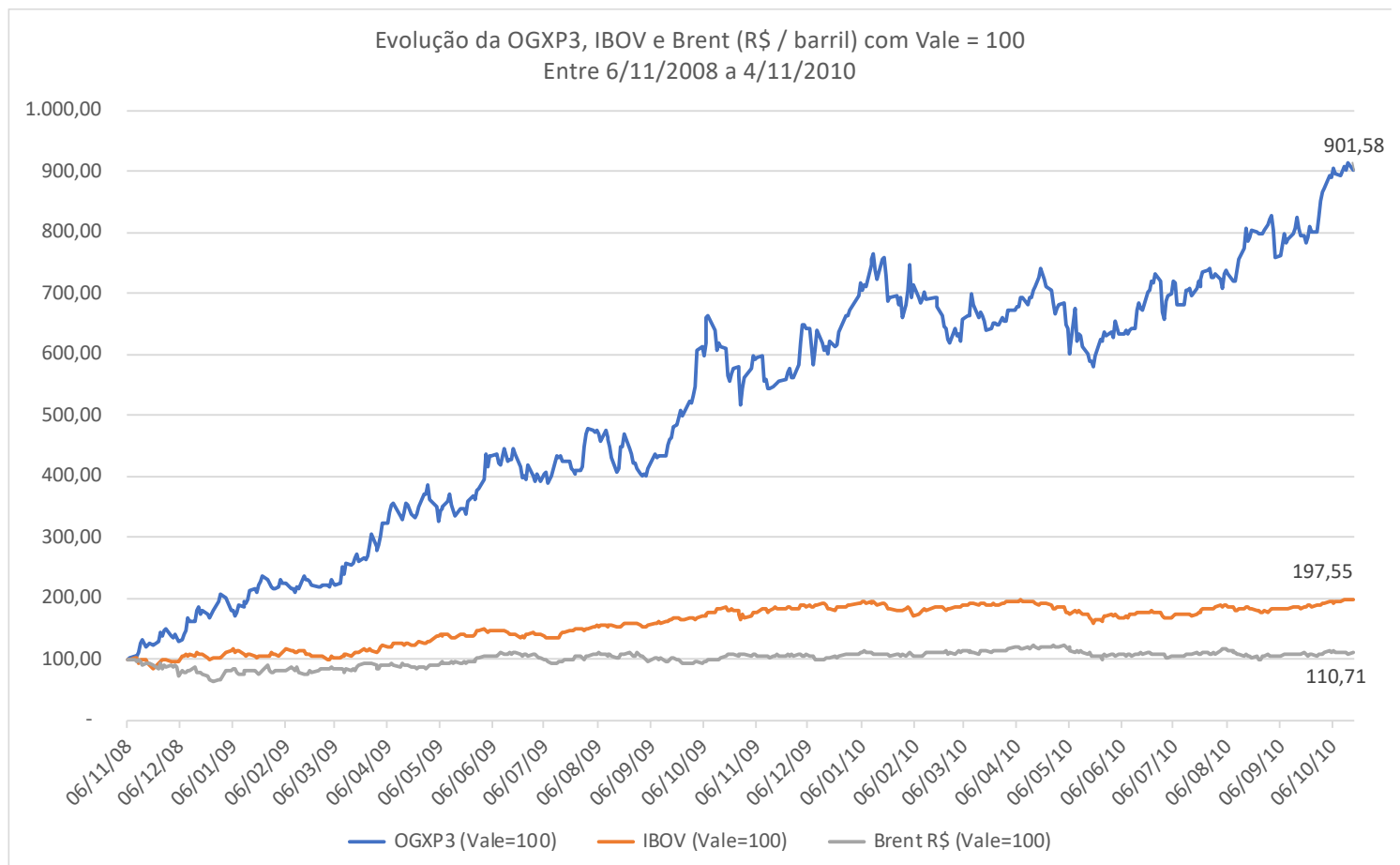

97 De acordo com EDWARDS \& MAGEE [1992, p. 16 e 17], uma "tendência primária" (ou major) é caracterizada por "extensivos movimentos de alta ou baixa que usualmente duram por um ano ou mais e resultam em apreciações ou depreciações de mais de $20 \%$. Movimentos em direção a uma tendência Primária são interrompidos em intervalos por "Secundárias" - reações ou "correções" em direções opostas que ocorrem quando o movimento da Primária temporariamente exagerou ["gotten ahead of itself'] (...) Secundárias normalmente duram de [ao menos três] semanas até muitos meses (...) retrocedendo de um a dois terços do ganho (ou perda) nos preços registrados na Primária anterior". 
Segunda Correção Depreciativa (de 4/11/10 a 08/08/11). Após o Rally, o Valor de Mercado passou por um período correção depreciativa ("bear"), ou uma secundária depreciativa, que terminou após 179 pregões, com a OGXP3 valendo $R \$ 9,20$, ou seja, equivalente a $39,5 \%$ do preço no pico do Rally (R\$ 23,27 ) e $81,3 \%$ do seu valor no IPO (R\$ 11,31). A depreciação da OGXP3 de 60,3\% superou a queda no IBOV $(-33,3 \%)$, enquanto o Brent, em $\mathrm{R} \$$ /barril, se valorizou em $15,6 \%$.

\section{Gráfico 11 - Evolução da OGXP3, IBOV e Brent entre 4/11/2010 e 8/08/2011 (Pico = 100)}

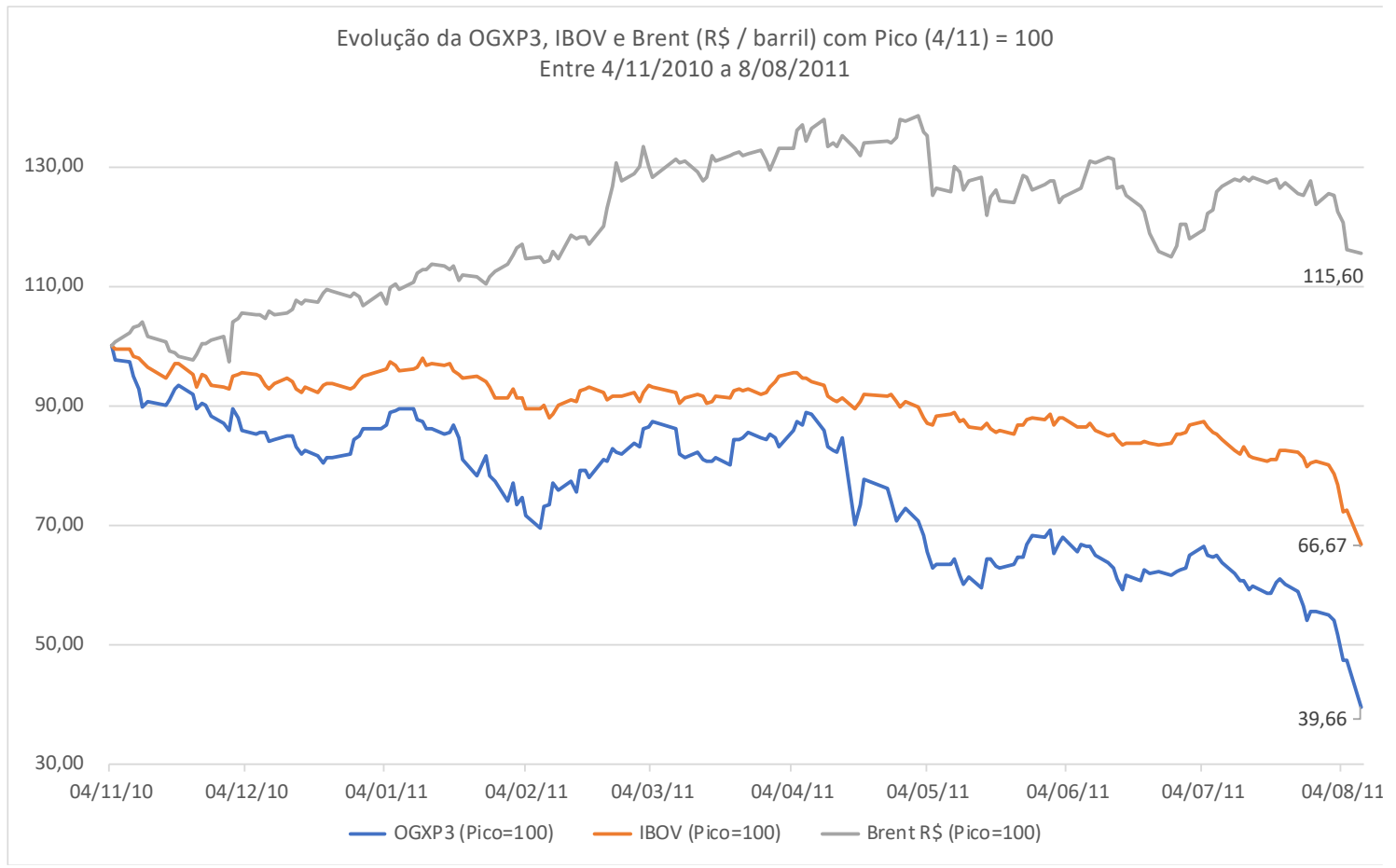

Como descrito no capítulo 3, o início desta secundária depreciativa pode refletir a frustração dos investidores quanto às negociações do farm-out em outubro de 2011. Seis meses antes, a publicação do 3 D\&M em 18/04/2011, que apesar de estimar um aumento no RPL de $123 \%$ em relação ao IPO, já havia frustrado as expectativas dos investidores. A frustração não foi pela quantidade estimada de RPL, mas sim pela sua qualidade. Aparentemente, os investidores esperavam indícios mais contundentes do de-risking, o que não foi confirmado pela D\&M.

Mesmo a conclusão da primeira captação de Senior Unsecured Notes, no montante de US\$ 2,6 bilhões (ou R\$ 4,0 bilhões, balão 7 anos, juros de 8,5\%) não foi capaz de reverter a secundária depreciativa. Aparentemente, a frustração quanto ao farm-out e a publicação do 3 o D\&M foram marcos no processo de perda de credibilidade do guidance, da Tese de Investimentos e, consequentemente, dos Gestores. 
Correção Apreciativa (de 08/08/11 a 23/02/12). A terceira correção, desta vez foi apreciativa, durou 128 pregões, menos do que a segunda correção (179 pregões). No período, a OGXP3 teve uma valorização significativa de 97,9\% ( $R \$ 18,21$ em 23/2/12), equivalente a $161,0 \%$ do preço do IPO, e 197,9\% em relação ao vale da Segunda Correção Depreciativa ( $R \$ 9,20$ em 8/8/11). No mesmo período, o IBOV se valorizou $35,2 \%$ e o Brent (em R\$) em $27,3 \%$.

Mas o valor máximo neste período não recuperou as perdas da secundária anterior: ficou $21,7 \%$ abaixo do preço pico do Rally ( $R \$ 23,27$, em moeda nominal). Entretanto foi uma recuperação significativa em relativamente pouco tempo.

Gráfico 12 - Evolução da OGXP3, IBOV e Brent entre 08/08/2011 e 23/02/2012 (Vale (2011) = 100)

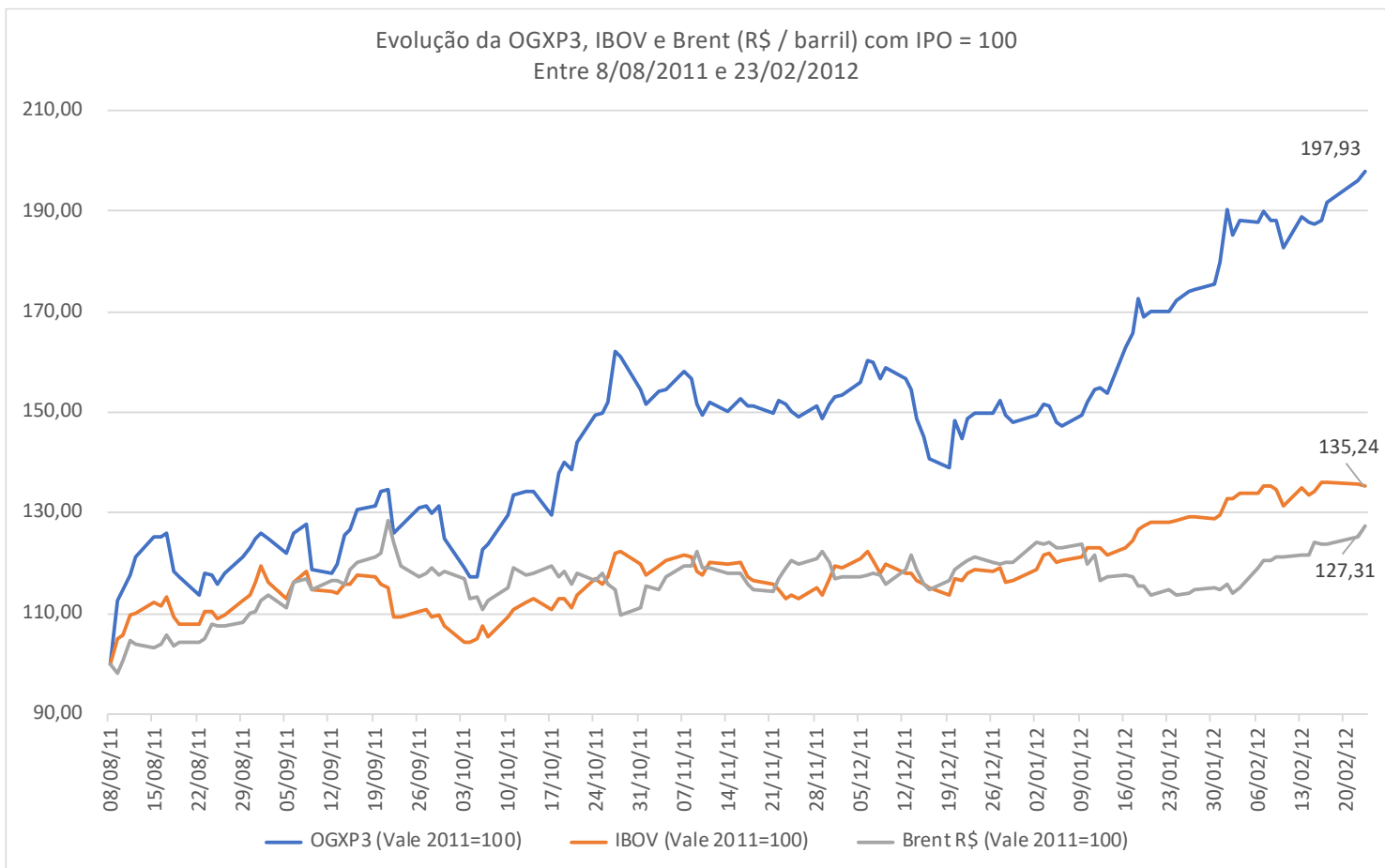

Os catalisadores desta correção podem estar relacionados ao sucesso da captação do 1‥ Note, ao desconto menor, em relação ao Brent, do preço de venda da primeira carga para Shell e o first oil de TBAZ. Ao fim de janeiro (28), a OGX passou de uma empresa puramente exploratória para a produção, e portanto, geração de receitas. Os Executivos estimavam que o TLD de TBAZ começaria em outubro de 2010, mas após atrasos operacionais, começou de fato o fim de janeiro de 2012.

Meltdown até RJ (de 23/02/12 a 31/10/13). Após o pico de $\mathrm{R} \$ 18,21$ de 23/2/12, a OGXP3 iniciou uma forte tendência de queda irreversível que durou 405 pregões, podendo ser considerada uma primária depreciativa. A OGXP3 perdeu 99,3\% de seu valor, sendo que a maior parte desta perda ocorreu em 86 pregões, entre 24/2 e $28 / 6 / 12$, quando passou de $\mathrm{R} \$ 18,21$ para $\mathrm{R} \$ 5,05$, uma perda de $72,3 \%$. O marco no 
guidance foi a teleconferência de 26/6/12 dos Executivos, AC e Analistas. Nesta ocasião, foi comunicado a revisão da ideal Waimea de $20 \mathrm{kbpd}$ (anunciado em setembro de 2011) para 5 kbpd e que a vazão e, consequentemente, o ramp-up da produção seria reduzido.

Logo após a fatídica teleconferência, o principal Executivo da OGX, o Dr. Oil, foi afastado da gestão (em 28/6). Em apenas dois pregões, 27 e 28/6, a OGXP3 perdeu 39,7\% de seu valor. Em 24/10/2012, nem a outorga de uma put do AC a favor da Empresa, no valor de US\$ 1 bilhão, pode interromper a forte depreciação da OGXP3. Em 14/6/2013, a OGXP3 ficou abaixo de R\$ 1,00 (R\$ 0,97): virou uma "penny stock".

Gráfico 13 - Evolução da OGXP3, IBOV e Brent entre 23/02/2012 e 31/10/2013 (Pico (2012) = 100)

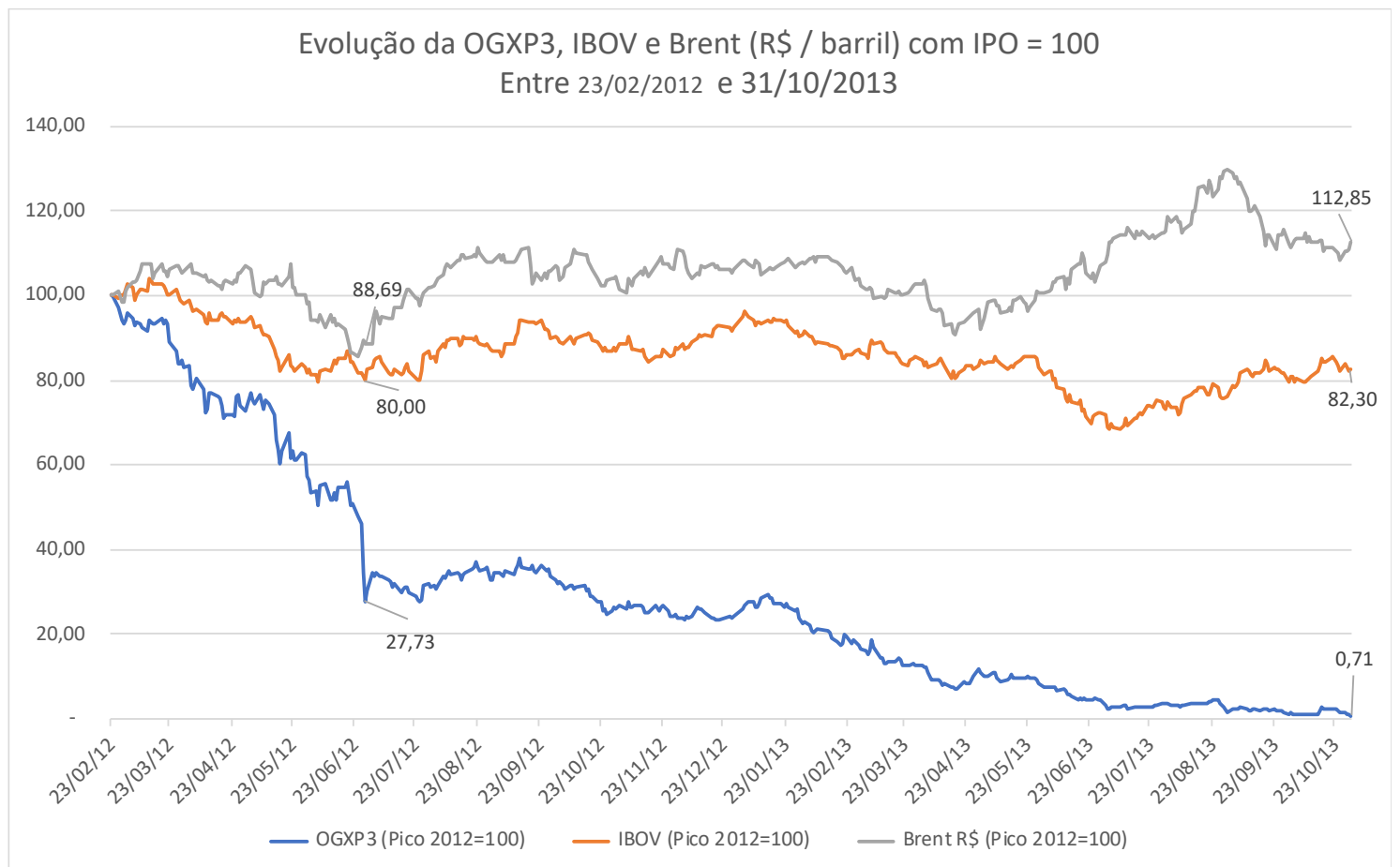

Quando do pedido de RJ em 31/10/13, a OGXP3 valia R\$ 0,13 por ação, correspondendo a um Valor de Mercado de $\mathrm{R} \$ 2,2$ bilhões, equivalente a $20 \%$ do valor patrimonial. Após o pedido de RJ, os Analistas encerraram a cobertura da OGXP3. O Valor de Mercado chegou a um mínimo de $R \$ 64$ milhões (em fevereiro de 2016). 
Por fim, vale destacar o aumento do VMD ao longo destes períodos que quase triplicou durante o Rally e continuou aumentando durante a 2a. Correção Depreciativa. Mesmo durante os dois últimos períodos, já com a OGXP3 valendo muito menos do que os níveis do Rally, o VMD manteve montantes significativos, indicando o expressivo giro do título.

Tabela 20 - Cinco Períodos da Evolução do VMD da OGXP3

\begin{tabular}{|l|l|r|r|r||}
\hline Datas de Início e Fim & Períodos & $\begin{array}{l}\text { Número } \\
\text { Pregões }\end{array}$ & $\begin{array}{l}\text { Var. \% } \\
\text { OGXP3 }\end{array}$ & \multicolumn{1}{|c||}{$\begin{array}{c}\text { VMD } \\
\text { Médio } \\
\text { (R\$ M/dia) }\end{array}$} \\
\hline De 25/06/08 a 06/11/08 & 1a Correção Depreciativa & 102 & $-81,4 \%$ & 68,2 \\
\hline De 06/11/08 a 04/11/10 & Primária Apreciativa (Rally) & 480 & $813,1 \%$ & 184,4 \\
\hline De 04/11/10 a 08/08/11 & 2a Correção Depreciativa & 179 & $-60,3 \%$ & 307,7 \\
\hline De 08/08/11 a 24/02/12 & Correção Apreciativa & 128 & $97,9 \%$ & 259,2 \\
\hline De 24/02/12 a 31/10/13 & Primária Depreciativa & 405 & $-99,3 \%$ & 219,9 \\
\hline
\end{tabular}

Fonte: Thompson Reuters.

\section{Gráfico 14 - Classificação da Evolução da OGXP3 em Cinco Períodos: 12/6/2008 a 30/10/2013 (R\$̣/ação pós split)}

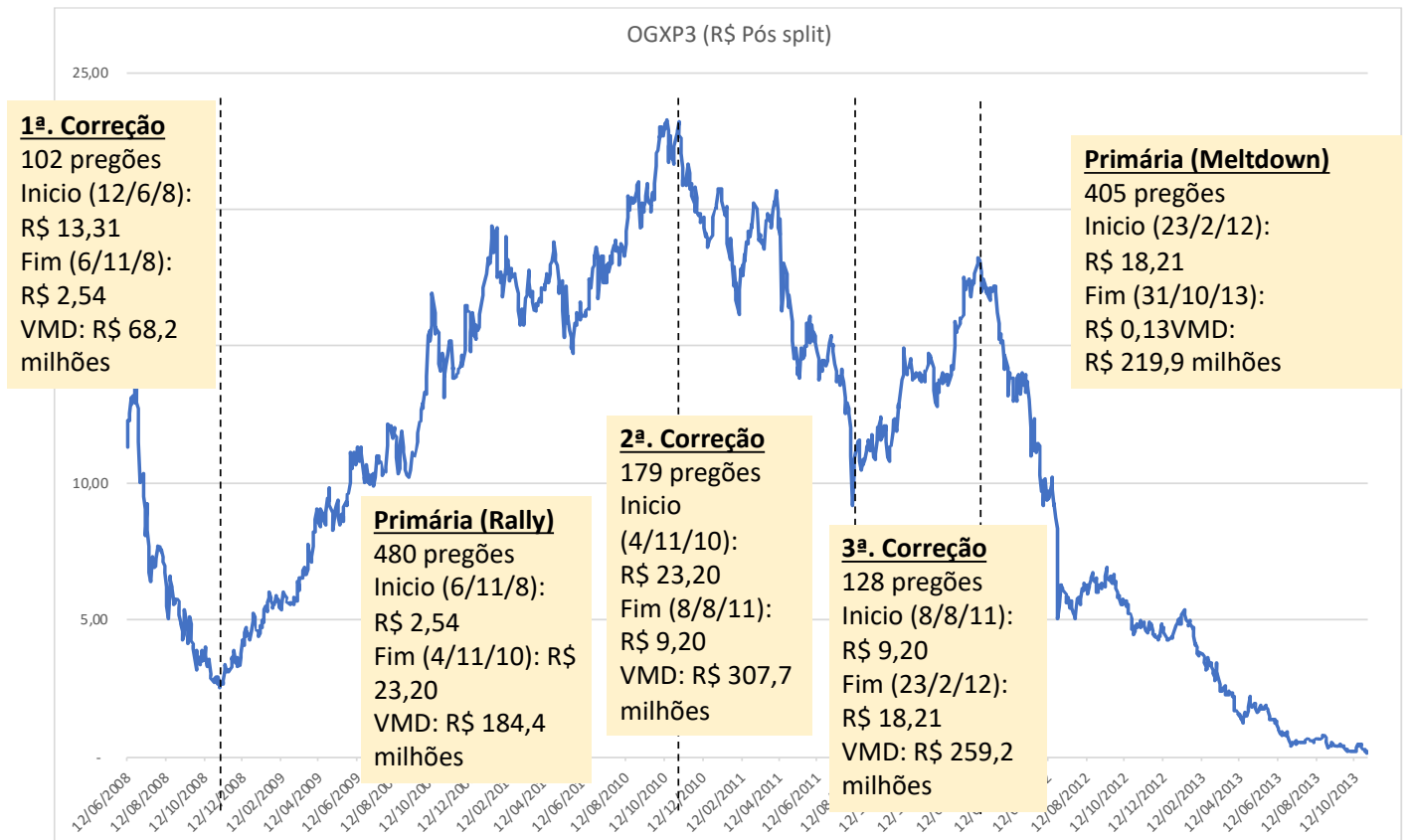




\subsection{Sub e Sobrevalorizações da OGXP3}

Conforme exposto no capítulo 1, na pesquisa sobre a Terceira Conjuntura, a Tese Central é que há indícios que um dos principais vetores de geração e destruição de valor da OGX foram os efeitos da Estrutura de Governança, em momentos de sub e sobrevalorizações da OGXP3, sobre o guidance, construído pelos Executivos, com endosso tácito ou explícito do $A C$ e do COAD. Não surpreende que estes períodos de sub e sobrevalorizações, em parte, coincidem com aqueles de under e overshooting identificados na seção 2.2: a Primeira Correção Depreciativa (de 25/06/08 a 05/11/08) e o Rally (de 06/11/08 a 4/11/10).

Comparações entre a média dos cenários do Valor de Referência e o Valor de Mercado produzem indícios de períodos sub e sobrevalorizações da OGXP3. Como o Valor de Referência é estimado sem considerar financiamentos, ou seja, sem dívida líquida, a comparação mais precisa seria entre Valor de Referência e o EV deduzido a partir do Valor de Mercado ${ }^{98}$.

No IPO, o EV da OGX era US\$17,363 bilhões, correspondia a 88,9\% da estimativa P90 (US\$ 19,52 bilhões) e 74,3\% da média dos cenários (US\$23,67 bilhões) do 10 D\&M. Em 25/6, nove pregões após o IPO, o Valor de Mercado chegou a US\$ 23,02 bilhões, equivalente a $98,5 \%$ da média do 10 D\&M, que era constituído de $100 \%$ Recursos Prospectivos. Como a recomendação SEC para avaliação de empresas abertas de O\&G se refere ao conceito de Reservas e não de Recursos Prospectivos, é possível que em 25/06/2008 a OGXP3 já estava sobrevalorizada.

Tabela 21 - Estimativas do 10 D\&M, EV e outros Indicadores (US\$ Bilhões)

\begin{tabular}{||l|c|c|c|c||}
\hline \multicolumn{1}{|c|}{ Indicadores } & US\$ Bilhões & $\mathbf{\% ~ M e ́ d i a ~}$ & $\mathbf{\% P 9 0}$ & $\mathbf{\% P 5 0}$ \\
\hline Estimativa Baixa (P90) & 19,521 & $83,5 \%$ & $100,0 \%$ & $84,4 \%$ \\
\hline Melhor Estimativa (P50) & 23,142 & $99,0 \%$ & $118,5 \%$ & $100,0 \%$ \\
\hline Estimativa Alta (P10) & 27,638 & $118,3 \%$ & $141,6 \%$ & $119,4 \%$ \\
\hline Média D\&M & 23,367 & $100,0 \%$ & $119,7 \%$ & $101,0 \%$ \\
\hline Capitalização IPO (sem caixa) & $\mathbf{1 7 , 3 6 3}$ & $\mathbf{7 4 , 3 \%}$ & $\mathbf{8 8 , 9 \%}$ & $\mathbf{7 5 , 0 \%}$ \\
\hline Patrimônio Líquido (sem Caixa) & 0,920 & $3,9 \%$ & $4,7 \%$ & $4,0 \%$ \\
\hline BA 9a. Rodada & 0,806 & $3,5 \%$ & $4,1 \%$ & $3,5 \%$ \\
\hline \hline
\end{tabular}

98 Para estimar o EV, somamos a capitalização de mercado (MC) com a dívida líquida da OGX (dívida bruta menos disponibilidades). Até junho de 2011, a OGX não possuía dívidas onerosas. Portanto, até este período, a dívida líquida da OGX era negativa, o que implica em valores do EV menores do que o MC. Pela mesma razão, em 2013, nas vésperas do colapso da OGX, os valores do EV eram superiores ao MC. Neste período, o EV era composto principalmente pela dívida. Vale destacar que, por se tratar de uma dedução a partir do preço observado no float da OGXP3 no BOVESPA (correspondente a participações minoritárias), o EV não considera prêmio de controle. 
Considerando como proxy para o Valor Ótimo as médias das estimativas (próximos ao P50) dos três Relatórios de Avaliação da D\&M e comparando-os com o EV, é possível identificar três períodos de possíveis sobrevalorizações da OGX:

1) Em 25/06/2008 (um pregão);

2) De $2 / 10$ a 19/10/2009 (durante 11 pregões consecutivos);

3) De 17/08/2010 a 15/04/2011 (durante 140 pregões [85,4\%] em um total de 164 pregões).

Gráfico 15 - EV versus VPL do Cenários Médios D\&M: Indícios de Sobrevalorização da OGXP3

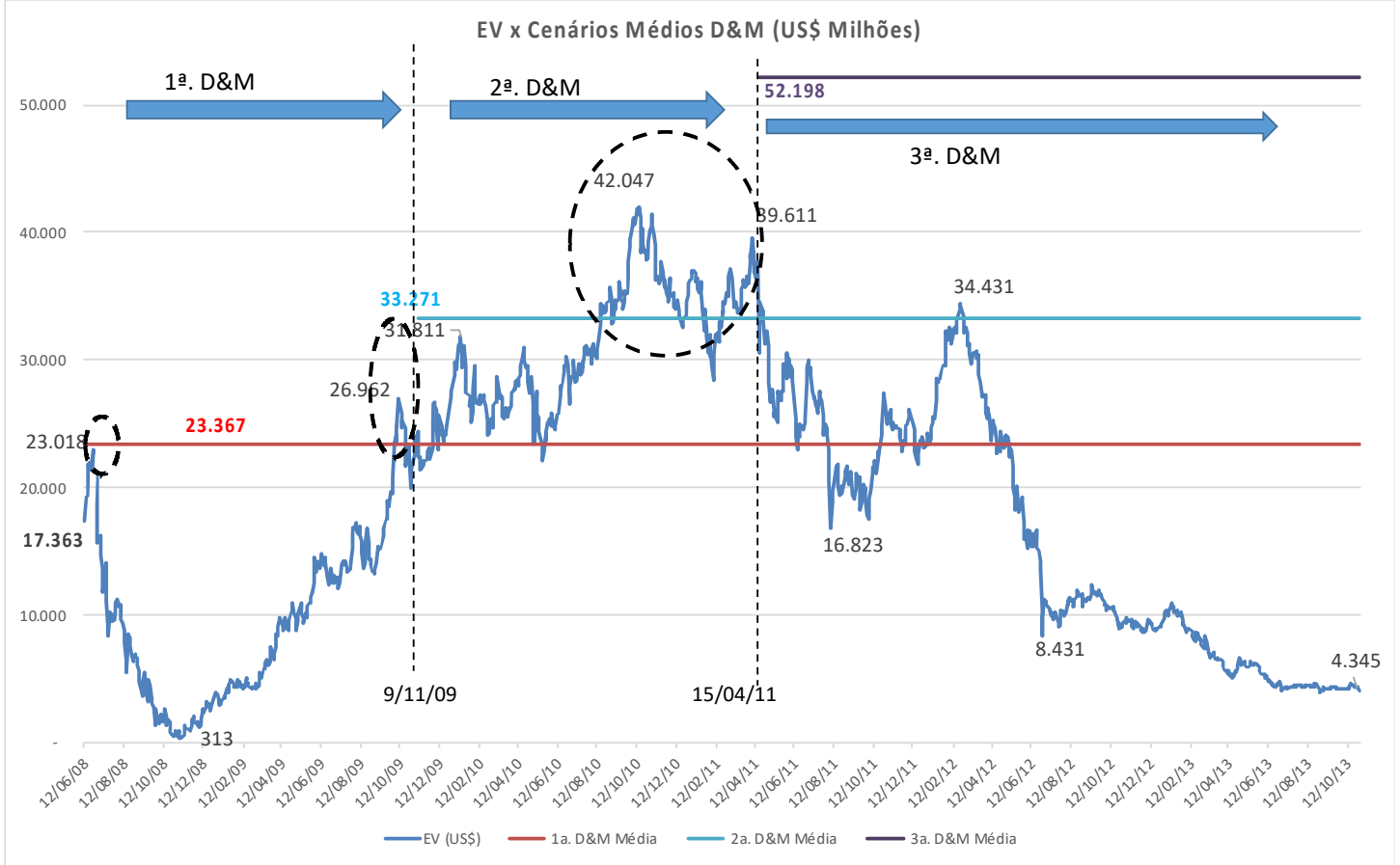

No pico, em 15/10/2010, o EV da OGX alcançou US\$ 42,047 bilhões (US\$ 6,11/boe) equivalente a $193 \%$ do valor no IPO e $26,4 \%$ acima do Valor de Referência do 20 D\&M (US\$ 33,271 bilhões). O terceiro e mais longo período de sobrevalorização termina em 15/04/2011, às vésperas da publicação do tão esperado 3 D\&M. Este dia foi um dos principais marcos na história da OGX e ponto de inflexão na evolução da OGXP3. Como descrito na seção 3.4, a publicação do 3 D\&M teve forte impacto na percepção do derisking da OGX e na credibilidade dos Executivos.

Pelo mesmo critério, o período de 317 pregões consecutivos (desde o IPO em 26/06/2008 a 01/10/2009) anterior à primeira sobrevalorização deveria ser classificado 
como um período de subvalorização ${ }^{99}$. Entretanto, a demarcação do período de subvalorização é menos óbvia, uma vez que houve dois eventos exógenos importantes no período: a implosão da "Bolha do Óleo do Verão de 2008", quando em um mês (entre $14 / 07$ e 14/08) o Brent caiu 21,5\% (de US\$142,43 para US\$111,82 por barril); e a quebra da Lehman Brothers em setembro. O aumento da aversão ao risco causado por estes dois eventos pode justificar parte da desvalorização da OGXP3 após 25/6/2008. Porém, no vale de 6/11/2008, o EV da OGX correspondia a US\$ 313 milhões (US\$ 0,06/boe), valor este $61,2 \%$ abaixo dos BAs dos blocos na 9a Rodada (US\$ 806,5 milhões ou US\$ $0,17 /$ boe).

Em suma, assumindo como proxy para o Valor Intrínseco a média dos cenários da D\&M, houve três períodos significativos de subavaliação.

1) De $26 / 06 / 2008$ a $1 / 10 / 2009$ (durante 317 pregões consecutivos);

2) De 09/11/2009 a 16/08/2010 (durante 188 pregões consecutivos);

3) De 15/04/2011 a 26/06/2012 (durante 298 pregões consecutivos).

Cabe destacar que a duração do segundo período de subavaliação vai até 26/06/2012, quando a OGX divulgou ao mercado dados sobre os fluxos do TBAZ que comprometiam o ramp-up da produção. A partir deste momento e dada a ausência de 40 D\&M para o portfólio todo, a média dos cenários do 3 D\&M como proxy para o Valor Ótimo não seria mais adequada.

Gráfico 16 - EV versus VPL do Cenários Médios D\&M: Indícios de Subvalorização da OGXP3

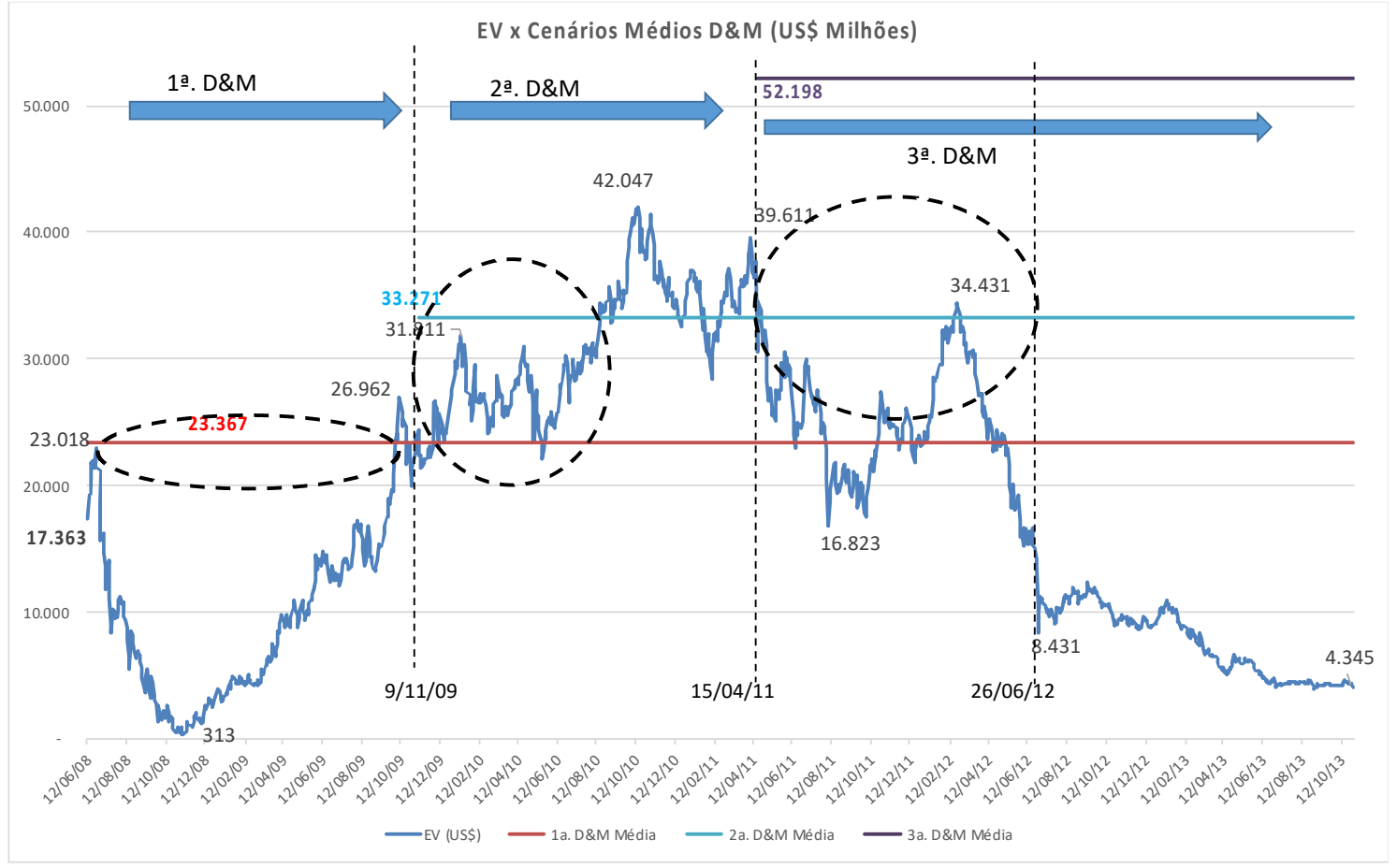

\footnotetext{
99 Se consideramos como critério de comparação o EV com o P90 do 10 D\&M (US\$ 19.521 milhões), o período de subvalorização se estenderia por 310 pregões consecutivos, de 01/07/2008 a 25/09/2009.
} 


\title{
2.4 Sentimentos do Mercado e Possíveis Implicações
}

\begin{abstract}
"Ações e bonds, por exemplo, dada suas próprias naturezas, são convites à especulação e até mesmo à corrupção: ninguém os adquire com o sublime propósito de tornar mais eficiente a alocação do capital da nação. As pessoas só os compram na esperança de pegar uma carona para a estrada da fortuna".
\end{abstract}

BERNSTEIN, 2005, p. 7.

Desde KEYNES [1936] economistas estudam os efeitos dos sentimentos na reação dos investidores e seus efeitos decorrentes nos preços de ativos. A questão central era como os investidores formam crenças que podem gerar subreação e sobrerreação, distorcendo preços e gerando oportunidades de ganhos extraordinários.

A teoria da economia comportamental que estuda os preços de ativos financeiros que demonstraram comportamentos "exuberantes", aparentemente irracionais, como a Bolha da Internet em 1990, considera duas premissas. A primeira, que certos investidores são sujeitos a sentimentos ("sentiments"). Os sentimentos destes investidores podem ser definidos como crenças, otimistas (high sentiment) ou pessimistas (low sentiment), sobre os fluxos de caixa e riscos futuros que não condizem com os fatos disponíveis (DELONG, SHLEIFER, SUMMERS \& WALDMANN [1990]) gerando bolhas e colapsos (crashes) ${ }^{100}$.

BARBERIS, SHLEIFER, VISHNY [1998] elaboraram um modelo de formação de sentimentos para explicar os fenômenos de subreação (underreaction) dos preços das ações à notícias (que pode durar de 1 a 12 meses) e sobrerreação (overreaction) das ações à um longo fluxo de notícias positivas, que pode durar de 3 a 5 anos, e acarretar na sobrevalorização da empresa. Fenômenos de subreação e sobrerreação desafiam a hipótese de eficiência de mercado, pois sugerem que investidores sofisticados podem lucrar nestes momentos sem estarem expostos a riscos adicionais.

A segunda premissa (SHLEIFER \& VISHNY [1997]) é que apostar contra o sentimento do investidor é custoso e arriscado ${ }^{101}$, inclusive porque a evolução dos sentimentos dos investidores pode ser, em parte, difícil de prever (BARBERIS, SHLEIFER, VISHNY [1998]).

100 Primeiros estudos: SHILLER [1981] sobre excesso de volatilidade; FAMA \& FRENCH [1988] e POTERBA \& SUMMERS [1988] sobre a reversão à media; CAMPBELL \& SHILLER [1988] e FAMA \& FRENCH (1989) sobre indicadores de valor.

101 Segundo BAKER \& WURGLER [2007], há pesquisas que mostram que a arbitragem tende a ser particularmente arriscada e cara para ações de empresas jovens, pequenas, não lucrativas ou que experimentam um crescimento extremo. Tais ações tendem a ser mais caras para comprar e vender a descoberto (D'AVOLIO [2002]). Tais ações têm um alto grau de variação idiossincrática em seus retornos, o que torna as apostas mais arriscadas (WURGLER \& ZHURAVSKAYA [2002]). 
Ou seja, dentre outros, os arbitradores correm o risco do "noise traders"102 no curto prazo.

SHLEIFER \& SUMMERS [1990] analisam os impactos dos noise traders que são caracterizados como investidores que não agem de maneira completamente racional e tomam decisões baseadas em suas crenças ou sentimentos que não podem ser plenamente justificados pelos fundamentos públicos. Os autores encontraram evidências que os noise traders têm influência significativa sobre os preços das ações e ganham retornos maiores do que investidores racionais.

Segundo KAPLANSKI \& LEVY [2017], "noise traders" seriam investidores que decidem comprar e vender ações sem considerar análise fundamentalista, mas sim considerando "pseudo sinais" (pseud-signals), como uma "dica" sobre uma suposta informação privilegiada. Geralmente, sobrerreagem às notícias boas e ruins, seguem tendências. Se os efeitos dos noise traders forem relevantes, então os preços das ações podem se distanciar de seus fundamentos.

Distinguir entre noise traders e investidores sofisticados não é uma tarefa trivial. Noise traders tornam as ações de sua escolha mais arriscadas, pois ficam sujeitas aos seus caprichos. Investidores sofisticados e avessos a riscos evitam estas ações, a não ser que sejam recompensados pela exposição ao risco fundamental e ao risco gerado pelos noise traders. Se o comportamento dos noise traders responde por parte significativa da volatilidade das ações, então é racional para investidores sofisticados monitorarem indicadores de tendências futuras dos noise traders, e preferirem adotar estratégias que sigam o tempo do mercado (como momentum trading ${ }^{103}$ ) que não necessariamente se assemelham a estratégias de compra e manutenção ("buy-and-hold strategies"). No caso da OGXP3, alguns investidores poderiam acreditar que o Valor Ótimo era baixo ou nulo, mas nem por isso deixaram de comprar a OGXP3 durante suas tendências apreciativas aguardando o melhor momento para vendê-la antes do próximo ponto de inflexão (a chamada estratégia de "dança das cadeiras").

Como consequência dos noise traders e as oportunidades para tradings de tendência, investidores racionais ou arbitradores não atuam de forma tão agressiva para forçar os preços dos ativos aos níveis justificados pelos seus fundamentos, como o paradigma da eficiência de mercado sugere. Ou seja, quando os sentimentos dos investidores predominam, há limites nas forças de arbitragem. Durante a Bolha da Internet em 1990, BAKER \& WURGLER [2007] relatam que muitos arbitradores tiveram grandes perdas e/ou foram à falência.

Estas duas premissas implicam na existência de dois tipos de investidores: aqueles racionais e imunes aos sentimentos; e os irracionais, propensos a serem influenciados por sentimentos exógenos, os noise traders e o "dumb money" (FRAZZINI \& LAMONT [2008]). Ambos competem no mercado para definir preços e retornos, que pode levar a

\footnotetext{
102 Outras referências de noise traders: LEE, SHLEIFER \& THALER [1991]; SHLEIFER \& SUMMERS [1990].

103 KAHN [2009, p. 5] ilustra momentum trading no contexto de comodities, mas que pode ser replicado para o caso de ações: "(...) essencialmente comprar comodities que tenham tido altos retornos durantes períodos recentes e vender (ou vender à descoberto) aqueles com baixos retornos (...)"
} 
distorções de valor quando os irracionais predominam e/ou quando há limites para transações de arbitragem dos racionais.

Como medir os sentimentos dos investidores e seus efeitos? Há um "beta sentimento"? Empiricamente, é difícil comprovar a existência destes sentimentos e seus efeitos, pois estes não são diretamente observáveis. Sentimentos dos investidores compõe um fenômeno complexo cujo mecanismo de propagação é vago e possivelmente associado com outras tendências anômalas de preços ${ }^{104}$.

Uma abordagem é microeconômica, que estuda a psicologia dos investidores, como excesso de confiança ("overconfidence"), a heurística da representatividade (representativeness ${ }^{105}$ ), e conservadorismo (conservatism ${ }^{106}$ ), que podem gerar avaliações distorcidas ("misvaluation") ${ }^{107}$ e afetar preços das ações, volumes e os sentimentos dos investidores.

No caso da OGX e outras empresas percebidas como de alto crescimento (high-growth companies), a heurística da representatividade pode ter levado os investidores a interpretar o histórico de sucesso dos Executivos, do AC e da valorização da OGXP3 como tendências futuras, sem considerar que poucas empresas, em particular em E\&P de $O \& G$, conseguem continuar a crescer por muito tempo.

O fenômeno do conservadorismo pode ter levado os investidores da OGX a não considerar a devida dimensão do impacto da falta de notícias (por exemplo, sobre o insucesso no BM-S-29, o baixo volume de recursos contingentes no 20 D\&M, o insucesso do farm-out de Campos) ou de notícias incompletas (como a crescente falta de detalhes no 2 ㅇ D\&M e 3을 D\&) em seus modelos de avaliação da OGX.

O fato da equipe da OGX ter tido alta taxa de sucesso nas descobertas em Campos durante seu trabalho na PETR não seria garantia que o mesmo sucesso iria se repetir na OGX. Talvez por isso, os Executivos valorizaram tanto suas primeiras descobertas na OGX, com $100 \%$ de taxa de sucesso, incluindo estimativas prematuras de volumes recuperáveis (em Vesúvio e Pipeline, por exemplo), ao mesmo tempo em que notícias negativas (por exemplo, o insucesso do BM-S-29) foram ocultadas.

BAKER \& WURGLER [2007] relatam que ações particularmente e desproporcionalmente sensíveis aos sentimentos de mercado são de empresas cujo valor intrínseco é difícil de

\footnotetext{
${ }^{104}$ Por exemplo, cf. AISSIA [2016] e LISTON [2016].

105 "Representatividade" é a tendência dos investidores em interpretar eventos como típicos ou representativos de alguma classe específica e a ignorar as leis da probabilidade no processo. Ou seja, na heurística da representatividade, os investidores identificam tendências em fenômenos aleatórios. O artigo seminal sobre representatividade é de TVERSKY \& KAHNEMAN [1974].

106 "Conservadorismo" é definido como a lenta atualização dos modelos de avaliação dos investidores (no caso de ações) frente a novas evidências (EDWARDS [1968]). Esta lentidão pode ser causada pela crença que os efeitos de um novo fato podem ser temporários, por exemplo. Neste caso, os ajustes nos modelos de avaliação seriam parciais, preservando a crença original sobre o valor da empresa, o que seria uma forma de excesso de confiança do investidor. A evidência de subreação, em particular, é consistente com o conservadorismo.

107 BARBERIS, SHLEIFER, VISHNY [1998]; DANIEL, HIRSHLEIFER, SUBRAHMANYMAN [1998].
} 
estimar e/ou possui um teor altamente subjetivo. Os autores citam um exemplo que pode se aplicar ao caso da OGX ${ }^{108}$ :

Por exemplo, no caso de uma empresa de crescimento jovem, atualmente não rentável, mas potencialmente extremamente lucrativa, a combinação de nenhum histórico de lucros e um futuro altamente incerto permite que os investidores defendam avaliações que variam de muito baixas a muito altas, como convém a sentimento. Durante uma bolha, quando a propensão a especular é alta, os banqueiros de investimento podem juntar-se ao coro, defendendo altas avaliações. Por outro lado, o valor de uma empresa com um longo histórico de lucros, ativos tangíveis e dividendos estáveis é muito menos subjetivo e, portanto, seu estoque provavelmente será menos sensivel ao sentimento [BAKER \& WURGLER, 2007, p. 4].

Esse tipo de ação que é difícil de avaliar, e pela mesma razão é difícil de arbitrar.

Outro paradigma de pesquisa dos Sentimentos de Mercado, conhecida como "de cima para baixo", reconhece que investidores reais e mercados são demasiadamente complexos para serem mensurados. Neste paradigma, as variações nos sentimentos dos analistas são exógenas, e como tal foca em medidas do sentimento agregado e investiga seus efeitos sobre os preços de ações individuais, com o objetivo de elucidar quais ações são potencialmente mais suscetíveis aos sentimentos.

Há duas principais previsões da abordagem "de cima para baixo". A primeira é que quando há choques de demanda, oriundos de sentimentos, que variem entre empresas, ao mesmo tempo em que arbitragem é difícil entre as empresas, então o sentimento gera uma demanda maior por ações mais especulativas. Assim, quando o sentimento aumenta, a ação "especulativa" gera retornos mais altos, podendo ficar sobrevalorizadas, como pode ter sido o caso da OGXP3. Mas, quando seu valor intrínseco é revelado, seu retorno cai. Portanto, quando uma ação se torna suscetível a sentimentos otimistas, seus retornos futuros serão menores do que aqueles das ações de empresas mais estáveis ("bond-like stocks"), como empresas de infraestrutura.

Ainda segundo BAKER \& WURGLER [2007], mensurar os sentimentos dos investidores não é trivial, o que não impede de haver combinações de algumas métricas imperfeitas que podem ser úteis. Nas métricas é difícil distinguir os efeitos de potenciais causas comportamentais de causas macroeconômicas e idiossincrasias setoriais ${ }^{109}$.

108 Outros exemplos de empresas suscetíveis aos sentimentos citados por BAKER \& WURGLER [2007] incluem empresas: com baixa capitalização de mercado; jovens, portanto sem histórico operacional; que não geram lucros; altamente voláteis; que não pagam dividendos; com alto potencial de crescimento; ou em crise de liquidez. Por exemplo, as pequenas startups que provocaram a maior parte do entusiasmo e o colapso da bolha da Internet. Este tipo de ação pode ser mais difícil de avaliar e de arbitrar (por exemplo, por elevados custos de transação).

109 As possíveis métricas incluem: retornos dos primeiros dias pós IPO; volume do IPO; indicadores de humor (mood proxies); volume transacionado; volume transacionado por pequenos investidores ou investidores individuais (retail investors); insider trading; volatilidade implícita de opções; dentre outras. Nos EUA, os sentimentos podem ser medidos através de indicadores como: CBOE Volatility 
Sentimentos distorcem preços, que podem gerar comportamentos oportunistas por parte dos executivos da empresa em questão. Possuidores de informações privilegiadas, estes executivos podem manipular a contabilidade da empresa. Mas a contabilidade da empresa também pode ser resultante das condições de mercado. Ou seja, não é trivial mensurar sentimentos e seus efeitos.

KAPLANSKI \& LEVY [2017] investigaram os efeitos dos Analistas sobre os sentimentos dos investidores em uma amostra com 34 anos (1980-2013) e 3 milhões de dados sobre ações nos EUA. A análise de causalidade revelou que o sentimento afetou "profundamente" vários aspectos das previsões e recomendações dos Analistas. Sentimentos positivos (de alta) precedem revisões das projeções e recomendações dos Analistas, mas não encontraram evidências claras que os Analistas podem ter iniciado os sentimentos, tampouco teriam afetado sua evolução.

KAPLANSKI \& LEVY [2017] investigaram se o sentimento afeta os Analistas ou se os Analistas afetam o sentimento. Descobriram que o sentimento afeta os Analistas. Analistas não iniciam o sentimento, tampouco afetam sua forma, entretanto aceleram a propagação do sentimento nos preços das ações, através da sua capacidade de influenciar investidores mais sofisticados.

Ao influenciar investidores racionais, como investidores institucionais, os Analistas contribuíram para a propagação do sentimento para os preços das ações e, provavelmente, aumentaram seu efeito. Entretanto, vários estudos mostraram os efeitos dos conflitos de interesse com bancos de investimentos nas recomendações dos Analistas (MEHRAN \& STULZ [2007]; MILLER \& SEDOR [2014]; MOLA \& GUIDOLIN [2009]), o que pode ter gerado uma falsa casualidade com os sentimentos. Para isolar os efeitos dos conflitos de interesse, em 2002, a SEC impôs nova regulação e instaurou processos contra bancos de investimentos suspeitos de influenciar as recomendações de seus Analistas.

Ao analisar os dados antes e depois da nova regulamentação, KAPLANSKI \& LEVY [2017] puderam isolar o efeito do conflito de interesses. Eles encontraram evidências que os Analistas mais experientes estavam cientes do sentimento e conscientemente o incorporam em suas previsões e recomendações, um fenômeno que era mais profundo antes que as novas regulamentações fossem impostas em 2002.

O resultado que os analistas conscientemente incorporam $o$ sentimento em suas previsões e recomendações fornece um exemplo extremo no qual mesmos analistas financeiros profissionais, sem falar

Index (VIX, conhecido como o índice do medo), 52 week High/Low Sentiment Ratio, Bullish Percentage, 50-day moving average and 200-day moving average.

Devido à falta de informações públicas no Brasil, um indicador acessível é o volume transacionado. SCHEINKMAN \& XIONG [2003] consideram que o volume transacionado revela diferenças subjacentes de opinião, que por sua vez estão relacionadas a níveis de avaliação quando a venda a descoberto é difícil.

A dispersão entre as projeções de lucros de analistas foi utilizada como proxy para identificar ações especulativas. A volatilidade dos retornos, medida pelo desvio padrão mensal dos retornos relativos ao ano anterior, também foi utilizada para identificar ações especulativas [BAKER \& WURGLER, 2007, p. 144]. 
em investidores privados, podem achar que nem sempre é benéfico apostar contra os noise traders, como defendido por DE LONG et al. (1990). Também ilustra a importante função que as regulamentações podem desempenhar no controle e mitigação de tais fenômenos [KAPLANSKI \& LEVY, 2017, p. 316].

A presença de noise traders poderia justificar o receio de alguns executivos de empresas listadas que o horizonte de curto prazo dos investidores típicos nos EUA poderia prejudicar a economia (DONALDSON [1984]), ao exigir retornos excessivamente altos para os projetos de investimento. Neste sentido, noise traders geram custos sociais. Desencorajá-los poderia aumentar o bem-estar social. Se fosse este o caso, por que todas as empresas não fecham seus capitais para evitar o efeito dos noise traders? Provavelmente porque os benefícios do capital aberto (acesso a capital, liquidez) excedem o efeito dos noise traders.

O presente estudo não pretende investigar com a devida profundidade a atuação de noise traders e as influências do momentum trading na evolução da OGXP3, mas nem por isso o tema é ignorado. Pelo contrário: o presente estudo analisa graficamente a evolução da OGXP3 com outros indicadores, como o Brent, o IBOV, o índice de O\&G e E\&P da S\&P, a participação de investidores nas AGEs, dentre outros, com o objetivo de capturar indícios de sentimentos otimistas e pessimistas. 


\title{
2.5 Sistemas Dinâmicos
}

\begin{abstract}
"Quando uma mesma ação produz efeitos dramaticamente diferentes no curto e no longo prazo, há complexidade dinâmica. Quando uma ação tem um conjunto de consequências locais e um outro conjunto de consequências em outra parte do sistema, há complexidade dinâmica. Quando intervenções óbvias produzem consequências não óbvias, há complexidade dinâmica."
\end{abstract}

SENGE, 2006, p. 71

O que, em um primeiro momento, pode ter gerado tanto Valor de Mercado? O que, posteriormente, pode ter destruído tanto Valor de Mercado?

Conforme proposto na seção 1.4, a Tese Central é que há indícios que a geração e destruição de valor da OGX foram causadas por Condutas de Valor, dentro e fora da OGX, originadas pela dinâmica da Heroína Organizacional na Estrutura de Governança. As Condutas de Valor adotadas pelos Executivos, com apoio tácito ou explicito do AC, se materializaram em uma intensa, dispersa campanha exploratória e, como tal, de elevado risco, com implicações de curto e médio prazo para a liquidez da Empresa. A ampla Agenda de Catalisadores que compunha o guidance otimista, manifestações públicas destas Condutas de Valor. Na evolução do guidance, há indícios que a mediana dos Analistas, por sua vez, atuando, direta ou indiretamente, como interlocutores entre os investidores e os Executivos endossaram, ou não se contrapuseram, ao guidance otimista por anos.

O capítulo 3, ao reconstruir a evolução do guidance sobre a Agenda de Catalisadores e seus impactos qualitativos e quantitativos sobre os Analistas, fornece indícios da dinâmica Heroína Gerencial que acometeu os Executivos e o AC e suas consequências para a OGX. A evolução do guidance também fornece insights sobre os sistemas dinâmicos que envolveram os Stakeholders.

Há indícios que a evolução do Valor de Mercado, com períodos de sub e sobrevalorizações, combinada com a Estrutura de Governança produziu sutis relações não lineares e interdependentes de causas e efeitos não óbvios para os Stakeholders. As Condutas de Valor foram produzidas por um "sistema" do tipo "limites para o crescimento" descrito por SENGE [2006, p. 92-103] em seu livro seminal, que por sua vez se baseou nos estudos de Jay Forrester, ambos do MIT.

Sistemas são formados por inter-relações que influenciam comportamentos ao longo do tempo. Comportamentos estes que o presente estudo denominou de Condutas de Valor. Não se trata de inter-relações entre pessoas, mas entre variáveis críticas [SENGE, 
2006, p. 44]. O sistema "tem sua própria agenda"110, "tem vontade própria"111 que frequentemente passam desapercebidas pelos agentes nele inseridos.

Sistemas são formados por variáveis críticas e "processos de feedback" (feedback processes). Processos de feedback se referem a quaisquer fluxos de influências recíprocas, onde cada variável é causa e efeito ao mesmo tempo. Nenhuma variável é influenciada em apenas uma direção, por isso estes processos são representados graficamente por círculos. Cada círculo descreve uma estória de como a estrutura cria padrões particulares de comportamentos e como estes padrões podem ser influenciados.

Há dois tipos de processos de feedback: processo de reforço ("Processo de Reforço", ou reinforcing processes) e de balanceamento ("Processo de Balanceamento", ou balancing processes). Processos de Reforço são processos de feedback amplificadores, são motores de crescimento. Mas os Processos de Reforço também podem gerar declínios acelerados: o declínio começa lentamente e se amplifica até o sistema entrar em colapso. SENGE [2005] cita como exemplo a evolução de uma crise bancária, que começa com a depreciação de ativos financeiros, seguida das primeiras crises de liquidez em bancos mais vulneráveis até contaminar o setor bancário inteiro. Alguns processos de reforço são círculos viciosos, outros círculos virtuosos.

No caso da OGX, nos períodos de sub e sobrevalorização da OGXP3, houve Processos de Reforço em ação. Um dos Processos de Reforço foi a evolução do Valor de Mercado, em períodos de under (como a 1a Correção Depreciativa de 25/06 a 6/11/2008) e overshoot (como o Rally de 6/11/2008 a 4/11/2010), que incluíram momentos de sub e sobrevalorizações. Estes períodos de distorção do Valor de Mercado podem ter gerado a Heroína Organizacional e motivou investidores, incluindo o AC, financiadores e fornecedores a aumentarem sua exposição ao risco OGX e às Partes Relacionadas. Comportamentos de investidores e financiadores motivados por herding e/ou detracking risk trading são exemplos de outros tipos de Condutas de Valor que podem ter contribuído para o overshoot do Valor de Mercado.

Remunerações por metas dos Stakeholders externos (fornecedores, prestadores de serviços, financiadores, investidores) e internos à Empresa, incluindo o SOP OGX e SOP $A C$, podem ser entendidos como Processos Reforçadores que, em um primeiro momento, foram implantadas para alinhar os interesses e reduzir custos de agência, mas com a sub e sobrevalorizações da OGPXP3, podem ter produzido o efeito oposto: a Heroína Organizacional da OGX e de outros Stakeholders externos.

Processos de Reforço podem criar uma espiral de sucesso, mas também podem criar efeitos secundários, manifestados nos Processos de Balanceamento que eventualmente podem retardar, limitar e/ou comprometer o crescimento. Processos de Balanceamento são formados quando há um comportamento orientado a objetivos: a Agenda de Catalisadores, cuja aspecto central era o de-risking e crescimento do portfólio, geração de sinergias com Partes Relacionadas e, especialmente, o ramp-up da produção. $O$ ramp-up era crucial, pois era produzindo e vendendo O\&G com margens que a OGX

110 SENGE, 2006, p. 84.

${ }^{111}$ SENGE, 2006, p. 88. 
poderia gerar fluxos de caixa. O cronograma de amortizações dos financiamentos da OSX e outras Partes Relacionadas. O valor das participações societária do AC na OGX dados como garantias a estes financiamentos. Todas estas metas e métricas formavam Processos de Balanceamento que vieram a limitar o crescimento dos Processos Reforçadores até revertê-los.

Em todo sistema ocorrem atrasos (delays, SENGE, p. 89) que podem não ser bem compreendidos e resultar em um "overshoot", instabilidade e até a quebra do sistema se os atrasos forem muito extensos. No caso OGX, quando a confirmação de parâmetros e metas da Agenda de Catalisadores sofreram atrasos ou simplesmente desapareceram da pauta do guidance, a credibilidade começou a ser questionada. O farm-out, o 3요 DM e o ramp-up do fluxo de TBAZ foram exemplos mais contundentes dos efeitos nefastos dos atrasos.

O capítulo 4 descreve como as variáveis do sistema de crescimento da OGX, seus Processos Reforçadores e Condutas de Valor criaram Valor de Mercado em um primeiro momento (primeira Questão de Pesquisa). O capítulo 5 descreve como Processos de Balanceamento combinados com atrasos e percalços reverteram os Processos Reforçadores a ponto de inviabilizar não apenas a continuidade da OGX, mas também de outras Partes Relacionadas (segunda Questão de Pesquisa). 


\section{Evolução do Guidance, Sentimento de Mercado e Reação}

dos Analistas

Para analisar a evolução histórica da OGX, é possível combinar duas abordagens que se complementam. A primeira é a evolução do Valor de Mercado, buscando identificar tendências, pontos de inflexão, enfim, Sentimentos de Mercado, e analisa-los não apenas do ponto de vista gráfico, mas articulando-os com eventos qualitativos e quantitativos. Esta articulação requer a segunda abordagem: a evolução do guidance e da reação qualitativa e quantitativa (através dos PAs e projeções) dos Analistas.

Para identificar elementos e eventos na Tese de Investimentos e no guidance e seus possíveis efeitos sobre a geração de valor da OGX, objeto da Primeira e Segunda Questões de Pesquisa, o presente capítulo se baseou em: Relatórios; a evolução de estatísticas básicas (mediana, máximo e mínimo) dos PAs da Amostra TR; denúncias e defesas dos processos judiciais abertos pelo Ministério Público Federal ("MPF") pela CVM; artigos do Jornal Valor Econômico ("JVE"), Wall Street Journal, The Economist, Financial Times. Apesar da amplitude de informações, dada a complexidade do Grupo $X$, do setor de O\&G no Brasil e no mundo, o presente capítulo faz uma descrição parcial dos eventos que podem estar envolvidos na Primeira e Segunda Questões de Pesquisa. 


\subsection{8: IPO, Início da Cobertura e Primeira Correção Depreciativa}

Evolução do Valor de Mercado em 2008: do Céu ao Inferno

A Bolha de Verão de 2008, para os índices S\&P Oil \& Gas Exploration and Production 600 ("S\&P OGEP 600") e o S\&P Oil \& Gas Exploration and Production 1500 ("S\&P OGEP 1500 "), implodiu em 25/06 e atingiu seu mínimo em 20/11, com desvalorizações em relação ao pico, de 50,8\% e 69,0\% respectivamente. Mas a OGXP3, possivelmente devido ao fato de nem ter iniciado sua campanha exploratória e à desvalorização do R\$, se depreciou mais do que o Brent, S\&P OGEP 600 e 1500. Ao fim de 2008, sem nenhum evento corporativo que poderia explica-la, houve uma recuperação da OGXP3 relativamente maior do que os outros três indicadores.

\section{Gráfico 17 - Evolução do S\&P OGPE 600, S\&P OGPE 1500, OGXP3 e Brent em 2008 \\ $(12 / 06 / 2008=100)$}

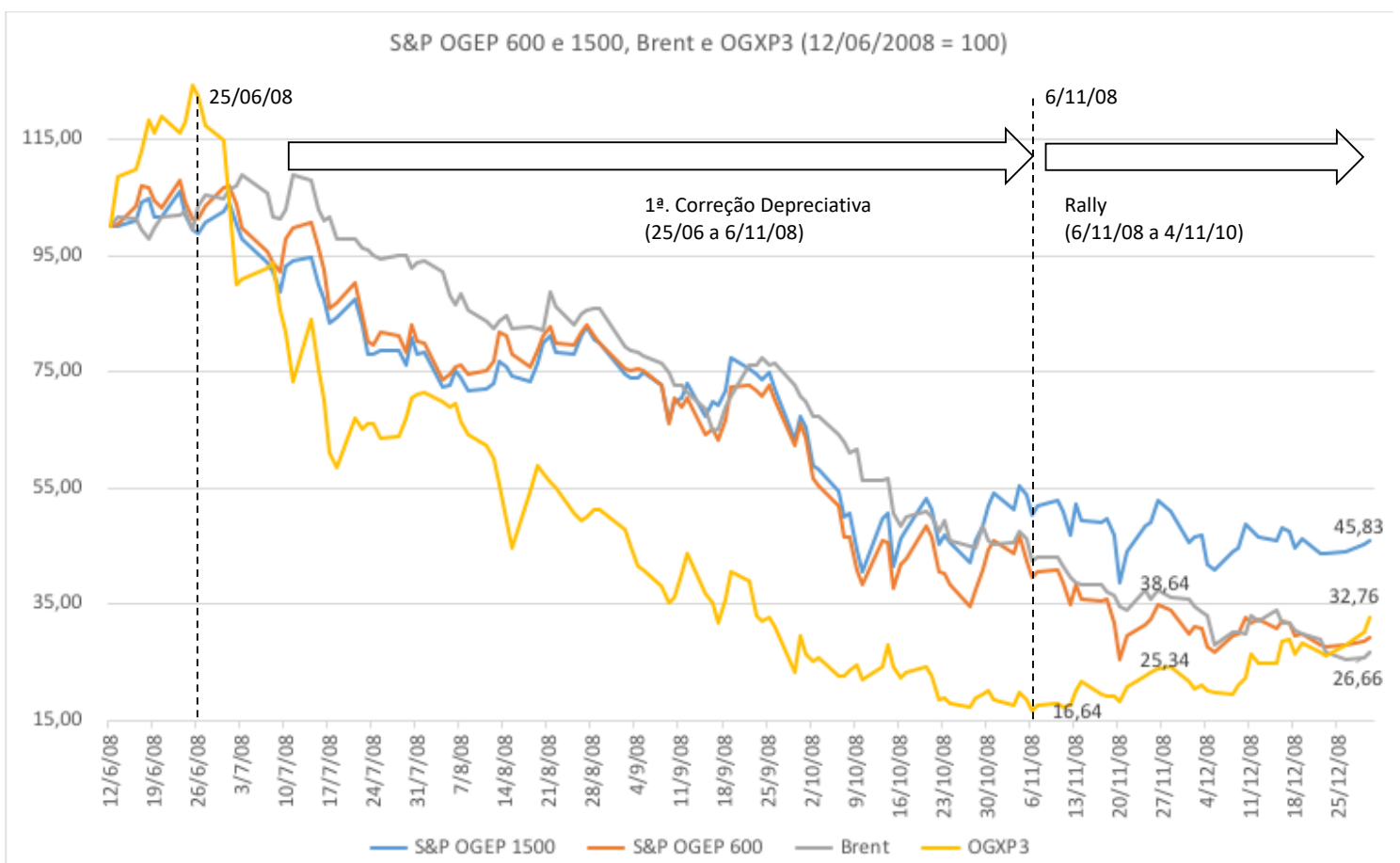

Conforme descrito na seção 2.2, em duas semanas após o IPO, o Valor de Mercado chegou a US\$23,02 bilhões ( $R \$ 36,83$ bilhões, em $25 / 6$ ), equivalente a um múltiplo de EV de US\$ 4,76/boe e 5,5x seu patrimônio líquido. Após a expressiva alta de $20,6 \%$, a OGPX3 começou uma trajetória de queda que se acentuou com implosão da "bolha do óleo do verão de 2008" (15/7) e a quebra da Lehman Brothers (15/9), quando chegou a $\mathrm{R} \$ 3,95$ (26/9/08). A desvalorização prosseguiu até a OGXP3 atingir um vale em 6/11/08 com $R \$ 2,54$, equivalente a $24,2 \%$ do valor do IPO. 
Gráfico 18 - Evolução da OGXP3 em 2008 (em R\$̣ nominais por ação, pós Split)

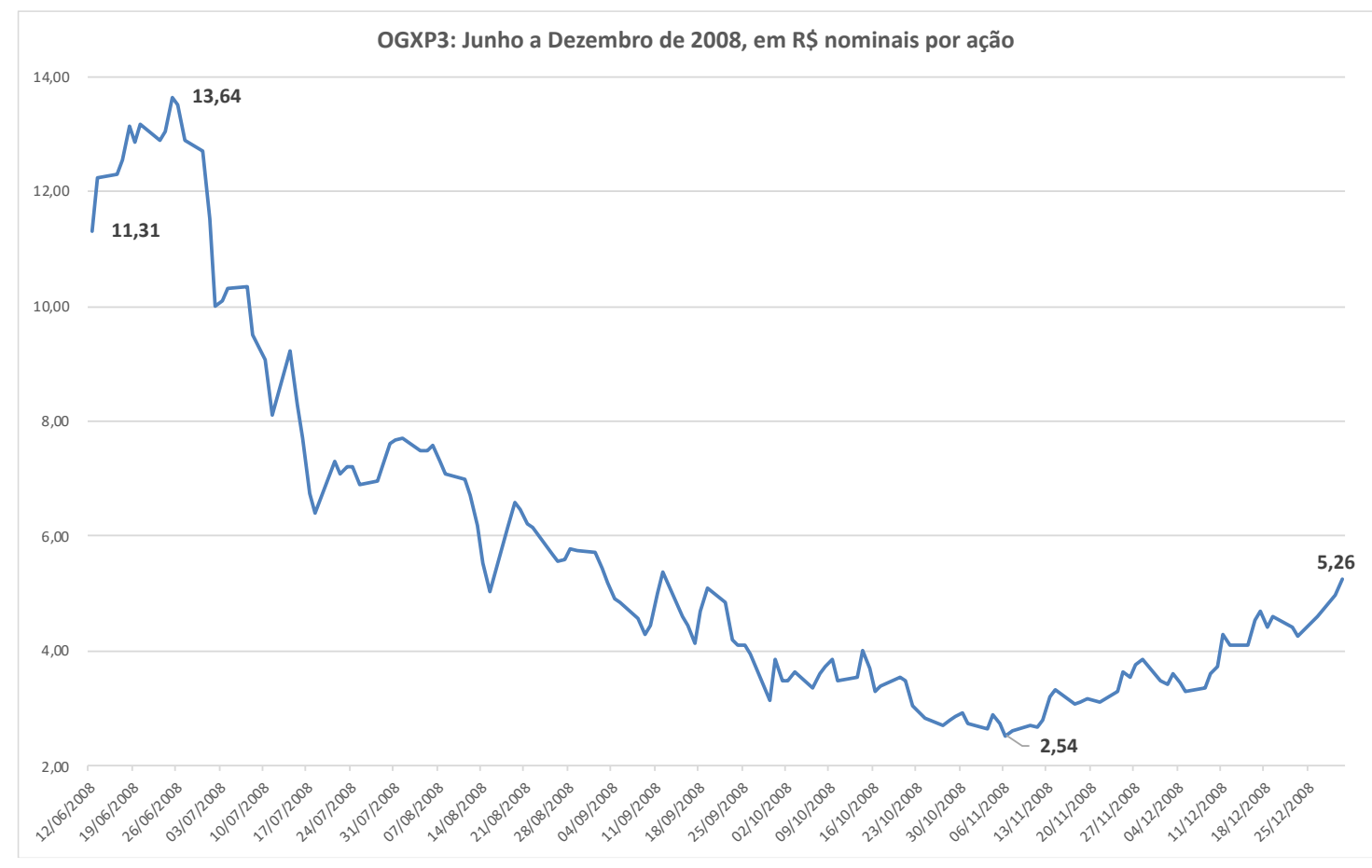

Ao todo, na 1 a Correção Depreciativa, entre o pico pós-IPO (25/6) e o vale em 6/11/08 (93 pregões), a OGXP3 acumulou perda de 81,4\% (de $\mathrm{R} \$$ 13,64 para $\mathrm{R} \$ 2,54$ ). Descontado o valor das disponibilidades, o Valor de Mercado da OGX se desvalorizou de $\mathrm{R} \$ 36,83$ bilhões para $\mathrm{R} \$ 0,68$ bilhão (US\$ 0,31 bilhão). Foi uma desvalorização mais acentuada que a do Brent (57,3\%, de US\$131,59 para US\$ 56,14 por barril) e do IBOV, que perdeu 44,7\% (de 65.853 para 36.361). Em 15/09, quando a Lehman Brothers quebrou, o IBOV perdeu 7,6\% e a OGXP3 se desvalorizou 14,7\% em um único pregão (de $R \$ 5,39$ para $R \$ 4,60)$. 
Gráfico 19 - Evolução da OGXP3, Brent e IBOV em 2008 (Base 100 = 12/6/2008 [IPO])

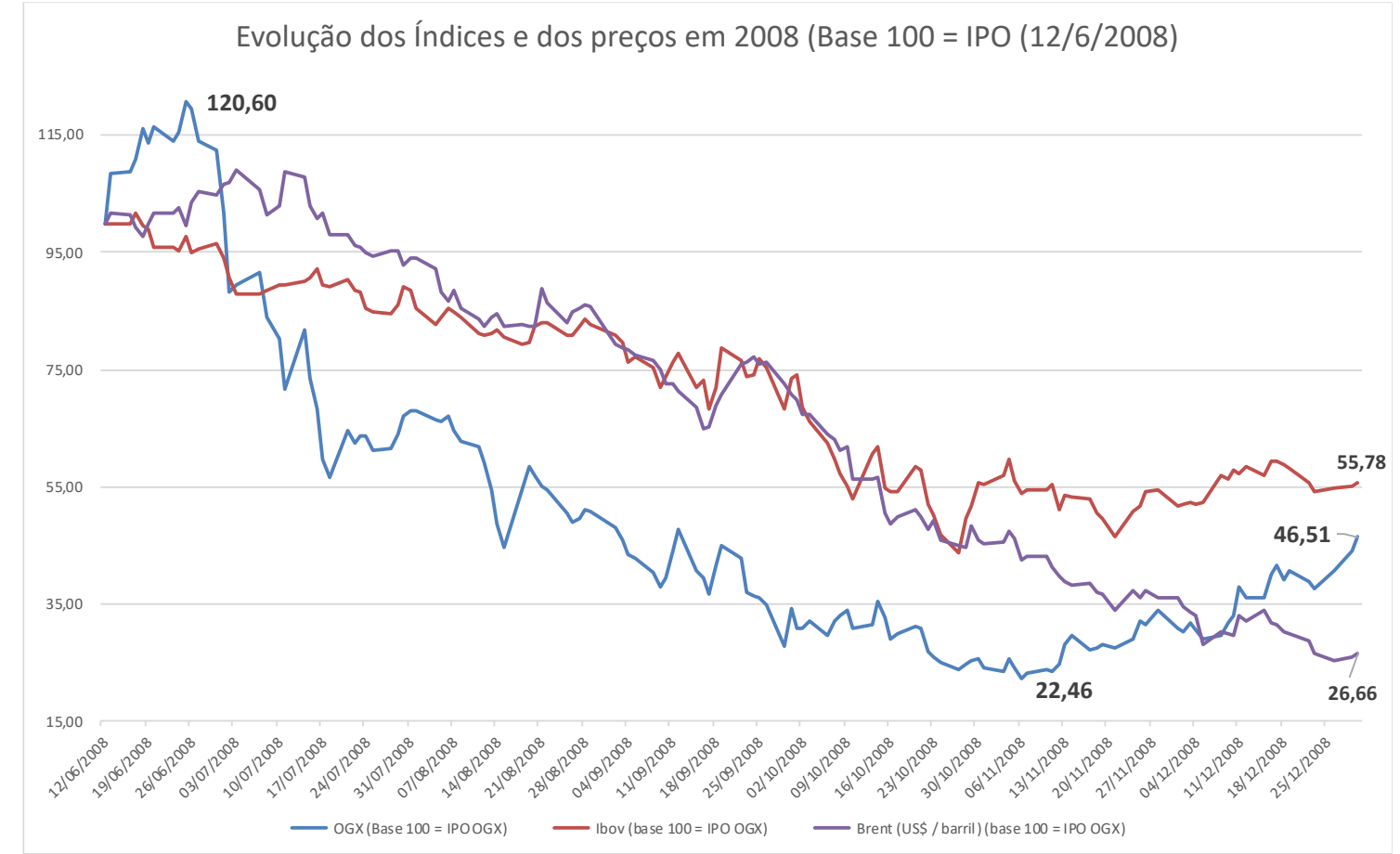

O vale em $6 / 11$, mensurado pelo múltiplo $E V / 2 C$, indicava uma depreciação ainda mais dramática, pois correspondia a 1,34\% do Valor de Referência do 1요 D\&. O EV/2C equivalia a US\$ $0,06 /$ boe, valor este abaixo do valor pago nos BAs dos blocos na 9a Rodada (US\$ 0,81/boe). Ou seja, em 6/11, o portfólio da OGX chegou a valer menos do que o valor de liquidação dos blocos.

Gráfico 20 - Evolução do EV/2C da OGX em 2008 (em US\$/boe)

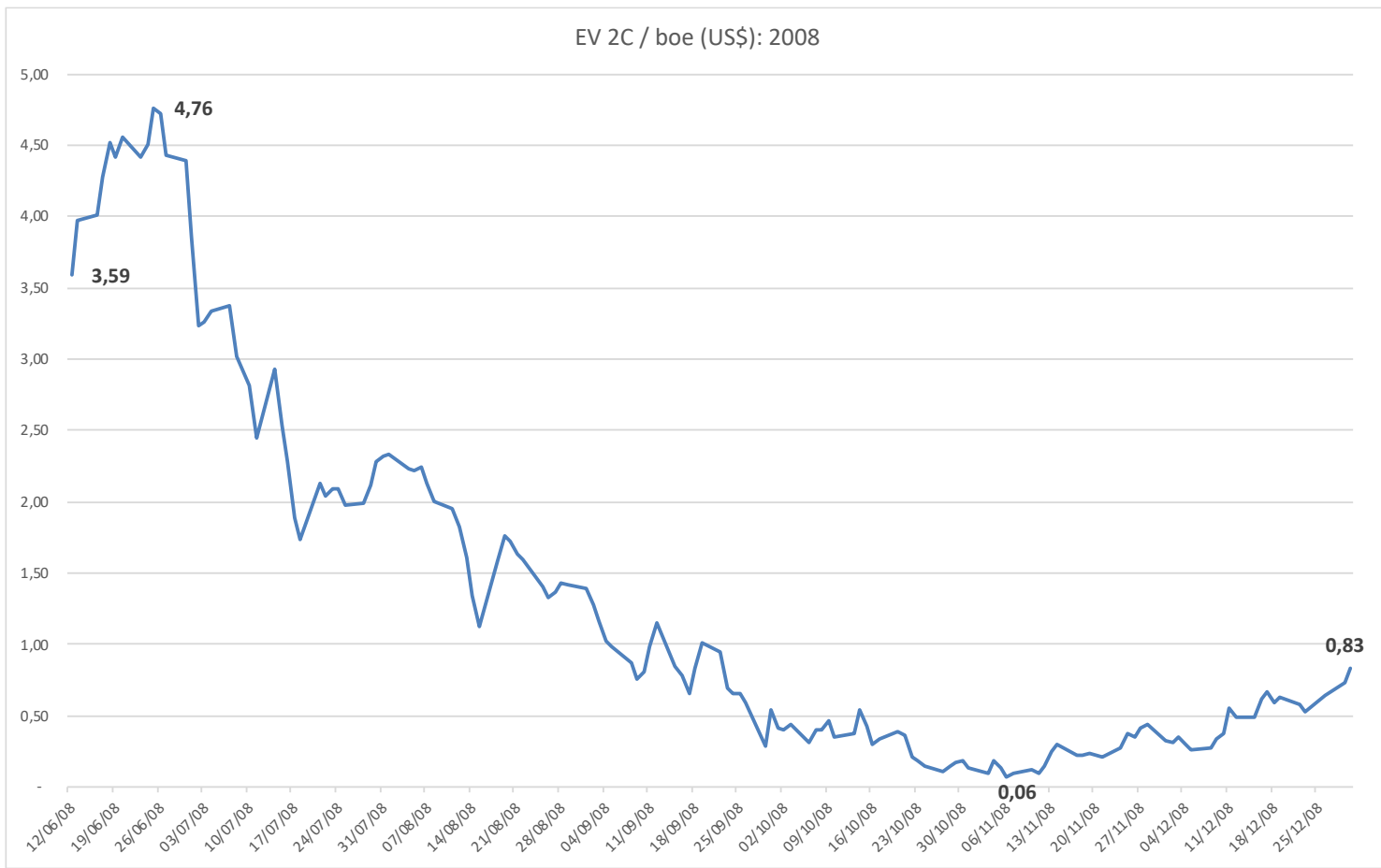


Em 6/11, o Brent estava cotado a US\$ 56,14 por barril, uma queda de 60,6\% em relação ao pico da Bolha de Julho. O Brent continuaria caindo até atingir a mínima no ano, de US\$ 33,73 em 26/12 (queda de 76,3\% em relação ao pico da Bolha). Ao longo de 2008, a OGXP3 apresentou uma evolução na forma de "u". Ainda em 2008, a OGXP3 iniciou uma trajetória de recuperação que posteriormente mostraria ser um Rally que se estenderia até outubro de 2010.

Início da Cobertura dos Analistas

O Brasil oferece um grande potencial no upstream. Se assumirmos que isso seja verdadeiro e considerando a estabilidade econômica e o marco regulatório atraente, então investir em projetos no upstream no Brasil parece ser uma boa ideia. Junte a isso altos preços de petróleo e uma boa ideia se transforma em uma ótima ideia. Então, qual é o melhor caminho para fazer seu dinheiro render nesta indústria promissora? Nós pensamos que investidores devem considerar OGXo empreendimento em Óleo \& Gás de Eike Batista [KOVARSKY \& MENDES, 2008a, p. 18].

Nós não conhecemos nenhuma outra companhia no setor de O\&G que tentou fazer algo similar com que a OGX pretende fazer. Como resultado, embora o plano da Empresa esteja entre o mais ousado e o mais interessante acontecimento no Brasil desde a abertura do setor de O\&G em 1997-8, na nossa visão, ele envolve muitos desafios e riscos significativos [MCGANN \& KOYA, 2008a, p. 3].

Analistas de grandes bancos nacionais e internacionais iniciaram a cobertura da Empresa em 28/7, quando a OGXP3 valia $R \$$ 6,95, uma desvalorização de $38,5 \%$ em relação ao IPO (R\$11,31). Entretanto, o início da cobertura foi entusiasmada por alguns Analistas que endossaram a Tese de Investimento apresentada no IPO: experiência dos executivos em E\&P ("dream team"112), que indicava que a probabilidade de sucesso de $27 \%$ estimada pela D\&M seria conservadora; gestão ágil e focada em resultados (diferente da PETR); portfólio "premium" de blocos exploratórios; potencial para transações de $M \& A$ envolvendo novos entrantes estrangeiros interessados no vasto potencial brasileiro ${ }^{113}$.

112 KOVARSKY \& MENDES, 2008a, p. 3.

${ }^{113}$ Alguns exemplos destes Analistas são: LEITE, CANHEU \& CUSTODIO [2008a], KOVARSKY \& MENDES [2008a]. 
Tabela 22 - PAs no Início de Cobertura (28/7/2008, ajustados para o split) e Respectivo Múltiplo de Valor por boe de RPL de óleo (excluindo GN)

\begin{tabular}{|l|l|c|c|c||}
\hline \multicolumn{1}{|c|}{ Análise } & \multicolumn{1}{|c|}{ Analistas } & $\begin{array}{c}\text { PA } \\
\text { R\$/ação }\end{array}$ & $\begin{array}{c}\text { \% } \\
\text { Cotação }\end{array}$ & $\begin{array}{c}\text { EV/ boe } \\
\text { (US\$) }\end{array}$ \\
\hline OGXP3 (12/6/08) & & 11,31 & $163,7 \%$ & 4,5 \\
\hline OGXP3 (28/7/08) & & 6,91 & $100,0 \%$ & 2,9 \\
\hline CS & LEITE, CANHEU, CUSTODIO & 17,00 & $246,0 \%$ & 8,6 \\
\hline IBBA & KOVARSKY, MENDES & 13,67 & $197,8 \%$ & 6,6 \\
\hline MER & MCGANN, KOYA & 8,25 & $112,7 \%$ & 3,3 \\
\hline MS & DARIPA, SILVA & 8,49 & $122,9 \%$ & 3,7 \\
\hline JPM & TORRES, YANG, SOUSA NETO & 7,60 & $110,0 \%$ & 3,2 \\
\hline UBS Pactual & GATTASS, MEDEIROS, ESPIRITO SANTO & 16,63 & $240,7 \%$ & 8,3 \\
\hline Média PA & & $\mathbf{1 1 , 8 6}$ & $\mathbf{1 7 1 , 7 \%}$ & $\mathbf{5 , 6}$ \\
\hline Mediana PA & & $\mathbf{1 1 , 0 8}$ & $\mathbf{1 6 0 , 3 \%}$ & $\mathbf{5 , 2}$ \\
\hline Desvio Padrão PA & & $\mathbf{3 , 9 0}$ & & $\mathbf{2 , 2}$ \\
\hline Média D\&M (IPO) & D\&M (IPO) & & & 6,5 \\
\hline
\end{tabular}

Nota: para calcular o EV/boe, excluindo disponibilidades, consideramos as seguintes premissas: 32.319.606 ações; PTXA de R\$ 1,575; dívida zero e disponibilidades de US\$ 4,26 bilhões; 3,578 bboe de RPL de óleo (excluindo GN, por causa da dificuldade de monetização). Para estimar o valor presente dos recursos prospectivos, a D\&M utilizou as seguintes premissas: taxa de desconto de $10 \%$ em moeda constante; preços do Brent de US\$ 60/barril (Low), US\$ 80 (Best), US\$ 100 (High); preços do GN de US\$ $5 / 10^{3} \mathrm{ft}^{3}$ (Low), US\$ 6 (Best), US\$ 7 (High); despesas operacionais variáveis de US\$ 5,3 a 8,0/barril, incluindo custos de transporte; despesas fixas operacionais de US\$ 30 (águas rasas) a US\$ 80 milhões (águas profundas) por FPSO por ano mais outras despesas fixas (embarcações de apoio, peças de manutenção, etc.); despesas operacionais variáveis de US\$ 0,15 a $0,25 / 10^{3} \mathrm{ft}^{3}$, incluindo custos de transporte.

No Prospecto, a Empresa se apresentou como "a maior companhia privada brasileira do setor de petróleo e gás natural em termos de área marítima de exploração" [Prospecto OGX, 2008, p. 95]. Essa autodenominação seria, posteriormente, difundida por alguns Analistas.

Alguns Analistas entendiam que o limitado capital da PETR, aliado às recentes descobertas de poços gigantes, teriam deixado muitas oportunidades atraentes de exploração que poderiam ser capturadas por outras empresas competentes, dentre elas, a OGX $\mathrm{X}^{114}$. Os Analistas também acreditavam que os preços do petróleo no mercado internacional continuariam altos, devido aos atrasos no desenvolvimento da produção em alguns países não-OPEC, alta taxa de depreciação dos campos da OPEC e pressões de custos em projetos globais ${ }^{115}$.

Os Analistas ressaltavam que a alta capacidade de execução dos Executivos era comparável às realizações da equipe da MMX:

Seu plano de negócios, embora envolva numerosos desafios, será executado por um time de gestores que enfrentaram desafios similares

114 LEITE, CANHEU \& CUSTODIO, 2008a, p. 9.
115 LEITE, CANHEU \& CUSTODIO, 2008a, p. 11. 
na MMX (por exemplo, Sr. Landim, atual CEO da OGX e ex-CEO da $M M X$ ), com resultados de sucessão, até então [LEITE, CANHEU \& CUSTODIO, 2008a, p. 10].

Até mesmo na obtenção das várias licenças ambientais, alguns Analistas consideravam o histórico de outras empresas do Grupo X:

(...) empresas do grupo EBX têm demonstrado um impressionante histórico de sucesso em obter licenças ambientais sem atrasos (MMX, LLX, MPX, por exemplo). [LEITE, CANHEU \& CUSTODIO, 2008a, p. 12]

LEITE, CANHEU \& CUSTODIO [2008a], do CS, por exemplo, estimavam o PA da OGXP3 em US\$10,60, ou R\$17,00 (equivalente a US\$ 6,2/boe) para uma cotação na época de US\$ 4,47 (22/7/2008, equivalente a US\$ 2,1/boe). Eles consideravam que a Empresa estava "bem posicionada para ocupar um papel definitivo na indústria do petróleo Brasileiro", com "uma combinação de força de gestão, capacidade de execução, solidez financeira e comprometimento do acionista controlador (...)". "O coração da estratégia da OGX era sua equipe executiva", com uma experiência média de 30 anos no setor de petróleo, incluindo um ex-CEO (Francisco Gros) e o ex-diretor de E\&P (Paulo Mendonça) da PETR [LEITE, CANHEU \& CUSTODIO, 2008a, p.7]. Mendonça participou da campanha exploratória "mais bem sucedida da Petrobras, incluindo a descoberta do campo de Tupi."

KOVARSKY \& MENDES [2008a], do IBBA, iniciaram a cobertura com um PA um pouco mais conservador ( $R \$ 13,67$, equivalente a US\$ $4,8 /$ boe) do que o CS, porém não menos entusiasta. Com a "equipe dos sonhos" (dream team), foco em portfólio relativamente pequeno ao da concorrência, mas de qualidade, e abordagem orientada a resultados seria a "tríade" do diferencial da OGX. Além do seu valor por si próprio (stand alone), os Analistas acreditavam em potenciais ganhos para os investidores advindos de possíveis transações de M\&A envolvendo a OGX. O histórico das transações da MMX com a AA reforçava esta expectativa.

Outros Analistas, entretanto, iniciaram a cobertura com uma abordagem mais conservadora. MCGANN \& KOYA [2008a], da MER, por exemplo, estimaram o PA em R\$ 8,25 por ação, ou seja, abaixo do preço observado no IPO $(R \$ 11,31)$ apenas algumas semanas atrás.

Apesar do nosso otimismo sobre do eventual sucesso da OGX, há uma significativa incerteza quanto ao timing de qualquer produção e rampup [MCGANN \& KOYA, 2008a, p. 10].

As premissas de produção incluídas no relatório da D\&M sugerem que a produção pode alcançar 877 kboed em 2019. Embora esse objetivo não seja impossivel, a história sugere que é desafiador, e nós acreditamos que requereria um sucesso não usual na exploração $e$ desenvolvimento [MCGANN \& KOYA, 2008a, p. 20]. 
08/07. OGX contrata sua primeira unidade flutuante da Queiroz Galvão.

Repercussões. A Queiroz Galvão, um conhecido fornecedor deste equipamento no Brasil, fornecedor e sócio da PETR na exploração de O\&G no Nordeste. A contratação foi uma sinalização importante ao mercado, que receava que a PETR pudesse pressionar seus fornecedores a não atender as demandas da OGX ${ }^{116}$. Em novembro, a OGX já havia assegurado 4 sondas, com um aluguel médio de US\$330 mil por dia.

11/07. A Polícia Federal executou a operação "Toque de Midas" para investigar irregularidades na obtenção da concessão da Estrada de Ferro do Amapá para a MMX.

Repercussões. Alguns Analistas ${ }^{117}$ questionavam se parte da desvalorização da OGXP3 poderia estar relacionada à Operação. No dia, as ações da MMX perderam $9,8 \%$ de seu valor em um pregão. A OGXP3 perdeu 10,5\% e a MPX, 11,4\%. Seria o início de uma crise de credibilidade que comprometeria o Grupo X? Poucos Analistas abordaram este tema.

15/07. Implosão da "bolha do óleo do verão de 2008". Entre 14/07 e 14/08, o Brent caiu $21,5 \%$ (de US\$ 142,43 para US\$ 111,82 por barril).

28/07. Analistas iniciam a cobertura da Empresa, quando a OGXP3 valia $\mathrm{R} \$ 6,95$, uma desvalorização de $38,5 \%$ em relação ao IPO (R\$ 11,31).

15/09. Quebra da Lehman Brothers. OGXP3 se desvaloriza $14,7 \%$ em um único pregão (de $\mathrm{R} \$ 5,39$ para $\mathrm{R} \$ 4,60)$.

Repercussões. Apesar do Crash e da desvalorização da OGXP3, na mediana, os Analistas da Amostra TR se mantiveram otimistas no valor da OGX. Houve reajustes nos PAs, mas ainda acima do Valor de Mercado. Houve Analistas também mais conservadores, como a MER, que em 28/10/2008 reduziu seu PA de $R \$ 7,20$ para $R \$ 3,70$ e recomendou a venda da OGXP3 devido à piora nas condições de mercado ${ }^{118}$.

06/11. Em cerca de cinco meses, a OGXP3 valia $\mathrm{R} \$ 2,54$, equivalente a $22,5 \%$ de seu valor no IPO. No dia seguinte, a OGXP3 começaria um longo período de valorização até chegar ao seu pico histórico de valor em 15/10/2010 (R\$23,27).

Repercussões. Em outubro (3/10), quando a OGXP3 já havia se desvalorizado muito, o CS ponderou que a OGX tinha US\$ 4,5 bilhões no caixa, o que deveria ser suficiente para seus investimentos e despesas até $2012^{119}$. Sem dívidas (o PEM de US\$ 300 milhões estaria coberto por seguros), e com valor de liquidação estimado em US\$ 5,3 bilhões (US\$ 4,5 bilhões em caixa mais US\$ 0,8 bilhão em bônus de assinatura) a OGXP3,

116 KOVARSKY \& MENDES, 2008a, p. 35.

117 ROZENBAUM \& VARELLA [2009a].

118 MCGAN \& KOYA [2008b].

119 LEITE, CANHEU \& CUSTODIO [2008b, p. 5]: do total de US\$ 4,5 bilhões, US\$ 2,0 bilhões seriam suficientes para custear toda campanha exploratória com 51 poços. Estimava-se ainda US\$ 0,2 bilhão em SG\&A, e os US\$2,3 bilhões restantes seriam utilizados para custear o início do desenvolvimento da produção (US\$ 1,0 bilhão) e farm-in em novos blocos (até US\$ 1,3 bilhão). 
defendia o CS, não deveria valer menos que $R \$ 2,70$. Apesar disso, em 6/11, a OGXP3 fechou em $R \$ 2,54$, ou seja, abaixo do seu valor de liquidação. Mesmo o otimista CS cedeu à significativa desvalorização da OGXP3 e ao aumento da aversão ao risco: reduziu seu PA em 32\%, de $\mathrm{R} \$ 17,00$ para $\mathrm{R} \$ 10,50$ (equivalente a US\$ 3,9/boe) em $7 / 10$ (elevou o WACC real de $11 \%$ para $15 \%$, mas manteve a premissa de preço de petróleo em US\$ 100/barril). Algumas semanas depois (29/11), o IBBA também reduziu seu PA em 25\%, de $\mathrm{R} \$ 13,67$ para $\mathrm{R} \$ 10,26$, portanto, próximo ao PA do CS.

Novembro e Dezembro. A partir do vale de 6/11, a OGXP3 iniciou uma trajetória de valorização e fechou o ano valendo $\mathrm{R} \$$ 5,26, uma valorização de $107,1 \%$ em relação ao vale.

Repercussões. Apesar da volatilidade da OGXP3 no 2S2008, os Executivos dedicaram ao processo de contratação de materiais, bens e serviços vitais para a campanha exploratória, incluindo a contratação de 4 sondas de perfuração, 6 embarcações marítimas de apoio, 5 das quais em construção. A Empresa conduziu o planejamento do seu plano de exploração "com disciplina", segundo Analistas ${ }^{120}$, incluindo a contratação de mais executivos (ex-PETR), equipamentos, medições sísmicas em 3D. A campanha de exploração começaria em setembro de 2009 nos prospectos de menor risco, no pós-sal do Sudeste de Campos, onde se concentrava a experiência dos Executivos ${ }^{121}$. As campanhas em Santos (incluindo pré-sal), ES e PA-MA provavelmente começariam em 2010-11 122 .

$\mathrm{Na}$ época, a expectativa era a campanha exploratória em Campos e Santos ${ }^{123}$. A Empresa montou dois grupos: um para estudar oportunidades no pré-sal e outro para o pós-sal ${ }^{124}$. Os blocos da OGX estavam no centro de grandes descobertas recentes: Mexilhão em Santos; Polvo, Peregrino, Maromba e Papa-Terra em Campos; Golfinho no ES ${ }^{125}$. Dos 51 prospetos identificados pela D\&M (44 de óleo e 17 de GN) nos 22 blocos da OGX, 6 estavam em camadas do pré-sal de Santos (em um total de 8 prospectos de óleo em 4 blocos) e 2 em Campos (em um total de 24 prospectos em 7 blocos) ${ }^{126}$. A proximidade de muitos blocos da OGX a outros já em desenvolvimento pelos concorrentes sugeria a possibilidade de compartilhamento da infraestrutura de escoamento que futuramente seria construída ${ }^{127}$. Havia também potenciais sinergias com a LLX: os blocos de Campos, por exemplo, estavam localizados a cerca de $200 \mathrm{~km}$ do local onde futuramente seria construído o Porto de Açu (e a 250 km do Porto de Sepetiba, ambos no RJ).

Cerca de 94\% do RPL da OGX estava localizado em águas rasas, o que representava uma vantagem competitiva importante em relação aos projetos em águas profundas no

\footnotetext{
120 KOVARSKY \& MENDES, 2008a, p. 3.

${ }^{121}$ Segundo LEITE, CANHEU \& CUSTODIO, 2008a, p. 8.

122 MCGANN \& KOYA, 2008a, p. 14.

${ }^{123}$ Dada a falta de informações sobre Santos, na época, e o potencial estar em águas profundas, estimavase que o custo de perfuração por poço seria de US\$ 48 milhões contra US\$ 26 milhões por poço na média de Campos [LEITE, CANHEU \& CUSTODIO, 2008a, p. 38].

${ }^{124}$ Segundo relato de KOVARSKY \& MENDES, 2008a, p. 21.

125 Há tabela com detalhes em LEITE, CANHEU \& CUSTODIO, 2008a, p. 29.

126 LEITE, CANHEU \& CUSTODIO, 2008a, p. 8 e 27.

127 LEITE, CANHEU \& CUSTODIO, 2008a, p. 8.
} 
Brasil. Perfurações em águas rasas são mais baratas e havia maior disponibilidade de equipamentos no mercado internacional ${ }^{128}$.

Um dos desafios que a OGX enfrentava era a disponibilidade de "unidades de sondagem" ("drilling rigs") que ajudariam no de-risking. Na época, a demanda pelas unidades de sondagens para águas de meia profundidade estava em alta e $99 \%$ da capacidade global estava contratada. A Empresa precisava de ao menos 3 unidades para 2009, a preços competitivos (de US\$250 a 400 mil por dia de aluguel).

Outra fragilidade da OGX, bem como de todos os produtores de GN, era o acesso a gasodutos. Na época, a PETR detinha $100 \%$ dos gasodutos e não permitia acesso a terceiros. A tese da OGX para seu GN seria a venda para a MPX, que planejava construir uma UTE de 4 GW no Porto de Açu até 2019.

Em suma, apesar do Crash e da significativa desvalorização da OGXP3, na mediana, os Analistas da Amostra TR se mantiveram otimistas no valor da OGX. Até os Analistas mais pessimistas mantiveram seus PAs acima do valor da OGXP3 por longos períodos dentro do ano. Ou seja, até mesmo os pessimistas consideraram que o portfólio da OGX tinha valor acima do múltiplo do BA.

\section{Gráfico 21 - Amostra da TR: Evolução da Mediana, Máximo e Mínimo do PA em 2008 (em R\$̧/ação, pré split)}

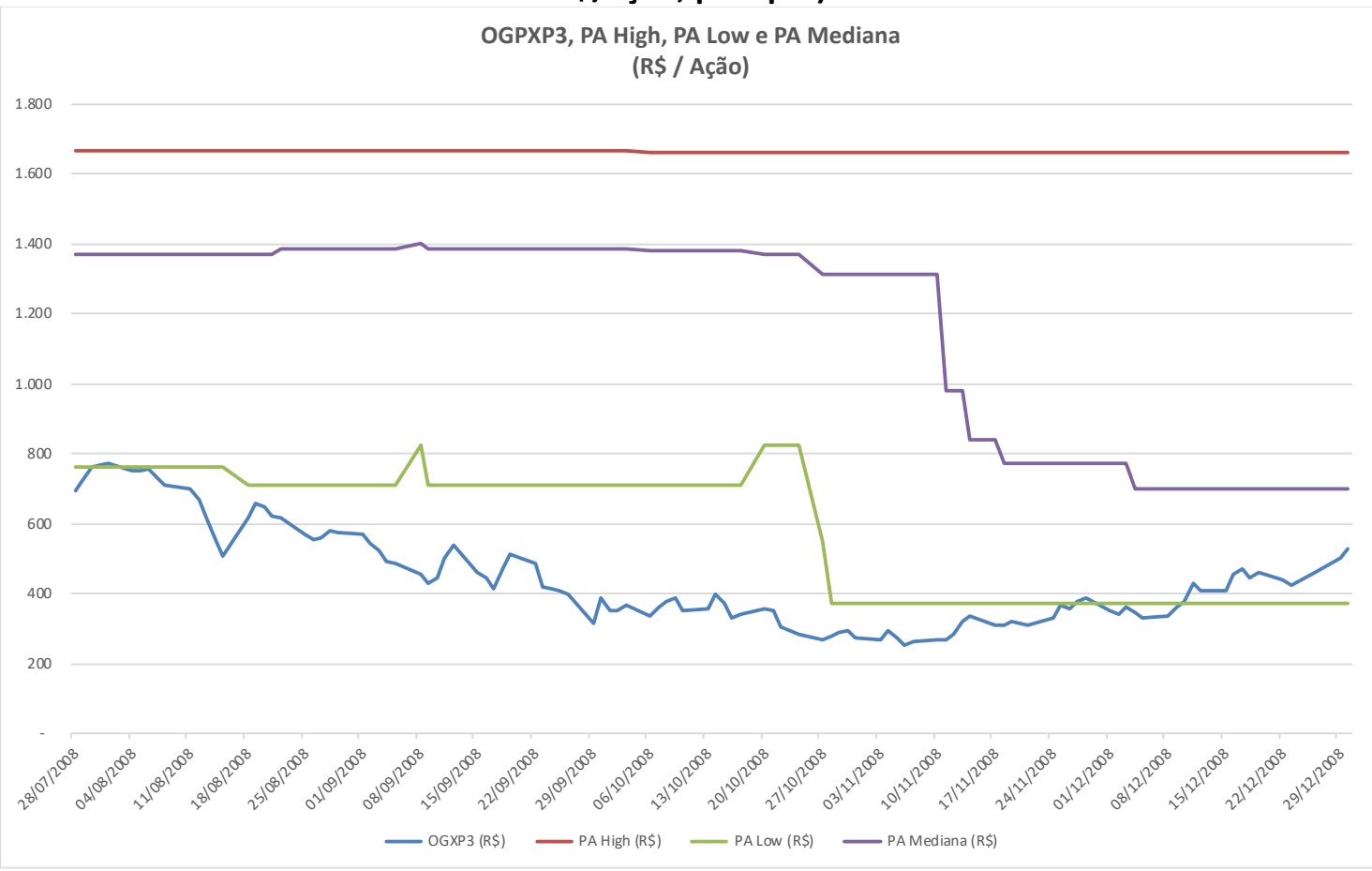

128 Segundo LEITE, CANHEU \& CUSTODIO [2008a, p. 8], embora no curto prazo (2008), a disponibilidade de equipamentos para águas de média profundidade fosse limitada (6\%), para 2010, a projeção é que haveria uma ampla disponibilidade (69\%). 


\subsection{9: Início da Campanha e Construção do Guidance Otimista}

Evolução do Valor de Mercado em 2009

O ano de 2009 foi marcado por significativa valorização da OGXP3. Foi um ano inteiro de Rally, que em termos nominais levou a OGXP3 a triplicar de valor na BOVESPA. No fim de julho (29/07), a OGXP3 fechou o dia em $R \$ 11,40$, recuperando seu valor nominal do IPO (R\$ 11,31 por ação), há pouco mais de um ano. A OGXP3 encerrou o ano com um

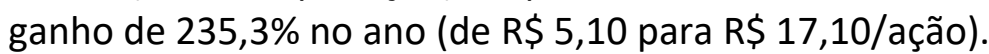

Gráfico 22 - Evolução da OGXP3 em 2009 (em R\$̣ nominais por ação, pós Split)

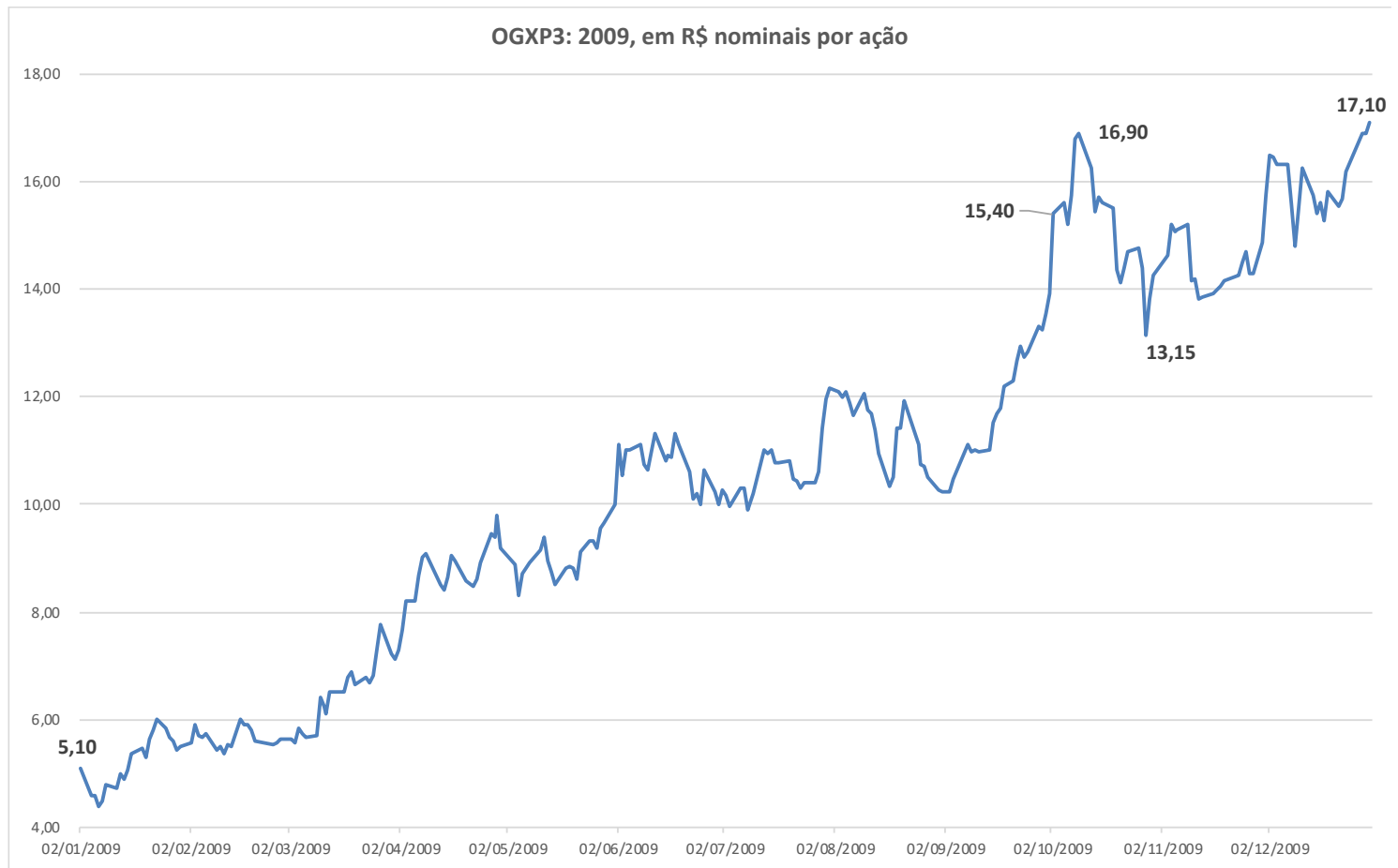

A apreciação da OGXP3 foi substancialmente maior do que aquela do S\&P OGEP 600 e 1500. 
Gráfico 23 - Evolução do S\&P OGPE 600, S\&P OGPE 1500, OGXP3 e Brent em 2009

$(12 / 06 / 2008=100)$

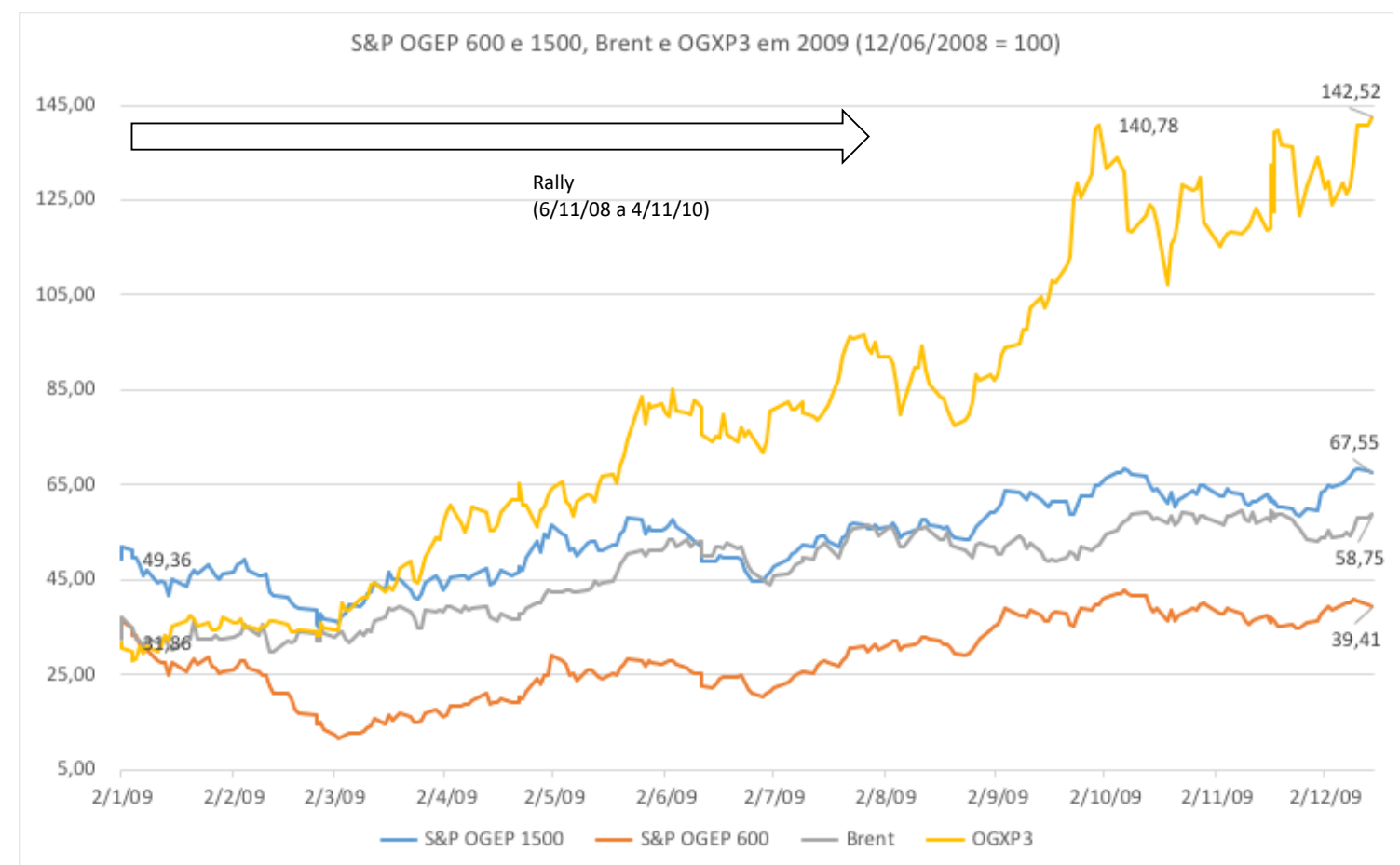

O quarto trimestre foi marcado por vários anúncios das primeiras descobertas de hidrocarbonetos nos blocos da OGX, logo complementadas por estimativas de elevados volumes recuperáveis nos prospectos de Vesúvio, Pipeline e Waimea. Anunciar uma descoberta e poucos dias depois estimar os possíveis volumes recuperáveis era considerado, no mínimo, precipitado por especialistas em O\&G. Geralmente, essas estimativas só seriam publicadas após mais perfurações e testes bem-sucedidos. Mas entre $6 / 11 / 2008$ e 30/12/2009, o mercado respondeu significativamente à expectativa do aumento de volumes recuperáveis e a OGXP3 se valorizou $(+573,2 \%)$ mais do que o IBOV $(+87,8 \%)$ e o Brent $(+9,1 \%)$. 
Gráfico 24 - Evolução da OGXP3, Brent e IBOV em 2009 (Base 100 = 6/11/2008)

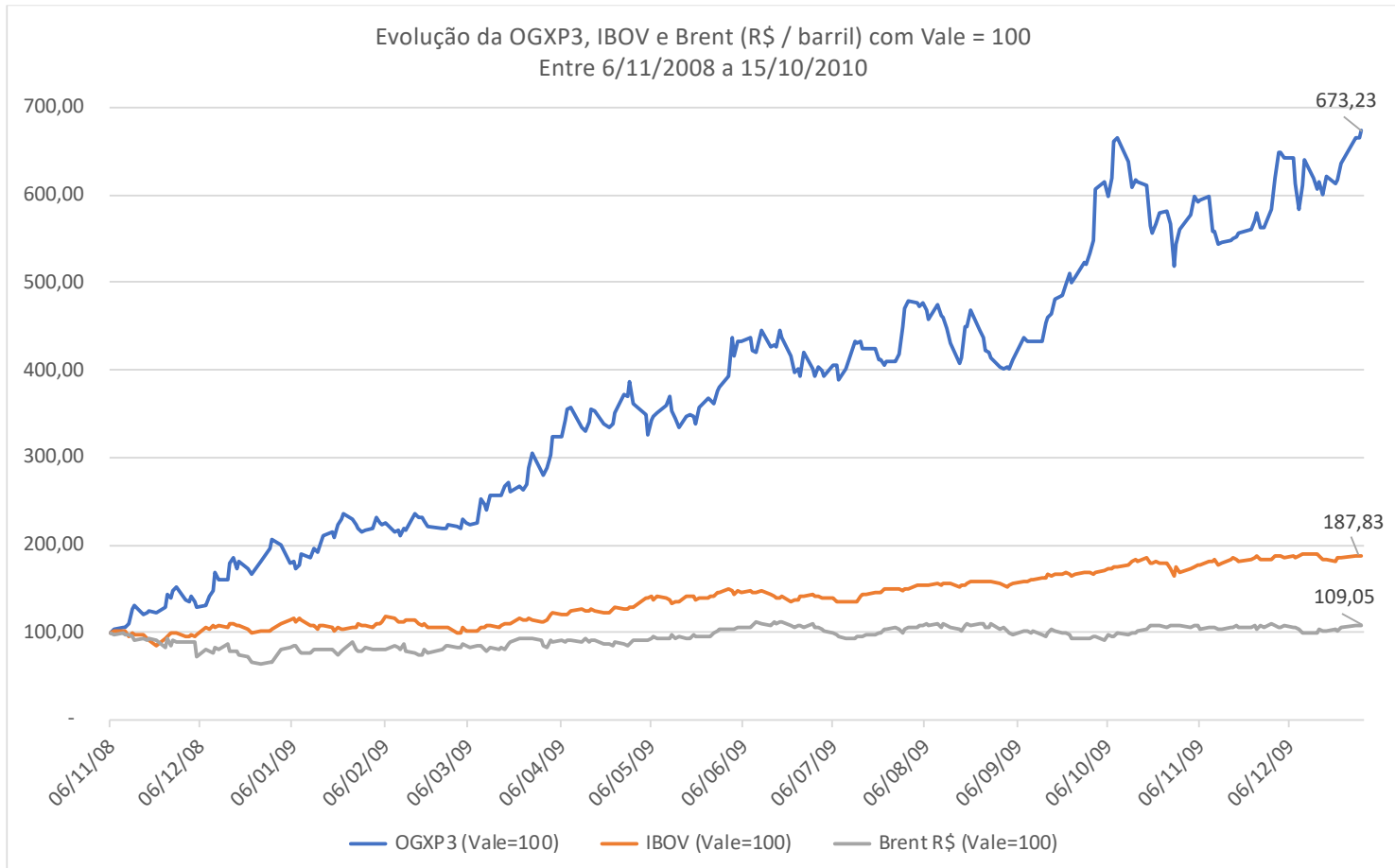

Ao longo do ano, a campanha exploratória da OGX ganhou "momentum", com os resultados das pesquisas sísmicas em 3D ${ }^{129}$ nos blocos de PA-MA, Campos e Santos. As pesquisas teriam identificados de 8 a 10 novos prospectos, além dos 51 anteriormente considerados. A execução do plano de negócios estava adiantada em relação ao seu cronograma original.

O entusiasmo com os resultados das pesquisas 3D levou a Empresa a contratar uma atualização do relatório da D\&M para agosto, mas que só seria divulgada em setembro (9/11). O 20 D\&M elevou as estimativas de recursos prospectivos de 4,8 bboe (baseado em pesquisas 2D) para 6,7 bboe (aumento de 38\%). O mercado e os Analistas responderam com entusiasmo. Até mesmo a venda de $\mathrm{R} \$ 31,33$ milhões em ações por parte dos Executivos em três dias em dezembro de 2009 (de 7 a 10/12), divulgada através da CMV 358 em janeiro de 2010, passou desapercebida pelos Analistas.

No início de 2009 , o EV/2C no início do ano correspondia a US\$ 0,79/boe, chegou a se valorizar 333,3\% no pico de US\$ 5,58 (9/10) e terminou o ano a US\$ 4,00/boe, ou seja, uma valorização no ano de $407,5 \%$. Mas vale ressaltar que a valorização do $E V / 2 C$ só não foi maior porque em 9/11/2009 foi publicado o 20 D\&M, que aumentou o RPL em $38 \%$ (de 4,835 bboe para 6,883 bboe).

${ }^{129}$ Enquanto as pesquisas em 2D eram conduzidas em distâncias de 8 quilômetros, as pesquisas em 3D ocorriam a 25 metros. Segundo os geólogos, as pesquisas em 2D geravam "buracos" (lacunas) de 8 $\mathrm{km}^{2}$. Portanto as pesquisas em 3D não só melhoravam o dimensionamento dos recursos, mas também a probabilidade de sucesso e a precisão dos locais para perfuração. 
Gráfico 25 - Evolução do EV/2C da OGX em 2009 (em US\$/boe)

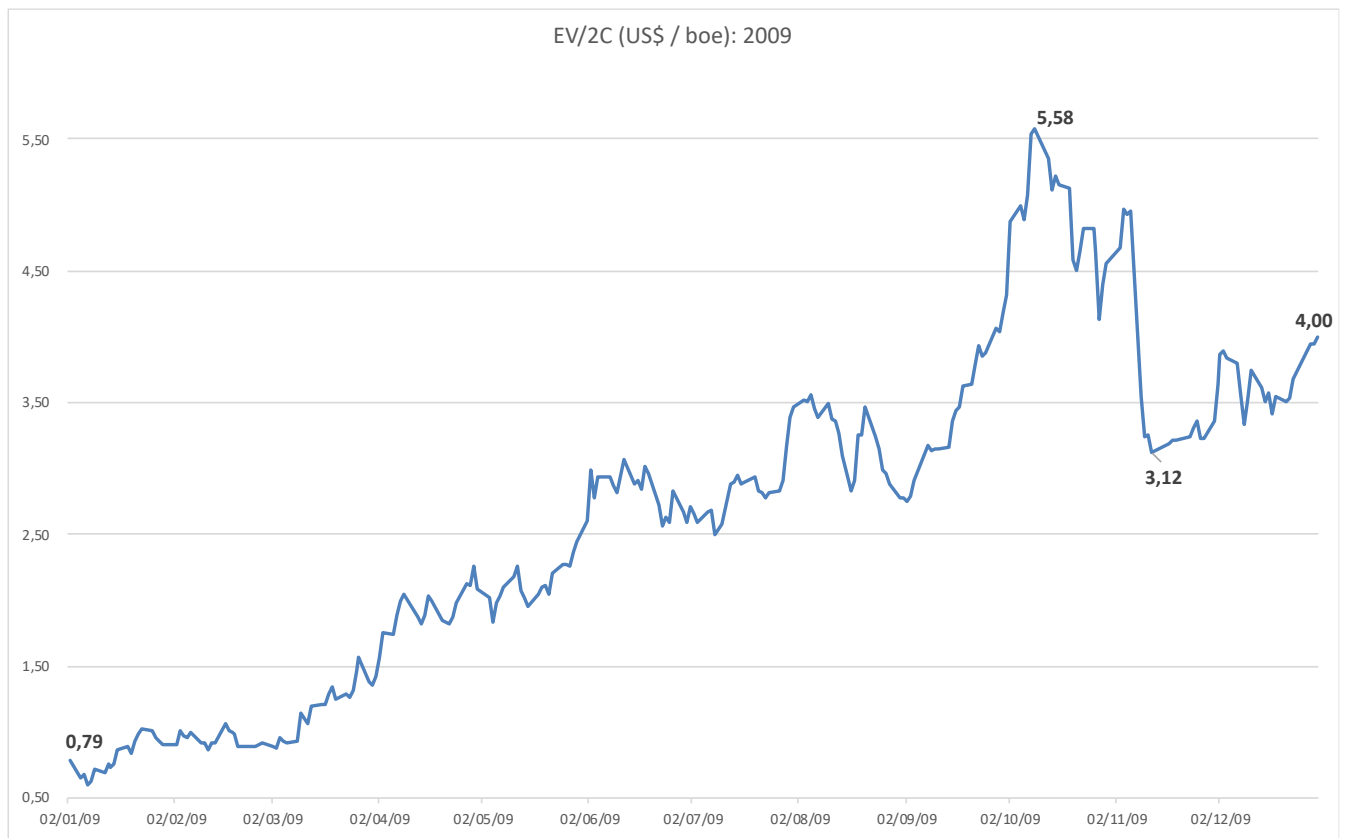

Evolução do Guidance e suas Repercussões sobre os Analistas em 2009

26/03. Testes sísmicos indicavam 1,0 bboe nos blocos da bacia do ES e não 0,27 bboe como fora estimado pelo 1을 $\mathrm{D} \& \mathrm{M}^{130}$.

Repercussões. A OGXP3 se apreciou $6,9 \%$ no pregão (de $R \$ 6,83$ para $R \$ 7,30$ ). A campanha exploratória no ES, que só começaria em 2011, poderia ser antecipada para o 2S2010. Estes resultados e a expectativa do 20 D\&M para agosto levaram o IBBA a aumentar seu PA em $18 \%$, de $\mathrm{R} \$ 10,26$ para $\mathrm{R} \$ 12,10$ no início de maio (4/5). Poucas semanas depois (29/4), o MS revisou seu PA de $R \$ 8,40$ para $R \$ 10,19 /$ ação, pois acreditava que o possível sucesso com o BM-S-29 e com os blocos em Campos poderiam confirmar 1,1 bboe em reservas ${ }^{131}$.

Em abril de 2009, o BBI publicou um relatório que chamou a OGX de "uma estrela em ascensão", "uma oportunidade única no setor de petróleo e gás acontecendo no lugar certo (Brasil) e na hora certa. A empresa combina um notório empreendedor, Eike Batista, e sua equipe de profissionais altamente qualificados (...)"132.

04/05. OGXP3 já se destacava entre as ações mais líquidas do BOVESPA e, como tal, passou a incorporar o IBrX-50 $50^{133}$ (com peso de 1,91\%) e o IBrX-100 (1,68\%).

\footnotetext{
130 KOVARSKY \& MENDES, 2009b, p. 2.

131 DARIPA \& SILVA [2009b].

132 ROZENBAUM \& VARELLA, 2009a, p. 1

133 O índice IBrX-50 é composto por cinquenta papéis selecionados numa relação de ações após serem classificadas em ordem decrescente de liquidez, de acordo com seu índice de negociabilidade, que é
} 
Repercussões. Analistas consideraram que a inclusão da OGXP3 nos índices iria melhorar sua liquidez e contribuir para sua reputação ${ }^{134}$.

11/05. Repsol descobre hidrocarbonetos nas águas rasas de Santos (Panoramix), próximo ao BM-S-29. Confiante em seu potencial, a OGX aumentou sua participação societária de $50 \%$ para $65 \%$.

Repercussões. No início de 2009, a Empresa demonstrava especial interesse no único bloco que não havia adquirido na 9 a Rodada, o BM-S-29 (prospecto de Abacate). A cerca de 40 quilômetros do BM-S-29, a PETR havia encontrado uma importante acumulação de gás (BM-S-7). Esta descoberta reforçava uma teoria que poderia haver uma formação rica em óleo leve na região. No 10 D\&M avaliava a participação da OGX no BM-S-29 em $145 \mathrm{mboe}^{135}$. Foi este o primeiro poço da campanha exploratória da OGX em Santos, perfurado e operado pela MAERSK.

Como o primeiro bloco a ser perfurado, nós esperamos que o BM-S-29 seja um marco que trará a atenção dos investidores para a OGX. O risco de um campo seco existe, mas a natureza conservadora dos geólogos combinada com a confiança que nós sentimos na equipe da OGX nos leva a associar um baixo risco a esta possibilidade [KOVARSKY \& MENDES, 2009a, p. 1].

Quando a Repsol anunciou a descoberta em Panoramix, a OGX, ainda em maio, aumentou sua participação no BM-S-29 para 65\% (anúncio em 11/5). O RPL do BM-S-29 foi revisado para 227 mboe. Não havia informação de nenhum pagamento direto à MAERSK, que poderia ser mais um sinal do valor esperado do BM-S-29136. Na data do anúncio do farm-in (em 11/5), a OGXP3 se apreciou 2,5\% no pregão (de R\$ 8,93 para R\$ 9,15).

14/05. Empresa acelera a campanha de exploração com a contratação de sete sondas, uma a mais do que o planejado.

Repercussões em Junho e Julho. Apesar dos boatos sobre resultados negativos no BMS-29, em junho, alguns Analistas aumentaram seus PAs pela melhora das condições

medido sempre nos últimos doze meses, observados os demais critérios de inclusão das empresas que são:

a) as ações devem estar entre as cinquenta melhores classificadas em seu índice de negociabilidade, apurados nos doze meses anteriores à reavaliação;

b) as ações devem ter sido negociadas em pelo menos $80 \%$ dos pregões ocorridos nos doze meses anteriores à formação da carteira.

c) As companhias que estiverem sob regime de recuperação judicial, processo falimentar, situação especial, ou ainda que estiverem sujeitas a prolongado período de suspensão de negociação, não podem integrar o IBrX-50.

A carteira teórica do índice tem vigência determinada de quatro meses, vigorando para os três quadrimestres: períodos de janeiro a abril, maio a agosto e setembro a dezembro. A BM\&FBovespa divulga três prévias antes da mudança da carteira, que desde 2011 ocorre sempre na primeira segunda-feira útil dos meses de janeiro, maio e setembro.

134 KOVARSKY, MENDES \& ARAUJO, 2009c, p. 5.

135 Considerando uma taxa de sucesso de $27 \%$ : 1,075 bboe $\times 27 \%=290 \mathrm{mboe} \times 50 \%=145 \mathrm{mboe}$ [KOVARSKY \& MENDES, 2009a, p. 1].

${ }^{136}$ KOVARSKY, MENDES \& ARAUJO, 2009d, p. 1. 
macroeconômicas (reduzindo o custo de oportunidade do capital), revisão de premissas sobre a taxa de sucesso em Campos (de $33 \%$ para $50 \%$ ) e o potencial do ES (que poderia aumentar o RPL de 0,9 a 2,0 bboe), aceleração da campanha de exploração ${ }^{137}$.

Nós reforçamos nossa recomendação de outperfomance da OGX. Prevemos uma sequência de boas notícias que darão suporte à performance da ação para o restante do ano, agora mais reforçada com a tendência de de-risking. Os resultados do BM-S-29 poderiam ser percebidos pelos investidores como um risco, catalisando a realização de lucros, entretanto nós entendemos que a probabilidade é alta após várias interações com a Empresa na sala 3D. Por sua vez, o fluxo de notícias gerado pelo relatório da D\&M revisando a bacia de Campos seguido da agressiva campanha exploratória no segundo semestre, agora reforçada com uma sonda adicional (num total de 7 no ano), nos deixa bem confortáveis em reiterar nossa percepção positiva da Empresa [KOVARSKY, MENDES \& ARAUJO, 2009e, p. 1].

Com base em percepções semelhantes, o MS revisou novamente seu PA em 55\% (de R\$ 10,19 para $R \$ 15,83$ em 1/7), pois, segundo seus Analistas, já havia indícios que a D\&M iria aumentar o RPL e o valor da OGXP3 na época (R\$ 10,26 em 1/7) ainda estava abaixo do IPO (R\$ 11,31) e embutia um desconto de $67 \%$ em relação aos múltiplos de EV/Reservas de empresas similares [p. 4]:

Nós esperamos fortemente que catalisadores [revisão D\&M, descobertas em Santos (BM-S-29) e Campos] elevarão os preços da ação nos próximos 6 meses e insistimos para que os investidores comprem OGX. (...) Se os catalisadores forem confirmados, os investidores podem ficar mais confortáveis com a estimativa [Preço Alvo] do nosso cenário otimista de $R \$ 31,75$ (próximo ao cenário "alto" [P10] da D\&M) [DARIPA \& SILVA, 2009b, p. 1].

Mas algumas análises de múltiplos de empresas comparáveis pareciam considerar empresas em estágios de maturidade bem distintos, já produzindo, com a OGX ainda em fase exploratória.

${ }^{137}$ KOVARSKY, MENDES \& ARAUJO [2009e]; DARIPA \& SILVA [2009b]. 
Tabela 23 - Múltiplos de Empresas Similares Utilizadas pelo MS para Comparar com a OGX

\begin{tabular}{|l|c|c|c|}
\hline \multicolumn{1}{|c|}{ Empresas } & $\begin{array}{c}\text { Capitalização } \\
\text { de Mercado } \\
\text { (US\$ Bilhões) }\end{array}$ & $\begin{array}{c}\text { Produção } \\
\text { (2008, } \\
\text { kboed) }\end{array}$ & $\begin{array}{c}\text { EV/boe } \\
\text { Riscado }\end{array}$ \\
\hline Tullow Oil & 11,53 & $66,6 \mathrm{e}$ & 7,2 \\
\hline Afren & 0,30 & 3,3 & 5,1 \\
\hline Addax Petroleum Corp. & 5,35 & 136,5 & 9,4 \\
\hline Premier Oil & 1,45 & 36,8 & - \\
\hline SOCO International & 1,70 & 6,4 & 7,8 \\
\hline Dana Petroleum & 2,03 & 39,4 & 7,3 \\
\hline Caim Energy & 5,39 & 12,8 & 8,4 \\
\hline OGX & 15,58 & 0,0 & 1,6 \\
\hline
\end{tabular}

Fonte: DARIPA \& SILVA, 2009b, p. 8.

Os Analistas demonstravam entusiasmo com o 2요 DMe, segundo a OGX, poderia adicionar de 2 a 3 bboe ao RPL e aumentar o POS em Campos de 33\% para 50\%. Ao todo, os Analistas aventavam a possibilidade de o RPL chegar a 10 bboe, dos quais 1 bboe poderiam advir de eventuais bons resultados no BM-S-29. A PETR havia encontrado óleo em dois blocos próximos (BM-S-7 e BM-S-3). Uma possível descoberta de óleo no BM-S29 , cujo anúncio era esperado para setembro/outubro, não só afetaria as premissas da taxa de sucesso, mas também reforçaria o suposto diferencial da expertise da equipe de exploração da OGX em Santos. A expertise dos Executivos em Campos parecia ser inconteste, pois a taxa de sucesso histórica obtida entre 2005-06 fora de $90 \%$, contra a média de $20 \%$ observada mundialmente ${ }^{138}$.

Em julho, a Empresa participou de um road show na Ásia em busca de parceiros estratégicos para o farm-out de alguns blocos. As perfurações no BM-S-29 estavam atrasadas (começaram em 13/8 e os primeiros resultados deveriam estar disponíveis em 2 meses, ou seja, outubro) e a publicação do 20 D\&M também foi adiada para outubro. Mas a Repsol descobriu hidrocarbonetos em Vampira, a apenas 18 quilômetros do BMS-29, o que foi recebido como um indício auspicioso. Os Analistas acreditavam que o 2 o D\&M poderia: aumentar o volume de RPL, incluindo o BM-S-29 e os prospectos no ES; e aumentar a estimativa da taxa de sucesso. O MS associou uma probabilidade de $80 \%$ desta expectativa ser confirmada ${ }^{139}$. O IBBA o considerou aumento "altamente provável"140.

No fim de julho (29/07), a OGXP3 fechou o pregão em $R \$ 11,40$, recuperando seu valor nominal do IPO (R\$11,31 por ação), pouco mais de um ano atrás.

Agosto. Início da campanha exploratória em Campos e Santos. Começam as perfurações no BM-S-29 (17/8).

\footnotetext{
138 DARIPA \& SILVA [2009a].

139 DARIPA \& SILVA [2009c].

140 KOVARSKY, MENDES \& ARAUJO [2009g].
} 
Repercussões. Em 20/8, a PETR anunciou a descoberta de 280 mboe de óleo leve recuperável no BM-C-36, próximos a dois blocos da OGX (BM-C-40 e BM-C-39), o que reforçava a expectativa de sucesso em Campos. Poucos dias depois (23/8), a BG anunciou um poço seco em Corcovado-2, no bloco BM-S-52, a $140 \mathrm{~km}$ do BM-S-29 e 60 km do BM-S-59, ambos da OGX. Alguns Analistas mantiveram seu otimismo em relação ao BM-S-29, afinal "geologia é tudo menos uma ciência exata..." ${ }^{141}$. De fato, três dias depois, o IBBA elevou seu PA mais uma vez, de $\mathrm{R} \$ 13,19$ para $\mathrm{R} \$ 14,79$.

24/09. OGX adquire 70\% da Petra Energia, que detinha concessões de 7 blocos terrestres na bacia do Parnaíba (interior do Maranhão), com grande potencial de GN. Constituição da OGX Maranhão (66,7\% OGX e 33,3\% MPX) para viabilizar a UTG Parnaíba (1,0 GW).

Repercussões. Alguns Analistas ${ }^{142}$ interpretaram esta aquisição da Petra como uma "opção grátis", pois envolveu o pagamento de R\$ 12 milhões à vista, referente ao BA pago pela Petra na $9^{a}$ Rodada, mais a assunção do compromisso de exploração (estimado em até R\$ 78 milhões). Entretanto, os mesmos Analistas consideraram muito cedo para precificar o impacto das novas reservas e da SPE com a MPX.

2/10. Em menos de 2 meses após o início das perfurações, a OGX anunciou a descoberta de hidrocarbonetos no BM-S-29.

Repercussões. Os Analistas consideraram a descoberta um marco histórico para a OGX, uma prova do diferencial do seu "dream team"143, uma vez que a MAERSK já havia perfurado o BM-S-29, anteriormente, e só havia encontrado água. $O$ anúncio causou um aumento na OGXP3 de 10\% em um dia. Os Analistas se apressaram em aumentar suas estimativas para o RPL e revisar seus PAs. O IBBA, por exemplo, aumentou seu PA de R\$ 14,79 para $\mathrm{R} \$ 16,30$ (RPL de 5,7 para 6,2 bboe $^{144}$ ).

7 a 14/10. Descoberta de hidrocarbonetos em Vesúvio (BM-C-43, poço OGX-1), cujo reservatório poderia conter de 0,5 a 1,5 bboe. Em um único bloco poderia haver $39 \%$ do óleo estimado no IPO para Campos (o total era de 2,6 bboe de RPL). Em paralelo ao Vesúvio, a campanha exploratória continuava: outras sondas começaram a perfurar poços no BM-C-41 (prospecto de Pipeline) e BM-S-43 (Waimea).

Repercussões. A perfuração em Vesúvio começou em 17/9, ou seja, descobriu-se óleo em menos de um mês de perfuração ${ }^{145}$. A estimativa de 0,5 a 1,5 bboe poderia ser revisada para cima, pois a perfuração ainda não havia sido completada. A descoberta de Vesúvio era muito maior do que outras recentemente anunciadas pela PETR em Campos, por exemplo: o BM-C-36, com um volume total recuperável estimado em 280 mboe; reservatórios em Marlim Sul e Marlim Leste com 350 mboe; Jabuti com 350 mboe.

141 KOVARSKY, MENDES \& ARAUJO, 2009f, p. 1.

142 KOVARSKY, MENDES \& ARAUJO [2009h].

143 KOVARSKY, MENDES \& ARAUJO [2009i].

144 KOVARSKY, MENDES \& ARAUJO [2009k]. Destes 0,5 bboe a mais, 0,1 se referiam a ajustes na estimativa do BM-S-29 (POS de $27 \%$ para $37 \%$ ) e 0,35 do ES (POS de $19 \%$ para $27 \%$ ).

145 Já em 2008, havia expectativas de sucesso neste bloco, pois houve descobertas no passado, mas que devido a condições técnicas e comerciais desfavoráveis não foram desenvolvidas [LEITE, CANHEU \& CUSTODIO, 2008a, p. 29]. 
Vesúvio teria uma coluna de petróleo de 200 metros, incomum na região, com 57 metros de net pay. Novas revisões dos PAs se seguiram. Em menos de um mês, o IBBA reajustou seu PA três vezes, de $R \$ 13,19$ (24/8) para $R \$ 17,80$ (14/10), um aumento de $35 \%$.

09/11. Publicação do 20 D\&M, que elevou as estimativas do portfólio em $38 \%$ : de 4,8 bboe do 1으 D\&M para 6,7 bboe. Destes recursos, $95 \%$ se localizariam em blocos de águas rasas com duas implicações positivas: custos menores de E\&P, além de maior disponibilidade de equipamentos.

Repercussões. A nova estimativa equivalia a 34\% dos recursos da PETR. O aumento do RPL em 38\% foi principalmente causado por três variações: aumento de 1,131 bboe no RPL de Campos; POS maiores para Campos (de 33,0\% para 44,1\%) e ES (de 18,0\% para $32,6 \%$ ). O aumento do POS total, de $27,0 \%$ para $34,5 \%$, foi maior do que o previsto por alguns Analistas ${ }^{146}$ :

É importante notar que há muita confusão no mercado sobre a "taxa de sucesso". A taxa de sucesso é composta pela combinação de dois fatores: a chance de se descobrir óleo ou gás com a chance destas descobertas serem economicamente viáveis. De fato, a Empresa foi bem-sucedida nos seus primeiros dois poços [Abacate e Vesúvio], mas daí para acreditar que a revisão da D\&M confirmaria um fator de sucesso materialmente maior do que o usual da indústria é outra estória. Isto realmente iria contra a natureza do exercício conduzido por uma consultoria e dos riscos que ela estaria preparada para defender. Então, pode haver um potencial mais alto de reservas, o que provavelmente será de-risked ao longo do tempo, a medida que a Empresa prosseguir com sua campanha exploratória [KOVARSKY, MENDES \& ARAUJO, 2009l, p. 2].

As revisões do 20 D\&M teriam sido justificadas pelos novos dados dos testes sísmicos em 3D, "porém e mais importante, pelo massivo esforço interpretativo conduzido pela equipe de exploração da Empresa nos 16 meses desde o IPO. Novos prospectos foram identificados e outros unificados, aumentando a área potencial da OGX (...) $)^{147 " \text {. }}$

146 KOVARSKY, MENDES \& ARAUJO, 2009I, p. 2.

147 KOVARSKY, MENDES \& ARAUJO, 2009I, p. 2. 
Tabela 24 - Resumo dos Relatórios D\&M (em bboe de hidrocarbonetos)

\begin{tabular}{||l|c|c|c|c|c|c||}
\hline & \multicolumn{2}{|c|}{$\begin{array}{c}\text { IPO 2008 } \\
\text { (3/2008) }\end{array}$} & \multicolumn{4}{c|}{ Revisão 2009 (10/2009) } \\
\hline Bacias & RPL & POS & RPL & POS & Var. & Var.\% \\
\hline Campos & 2,562 & $33,0 \%$ & 3,693 & $44,1 \%$ & 1,131 & $44,1 \%$ \\
\hline Santos & 1,569 & $25,0 \%$ & 1,688 & $27,0 \%$ & 0,119 & $7,6 \%$ \\
\hline ES & 0,270 & $18,0 \%$ & 0,817 & $32,6 \%$ & 0,547 & $202,6 \%$ \\
\hline PA-MA & 0,434 & $20,0 \%$ & 0,447 & $21,2 \%$ & 0,013 & $3,0 \%$ \\
\hline Parnaíba & - & - & 0,026 & $19,9 \%$ & & \\
\hline RPL Subtotal & $\mathbf{4 , 8 3 5}$ & $\mathbf{2 7 , 0 \%}$ & $\mathbf{6 , 6 7 2}$ & $\mathbf{3 4 , 5 \%}$ & $\mathbf{1 , 8 3 7}$ & $\mathbf{3 8 , 0 \%}$ \\
\hline Rec. Contingentes $\mathbf{1 4 8}$ & $\mathbf{0}$ & - & $\mathbf{0 , 2 1 2}$ & - & $\mathbf{0 , 2 1 2}$ & - \\
\hline RPL Total & $\mathbf{4 , 8 3 5}$ & & $\mathbf{6 , 8 8 3}$ & & $\mathbf{2 , 0 4 9}$ & $\mathbf{4 2 , 4 \%}$ \\
\hline
\end{tabular}

Fontes: Prospecto, p. 113, e KOVARSKY, MENDES \& ARAUJO, 2009I, p. 2. Como alerta KOVARSKY, MENDES \& ARAUJO, 2009l, p. 2, vale notar que a comparação entre estes dois relatórios é impossível, pois foram elaborados com base em dados diferentes, com prospectos diferentes.

Adicionalmente, a D\&M incluiu mais 0,212 bboe de recursos contingentes da bacia do Parnaíba, que teria GN suficiente para alimentar uma UTE de $1 \mathrm{GW}$ por 30 anos. Entretanto, alguns Analistas ${ }^{149}$ consideravam que o efeito da UTE no PA poderia ser pequeno. Ou seja, a maior parte dos volumes recuperáveis da OGX (6,672 bboe) ainda permanecia classificada na categoria de maior risco (Recursos Prospectivos). Os 0,2 bboe de Recursos Contingentes eram de GN, portanto com valor menor do que se fosse de óleo. O mercado recebeu o 2여 $\mathrm{M}$ com cautela: em quatro pregões após a publicação, o $\mathrm{EV} / 2 \mathrm{C}$ perdeu $37,1 \%$ (de 4,96 em $6 / 11$ para 3,12 em $12 / 11$ ).

O 2 D\&M foi baseado nas informações disponibilizadas até 30/9/2009, o que, aparentemente, não incluía as descobertas do Vesúvio (254 mboe adicionais), BM-C-41 (Pipeline), BM-S-43 (Waimea), o que, segundo alguns Analistas, poderia aumentar o volume para 7,0 a 8,0 bboe ${ }^{150}$. De fato, o 2을 anúncios positivos (ou seja, mais "catalisadores"):

Esperamos que os próximos 12 meses tragam tantas surpresas como os últimos três meses [DARIPA, 2009e, p. 1].

Na teleconferência de 10/11 sobre o 20 D\&M, os Executivos pouco informaram sobre a campanha no ES, que possuiria 817 mboe, apesar de aumentar o número de poços a serem perfurados de 4 para 7 em 2010. Quanto ao BM-S-29, a OGX não tinha declarações a fazer, uma vez que a MAERSK era o operador:

(...) a perfuração [BM-S-29] também ainda está em andamento. O que temos até agora são resultados muito promissores. Nós estamos muito

\footnotetext{
${ }^{148}$ A D\&M considerava "recursos contingentes como o volume de petróleo que potencialmente poderia ser recuperável de acumulações conhecidas através de projetos de desenvolvimento, porém que não são atualmente considerados como comercialmente recuperável devido a uma ou mais contingências" [Prospecto, 2008, p. 270].

149 KOVARSKY, MENDES \& ARAUJO [2009m].

${ }^{150}$ KOVARSKY, MENDES \& ARAUJO [2009m]; DARIPA [2009e].
} 
animados. Como todos sabem, não somos os operadores do bloco. Assim, o operador é o encarregado de fazer as divulgações e a comunicação com o mercado. Assim, apenas declararemos o fato de que aquilo que temos em nossas mãos é algo de que gostamos muito [Compilação da Teleconferência pela Thompson Reuters, p. 2].

O 2 D\&M não considerou os resultados de Abacate (BM-S-29), devido a "dificuldades técnicas"151. De fato, a D\&M aumentou ligeiramente o POS médio de Santos: de 25\% para $27 \%$. Outro fato curioso foi que, aparentemente, os Analistas consideraram o RPL de hidrocarbonetos do 2 o D\&M sem distinguir entre óleo e GN, este último de difícil monetização.

A nova estimativa do RPL da OGX (6,7 bboe) equivalia a $34 \%$ daqueles da PETR. Destacava-se também que destes recursos, $95 \%$ se localizariam em blocos de águas rasas (entre 140 a 150 metros), o que poderiam implicar em custos menores de E\&P ${ }^{152}$, além de uma disponibilidade maior de equipamentos no mercado internacional.

O MS louvou os executivos da OGX que haviam entregado o que fora prometido 18 meses atrás: "descobertas em seus blocos e uma elevada base de recursos riscados (de 4,8 para 6,2 bboe], agora oficialmente considerada subestimada [em 50\%] pela D\&M" 153 .

12 e 16/11 e 4/12. Descoberta de hidrocarbonetos no bloco BM-C-41 (Pipeline, prospecto C09, poço OGX-2). Inicialmente, a Empresa estimou a descoberta entre 0,4 e 0,5 bboe $(16 / 11)$.

Repercussões. À medida que a perfuração se aprofundava, a OGX anunciou indícios ainda mais auspiciosos, o que levou alguns Analistas a especularem que Pipeline poderia ser maior que Vesúvio ${ }^{154}$, o que tornaria as estimativas do 2ㅇ D\&M conservadoras $(1,44$ bboe).

18/12. Descoberta em Waimea (BM-S-41), a apenas 5 quilômetros de Pipeline. Em $22 / 12$, anunciou que as perfurações estavam finalizadas em Pipeline e revisou as estimativas iniciais para 1,0 a 2,0 bboe de óleo recuperável (incluindo os 0,4 e 0,5 bboe ora anunciados em 16/11). Na média, a descoberta poderia somar 0,33 bboe ao RPL (1,5 médio do Pipeline $-1,17$ bboe estimados no $2^{\circ} \mathrm{D} \& M$ ).

Repercussões. Alguns Analistas ficaram muito entusiasmados com as descobertas, o que tornaria a região Sudeste de Campos uma nova província petrolífera. Especulava-se que a OGX poderia acelerar o desenvolvimento destas descobertas através de acordos de farm-out. De fato, IOCs pareciam estar ávidas por farm-outs no Brasil, como foi o caso da aquisição da XTO pela Exxon em meados de dezembro ${ }^{155}$.

151 KOVARSKY, MENDES \& ARAUJO, 2009m, p. 3.

152 ROZENBAUM \& VARELLA [2009a, p. 2] estimavam custos de desenvolvimento de US\$ 2,5/bbl e despesas operacionais de US\$ 8/bbl.

153 DARIPA, 2009e, p. 1.

${ }^{154}$ KOVARSKY, MENDES \& ARAUJO [2009n].

155 KOVARSKY, MENDES \& ARAUJO [2009o]. 
07 a 10/12. Parte dos Executivos (Diretor de Exploração e o Diretor de Relações com Investidores) vendeu $\mathrm{R} \$ 31,33$ milhões em ações da OGX. Dados da CVM 358 revelaram a movimentação ao público, mas não identificavam seus autores que só vieram a ser conhecidos anos depois através de processos judiciais.

21/12. Empresa desdobra suas ações (split) na proporção de 1 para 100, aumentando a liquidez da OGXP3 ${ }^{156}$.

Repercussões. A expectativa dos Analistas é que o aumento da liquidez das ações teria um impacto positivo no valor da OGXP3 ${ }^{157}$.

22/12. Fim das perfurações em Pipeline com estimativas revisadas dos iniciais de 0,4 e 0,5 bboe (em 16/11) para 1,0 a 2,0 bboe. Ou seja, Vesúvio e Pipeline somados poderiam conter 1,5 a 3,5 bboe. Especulava-se que a OGX poderia acelerar o desenvolvimento destas descobertas através de acordos de farm-out. De fato, IOCs pareciam estar ávidas por farm-outs no Brasil.

28/12. Descoberta de hidrocarbonetos em Waimea que poderia conter de 0,5 a 0,9 bboe, contra 0,15 bboe previstos no 20 D\&M. Devido à sua proximidade, Waimea e Pipeline poderiam estar conectados geologicamente, o que geraria sinergias na produção. Juntas Waimea e Pipeline poderiam ter entre 1,5 e 2,9 bboe. Estas recentes descobertas poderiam aumentar o RPL para 7,0 a 8,0 bboe.

Repercussões: No 4T09, ao todo, a OGX fez nove anúncios de descobertas em um intervalo de três meses. Apenas o volume total de óleo recuperável estimado para Pipeline e Vesúvio poderia somar de 1,5 a 3,5 bboe, contra a estimativa para o total do portfólio de 4,8 bboe descrita no IPO. No fim do ano começaram as perfurações em dois outros prospectos: Kilawea (BM-C-42, a 10 quilômetros do Vesúvio), e Krakatoa (BM-C43). Foi um quarto trimestre intenso para a OGXP3.

Ao todo, ao longo de 2009, a Empresa perfurou mais 6 poços, 4 em Campos e 2 em Santos. Sua taxa de sucesso até então tinha sido de $100 \%$ em quatro blocos (BM-C-41, BM-C-43, BM-C-43 e BS-C-29) e a Empresa demonstrava muita autoconfiança:

O ano de 2009 representou um período histórico para a OGX, marcado pelo sucesso da campanha exploratória (...) importantes descobertas de hidrocarbonetos realizadas e na identificação de uma nova província petrolífera no sul da bacia de Campos, até então subexplorada. Tais resultados representam uma quebra de paradigmas na indústria do petróleo, tanto sob o ponto de vista da agilidade com que foram obtidos, quanto também pelo índice de sucesso atingido pela OGX em todos os poços perfurados em 2009, posicionando a companhia num novo patamar na indústria do petróleo brasileira e mundial [OGX, DFP 2009, p. 3].

${ }^{156}$ O Prospecto da OGX [p. 8], por exemplo, previa que estava vedado qualquer desdobramento das ações por 18 meses após o IPO.

${ }^{157}$ ROZENBAUM \& VARELLA, 2009b, p. 3. 
Em sua apresentação corporativa do 4T2009 lia-se: "A OGX está diante de uma história de 10 anos de crescimento sem paralelo, calcada em ativos 'world class', de extraordinária qualidade". Apenas em dezembro de 2009, a OGXP3 valorizou 16\%, devido aos anúncios de descobertas em Pipeline e Waimea, segundo alguns Analistas ${ }^{158}$.

Embora o mercado pareça ter recebido o 2으 DM com cautela, os Analistas da Amostra TR também responderam com otimismo às descobertas e revisões de volumes recuperáveis, especialmente no quarto trimestre, com a descoberta de Vesúvio, Pipeline e Waimea. Cabe destacar que por um curto período, de 24/9 a 15/10, a OGXP3 foi transacionada acima da mediana dos PAs. Mas após 15/10, a OGXP3 se descolou, para menor, da mediana dos PAs, data esta que coincide com o inesperado e pouco usual anúncio dos volumes recuperáveis de Vesúvio (7 e 14/10) e Pipeline (12/11 a 22/12), que somados poderiam conter 1,5 a 3,5 bboe.

Gráfico 26 - Amostra da TR: Evolução da Mediana, Máximo e Mínimo do PA em 2009 (em $\mathbf{R}$ /ação)

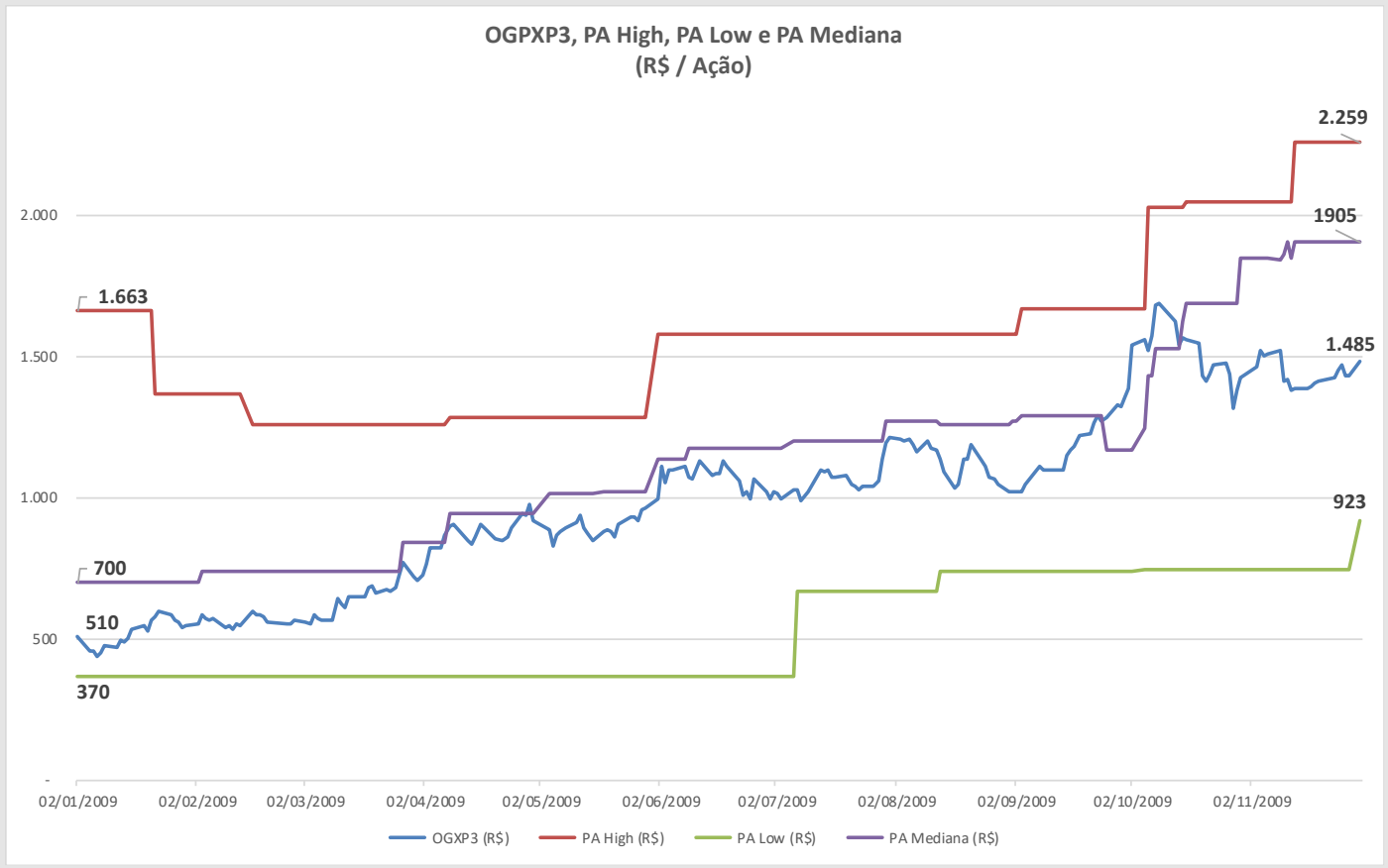

${ }^{158}$ LEITE \& CANHEU [2010a]. 


\subsection{0: Farm-out, OSX e o Desgaste do Guidance}

"If the ducks are quacking, feed the ducks."

Ditado de Wall Street

"O ano de 2010 foi de conquistas imensuráveis e grandes realizações para a OGX, tendo sido marcado por grandiosas descobertas e pela comprovação do potencial produtivo de nossas principais acumulações de hidrocarbonetos"

OGX, DFP 2010, p. 3.

Evolução do Valor de Mercado em 2010

A OGXP3 encerrou o ano de 2009 com uma valorização espetacular de 225,3\% (de R\$ 5,26 em 30/12/2008 para R\$ 17,10 30/12/2009). Em relação ao S\&P OGEP 600 e 1500, que praticamente não se apreciaram no ano, a OGXP3 também se destacou.

Gráfico 27 - Evolução do S\&P OGPE 600, S\&P OGPE 1500, OGXP3 e Brent em 2010

$(12 / 06 / 2008=100)$

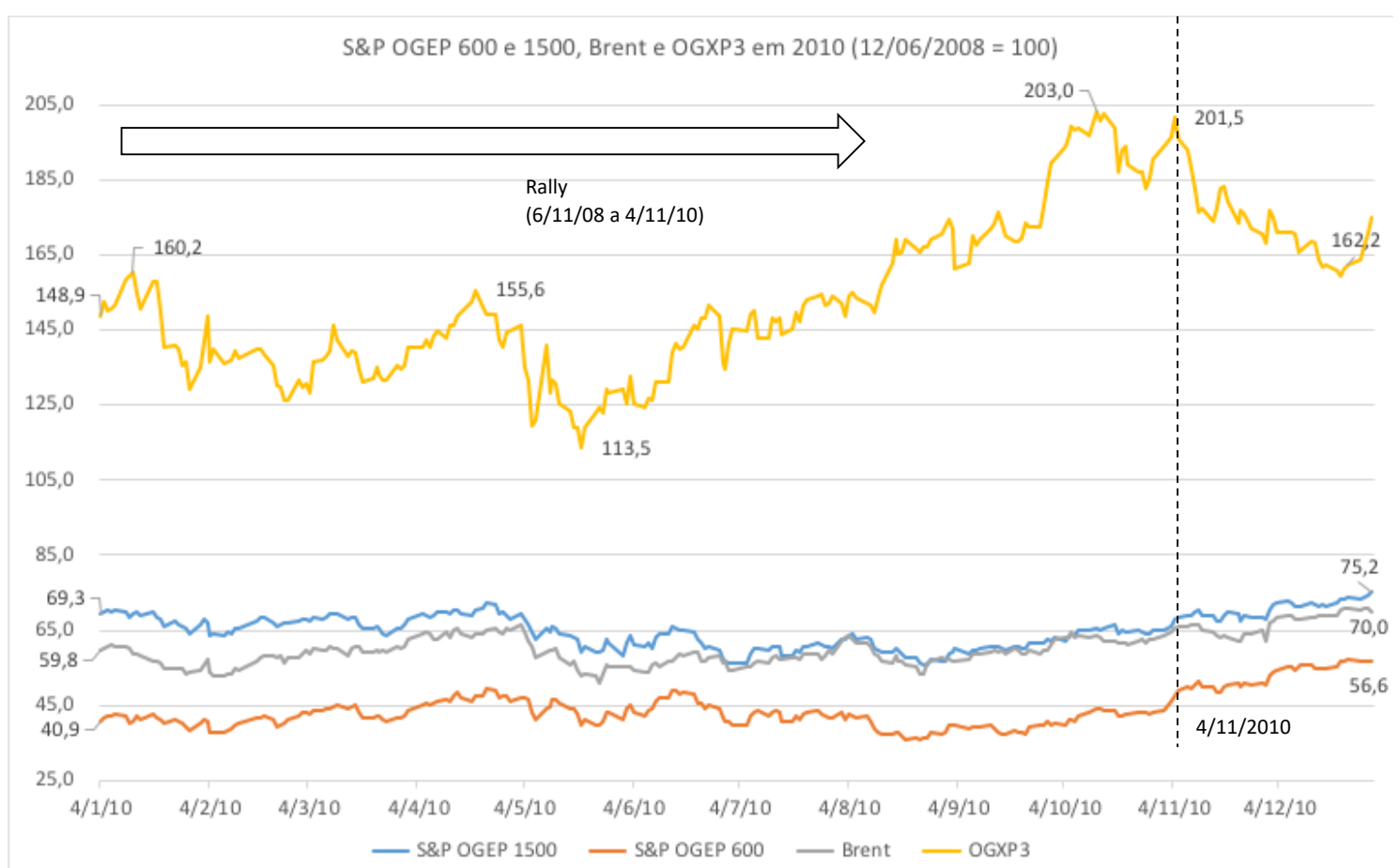

O Rally continuou ao longo de 2010, mas mostrou um período de enfraquecimento entre janeiro e agosto que pode ter sido causado pelo overhang do follow-on de $\mathrm{R} \$$ 
120,2 bilhões da PETR, concluída em 24 de setembro ${ }^{159}$, e IPOs de outras junior oils. Era preciso manter e reforçar a produção de catalisadores que a OGX sinalizava aos investidores através do guidance.

O ritmo acelerado e anúncios de novas descobertas do 4T2009 continuou ao longo de 2010. Entretanto, em 2010, a OGXP3 não repetiu a valorização exuberante de 2009, apesar de que, em nenhum momento, a OGXP3 chegou a valer menos do que em seu IPO (o mínimo foi de $\mathrm{R} \$ 14,72$ em 20/5, uma perda de 13,9\% em relação ao fechamento de 2009) e chegou a um pico de $\mathrm{R} \$ 23,27$ (em 15/10), representando uma valorização de $36,1 \%$ em relação ao fechamento de 2009. Em 15/10/2010, pouco mais de dois anos após o IPO e ainda em fase pré-operacional, o Valor de Mercado alcançou seu máximo: US\$ 42,05 bilhões (R\$ 69,81 bilhões), ou seja, 142,2\% acima da capitalização do IPO e $26,4 \%$ acima da estimativa do 20 D\&M de US\$ 33,27 bilhões, divulgado em 9/11/2009.

Foi o fim do Rally e o início da Segunda Correção Depreciativa que duraria 179 pregões (de 4/11/10 a 08/08/11). A OGXP3 encerrou o ano com valorização de "apenas" 17,0\% (de $\mathrm{R} \$ 17,10$ em 30/12/2009 para $\mathrm{R} \$ 20,00$ ). Foi um ano de muita volatilidade.

159 Na época, a PETR era a quarta maior empresa de energia do mundo com uma capitalização de mercado de US\$1 199,2 bilhões (31/12/2009). Produzia uma média diária de 2,3 mboe de petróleo e 2,1 mboe de GN (base 1S2010). Na época, 90\% de todas as reservas provadas da PETR estavam em Campos. Santos ainda era "uma das áreas de exploração mais promissoras da costa brasileira". Tupi ainda estava na fase do TLD. Até 31/12/2009, a PETR havia perfurado 41 poços em Santos, com um índice de sucesso de $85,0 \%$. Na bacia do ES, a Petrobras fez diversas descobertas de petróleo de leve no póssal. O follow-on de R\$120,2 bilhões (US\$ 69,9 bilhões), dos quais R\$ 45,5 bilhões foram para o caixa e $\mathrm{R} \$ 74,8$ bilhões destinaram-se ao pagamento da cessão onerosa dos direitos de produção de até 5 bboe em áreas não licitadas do pré-Sal (Relatório de Atividades da Petrobras de 2010, p. 15). Na época do IPO, a PETR tinha entre 11,6 (critério SEC, regulation X) e 14,9 bboe (critério ANP/SPE) de reservas provadas no Brasil (base 31/12/2009, auditadas pela D\&M). Em 31/12/2010, as reservas provadas de óleo e GN da PETR, segundo o critério ANP/SPE, alcançaram 15,986 bboe. 
Gráfico 28 - Evolução da OGXP3 em 2010 (em R\$ nominais por ação, pré Split)

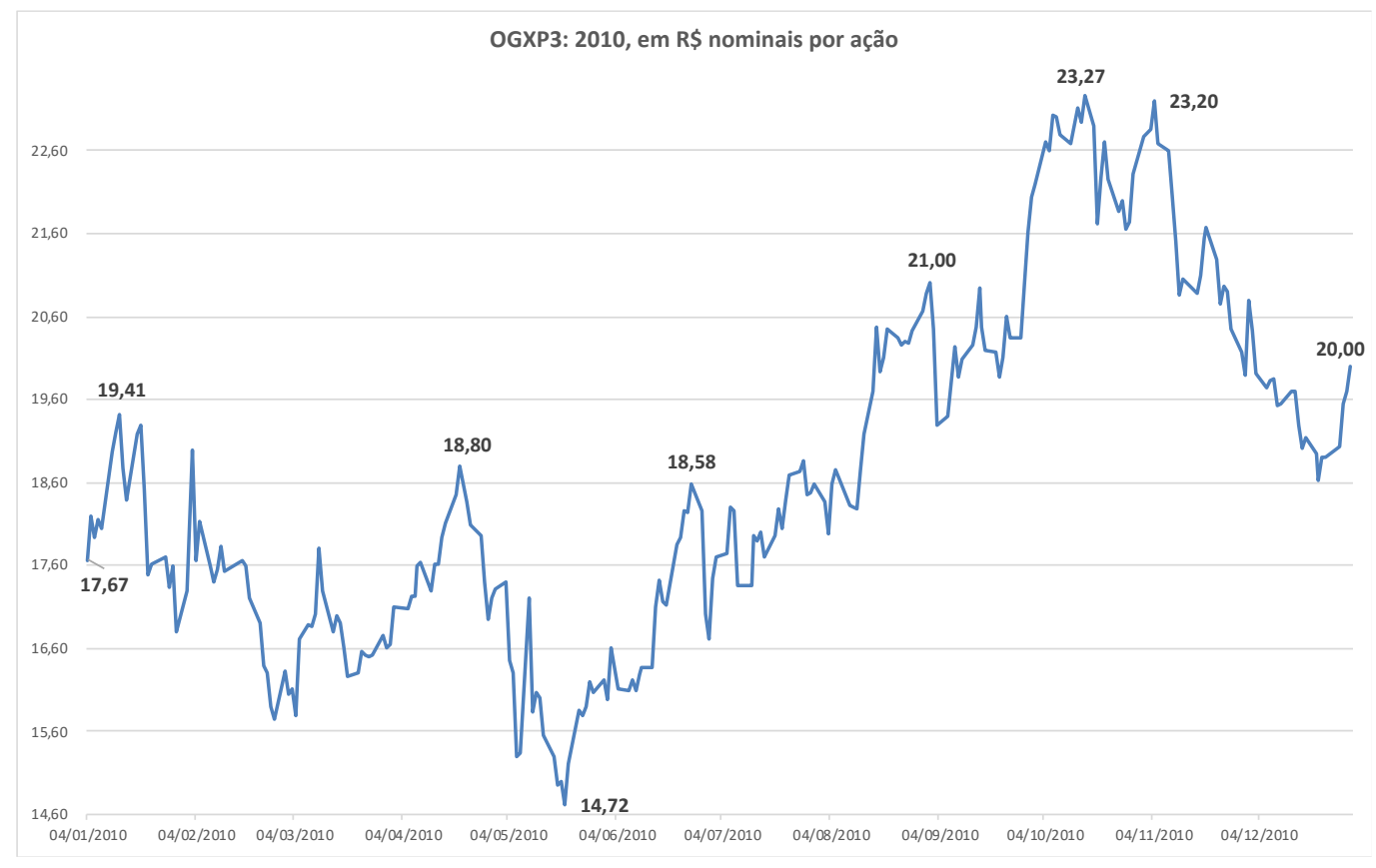

Mas o pico de 2010 não se sustentou. Com o fim do Rally, começou a 2a Correção Depreciativa. Ao fim de 2010, enquanto a OGXP3 se valorizou "apenas" 17,0\%, o IBOV de desvalorizou 1,1\% e o preço do petróleo (Brent) se valorizou $17,0 \%$, oscilando entre US\$ 70 a US\$ 90 durante a maior parte do ano.

\section{Gráfico 29 - Evolução da OGXP3, IBOV e Brent em 2010 (Base IPO = 100)}

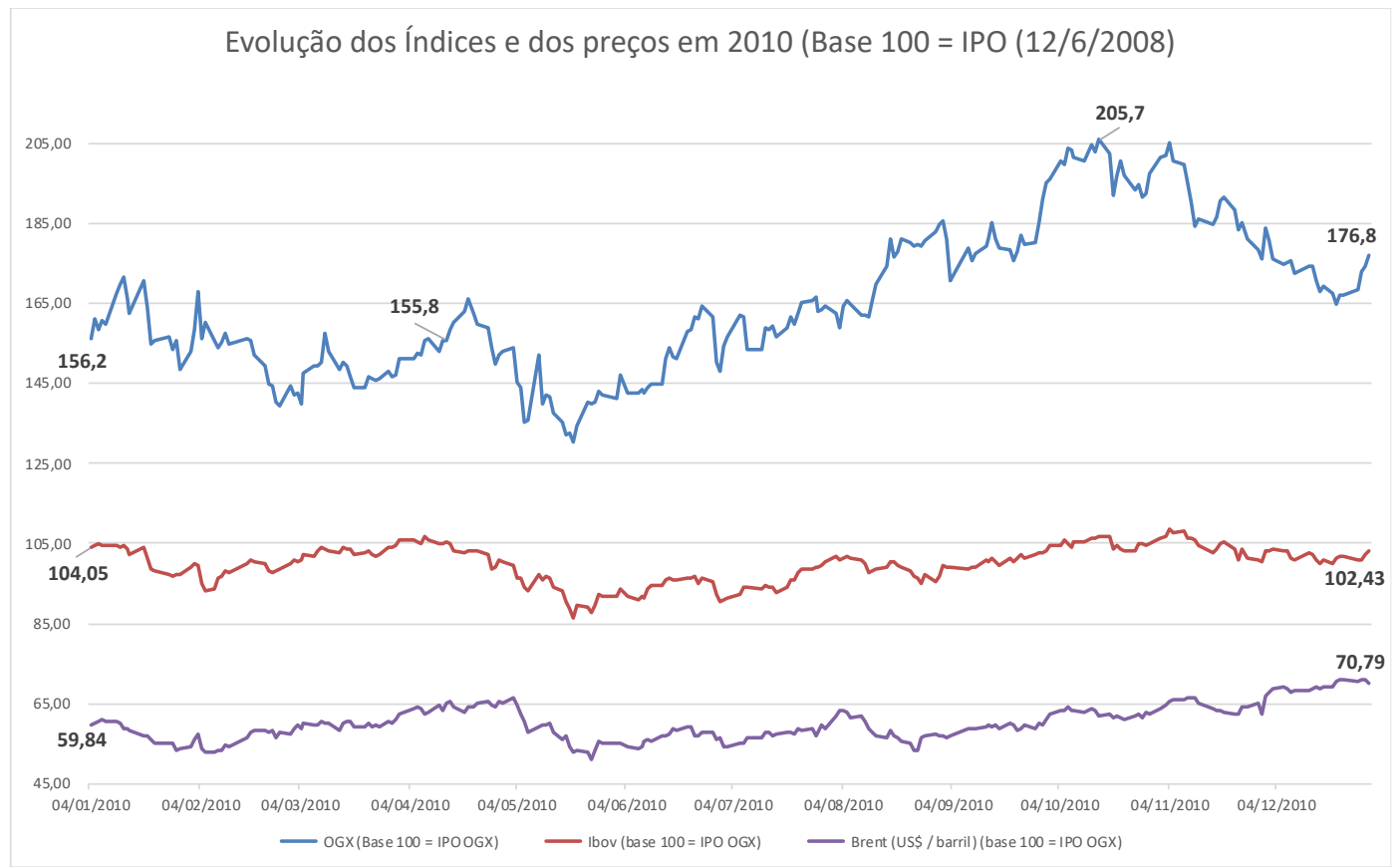


A valorização do $\mathrm{EV} / 2 \mathrm{C}$ da OGX foi de $30,5 \%$, portanto acima do desempenho da OGXP3 (17,0\%). Ou seja, depois do mercado ter precificado boa parte do ganho do 20 D\&M (US\$ 6,6/boe, equivalente a uma valorização de 36,8\% em 15/10), que aumentou a estimativa média do portfólio da OGX em 42,4\% (de US\$ 23,4 para US\$ 33,27 bilhões), a OGX terminou o ano precificada a US\$ 5,2/boe.

\section{Gráfico 30 - Evolução do EV/2C em 2010 (em US\$/boe)}

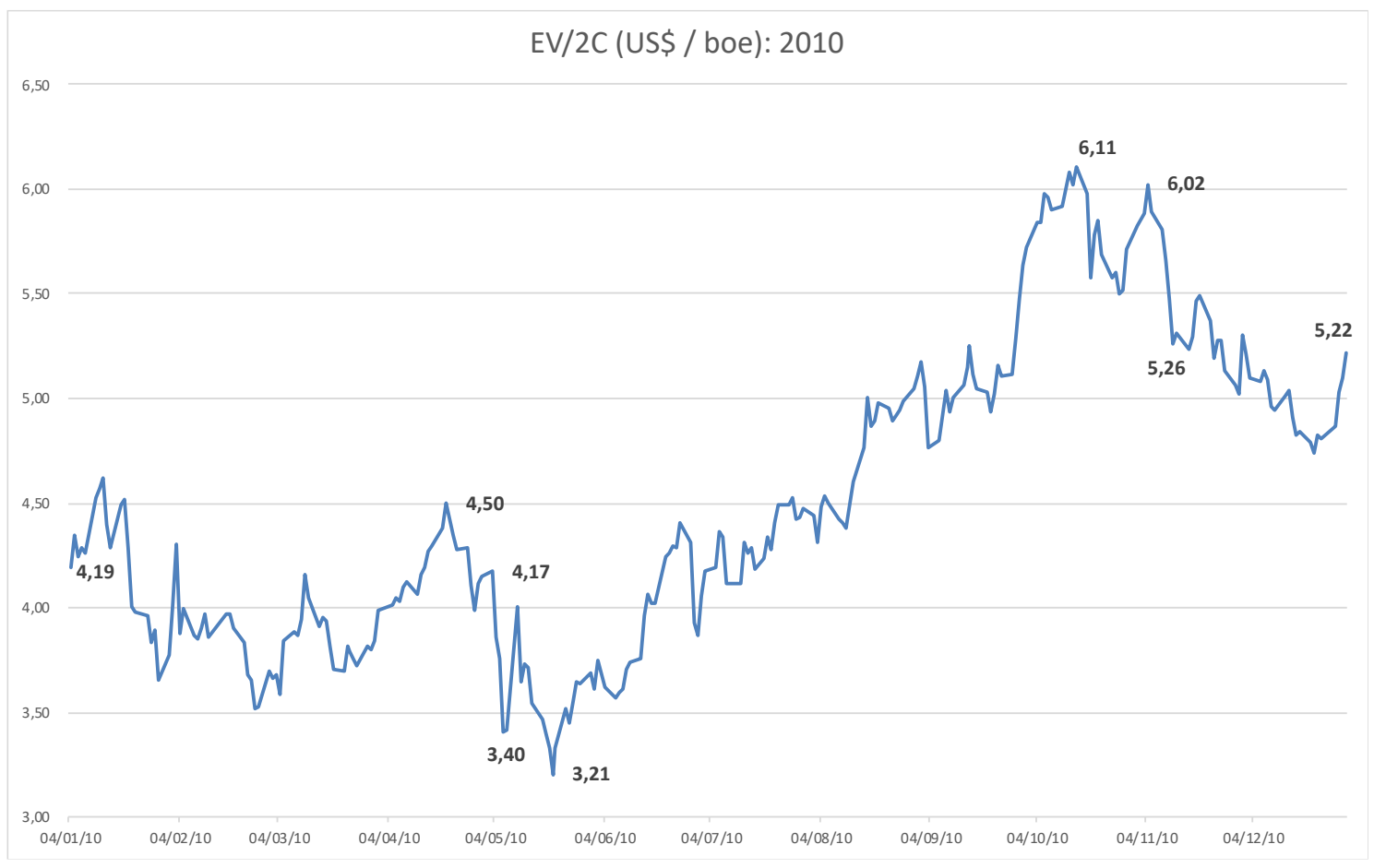

\section{Evolução do Guidance e suas Repercussões sobre os Analistas em 2010}

11/01. Descoberta de hidrocarbonetos em Kilawea (BM-C-42, OGX-4, com uma coluna de 90 metros e net pay de 17 metros) próximo a Vesúvio. A Empresa poderia rever seu plano de E\&P: as descobertas de Vesúvio ou Pipeline seriam certificadas como Reservas em 1S2010 com o first oil em 2S2011.

Repercussões. Um ramp-up na projeção de produção poderia aumentar o PA de alguns Analistas em $10 \%{ }^{160}$. O ramp-up, as certificações de Vesúvio ou Pipeline e o primeiro óleo nestes prospectos para 2S2011 poderiam levar a Empresa a alienar (farm-out) participações minoritárias para acelerar o desenvolvimento das reservas de Pipeline ${ }^{161}$. Aos múltiplos da época, o farm-out poderia ocorrer a US\$10,0/boe, o que serviria como

160 KOVARSKY, MENDES \& ARAUJO [2010b]: a D\&M assumiu US\$ $274 \mathrm{mil} /$ dia para uma FFSO com capacidade para uma produção de $100 \mathrm{kbd}$, enquanto a OSX1 teria capacidade para $80 \mathrm{kbd}$, que poderiam ser expandidos para $100 \mathrm{kbd}$.

161 LEITE \& CANHEU [2010a]. Os analistas consideravam que uma vez melhor dimensionado os riscos de desenvolvimento, a OGX deveria vender participações para IOCs estratégicas e otimizar seu capex. 
um importante "read-across" para o portfólio. Outros catalisadores seriam os múltiplos de M\&A resultantes das vendas de duas reservas próximas a Vesúvio, a de Peregrino ${ }^{162}$ (a venda pela Statoil) e do Polvo ${ }^{163}$ (Devon) ainda no $1 S 2010^{164}$. Ou seja, a expectativa estava se formando para a OGX se transformar de uma empresa puramente exploratória para produção.

22/01. Em menos de um mês do início da perfuração (26/12/09), outra descoberta de hidrocarbonetos: Krakatoa (BM-C-43, com uma coluna de 130 metros e net pay de 30 metros).

27/01. Empresa aumentou metas de produção e antecipou o first oil para o início de 2011 (20 kboed contra 5 kboed previstos anteriormente) em Waimea. O ramp-up aumentou de 398 para 730 kboepd em 2015 (aumento de 83\%). A OGX divulgou intenção de adquirir equipamentos da recém-criada OSX, em parceria com a Hyundai.

Repercussões. As novas metas de produção teriam um impacto pequeno no PA.

Tabela 25 - Projeções das Metas de Produção (em mil boe/dia de Petróleo e GN)

\begin{tabular}{||l|c|c|c||}
\hline & $\mathbf{2 0 1 1}$ & $\mathbf{2 0 1 5}$ & $\mathbf{2 0 1 9}$ \\
\hline IPO (2008) & 5 & 398 & 1.130 \\
\hline Revisão jan./2010 & 20 & 730 & 1.380 \\
\hline Var.\% & $900 \%$ & $83 \%$ & $22 \%$ \\
\hline \multicolumn{4}{|c|}{ Fonte para 2009 foi OGX, DFP, 2009, p. 5}
\end{tabular}

O acordo para adquirir equipamentos da recém-criada OSX, a "Embraer dos mares ${ }^{165 ",}$ com a Hyundai "o melhor fabricante de equipamentos offshore do mundo", viabilizaria a conformidade com o requisito de conteúdo local e "ultrapassar o gargalo nos estaleiros brasileiros" 166 :

162 Segundo SEQUEIRA [2010a, p. 19], a transação com Peregrino seria um "comparable" mais próximo para a OGX do que Polvo (albiano carbonato, mas com apenas 45 mboe recuperáveis), porém Peregrino estava em um estágio de desenvolvimento mais avançado (desenvolvimento começaria em meados de 2010), além de não ser um reservatório albiano. A Sinochem comprou $40 \%$ de Peregrino (1 bboe de óleo pesado de 14o. API, segundo a Wood Mackenzie) da Statoil por US\$ 3,1 bilhões e marcou a entrada da chinesa no Brasil. Localizado entre os blocos BM-C-7 e BM-C-47, nas águas rasas do sudoeste de Campos.

${ }^{163}$ Segundo SEQUEIRA [2010a, p. 19], Polvo havia sido descoberto em 2014 nas águas rasas de Campos. O primeiro óleo foi extraído em 2007, mas a produção desapontou. A venda de Polvo para BP também incluiu seus ativos nas águas profundas do Golfo do México e no Azerbaijão (ao todo, foi uma transação de US\$ 7 bilhões). Portanto, é difícil comparar o múltiplo desta transação com a OGX.

${ }^{164}$ DARIPA [2010a]. Apesar de reconhecer o potencial de mais 3,5 bboe de Vesúvio e Pipeline, DARIPA elevou seu preço alvo de $R \$ 16$ para $R \$ 22$, uma média ponderada de $70 \%$ seu cenário base $(R \$ 18)$ e $30 \%$ seu cenário otimista $(R \$ 31)$.

165 GASPAR, 2014, p. 246; BATISTA, 2011, p. 127-129. A OSX foi concebida para atuar de maneira integrada em três segmentos: construção naval; afretamento de unidades de exploração e produção; e serviços de operação e manutenção.

${ }^{166}$ DARIPA, 2010b, p. 1. 
Os equipamentos fornecidos pela OSX contribuirão para que seja atendido, a preços competitivos, o compromisso de conteúdo local assumido pela OGX nos contratos de concessão celebrados com a ANP. Estes equipamentos serão contratados pelo sistema de afretamento (leasing), o que minimizará a necessidade de capital da OGX em curto e médio prazos, otimizando assim o caixa da companhia neste período. A OGX estima que serão necessários 48 equipamentos de produção até 2019, notadamente 19 FPSOs, 5 TLWP e 24 WHP [OGX, DFP 2009, p. 5].

De fato, o FFSO OSX1 seria alugado por 20 anos por US\$2 $263 \mathrm{mil} / \mathrm{dia}$, "aproximadamente dentro do intervalo previsto pela $\mathrm{D} \& M^{\prime 167}$. Mas para dimensionar o que 48 equipamentos significavam, entre 2012 a 2020, a PETR compraria 43 plataformas submersíveis e FPSO, e 6 jackets e TLWP168.

Os Analistas pareciam estar cientes do risco de potencial conflito de interesse entre OSX e OGX, mas entendiam que pelo menos no curto e médio prazo, a associação reduziria a necessidade de capital da OGX169.

Alguns Analistas ${ }^{170}$ insistiam que o mercado ainda avaliava a OGX como uma empresa de exploração, com um múltiplo de US\$ 7,3/boe (incluindo 3,5 bboe de descobertas anunciadas), 56\% abaixo da média de seus peers na Grã-Bretanha (US\$ 15,0/boe).

O $\mathrm{CS}^{171}$ estimava o maior PA (R\$25,0) entre os Analistas da Amostra Própria: além de considerar Pipeline (1,0 a 2,0 bboe), Waimea (158 mboe) incluíram também 894 mboe no ES e US\$1,0/boe referentes ao GN de Parnaíba. Relataram ainda que a Empresa pretendia terminar a perfuração em Abacate (BM-S-29) até o final de janeiro, onde estes Analistas estimavam que o RPL da OGX poderia chegar a 0,714 bboe (já considerando o $65 \%$ da OGX), enquanto que o relatório da 2ㅇ D\&M estimava em 198 mboe (prospecto S-06).

01/02. Em menos de um mês após sua descoberta (11/01), a OGX estimou que o reservatório de Kilawea poderia conter entre 0,1 e 0,2 bboe.

Repercussões. No dia do anúncio das estimativas para Kilawea, a OGXP3 se apreciou $3,0 \%$ no pregão. Poucos dias depois (3/2), a OGX finalmente divulgou sua estimativa para Waimea: 0,5 a 0,9 bboe, contra os 0,15 previstos no 2 ㅇ D\&M. A OGXP3 se apreciou $6,2 \%$ no pregão. $E$ as perspectivas podiam melhorar ainda mais: testes preliminares indicavam óleo leve (API de $19-20^{\circ}$.). Acreditava-se também que, devido à sua proximidade, haveria uma conexão geológica entre Waimea e Pipeline, o que poderia gerar sinergias na produção. Juntas Waimea e Pipeline poderiam ter volumes entre 1,5 e 2,9 bboe:

Outro número interessante para se prestar atenção é que somando todos os anúncios relacionados ao sudeste de Campos, nós teríamos um volume estimado de 2,1 a 4,6 bboe, contra a estimativa da D\&M de

\footnotetext{
167 KOVARSKY, MENDES \& ARAUJO [2010a].

168 SEQUEIRA \& FONSECA, 2010a, p. 33; SEQUEIRA \& FONSECA, 2012a, p. 14.

${ }^{169}$ Segundo SEQUEIRA [2010a] estes equipamentos estavam avaliados em US\$ 30 bilhões.

170 DARIPA, 2010b, p. 1.

${ }^{171}$ LEITE \& CANHEU [2010a].
} 
3 bboe para esta região. E ainda há muitos poços a perfurar! [KOVARSKY, MENDES \& ARAUJO, 2010c, p. 2].

2/03. OGX anunciou que completou a perfuração de Abacate, sem estimativa de volume.

\section{Repercussões.}

OGX não forneceu estimativas de volume, porém a empresa, junto com a Maersk, irá registrar na ANP um plano de avaliação para dimensionar a descoberta. A Maersk, como operadora, aparentemente impediu que a OGX provesse qualquer divulgação sobre o volume.

Nós acreditamos que essa notícia é neutra para a OGX. O registro significa que as duas empresas permanecem interessadas no bloco, portanto há uma probabilidade de haver algo lá. Entretanto, o fato de não haver nenhuma menção sobre hidrocarbonetos abaixo das camadas de pré-sal diminui qualquer expectativa de potencial ganho em descobertas no pré-sal deste bloco. Após tantos atrasos e problemas técnicos na perfuração deste poço, os investidores já consideram um poço seco como fato [KOVARSKY, MENDES \& ARAUJO, 2010d, p. 1].

No pregão (2/3), a OGXP3 perdeu $1,65 \%$ (de $\mathrm{R} \$ 16,32$ para $\mathrm{R} \$ 16,05$ ). Em termos quantitativos, o IBBA considerou o impacto do BM-S-29 como pequeno: $R \$$ 0,6/ação em um PA de R\$ 24,20. Embora ainda não anunciado oficialmente, o BM-S-29 seria o primeiro poço seco da OGX ${ }^{172}$.

5 e 12/03. Descoberta de hidrocarbonetos em Etna (BM-C-41, com coluna com 70 metros e net pay de 28 metros).

Repercussões. A OGXP3 se apreciou 5,8\% no pregão de 5/3. Talvez mais importante do que a descoberta em si, poderia ser a conexão geológica entre Etna, Waimea e Pipeline, que formaria um triângulo, com possíveis sinergias na produção (maior taxa de recuperação) e no compartilhamento de infraestrutura ${ }^{173}$. O Executivo responsável de exploração estava "muito entusiasmado" com Etna e ainda "estava apaixonado" pelo BM-S-29, embora não pudesse dar nenhuma nova notícia ${ }^{174}$. Em 12/3, a terceira nova descoberta no Etna indicava que o triângulo Etna-Waimea-Pipeline poderia prover de um único reservatório, cujas fronteiras poderiam ser mais extensas.

24/03. Descoberta de hidrocarbonetos em Fuji (BM-C-41) com características semelhantes ao triângulo Etna-Waimea-Pipeline.

Repercussões. A descoberta de Fuji foi mais uma indicação do "enorme potencial no sudeste de Campos" ${ }^{175}$. Agora, trava-se de um quadrilátero, Etna, Waimea, Pipeline e Fuji.

\footnotetext{
172 KOVARSKY, MENDES \& ARAUJO [2010d].

173 KOVARSKY, MENDES \& ARAUJO [2010e].

${ }^{174}$ KOVARSKY, MENDES \& ARAUJO [2010f].

175 KOVARSKY, MENDES \& ARAUJO [2010g].
} 
Aparentemente, até março não havia nenhum plano para acelerar a exploração no ES. A campanha se concentrava no BM-C-41 e BM-C-42, onde cinco poços estavam sendo perfurados (Etna [OGX-6], Waimea, Pipeline [OGX-2], Fuji [OGX-8] e Hawaii [OGX-10]). Em abril, a OGX retomou a exploração em Santos com Natal (BM-S-59, OGX11D) e Niterói (BM-S-57, OGX12).

Apesar das boas notícias de março, o valor da OGXP3 estava "estacionado" no intervalo $\mathrm{R} \$ 16,0$ a $\mathrm{R} \$ 17,0$. Uma possível interpretação seria que o "mercado", à medida que a OGX rumava para a fase de produção, temia-se o risco de execução no agressivo seu plano de negócios: haveria plataformas suficientes, que preenchessem as regras de conteúdo local? ${ }^{176}$

5 e 8/04. Descobertas nos poços de Huna (OGX-7A) e Hawaii (OGX-10), ambos no BM-C42.

12/04. Descoberta de hidrocarbonetos em poço horizontal reforçou a expectativa que o volume estimado para Vesúvio poderia estar mais próximo de 1,5 bboe.

14 e 15/04. Em entrevista à XPTV, o AC afirmou a descoberta de uma nova província petrolífera, em águas rasas, ao Sul de Campos, com o equivalente a US\$1,0 trilhão em "reservas", onde produção começaria em 1T2011. Anunciou que negociava a venda de 20\% das ações da OGX para fazer uma "megamonetização".

Repercussões. Quando a entrevista foi divulgada (15/04), o volume de negociações triplicaria de $\mathrm{R} \$ 244$ milhões para $\mathrm{R} \$ \mathbf{7 3 4}$ milhões por dia ${ }^{177}$, mas no pregão a OGXP3 se apreciou apenas 1,8\%. Dentro da Empresa, começou um esforço para tentar justificar a existência dos 10 bboe "a gente começou a contabilizar todo e qualquer traço que aparecesse nas sísmicas. Até espirro valia"178. O 3으 DM que descreveria a atualização para 10,8 bboe só seria divulgado em 15 de abril de 2011, um ano após a entrevista à XPTV.

A referida entrevista do $A C$ e os 10,0 bboe da OGX não foram mencionados nos relatórios em abril dos Analistas da Amostra Própria. Foi somente em maio que o tema surgiu como a possibilidade de farm-out de $20 \%$ dos blocos de Campos que confirmariam, ou não, a qualidade do portfólio da OGX, além da capitalização adicional.

13/05. OGX confirmou que Pipeline-Etna correspondiam a um mesmo reservatório que poderia conter de 1,4 a 2,6 bboe, e que Waimea-Fuji correspondiam a outro reservatório com 0,6 a 1,1 bboe.

Repercussões. Com o resultado de Pipeline-Etna e Waimea-Fuji, o RPL da OGX aumentaria em 0,587 bboe para um total de 8,5 bboe. Poucos dias depois (17/5), em teleconferência, os Executivos afirmaram que a campanha exploratória em Campos focaria em "dois elefantes, Vesúvio e Waimea, com o objetivo de prepara-los para

\footnotetext{
176 KOVARSKY, MENDES \& ARAUJO [2010h].

177 GASPAR, 2014, p. 246-249.

178 GASPAR, 2014, p. 255.
} 
começar a produzir no ano que vem, e também para assegurar uma quantidade decente de provas para quando o 3ㅇ D\&M vier em novembro"179.

Os Executivos também relataram a intenção de farm-out $20 \%{ }^{180}$ de blocos em Campos, revelada pelo $A C$ no mês anterior. Ou seja, em uma só teleconferência, os Executivos divulgaram três informações importantes: a produção estaria próxima (20 kboepd em

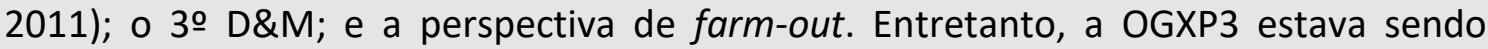
transacionada a $R \$ 15,00$. Uma possível explicação para a apática estabilidade da OGXP3 era que os investidores buscavam liquidez para participar da oferta subsequente da PETR, que seria concluída em setembro de 2010.

Ainda em 17/5, a OGX anunciou que as perfurações em BM-C-37 e BM-C-38, em parceria com a MAERSK, começariam em agosto/setembro. A OGX também confirmou sua intenção de participar em leilão na Colômbia, onde os Executivos também tinham expertise. Vale destacar que as perfurações nos blocos, BM-C-39 e o BM-S-58, onde a OGX pagou o maior BA $/ \mathrm{km}$ e o maior BA total, respectivamente, na 9a Rodada ainda nem sequer haviam começado. Ou seja, a OGX estava ampliando seu portfólio internacionalmente, sem ter concluído a campanha exploratória em blocos que, na 9a Rodada, foram tidos como os mais valiosos.

23/06. OGX adquiriu 5 blocos terrestres na Colômbia $\left(12.580 \mathrm{~km}^{2}\right)$, por US\$ 125 milhões (R\$ 223,9 milhões), a serem explorados entre 2011 e 2013.

Repercussões. Apesar do valor relativamente baixo pagos no equivalente ao $B A$ (R\$ 17,8 $\mathrm{mil} / \mathrm{m}^{2}$ contra $\mathrm{R} \$ 243,7 \mathrm{mil} / \mathrm{km}^{2}$ da 9 a Rodada) as áreas a serem exploradas na Colômbia eram maiores do que as áreas arrematadas pela OGX na 9a Rodada $\left(6.883 \mathrm{~m}^{2}\right)$. O baixo custo da concessão colombiana indicava a compra de uma opção de crescimento a um baixo custo. Mas para uma empresa com portfólio tão amplo no Brasil, que exigiria elevados investimentos, a exploração na Colômbia poderia indicar um desvio de foco operacional, ou ainda, uma tentativa de desviar a atenção dos investidores para a falta de notícias e possível fracasso do BM-S-29.

Alguns Analistas ${ }^{181}$ consideraram o investimento na Colômbia interessante pela formação geológica parecida com a Baia Maracaibo na Venezuela, o ambiente regulatório favorável e o impacto limitado no programa de investimentos da OGX. Entretanto, apesar destes atributos, estes Analistas não precificaram estes ativos em seu PA. Compararam a atuação da OGX no leilão colombiano com sua atuação na 9a Rodada:

A atuação [no leilão] na Colômbia se assemelha à atuação agressiva da OGX na ga Rodada. Enquanto a competição entre os ofertantes se concentrou na área de Lianos, a qual chegou a receber até 19 ofertas por um único bloco, OGX surpreendeu o mercado novamente ao ofertar sozinho pela bacia de Cesar Rancheria, arrematando $9.591 \mathrm{~km}^{2}$ de área inexplorada próxima a Baia Maracaibo, uma das bacias petrolíferas

\footnotetext{
179 KOVARSKY, MENDES \& ARAUJO [2010i].

180 Segundo explicam KOVARSKY, MENDES \& ARAUJO [2010o], a venda de até 30\% de participação nos blocos evitaria trocar o contrato de concessão com a ANP e a necessidade de novas licenças ambientais.

${ }^{181}$ KOVARSKY, MENDES \& ARAUJO [2010j].
} 
mais proliferas no mundo, localizada na Venezuela, o vizinho rico em óleo da Colômbia. Desde sua descoberta em 1914, Maracaibo já produziu mais de 30 bboe de óleo e tem reservas estimadas em 1,4 bboe [KOVARSKY, MENDES \& ARAUJO, 2010l, p. 1].

E ainda ironizaram o desprezo do mercado em relação aos investimentos na Colômbia:

A questão que sempre ouvimos sobre a OGX é: o que a OGX viu que ninguém mais viu? Como não havia concorrência nos blocos que a empresa arrematou? Como que ninguém notou o potencial das águas rasas na bacia de Campos no Brasil? [KOVARSKY, MENDES \& ARAUJO, 2010l, p. 3].

28/06 e 15/07. Descoberta de hidrocarbonetos em Pero. Os resultados foram tão positivos que a Empresa tornou a exploração na área uma prioridade.

Repercussões. A notícia da descoberta de Pero (BM-C-40), no nordeste de Campos onde o 2 D\&M estimou poder haver 0,94 bboe (BM-C-39 e BM-C-40), foi recebida como positiva por alguns Analistas, mas que não ajustaram seu PAs, por acreditarem que esta área teria reservatórios menores do que aqueles descobertos no sudeste de Campos ${ }^{182}$. Na 9a Rodada, a OGX pagou pelo BM-C-39 e BM-C-40 o segundo e o terceiro maior $\mathrm{BA} / \mathrm{km}^{2}$ :

Tabela 26 - Indicadores dos Principais Blocos Arrematados no Leilão da 9a Rodada pela OGX

\begin{tabular}{|c|c|c|c|c|c|}
\hline Blocos & $\begin{array}{c}\mathrm{BA}^{183} \\
\text { (R\$ mil) } \\
\text { (A) }\end{array}$ & $\begin{array}{c}\text { PEM } \\
\text { (R\$ mil) } \\
\text { (C) }\end{array}$ & $\begin{array}{c}\text { Área } \\
\left(\mathrm{km}^{2}\right) \\
(\mathrm{B})\end{array}$ & $\begin{array}{c}\text { A/B } \\
\left(\mathrm{R} \$ \mathrm{mil} / \mathrm{km}^{2}\right)\end{array}$ & $\begin{array}{c}\mathrm{C} / \mathrm{B} \\
(\mathrm{R} \$ \\
\left.\mathrm{mil} / \mathrm{km}^{2}\right)\end{array}$ \\
\hline BM-C-39 & 237.241 & 73.584 & 109 & $2.176,5$ & 675,1 \\
\hline BM-C-40 & 126.770 & 37.782 & 124 & $1.022,3$ & 304,7 \\
\hline BM-C-41 & 237.241 & 75.402 & 236 & $1.005,3$ & 319,5 \\
\hline Total / Média Campos & 869.852 & 304.880 & 1.177 & 739,0 & 259,0 \\
\hline BM-S-58 & 344.090 & 55.512 & 176 & $1.955,1$ & 315,4 \\
\hline Total / Média Santos & 599.441 & 149.832 & 677 & 885,4 & 221,3 \\
\hline Total / Média ES & 88.800 & 106.848 & 3.620 & 24,5 & 29,5 \\
\hline Total / Média PA-MA & 9.781 & 48.204 & 960 & 10,2 & 94,8 \\
\hline
\end{tabular}

Em julho, alguns Analistas já consideravam o peso do farm-out sobre qualquer outra notícia da OGX:

Nos últimos dois a três meses, a maior parte do foco na OGX tem sido no potencial do farm-out de $20 \%$ a $30 \%$ dos blocos de Campos. Em nossa opinião, o potencial do farm-out é, de longe, o mais importante gatilho para a performance das ações no 2\$2010. Mas, neste meio tempo, a empresa fez importantes movimentos na Colômbia e

182 KOVARSKY, MENDES \& ARAUJO [2010k].

${ }^{183}$ Considerando $100 \%$ do bloco. 
encontrou mais dados encorajadores em Santos, [em Natal, no BM-S59] pelos quais nós tememos que o mercado não prestou muita atenção [KOVARSKY, MENDES \& ARAUJO, 2010l, p. 1].

(...) O Acionista controlador da empresa gerou publicidade sobre a potencial venda de parte dos ativos upstream da bacia [KOVARSKY, MENDES \& ARAUJO, 2010l, p. 2].

Segundo relatos não oficiais, as negociações do farm-out prosseguiam com cinco empresas interessadas: duas estatais chinesas, CNOOC e Sinopec (receberam dados em junho de 2010), a francesa Total, a italiana Eni, a norueguesa Statoil ${ }^{184}$.

16/07. Anúncio do primeiro poço seco em uma campanha com $100 \%$ de taxa de sucesso até então: o Niterói (BM-S-57). Com baixo potencial de GN, o evento não foi considerado relevante.

Repercussões. Como a D\&M havia estimado um baixo potencial de GN ao bloco, o evento em si não foi considerado relevante pelos Analistas. Era o primeiro poço seco, reconhecido formalmente, em uma campanha com $100 \%$ de taxa de sucesso até então. Alguns dias depois (20 e 22) a Empresa anunciou descobertas em um novo poço (Santa Helena, BM-C-41) há pouco quilômetros de Etna, o que seria interpretado como mais uma evidência do potencial do complexo Etna-Pipeline.

12/08. Em teleconferência, os Executivos reiteraram os planos de iniciar a produção em 1S2011. O AC informou que aguardava propostas para o farm-out para 18/10.

Repercussões. Poucas semanas antes da teleconferência (2/8), OGX teria constituído uma subsidiária integral, a OGX Campos, para segregar os ativos que seriam objetos do farm-out. O valor patrimonial contábil da OGX Campos era de $\mathrm{R} \$ 12,8$ milhões em $31 / 12 / 2010$ e posteriormente foi aumentado para $\mathrm{R} \$ 1$ 1,55 bilhão em 31/03/2011. Alguns Analistas acreditavam que se o farm-out fosse confirmado, a OGXP3 poderia chegar a $\mathrm{R} \$ 31,00^{185}$.

A perspectiva do farm-out e o potencial de-risking do 30 D\&M, esperado para o 1T11, atraiu novos Analistas para a OGX, como foi o caso do Deutsche Bank ("DB"), com um PA de $R \$ 28,00$ (16/8), endossando as virtudes propagadas no IPO e os sucessos na campanha de 2009, mas requer que o investidor tenha um "coração forte", uma vez que ainda se trata de uma "e-company"186. O DB inclusive citou um relatório do Wood Mackenzie que considerou duas descobertas da OGX entre as 10 melhores do mundo em 2009. Novamente, a estratégia de monetização das reservas da OGX era comparada com aquela executada com sucesso pelo $\mathrm{AC}$ na MMX, mas o DB ponderava que, devido

${ }^{184}$ A China National Offshore Oil Company (CNOOC) é sócia da PETR no campo de Libra, no pré-sal da Bacia de Santos. Em 2017, a CNOOC estudava investir em E\&P de óleo tanto no mar quanto na terra, em associação com a PETR e outras empresas internacionais atuantes no Brasil [RAMALHO, A.; POLITO, R. "Sócia em Libra, chinesa planeja investir mais", Jornal Valor Econômico, 8/8/2017, p. B1].

185 DARIPA [2010c].

186 SEQUEIRA, 2010a, usou um WACC de 12\%, US\$ 80/barril para o Brent e US\$ 6,00/mbtu, RPL de 8,256 bboe (considera POS de 42,8\%). Considerou que Parnaíba acresceria em R\$ 2,0/ação. 
à grande heterogeneidade dos múltiplos de M\&A disponíveis, era muito difícil estimar quanto valeria uma participação minoritária no portfólio da OGX em Campos ${ }^{187}$.

O DB ponderou que $E$-Companies frequentemente enfrentam atrasos e sobrecustos, que também acometem empresas maduras, como a PETR. E-Companies estavam sempre limitadas pela indisponibilidade de equipamentos e mão de obra qualificada. Além disso, o Governo brasileiro sinalizava regulação mais restrita ao capital privado. Por outro lado, o potencial do Brasil era enorme: apenas $4 \%$ das 29 bacias sedimentares, com potencial para hidrocarbonetos, haviam sido ofertados ao mercado.

Segundo o DB, o desempenho da OGXP3 poderia estar sendo limitado (overhang) pela oferta da PETR e por IPOs (ex. a subsidiária da Repsol-YPF no Brasil ${ }^{188}$, HRT ${ }^{189}$ ). Outras empresas também estavam buscando farm-outs no Brasil (ex. Karoon Gas Australian estava vendendo $30 \%$ de seus blocos em Santos ${ }^{190}$ ). Ao descrever a bem-sucedida campanha exploratória, o DB não mencionou as dificuldades com o BM-S-29.

16/08 a 24/11. Empresa identificou grande potencial petrolífero de Parnaíba [OGX-16 e OGX-22]: 20 novos prospectos com 15 Tcf de GN e uma capacidade produtiva de 18,4 Mcf por dia.

Repercussões. Para alguns Analistas, Parnaíba poderia ser "uma joia escondida" 191.

22/09. Em conferência em Nova lorque, Executivos e o AC foram questionados sobre a capacidade da OSX em servir a OGX e o farm-out.

Repercussões. Na conferência, alguns Analistas questionavam o AC na capacidade da OSX em servir a OGX, pois o licenciamento ambiental estava atrasando a construção do estaleiro em Santa Catarina ${ }^{192}$. Mas a OGX explicou que a licença deveria sair em novembro e a primeira plataforma (FPSO OSX 1 para Waimea) já estava comissionada. Posteriormente, a OSX resolveu construir seu estaleiro no Porto de Açu, pertencente à LLX.

O AC aproveitou a ocasião para reiterar sua expectativa que as ofertas para farm-out deveriam chegar em meados de outubro.

Ao longo das últimas várias semanas, tem havido muitas notícias sobre o farm-out de uma participação minoritária no portfólio da bacia de Campos: de acordo com a Bloomberg, a transação estaria avaliada em

${ }^{187}$ SEQUEIRA, 2010a, p. 18.

188 Segundo SEQUEIRA [2010a, p. 24], a Repsol-YPF é a IOC com mais extenso portfólio de exploração no Brasil e um longo histórico de associação com a Petrobras, com 1,2 bboe de recursos contingentes (BM-S-67, BM-S-9 e BM-S-48), e 0,6 bboe em recursos prospectivos.

189 Segundo SEQUEIRA [2010a, p. 25], a HRT detinha 0,505 bboe de recursos contingentes e 1,5 bboe em recursos prospectivos no Brasil (bacia do Solimões) e Namíbia.

190 BM-S-61, BM-S-62, BM-S-68, BM-S-69 e BM-S-70.

191 DARIPA, 2010c, p. 1. SEQUEIRA [2010a] estimou que Parnaíba acresceria em US\$ 2,0/boe (Preço Alvo de R\$ 28,00) enquanto KOVARSKY, MENDES \& ARAUJO [2010m] estimaram em US\$1,85/boe, mas não incluíram em sua estimativa de Preço Alvo ( $R \$ 27,90)$. Circulava na imprensa comentários que Parnaíba poderia conter "meia Bolívia” (15 Tcf).

192 SEQUEIRA [2010b]. 
US\$ 7 bilhões por 20-30\% dos ativos, enquanto que o Dow Jones, a transação estaria avaliada em US\$ 12-14 bilhões por 30\% dos ativos. Em ambos relatos, chineses, europeus e norte-americanos estariam entre os interessados.

Então, a questão é: o que podemos inferir sobre estes relatos da imprensa? Não muito. Dependendo das premissas de volume na bacia de Campos, que podem estar em qualquer lugar entre 3,693 bboe (recursos riscados, de acordo com o relatório da D\&M) a 8,337 boe (recursos "unrisked", também de acordo com o relatório da D\&M), o valor por boe varia entre US\$ 2,8 a 17,6 para um valor de transação entre US\$ 7-14 bilhões, de acordo com a imprensa. (...)

Importante, OGX espera que o preço pago pelo farm-out seja superior ao investimento necessário para desenvolver e operar os campos [US\$ 15,0/boe], o que se traduziria em um influxo real de caixa na empresa.

Os valores de transações recentes de E\&P variam significativamente, devido às particularidades dos ativos envolvidos. Nós somos questionados constantemente sobre o significado destes valores para a OGX. Em nossa opinião, é muito difícil encontrar um similar ['comparable'] real para a OGX [SEQUEIRA, 2010b, p. 3].

Outros Analistas estimavam que o possível farm-out, além de favorecer o de-risking do restante do portfólio, reduzir a pressão de caixa, poderia também possibilitar a distribuição de dividendos que poderiam chegar a $\mathrm{R} \$ 2,93$ por ação ${ }^{193}$.

27/09. Descoberta de óleo leve (27으 API) em Inga, ao Nordeste de Campos (BM-C-40), dentro da área objeto do farm-out.

Repercussões. A nova descoberta fez com que alguns Analistas aumentassem seus PAs em mais de $10 \%{ }^{194}$. O teste em Inga indicou também bom fluxo de óleo (8-12 kbpd, podendo chegar a $25-35 \mathrm{kbpd}$ ) o que, se confirmado, implicaria em menores custos de desenvolvimento. Essa descoberta endossaria outra recente feita em Pero, onde também se encontrou óleo leve (26-28요 API). As descobertas de óleo leve em Inga e Pero contrastavam com o óleo encontrado em Peregrino pela Statoil, um parâmetro frequentemente citado para o farm-out da OGX.

30/09. Descoberta de óleo leve em Aracaju nas águas rasas de Santos.

Repercussões. Essa descoberta tinha um significado especial, pois indicava a possível presença de óleo leve nas águas rasas de Santos, onde o "mercado" não estava dando muita importância ${ }^{195}$, inclusive porque fora em Santos que a Empresa, recentemente, havia reconhecido um poço seco (o poço de Niterói, no BM-S-57). No início de outubro

193 KOVARSKY, MENDES \& ARAUJO [2010o], assumindo uma venda de 20\% por 5,5 bboe geraria US\$ 11 bilhões bruto (US\$ 10/boe), ou US\$ 9,4 liquido de impostos, dos quais a OGX reteria US\$ 4 bilhões para investimentos e distribuísse o restante em dividendos. Posteriormente, AUDI [2010a], também endossou a expectativa que o farm-out poderia viabilizar a distribuição de dividendos.

194 KOVARSKY, MENDES \& ARAUJO [2010n].

195 KOVARSKY, MENDES \& ARAUJO [2010o]. 
(8), outra descoberta em Santos (Belém, no BM-S-56) que poderia ser interpretado como um follow-up à Niterói (seco), que agora teria sido perfurado na direção correta. Aracaju se localizava no BM-S-58, o bloco com o BA mais alto da 9a Rodada.

1/10. Sinopec comprou 40\% dos negócios da Repsol na América Latina por US\$ 7,1 bilhões.

Repercussões. A aquisição, via aporte de capital, equivalente a um múltiplo de US\$ 5,4 a 6,0/boe. Os Analistas analisaram os efeitos que esta transação poderia trazer para a OGX. Primeiro, uma leitura negativa: um interessado a menos no farm-out da OGX. Segundo, a leitura positiva: (1) com o referido aporte, a Repsol não precisaria fazer o IPO no Brasil, o que removeria o overhang na OGXP3; (2) confirmava o interesse de IOCs no Brasil; (3) um possível argumento para defender o múltiplo de US\$ 5,4/boe (baseado no meio do intervalo do 2ㅇM). Entretanto, o argumento do múltiplo de M\&A era frágil, uma vez que a exposição da Repsol ao pré-sal era elevada ${ }^{196}$.

Outros Analistas ${ }^{197}$ foram mais otimistas: (1) apesar da Repsol possuir $90 \%$ de suas reservas no pré-sal, a transação representou um múltiplo de US\$6,8/boe, enquanto que a OGXP3 estava sendo transacionada por US\$ 4,5/boe (no mesmo critério de avaliação de recursos); (2) as empresas chinesas continuariam a demonstrar interesse em outras oportunidades de E\&P no Brasil, uma vez que os $40 \%$ de participação na Repsol Brasil representava "apenas" 0,60 bboe, ou seja, os chineses estariam apenas começando. Entre os pregões de 29/9 e 5/10, a OGXP3 se apreciou em 5,0\%.

Os Analistas também mencionavam a transação recente de outra chinesa, em maio, como possível indicador para o farm-out. A Sinochem comprou $40 \%$ do campo de Peregrino, em Campos, da norueguesa Statoil, pelo equivalente a US\$15,0/boe de uma reserva de 0,6 bboe de óleo pesado (14-16 API), porém já na fase de desenvolvimento e com start-up esperado para o começo de 2011. Entretanto, alguns Analistas também recomendavam cautela com o uso deste múltiplo, pois os 0,6 bboe de Peregrino eram classificados como reservas prováveis $2 \mathrm{P}$, bem diferentes dos recursos prospectivos da OGX (Recursos Prospectivos $2 \mathrm{C}$ ). Para ajustar o múltiplo EV/2P para o EV/2C era recomendável usar a média de desconto de $35 \%$ praticada na indústria de $E \& P$, o que geraria um múltiplo de US\$10,0/boe ${ }^{198}$.

Em 26/10, outro grande banco, o Santander ("SAN"), iniciou a cobertura da OGXP3 com PA de R\$33,00199. Em seu relatório de inicio de cobertura, o SAN chamou a OGX de "a empresa upstream mais completa do Brasil: rica em catalisadores e pronta para iniciar um novo capítulo", "um gigante recém-nascido", reiterando o tripé de valor defendido no IPO (portfólio, Executivos e AC) mais o possível farm-out.

Para o SAN, a magnitude do portfólio da OGX, que poderia ter 9,9 bboe, era próxima a gigantes como a Chevron (10,3 bboe) e Conoco Phillips (11,3 bboe), porém em águas

\footnotetext{
${ }^{196}$ SEQUEIRA [2010c].

197 DARIPA [2010d].

${ }^{198}$ AUDI \& FALANGA NETO, 2010a, p. 6.

${ }^{199}$ AUDI \& FALANGA NETO [2010a]. Usou um WACC de 10\% (real), US\$ 85/barril para o Brent, US\$ 4,0/bcf para o GN.
} 
rasas. A relação com a OSX, cuja licença ambiental agora era esperada para dezembro, foi considerada como essencial para assegurar a viabilidade do ambicioso plano de produção da OGX. Naquele momento, o SAN identificou alguns catalisadores, além do farm-out: (1) first-oil em $1 \mathrm{~S} 11$ em Waimea, pois até então, o valor da OGX era "conceitual"; (2) os riscos de execução na fase de produção que eram mais elevados do que os riscos da fase de exploração; (3) devido a (1) e (2), a OGXP3 pode estar sobrevalorizada; (4) capital e/ou financiamentos adicionais, pois o caixa que a OGX precisava para sustentar sua agressiva campanha de exploração e produção era maior do que sua disponibilidade. A captação de recursos no mercado de capitais poderia ser comprometida se o farm-out não se concretizasse.

O SAN foi o primeiro Analista da Amostra Própria a questionar se a OGXP3 estaria sobrevalorizada. Poucos dias depois (11/11), os Analistas do BTG também abordariam a possível sobrevalorização da OGXP3200.

4/11. Esperada para outubro, os Executivos, agora, estimavam que o farm-out seria concluído no $1 \mathrm{~T} 2011$.

Repercussões. Em uma entrevista ao jornal OESP, o AC revelou que esperava um múltiplo acima de US\$ 8,5/boe no farm-out ${ }^{201}$. O fato que, nos últimos 12 meses, as transações Repsol-Sinopec e Statoil-Sinochem no Brasil sustentavam as expectativas sobre o sucesso do farm-out da OGX.

11/11 a 21/12. Após um 3 T2010 com 8 descobertas, não havia notícias sobre estimativas para Waimea, cujo início de produção (20 kbpd) foi adiado do 1T para o 2T2011.

Repercussões. De fato, em 11/11, após 8 descobertas anunciadas no ano, alguns Analistas começaram a demonstrar desconforto com a falta de notícias sobre estimativas de volumes da campanha em andamento, especialmente em Waimea. 0 início de produção de Waimea era esperado para meados de 2011 e não mais para o início do ano, entretanto todos os equipamentos necessários já estavam contratados. Depois de uma forte valorização, em 4/11, a OGXP3 chegou a valer $\mathrm{R} \$ 23,20$, pouco abaixo do pico registrado desde o IPO (R\$ 23,27 em 15/10/10). Desde então e até 21/12, a OGXP3 se desvalorizaria continuamente até alcançar $\mathrm{R} \$ 18,63$. Uma queda de $19,7 \%$ em 33 dias úteis.

Alguns Analistas consideraram os movimentos da OGXP3 como "injustificados", "ruídos" gerados pelas expectativas do farm-out, mas que os fundamentos da OGX eram sólidos e haveria um investidor chinês, "particularmente, faminto" pelo farm-out. Portanto, os investidores "não deveriam prestar atenção ao ruído..."202. Outro Analista, entretanto, ironizou: "falta de notícia é má notícia?"203

Permanecemos positivos, mas nós amaríamos ter mais apoio na avaliação (...). Daqui para frente, nós acreditamos que um maior

\footnotetext{
200 GATTASS, FONSECA \& VALENTE, 2010a, p. 2

201 Relatado em DARIPA, 2010e, p. 4.

202 AUDI \& FALANGA NETO, 2010b, p. 1.

${ }^{203}$ SEQUEIRA [2010d].
} 
volume de revelações [disclosure] é necessário para apoiar a forte apreciação [rally]. Isso ou o farm out [GATTASS, FONSECA \& VALENTE, 2010a, p. 1].

(...) Entretanto, com a ação tendo se valorizado significativamente, $e$ o valor por barril descoberto ter ultrapassado o intervalo 6-8/boe, dentro do qual nos sentimos confortáveis, as ações da OGX parecem já estar precificando mais do que já se tornou público. [grifo nosso]

O que nos deixa com a questão... Qual será o vetor [driver] marginal? Um deslocamento para cima do valor de consenso por barril descoberto? Ou um aumento no número de barris encontrados? Talvez, ambos.

No presente, nós acreditamos que os investidores estão assumindo que a OGX já encontrou mais [barris]. Nós tendemos acreditar que isso seja verdade. A OGX tem, de fato, 6 poços que ainda não tiveram seus volumes revelados.

Mas no fundo, nós nos sentiríamos simplesmente mais confortáveis se estes volumes estivem sido relevados ao mercado. O histórico da OGX com os investidores é relativamente curto, e nós preferiríamos um ganho sólido no consenso de valor que reduzir o nível de confiança nos múltiplos. [GATTASS, FONSECA \& VALENTE, 2010a, p. 2].

Outro Analista demonstrou preocupação com o comportamento do mercado que parecia esperar apenas pelo farm-out e desconsiderar outras conquistas na campanha exploratória:

(...) Embora a transação seja provavelmente um desenvolvimento positivo para a empresa, o farm-out não é o pilar da estória da OGX. Nós estamos preocupados que a performance da ação se torne função das notícias sobre o farm-out, em parte por causa do marketing intensivo dos executivos [da empresa] sobre este tema. O mercado está ignorando um programa exploratório bem-sucedido até agora e o fato de não haver outros catalisadores para a ação no curto/médio prazo, e está focando apenas no processo de farm-out. [SEQUEIRA, 2010d, p. 1].

12/11. Após atrasos e problemas técnicos que levaram os investidores a especularem que se tratava de um poço seco, a OGX comprou o restante da participação da MAERSK (35\%) no BM-S-29, um dos primeiros blocos perfurados na campanha da OGX.

Repercussões. O valor pago não foi revelado, mas provavelmente foi pelo valor do investimento restante necessário (capex carry agreement). O farm-in teria sido motivado por divergências entre a OGX e a MAERSK quanto ao potencial do bloco, o que estaria impedindo que a Empresa "se tornasse mais ativa nos planos de perfuração" 204 . O 2 o D\&M estimava que o BM-S-29 poderia ter 0,305 bboe.

204 KOVARSKY, MENDES \& ARAUJO [2010q]. 
Alguns Analistas questionaram a aquisição: "uma boa decisão estratégica ou jogo? ${ }^{205 "}$ Afinal, por que a MAERSK venderia, de graça, sua participação em um bloco promissor? Posteriormente (21/12), a OGX concluiu a perfuração de Itagi em Santos (BM-S-56) e o declarou uma descoberta não comercial. A notícia foi interpretada como negativa para o BM-S-29 e considerando que Niterói foi declarado seco, trazia mais dúvidas sobre o potencial de Santos. Até então, a OGX havia perfurado cinco poços na bacia, com três descobertas (Natal, Belém e Aracaju).

8/12. Descoberta de hidrocarbonetos em Waikiki (BM-C-39) reforçou o potencial do Nordeste de Campos (com estimativas anteriores de 2,6 a 5,5 bboe), que poderia ser tão prolífero quanto o Sudeste. Até aquele momento, a OGX havia perfurado 18 poços em Campos, "todos com identificação de hidrocarbonetos, confirmando a taxa de sucesso de 100\% nesta bacia". Apesar destes indicadores, a OGXP3 encerrou o ano com valorização de "apenas" 13,2\% (R\$ 20,00) em um ano de muita volatilidade.

Repercussões. O bloco BM-C-39 foi o maior valor de BA $/ \mathrm{km}^{2}$ da 9a Rodada. Pela primeira vez, Analistas mencionam a possibilidade deste anúncio ser considerado uma notícia ruim, pois a Empresa estaria sendo criticada por "excesso de otimismo". Vale notar que, apesar desta menção, estes Analistas discordaram desta interpretação negativa e consideraram o anúncio positivo ${ }^{206}$. De fato, ao longo de 2010 foram 36 FRs publicados, quase todos sobre novas descobertas de hidrocarbonetos.

22/12. Congresso aprovou a Lei de Partilha da Produção, o que poderia vir a ser positivo para a OGX pois a ANP retomaria os leilões.

Fim do ano. O ano de 2010 terminou sem notícias sobre o farm out da OGX.

Repercussões. Apesar da falta de notícias, duas outras transações mantiveram os Analistas otimistas: a compra dos ativos da Occidental Pretroleum ("OXY") na Argentina pela chinesa Sinopec (US\$ 2,45 bilhões, representando U\$ 6,2/boe de EV/2P em 13/12); a compra dos blocos da sul coreana SK Energy em Campos pela MAERSK (US\$ 2,4 bilhões, representando $U \$ 14,9 /$ boe de reservas em 23/12).

O possível múltiplo de US\$10,0/boe do farm-out, endossado pela análise de transações similares e usado na famosa entrevista do $A C$ em 14/4, era um parâmetro alvissareiro considerando que a OGXP3 começou o ano valendo o equivalente a US\$ 4,2 e, mesmo no seu ápice, chegou a US\$ 6,1 (15/10), ligeiramente superior ao pico de 2009 (US\$ 5,6, em 9/10/2009). Mas a narrativa não foi capaz de sustentar o valor da OGX, especialmente após $15 / 10$, quando o mercado parece ter se frustrado com a falta de notícias sobre o farm-out e a produção em Waimea.

Antes esperada para outubro, os Executivos, agora, estimavam que o farm-out estaria concluído no 1T2011. Esse "atraso" não necessariamente era negativo, uma vez que é comum em transações deste tipo, especialmente se o objetivo for maximizar o valor da venda. Além disso, a Empresa detinha boa reserva de caixa e tinha tempo para negociar. Entretanto, como o mercado estava focado no farm-out, o atraso não seria bem

\footnotetext{
205 AUDI \& FALANGA NETO, 2010c, p. 1.

${ }^{206}$ KOVARSKY, MENDES \& ARAUJO [2010r].
} 
recebido ${ }^{207}$. De fato, a OGXP3 encerraria 2010 valendo $\mathrm{R} \$ 20,00,36,7 \%$ abaixo do segundo pico de $R \$ 23,20$ em 4/11. Uma perda de $36,7 \%$ em menos de dois meses não era um bom jeito de terminar 0 ano.

O fim do Rally (4/11) coincidiu com o anúncio do adiamento do farm-out e foi nesta época que alguns Analistas relataram, pela primeira vez, críticas aos Executivos que poderiam estar sendo "excessivamente otimistas" no seu guidance ${ }^{208}$. A percepção de otimismo excessivo que pode ter motivado a 2a Correção Depreciativa e não eram infundadas. Havia já alguns catalisadores cujas resoluções permaneciam pendentes: a falta de atualizações sobre o BM-S-29, que estariam sob responsabilidade do operador (MAERSK); a falta de notícias sobre o Waimea, cuja produção deveria começar no $1 T 2011$ e só começaria em 2012. Ao longo do ano, outras frustrações foram acumuladas com as sucessivas postergações do anúncio do farm-out de Campos, cuja intenção foi anunciada em 15/4, mas não se concretizou. Estes catalisadores sem resolução podem ter sido as primeiras fraturas do guidance da OGX.

Durante 2010, a OGX revisou seu plano de negócios quadrienal (2010-2013) por duas vezes, aumentando a previsão de investimentos na exploração de US\$ 2 para US\$ 3 bilhões (primeiro de 51 poços até 2013 para 79 poços, e depois para 87). A Empresa elegeu Campos como foco, onde o número de poços aumentaria de 27 para 40 . 0 aumento seria possível graças às reduções das perfurações planejadas para Santos (menos 9) e a contratação de sondas adicionais. A ideia de priorizar Campos era focar onde o conhecimento geológico era maior, portanto, o risco menor. A partir de 2011, a Empresa investiria na exploração de todas as suas bacias, incluindo ES e PA-MA.

Tabela 27 - Número de Poços Perfurados (Pioneiros e Appraisals)

\begin{tabular}{|l|c|c|c|c|c|c||}
\hline & $\mathbf{2 0 0 9}$ & $\mathbf{2 0 1 0}$ & $\mathbf{2 0 1 1}$ & $\mathbf{2 0 1 2}$ & $\mathbf{2 0 1 3}$ & Total \\
\hline Revisão 2009 & $\mathbf{6}$ & $\mathbf{2 7}$ & $\mathbf{2 4}$ & $\mathbf{1 9}$ & $\mathbf{3}$ & $\mathbf{7 9}$ \\
\hline Campos & 5 & 17 & 10 & 7 & 1 & 40 \\
\hline Santos & 1 & 9 & 4 & 4 & - & 18 \\
\hline Parnaíba & - & 1 & 5 & 1 & - & 7 \\
\hline ES & - & - & 3 & 4 & - & 7 \\
\hline PA-MA & - & - & 2 & 3 & 2 & 7 \\
\hline Planejamento 2008 & $\mathbf{6}$ & $\mathbf{1 9}$ & $\mathbf{1 9}$ & $\mathbf{7}$ & - & $\mathbf{5 1}$ \\
\hline Campos & 4 & 11 & 10 & 2 & - & 27 \\
\hline Santos & 2 & 8 & 4 & - & - & 14 \\
\hline Parnaíba & - & - & - & - & - & - \\
\hline ES & - & - & 3 & 3 & - & 6 \\
\hline PA-MA & - & - & 2 & 2 & - & 4 \\
\hline \hline
\end{tabular}

Fonte: Relatório Bradesco, IBBA [2009m]

${ }^{207}$ SEQUEIRA [2010d] e KOVARSKY, MENDES \& ARAUJO [2010p].
${ }^{208}$ KOVARSKY, MENDES \& ARAUJO, 2010r. 
Em 2010, na mediana, os Analistas da Amostra TR endossaram o guidance otimista mantendo seus PAs acima do valor da OGXP3 ao longo do ano todo. Os Analistas mais otimistas se tornaram ainda mais otimistas aumentando seus PAs de $\mathrm{R} \$ 22,59$ no início do ano para $\mathrm{R} \$ 37,40$ no fim do ano. Até os Analistas mais pessimistas resistiram em rever seu PA por boa parte do ano, e em dezembro ajustou de $R \$ 9,23$ para $R \$ 15,00^{209}$.

Gráfico 31 - Evolução da OGXP3, do PA Máximo, Mínimo e Mediano da Amostra TR em 2010 OGPXP3, PA High, PA Low e PA Mediana (R\$ / Ação)

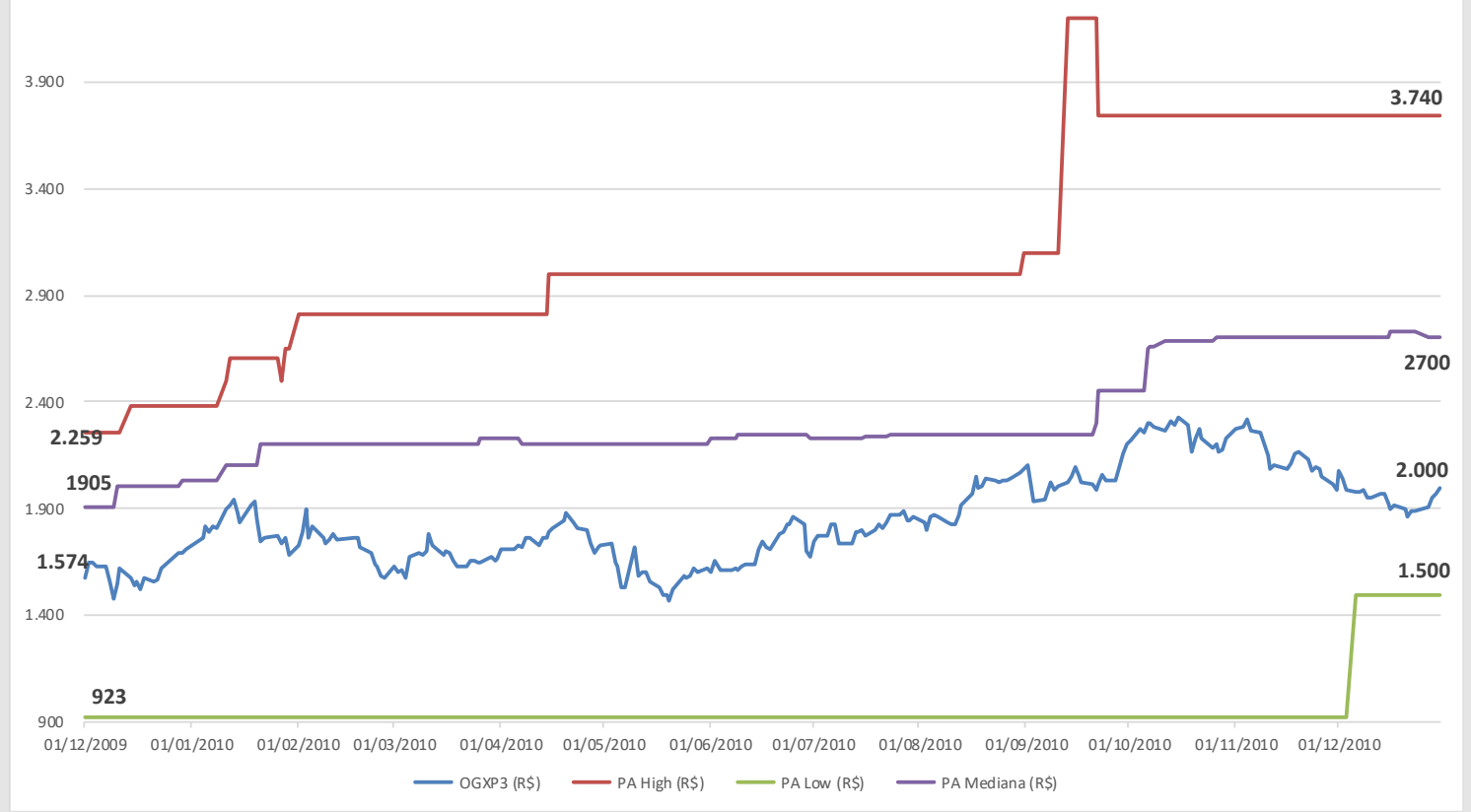

${ }^{209}$ Vale ressaltar que não se pode afirmar que os Analistas otimistas se tratam das mesmas pessoas ao longo do ano. O mesmo se aplica aos pessimistas. 


\subsection{1: "Ano da Virada"... da Credibilidade}

O AC havia prometido ao mercado que 2011 seria "o ano da virada" para o Grupo X: a MMX aumentaria sua produção de 7,7 milhões para 37 milhões de toneladas; a MPX inauguraria duas UTEs (Pecém, no Ceará e Maranhão); a OGX começaria a produzir no fim do ano; LLX começaria as operações do Porto de Açu; a OSX avançaria as obras do estaleiro, orçado em $\mathrm{R} \$ 3$ bilhões, capaz de produzir as 48 plataformas que a OGX precisaria. Todos estes projetos estavam atrasados, com sobre preços e precisando de novos recursos financeiros. Açu sofria com a concorrência dos operadores do Porto de Santos ${ }^{210}$.

A OGX previa o início da produção do primeiro poço produtor na acumulação de Waimea, o OGX-26HP (Bloco BM-C-41), através de um TLD, onde se esperava uma produção de até $20 \mathrm{kbpd}$ em 2011.

\section{Evolução do Valor de Mercado em 2011}

A 2a Correção Depreciativa, que começou em 16/10/2010, ocupou os oito primeiros meses de 2011 (até 8/8), quando começa uma correção apreciativa de pouco força (134 pregões). Em 8/8, o mercado financeiro internacional sofreu um abalo com 0 rebaixamento da dívida dos EUA para AA+ pela S\&P. Em 3/10, outro forte abalo com a crise da dívida europeia e o anúncio do default do governo grego. As ações de grandes bancos internacionais se depreciaram substancialmente com o receio de outros possíveis defaults na Europa. As ações do Bank of America perderam 9,6\% e as do MS fecharam "em seu nível mais baixo desde dezembro de 2008 - o custo do seguro de sal dívida disparou" 211 .

\footnotetext{
${ }^{210}$ GASPAR, 2014, p. 310-311.

211 "Mercados Intranquilos punem ações de bancos", Jornal Valor Econômico, 4/10/2011, edição eletrônica. Disponível em: https://www.valor.com.br/impresso/primeira-pagina/mercadosintranquilos-punem-acoes-de-bancos. Acesso em 9/2/2019.
} 
Gráfico 32 - Evolução do S\&P OGPE 600, S\&P OGPE 1500, OGXP3 e Brent em 2011

$(12 / 06 / 2008=100)$

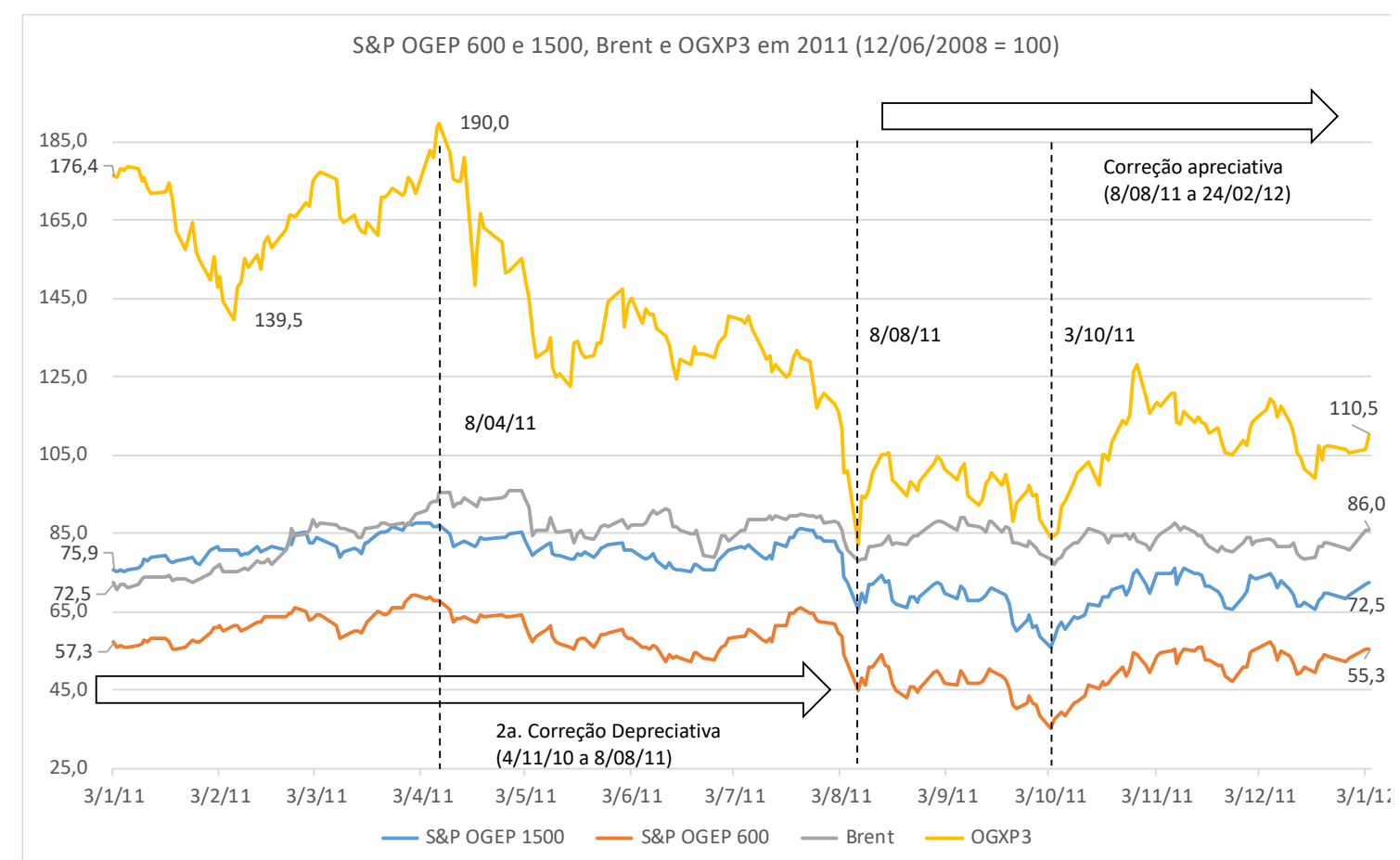

A 2a Correção parecia ter chegado ao fim em fevereiro quando as expectativas positivas sobre o 3으 D\&M impulsionaram a OGXP3 de R\$16,15 (7/2) para R\$20,65 (8/4). Porém, a partir de 9/4, a OGXP3 começou um movimento de queda que parece ter sido reforçada com a divulgação do 3 o D\&M, que não foi bem recebida pelo mercado: a OGXP3 se desvalorizou em 17,3\% em um único pregão (18/4). No início de agosto (4), pela primeira vez desde 28/9/2009, a OGXP3 rompeu o preço do IPO (R\$ 11,31) até alcançar o vale do ano em $\mathrm{R} \$ 9,20$ (8/8). No início de outubro, o $A C$ anunciou que desistira do farm-out, e a OGXP3 depreciou ainda mais. Em um único pregão perdeu $16,4 \%$ (de $R \$ 11,00$ em 7/08 para $R \$ 9,20$ em 8/08). 
Gráfico 33 - Evolução da OGXP3 em 2011 (em R\$ nominais por ação, pré Split)

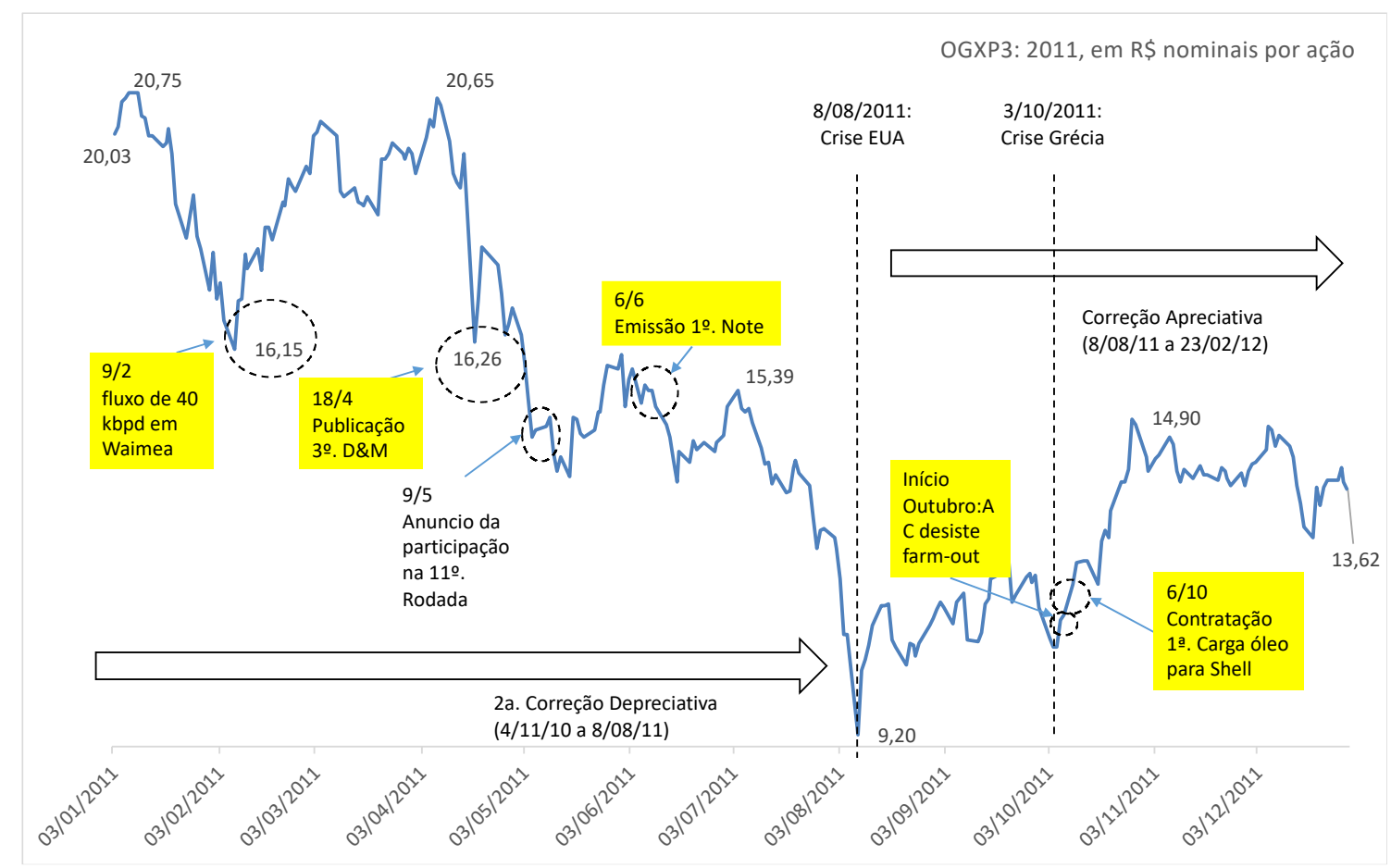

A desvalorização ponta a ponta da OGXP3 em 2011 foi de 32,0\%, maior do que do IBOV (-18,9\%), enquanto o Brent registrou uma apreciação de $11,6 \%$.

Gráfico 34 - Evolução da OGXP3, Brent e IBOVESPA em 2011 (Base 100 = 12/6/2008 [IPO])

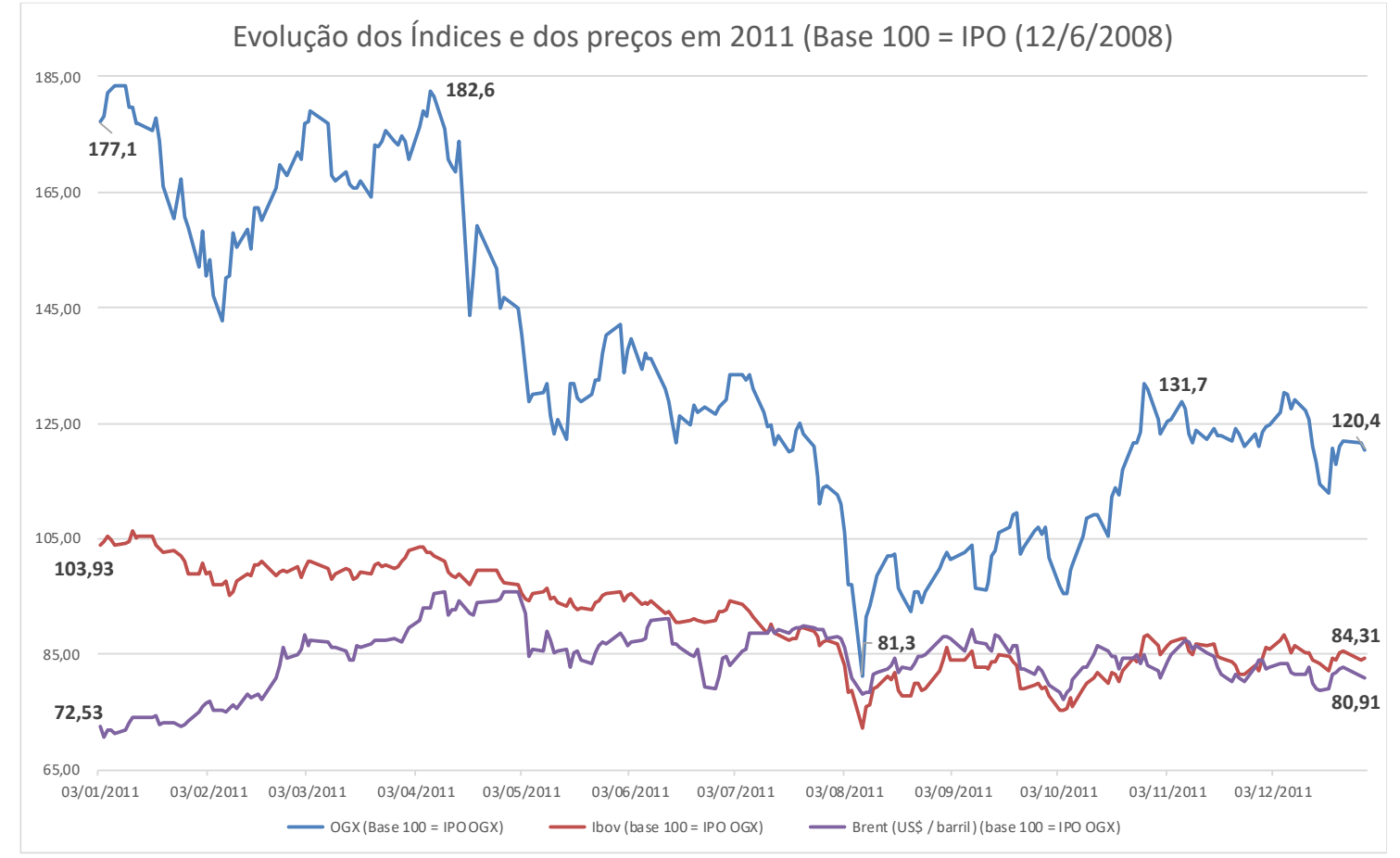


Se considerarmos a nova estimativa de volumes recuperáveis do 3은 (10,8 bboe), a queda do valor da OGX (EV 2C) seria ainda mais significativa: 47,7\% (de US\$ 5,85 para 3,06/boe).

\section{Gráfico 35 - Evolução do Enterprise Value (EV 2C) em 2011 (em US\$/boe)}

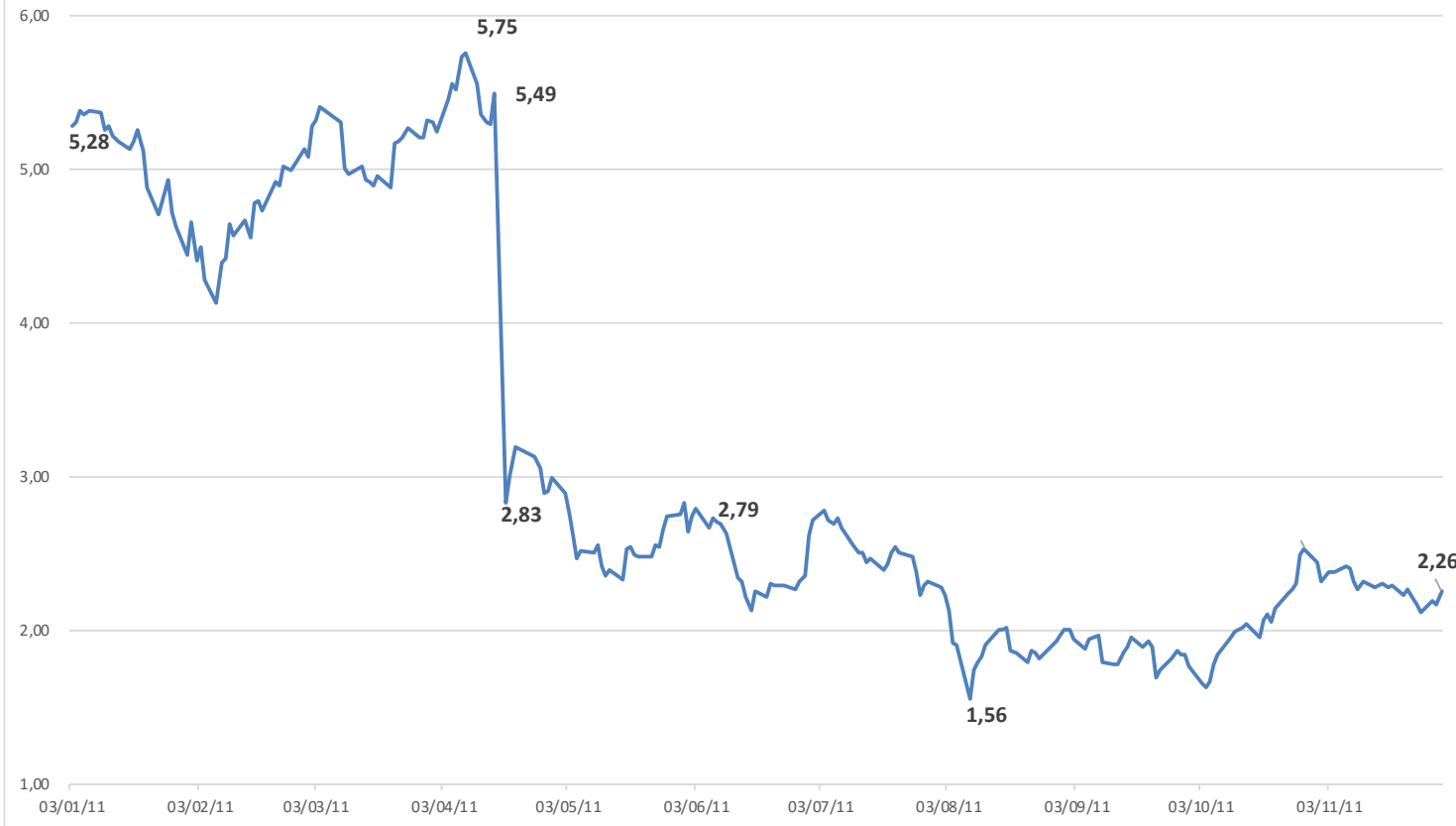

Os financiadores da OGX também tiveram uma reação tão significativa quanto os acionistas minoritários frente ao 3을 $\mathrm{DM}$ e a desistência do farm-out. O valor das Notas com vencimento em 2018 (OGXPBZ18) se desvalorizaram relativamente menos, aparentemente divergindo do sentimento do BOVESPA. De fato, entre a sua estreia (3/6) até o início de agosto (2/8), o OGXPBZ18 foi transacionado com ágio em relação ao seu valor de face. No pior momento, entre 19/9 e 4/10, o OGXPBZ18 sofreu uma desvalorização de 14\%, muito próxima daquela sofrida pelo EV (de US\$1,90/boe para US\$ 1,63, ou 14,3\%), mas recuperou boa parte de sua desvalorização até o fim do ano quando fechou próxima do valor de face (98,125\%), o que não ocorreu com o EV da OGX (de US\$3,0/boe para US\$2,26, equivalente a uma desvalorização de $24,7 \%$ ). 
Gráfico 36 - Evolução do Valor de Mercado do OGXPBZ18 ao longo de 2011

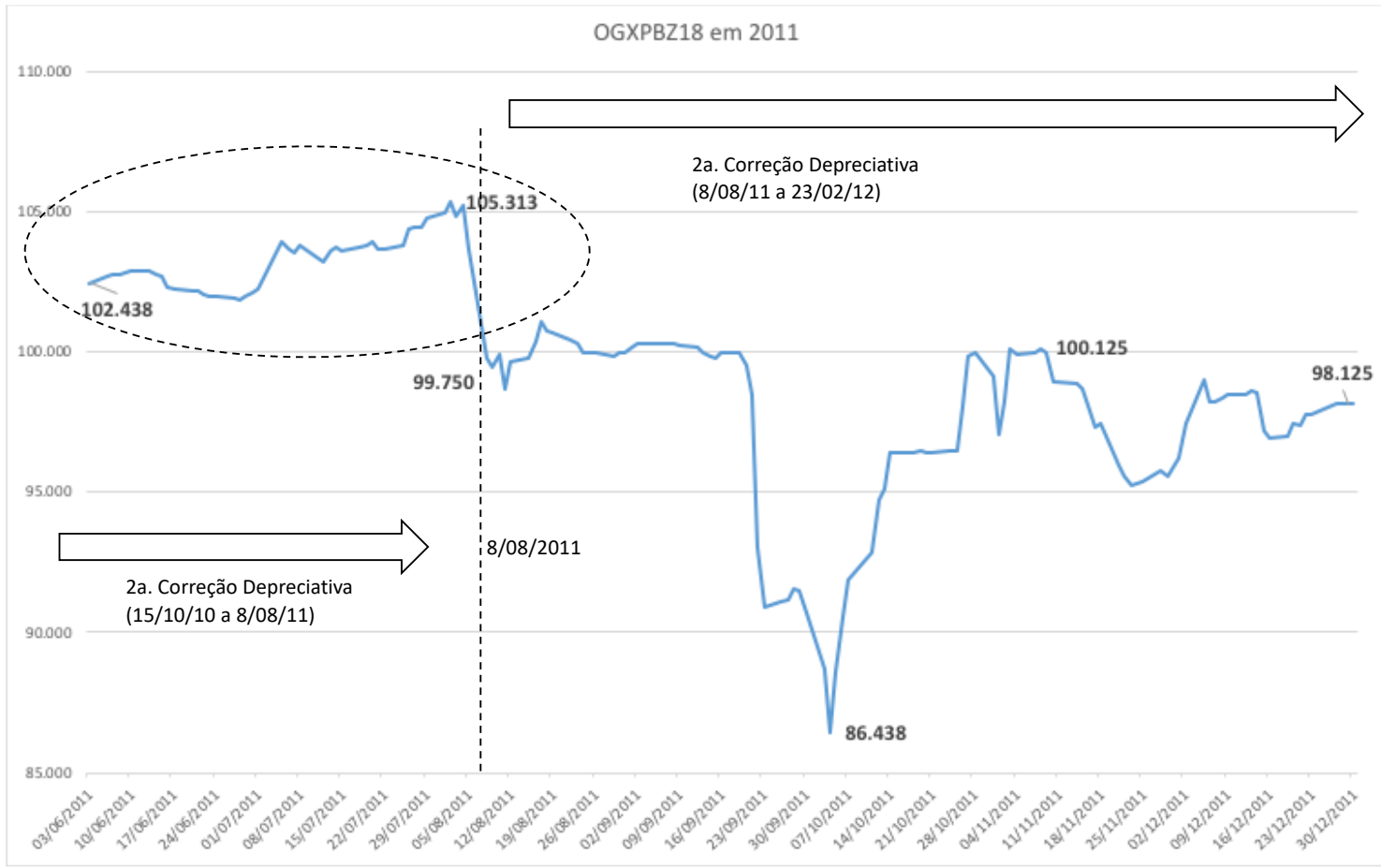

Evolução do Guidance e suas Repercussões sobre os Analistas em 2011

9/02. Em teleconferência, o $A C$ anunciou que recebera várias propostas para o farm-out, mas ainda não havia concluído a transação ${ }^{212}$. O primeiro poço de produção em Waimea gerou o "impressionante" fluxo de $40 \mathrm{kbpd} /$ poço de óleo leve: "um marco na história da Companhia". A expectativa era manter a média de $20 \mathrm{kbpd}$, devido a limitações dos equipamentos.

Repercussões. Na teleconferência, o AC explicou que a capitalização da PETR e as incertezas geradas pela eleição presidencial criaram um "ambiente que não era ótimo para o farm-out". Apesar disso, o AC "expressou sua forte conviç̧ão na continuidade do processo de farm-out, reiterando o interesse expresso por vários interessados não nomeados" 213 .

O AC ponderou que se o potencial investidor não alcançasse o múltiplo justo, a OGX teria três opções: i) reduzir a participação à venda; ii) reduzir o número de blocos para aqueles onde já houve o maior número de perfurações, portanto onde a incerteza era relativamente menor; iii) postergar o processo de farm-out.

O que isso significa para os investidores? Nós continuamos a acreditar que a OGX é uma excelente oportunidade. Nós também acreditamos que o valor [da OGXP3] é atrativo e que as coisas estão evoluindo

212 SEQUEIRA \& FONSECA, 2011 a, p. 2.

${ }^{213}$ Relatado por AUDI \& FALANGA NETO, 2011a, p. 1. GATTASS \& FONSECA [2011a, p.3] relatam que o AC mencionou que haveria doze interessados no farm-out. 
melhor do que o esperado na campanha exploratória da empresa. Mas não se engane, na ausência de transparência sobre o farm-out, a performance terá de seguir os fundamentos, o que significa que os barris não serão re-precificados durante a noite baseados em um único anúncio. Em outras palavras, compre se você acreditar nos fundamentos, como nós, e trate o farm-out como uma opção considerando que: i) aos níveis atuais, se precificarmos 2 bboe em Campos a US\$10/boe, adotando uma abordagem mais conservadora para o farm-out, o restante do portfólio da OGX seria transacionado ao redor de US\$2/boe, mesmo se considerarmos a perda total (write-off) de Santos, para ser novamente conservadores; e ii) uma taxa de sucesso de 50\% para o farm-out (razoável se tratada como qualquer evento estatístico) ainda é mais alto que a taxa de sucesso média da indústria. Mas lembre-se que a volatilidade provavelmente continuará... [KOVARSKY \& MENDES, 2011a, p. 1].

Alguns Analistas explicitamente relataram que "nos últimos meses, com a desvalorização das ações da OGX, a credibilidade do grupo [EBX] estava sendo cada vez mais questionada, e que isso poderia aumentar a probabilidade do anúncio do farm-out"214. Se o farm-out não fosse efetivado, para manter o guidance otimista, a OGX precisaria substituí-lo por novos e poderosos catalisadores.

Outros Analistas ${ }^{215}$ deram pouca ênfase ao farm-out, pois consideravam como principal catalisador o 3ㅇ D\&M, aguardado para o 1T2011. O relatório substanciaria a revisão para 10,8 bilhões de boe, antecipada pelo AC na entrevista de 15/4/2010. O relatório seria o principal vetor para a confiança dos investidores, que questionavam o real potencial das reservas da OGX. Afinal de contas, "não faria sentido contratar um relatório se este provavelmente não corroborasse com a visão dos executivos [da OGX]" 216 .

Outro Analista ${ }^{217}$ considerou que o foco dos investidores no relatório da D\&M era excessivo, ao mesmo tempo em que os investidores subestimaram a importância dos primeiros resultados de Waimea, também anunciados na referida teleconferência. $A$ OGX iniciaria o TLD, cuja expectativa era de sustentar uma média de $20 \mathrm{kbpd}$, devido a limitações dos equipamentos. Em 2010, a expectativa para a produção de Waimea era de 15 kbpd. Alguns Analistas ${ }^{218}$ consideravam 8 kbpd. Alguns Analistas ${ }^{219}$ consideraram os resultados de Waimea especialmente interessantes, pois se tratava de uma descoberta na camada Albiana de Waimea, que geologicamente se comparava à Jabuti, o campo de produção mais elevada da PETR até então $(28 \mathrm{kbpd})$. Jabuti teria sido uma surpresa tão significativa para a PETR que a fez retomar seu interesse em Campos. Da mesma maneira que Jabuti representava um caso de sucesso para PETR, Waimea poderia ter a mesma importância para a OGX. Em suma:

\footnotetext{
${ }^{214}$ AUDI \& FALANGA NETO, 2011a, p. 1.

215 Por exemplo, GATTASS \& FONSECA [2011a].

216 GATTASS \& FONSECA, $2011 a$, p. 2.

217 Por exemplo, DARIPA [2011a].

218 GATTASS \& FONSECA [2011a].

${ }^{219}$ Por exemplo, GATTASS \& FONSECA [2011a]; DARIPA [2011a].
} 
o mercado deveria ser mais paciente com a OGX (...) as ações deveriam responder mais às notícias relacionadas com a produção. Enquanto isso, nós pensamos que os executivos da OGX precisam entender que o mercado não está tão receptivo à promessas como quanto estava no passado e muito menos tolerante quando estas promessas não são cumpridas, especialmente em uma empresa pré-operacional [SEQUEIRA \& FONSECA, 2011a, p. 1].

De fato, entre fevereiro e março, alguns Analistas mudaram o foco do farm-out para o novo relatório da $\mathrm{D} \& \mathrm{M}^{220}$. A expectativa era que o 3을 $\mathrm{D}$. deveria incluir as descobertas de óleo em Campos. Lá a Empresa havia perfurado 21 poços (17 no Sudeste [BM-C-41, em particular] e 4 no Norte [BM-C-39, em particular]) desde o início da campanha exploratória em 2009, com taxa de sucesso de $100 \%$ até então. Portanto, era a região onde a Empresa havia acumulado mais informações e resultados que embasariam a revisão da D\&M.

Tabela 28 - Perfurações na Bacia de Campos até março de 2011

\begin{tabular}{|c|c|c|c|c|c|}
\hline Blocos & $\begin{array}{c}\mathrm{BA}^{221} \\
\text { (R\$ mil) } \\
\text { (A) }\end{array}$ & $\begin{array}{c}\text { Área } \\
\left(\mathrm{km}^{2}\right) \\
(\mathrm{B})\end{array}$ & $\begin{array}{c}\mathrm{A} / \mathrm{B} \\
(\mathrm{R} \$ \\
\left.\mathrm{mil} / \mathrm{km}^{2}\right) \\
\end{array}$ & $\begin{array}{l}\text { Poços Perfurados } \\
\text { (datas anúncios) }\end{array}$ & $\begin{array}{l}\text { RPL Óleo } \\
\text { (bboe) }\end{array}$ \\
\hline $\begin{array}{l}\text { BM-C-37 } \\
\text { (SE Campos) }\end{array}$ & 70.000 & 177 & 395,5 & $\begin{array}{l}\text { Carambola A: 5/1/11 } \\
\text { Carambola B: } 21 / 2 / 11\end{array}$ & \\
\hline BM-C-38 & 17.500 & 177 & 98,9 & & \\
\hline $\begin{array}{l}\text { BM-C-39 } \\
\text { (NE Campos) }\end{array}$ & 237.241 & 109 & $2.176,5$ & Waikiki: $8 / 12 / 10,24 / 3 / 11$ & \\
\hline $\begin{array}{l}\text { BM-C-40 } \\
\text { (NE Campos) }\end{array}$ & 126.770 & 124 & $1.022,3$ & $\begin{array}{l}\text { Pero: } 28 / 6,15 / 7 / 10 \\
\text { Inga: } 27 / 9 / 10 \\
\end{array}$ & $\begin{array}{l}\text { Pero: } 26-28 \mathrm{API} \\
\text { Inga: } 27 \mathrm{API} \\
\end{array}$ \\
\hline $\begin{array}{l}\text { BM-C-41 } \\
\text { (SE Campos) }\end{array}$ & 237.241 & 236 & $1.005,3$ & $\begin{array}{l}\text { Pipeline: } 12 / 11 \text { a } 22 / 12 / 9,22 / 3 / 11 \\
\text { Waimea: } 28 / 12 / 9,3 / 2 / 10 \\
\text { Etna: } 5,12 / 3,13 / 5 / 10 \\
\text { Fuji: } 24,31 / 3,13 / 5 / 10 \\
\text { Santa Helena: } 20,22 / 7 / 10 \\
\text { Tupungato: } 5 \text { e } 15 / 10 / 10 \\
\text { Illimani: } 24 / 1 / 11 \\
\text { Osomo: } 1 / 3 / 11\end{array}$ & $\begin{array}{l}\text { Pipeline: } 1,0 \text { a } 2,0 \\
\text { Etna: } 0,4 \text { a } 0,6 \\
\text { Waimea: } 0,5 \text { a } 0,9 \\
\text { Fuji: } 0,1 \text { a } 0,2 \text {, ou seja: } \\
\text { Pipe+Etna: } 1,4 \text { a } 2,6 \\
\text { Waimea+Fuji: } 0,6 \text { a } \\
1,1\end{array}$ \\
\hline BM-C-42 & 72.400 & 177 & 409,0 & $\begin{array}{l}\text { Kilawea (10 kms do Vesúvio) } 11 / 1 / 10 \\
\text { Huna: } 5,8 / 4 / 10 \\
\text { Hawaii: } 5 / 4,27 / 5 / 10\end{array}$ & Kilawea: 0,1 a 0,2 \\
\hline BM-C-43 & 108.700 & 177 & 614,1 & $\begin{array}{l}\text { Vesúvio: } 7 \text { a 14/10/9; 12/4, 27/5, } \\
\text { 6/12/10222 } \\
\text { Krakatoa: } 22 / 1 / 10,24 / 2 / 10\end{array}$ & $\begin{array}{l}\text { Vesúvio: } 0,5 \text { a } 1,5 \\
\text { Krakatoa: } 0,03 \text { a } 0,09\end{array}$ \\
\hline Sub. Campos & 869.852 & 1.177 & 739,0 & & 2,6 a 5,5 \\
\hline
\end{tabular}

Fonte: compilado pelo Autor a partir dos fatos relevantes e relatórios dos Analistas.

Com base nos dados acumulados até setembro de 2009, praticamente todo o portfólio da OGX fora classificado como "recursos prospectivos" no 2 D\&M. Nesta nova revisão,

\footnotetext{
220 Por exemplo, KOVARSKY \& MENDES [2011b]; DARIPA [2011a]; AUDI \& FALANGA NETO [2011b].

${ }^{221}$ Considerando $100 \%$ do bloco.

222 Ao fim de 2010, a Empresa anunciou que os testes de formação de Vesúvio foram inconclusivos pela ocorrência de emulsões, mas, a princípio, isso não mudaria suas expectativas anunciadas para o volume (SEQUEIRA \& FONSECA [2010e]).
} 
alguns Analistas ${ }^{223}$ esperavam que parte dos "recursos prospectivos" fosse reclassificada como "recursos contingentes", o conceito imediatamente anterior ao de "reservas". No Brasil, a diferença entre recursos contingentes e reservas era a entrega da Declaração de Comercialidade à ANP, a partir do qual o prazo da concessão de desenvolvimento começa a contar. Portanto, por questões de gestão de fluxo de caixa, as empresas operando no Brasil geralmente mantinham seus recursos classificados como contingentes, embora eles já pudessem ser considerados comercializáveis. Portanto, no Brasil, recursos contingentes eram interpretados como proxy para reservas, diferentemente do que acontecia nos EUA.

O mercado então se perguntava quanto a OGX teria de recursos contingentes, após a famosa entrevista do AC (15/4/10) que, entusiasmado, declarou que a Empresa teria 10,8 bboe. Para alguns Analistas ${ }^{224}$, o total de recursos prospectivos e contingentes poderia alcançar entre 8 e 9 bboe, dos quais 4 bboe poderiam ser contingentes (3C, equivalentes à média entre 2,6 e 5,5 bboe). Destes, entre 1,5 e 2,0 (média 1,7) bboe poderiam ser classificados como $2 \mathrm{C}$, endossados pelos resultados positivos na seção Albiana de Waimea. Os resultados do TLD em Waimea (0,5 a 0,9 bboe) seria o grande catalisador do momento para a OGXP3, seguidos dos resultados em Pipeline (1,4 a 2,6 bboe) e Waikiki, cujos testes de formação seriam iniciados.

Se nossas expectativas sobre o relatório da D\&M estiverem corretas, três anos após o IPO, quando o portfólio da OGX era estimado em 4,8 bboe em recursos prospectivos, a empresa apresentará ao mercado cerca de 4 bboe em recursos contingentes; uma conquista considerável [KOVARSKY \& MENDES, 2011b, p. 1]. (17/3)

O DB, em contraponto, resumiu o momento da OGX:

(...) hoje OGX nada mais é do que um potencial. Portanto a estória carrega uma quantidade substancial de incertezas. A principal destas é o fato que os recursos de óleo e gás da OGX são estimativas. (...) até a conclusão da fase de exploração, a existência de reservas comerciais não é uma garantia [SEQUEIRA \& FONSECA, 2011b, p. 8]. (27/3)

Nós reiteramos nossa visão que os dias de excitação com as notícias da exploração terminaram e que o mercado quer ver progresso na frente da produção. Nós não esperamos que o farm-out aconteça no curto prazo, e pensamos que qualquer transação de M\&A provavelmente será de escopo mais limitado que inicialmente vendido pela empresa [SEQUEIRA \& FONSECA, 2011c, p. 8]. (27/3)

28/03. Em teleconferência, a OGX relatou que planejava o início da produção em Waimea para o 3T11 com 20 kbpd. A Declaração de Comercialidade de Waimea deveria sair até o final do ano, podendo chegar a $60 \mathrm{kbpd}$ com 20,4 $4^{\circ}$. API. As Declarações de Comercialidade de Pipeline e Wakiki deveriam sair em 2012, confirmando as elevadas expectativas da Empresa sobre as duas acumulações, em especial Wakiki.

\footnotetext{
${ }^{223}$ KOVARSKY \& MENDES, 2011b, p. 3.

224 Por exemplo, KOVARSKY \& MENDES [2011b]; DARIPA [2011a].
} 
15/04. Finalmente, após o fechamento do mercado, o 3 D\&M se tornou público.

Repercussões. Em uma leitura superficial, o relatório parecia trazer boas notícias, pois confirmava um total de 10,8 bboe de recursos prospectivos, recursos contingentes, recursos potenciais e "recursos delineados". Este total considerava 1 bboe de recursos potenciais na Colômbia, 1 bboe de recursos contingentes na bacia do Parnaíba e 1,3 bboe em Campos com uma nova classificação: "recursos delineados".

\section{Tabela 29 - Resumo dos Três Relatórios de Avaliação da D\&M}

\begin{tabular}{|c|c|c|c|c|c|c|c|c|c|}
\hline \multirow{2}{*}{$\begin{array}{c}\text { Relatórios } \\
\text { Bacias }\end{array}$} & \multicolumn{2}{|c|}{ IPO 2008 (3/2008) } & \multicolumn{4}{|c|}{ 20 D\&M (10/2009) } & \multicolumn{3}{|c|}{ 3 D\&M (4/2011) } \\
\hline & RPL & POS & RPL & POS & Var. IPO & Var.\% IPO & RPL & Var. IPO & Var.\% IPO \\
\hline Campos & 2,562 & $33,0 \%$ & 3,693 & $44,1 \%$ & 1,131 & $44,1 \%$ & 1,400 & $(1,162)$ & $-45,4 \%$ \\
\hline Santos & 1,569 & $25,0 \%$ & 1,688 & $27,0 \%$ & 0,119 & $7,6 \%$ & 1,800 & 0,231 & $14,7 \%$ \\
\hline ES & 0,27 & $18,0 \%$ & 0,817 & $32,6 \%$ & 0,547 & $202,6 \%$ & 0,800 & 0,530 & $196,3 \%$ \\
\hline PA-MA & 0,434 & $20,0 \%$ & 0,447 & $21,2 \%$ & 0,013 & $3,0 \%$ & 0,400 & $(0,034)$ & $-7,8 \%$ \\
\hline Parnaíba & 0 & $0,0 \%$ & 0,026 & $19,9 \%$ & 0,026 & & 1,000 & 1,000 & \\
\hline Colômbia & - & - & - & - & - & & 0,100 & 0,100 & \\
\hline ST Prospectivo & 4,835 & $27,0 \%$ & 6,671 & $26,5 \%$ & 1,836 & $38,0 \%$ & 5,500 & 0,665 & $13,8 \%$ \\
\hline Delineados & - & - & & - & & - & 1,300 & - & \\
\hline Contingentes & - & - & 0,212 & - & 0,212 & - & 3,100 & - & \\
\hline Vol. Potencial & - & - & & - & & - & 1,000 & - & \\
\hline Total & 4,835 & & 6,883 & & 2,048 & $42,4 \%$ & 10,80 & 5,965 & $123,4 \%$ \\
\hline$\% G N$ & $26 \%$ & & $19 \%$ & & & & $21 \%$ & & \\
\hline
\end{tabular}

Entretanto, uma análise mais atenta provocou questionamentos e desapontamentos: foi um "choque de realidade" (reality check) ${ }^{225}$. O grande desapontamento foi que a estimativa de recursos contingentes (2C) para Campos ficou em 0,7 bboe, bem abaixo da média de 4,0 bboe do intervalo esperado (entre 2,6 e 5,5 bboe), anunciados pela OGX ao longo de 2010. Em 1C, os recursos contingentes somariam 0,1 bboe. Isso foi considerado uma má notícia, apesar do aumento do RPL para 10,8 bboe $(6,9$ bboe do 2 o D\&M).

Tabela 30 - Uma Interpretação dos Recursos Totais em Campos baseada no Relatório de abril de 2011 da D\&M (bboe)

\begin{tabular}{|l|c|c|c|}
\hline Em bboe & $\mathbf{1 C}$ & $\mathbf{2 C}$ & $\mathbf{3 C}$ \\
\hline Contingentes & 0,1 & 0,7 & 3,0 \\
\hline Delineados & 0,5 & 0,5 & 0,5 \\
\hline Prospectivos & 1,4 & 1,4 & 1,4 \\
\hline Total D\&M & $\mathbf{2 , 0}$ & $\mathbf{2 , 6}$ & $\mathbf{4 , 9}$ \\
\hline Estimativa OGX & $\mathbf{4 , 1}$ & $\mathbf{5 , 5}$ & $\mathbf{7 , 0}$ \\
\hline
\end{tabular}

Fonte: AUDI \& FALANGA NETO, 2011b, p. 4

${ }^{225}$ KOVARSKY \& MENDES, 2011 h, p. 1. 
A estimativa $2 C$ ficar muito aquém do que a OGX estimava (e muitos Analistas acreditaram) levou alguns a constatar que os Executivos estavam sendo muito otimistas, especialmente para os volumes de Campos $^{226}$. O desapontamento comprometia também a capacidade da OGX negociar termos favoráveis (ou seja, um EV/boe acima do capex/boe) em um eventual farm-out ${ }^{227}$. A partir deste momento, o farm-out se consolidou um catalisador secundário: "(...) o processo de farm-out foi para o banco de traz (...)"228. Em entrevista, o AC agora falava em vender $10 \%$ dos blocos em Campos, o que levou alguns Analistas a desconsiderar o impacto do farm out em suas estimativas de $\mathrm{PA}^{229}$.

$\mathrm{O}$ relatório trouxe também quatro questionamentos. Primeiro, por que o relatório se baseou em informações coletadas até 31/12/2010 para o Brasil e 31/3/2011 para a Colômbia, onde nenhum teste sísmico havia sido feito ${ }^{230}$ ? Até $31 / 12 / 2010$, a OGX havia perfurado 19 poços. Por que a D\&M não considerou as informações de 15 perfurações efetuadas em 2011 com novos resultados importantes, como por exemplo, perfurações e produção em Waimea (seção Albiana)? Segundos alguns Analistas, o pré-sal em Campos (seções Aptiana e Barreminiana) poderia ser um "grande upside no portfólio da OGX"231 adicionando entre 0,8 a 1,7 bboe de recursos recuperáveis além dos volumes já descobertos no nordeste e sudeste da bacia ${ }^{232}$.

O segundo questionamento foi gerado pelo uso e o significado de um novo conceito: "recursos delineados". Tratava-se de uma classificação intermediária entre recursos prospectivos e contingentes ${ }^{233}$ e se referiam aos resultados de 15 poços adicionais perfurados desde 31/12/2010. O intenso debate entre Analistas e investidores fomentou discussões técnicas sobre definições estatísticas básicas das classificações utilizadas na indústria do petróleo. O novo conceito "trouxe mais confusão ao mercado do que o ajudou"234. O mercado não recebeu bem o novo conceito de "recursos delineados"235.

Questionados sobre o novo conceito, os Executivos orientaram Analistas a somar os recursos delineados ( 1,3 bboe) às estimativas de recursos contingentes ( $3 C$, de 3,0 bboe), totalizando 4,3 bboe. Mesmo seguindo este guidance, a terceira questão que surgia era se esse volume ( 4,3 bboe) sustentaria as metas de produção. A OGX considerou a meta de produzir $730 \mathrm{kbpd}$ em 2015 como factível, mas não a meta de $1.390 \mathrm{kbpd}$ em 2019, o que exigiria que mais recursos contingentes em $3 \mathrm{C}$ fossem reclassificados para $2 \mathrm{C}$.

Os possíveis atrasos na entrega de embarcações necessárias (oito WHPs e nove FPSOs para produzir $730 \mathrm{kbpd}$ em 2015) reforçavam as dúvidas sobre a viabilidade do ramp-

\footnotetext{
${ }^{226}$ Por exemplo, AUDI \& FALANGA NETO [2011b]; GATTASS \& FONSECA [2011b].

227 Por exemplo, AUDI \& FALANGA NETO [2011b].

228 DARIPA, 2011b, p. 1.

229 DARIPA, 2011b, p. 1.

${ }^{230}$ Segundo AUDI \& FALANGA NETO [2011b], a estimativa de 1,0 bboe foi baseada em análises estatísticas de campos análogos.

${ }^{231}$ KOVARSKY \& MENDES, 2011f, p.2.

232 DARIPA, 2011b, p. 6.

233 Por exemplo, KOVARSKY \& MENDES [2011c].

${ }^{234}$ KOVARSKY \& MENDES, 2011g, p.1.

${ }^{235}$ KOVARSKY \& MENDES, 2011g, p.3.
} 
up. Até então, a OGX havia assegurado apenas cinco FPSOs e duas WHPs ${ }^{236}$ encomendadas à OSX.

O quarto questionamento foi por que a D\&M não detalhou as estimativas por poço/bloco, como fizera nos seus dois relatórios anteriores? Os Executivos também não forneceram mais informações e avisaram os Analistas que não poderiam questionar a D\&M diretamente, pois havia cláusula de confidencialidade entre a D\&M e a OGX. A Empresa também não elucidou as premissas para investimentos (capex) e despesas operacionais (opex).

Na segunda-feira, 18/4, após a publicação do relatório da D\&M, a OGXP3 sofreu um maciço sell-off. Em cerca de um mês, entre 15/4 a 18/5, a empresa perderia quase um terço ( $R \$ 20$ bilhões) de sua capitalização de mercado (de $R \$ 63,3$ bilhões em 15/4 para $\mathrm{R} \$ 44,8$ bilhões em 18/5).

Apesar da significativa desvalorização, alguns Analistas relutaram em reduzir suas estimativas de PAs, considerando a desvalorização "exagerada"237. Mas outros Analistas reduziram seus $\mathrm{PAs}^{238}$. Para estes, seria a primeira redução do PA desde o IPO. Mesmo aqueles que relutaram em rever seus PAs acabaram por fazê-lo algumas semanas depois $^{239}$.

Tabela 31 - Redução nos Preços Alvo da OGXP3 (R\$̣/ação)

\begin{tabular}{||l|c|c|c|c||}
\hline Banco & $\begin{array}{c}\text { PA Início } \\
\text { Cobertura }\end{array}$ & $\begin{array}{c}\text { PA Pré } \\
\text { 3o D\&M }\end{array}$ & $\begin{array}{c}\text { Pós D\&M } \\
\text { (Data Atual) }\end{array}$ & Var.\% \\
\hline BTG & $16,63($ UBS) & 27,63 & $21,63(18 / 4 / 11)$ & $-21,7$ \\
\hline DB & $28,00(16 / 8 / 10)$ & 28,00 & $23,00(18 / 4 / 11)$ & $-17,9$ \\
\hline IBBA & $13,67(28 / 7 / 10)$ & 33,30 & $27,00(5 / 5 / 11)^{240}$ & $-18,9$ \\
\hline MS & $8,40(11 / 8 / 09)$ & 27,00 & $23,00(17 / 4 / 11)$ & $-14,8$ \\
\hline SAN & $33,00(26 / 10 / 10)$ & 33,00 & $25,00(17 / 4 / 11)$ & $-24,2$ \\
\hline
\end{tabular}

Fonte: compiladas pelo Autor a partir dos relatórios disponíveis.

Em suas revisões, os Analistas não consideraram o valor de: 1,0 bboe na Colômbia; 0,7 bboe de recursos delineados; e 0,4 bboe de Parnaíba. Alguns Analistas também não consideravam os recursos prospectivos de Santos ${ }^{241}$ devido a: falta de informações sobre o BM-S-29; três poços secos perfurados; o relatório da D\&M que reportou que $67 \%$ dos recursos prospectivos da bacia eram de $\mathrm{GN}^{242}$.

${ }^{236}$ KOVARSKY \& MENDES, 2011l, p.3.

${ }^{237}$ KOVARSKY \& MENDES, 2011i, p.3.

238 Por exemplo, AUDI \& FALANGA NETO [2011b]; GATTASS \& FONSECA [2011b]; DARIPA [2011b]; SEQUEIRA \& FONSECA [2011d].

239 Por exemplo, KOVARSKY \& MENDES [2011h].

240 Vale notar que o ajuste no PA feito por KOVARSKY \& MENDES [2011h] deveu-se principalmente à valorização do câmbio. Eles também deslocaram a curva de produção original em dois anos, reduziram o capex/boe em $40 \%$.

241 Por exemplo, AUDI \& FALANGA NETO [2011b].

242 KOVARSKY \& MENDES, 2011g, p. 6. 
Alguns Analistas continuaram a acreditar na estória da OGX ("investment case"), entretanto consideraram três vetores negativos que os levaram a "perder a fé" e reduzir seus PAs ${ }^{243}:$ i) a estimativa $2 \mathrm{C}$ abaixo da expectativa ( 0,668 bboe em Campos equivaleria a um múltiplo de US\$ 53/boe de EV/2C); ii) "muito, muito" pouca informação disponível no relatório; e, principalmente, iii) a ausência de defesa, por parte da OGX, das estimativas anteriores, o que comprometeria a capacidade da OGX em orientar (guide) os investidores no período entre relatórios. Após reduzir seu PA em 21,7\%, o BTG comentou:

É curioso notar que nós acreditamos que a estória de longo prazo da OGX permanece inalterada [GATTASS \& FONSECA, 2011b, p. 1].

Apesar da nossa visão positiva sobre os recursos e a habilidade da OGX em capturar valor com estas descobertas, nós não acreditamos que o potencial se tornará visivel nos relatórios [da D\&M] nos próximos 18 meses e nós tememos que a habilidade da OGX em orientar [os investidores] pode ter sido maculada [GATTASS \& FONSECA, 2011b, p. 3].

Não há outra maneira de dizer isso. Nós estávamos errados. O relatório não apenas não confirmou os 4 bboe que usamos como premissa em nosso cenário base para a avaliação da empresa, com o número de $2 C$ a 0,7 bboe e o cenário (3C) com 3,0 bboe. Mas o relatório o fez considerando 11 acumulações e não 7 como no relatório original [GATTASS \& FONSECA, 2011b, p. 10].

Diante destas constatações e reações, Analistas indagavam: por que reduzir a transparência agora? ${ }^{244}$ Só foram disponibilizadas as estimativas consolidadas das bacias. Não foram abertas as informações por prospectos e campos, disponíveis nos relatórios anteriores. As implicações eram importantes, pois havia implicações tributárias (quanto maior a reserva, maior a alíquota do Imposto de Participação Especial) e econômicas (quanto maior a reserva, mais produtiva ela poderá ser). Então, por que limitar informações? A resposta dos Executivos foi extemporânea: empresas similares de E\&P também limitavam as informações disponíveis aos investidores.

Outra possível explicação para a falta de transparência seria de natureza regulatória: a OGX estaria prestes a submeter à ANP avaliações, que o mercado estaria recebendo antes, o que poderia ser interpretada pela ANP de forma negativa. Esse argumento poderia até ser razoável, mas nas circunstâncias de tantas dúvidas sobre a OGX, "não é o melhor momento para mudar a política de divulgação [disclosure]"245.

A Empresa precisaria converter mais recursos prospectivos em contingentes. O mercado precisava acreditar que seria factível obter entre 4,0 e 4,3 bboe em recursos contingentes. Para tanto, os resultados das três acumulações de Campos, Waimea, Pipeline e Wakiki, seriam cruciais.

243 GATTASS \& FONSECA [2011b].

${ }^{244}$ GATTASS \& FONSECA, 2011b, p. 22 e 23.

${ }^{245}$ GATTASS \& FONSECA, 2011b, p. 23. 
Os resultados da bacia da Parnaíba, que adicionaram mais 1,0 bboe ao portfólio da OGX (15 Tcf de GN e $45 \mathrm{mmbbl}$ ) foram recebidos com pouco entusiasmo pelos Analistas devido ao custo de transporte do gás. A maneira mais concreta de monetizar as reservas de GN seria através das UTEs da MPX, próximas de linhas de transmissão. Os planos da MPX eram oferecer $1 \mathrm{GW}$ no próximo leilão de energia e entregar $300 \mathrm{MW}$ em $2013 \mathrm{e}$ $700 \mathrm{MW}$ em 2014. Isso poderia representar um consumo de 6,5 milhões de $\mathrm{m}^{3} / \mathrm{d}$ em 2014 contra uma produção estimada em 15,0 milhões de $\mathrm{m}^{3} / \mathrm{d}$. O impacto econômico da operação da UTE Parnaíba seria pequeno no valor da OGX: R\$ 0,12 por ação para um $\mathrm{PA}$ de $\mathrm{R} \$ 33,3^{246}$. Estimava-se que uma UTE de $1 \mathrm{GW}$ consumiria $3 \mathrm{Tcf}$ ao longo de 20 anos $^{247}$.

Apesar da Empresa insistir no potencial da bacia de Cesar Rancheria na Colômbia, onde ficam seus campos, que é muito próxima à grande bacia de Maracaibo na Venezuela (com 80 bilhões de boe), separadas apenas por uma cadeia de montanhas, os Analistas a consideravam uma bacia de alto risco. Ainda não havia atividade exploratória significativa devido à atuação de guerrilhas na região. O potencial poderia ser maior em GN do que em óleo. Alguns Analistas acreditavam ser prematuro associar valor às estimativas de recursos na Colômbia ${ }^{248}$.

Após um longo período de alta, a OGXP3 entrava em uma fase de baixa: "no território do urso" ("in bear case territory"). Os Executivos teriam de reconquistar a confiança do mercado ${ }^{249}$. Para reconquistar esta confiança, alguns Analistas consideravam que a OGX deveria:

(...) i) anunciar os resultados dos poços em Pipeline e Waikiki, que seriam cruciais para aumentar a taxa de recuperação por trás das estimativas 2C; ii) prover orientação ("guidance") transparente $e$ razoável para o plano de negócio de 4,1 bboe, incluindo capex, opex, a curva de produção; e o cronograma de entregas da OSX; e, iii) efetivamente iniciar a produção $0^{250}$ (KOVARSKY \& MENDES, 2011g, p.1),

9/05. Em teleconferência, os Executivos anunciaram a intenção de participar da 11á Rodada em setembro e os planos para captar financiamentos para prosseguir com a E\&P.

Repercussões. A 11aㅡ Rodada incluíria blocos do pós-sal em novas fronteiras, portanto com maior risco e provavelmente BA mais baixos. Alguns Analistas estimavam que a OGX não ofertaria mais do que $\mathrm{R} \$ 0,5$ bilhão ${ }^{251}$. A OGX também anunciou planos para captar financiamentos (project finance, bonds e securitização de vendas futuras) para prosseguir com a exploração e desenvolvimento. O plano de investimento para os próximos 12 meses estava orçado entre US\$1,8 e US\$2,0 bilhões e o excedente de caixa

\footnotetext{
${ }^{246}$ KOVARSKY \& MENDES, $2011 \mathrm{f}, \mathrm{p} .7$.

247 KOVARSKY \& MENDES, 2011h, p.1.

248 AUDI \& FALANGA NETO [2011b]; KOVARSKY \& MENDES, 2011f, p.8.

249 DARIPA, 2011c, p. 1.

250 AUDI \& FALANGA NETO [2011e] explicaram que o TLD em Waimea deveria começar em setembro/outubro de 2011 e a Declaração de Comercialidade deveria ser enviada à ANP até 1T12. A produção em 2012 seria, em média, 50-60 kbpd, com 3 poços. A OGX teria até, no máximo, o 1T13 para informar a ANP seus planos para desenvolver os blocos de Campos.

${ }^{251}$ AUDI \& FALANGA NETO [2011e].
} 
em 31/3/2011 era de US\$ 2,5 bilhões. Ou seja, a Empresa teria caixa para os próximos 18 meses, aproximadamente. Alguns Analistas ${ }^{252}$ estimavam que a OGX precisasse captar cerca de US\$2,0 bilhões para completar o plano de negócio do portfólio atual (excluindo novas aquisições). A Empresa confirmou que estava em conversa com "vários bancos" que aceitariam os recursos em $2 \mathrm{C}$ e $3 \mathrm{C}$ como garantia.

A questão do financiamento se tornaria cada vez mais importante e, apesar de ainda ter dinheiro para os próximos 18 meses, seria interessante que a Empresa concluísse a captação antes, especialmente antes da 11 a Rodada ${ }^{253}$.

Ainda em maio, a PERENCO, sócia da OGX na bacia do ES, publicou um relatório que estimava seus recursos prospectivos $19 \%$ menores do que aqueles recentemente estimados no 3 D\&M. Alguns Analistas consideraram que, embora o impacto destes recursos seja pequeno no valor da OGX, este tipo de diferença de opinião não ajudava a OGX ${ }^{254}$.

17/5. A OGX anunciou a Declaração de Comercialidade das acumulações Califórnia (OGX16), rebatizado de Campo Gavião Azul, e Fazenda São José (OGX-22), rebatizado de Campo Gavião Real, ambos na bacia da Parnaíba (PN-T-68), com volume total de 1,1 Tcf e produção estimada em 5,7 milhões de $\mathrm{m}^{3}$ /dia já em 2013. A OGX Maranhão também obteve a licença de instalação da UTE, com $1.863 \mathrm{MW}$ de capacidade instalada, e gasoduto para ligar ao Complexo Termoelétrico MPX Parnaíba (associação entre MPX e Petra Energia). A Empresa também estava pleiteando uma licença adicional de 1.859 MW. Se ambas licenças fossem obtidas, a demanda por GN seria de 10 Tcf ao longo de 10 anos. A Empresa planejava participar do leilão A-3 agendado para julho/agosto com $1.859 \mathrm{MW}$.

Repercussões. No dia do anúncio da Declaração de Comercialidade dos poços na Parnaíba (17/5), a OGXP3 teve uma apreciação de $\mathrm{R} \$ 1,00 /$ ações, aproximadamente $9 \%$, correspondendo a um EV/boe de US\$22,00 para os recursos de GN na Parnaíba. Essa apreciação pareceu excessiva para alguns Analistas, que estimavam o impacto destas descobertas e operações com a MPX como positivamente marginal: $\mathrm{R} \$ 0,20$ por ação (US\$ 0,80/boe de GN da Parnaíba) para um PA de R\$ 25,00255.

6/06. Primeira captação de Senior Unsecured Notes de US\$ 2,563 bilhões, ou $\mathrm{R} \$ 4,808$ bilhões, com vencimento bullet em 1/6/2018 (sete anos) ${ }^{256}$.

Repercussões. Para alguns Analistas, a emissão foi uma notícia positiva e relevante, pois os investidores em ações questionavam a capacidade da Empresa em obter recursos após 2012, além de melhorar a estrutura de capital, até então integralmente constituída

\footnotetext{
252 AUDI \& FALANGA NETO [2011e].

${ }^{253}$ AUDI \& FALANGA NETO [2011e].

${ }^{254}$ AUDI \& FALANGA NETO [2011d].

${ }^{255}$ AUDI \& FALANGA NETO [2011f]; GATTASS \& FONSECA, 2011c, p. 7, estimavam em US\$2,0/boe ou R\$ 0,63/ação para o GN de Parnaíba.

256 Concluída em 26/5/2011. Covenants: endividamento líquido não poderia ultrapassar US\$ 4 B e a relação Dívida Líquida/EBITDA não poderia ultrapassar 3,5. [p. 71]
} 
por capital próprio ${ }^{257}$. Outros Analistas ${ }^{258}$ ponderaram que a taxa de $8,5 \%$ foi mais alta do que os 7,5\% inicialmente esperada pela OGX. A PETR, por exemplo, havia captado em janeiro notas de 10 anos com uma taxa de $5,4 \%$.

Maio e Junho. Ao longo de maio e junho, a Empresa ajustou suas premissas de custos, investimentos e produção.

Repercussões. A Empresa ajustou suas premissas de custos e investimentos por causa da inflação (de US\$ 15,20/boe para US\$ 18,00/boe) e atualizou a curva de produção:

Tabela 32 - Revisões da Curva de Produção Fim do Ano (kbpd)

\begin{tabular}{|l|c|c|c|c|c|c|c||}
\hline & $\mathbf{2 0 1 1}$ & $\mathbf{2 0 1 2}$ & $\mathbf{2 0 1 3}$ & $\mathbf{2 0 1 4}$ & $\mathbf{2 0 1 5}$ & $\mathbf{2 0 1 7}$ & $\mathbf{2 0 1 9}$ \\
\hline IPO & 2 & nd & nd & nd & 398 & nd & 1.130 \\
\hline Revisão OGX 2009 & 20 & nd & nd & nd & 730 & nd & 1.380 \\
\hline Revisão OGX 6/2011 & 20 & 50 & 165 & nd & 730 & nd & 1.380 \\
\hline
\end{tabular}

Fonte: compilado pelo Autor, AUDI \& FALANGA NETO [2011g].

A Empresa insistia na premissa de 4,1 bboe em Campos (contingentes $3 C+$ delineados). Com estas premissas, a Empresa estimava que seu fluxo de caixa se tornasse positivo em 2014, projeção esta ratificada por alguns Analistas ${ }^{259}$.

Em julho (4), o DB publicou um relatório setorial sobre O\&G na América Latina ${ }^{260} \mathrm{com}$ grande ênfase no potencial no Brasil e na Colômbia, cujas indústrias estavam em franca expansão ("booming"), apesar das reservas brasileiras serem 15 vezes maiores do que as colombianas (se excluirmos o pré-sal, as reservas brasileiras seriam 5 vezes maiores do que as colombianas).

Uma questão importante que os Analistas pontuaram era a exigência do alto índice de nacionalização nos equipamentos utilizados no Brasil. Esta exigência poderia atrasar a produção além de gerar custos mais elevados. Além disso, o Brasil possuía dois grandes gargalos: infraestrutura e licenciamentos (ambiental).

27/7. A PETR divulgou seu novo plano estratégico para 2011-15, que incluía farm-outs que disputariam o interesse de potenciais compradores pelos ativos da OGX.

Repercussões. Alguns Analistas ${ }^{261}$ recomendaram que os investidores vendessem suas ações da OGX para comprar ações da PETR. Pois, com ativos da PETR à venda, potenciais

\footnotetext{
257 KOVARSKY \& MENDES [2011I].

258 SEQUEIRA \& FONSECA [2011f].

${ }^{259}$ AUDI \& FALANGA NETO, 2011g, p. 2.

260 SEQUEIRA \& FONSECA [2011]].

${ }^{261}$ AUDI \& FALANGA NETO [2011h].
} 
compradores poderiam ter menos interesse no farm-out da OGX. Mas após a captação das Secured Notes, a OGX encerrou o 1 S11 com muito caixa ("plenty of cash" ${ }^{262}$ ).

Os investidores pareciam estar confusos. Alguns Analistas ${ }^{263}$ relataram que após reduzirem seu PA, foram questionados por investidores que criticaram a redução por considera-la excessiva. Outros investidores criticaram em sentido oposto: a redução teria de ser maior.

Entre o fim de julho e início de agosto, o BTG promoveu um seminário de um dia com a $D \& M$, que focou nos seus princípios e procedimentos para avaliação de recursos. Causou "surpresa" aos Analistas do BTG constatar a quantidade de estudos independentes que a D\&M faz nos dados primários brutos fornecidos por seus clientes.

Nós, inicialmente, pensamos que os clientes da D\&M poderiam ser capazes de influenciá-la, de algum modo ou em alguma variável, mas, agora, acreditamos que isso é muito pouco provável [GATTASS \& FONSECA, 2011c, p. 25].

Embora as avaliações de nenhum dos clientes da D\&M tenham sido abordadas no seminário ${ }^{264}$, os Analistas do BTG saíram do seminário com a "fé renovada" ${ }^{265} \mathrm{em}$ seu entendimento do 3으 $\mathrm{QM}$ e as perspectivas para o ano: a OGX poderia converter 4,3 boe de recursos contingente em $3 C$ para $2 C$. Se esta conversão de fato ocorresse, " $a$ OGXP3 seria hoje [2 de agosto] uma das ações mais baratas e atraentes em O\&G do mercado"266. Mas, para fazer a conversão, mais perfurações e testes seriam necessários. Portanto, a questão permanecia:

(...) quão bem-sucedidas têm sido as perfurações de avaliação $e$ quando a Empresa divulgaria os resultados destas perfurações e suas relações com os volumes em questão? (...) Exploração ainda continua a ser um vetor crítico ['key driver']. (...) nós acreditamos que, isoladamente, o catalisador mais importante no futuro é uma atualização do relatório de recursos ${ }^{267}$.

Nós ainda acreditamos que houve uma monumental melhora no front das perfurações e recursos também. Infelizmente, a OGX não tem falado sobre estes desenvolvimentos de maneira organizada como falou sobre seus planos de desenvolvimento [GATTASS \& FONSECA, 2011c, p. 14].

Desde a divulgação do relatório da D\&M em 15/4, a OGXP3 havia desvalorizado 37\%, enquanto o IBOVESPA havia variado $-6 \%$. Ações de outras empresas de petróleo se valorizaram (QGEP ganhou 9\%, HRT ganhou 4\%). Tamanha desvalorização,

\footnotetext{
262 GATTASS \& FONSECA, 2011d, p. 2.

263 GATTASS \& FONSECA, 2011c, p. 2.

${ }^{264} \mathrm{Na}$ época, além da Petrobras e da OGX, a D\&M também avaliava os recursos de outra E\&P brasileira, a HRT.

265 GATTASS \& FONSECA, 2011c, p. 2.

266 GATTASS \& FONSECA, 2011c, p. 2.

267 GATTASS \& FONSECA, 2011c, p. 2, 5 e 9.
} 
consideravam alguns Analistas ${ }^{268}$, poderia ser resultado de especulações sobre o relatório da D\&M, mas que poderia ser revertida se a Empresa divulgasse mais informações, pois na teleconferência de 14 de abril, os Executivos insistiam que era uma questão de tempo para converter 4,3 boe de $3 C$ para $2 C$, porém sem fornecer explicações mais profundas.

Apesar da desvalorização, a OGX tinha um valor de mercado de US\$ 26 bilhões (EV), sem nenhuma produção ou reservas. Se comparada com outras empresas, já produtivas e com reservas, e considerando a meta de produção da OGX para 2013 (165 kbpd), seu múltiplo seria de US\$ 157,0/kboe, contra US\$ 98,4/kboe da PETR, por exemplo:

Tabela 33 - Múltiplos de Empresas de O\&G na América Latina

\begin{tabular}{|l|c|c|c|c|c|c|}
\hline & PBR & $\begin{array}{c}\text { Ecopetrol } \\
\text { (Colômbia) }\end{array}$ & YPF & PRE CN & QGEP3 & OGXP3 \\
\hline US\$/kboe & 98,4 & 127,0 & 37,3 & 73,3 & 111,6 & 157,0 \\
\hline \multicolumn{7}{|c|}{ Fonte: GATTASS \& FONSECA, 2011c, p. 11.}
\end{tabular}

Na reunião com a D\&M, alguns Analistas do BTG conseguiram detalhes sobre o que foi e o que não foi considerado das estimativas: i) não considerou 7 perfurações em Santos; ii) analisou 19 perfurações em Campos em 4 clusters, mas, à pedido da OGX, importantes dados sobre o pré-sal na região não foram submetidos, incluindo o óleo encontrado nas geologias pré-sal (Aptiana e outras mais antigas). Concluíram que o relatório da D\&M foi "excessivamente conservador" tanto na avaliação das descobertas (que poderia adicionar mais 2,2 bboe em $2 \mathrm{C}$ ) quanto nas taxas de recuperação (que poderia adicionar mais 1,4 bboe em 2C), o que levou à estimativa de 0,696 bboe de recursos contingentes $2 \mathrm{C}^{269}$. No seminário, os Analistas entenderam que a $\mathrm{D} \& \mathrm{M}$ fora bem conservadora nas suas estimativas $2 \mathrm{C}$ por acreditar que, com maiores informações, podem convertê-las diretamente em reservas $2 \mathrm{P}$.

Tabela 34 - O que foi considerado no Relatório da D\&M de abril/2011

\begin{tabular}{|l|c|c|}
\hline \multicolumn{1}{|c|}{ Tipo Poço } & Campos & Parnaíba \\
\hline Poços Analisados & 19 & 2 \\
\hline Acumulações analisadas & 11 & 2 \\
\hline Prospecções não analisadas & 11 & 24 \\
\hline
\end{tabular}

Fonte: relatórios da Empresa apud GATTASS \& FONSECA, 2011c, p. 15.

10/08. Executivos divulgaram mais e melhores informações sobre os resultados das perfurações (Waimea, Waikiki, Pipeline, Illimanu, Fuji e Tambora) e os preparativos para o primeiro óleo (Waimea). A Empresa também declarou otimismo em relação às campanhas exploratórias nas bacias do ES e PA-MA, que deveriam começar em breve.

Repercussões. Aparentemente, a OGX deu ouvidos aos clamores dos Analistas e divulgou mais e melhores informações. Desde 31/12/2010, a OGX perfurou mais 23

\footnotetext{
268 GATTASS \& FONSECA, 2011c, p. 2.

${ }^{269}$ GATTASS \& FONSECA, 2011c, p. 16.
} 
poços, com outros 2 poços testados e outros 5 em perfuração. Alguns Analistas consideraram que estes poços têm obtido uma "tremenda quantidade de sucesso" 270 que poderia provar que as descobertas da OGX poderiam ser muito maiores que a estimativa $2 C$ do 3 ㅇ D\&M, porém mais perfurações e o início efetivo da produção seriam necessários para substanciar as avaliações. Se a OGX conseguisse converter seus 3,6 bboe de recursos $3 \mathrm{C}$ para $2 \mathrm{C}$, o que poderia ser "excessivamente otimista", a OGXP3 poderia valer US\$ 7,6/boe.

Tabela 35 - Resultados dos Poços Perfurados em Campos desde o fim de 2010

\begin{tabular}{||l|c|c|c|c||}
\hline \multicolumn{1}{|c|}{ Tipo Poço } & $\begin{array}{c}\text { Quantidade } \\
\text { Perfurada }\end{array}$ & Sucesso & Sucesso (\%) & $\begin{array}{c}\text { Poços em } \\
\text { perfuração }\end{array}$ \\
\hline Áreas 1C/2C & 6 & 4 & 100 & 2 \\
\hline Áreas 3C & 8 & 7 & 100 & 1 \\
\hline Delineação & 4 & 1 & 50 & 2 \\
\hline Pioneiros & 8 & 6 & 75 & 0 \\
\hline Total & $\mathbf{2 6}$ & $\mathbf{1 8}$ & $\mathbf{8 6}$ & $\mathbf{5}$ \\
\hline
\end{tabular}

Fonte: relatórios da Empresa, apud GATTASS \& FONSECA, 2011d, p. 10.

Dos 26 poços perfurados em Campos desde o fim de 2010, 12 foram perfurados em Waimea, dos quais 3 eram pioneiros e 9 eram de avaliação. Em Waikiki foram 4 poços, dos quais 3 eram de avaliação sem bons resultados, mas a Empresa ainda acreditava em seu potencial de desenvolvimento. Em Pipeline foram perfurados 8 poços, dos quais 3 eram de avaliação.

Tabela 36 - Testes de Produção em Poços Horizontais da OGX

\begin{tabular}{|l|c|c|c||}
\hline Testes & Data & $\begin{array}{c}\text { Capacidade } \\
\text { de Produção } \\
\text { (kbpd) }\end{array}$ & $\begin{array}{c}\text { Qualidade } \\
\text { (' } \text { API) }\end{array}$ \\
\hline Pipeline & $15 /$ jul. & 10,0 & 19 \\
\hline Waikiki & $20 /$ jun. & 40,0 & 23 \\
\hline Waimea & $9 /$ fev. & 40,0 & 20 \\
\hline
\end{tabular}

Fonte: relatórios da Empresa, apud GATTASS \& FONSECA, 2011c, p. 16.

As informações parecem ter ajudado a entender a capacidade da Empresa em converter recursos, o que causou boa impressão em alguns Analistas ${ }^{271}$, que acreditaram que os bons resultados da campanha de avaliação surpreenderiam os investidores no $2 \mathrm{~S} 11$ :

Nós acreditamos que eles [executivos da OGX] ainda não fizeram o suficiente para recuperar totalmente a credibilidade que parece ter sido perdida em abril, e, em certo sentido, receamos que um novo

\footnotetext{
270 GATTASS \& FONSECA, 2011c, p. 16.
}

${ }^{271}$ GATTASS \& FONSECA [2011d]. 
relatório de avaliação independente que confirme uma mensagem otimista poderia ser necessário antes de um novo grande rally.

Mas, apesar deste receio, nós acreditamos que os passos certos estão sendo tomados pela gestão e que, em conjunção com o que acreditamos ser uma campanha de avaliação de muito sucesso até agora, possam, mais cedo ou mais tarde, se tornar uma estória monumental [GATTASS \& FONSECA, 2011d, p. 2].

Curiosamente, no complexo de Vesúvio (BM-C-43), onde a OGX havia anunciado uma grande descoberta (com 0,5 a 1,5 bboe) e que seria o local do seu primeiro óleo, aparentemente não foram feitas novas perfurações ou testes. Um poço havia sido perfurado mais recentemente e, segundo a opinião de alguns Analistas, se provou ser um poço seco. Portanto, estes Analistas tinham dúvidas sobre a relevância de Vesúvio para os recursos $1 C, 2 C$ e $3 C$ da OGX ${ }^{272}$.

A campanha exploratória continuava também em Santos onde logo começaria a campanha de avaliação. Os investidores pareciam estar muito céticos com as perspectivas em Santos.

Os Analistas do BTG relataram surpresa com a alta ansiedade de seus colegas ("concorrentes") pelo primeiro óleo de Waimea (esperado para outubro/novembro). Para o BTG, embora reconhecessem a importância deste marco, o risco de insucesso (fluxo abaixo de 10-20 kbpd ou atraso na obtenção da LO) era "muito baixo"273, pois os resultados dos testes realizados foram positivos. O BTG esperava que o óleo de Waimea fosse vendido com um desconto de 17,3\% em relação ao Brent (mais US\$ 2/boe para transportá-lo para fora da FPSO).

Setembro. No início do mês, a OGX obteve a Licença Ambiental Prévia para Waimea e a expectativa era obter a Licença de Instalação e a Licença de Operação em até 60 dias, que permitiria o início do TLD. O FPSO (OSX-1) deveria chegar ao Brasil no fim de setembro.

Repercussões. Em aparente contraponto com outros Analistas, o MS reduziu seu PA significativamente no início de setembro (11). Em abril (18), após a divulgação do relatório $D \& M$, o MS reduziu seu $P A$ de $R \$ 27$ para $R \$ 23$ e agora para $R \$ 16 / a c ̧ a ̃ o . ~ O u$ seja, em menos de 5 meses, o MS reduziu seu PA em 40,7\% ${ }^{274}$. A redução ocorreu "após revisar as informações disponíveis e checa-las com consultores especializados em O\&G ("consultores externos e geólogos de outras empresas, etc."). Dois fatores causaram o ajuste no PA: redução na estimativa dos RPL de 5,3 bboe para 3,5 bboe; e redução na estimativa dos volumes delineados mais contingentes (2C) de Campos de 4,3 para 2,7 bboe.

272 GATTASS \& FONSECA, 2011c, p. 23.

273 GATTASS \& FONSECA, 2011d, p. 10.

${ }^{274}$ DARIPA [2011d]. 
Tabela 37 - Ajuste na Estimativa dos Recursos Prospectivos na opinião do MS (em mboe)

\begin{tabular}{|l|c|c|c|}
\hline & RPL 30 D\&M & Ajuste & RPL Ajustado \\
\hline Campos & 1.400 & $65,8 \%$ & 921 \\
\hline Santos & 1.800 & $65,8 \%$ & 1.184 \\
\hline ES & 800 & $65,8 \%$ & 526 \\
\hline PA-MA & 400 & $65,8 \%$ & 263 \\
\hline Parnaíba & 912 & $65,8 \%$ & 600 \\
\hline Total & $\mathbf{5 . 3 1 2}$ & $\mathbf{6 5 , 8 \%}$ & $\mathbf{3 . 4 9 4}$ \\
\hline
\end{tabular}

Fonte: DARIPA, 2011d, p. 4.

Tabela 38 - Ajuste na Estimativa dos Recursos Delineados e Contingentes das Acumulações de Campos na opinião do MS

\begin{tabular}{|l|c|c|c|c|c|c|}
\hline Acumulações & $\begin{array}{c}\text { Delineados + } \\
\text { Contingentes } \\
\text { (2C) (bboe) }\end{array}$ & $\%$ & $\begin{array}{c}\text { Fator de } \\
\text { Recuperação } \\
\text { (\%) }\end{array}$ & $\begin{array}{c}\text { RPL } \\
\text { (bboe) }\end{array}$ & $\%$ & Comentários \\
\hline Waimea & 1,126 & $26,0 \%$ & $100 \%$ & 1,126 & $41,7 \%$ & $\begin{array}{c}\text { Testes de } \\
\text { produção em } \\
\text { andamento. }\end{array}$ \\
\hline Pipeline & 2,063 & $47,7 \%$ & $50 \%$ & 1,031 & $38,2 \%$ & $\begin{array}{c}\text { Avaliação em } \\
\text { andamento. }\end{array}$ \\
\hline Vesúvio & 0,738 & $17,1 \%$ & $20 \%$ & 0,148 & $5,5 \%$ & $\begin{array}{c}\text { 10 teste de } \\
\text { produção falhou, } \\
\text { e OGX não } \\
\text { retomou } \\
\text { perfurações. }\end{array}$ \\
\hline Waikiki & 0,396 & $9,2 \%$ & $100 \%$ & 0,396 & $14,7 \%$ & $\begin{array}{c}\text { Excelente } \\
\text { reservatório, mas } \\
\text { pequeno. Testes } \\
\text { de avaliação e } \\
\text { produção sendo } \\
\text { finalizados. }\end{array}$ \\
\hline $\begin{array}{l}\text { Volume } \\
\text { Recuperável }\end{array}$ & $\mathbf{4 , 3 2 3}$ & $\mathbf{1 0 0 \%}$ & $\mathbf{6 2 \%}$ & $\mathbf{2 , 7 0 1}$ & $\mathbf{1 0 0 \%}$ & \\
\hline
\end{tabular}

Fonte: DARIPA, 2011d, p. 4, 8.

Os ajustes são motivados por uma preocupação que o Analista do MS já havia levantado em outros relatórios: evitar aplicar premissas (por exemplo, o fator de recuperação) e múltiplos deduzidos de bases diferentes para comparar "maçã-com-maçã":

Por exemplo, alguém pode argumentar que os ativos da HRT na bacia do Solimões estão subestimados em $50 \%$ pois o fator de recuperação usado pela D\&M foi de $28 \%$ enquanto que no campo de Urucu, já campo operacional, tem um fator de recuperação entre 50-60\%. Ao 
comparar OGX e HRT usando múltiplos de ativos derivados de fatores de recuperação diferentes seria uma distorção" [DARIPA, 2011d, p. 6].

DARIPA ilustrou a dificuldade em estimar o fator de recuperação com um caso real, o bloco de Nanpu na baia de Bohai no nordeste da China. Em Nampu, a Petrochina estimou haver 1 bilhão de toneladas de óleo equivalente, dos quais 0,405 bilhão foi classificado como reservas. A estimativa baseou-se em um fator de recuperação de $40 \%$, que posteriormente foi reduzido para $20 \%$, após se constatar que a estrutura geológica do bloco continha muitas falhas. O óleo estava em pequenas "piscinas" e não em um grande reservatório, o que aumentou muito os custos de extração, pois muitos poços verticais tiveram de ser perfurados para extrair o óleo. Adicionalmente, seria muito difícil usar técnicas de injeção de fluídos (pode ser água, $\mathrm{CO}_{2}, \mathrm{O}_{2}, \mathrm{GN}$, por exemplo) para assegurar a pressão adequada que impulsionaria o óleo através dos poços.

Para resumir, o 3 D\&M causou uma crise de reputação no guidance dos Executivos levando alguns Analistas a serem mais conservadores enquanto aguardavam mais e melhores informações:

Nós não estamos contradizendo as conclusões dos executivos da OGX, tampouco estamos afirmando que a OGX não poderá recuperar 4,1 bboe. Ao continuar seus testes de produção e divulgar mais informações sobre as acumulações (através de revisões da D\&M ou Declaração de Comercialidade), nós poderemos revisar nossos fatores de risco [DARIPA, 2011d, p. 4].

No início de outubro (3), outro banco, o SAN, também reduziu seu PA para R\$2 21/ação ${ }^{275}$. Em abril, antes do 3 D\&M, seu PA era de $R \$ 33 /$ ação, ou seja, uma redução de $36,4 \%$ em menos de 6 meses. Apesar da redução no PA, assim como o MS, o SAN recomendava a seus clientes manter suas ações da OGX, pois seu potencial era diferenciado em relação aos peers.

Início Outubro. AC anuncia que não perseguiria mais o farm-out no curto prazo ${ }^{276}$.

Repercussões. Se a intenção do AC foi "trocar" a captação pelo 1ํ Note, o mercado não gostou. Não era apenas menos dinheiro, mas o sinal para o de-risking.

Segundo os Analistas, não havia catalisadores de curto prazo, mesmo na eminência do anúncio de um contrato de venda de óleo do TLD de Waimea. Exceção seria feita se o contrato de venda de óleo incluísse um desconto inferior a $15 \%$ do Brent. Os Analistas estimavam que para cada $5 \%$ a menos de desconto, o PA aumentaria em $\mathrm{R}$ \$ 0,10/ação. Se todo o óleo dos blocos de Campos fosse vendido com $5 \%$ a menos de desconto, o PA aumentaria em $\mathrm{R} \$ 1$, 40 /ação.

${ }^{275}$ AUDI \& FALANGA NETO [2011i].

276 Diante do desinteresse dos IOCs na "megamonetização" da OGX, GASPAR [2014, p. 293, 336] relata que o AC então teria abordado outro tipo de investidor: os fundos de investimentos que já havia comprado US\$ 2,6 bilhões das Unsecured Notes da OGX, dentre eles a PIMCO e a BlackRock. Itaú e Bradesco emprestaram US\$ 1,3 B, com garantias pessoais do AC. O BNDES e o Gávea emprestaram (ou aportaram) R\$ 1,3 B na MPX. 
6/10. Empresa assinou o contrato de venda dos primeiros 1,2 milhão de barris do TLD de Waimea para a Shell, equivalentes a 80 dias de produção (assumindo uma produção média de $15 \mathrm{kbpd}$ ). Seriam duas cargas com 600 mil barris, ambas com $20^{\circ}$ API, produzidos pela FPSO OSX-1.

Repercussões. De acordo com a OGX, o contrato era renovável e poderia incluir aumentos nos volumes. A Empresa explicou que "não assinou um contrato de longo prazo, pois pretende avaliar outras opções, uma vez que recebeu propostas de várias outras importantes refinarias" 277 .

O preço de venda foi definido com desconto de US\$ 5,50/barril em relação ao Brent, equivalente a um desconto de cerca de $6,9 \%{ }^{278}$. Alguns Analistas consideraram a notícia como positiva, pois além de reforçar que a OGX estava próxima a se tornar operacional, o desconto do preço em relação ao Brent foi menor do que o esperado $\left(10 \%{ }^{279}\right.$ a $15 \%{ }^{280}$ do Brent para a bacia de Campos). Além desta venda, a Shell e a OGX também firmaram uma Carta de Intenções para explorar novas oportunidades em óleo e GN. Entretanto, os referidos Analistas não consideraram que o impacto no valor da OGXP3 seria significativo.

Fim do Ano. O tão esperado first oil de Waimea, anunciado originalmente para outubro sofreu atrasos por várias razões: condições climáticas, atrasos na entrega e/ou no licenciamento da FPSO. Em seu último Comunicado ao Mercado do Ano (14/12/2011), a OGX anunciou que a FPSO OSX-1 estaria preparada para iniciar a produção de Waimea (OGX-26HP) em 23 de janeiro de 2012.

Repercussões. Apesar dos atrasos em Waimea, alguns analistas mantiveram sua recomendação de "outperform". Waikiki, onde se localizaria TBMT deveria iniciar a produção em 2013. Entre 2009/11, a OGX havia perfurado 64 poços contra os 44 planejados.

A OSX era o tema "mais melindroso": como fazê-la deslanchar? O AC conseguiu um empréstimo do Fundo da Marinha Mercante de R\$ 2,7 bilhões a juros fixos de 3,38\%, com os avais do $A C^{281}$. No final de 2011, a E.ON. adquiriu $11,7 \%$ da MPX por R\$ 1,0 bilhão.

Em 2011, a Empresa manteve seu guidance otimista sobre sua campanha exploratória, com 47 poços perfurados, com uma taxa de sucesso média superior a $90 \%$. Ao longo de 2011, a Empresa publicou 17 FRs, a grande maioria com notícias positivas. O poço TBMT deveria iniciar a produção em 2013.

A OGX vem quebrando paradigmas desde que foi criada, há pouco mais de quatro anos, e estabelecendo novos parâmetros para indústria do petróleo mundial (...) Ninguém ousou tanto quanto a OGX e os resultados não demoraram a aparecer: descobertas de bilhões de

\footnotetext{
277 Relatado por AUDI \& FALANGA NETO, 2011j, p. 2.

${ }^{278}$ AUDI \& FALANGA NETO [2011j] estimou que um desconto de $5 \%$ em relação ao Brent equivalia a cerca de US\$ 4,0 a menos por barril.

${ }^{279}$ KOVARSKY \& MENDES [2011p].

280 AUDI \& FALANGA NETO [2011h].

281 GASPAR, 2014, p. 317.
} 
barris em Campos, Santos e Parnaíba, produção em ritmo intenso em Waimea, primeiros contratos de comercialização assinados (...) [DFP, 2011, p. 3].

Na Amostra da TR, ao longo de todo o ano de 2011, o mercado se tornou mais pessimista do que a mediana dos Analistas. A partir de 5/5, o mercado precificou a OGX abaixo do PA dos Analistas mais pessimistas. Os Analistas otimistas parecem ter ficado alienados do mercado e até mesmo da mediana de seus colegas. O que o mercado estava considerando que os Analistas parecem ter relevado? Talvez a resposta esteja na credibilidade do guidance. De fato, alguns Analistas explicitamente relataram que, "nos últimos meses, com a desvalorização das ações da OGX, a credibilidade do grupo [EBX] estava sendo cada vez mais questionada (...)"282.

\section{Gráfico 37 - Amostra da TR: Evolução da Mediana, Máximo e Mínimo do PA em 2011 (em} $\mathbf{R}$ /ação)

OGPXP3, PA High, PA Low e PA Mediana

$$
\text { (R\$ / Ação) }
$$

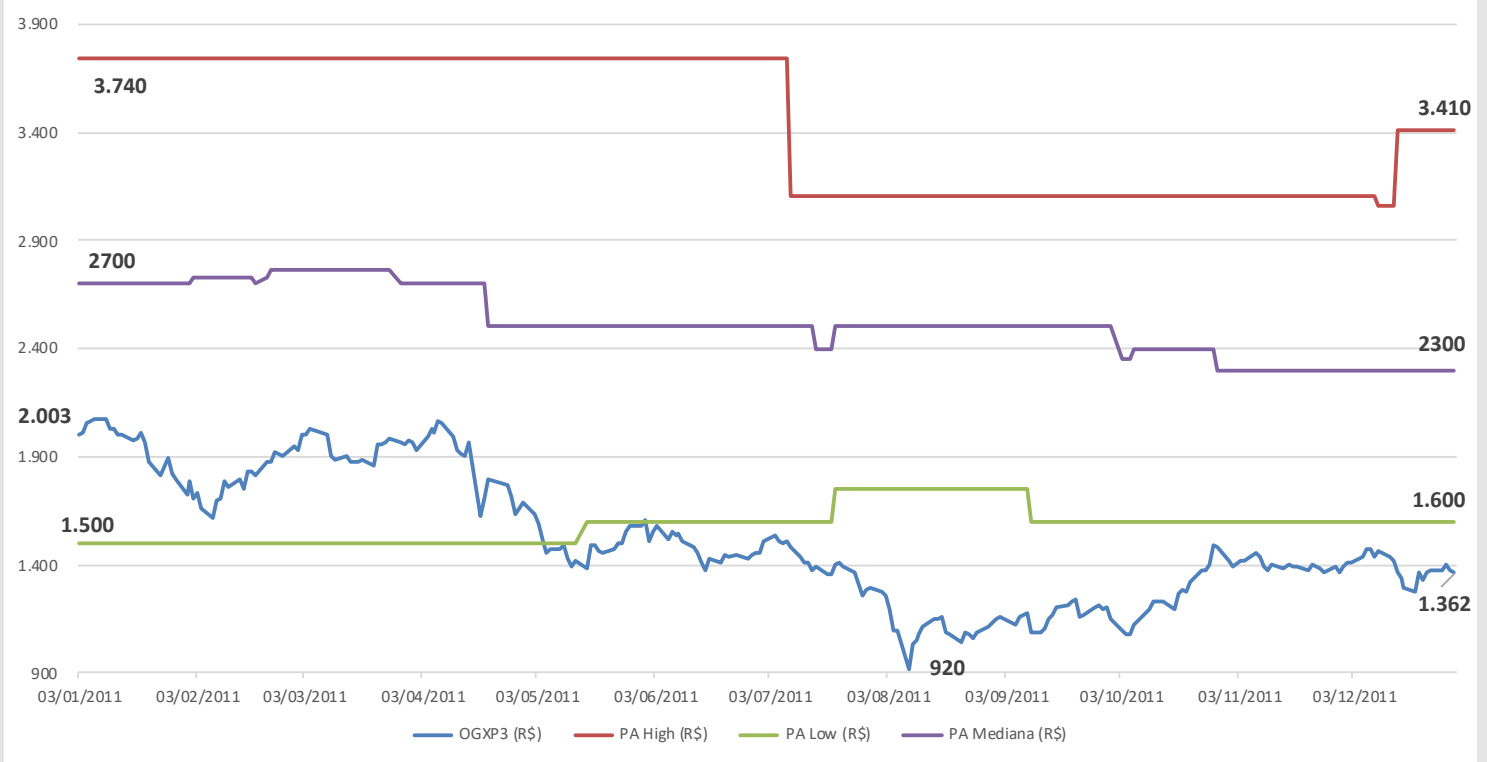

${ }^{282}$ AUDI \& FALANGA NETO, 2011a, p. 1. 


\title{
3.5 2012: Start-up Operacional e Substituição de Executivos
}

\author{
"Avaliar um barril de petróleo não é uma tarefa fácil. \\ A qualidade do óleo, tributação e custos de \\ desenvolvimento e produção têm significativas \\ implicações na avaliação de hidrocarbonetos. A \\ produtividade do poço geralmente afeta os custos de \\ desenvolvimento e produção que alimentam a \\ estória, enquanto que a falta de credibilidade \\ também confunde o quadro." \\ GATTASS, CARVALHO \& VALDIZAN, 2012a, p. 12. \\ "2012 foi um ano de grandes conquistas $e$ \\ importantes desafios para a OGX".
}

Relatório da Administração, DFP 2012 p. 1

Se 2011 se mostrou um ano ambivalente, com investidores impacientes e financiadores de longo prazo, 2012, especialmente no segundo trimestre, foi marcado por fraturas significativas no guidance, incluindo a substituição do CEO em 28/6. A 1a Correção Apreciativa, que começou em 8/08/2011, terminou no primeiro trimestre (23/02/2012). Impulsionada pelas expectativas do first oil e a captação do 2a Note, a Correção foi um "voo de galinha", após o qual o valor da OGXP3 não se recuperaria.

Evolução do Valor de Mercado em 2012: Voo de galinha

Como descrito anteriormente, entre 8/08/2011 ( $R \$ 9,20)$ e 24/02/2012 ( $R \$ 18,21)$, a OGXP3 se valorizou 97,9\% em 128 pregões. Mas, a partir de 24/02, se formou uma tendência depreciativa praticamente irreversível. A perda de valor de ponta a ponta do ano foi de $68,1 \%$, enquanto o IBOV se valorizou em $5,4 \%$ e o Brent se desvalorizou $1,0 \%$.

Pelo gráfico da OGXP3 destacam-se três marcos: o pico do ano em $24 / 2$ e as fortes depreciações após $7 / 5$ e 19/6. O pior momento foi entre 25/06 ( $R \$ 8,70$ ) e 28/06 (R\$ $5,05)$, quando a OGXP3 perdeu $42,0 \%$ de seu valor em três pregões. 
Gráfico 38 - Evolução da OGXP3 em 2012, em R\$̣ Nominais, pós-Split

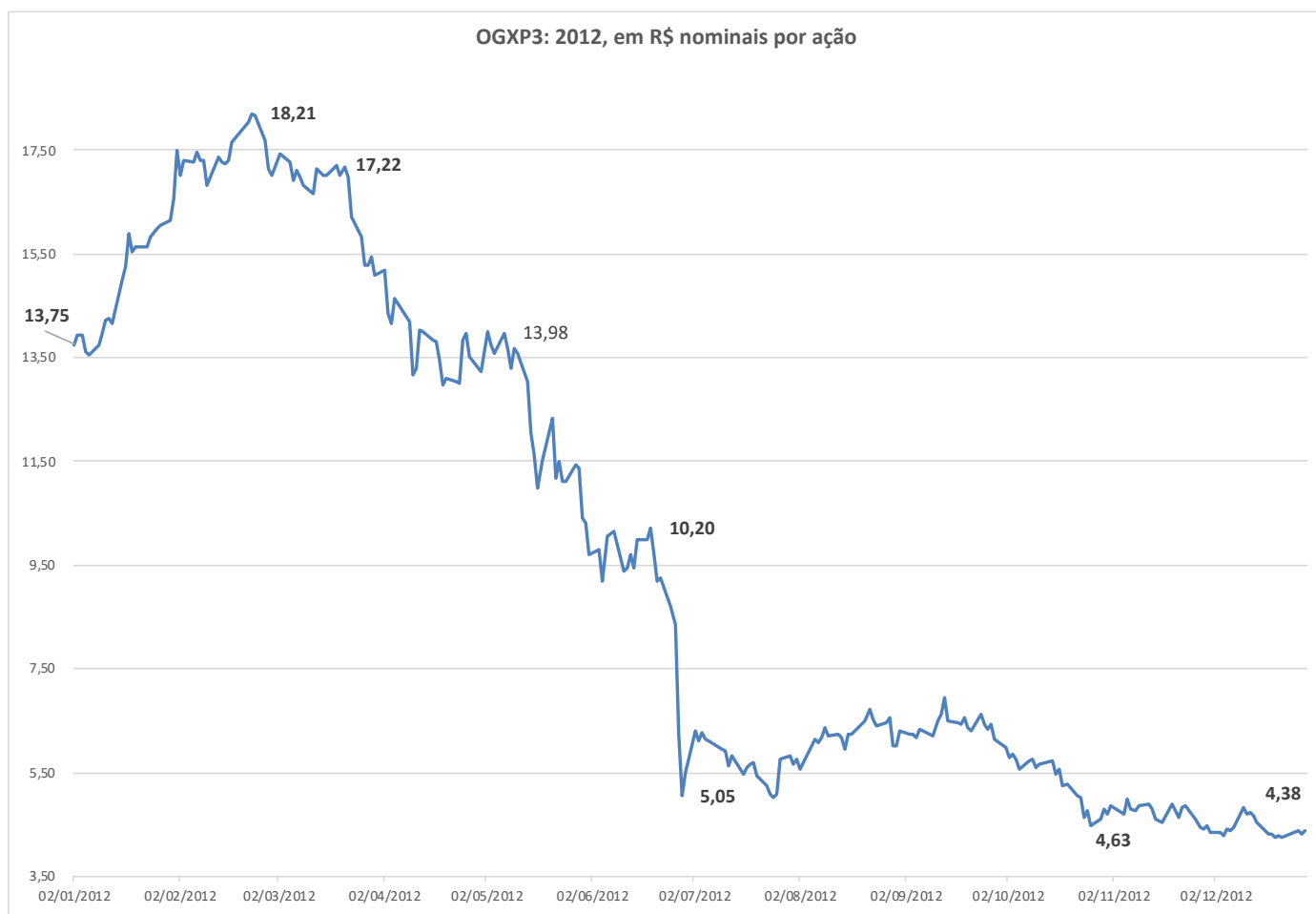

Entre novembro de 2011 e fevereiro de 2012, a OGXP3 experimentou uma valorização acima da do IBOV e do preço do Brent, que também se valorizaram no período. Mas, a partir de 14/02/2012 (US\$ 126,98/barril), o preço do Brent se depreciou significativamente até 25/06 (US\$ 88,69/barril), para depois se apreciar gradualmente até terminar o ano (US\$110,05/barril em 28/12) aos níveis próximos de janeiro (US\$ 111,12/barril, em 2/1). O crescimento da demanda por petróleo advinha do consumo nos países não-OCDE, uma vez que a demanda da OCDE era declinante ${ }^{283}$.

A forte depreciação do Brent entre março e junho pode ter contribuído para a depreciação da OGXP3, mas esta última se acentuou devido a mais uma crise de credibilidade no guidance gerada pelos resultados ruins da produção de TBAZ.

Em 15/05, a OGXP3, pela primeira vez desde o fim de 2008, se desvalorizou mais que o S\&P OGEP 600 e 1500 e nunca mais se recuperou.

${ }^{283}$ SEQUEIRA \& FONSECA [2012a]. 
Gráfico 39 - Evolução do S\&P OGPE 600, S\&P OGPE 1500, OGXP3 e Brent em 2012

$(12 / 06 / 2008=100)$

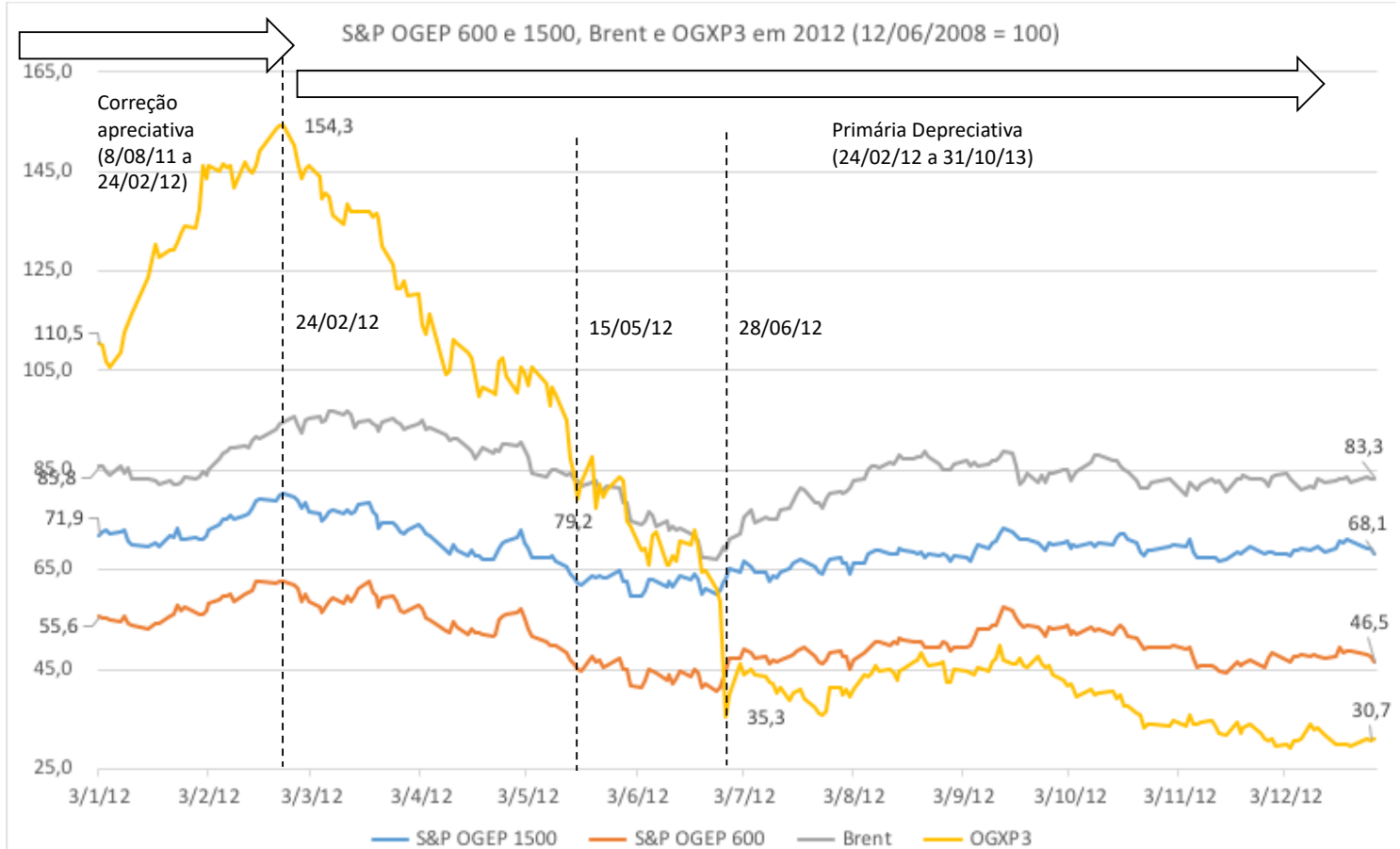

O início da produção TBAZ, esperado para outubro de 2011, só começou de fato em 28/01/2012. A OGX estimava que a produção durante o TLD fosse, em média, $15 \mathrm{kbpd}$.

\section{Gráfico 40 - Evolução da OGXP3, Brent e IBOV em 2012 (Base 100 = 12/6/2008 [IPO])}

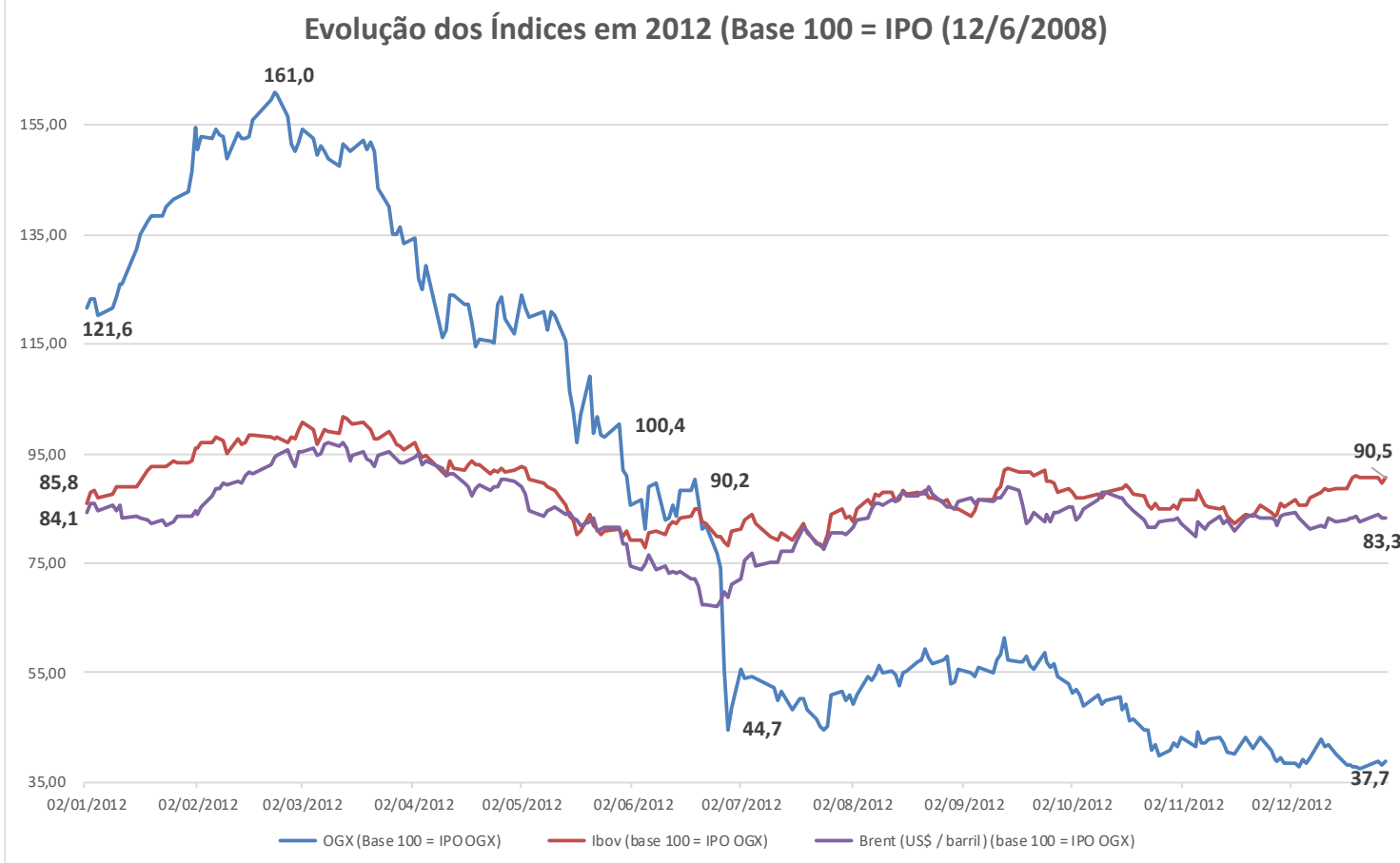


Os movimentos na OGXP3 afetaram diretamente o seu múltiplo de EV/2C que chegou a US\$ 0,78 em 28/6, ou seja, abaixo do valor de liquidação da Empresa se considerarmos o valor pago pelos BAs (US\$ 0,19). Ou seja, cerca de 3 anos e meio depois, após investir bilhões em sua campanha exploratória, a OGXP3 valia menos do que quando não havia perfurado seu primeiro poço.

\section{Gráfico 41 - Evolução do EV/2C da OGX em 2012 (em US\$̧/boe)}

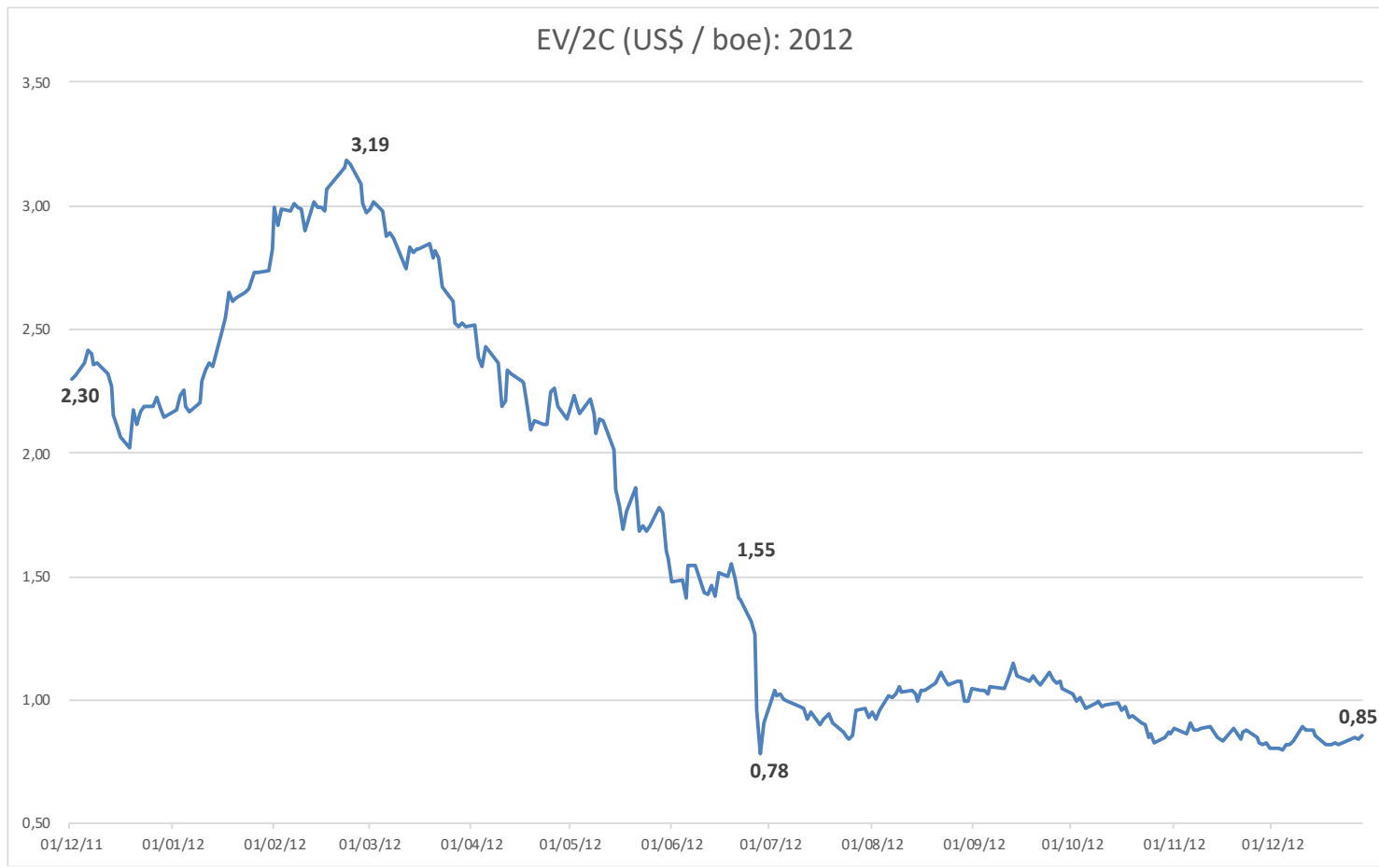

O colapso de valor da OGXP3 em junho também foi observado nos Notes. Os financiadores do OGXPBZ18 parecem ter alterado sua percepção de risco em maio de 2013, portanto ainda a tempo de viabilizar a emissão do 2 ㅇ Note (OGXPBZ22) em 30/3. 
Gráfico 42 - Evolução do Valor de Mercado do OGXPBZ 2018 em 2012

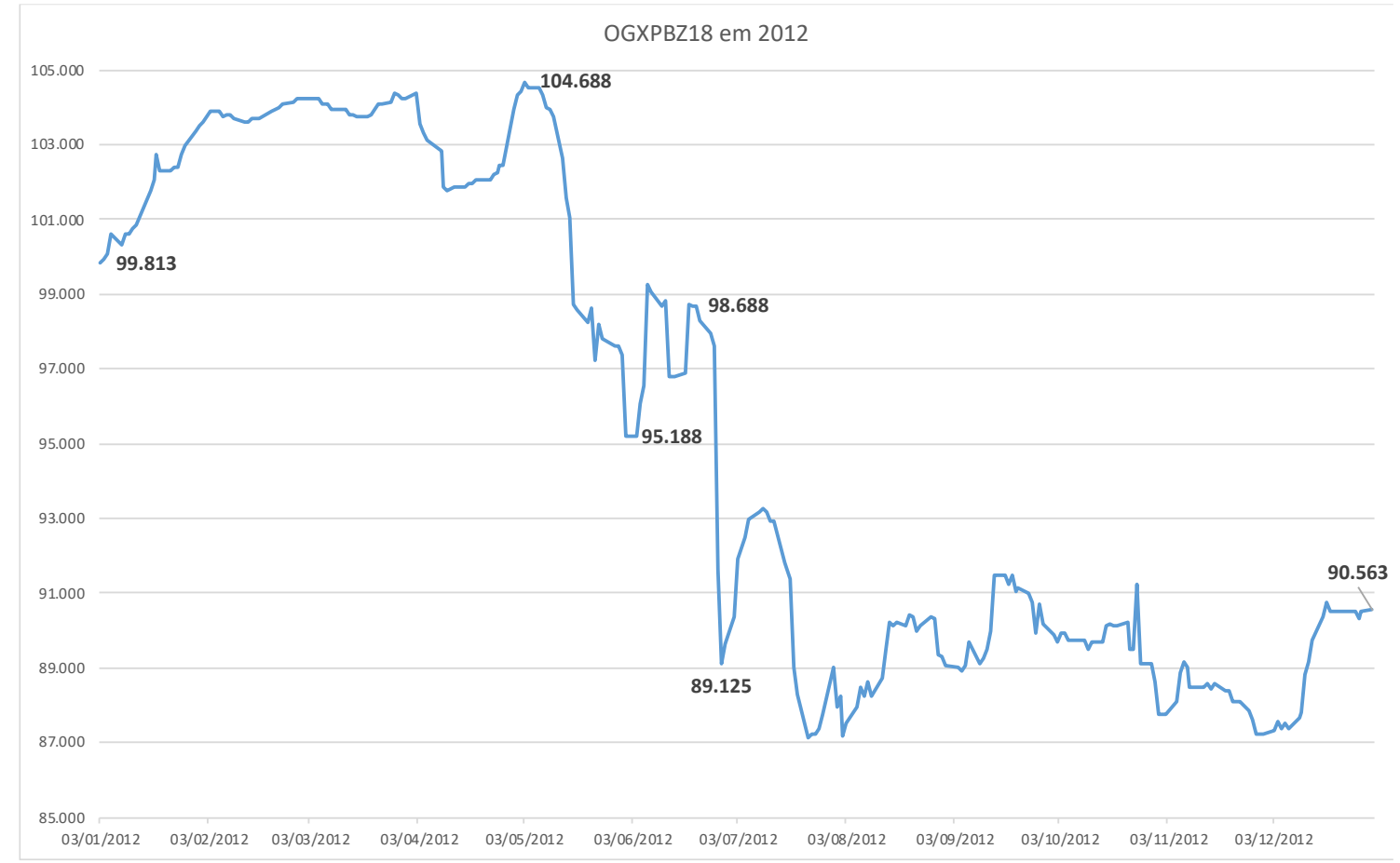

Como era esperado, por ser mais longo, a desvalorização sofrida pelo OGXPBZ22 foi mais acentuada (encerrou o ano a 84.313, ou seja, deságio de $15,7 \%$ ) do que o OGXPBZ18 (90.563 ou deságio de $9,44 \%$ ).

Gráfico 43 - Evolução do Valor de Mercado do OGXPBZ 2022 em 2012

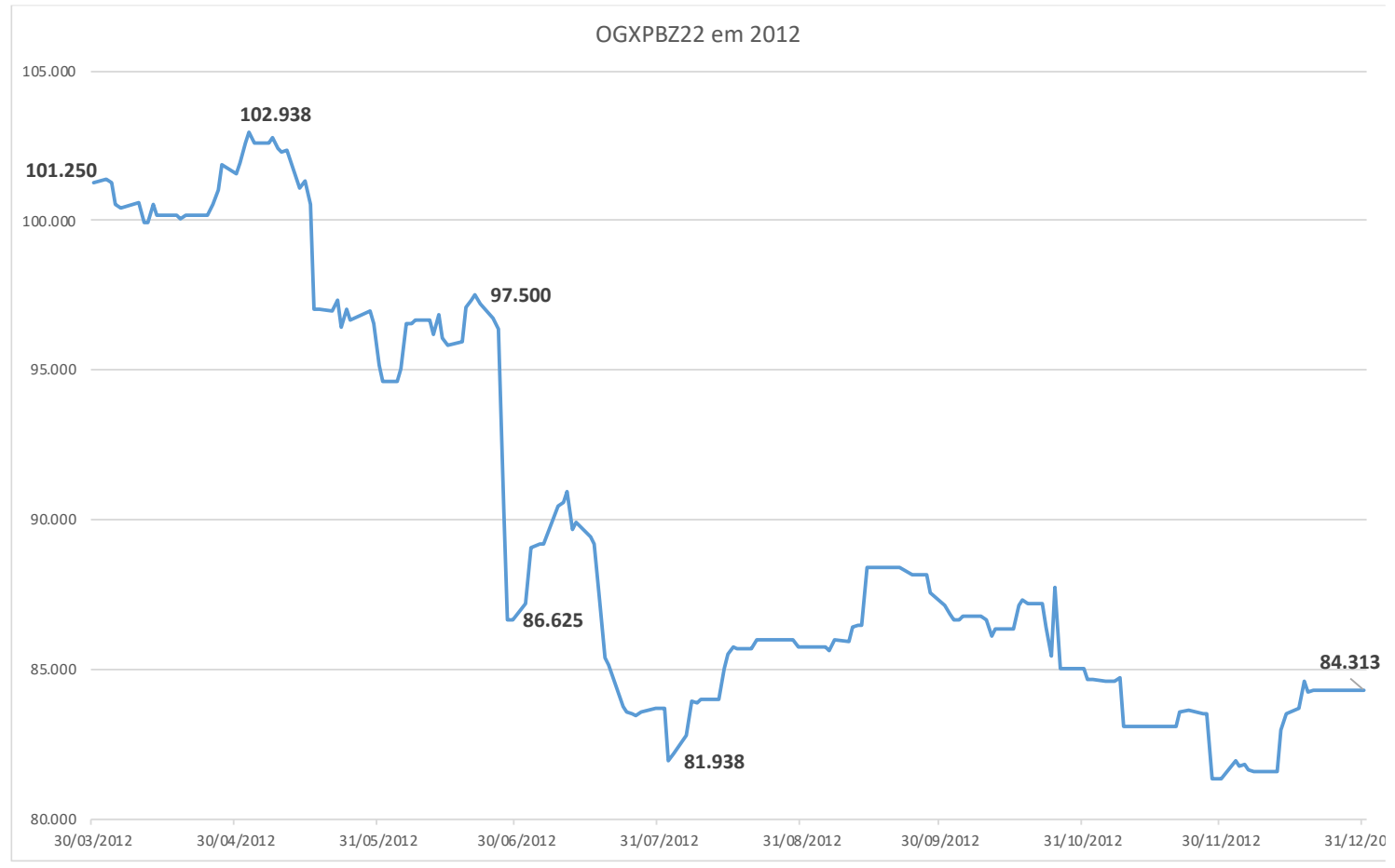




\section{Evolução do Guidance e suas Repercussões sobre os Analistas em 2012}

6/01. O primeiro poço perfurado na bacia do ES resultou seco.

Repercussões. No início de janeiro (6), duas notícias, uma boa e outra ruim. A boa foi que a PERENCO, sócia operadora da OGX nos blocos do ES, vendeu $10 \%$ destes para a Sinochem. Apesar de não ter o valor divulgado, a notícia foi interpretada por alguns Analistas $^{284}$ como positiva, pois a OGX teria um novo sócio capitalizado. A PERENCO buscava captar recursos financeiros, inclusive através de uma tentativa malsucedida de IPO em 2011. Essa notícia reforçava o interesse dos chineses no O\&G brasileiro.

A notícia negativa foi que o primeiro poço perfurado na bacia do ES (PERN-1, ao norte do bloco BM-ES-37) resultou seco. Apesar de não haver expectativas sobre o potencial do norte do bloco BM-ES-37, mas sim de sua parte sul, a notícia não foi boa ${ }^{285}$.

13/01. OGX Maranhão captou R\$ 600 milhões (com bridge do IBBA, SAN e MS, dos quais $R \$ 400$ milhões foram através de debêntures com vencimento em 13/01/2014) para financiar o desenvolvimento de Gavião Real e Gavião Azul (incluindo a UTE) ${ }^{286}$.

16/01. Descoberta de hidrocarbonetos no prospecto de Fortaleza (OGX-63, com coluna de 1.000 metros e net pay de 110 metros no BM-S-57), em Santos, cujo reservatório poderia conter 2,0 a 4,0 bboe.

Repercussões. Incialmente, o anúncio foi recebido com cautela por alguns Analistas, uma vez que a OGX não podia confirmar se tratava de óleo ou $\mathrm{GN}^{287}$. O IBBA 288 considerou a notícia neutra pelo excesso de oferta de GN e os gargalos na infraestrutura que impunham significativos obstáculos na monetização do GN na bacia de Santos. $O$ SAN ${ }^{289}$, por outro lado, considerou a descoberta significativa pela altura do net pay e da coluna. Em perfurações passadas, as colunas não ultrapassaram 195 metros de coluna. Apesar do GN inicial, havia a possibilidade de se encontrar óleo.

28/01. Início da produção no primeiro poço (OGX-26HP) de TBAZ, que inicialmente era esperado para outubro de 2011.

\footnotetext{
${ }^{284}$ AUDI \& FALANGA NETO [2012a].

285 KOVARSKY \& MENDES [2012a].

${ }^{286} \mathrm{O}$ empréstimo ponte de R\$ 600 milhões foi feito em parcelas idênticas pelos bancos IBBA, SAN e MS a um custo de $\mathrm{CDI}+2,3 \%$ a.a., $\mathrm{CDI}+2,3 \%$ a.a e Libor $+2,75 \%$ a.a., respectivamente. Os recursos providos pelo IBBA e pelo SAN foram captados através da emissão de debêntures quirografárias, não conversíveis, com distribuição pública destinada a investidores qualificados, nos termos do artigo 4 은 da Instrução CVM 476. Em 13 de janeiro de 2012 foram emitidas 40.000 debêntures com valor nominal global de $R \$ 400.000$ e vencimento em 13 de janeiro de 2014, com juros devidos semestralmente a partir de 13 de julho de 2012.

O financiamento junto ao MS foi obtido através da celebração de Credit Agreement em 13 de janeiro de 2012, nos termos da Resolução 4.131 do BACEN, num montante em US\$ equivalente a R\$ 200 milhões. Essa captação previa juros semestrais a partir de 13 de julho de 2012, e amortização do principal em 13 de janeiro de 2014

287 GASPAR, 2014, p. 328.

288 KOVARSKY \& MENDES [2012b].

${ }^{289}$ AUDI \& FALANGA NETO [2012b].
} 
30/01. Primeiro óleo do TBAZ, no primeiro dos três poços da "pequena Waimea": a OGX se tornou operacional em apenas dois anos após as descobertas.

Repercussões. No fim de 2011, havia rumores que a OGX estava protelando o TLD no TBAZ. A fase mais arriscada do processo de E\&P era a exploração e o potencial para geração de valor era imenso. Mas era crucial transformar descobertas em produção.

Apesar do atraso, começar a produzir após apenas dois anos da descoberta era uma conquista significativa ${ }^{290}$. Curiosamente, o tão esperado "primeiro óleo" de Waimea foi divulgado na forma de $\mathrm{CM}$ (31/01) e não de FR. Finalmente a OGX se tornava operacional, entretanto, alguns Analistas consideravam que, embora fosse uma boa notícia, esta já estava precificada ${ }^{291}$. Alguns Analistas projetavam que a Empresa poderia terminar o ano com lucro 292 .

A OGX estimava que a produção durante o TLD fosse, em média, $15 \mathrm{kbpd}$. Ainda em 1S2012, a Empresa pretendia enviar a Declaração de Comercialidade à ANP, incluindo planos para alcançar 40-50 kbpd no 2 S2012.

1/02. Duas semanas depois da descoberta em Fortaleza, a Empresa confirmou a presença de óleo de boa qualidade em reservatórios pré-sal em Santos (BM-S-57).

Repercussões. Originalmente, a D\&M estimava haver 1,8 bboe em recursos prospectivos nos blocos de Santos da OGX. Notícia veiculada em O Globo estimava que pudesse haver 4,0 bboe, somente no BM-S- $57^{293}$. Por estar em águas rasas, os custos de produção seriam menores do que os incorridos no pré-sal da PETR. A OGXP3 se valorizou 8,3\% em um único dia (de $\mathrm{R} \$ 16,15 \mathrm{em} 30 / 01$ para $\mathrm{R} \$ 17,49 \mathrm{em} 1 / 02$ ). Ainda seria preciso mais perfurações que poderiam levar de 4 a 5 meses para confirmar o que poderia ser uma grande descoberta, um "game-changer para a bacia de Santos", mas, desta vez, alguns Analistas recomendaram aguardar as confirmações antes de alterar o PA ${ }^{294}$.

Fevereiro. Ao longo do mês, a taxa do fluxo de TBAZ foi, na média, 11,6 kbpd, ou seja, no limite inferior do intervalo originalmente estimado entre $10-20 \mathrm{kbpd}$. A média, então, foi revisada para 10-13 kbpd por poço. A OGX insistia que terminaria $2012 \mathrm{com}$ uma produção média de $40-50 \mathrm{kbpd}$ com quatro poços. Executivos reiteraram a meta de produzir $150 \mathrm{kbpd}$ em 2013, com Waikiki (TBMT), onde se esperava uma taxa de fluxo maior do que TBAZ.

Repercussões. Os Executivos mantiveram o guidance otimista:

Estimamos manter a produção desse poço [TBAZ] em níveis entre 10 e 13 kbpd durante os próximos meses, sem contemplar ainda a injeção de água no reservatório (...) esperamos conectar os dois poços

\footnotetext{
290 KOVARSKY \& MENDES, 2012g, p. 2.

291 KOVARSKY \& MENDES [2012c].

292 KOVARSKY \& MENDES, 2012c, p. 1

293 Relatado por SEQUEIRA \& FONSECA [2012b].

294 KOVARSKY \& MENDES, 2012d, p. 1, e KOVARSKY \& MENDES, 2012g, p. 2. AUDI \& FALANGA NETO [2012b] também recomendaram cautela aos investidores.
} 
horizontais adicionais que devem elevar a produção para níveis em torno de 40-50 kbpd ao final de 2012 [OGX, DFP, 2011, p. 6].

A projeção de terminar 2012 com uma produção média de 40-50 kbpd com três poços seria um grande desafio frente aos resultados iniciais de Waimea. Na teleconferência, muitas questões feitas pelos Analistas permaneceram sem respostas. Como estas novas taxas afetariam as premissas de produção e investimentos, afinal, "a OGX considerava que Waimea seria uma boa referência para toda a bacia de Campos" ${ }^{295}$ ?

Os Executivos insistiam que era possível atingir a produção média de 40 a $50 \mathrm{kbpd}$ e considerava agregar um quarto poço à plataforma. Questionada sobre a viabilidade da meta de produzir 150 kbpd em 2013, a Empresa reiterou sua projeção. Aparentemente, a OGX esperava obter em Waikiki (TBMT) uma taxa de fluxo maior do que Waimea.

A OGX explicou que a decisão de produzir menos (10 a $13 \mathrm{kbpd}$ versus 15 a $20 \mathrm{kbpd}$ ) em Waimea foi técnica e visava proteger o reservatório, mas não afetaria, necessariamente, o volume total recuperável. Um fluxo mais elevado poderia aumentar a infiltração de água, contaminando o reservatório, como aconteceu em Polvo. Mas, considerando um mesmo preço de venda do óleo, a "suavização do fluxo" não teria impacto a valor presente ${ }^{296}$.

Entre 2009/11, a OGX havia perfurado 64 poços contra os 44 planejados. No total, até 2013, a Empresa planejava um total de 109 poços, contra 51 planejados na época do IPO.

295 KOVARSKY \& MENDES, 2012g, p. 2.

${ }^{296}$ KOVARSKY \& MENDES, 2012g, p. 9. 
Tabela 39 - Campanha Exploratória: Números de Poços Pioneiros e de Avaliação (Pioneer Wells and Appraisals)

\begin{tabular}{||l|c|c|c|c|c|c|c|}
\hline & $\mathbf{2 0 0 9 R}$ & $\mathbf{2 0 1 0 R}$ & $\mathbf{2 0 1 1 R}$ & $\mathbf{2 0 1 2 E}$ & $\mathbf{2 0 1 3 E}$ & Total & $\mathbf{\%}$ \\
\hline Atualização abr./12 & $\mathbf{6}$ & $\mathbf{2 6}$ & $\mathbf{3 2}$ & $\mathbf{2 6}$ & $\mathbf{1 9}$ & $\mathbf{1 0 9}$ & $\mathbf{1 0 0 , 0 \%}$ \\
\hline Campos & 5 & 18 & 18 & 12 & 2 & 55 & $50,5 \%$ \\
\hline Santos & 1 & 6 & 3 & 4 & 1 & 15 & $13,8 \%$ \\
\hline Parnaíba & - & 2 & 9 & 6 & 8 & 25 & $22,9 \%$ \\
\hline ES & - & - & 2 & 1 & 2 & 5 & $4,6 \%$ \\
\hline PA-MA & - & - & - & 2 & 3 & 5 & $4,6 \%$ \\
\hline Colômbia & & & & 1 & 3 & 4 & $3,7 \%$ \\
\hline & $\mathbf{2 0 0 9 E}$ & $\mathbf{2 0 1 0 E}$ & $\mathbf{2 0 1 1 E}$ & $\mathbf{2 0 1 2 E}$ & $\mathbf{2 0 1 3 E}$ & Total & $\mathbf{\%}$ \\
\hline Planejamento 2008 & $\mathbf{6}$ & $\mathbf{1 9}$ & $\mathbf{1 9}$ & $\mathbf{7}$ & - & $\mathbf{5 1}$ & $\mathbf{1 0 0 , 0 \%}$ \\
\hline Campos & 4 & 11 & 10 & 2 & - & 27 & $52,9 \%$ \\
\hline Santos & 2 & 8 & 4 & - & - & 14 & $27,5 \%$ \\
\hline Parnaíba & - & - & - & - & - & - & $0,0 \%$ \\
\hline ES & - & - & 3 & 3 & - & 6 & $11,8 \%$ \\
\hline PA-MA & - & - & 2 & 2 & - & 4 & $7,8 \%$ \\
\hline
\end{tabular}

Fontes: Planejamento 2008: Prospecto IPO. Realizados 2009 a 2011: SEQUEIRA \& FONSECA, 2012a, p. 10. Projeções 2012 e 2013: KOVARSKY \& MENDES [2012g].

No final de fevereiro, a valorização da OGXP3 se reverteu e seu valor nunca mais se recuperou. Alguns Analistas já não incluíam a OGXP3 entre seus "top picks" de O\&G no Brasil, preferindo a QGEP e até mesmo a volátil HRT ${ }^{297}$. Para eles, 2012 seria um ano crucial para as empresas brasileira de E\&P: o mercado aguardava os resultados da exploração da HRT (Solimões e Namíbia), QGEP (bacias de Santos e Jequitinhonha) e OGX (com a maior campanha entre as três empresas, com 64 poços perfurados).

A produção da PETR "continuava a desapontar, apesar dos investimentos pesados dos últimos anos". Apesar da aposta no pré-sal de Santos para o futuro da PETR, Campos ainda era a província mais importante, cuja produção declinava, sem explicações convincentes: pausas inesperadas para manutenção, declínio dos campos ou indisponibilidade de equipamentos para novos campos? Entre 2010 e 2011 a PETR aumentou apenas $1 \%$ sua produção média diária (para 2,022 mbpd) que ficou $4 \%$ abaixo da meta para o ano $(2,100 \mathrm{mbpd})$.

20/03. OGX aumentou sua participação de $50 \%$ para $70 \%$ nos blocos BM-C-37 e BM-C38 devido "ao excelente potencial das águas rasas" de Campos. Devido à proximidade geográfica, o aumento na participação societária poderia acelerar o desenvolvimento de Pipeline (com volume estimado entre 1,0 e 2,0 bboe) e Carambola. A OGX considerava que a região poderia ser uma nova "província".

297 Por exemplo, SEQUEIRA \& FONSECA [2012a]. 
Repercussões. Devido à proximidade com o BM-C-37, o aumento na participação societária poderia acelerar o desenvolvimento de Pipeline (com volume estimado entre 1,0 e 2,0 bboe) e Carambola. A aquisição refletiria o otimismo da OGX na "província".

Em contraste com o farm-in do BM-S-29, executado de graça à OGX em 2009 e 2010, o farm-in do BM-C-37 e BM-C38 envolveria um pagamento à vista além da assunção do PEM. Esse valor seria um indicador "de mercado" para o de-risking dos blocos. Entretanto, a divulgação do valor da parcela à vista, que fora prometida quando da divulgação do 1 T2012 em 23/03, não aconteceu ${ }^{298}$. Os Analistas do IBBA ${ }^{299}$ estimaram que se este valor não fosse um montante considerável, o mercado poderia considerar o farm-in como "destruidora de valor". Se a OGX tivesse pagado barato, isto poderia ser interpretado pelo mercado como uma proxy para o valor dos volumes em Campos. Somente dois poços (Carambola A e B) haviam sido perfurados no BM-C-37, porém se ele de fato contivesse $1 / 3$ de Pipeline, a MAERSK não deveria vender barato sua participação.

Os Analistas do SAN ${ }^{300}$ ponderaram que quando a MAERSK vendeu sua participação no BM-S-29 para a OGX, os investidores se perguntaram por quê. Na época, a OGX explicou que as duas empresas tinham visões diferentes sobre o potencial do bloco e a MAERSK não queria arcar com o restante do PEM. Um mês depois, a MAERSK comprou três blocos em Campos da SK Energy com 35 mboe de reservas 2P e produção diária de $10 \mathrm{kbpd}$ (campo de Polvo). Ou seja, a MAERSK preferiria a certeza de reservas em produção do que a incerteza inerente às campanhas exploratórias.

Apesar do feito da OGX se tornar operacional em dois anos após as descobertas, em março, os Analistas aguardavam ansiosos pelas taxas de fluxo (flow rates) do petróleo que iriam determinar volumes de produção, investimentos, fatores de recuperação (recovery factors). No final de março (23/03), este foi o tema central de uma teleconferência sobre os resultados do 4T2011.

23/03. Divulgação dos resultados do 4T2011: prejuízo contábil R\$ 321 milhões, incluindo despesas com o primeiro write off da OGX.

Repercussões. Na teleconferência, alguns Analistas não enfatizaram a taxa do fluxo de Waimea, mas sim o prejuízo contábil no 4T2011 de R\$ 321 milhões, muito acima do esperado, que seria um lucro de $\mathrm{R} \$ 1$ 19,5 milhões $^{301}$. O maior responsável pela diferença seriam despesas com exploração (em Campos, Santos e ES) de R\$ 301 milhões contra a projetação de $\mathrm{R} \$ 53$ milhões. Estas despesas incluíam o reconhecimento da perda (write off) de: quatros poços ( 3 em Santos e 1 em Campos), três na Parnaíba e do total das despesas exploratórias no PA-MA (R\$ 196 milhões). Segundo a OGX, a perda no PA-MA

\footnotetext{
298 KOVARSKY \& MENDES, 2012f, p. 2.

299 KOVARSKY \& MENDES, 2012e, p. 1.

${ }^{300}$ AUDI \& FALANGA NETO [2012d].

${ }^{301}$ SEQUEIRA \& FONSECA [2012c].
} 
deveu-se ao atraso na aprovação da licença ambiental, requisitada em janeiro de 2011 e ainda não concedida ${ }^{302}$.

No pregão, a OGXP3 perdeu 4,5\% de seu valor (de $\mathrm{R} \$ 16,99$ para $\mathrm{R} \$ 16,22$ ). A perda em valor de EV foi de R\$2,31 bilhões ou US\$1,27 bilhões.

28/03. Conclusão da segunda emissão de Unsecured Notes: captação de US\$ 1,063 bilhão (equivalente a $\mathrm{R} \$ 1,937$ bilhão, por 10 anos, com vencimento bullet em abril de 2022, com juros de $8,375 \%$, pagos semestralmente).

Entrega da primeira carga de 600 mil barris do TBAZ (US\$ 145 milhões em receitas) para a Shell.

Repercussões. A baixa de $\mathrm{R} \$ 196$ milhões do 4T2011 poderia ter sido um sinal negativo para os financiadores, pois indicava que o valor contábil dos ativos poderia vir a sofrer novas revisões afetando o risco de crédito. Entretanto, o valor do OGXPBZ18 não foi afetado e a emissão da 2a. Note da OGX foi concluída com juros em linha com o da anterior $\left(8,5 \%\right.$, com vencimento em 2018) ${ }^{303}$. A segunda captação em menos de 12 meses atestava o "sólido acesso da Empresa ao mercado de financiamentos, que poderiam ser garantidos pelos seus ativos em Campos e pelo início de sua produção" ${ }^{304}$.

Os recursos do 2 ․ Note seriam usados na campanha exploratório de Campos (BM-C-37 e BM-C-38) e Santos, além de manter uma reserva em caixa para aproveitar novas oportunidades de aquisição. Segundo alguns Analistas ${ }^{305}$, a estrutura de capital da OGX (35\% de dívida/patrimônio) teria espaço para captações adicionais se estas fossem necessárias.

Possivelmente, a má notícia da primeira baixa de ativos foi compensada com a primeira carga de 600 mil barris de Waimea entregue à Shell no mesmo dia. A expectativa era que as duas cargas renderiam US\$ 145 milhões em receitas para a OGX. Waimea era considerada pela OGX como uma boa referência para a média do resto da bacia de Campos $^{306}$.

4/04. OGX anunciou que novas captações poderiam envolver o BNDES e Project Finance, como fora feito na Parnaíba.

Conferência no Rio de Janeiro, os Executivos anunciaram que a Declaração de Comercialidade do TBAZ, que poderia conter $150 \mathrm{mboe}^{307}$, seria anunciada até o final do mês. $O$ segundo poço de TBAZ seria conectado também até o final do mês. O terceiro poço seria conectado em agosto.

\footnotetext{
302 KOVARSKY \& MENDES, 2012g, p. 12, relatam que o IBAMA requisitava muitos estudos para emitir as licenças que estavam "emperradas" (deadlock), o que levou o IBBA a desconsiderar o potencial de PAMA na sua estimativa do PA.

${ }^{303}$ AUDI \& FALANGA NETO [2012e].

${ }^{304}$ AUDI \& FALANGA NETO, 2012e, p. 1.

305 AUDI \& FALANGA NETO [2012e].

${ }^{306}$ KOVARSKY \& MENDES, 2012g, p. 2.

${ }^{307}$ Estimativa de KOVARSKY \& MENDES, 2012g, p. 9.
} 
A produtividade do primeiro poço do TBAZ deveria melhorar da média de 11 para 18 kbpd com uma mudança na bomba do poço. Os Executivos ponderaram que $11 \mathrm{kbpd}$ não era uma baixa produtividade se comparada com outros poços no Brasil e com a estimativa inicial da D\&M (3 a 5 kbpd). Segundo eles, no Brasil, não haveria mais de 20 poços com $11 \mathrm{kbpd}$ de produtividade. Metas de produção para 2013/15 foram reiteradas. Para cumprir 2015 (730 kbpd), o SAN estimava que a Empresa precisaria de 8 FPSOs, dos quais apenas 5 já haviam sido encomendadas à OSX. A D\&M emitiria um novo relatório em 1S2013, que incluiria descobertas no pré-sal dos blocos adquiridos da MAERSK (BM-C-37 e BM-C-38). Com base neste relatório, a Empresa consideraria rever seu plano de negócio.

Além dos 1,2 milhão de barris já vendidos para a Shell, a OGX teria vendido outros 0,4 a 0,5 milhão de barris por um preço mais alto (porém não divulgado).

Campanhas exploratórias em $\mathrm{ES}^{308}$, PA-MA e Colômbia avançavam. Dos cinco blocos da OGX no PA-MA, os Executivos consideravam que dois teriam alto potencial. OGX participaria da 11a Rodada, no 2S2012, e Colômbia.

Repercussões. Em 4/04, o principal Executivo, responsável pela campanha de exploração e na época também CEO da OGX, liderou um roadshow no RJ, considerado "produtivo" por alguns Analistas ${ }^{309}$. Além dos temas descritos acima, os Executivos informaram que, em 15 dias, a OGX divulgaria os resultados do OGX-74 na acumulação de Natal (BM-S-59) em Santos. Em 2 meses (junho), a OGX divulgaria os resultados do OGX-63 (Fortaleza). Mas, na ocasião do roadshow, a Empresa ainda não havia divulgado o valor pago à MAERSK pelo BM-C-37 e BM-C-38.

Segundo alguns Analistas ${ }^{310}$, a falta de respostas claras combinada com "expectativas demasiadamente otimistas" baseadas em informações preliminares que a OGX havia divulgado explicavam a evolução do preço da OGXP3 abaixo do IBOV (entre março de 2011 a março de 2012).

12/04. Descoberta de óleo leve em Fortaleza.

Repercussões. O anúncio da descoberta de óleo leve (38 API) ocorreu poucos dias depois do roadshow e bem antes do estimados pelos Executivos. O anúncio foi considerado positivo, "pois até então o mercado considerava Santos como uma bacia de GN".

Mas poucos dias após o roadshow (e a descoberta em Fortaleza), o IBBA reduziu seu PA

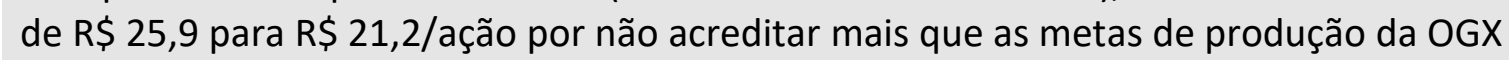
eram factíveis ${ }^{311}$. A Empresa se encontrava em um "ponto decisivo" (turning point), ao se aproximar da produção, com 78 poços perfurados desde o início de sua campanha

308 De acordo com o relato de KOVARSKY \& MENDES, 2012g, p. 12, os primeiros dois poços perfurados atendiam os requerimentos da ANP. Os blocos a sudeste da bacia poderiam ser mais prolíficos, dadas as descobertas da PETR nos poços de Brigadeiro e Indra.

${ }^{309}$ AUDI \& FALANGA NETO [2012f].

310 KOVARSKY \& MENDES, 2012f, p. 1.

${ }^{311}$ KOVARSKY \& MENDES [2012g]. 
exploratória, com a notável POS de 90\%. Enquanto a OGX insistia em $730 \mathrm{kbpd}$ em 2015, o IBBA que já havia reduzido sua projeção para $550 \mathrm{kbpd}$, agora considerava $345 \mathrm{kbpd}$ (12 kbpd/poço em Waimea). A estimativa considerava que apenas Campos estaria produzindo (com $5 \mathrm{FPSOs}^{312}$ ).

Sistemas produtivos em outras bacias, se confirmados, poderiam produzir a partir de 2015. "Era provavelmente muito cedo para estimar o tamanho da acumulação do présal descoberta pela OGX em Santos" ${ }^{313}$. Adicionalmente:

Nós estamos particularmente preocupados com a [não] divulgação do pagamento à vista referente à aquisição dos $20 \%$ adicionais dos blocos operados pela Maersk (BM-C-37 e BM-C-38) agregando mais incerteza sobre o valor dos barris de Campos [KOVARSKY \& MENDES, 2012g, p. 1].

O sucesso exploratório na bacia de Campos é surpreendentemente positivo, levando a Empresa a contratar a implantação de cinco sistemas de produção naquela bacia, mas as expectativas de produção para as outras bacias foram demasiadamente otimistas (...) A bacia de Santos ganhou momento com as recentes descobertas no pré-sal, mas estudos adicionais são necessários para estimar a qualidade e o potencial das descobertas. O desenvolvimento da bacia do ES ainda é um ponto de interrogação devido aos poços secos, e ainda não há cronograma de obtenção das licenças necessárias para iniciar as perfurações na bacia do PA-MA [KOVARSKY \& MENDES, 2012g, p. 2].

Em Santos, resultados de perfurações adicionais poderiam demorar pelo menos 5 meses. Apesar de localizada em águas rasas (155 metros), as perfurações na área são particularmente desafiadoras por causa da alta pressão. Outras empresas (XOM e BG) perderam poços na área devido a gas kicks ou pressão excessiva. O 3 D\&M estimava o potencial total dos blocos de Santos em 1,8 bboe, mas não fornecia detalhes dos prospectos, tampouco quais seriam os percentuais de óleo e GN. As descobertas até então estimavam entre $70 \%$ e $80 \%$ de $\mathrm{GN}$ e $20 \%$ e $30 \%$ de condensados. Analistas estimavam que poderia haver $30 \%$ de óleo (0,54 bboe). A monetização do GN era duvidosa (5 Tcf) e exigiria uma UTE de $6 \mathrm{GW}$.

Havia outro risco também: a unitização. A OGX acreditava que seu reservatório em Santos poderia se estender além da área concedida. Nenhum dos blocos vizinhos aos da OGX haviam sido leiloados, portanto ainda pertenciam ao Governo. Se o potencial do pré-sal for confirmado na região, o Governo poderia então definir "áreas estratégicas" e

312 KOVARSKY \& MENDES [2012g, p. 10] consideravam que cada conjunto, formado por uma FPSO e uma WHP, poderiam produzir 400 mboe durante a vida útil do projeto, de cerca de 25 anos. Portanto, para explorar os 3 bboe (3C) de Campos seriam necessários 8 conjuntos. OSX-1 e OSX-2 estariam alocadas nos dois campos de Waimea (o "pequeno" e o "grande", que seriam estruturas distintas com pressões diferentes), e OSX-3 e o WHP2 em Waikiki, OSX-4 no complexo FITTO (Fuji/llimani/Tupungato/Tambora/Osorno), OSX-5 em Pipeline.

${ }^{313}$ KOVARSKY \& MENDES, 2012g, p. 1. 
submetê-las a novos leilões dentro do regime de PSC. A capitalização da PETR em 2010 com áreas do pré-sal surgiu com a questão da unitização ${ }^{314}$.

25/04. OGX declarou a comercialidade do TBMT (OGX-25, acumulação de Waikiki [BMC-39]) com 285 mboe.

Repercussões. O volume declarado surpreendeu os Analistas: a D\&M havia estimado o potencial de Waikiki em 212 mboe (2C) e 312 mboe (3C). Aparentemente, a ANP não definia um padrão de qualificação de volume. A PETR, por exemplo, geralmente utilizava a estimativa $3 C$, que se tornaria $3 P$ uma vez declarada sua comercialidade. Mas, de acordo com a OGX, os 285 mboe seria a estimativa da Empresa para o volume $2 \mathrm{C} / 2 \mathrm{P}^{315}$. Com base nas informações da própria OGX, os Analistas esperavam que a primeira Declaração de Comercialidade seria de TBAZ, onde o TLD já durava cerca de três meses, já com o segundo poço conectado à OSX1-FPSO.

A Declaração de TBMT ocorreu mais de um ano antes da chegada programada da plataforma que garantiria o início da sua produção. Aparentemente, após a aprovação da Declaração (poderia demorar 180 dias), a OGX já iniciaria a perfuração de três poços conectados à FPSO-OSX-3 em 4T2013 (WHP2 chegaria em 1T2014), e não conduziria o TLD.

14/05. OGX declarou a comercialidade do TBAZ com 110 mboe recuperáveis ${ }^{316}$. A Empresa também revelou que o fluxo em TBAZ em março foi de 10,4 kbpd, contra 11,6 kbpd em fevereiro.

Repercussões. A tão esperada Declaração de Comercialidade do TBAZ decepcionou a expectativa de alguns Analistas que esperavam 150 mboe $(2 \mathrm{C})^{317}$. O volume total recuperável para todo o complexo de Waimea, na época, era estimado em 700 mboe (dos quais $30 \%$ estariam no pré-sal), mas TBAZ seria apenas uma pequena parte do complexo.

A OGX também anunciou o prejuízo do 1T2012 (R\$ 132,4 milhões, abaixo da expectativa de prejuízo $\mathrm{R} \$ 105$ milhões), mas a GS e o DB consideravam que resultados trimestrais não deveriam ser interpretados catalisadores para a OGX devido ao seu status préoperacional $^{318}$. A partir da Declaração de Comercialidade de TBAZ, pelo IFRS, a OGX poderia contabilizar as receitas oriundas das vendas para Shell, que no 1 T2012 somaram R\$ 118 milhões.

Perante a ANP, a OGX tratava Waimea como duas estruturas separadas, o que implicava em uma alíquota de SPT mais baixa. Como tal, a ANP poderia contestar tal tratamento, como já estava fazendo com outras áreas da PETR ${ }^{319}$.

\footnotetext{
${ }^{314}$ KOVARSKY \& MENDES, 2012g, p. 5-8.

${ }^{315}$ KOVARSKY \& MENDES [2012h].

${ }^{316}$ KOVARSKY \& MENDES [2012j, p. 2] explicam que a estimativa considerava quatro poços, incluindo injeção de água.

317 KOVARSKY \& MENDES [2012i].

318 MATTAR et al., 2012a, p. 1; SEQUEIRA \& FONSECA [2012d].

${ }^{319}$ KOVARSKY \& MENDES [2012i].
} 
A Empresa também revelou que o fluxo em TBAZ em março foi de 10,4 kbpd, contra 11,6 kbpd em fevereiro, o que não surpreendeu alguns, que consideraram "em linha com as expectativas da empresa" ${ }^{320}$. Vale notar também que esse volume foi atingido sem injeção de água e que a Declaração de Comercialidade permitiria à OGX perfurar poços horizontais, o que aumentaria a produção ${ }^{321}$. "Todos os olhos estavam voltados à produtividade do segundo poço" (OGX-68), que deveria ficar próxima à do primeiro (1112 kbpd $)^{322}$.

15/05. Durante conferência em Nova lorque, os investidores voltaram a questionar a OGX sobre Vesúvio: “onde está Vesúvio"? Em 2009, Vesúvio era um dos focos da Empresa que estimou que a acumulação teria entre 0,5 e 1,5 bboe. Os Executivos explicaram que outras descobertas ganharam prioridade e que, por se tratar de uma região vulcânica, "onde a geração de imagens era relativamente difícil"323.

Repercussões. O IBBA relatou que em Nova lorque, o âmago das discussões entre a Empresa e os investidores foi a extrapolação (o "read across") dos resultados da TBAZ para o resto do portfólio de Campos, o que pode ser uma extrapolação "exagerada" ${ }^{324}$. Entretanto, a soma dos volumes de Waimea (110) e Waikiki (285) declarados à ANP ficava aquém dos 700 mboe $2 C$ estimados pelo 3은 o que causava desconforto entre os Analistas. Seriam necessárias outras Declarações de Comercialidade (que não estavam programadas) ou um novo relatório da D\&M (que só deveria acontecer no 1T2013).

29/05. Em entrevista à Reuters, o CEO da OGX divulgou que a taxa do fluxo de TBAZ foi de $8,5 \mathrm{kbpd} /$ poço, na média de dois poços, portanto abaixo dos 10 a $13 \mathrm{kbpd}$ anunciados no final de março. O Executivo explicou que esta média de 8,5 se referia "a um dia em específico" ${ }^{325}$, portanto não deveria ser extrapolada para o mês. O CEO confirmou que a produção de 40 a 50 kbpd não seria alcançada em 2T2013, uma vez que o terceiro poço seria conectado no 2 S2012 e o quarto poço em 1 T2013.

Repercussões. Alguns Analistas reconheceram que a má notícia de fluxo de março iria afetar negativamente a OGXP3, pois o mercado iria questionar as estimativas $2 \mathrm{C}$ e $3 \mathrm{C}$ para toda a bacia de Campos, entretanto mantiveram suas estimativas de $\mathrm{PA}^{326}$. Não havia catalisadores à vista. Os Analistas aguardavam notícias sobre as perfurações em Pipeline (que se tornara uma prioridade) e Vesúvio. Resultados para Santos não eram esperados nos próximos 4 meses.

13/06. Descoberta de óleo no pré-sal de Campos, no prospecto de Honolulu (BM-C-43).

Repercussões. A descoberta "poderia ser um novo potencial na área". Entretanto, o mercado ainda desconfiava do volume 2 C da OGX, que só deveria ser confirmado pela

\footnotetext{
${ }^{320}$ AUDI \& FALANGA NETO, 2012g, p. 2.

321 SEQUEIRA \& FONSECA [2012d].

322 MATTAR et al., 2012a, p. 1; AUDI \& FALANGA NETO [2012g].

323 KOVARSKY \& MENDES, 2012j, p. 4.

324 KOVARSKY \& MENDES, 2012j, p. 1.

${ }^{325}$ AUDI \& FALANGA NETO, 2012h, p. 2.

${ }^{326}$ KOVARSKY \& MENDES [2012k].
} 
D\&M em 2013. Mas alguns Analistas esperavam que novas Declarações de Comercialidade (por exemplo, Pipeline, Vesúvio, Carambola, etc.) pudessem ser submetidas até março de 2013, quando expirariam as licenças de exploração da OGX em Campos $^{327}$.

Mas alguns Analistas começaram a rever seus PAs, pois, na fase de desenvolvimento, o risco da execução aumentaria. Além do inerente risco geológico, a OGX ainda não havia contratado todos os equipamentos que necessitaria. Em 21/6, o SAN, por exemplo, reduziu seu PA em 40,5\% em relação à sua última revisão de 8 meses atrás (de $R \$ 21,0$ em $3 / 10 / 2011$, para $R \$ 12,5 /$ ação) $)^{328}$. O novo PA correspondia a $62,1 \%$ do valor do PA no início da cobertura ( $R \$ 33,0$ em 26/10/2010).

Estamos rebaixando nossa recomendação para OGX de Comprar para Manter baseado em nossa nova e mais conservadora abordagem na modelagem da OGX, além da ausência de catalisadores potenciais para a ação. Apesar do forte histórico dos resultados exploratórios da OGX desde seu IPO em 2008 e da sua sólida posição financeira, nós acreditamos que uma análise mais atualizada da OGX merece uma abordagem mais conservadora na transição da Empresa para a fase operacional [AUDI \& FALANGA NETO, 2012i, p. 1].

26/06. Os Executivos declararam que após o término de cinco meses de TLD, a vazão ideal de $5 \mathrm{kbpd}$ por poço (sem injeção de água) para os dois primeiros poços (OGX-26HP e OGX-68HP), bem abaixo dos $20 \mathrm{kbpd}$ anunciado pela OGX em setembro de 2011.

Repercussões. A teleconferência de $26 / 6$ foi um derradeiro marco para a credibilidade do guidance. O valor da OGXP3 despencou 39,7\% em dois dias ( $R \$ 8,37$ em 26/6 para $R \$$ 5,05 em 28/6). Em relação ao seu último pico em 19/6/2012 (R\$ 10,20), sete pregões antes, a OGXP3 havia perdido 50,5\% de seu valor.

Reservatórios de carbonatos podem ser traiçoeiros como testemunhamos da experiência e desafios de outras empresas de petróleo com reservatórios de carbonatos na bacia de Campos. $O$ otimismo dos executivos da OGX, mais uma vez, atuou contra a OGX. No nosso modelo, nós adotamos taxas conservadoras (cerca de 5 kbpd), que devem estar entre as mais conservadoras do mercado, mas nós consideramos uma redução em nossas premissas de volume total recuperável [SEQUEIRA \& FONSECA, 2012e, p. 1].

Mesmo os Analistas "ponderados" acabaram por reduzir seus PAs significativamente, porém mantendo recomendação de compra. Alguns Analistas ajustaram seus PAs rapidamente. O SAN, que havia reduzido seu PA em 21/6 (de $\mathrm{R} \$ 21,0$ em 3/10/2011, para $\mathrm{R} \$ 12,5)$, o reduziu novamente em $26 / 6$ para $\mathrm{R} \$ 9,50 /$ ação, mesmo considerando

${ }^{327}$ KOVARSKY \& MENDES [2012I]; AUDI \& FALANGA NETO [2012i].

328 AUDI \& FALANGA NETO [2012i] reduziram o volume de Campos de 3,7 para 2,3 bboe (0,5 bboe Waimea, 0,6 Waikiki, 0,7 Pipeline, 0,5 Vesúvio) e 0,65 bboe em Paranaíba. Nenhum volume foi considerado para PA-MA, ES e Colômbia. WACC real de 10,5\% 
que com a injeção de água, a taxa média seria de $6 \mathrm{kbpd}$, e $7 \mathrm{kpdb}$ para Waikiki, Pipeline e Vesúvio 329.

O IBBA, apesar de reconhecer a má notícia, acreditava ser "injusto" extrapolar os resultados iniciais de TBAZ para toda a bacia de Campos ${ }^{330}$.

Uma das principais lições que aprendemos sobre carbonatos até agora é que são estruturas heterogêneas, diferentemente de arenito. A Petrobras, com toda sua experiência em Campos, decidiu adiar alguns de seus projetos em carbonatos para entendê-los melhor. Além disso, carbonatos exigem a customização de cada sistema produtivo, reduzindo o escopo para acelerar ou escalar os desenvolvimentos [KOVARSKY \& MENDES, 2012m, p. 1].

Dois dias depois, o próprio IBBA ajustou seu PA (de $R \$ 21,2$ para $R \$ 1$ 14,8/ação), extrapolando os resultados iniciais de TBAZ para toda a bacia de Campos. Apesar de conservador, os Analistas consideravam que "após tantos contratempos e na ausência de evidências do contrário, nós acreditamos ser uma premissa segura por enquanto." 331 Os impactos da redução dos fluxos incluíam aumentos nos custos operacionais e de investimentos, deslocamento e redução da curva de produção, aumento do risco nos recursos prospectivos, aumento no custo médio do capital (ambos o $k d$ e ke).

Tabela 40 - Curva de Produção da OGX x Histórico de Revisões de Alguns Analistas

\begin{tabular}{||l|c|c|c|c|c|c|c|c||}
\hline \hline Produção Média (kbpd) & $\mathbf{2 0 1 1}$ & $\mathbf{2 0 1 2}$ & $\mathbf{2 0 1 3}$ & $\mathbf{2 0 1 4}$ & $\mathbf{2 0 1 5}$ & $\mathbf{2 0 1 7}$ & $\mathbf{2 0 1 9}$ & PA \\
\hline IPO & 2 & & & & 398 & & 1.130 & \\
\hline Revisão OGX 2009 & 20 & & & & 730 & & 1.380 & \\
\hline Revisão OGX jun/2011 & 20 & 50 & 165 & & 730 & & 1.380 & \\
\hline IBBA (05/05/11) & & & & & 550 & 730 & & 27,0 \\
\hline IBBA (16/04/12) & & 32 & 125 & 236 & 345 & & & 21,2 \\
\hline IBBA (28/06/12) 332 & & 15 & 37 & 168 & 258 & & & 14,8 \\
\hline
\end{tabular}

Foi um choque de realidade significativo. A crise de confiança estava instalada. Em 27/6, após a OGXP3 perder 25,3\% de seu valor em um único pregão, a OGX promoveu uma teleconferência com Analistas que ficou famosa pela audácia de um Analista que levantou a possibilidade da OGX quebrar. No pregão seguinte, a OGXP3 perdeu mais $19,2 \%$ de seu valor. Naqueles dois dias, a OGXP3 havia perdido $39,7 \%$ de seu valor. Em relação ao seu último pico em 19/6/2012, sete pregões antes, a OGXP3 havia perdido $50,5 \%$ de seu valor. Os Notes também sofreram depreciações significativas entre 26 e

\footnotetext{
${ }^{329}$ AUDI \& FALANGA NETO [2012j].

${ }^{330}$ KOVARSKY \& MENDES, $2012 \mathrm{~m}, \mathrm{p} .1$.

${ }^{331}$ KOVARSKY \& MENDES, 2012n, p. 1. O Preço Alvo foi reduzido de R\$ 21,2 para R\$ 14,8 (redução de 30\%) devido a: i) redução da taxa de fluxo; ii) aumento de custos; iii) atrasos na curva de produção; iv) aumento do ajuste no fator de risco (desconto sobre o valor presente das projeções) de $20 \%$ para $50 \%$; v) aumento no Kd e Ke em 100 pontos base cada, devido ao maior risco de execução.

332 KOVARSKY \& MENDES [2012n].
} 
28/6: o OGXPBZ18 caiu 8,7\% (de 97.625 para 89.125 ) e o OGXPBZ22 caiu $10,1 \%$ (de 96.375 para 86.625).

28/06. Substituição do CEO por Luiz Carneiro, que foi Diretor Presidente da OSX de 2009 a 2011 e membro do COAD entre 2010/11. Paulo Mendonça foi realocado para o COAD.

Repercussões. Alguns Analistas acreditaram que a saída do CEO poderia afetar o potencial de execução da $O G X^{333}$. Apesar da reconhecida capacidade técnica de Carneiro, ele assumiria a liderança da OGX em um momento desafiador. Duas questões permaneciam:

(1) As reservas de caixa da OGX são suficientes para suportar as campanhas exploratórias e de desenvolvimento, ou a empresa precisará recorrer ao mercado de capitais? (2) Quão baixo o valor da OGXP3 pode chegar? [AUDI \& FALANGA NETO, 2012k, p. 1].

De fato, a redução na projeção da curva de produção poderia atrasar o atingimento das metas originais, o que suscitava questões sobre a posição de caixa da OGX e sua capacidade de acessar o mercado de capitais ${ }^{334}$. Paulo de Tarso Guimarães assumiu a Diretoria de Exploração ${ }^{335}$.

O BTG, que também reduziu seu PA (de $\mathrm{R} \$ 21,63$ para $\mathrm{R} \$ 17,63$ em $5 / 7$ ), manteve sua recomendação para Comprar: "coisas demasiadas aconteceram em uma semana... precipitação".

Da massiva venda [da OGXP3] da semana passada nos trouxeram duas conviç̧ões: (i) os investidores não sabem mais o que acreditar sobre a OGX; e (ii) a única fonte sólida para apoiar o valor da ação seria o relatório de avaliação de 2010.

A OGX [P3] está sendo transacionada pelo equivalente às suas 700 mboe de 2C que já ocorreu no fim de 2010 e que se reverteu posteriormente. Hoje, parece que a percepção de mercado é que a OGX deve ter algo entre 900 a 1.000 mboe.

Para nós, este é um ponto de entrada bem atrativo. (...)

\footnotetext{
${ }^{333}$ AUDI \& FALANGA NETO [2012k].

${ }^{334}$ KOVARSKY \& MENDES [2012o] relatam que havia um covenant nos bonds da OGX que estipulavam um limite de no seu endividamento (debt ceiling) de US\$ 4 bilhões e uma Dívida/EBITDA de no máximo 3,5x. No modelo do IBBA, a OGX poderia atingir este limite e precisar de mais caixa ao fim de 2014, quando a relação Dívida/EBITDA alcançaria 6,6x. Entretanto, de acordo com a OGX, ao fim de 2014, a Empresa estaria produzindo $90 \mathrm{kbpd}$, o que geraria um EBITDA de US\$ 1,7 bilhão em 2015, que poderia ser securitizável. Neste caso, a securitização de recebíveis não seria incluída nos limites dos covenants.

335 Segundo relata GASPAR [2014], uma das primeiras ações de Carneiro foi revisitar a lista de poços com as respectivas projeções de vazão: "qualquer campo que tivesse menos de 30 milhões de barris de reserva seria considerado antieconômico e teria de ser abandonado" [p. 374]. Só restaria Tubarão Azul e Tubarão Martelo, mas que ainda permaneciam incógnitas. No total, as reservas destes dois campos poderiam somar 315 milhões de barris, muito aquém dos 4,3 bilhões que Mendonça apregoava [p. 375].
} 
Lá em 2010, a OGX havia perfurado 19 poços em Campos. Agora são 57. Lá ela possuía 11 acumulações que foram aceitas como descobertas pela D\&M. Nós acreditamos que ela [a OGX] encontrou outras 10. O volume de descobertas pode ser muito maior.

Se nós estivermos certos nas nossas estimativas de quanto a OGX já encontrou, ou seja, entre 1,2 a 1,4 bboe adicionais, pode realmente existir um ganho significativo na ação agora. A questão é quando isso se tornará visivel... [GATTASS, CARVALHO \& VALDIZAN, 2012a, p. 2].

Nós acreditamos que a OGX tem caixa suficiente para suportar seus negócios e que o próximo relatório de avaliação [da D\&M] pode ser um vetor positivo nas descobertas até agora [GATTASS, CARVALHO \& VALDIZAN, 2012a, p. 1].

Mas os desafios de curto prazo eram significativos:

Os investidores não têm confiança alguma em nenhuma estimativa que a OGX fornece, negando a capacidade dos executivos em estimar e divulgar qualquer sucesso [GATTASS, CARVALHO \& VALDIZAN, 2012a, p. 7].

16/07. Polvo (da BP), outro poço carbonato albiano próximo ao TBMT e com estrutura geológica semelhante à de TBAZ, também apresentou baixas taxas de 1,2 kbpd/poço. Injeção de água não melhoraria o fluxo e poderia danificar o reservatório.

Repercussões. Em 16/7, quando a OGXP3 foi transacionada a R\$ 5,82/ação e as taxas de Polvo foram divulgadas, o DB reduziu seu PA em $77,8 \%$ (de $R \$ 18,0$ para $R \$ 4,0 /$ ação) e recomendou seus clientes a vender a OGXP3.

Desde o anúncio, nós conversamos com consultores e geólogos para entender melhor os blocos da OGX em Campos. Como tal, concluímos que a probabilidade dos campos da OGX ser tão desafiadora quanto a de outros campos carbonatos albianos na bacia de Campos é alta. Portanto, revisamos nossos números para refletir esse cenário.

(...) A OGX ainda precisa provar que é um "produtor de baixo custo", como seus altos executivos afirmavam em recente teleconferência [SEQUEIRA \& FONSECA, 2012f, p. 1].

Polvo teria 45 mboe recuperáveis (21을). A injeção de água não melhorou o fluxo e poderia danificar o reservatório. Segundo os Analistas do DB relataram, os Executivos da OGX várias vezes afirmaram que seus campos não seriam análogos ao de Polvo ${ }^{336}$. Por fim, os Analistas do DB estavam preocupados com a posição de caixa da Empresa: US\$

336 SEQUEIRA \& FONSECA, 2012f, p. 2. Polvo foi descoberto em 2004. Em três anos, produziu o first oil, como o TBAZ. Em agosto de 2011, com 9 poços produtores, a produção média era de 2 kbpd por poço. Os maiores desafios no desenvolvimento de Polvo foram: (1) perfurações demoraram muito mais do que esperado; (2) fragmentação resultou em um poço por zona; (3) dados sísmicos foram muito menos confiáveis do que se acreditava. Polvo está a 8 quilômetros a leste de TBMT. 
3,6 bilhões ( $R \$$ 6,6 bilhões) em caixa para uma dívida de US\$ 3,9 bilhões (31/3/2012) e a necessidade de investir $\mathrm{R} \$ 1$ bilhão por trimestre.

10/08. ANP divulgou a produção média do primeiro poço (OGX-26HP) em junho: 2,368 contra 4,665 kbpd em maio (11,037 kbpd em fevereiro). Em contraste, a produção média do segundo poço (OGX-68HP) aumentou em junho: 6,461 contra 4,065 kbpd em maio.

Repercussões. Embora um mês não fosse suficiente para confirmar uma tendência, a volatilidade preocupava.

15/08. Em uma teleconferência, os novos Executivos revelaram que o quarto poço (OGX84) perfurado (em área $1 C$ ) no prospecto de Inga (BM-C-40) provou ser seco, em local próximo à área considerada como Recurso Contingente no 3 은 $\mathrm{M}$. Inga ficava ao sul de TBMT (com comercialidade declarada de 285 mboe).

Repercussões. O poço seco em Inga e a não descoberta de hidrocarbonetos em outros dois poços (OGX-67 e OGX-71) em áreas 3C em 1T2012 foram considerados notícias negativas. A perfuração ocorreu perto do centro da acumulação de Inga, cujo volume estimado havia sido considerado como Recurso Contingente pela D\&M. A Empresa esperava que Ingá, Peró e Itacoatiara pudesse aumentar o volume comercializável de Waikiki, estimado em 600 mboe.

2/10. Os novos Executivos anunciaram que a OGX venderia a sua próxima carga de óleo para empresa asiática com um desconto de US\$ 4,5/barril. Anunciou também que reconheceria a perda contábil no BM-S-29 (US\$ 100 milhões) e o retornaria à ANP.

Repercussões. No pregão, a OGXP3 perdeu 3,2\% (de R\$ 5,99 para $\mathrm{R} \$ 5,80$ ). A perda em valor de EV foi de $R \$ 587,2$ milhões ou US\$ 289,8 milhões.

24/10. Quando OGXP3 chegou a $\mathrm{R} \$ 4,63$ (perda de 7,7\% em relação a $23 / 10$ ), o $A C$ outorgou à OGX uma put ao preço de exercício de $\mathrm{R} \$ 6,30$ e limite máximo de US\$ 1,0 bilhão. A put poderia ser exercida a qualquer momento até 30 de abril de 2014.

Repercussões. O objetivo da put era demonstrar a confiança do AC:

Essa opção enfatiza a confiança do acionista controlador na qualidade do corpo técnico e ativos da Companhia, bem como nas novas oportunidades que o setor de óleo e gás oferece [OGX, DFP 2012, p. 19].

Mas seus termos eram vagos:

(...) condicionado à necessidade da Companhia de capital social adicional e à ausência de alternativas mais favoráveis, condições estas que serão determinadas pela maioria dos membros independentes do Conselho de Administração da Companhia [OGX, DFP 2012, p. 4].

O IBBA 337 interpretou que a put serviria para reduzir as preocupações dos investidores em relação à liquidez financeira da Empresa, gerada pelas reduções consecutivas das

${ }^{337}$ KOVARSKY \& MENDES [2012p]. 
suas metas de produção. Na época, os Analistas do IBBA e SAN ${ }^{338}$ se perguntavam por que a OGX ainda não havia encomendado a OSX-4. Por que a OSX-2, originalmente planejada para Waimea, agora poderia ser compartilhada com Waikiki. Estas questões endossavam a interpretação que a curva de produção seria adiada. Neste contexto, a put funcionaria como um seguro contra produção aquém do projetado. Estes Analistas do IBBA estimavam que no fim de 2014 , os covenants da dívida atual impediriam a OGX de captar mais financiamentos.

Os Analistas do DB consideravam que embora a put fosse uma notícia positiva, não seria um divisor de águas, um "game-changer", frente às necessidades de investimentos (R\$ 10,2 bilhões entre 2012 a 2015) e a perspectiva de somente gerar fluxo livre de caixa em $2015^{339}$.

Ainda no mesmo dia (24/10), a OGX obteve a qualificação de Operador A pela ANP, o que lhe permitiria operar blocos em águas profundas e ultra profundas. Até então, a OGX era classificada como Operador $\mathrm{B}^{340}$. Isso poderia sinalizar que a OGX planejava participar da 11a Rodada da ANP planejada para $2013^{341}$.

No pregão seguinte (25/10), a OGXP3 se valorizou em $2,6 \%$ (de $R \$ 4,63$ para $R \$ 4,75)$ ) $O$ ganho no EV foi de R\$ 420,9 milhões ou US\$ 207,7 milhões.

8/11. No anúncio dos resultados do 3T2012, não houve notícias sobre as perfurações em Fortaleza. Mas houve notícias sobre as perfurações no BM-C-37/38, cuja concessão venceria em março de 2013: entre 0,861 e 1,196 bboe em cinco prospectos, que poderiam demandar 4 FPSOs. No 3T2012, a OGX reconheceu R\$294,0 milhões em perdas em poços secos (dos quais $\mathrm{R} \$ 213,0$ milhões se referiam ao BM-S-29).

Repercussões. Os Analistas aguardavam os resultados de Fortaleza. Se óleo fosse encontrado, a OGXP3 poderia se valorizar. Se os resultados não fossem bons, o mercado poderia precificar a OGXP3 entre $R \$ 2,00$ e 2,50, equivalente aos seus recursos com comercialidade declarada (Waimea e Waikiki com um total de 395 mboe). Mas não houve notícias.

No 3T2012, foram reconhecidas perdas em poço (R\$2 294,0 milhões) impactou o EBITDA que foi negativo em $\mathrm{R} \$ 343,6$ milhões, bem pior do que a estimativa de alguns Analistas $^{342}$. Se não fosse o reconhecimento das perdas, a margem EBITDA teria sido de

338 KOVARSKY \& MENDES [2012p]. O covenant estipulava um limite de Dívida/EBITDA de 3,5x. Considerando o preço do Brent em US\$ 90/barril, uma produção de $90 \mathrm{kbpd}$, ao fim de 2014, a dívida total somaria US\$ 4 bilhões para um EBITDA de US\$ 0,7 bilhão.

339 SEQUEIRA \& FONSECA [2012h].

340 Operadoras A estão habilitadas a apresentar propostas para todos os blocos, as operadoras B estão limitadas a blocos terrestres e em águas rasas, e as operadoras $C$ estão restritas a blocos terrestres. Na Nona Rodada de Licitação, exigia-se dos operadores $A$ um patrimônio líquido de pelo menos $R \$ 22$ milhões; dos operadores $B$ de pelo menos $R \$ 20$ milhões e dos operadores $C$ de pelo menos $R \$ 1$ milhão.

${ }^{341}$ SEQUEIRA \& FONSECA [2012h].

342 AUDI \& FALANGA NETO [2012m] estimavam um EBITDA negativo em R\$ 93,0 milhões. SEQUEIRA \& FONSECA [2012i] estimavam um EBITDA negativo em $\mathrm{R} \$ 162,0$ milhões. 
$17,3 \%$, abaixo da estimativa de $38 \%$. Essa diferença se deveu ao fechamento do poço OGX-26HP por mais de um mês para reposição de uma bomba.

As perdas reconhecidas no $3 T 2012$ incluíam $\mathrm{R} \$ 213,0$ milhões se referiam ao BM-S-29343. Alguns Analistas ${ }^{344}$ foram irônicos: obter uma área de graça é uma boa estratégia ou um jogo de azar?

Em agosto de 2012, a OGX devolveu à ANP o bloco BM-S-29, situado na Bacia de Santos, do qual detinha $100 \%$ de participação. Após o término do prazo do Plano de Avaliação de Descoberta dessa área, a Companhia decidiu pela não continuidade do seu desenvolvimento [OGX, DFP 2012, p. 38].

Outros Analistas ${ }^{345}$ consideraram que os custos operacionais estavam em linha (US\$ 557 $\mathrm{mil} /$ dia contra a expectativa de US\$565 $\mathrm{mil} / \mathrm{dia}$ ) e chamaram a atenção para a queda de $27 \%$ no consumo de caixa no trimestre para US\$ 478 milhões contra a média de US\$ 657 milhões por trimestre no 1S2012. Segundo eles, havia duas preocupações adicionais:

A tese de investimentos da OGX precisa de mais pilares para se sustentar. Uma maior produção em TBAZ com o próximo poço ${ }^{346}$ é chave para aumentar a rentabilidade [por barril] e a lucratividade.

Não há maneira de minimizar a necessidade do auditor independente da Empresa fornecer um quadro mais detalhado sobre os ativos. Mais de US\$ 4 bilhões foram gastos desde dezembro de 2010 e nós ainda não sabemos o que foi encontrado!

Mas essas são as incógnitas identificadas que, em nossa opinião, são indicadores que os investidores deveriam estar observando nos resultados, buscando sinais de fraqueza que poderiam mudar nossa visão sobre os valores que simplesmente não estavam lá [GATTASS \& CARVALHO, 2012b, p. 2].

Por fim, no anúncio do 3T2012, a OGX estimou um EBITDA pro forma incluindo os embarques do 4T2012 e excluindo as perdas ativas (write-offs), que implicaria em uma margem de $35 \%$, o que segundo alguns Analistas não corroborava com a visão dos Executivos da Empresa que a consideravam uma produtora de baixo custo ("low cost producer") $)^{347}$.

343 Em 2008, antes do IPO, a OGX adquiriu 50\% do campo BM-S-29 da MAERSK (homologada em 3/12/2008). DARIPA \& SILVA [2008a, p. 15] relataram que a participação adquirida pertencia à Shell. Nenhum pagamento direto foi feito à MAERSK, entretanto a OGX investiria, no mínimo, US\$ 40 milhões na perfuração de poços no BM-S-29.

Em 2009, a OGX aumentou sua participação para 65\% (homologada em 8/5/2009). Em 2010, passou a deter 100\% (homologada em 9/11/2010), quando a Empresa divulgou que sua taxa de sucesso em Santos era de 57\% [DPF 2010, p. 4]. Quando foi devolvido em agosto de 2012, a Empresa registrou uma despesa de R\$ 213 milhões a título de "poços secos ou subcomerciais".

${ }^{344}$ AUDI \& FALANGA NETO [2012m].

345 GATTASS \& CARVALHO [2012b].

${ }^{346}$ Refere-se ao terceiro poço, com início de produção planejado para dezembro de 2012.

347 SEQUEIRA \& FONSECA [2012i]. 
A posição do caixa no $3 T 2012$ (US\$ 2,5 milhões, ou $R \$ 5,1$ milhões) indicava que a Empresa poderia terminar 2013 com caixa próximo a zero (entre US\$ 400 a 500 milhões), segundo estimativas do SAN, BTG e IBBA. Em janeiro de 2013, a própria OGX viria a projetar que poderia terminar o ano de 2013 com US\$ 300 a 400 milhões em disponibilidades ${ }^{348}$.

No pregão (8/11), a OGXP3 se desvalorizou em $0,21 \%$ (de $R \$ 4,78$ para $R \$ 4,77$ ). A perda no EV foi de R\$ 29,1 milhões ou US\$ 14,3 milhões.

26/11. OGX adquiriu 40\% de participação no bloco BS-4 pertencente à PETR por R\$ 575 milhões (US\$ 270 milhões). O BS-4 era formado por dois campos pós-sal em águas profundas: Atlanta e Oliveira, com óleo pesado de $14^{\circ}$ a $16^{\circ} \mathrm{API}$.

Repercussões. O valor do farm-in representava um prêmio de $29 \%$ em relação ao valor pago pela QGEP em 24 de agosto de $2011^{349}$. No farm-in da BS-4, a OGX teria como sócios a QGEP, com 30\%, e a Barra Energia do Brasil Petróleo S.A. (30\%). Os investimentos previstos para 2S2013 eram estimados em US\$ 1,3 bilhão, com primeiro óleo para 2014. Estimava-se que Atlanta e Oliveira teriam 2,1 bboe, dos quais $15 \%$ a $19 \%$ poderiam ser recuperados (315 a 399 mboe, representando um múltiplo de M\&A de US\$ 2,14 a $1,69 /$ boe). Cerca de $80 \%$ destes recursos estimados estariam em Atlanta. Os blocos também poderiam ter potencial no pré-sal, uma vez que estavam próximos à Libra e Franco (volume estimado em 3,0 bboe).

Alguns Analistas ${ }^{350}$ interpretaram a notícia da aquisição do BS-4 como negativa, pois levantava quatro questões:

(1) dado o discurso consistentemente positivo da Empresa sobre seu portfólio [em águas rasas] em Campos, por que se aventurar em uma produção mais cara em águas profundas? (2) o potencial do pré-sal do BS-4 é tão significativo assim para justificar a aquisição? (3) dado o balanço patrimonial da Empresa (com US\$ 5,1 bilhões em dívida líquida e crescendo), vale a pena a OGX comprometer mais capital? (4) qual é o significado da aquisição para o restante do portfólio da OGX (Santos, ES, PA-MA, Colômbia [e até certo ponto para Parnaíba])? (...) [SEQUEIRA \& FONSECA, 2012j, p. 1].

Os Analistas do IBBA compartilhavam parte das questões do $\mathrm{DB}^{351}$. A aquisição surpreendeu, pois a OGX pretendia participação na 11a Rodada (prevista para maio de 2013) justamente para buscar novas opções de crescimento mais baratas do que possíveis farm-ins de áreas já descobertas, e assim estaria preservando o caixa. Segundo os Analistas do IBBA, a aquisição do BS-4 provavelmente levaria a OGX a exercer a put contra o AC.

Assim como o IBBA, o SAN considerou o múltiplo do farm-in do BS-4 como vantajoso, porém endossou parte das questões do $\mathrm{DB}$, em particular a potencial falta de caixa.

\footnotetext{
${ }^{348}$ AUDI \& FALANGA NETO [2013a].

${ }^{349}$ SEQUEIRA \& FONSECA [2012j].

350 SEQUEIRA \& FONSECA [2012j].

${ }^{351}$ KOVARSKY \& MENDES, 2012q, p. 1.
} 
Adicionalmente, o SAN considerou que, por se tratar de campos com potencial já avaliado, e, portanto, menos arriscados, a aquisição teria sido melhor do que investir em novas fronteiras ${ }^{352}$.

No pregão (26/11), a OGXP3 se desvalorizou em 5,34\% (de $R \$ 4,87$ para $R \$ 4,61$ ). A perda no EV foi de $R \$ 627,1$ milhões ou US\$ 301,7 milhões.

Fim Novembro. "Primeiro gás" em Gavião Real. UTE Parnaíba I seria comissionada em janeiro de 2013.

11/12. Artigo do JVE ${ }^{353}$ relata que ações das "empresas $X$ " lideraram ganhos no dia devido a boatos que o AC estaria negociando venda de participações nas "empresas X" para o BNDESPar. OGXP3 teve alta de $8,76 \%$, LLX com 7,33\% e OSX com $0,44 \%$. No dia seguinte (12), o AC e o BNDESPar vieram a público negar o hipotético aporte nas "empresas X"354.

Repercussões. Analistas da Amostra Própria não comentaram a notícia.

12/12. Empresa anunciou sua intenção de promover o farm-out de TBMT.

Repercussões. Novamente, o valor do farm-out seria um importante sinalizador para o mercado sobre o valor do portfólio da OGX. Se a OGX implementasse o farm-out de $30 \%$ por um múltiplo razoável de US\$10/boe, poderia captar cerca de US\$ 855 milhões $^{355}$. Entretanto, havia muitas empresas de O\&G no Brasil também tentando viabilizar farmouts $^{356}$. O farm-out, o exercício da put e uma possível securitização de recebíveis eram potenciais fontes de caixa que a Empresa considerava. Entretanto, alguns Analistas ${ }^{357}$ consideravam que a participação da OGX na 11a Rodada traria maiores questionamentos sobre a liquidez da Empresa.

Os indicadores da Amostra TR indicam que os Analistas pessimistas mantiveram suas apostas no valor da OGXP3 até junho, enquanto a mediana e os otimistas ajustaram seus PAs em junho, mas ainda os mantiveram acima do valor de mercado da OGXP3.

\footnotetext{
352 AUDI \& FALANGA NETO [2012h] estimaram o EV de US\$ 5,7/boe, sendo que a OGX teria pagado US\$ 2,2/boe.

353 Disponível em: https://www.valor.com.br/financas/2935256/ibovespa-sobe-13-empurrada-porempresas-x.

354 Disponível em: https://www.valor.com.br/valor-investe/casa-das-caldeiras/2937898/eike-tentaarrumar-casa.

355 AUDI \& FALANGA NETO [20120].

${ }^{356}$ LEITE, CANHEU \& SOBREIRA [2013b, p. 7] citam a PETR, HRT, BP, Anadarko, Vale e outras.

${ }^{357}$ AUDI \& FALANGA NETO [20120].
} 
Gráfico 44 - Amostra da TR: Evolução da Mediana, Máximo e Mínimo do PA em 2012 (em R\$/ação pré-split)

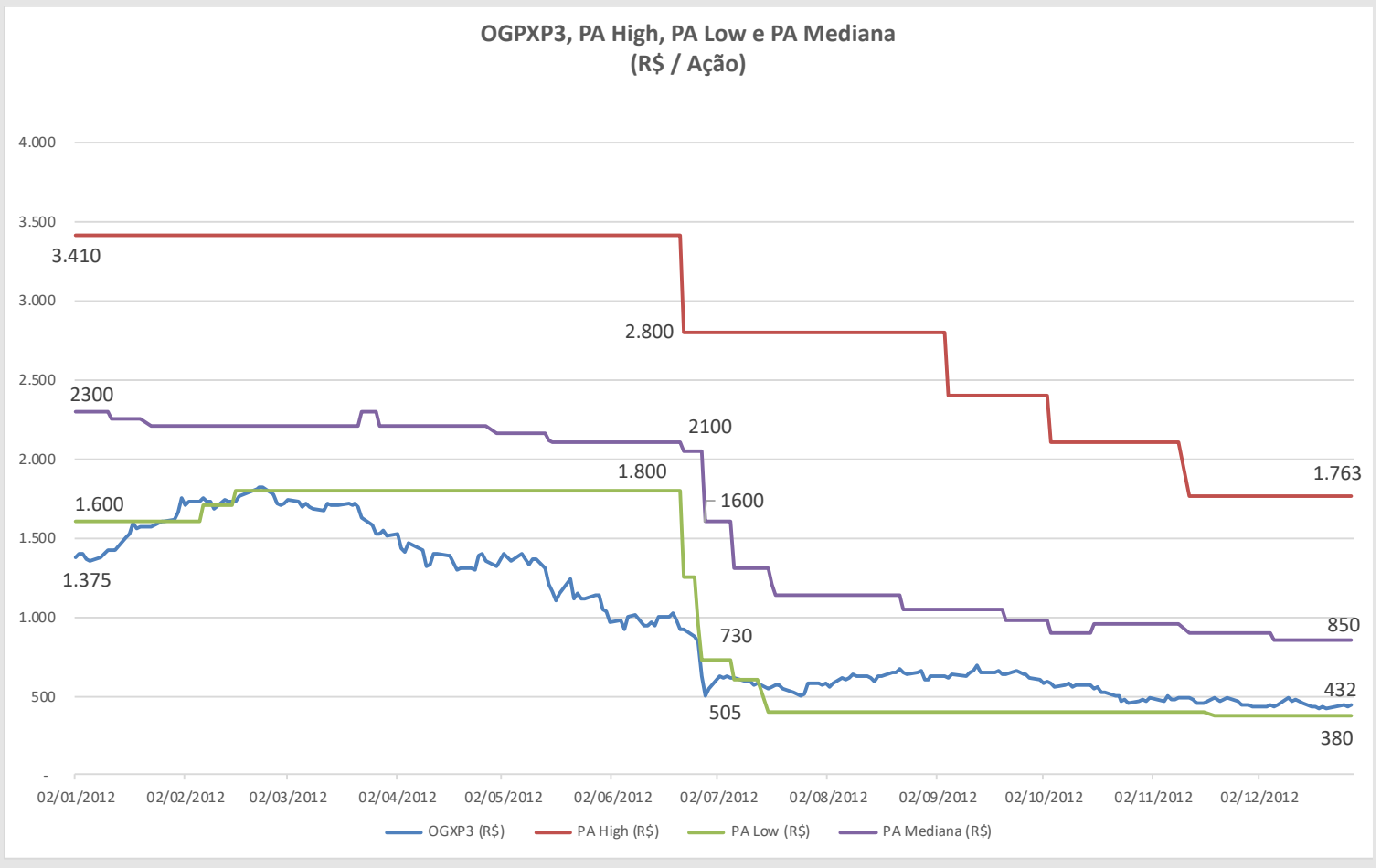




\subsection{3: Colapso do Guidance e Credibilidade do AC}

"Uma das máximas da indústria de petróleo diz que
exploração é negócio de baixo custo e alto risco, e
produção, é negócio de alto custo e baixo risco".

GASPAR, 2014, p. 244.

Evolução do Valor de Mercado em 2013: Colapso

Com a perda da credibilidade do guidance, disponibilidades em baixa, e OGXP3 depreciada, havia limitadas opções disponíveis para reverter o colapso da OGX em 2013. O exercício da put do AC, o farm-out de TBMT e a produção de TBAZ eram os poucos catalisadores que poderiam ter impacto significativo no curto prazo. Mas nenhum deles se materializou a tempo de prevenir a RJ.

Já em meados de abril (17), a OGXP3 perdeu boa parte do pouco valor que tinha quando do início do ano. $O$ valor de mercado dos Notes também registrou perdas significativas no período.

Gráfico 45 - Evolução da OGXP3 em 2013 (em R\$̣ nominais por ação, pós Split)

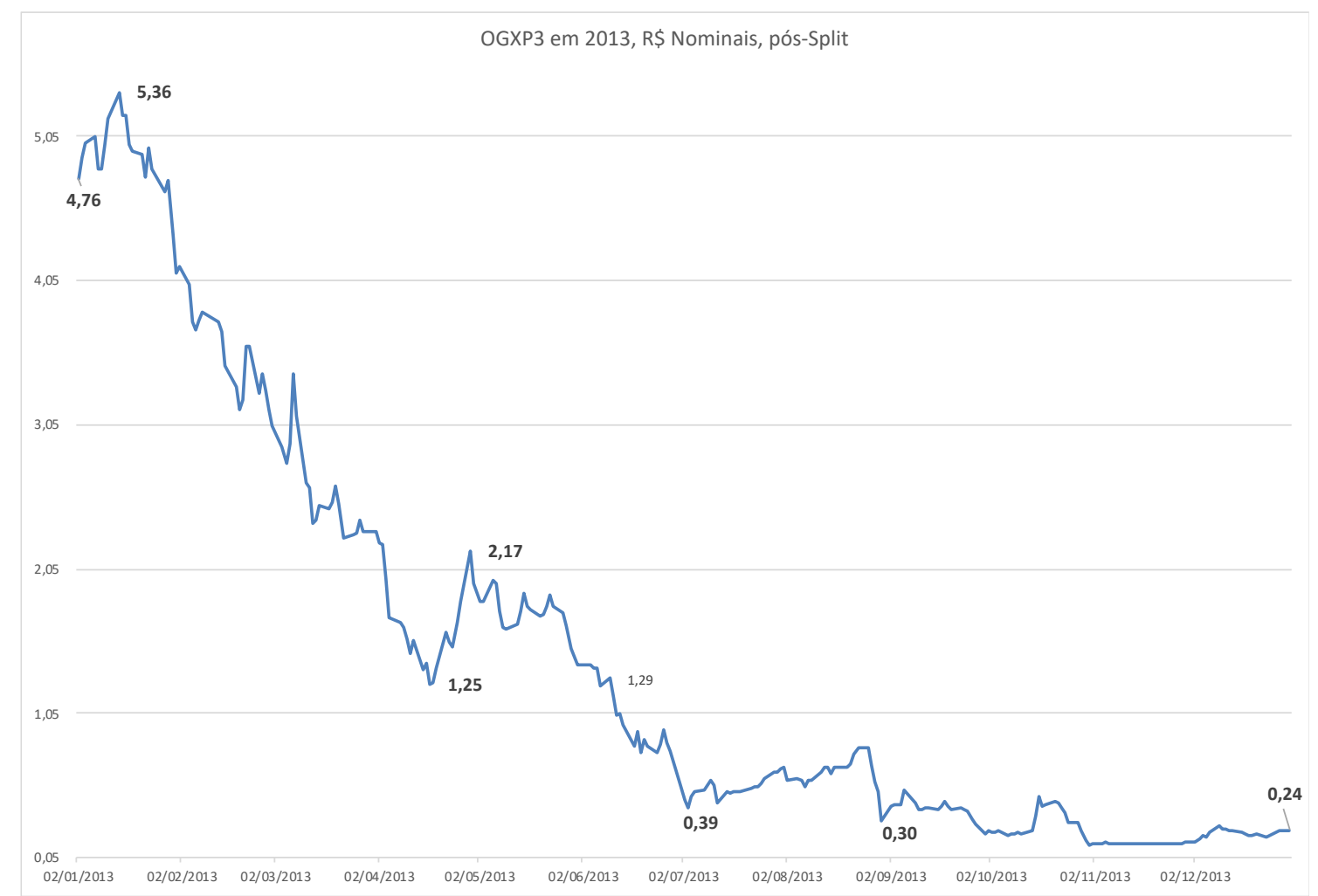


Ao longo de 2013, o Brent e a IBOV se depreciaram relativamente pouco, o que não explicaria a queda na OGXP3.

Gráfico 46 - Evolução da OGXP3, Brent e IBOVESPA em 2013 (Base 100 = 12/6/2008 [IPO])

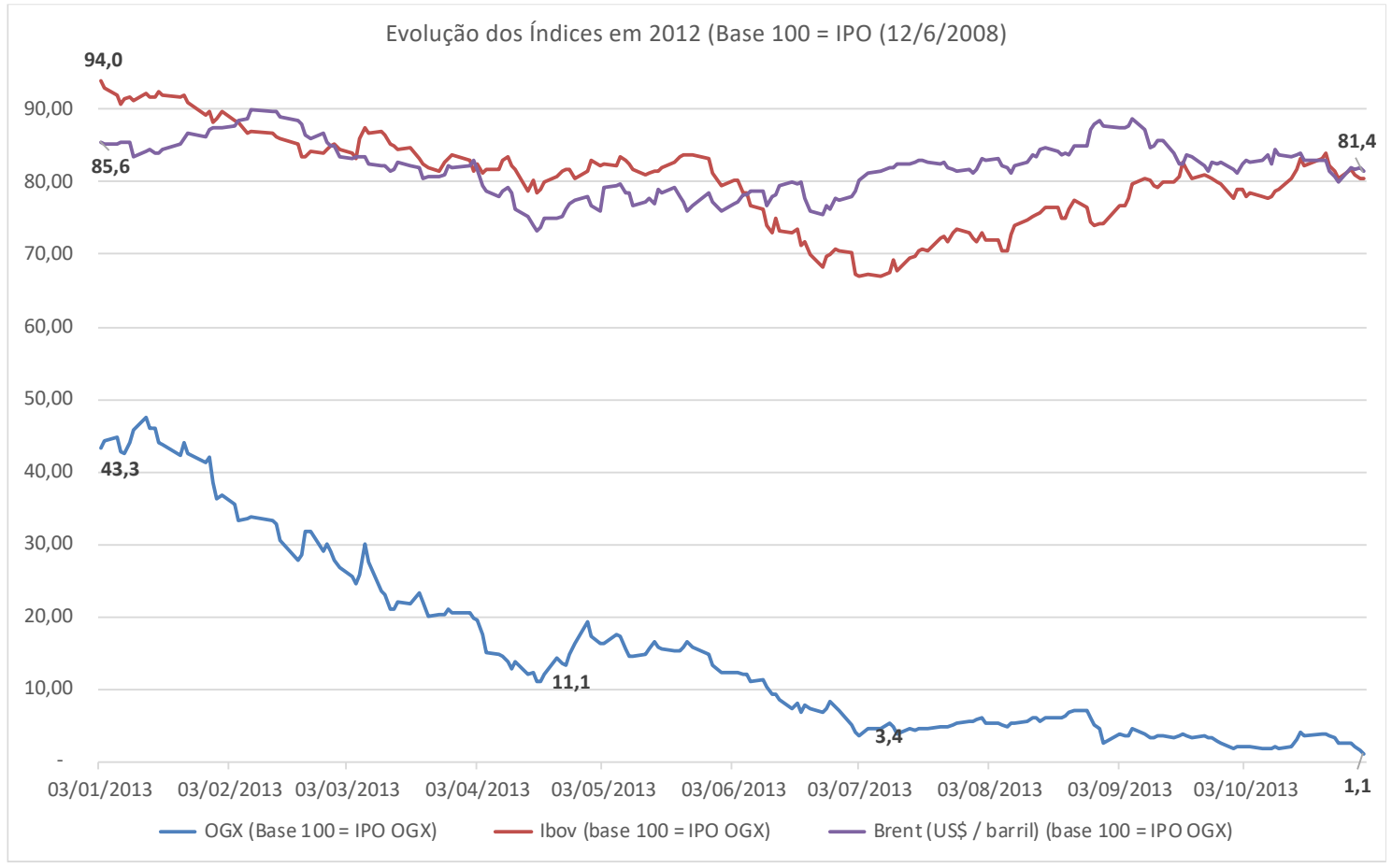

Gráfico 47 - Evolução do EV/2C em 2013 (em US\$/boe)

EV/2C (US\$ / boe): 2013

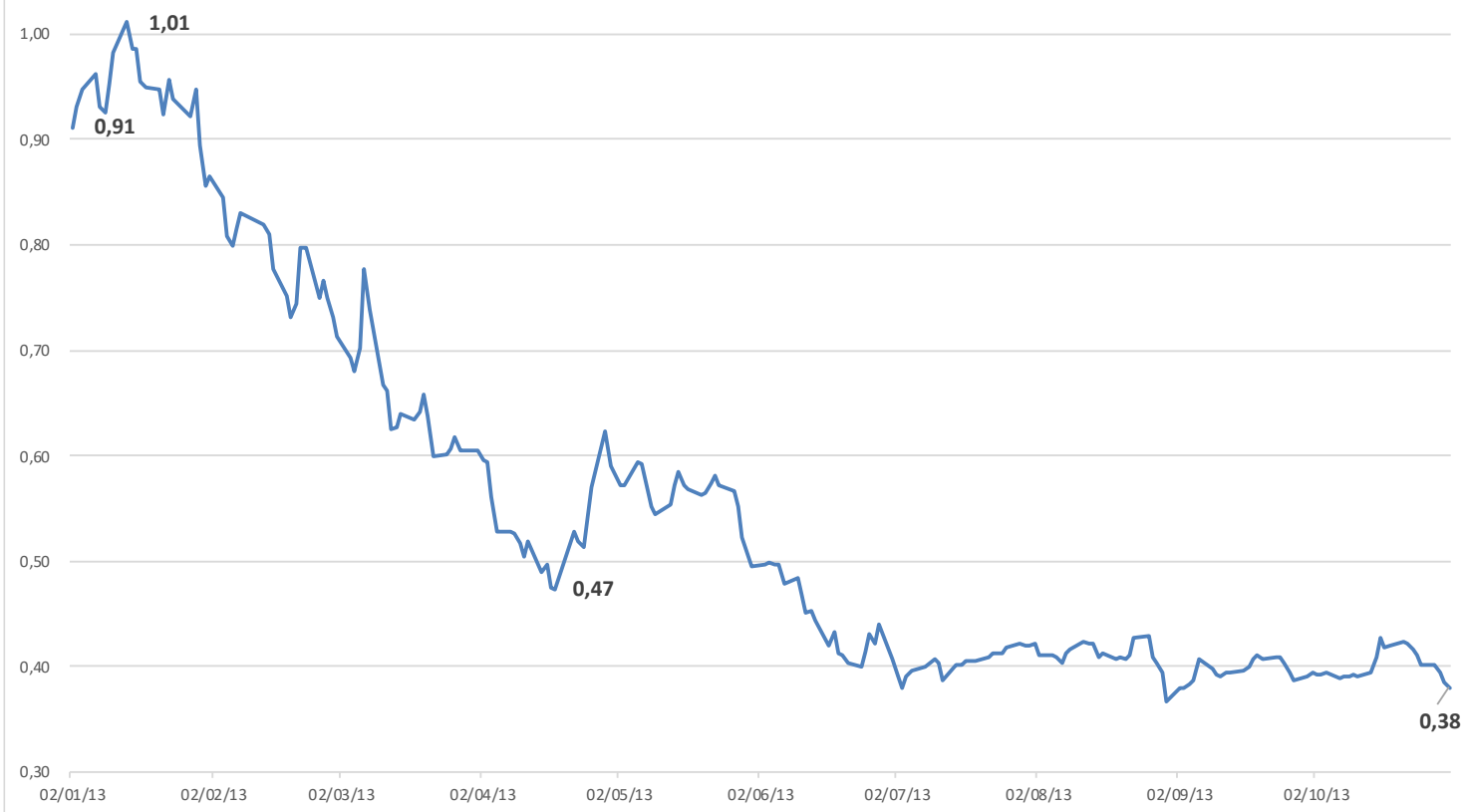


Os investidores e a mediana dos Analistas da Amostra TR parecem não ter concedido muito crédito aos novos Executivos após a substituição do CEO em junho de 2012.

\section{Gráfico 48 - Amostra da TR: Evolução da Mediana e Mínimo do PA em 2013 (em R\$̦/ação)}

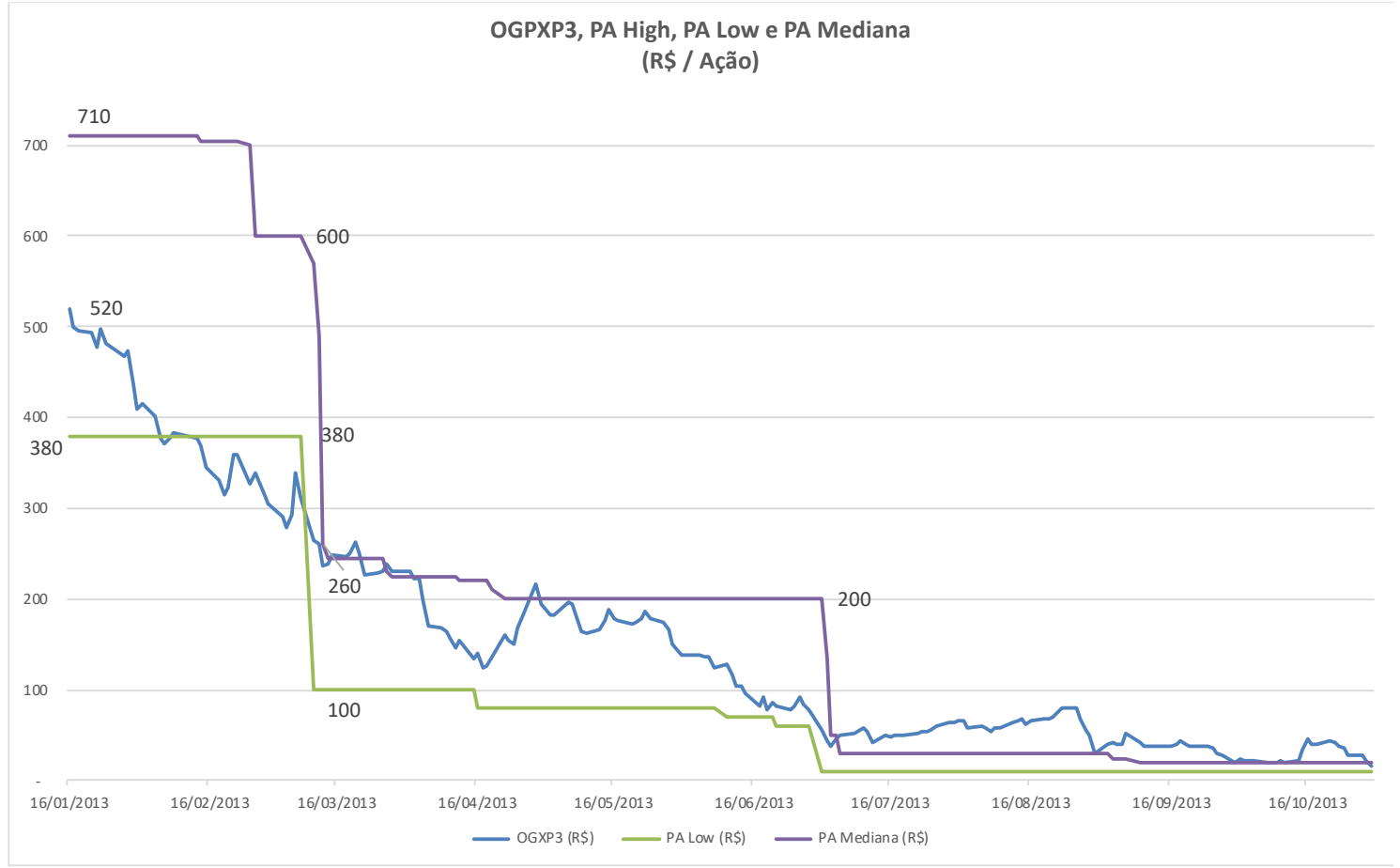

\section{Evolução do Guidance e suas Repercussões sobre os Analistas em 2013}

4/01. Após um atraso de um mês, a OGX conectou o terceiro poço em TBAZ. A expectativa era que este poço produzisse mais do que a média de $5 \mathrm{kbpd}$ dos outros dois primeiros. A confirmação do fluxo deveria levar duas semanas.

Início Janeiro. Dois anos depois de estimar seu potencial em 0,5 a 1,5 bboe, a Empresa considerou Vesúvio como baixa prioridade no portfólio, pois contém petróleo pesado em uma estrutura fragmentada. Outras áreas menos conhecidas, incluindo as prospectivas não-perfuradas dos BM-C-37/38, agora teriam prioridade sobre Vesúvio.

Repercussões. No início de janeiro, os Analistas do IBBA reduziram seu PA em $37 \%$ (de $\mathrm{R} \$ 13,20$ para $\mathrm{R} \$ \mathbf{8}, 30$ ). Dentre as justificativas do corte, destacava-se a redução na premissa de volume total de Campos $(2 C+3 C)$ : de 5,4 para 3,0 bboe. O potencial do présal do BS-4 não foi considerado e os volumes estimados para ES foram excluídos do PA. Além da baixa performance de TBAZ, a mudança de prioridade na exploração do BM-C$37 / 38$ em detrimento de Vesúvio chamava a atenção e motivou revisões conservadoras do potencial de volumes recuperáveis:

A primeira estimativa de volume da Empresa para Vesúvio foi de 0,51,5 bboe. Dois anos depois, a Empresa considera a área como baixa 
prioridade no portfólio, pois contém petróleo pesado em uma estrutura fragmentada. Outras áreas, incluindo as prospectivas não-perfuradas localizadas nos blocos BM-C-37/38, agora têm prioridade sobre Vesúvio. Portanto, decidimos excluir os volumes associados ao Vesúvio de nossa avaliação contingente, pelo menos até ter uma ideia mais clara dos volumes e dos planos de desenvolvimento da área.

O foco da OGX nos blocos adquiridos da Maersk [BM-C-37/38] também trazem dúvidas sobre o potencial do resto dos prospectos na bacia de Campos. Desde o IPO, a OGX perfurou mais de 80 poços na bacia de Campos, principalmente em blocos $100 \%$ operados por ela, o que acreditamos ser suficiente para obter uma boa compreensão do potencial dos blocos. Ainda assim, a Empresa decidiu colocar as próximas unidades produtoras em áreas menos conhecidas, indicando potencialmente desapontamentos no resto, aparentemente muito mais difícil de produzir, da bacia de Campos [KOVARSKY \& MENDES, 2013a, p. 2].

Os Analistas do IBBA reduziram suas estimativas para os recursos prospectivos $2 \mathrm{C}$ de 2,4 para 1,295 bboe em Campos: TBAZ (0,110 bboe), TBMT ( 0,285 bboe), OSX-2 no restante de Waimea (0,300 bboe), Pipeline e o restante do BM-C-41 (0,300 bboe), BM-C-37/38 $(0,300$ bboe $)$. As novas Declarações de Comercialidade, aguardadas para 12 de março (data limite da concessão da ANP para 11 blocos, 7 em Campos e 4 em Santos), poderiam ser essenciais para entender o potencial real de Campos. Faria sentido que março de 2013 fosse a data base para o 4ㅇ․ Relatório da D\&M que poderia ser divulgado em junho ${ }^{358}$.

Em 13/01, os Analistas do CS, ao retomarem a cobertura da OGXP3, interrompida em 16/4/2010, foram contundentes:

O que devemos fazer agora? Depois de dois anos de "euforia de exploração" pós IPO, desde 2011, a OGX entrou na fase da "realidade do desenvolvimento": o relatório da [3ㅇ] D\&M decepcionou o mercado, a redução da orientação de produção e as mudanças na gestão [mudança do CEO] contribuíram para que o preço da ação chegasse próximo de mínimos históricos. O que os investidores devem fazer agora? Temos uma oportunidade de valor, as ações são razoáveis, ou os riscos potenciais ainda estão subestimados? (...)

OGX oferece valor? Em nossa opinião, um dos aspectos cruciais do caso de investimento da OGX é que, mesmo com o preço da ação próximo a mínimos históricos, não é fácil ter conviç̧ão em uma sólida tese de valor [LEITE, CANHEU \& SOBREIRA, 2013x, p. 1].

O diagnóstico do CS se revelaria profético...

31/01. Poço seco em Cozumel (BM-C-37), onde se estimou haver entre 209 a 270 mboe. Descoberta de hidrocarbonetos em Tulum e Viedna. Produção do terceiro poço do TBAZ

358 KOVARSKY \& MENDES [2013a]. 
ficou na média de $5 \mathrm{kbpd}$ (a expectativa era de $7 \mathrm{kbpd}$ ). Em janeiro, a produção média em TBAZ foi de 4,9 kbpd/poço, mas a Empresa não disponibilizou os detalhes.

Repercussões. O DB, que tinha o PA mais baixo do mercado (R\$ 4,00$)$ achou a notícia negativa, reiterou sua recomendação de venda e questionou suas estimativas que poderiam ainda ser otimistas:

Para nós, a implicação de um poço seco em um bloco cujo período de exploração está programado para terminar em menos de dois meses é que levanta a questão de saber se a empresa manterá ou abandonará as áreas. Se o pior caso se materializar, serão feitas revisões significativas para baixo, pressionando a ação ainda mais [SEQUEIRA \& FONSECA, 2013a, p. 1].

Enquanto o IBBA I59 $^{350}$ ão destacou a notícia sobre o fluxo do terceiro poço, o CS enfatizou a surpresa negativa:

Ainda mais notável é o fato de que, em teoria, é o campo que a OGX conhece melhor. Não só já está produzindo dos dois primeiros poços desde o início de 2012, mas também, porque os dois primeiros poços sofreram de canibalização, a OGX contratou a Schlumberger para realizar análises sísmicas detalhadas e otimizar a localização do terceiro e i do quarto poços. E, no entanto, temos surpresas (negativas), o que nos deixa com pouca confiança para recomendar as ações, mesmo que estejam 25\% abaixo da alta em meados de janeiro [LEITE, CANHEU \& SOBREIRA, 2013a, p. 1].

As taxas de fluxo de TBAZ eram os tópicos mais discutidos entre Analistas dado seus impactos nas projeções de produção, custos e investimentos ${ }^{360}$.

Para complicar ainda mais, os reservatórios mapeados e já produtivos da OGX são maioritariamente carbonatos, que são os menos estudados pela indústria do petróleo, e têm um comportamento mais heterogêneo, o que os torna mais difícil modelar e prever (...)

Na nossa opinião, continua a ser muito difícil ter muita conviç̧ão na avaliação para a OGX: não sabemos quais são os níveis de produção sustentável e não sabemos quantas FPSOs (ou recursos recuperáveis) têm efetivamente a empresa [LEITE, CANHEU \& SOBREIRA, 2013a, p. 2].

Em janeiro, a produção média em TBAZ foi de 4,9 kbpd/poço, mas a Empresa não disponibilizou os detalhes. No início de fevereiro (4), as informações disponibilizadas para as taxas só iam até novembro e mostravam um declínio no OGX-68 parcialmente compensado por um aumento na média do OGX-26:

\footnotetext{
359 KOVARSKY \& MENDES [2013a].

${ }^{360}$ LEITE, CANHEU \& SOBREIRA [2013a].
} 
Tabela 41 - Evolução da Produção em TBAZ (kbpd)

\begin{tabular}{|l|c|c|c|c|c||}
\hline & OGX-26 & OGX-68 & TBAZ-1HP & Total & kbpd/poço \\
\hline fev-12 & 11,037 & - & - & 11,037 & 11,037 \\
\hline mar-12 & 10,064 & - & - & 10,064 & 10,064 \\
\hline abr-12 & 8,832 & - & - & 8,832 & 8,832 \\
\hline mai-12 & 4,665 & 4,065 & - & 8,730 & 4,365 \\
\hline jun-12 & 2,368 & 6,461 & - & 8,829 & 4,415 \\
\hline jul-12 & - & 7,000 & - & 7,000 & 3,500 \\
\hline ago-12 & 4,144 & 6,113 & - & 10,257 & 5,129 \\
\hline set-12 & 4,325 & 5,724 & - & 10,049 & 5,025 \\
\hline out-12 & 5,428 & 4,557 & - & 9,985 & 4,993 \\
\hline nov-12 & 5,963 & 3,815 & - & 9,778 & 4,889 \\
\hline Dez-12 & $\mathrm{Na}$ & $\mathrm{Na}$ & - & $\mathrm{Na}$ & 5,100 \\
\hline Jan-13 & $\mathrm{Na}$ & $\mathrm{Na}$ & - & $\mathrm{Na}$ & 4,900 \\
\hline
\end{tabular}

Fontes: SEQUEIRA \& FONSECA [2012g] até julho e [2013b] até janeiro.

21/2. JVE relatou que a Petronas da Malásia negociava aquisição de fatia na OGX.

Repercussões. A OGXP3 se valorizou em $11,8 \%$ no pregão. $O$ artigo ${ }^{361}$ cita a frustrada negociação com os chineses (CNOOC e Sinopec) em 2010 que teriam achado o valor pedido muito elevado. Na época o lifting cost foi estimado em US\$ 8/barril, mas somente com logística de transporte a empresa teria gasto US\$ 7/barril. A agressiva estratégia teria causado uma crise de confiança.

1/03. JVE ${ }^{362}$ relatou que investidores inquietos com a geração de caixa da OGX: em 31/12/12 a Empresa apresentou dívida liquida de $\mathrm{R} \$ 3$ bilhões (bruta de $\mathrm{R} \$$ 8,046 bilhões) para um ROB (4T12) de R\$ 150,7 milhões. A meta de produção para 2011 era de $20 \mathrm{kbpd}$ e em 2015 era de $730 \mathrm{kbpd}$, mas a média de 2013 até então era de 13,2 kbpd nos três poços do TBAZ, com lifting cost de US\$ 58,58 por barril para as quatro cargas já comercializadas contra a estimativa do AC de US\$ 8. O lifting cost médio da PETR foi de US\$ 13,92 em 2012, mas com uma escala muito diferente. $O$ alto lifting de TBAZ também estava relacionado a ociosidade da OSX-1 que era capaz de processar e armazenar 60 kbpd. Um quarto poço estava sendo perfurado em TBAZ e a Petronas ainda estaria interessada na aquisição de parte da OGX.

3/03. OGX ainda não havia divulgado os resultados do 4T2012 e sua posição de caixa.

${ }^{361}$ Disponível em: https://www.valor.com.br/empresas/3017680/petronas-da-malasia-negocia-fatia-naogx.

362 Disponível em: https://www.valor.com.br/empresas/3027580/ogx-decepciona-mas-tem-interessede-asiaticos. 
Repercussões. Alguns Analistas acreditavam que apesar do pouco caixa disponível, a OGX precisaria participar da 11a Rodada em maio para "revitalizar seu portfólio"363.

6/03. EBX e o BTG, um dos principais acionistas da Sete Brasil, assinaram um contratado de "cooperação estratégica de negócios". Não havia detalhes sobre o acordo: além de assessoria financeira, notícias veiculadas nos jornais mencionavam linhas de crédito, mas sem divulgar valores e alocações ao Grupo $X^{364}$.

Repercussões. O SAN (7/3) e o DB (8/3) interpretaram o acordo com o BTG como positivo, pois traria mais caixa para o Grupo X, porém "não traria mais barris ${ }^{365 ", ~ " n a ̃ o ~}$ mudaria a geologia". A OGXP3 se valorizou nos dias seguintes ao anúncio da parceria com o BTG, mas não durou muito.

O JVE ${ }^{366}$ relatou que após 3 semanas de negociações, o AC fechou acordo com BTG (6/3) visando melhorar a estrutura de capital da EBX través da venda de ativos (ex. MPX $x$ E.ON), aportes de capital do banco e fundos soberanos (Cingapura, Abu Dhabi e China) em projetos específicos. Alguns investidores entrevistados interpretaram que, para fechar o acordo com o BTG, o AC estaria "realmente sem fôlego financeiro". Como o acordo foi firmado entre a EBX e o BTG, não diretamente com as empresas de capital aberto, a EBX informou detalhes do acordo à CVM. O comunicado à CVM foi vago.

8/03. JVE ${ }^{367}$ relata que o AC se reuniu com Presidente Dilma para buscar apoio da PETR, que poderia incluir: a venda de FPSOs encomendadas pela OGX à OSX que podiam não ser mais necessárias; o arrendamento de área de Açu da LLX; e, venda de participações nas empresas X... "Pode ser qualquer coisa" teria dito o AC.

Repercussões. Os Analistas da Amostra Própria não comentaram.

${ }^{363}$ SEQUEIRA \& FONSECA [2013c].

${ }^{364}$ GASPAR [2014, p. 414] relatou que se tratava de um contrato de 3 anos. O BTG faria a reestruturação financeira do Grupo e aportaria recursos ( $R \$ 1$ bilhão de linha de crédito para projetos específicos mais apoio na oferta de ações para capitalizar a MPX). A remuneração do BTG seria $10 \%$ da valorização das ações do Grupo, mas o AC teria de se tornar minoritário. Naquele momento, o diagnóstico era que “o problema das empresas X se chama Eike Batista" [GASPAR, 2014, p. 418]. O AC, que antes fora um grande "ativo" do Grupo, agora se tornara um fardo.

Havia especulações que a verdadeira intenção do BTG era fazer uma "liquidação organizada" da OGX, onde o banco obteria informações antes dos outros credores". Como se disse no mercado, à época, a associação fez do BTG "o primeiro da fila do bufê", podendo escolher o que financiar, onde investir e o que descartar" [GASPAR, 2014, p. 422].

A "liquidação" começaria com a MPX, talvez o melhor negócio do grupo graças aos seus contratos de venda de energia de longo prazo, mas as obras de duas UTEs estavam atrasadas e gerando prejuízos. Em julho de 2013, a E.ON. que viria a aumentar sua participação no capital da MPX.

${ }^{365}$ AUDI \& FALANGA NETO [2013b].

366 Disponível em: https://www.valor.com.br/empresas/3036630/controladas-da-ebx-dizem-nao-fazerparte-de-acordo-com-btg

367 Disponível em: https://www.valor.com.br/empresas/3036708/apos-acordo-com-btg-pactual-eikebusca-o-apoio-da-petrobras 
11/03. OGX divulgou os resultados decepcionantes da produção do terceiro poço de TBAZ (estimada em 1,6 kbpd em fevereiro) e seu efeito negativo sobre a produção dos dois primeiros poços.

Repercussões. Foi um dia histórico. Restava então TBMT que poderia ser o único campo da OGX com algum valor. A OGXP3 caiu 14,8\% em um dia. O CS ajustou seu PA em $64,0 \%$ (de $\mathrm{R} \$ 5,70$ para $\mathrm{R} \$ 2,00$ ) e rebaixou sua recomendação de "neutro" para "venda" 368 .

$O D^{369}$, que já havia reduzido seu $P A$ para $R \$ 2,00$ /ação dias antes, levantou duas questões: TBAZ seria economicamente viável? A OGX não deveria fazer um TLD em TBMT para entender melhor a geologia e evitar surpresas? Diante dos resultados do 3 ㅇ poço e seu potencial impacto não só na curva de produção, mas também na possível necessidade de descolar a OSX-1 $1^{370}$ para outro lugar onde os fluxos poderiam ser melhores, os Analistas do IBBA, que ainda não havia revisto seu PA, consideravam que:

(...) a única esperança para o OGX no curto prazo é uma transação de M\&A. Há relatos de uma potencial venda de participação em Campos para a Petronas ${ }^{371}$, e até um possivel farm-out na Paranaíba. Mas nós já aprendemos que isso pode demorar muito e os valores podem desapontar [KOVARSKY \& MENDES, 2013b, p. 1].

Para piorar, o terceiro poço de TBAZ estava localizado em uma área com características muito similares às de Pipeline e do restante de Waimea. A extrapolação (read-across) era inevitável. No dia seguinte, finalmente, os Analistas IBBA reduziram seu PA de R\$ 8,30 para $\mathrm{R} \$ 2,90 /$ ação, ainda mais elevado do que o CS e o DB. O IBBA, pela primeira vez, também alterou sua recomendação de "compra" para "neutra".

Esta é a sexta vez consecutiva que reduzimos a avaliação da OGX após uma notícia decepcionante para a empresa. Em comentários anteriores, no entanto, ainda estávamos preparados para dar à OGX algum crédito pela campanha exploratória e pelo potencial do portfólio de Campos, e é por isso que a nossa recomendação de compra sobreviveu por tanto tempo. As taxas de fluxo mais baixas e a leitura negativa em todos os outros reservatórios de carbonato reduziram ainda mais a nossa confiança na capacidade da OGX de atender as expectativas de produção e, consequentemente, a geração de caixa, ao mesmo tempo em que impulsiona o desenvolvimento de qualquer potencial de exploração, desencorajando-nos a valorizá-los.

368 LEITE, CANHEU \& SOBREIRA [2013b].

${ }^{369}$ SEQUEIRA \& FONSECA [2013d].

370 AUDI \& FALANGA NETO [2013b] estimaram que a OSX-1 estava utilizando $25 \%$ de sua capacidade instalada, o que elevava seu custo de extração (lifting cost) para US\$30/barril). Os Analistas também recapitularam que até aquela data, a OGX já havia encomendado um total de cinco plataformas. A OSX-2 deveria chegar ao Brasil no fim de 2013.

${ }^{371}$ GASPAR [2014] relata que as negociações com a estatal malaia de petróleo foram interrompidas com a RJ da OGX. Apenas recentemente a empresa malaia voltaria a tentar investir no Brasil ao participar da $14^{a}$ rodada de blocos exploratórios da ANP. A Petronas é uma das maiores petroleiras do mundo, produzindo 2,39 milhões de boe/dia de O\&G. 
(...) Por que não uma recomendação de venda? Apesar do nosso ceticismo sobre notícias positivas na frente operacional nos próximos meses, não recomendamos que os investidores realizem (grandes) perdas agora. Em nossa opinião, os muitos desafios enfrentados pela empresa até agora deveriam ter aumentado o senso de urgência na condução de um processo de M\&A. Tubarão Martelo é o primeiro candidato, acreditamos, dado seu estágio de desenvolvimento e a vantagem de ser um reservatório de arenito, em vez de carbonato.

(...) de acordo com a OGX, o reservatório de Tubarão Azul é muito menos homogêneo e mais compartimentado do que o originalmente esperado, com áreas de menor permeabilidade, o que impede que o óleo flua como esperado em certas partes do reservatório [KOVARSKY \& MENDES, 2013c, p. 1-2].

No mesmo dia, o SAN também reduziu seu PA de $R \$ 5,70$ para $R \$ 1,80$, alterando sua recomendação de "manter" para "vender". Os Analistas ${ }^{372}$ alertaram os investidores para a alta volatilidade da OGXP3, impulsionada por "investidores de varejo" que predominavam no volume de transações diárias. Os Analistas do SAN e do IBBA reduziram seus $P A s$ na data limite das 11 concessões da $O G X^{373}$. Estes Analistas não aguardaram pela informação.

13/03. OGX anunciou a devolução de um dos seus quatro blocos de Santos, o BM-S-57, onde se localizava a acumulação de Fortaleza. A Empresa declarou também a comercialidade de três campos: TBTI, TBGA (Pipeline, BM-C-41) e TBAR (Fuji/Ilimani, BMC-41). Próximo da data de expiração de suas concessões, a OGX pleiteou PADs para apenas seis acumulações em Campos e três em Santos.

Repercussões. Volume não recuperável (in situ) dos três campos foram estimados entre 0,521 e 1,339 bboe. Por que divulgar o volume não recuperável, quando a prática da indústria é divulgar o volume recuperável ${ }^{374}$ ? Assumindo $25 \%$ de taxa de recuperação (utilizada no 3으 D\& ${ }^{375}$ ) no P50 (0,823 bboe), o volume recuperável seria de 0,206 bboe. A soma desta estimativa com as declarações de $\operatorname{TBAZ}(0,110)$ e TBMT $(0,285)$ não alcançaria o volume contingente $2 \mathrm{C}$ de 0,700 bboe estimado pelo 3 o $D \& M$ que, na época, a OGX considerou conservador. Esse volume estimado não justificaria mais do que três FPSOs $^{376}$, mas a OGX havia encomendado cinco: haveria uso para a OSX-4 e OSX-5?

Em Campos, a OGX pleiteou PADs para seis acumulações: Vesúvio, Veidma (BM-C-37), Tulum (BM-C-37), Itacoatiara (BM-C-39), Peró/Ingá (BM-C-40) e Tambora/Tupungato

\footnotetext{
372 AUDI \& FALANGA NETO [2013b].

${ }^{373}$ AUDI \& FALANGA NETO [2013b] explicam que, diante da data limite da concessão da ANP, a OGX poderia adotar três possíveis ações: (i) devolver alguns blocos onde não se descobriu óleo; (ii) "encolher" as áreas de alguns blocos e pleitear um PAD, que pode ou não ser aceito pela ANP (se for, a concessão é estendida por tempo determinado); e (iii) declarar a comercialidade de algumas áreas.

${ }^{374}$ LEITE, CANHEU \& SOBREIRA [2013c].

${ }^{375}$ SEQUEIRA \& FONSECA [2013e] replicaram essa extrapolação utilizando um fator de recuperação entre 10\%-15\%, "devido a presença de óleo pesado e a geologia desafiadora". Já AUDI \& FALANGA NETO [2013c] estimavam fator de recuperação entre 30\%-40\%, "devido à presença de óleo leve."

${ }^{376}$ OSX-1, OSX-2 e OSX-3. A OSX-3 deveria chegar ao Brasil no 3T2013 e começar a produzir no 4T13. AUDI \& FALANGA NETO [2013c].
} 
(BM-C-41). Em Santos, pleiteou PADs para três acumulações: Curitiba (BM-S-58), Belém (BM-S-56) e Natal (BM-S-59). Depois de tantos poços perfurados em Campos, a Empresa não era capaz de tomar decisões sobre a maior parte das acumulações descobertas ${ }^{377}$ ? A Empresa só era capaz de declarar a comercialidade em apenas três acumulações ${ }^{378}$ ?

Ainda em 13 de março, com a redução na premissa do fluxo de TBAZ, o $\mathrm{MS}^{379}$ revisou seu PA de $R \$ 4,90$ para $R \$ 1,90$, mas não recomendou a venda da OGXP3, pois ainda acreditava na capacidade da Empresa em captar recursos através da put, do farm-out e da associação com o BTG que poderia reestruturar seus ativos:

\begin{abstract}
Por que não recomendar a venda? Preferimos aguardar e não expor o ativo subjacente [a OGX], uma vez que o resultado de um processo de reestruturação pode ser binário e gerar grande ganho a partir dos níveis atuais [MONTANARI \& BELLINETTI, 2013a, p. 1].
\end{abstract}

14/03. A ANP divulgou dados sobre a produção dos três poços de TBAZ para janeiro que mostrou que os problemas não eram com o terceiro poço, mas os dois primeiros, cujas produções declinaram.

Repercussões. A GS, reduziu seu PA de $R \$ 4,90$ para $R \$ 2,60$. Dentre os ajustes feitos, a GS eliminou duas FPOS de suas projeções, a OSX-4 e OSX-5, por "falta de clareza as áreas onde seriam designadas e preocupações quanto ao caixa necessário para desenvolvêlas"380.

Ao contrário das estimativas dos Analistas para os três poços de TBAZ, o problema não foi o terceiro poço, mas os dois primeiros, cujas produções declinaram. A incômoda, porém, pertinente questão levantada pelo DB em 4 de fevereiro, era fundamental: TBAZ é economicamente viável ${ }^{381}$ ?

\footnotetext{
377 SEQUEIRA \& FONSECA [2013e].

${ }^{378}$ SEQUEIRA \& FONSECA [2013e]. Em entrevistas com alguns executivos de mercado, fomos informados que os executivos da OGX ganhavam bônus adicionais por poço perfurado.

379 MONTANARI \& BELLINETTI [2013a].

380 MATTAR et al. 2013a, p. 1.

381 SEQUEIRA \& FONSECA [2013f].
} 
Tabela 42 - Fluxos dos Três Poços de TBAZ entre Fev.2012 e Jan.2013

\begin{tabular}{|l|c|c|c|c|c|}
\hline & OGX-26 & OGX-68 & TBAZ-1HP & Total & kbpd/poço \\
\hline fev-12 & 11,037 & - & - & 11,037 & 11,037 \\
\hline mar-12 & 10,064 & - & - & 10,064 & 10,064 \\
\hline abr-12 & 8,832 & - & - & 8,832 & 8,832 \\
\hline mai-12 & 4,665 & 4,065 & - & 8,730 & 4,365 \\
\hline jun-12 & 2,368 & 6,461 & - & 8,829 & 4,415 \\
\hline jul-12 & - & 7,000 & - & 7,000 & 3,500 \\
\hline ago-12 & 4,144 & 6,113 & - & 10,257 & 5,129 \\
\hline set-12 & 4,325 & 5,724 & - & 10,049 & 5,025 \\
\hline out-12 & 5,428 & 4,557 & - & 9,985 & 4,993 \\
\hline nov-12 & 5,963 & 3,815 & & 9,778 & 4,889 \\
\hline dez-12 & 6,220 & 3,599 & & 9,819 & 4,910 \\
\hline jan-13 & 5,346 & 2,793 & 4,594 & 12,733 & 4,244 \\
\hline
\end{tabular}

Fonte: dados ANP. Média aritmética simples, sem considerar dias parados para manutenção.

O mercado já especulava que os "tubarões de Eike" não tinham valor. As três Declarações de Comercialidade apresentadas em 12/março referiam-se a campos adjacentes ao de TBAZ, cuja geologia era tão complexa que sua viabilidade econômica estava sendo questionada ${ }^{382}$. Era preciso abrir novas áreas. A Empresa ainda tinha US\$ 1,1 bilhão em caixa. Mas a LLX só tinha $\mathrm{R} \$ 50$ milhões em caixa.

26/03. OGX anunciou que, após três meses de produção, o terceiro poço de TBAZ ainda não havia se estabilizado.

Repercussões. A OGX também divulgou os resultados do 4T2012: receita de $\mathrm{R} \$ 175$ milhões, dos quais R\$ 23 milhões referem-se a vendas de GN de Parnaíba; EBITDA negativo de $\mathrm{R} \$ 277$ milhões (incluindo $\mathrm{R} \$ 231$ milhões em baixas de ativos ${ }^{383}$ ); margem EBITDA ajustada só considerando o OSX-1 aumentou de 39\% para 43\%; saldo de caixa de US\$ 1,65 bilhão; US\$ 1,3 bilhão de investimentos projetados para 2013 (não considerando sua participação na 11 1 a Rodada da ANP em maio) ${ }^{384}$.

${ }^{382}$ SEQUEIRA \& FONSECA [2013e].

383 O 4T12 era o terceiro trimestre de reconhecimentos de perdas significativos, apontou o MS (27/3/13).

${ }^{384}$ AUDI \& FALANGA NETO [2013d]. 
Tabela 43 - Resumo de Indicadores da OGX do 4T2011 ao 4T2012

\begin{tabular}{|l|c|c|c|c|}
\hline R\$ Milhões & 4T11 & 3T12 & 4T12 & Var. 4T/3T \\
\hline Vol. Vendas Óleo (kbd) & - & 8,6 & 8,8 & $2,3 \%$ \\
\hline Preço Médio (US\$/b) & - & 94,0 & 104,6 & $11,3 \%$ \\
\hline ROL & - & 150,7 & 174,7 & $15,9 \%$ \\
\hline EBITDAX 385 & $-99,1$ & $-57,1$ & 9,2 & $-116,1 \%$ \\
\hline M.EBITDAX & - & $-37,9 \%$ & $5,3 \%$ & $-114,0 \%$ \\
\hline EBITDA & $-399,7$ & $-388,0$ & $-276,8$ & $-28,7 \%$ \\
\hline Lucro Líquido & $-321,0$ & $-343,3$ & $-272,9$ & $-20,5 \%$ \\
\hline
\end{tabular}

Fonte: MONTANARI \& BELLINETTI, 2013b, p. 2.

A posição do caixa ficou abaixo daquela projetada por alguns analistas (SAN projetava US\$ 1,8 a 1,9 bilhão, GS projetava US\$ 2,7 bilhões) e frente aos investimentos projetados, a questão do exercício da put se tornou crucial, apesar dos Executivos considerarem que o saldo das disponibilidades mais o fluxo de caixa de 2013 seriam suficientes para cobrir os investimentos.

Os termos da put eram considerados vagos, o que trouxe dúvidas sobre a capacidade da OGX em exercê-la ${ }^{386}$. O IBBA previa que a put deveria ser exercida até, no máximo, o 4T2013. As implicações da associação entre EBX e o BTG para a captação de novos recursos financeiros ainda não haviam sido esclarecidas ${ }^{387}$.

Em paralelo, a OSX também enfrentava dificuldades: estava terminando a construção da OSX-2 e OSX-3, mas enfrentava uma severa limitação de caixa. Suas ações que, um mês antes, já tinham se desvalorizado a um patamar equivalente ao seu valor de liquidação $(R \$ 7,00)$, em 25 de março, estavam ainda valendo menos ( $R \$ 4,21)$. "Mas o mercado não se importava mais com valor", interpretava os analistas do CS:

Além das preocupações com a situação financeira do grupo EBX, números de produção pobres da empresa irmã OGX e a "falha" recente da OSX para captar US \$ 265 milhões para o FPSO OSX-3, as ações

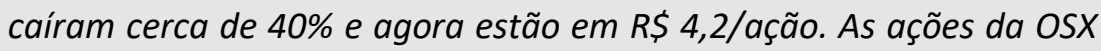
estão claramente precificando que a OGX nem poderá cumprir suas obrigações mínimas [LEITE, CANHEU \& SOBREIRA, 2013e, p. 1].

Com disponibilidades limitadas, o CS estimava que a OSX teria de exercer a put de US\$ 0,5 bilhão contra o $\mathrm{AC}$, caso contrário, seu caixa se esgotaria em novembro ${ }^{388}$.

385 Earnings Before Interest, Taxes, Depreciation, Depletion, Amortization and Exploration Expenses. Custos de exploração incluem, dentre outros, os custos de abandonar poços secos.

386 LEITE, CANHEU \& SOBREIRA [2013d].

387 SEQUEIRA \& FONSECA [2013f].

388 SEQUEIRA \& FONSECA [2013h, p. 7] relata que os FPSOs OSX-1, 2 e 3 estavam alugados pela OGX por 20 anos por US\$ $263 \mathrm{mil} / \mathrm{dia}$ (OSX-1) e US\$ $360 \mathrm{mil} / \mathrm{dia}$ (OSX2 e 3), enquanto os dois WHPs estavam 
1/04. JVE ${ }^{389}$ relata que foi consumada a venda da MPX para E.ON, que comprou $24,5 \%$ das ações do AC por R\$ 1,5 bilhão, o que não seria suficiente para honrar as puts de US\$ 0,5 bilhão na OSX e US\$ 1 bilhão na OGX.

4/04. Devido à baixa posição de caixa, a S\&P rebaixou a nota de crédito da OGX de $B$ para B- apenas três níveis acima da nota de default.

Repercussões. O rebaixamento atingiu o OGXPBZ 2018 que já estava sendo transacionado ao um desconto de $20 \%$ (80.938) e em poucos dias ampliou seu desconto para $42,5 \%$ (57.500 em 18/4).

Gráfico 49 - Evolução do Valor do OGXPBZ18 e OGXPBZ22 em 2013 (Valor de Face = 100)

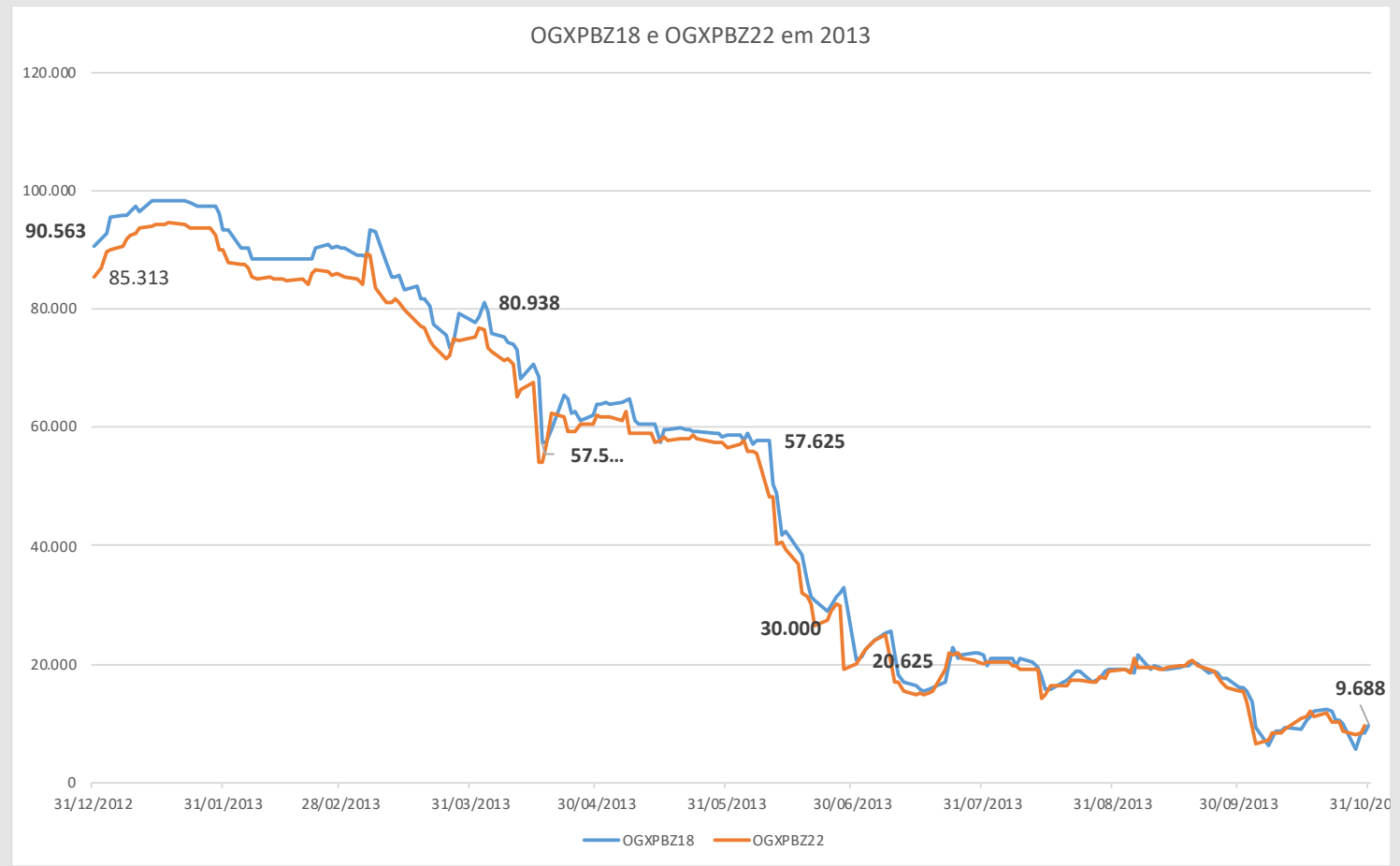

Fonte: Bloomberg.

Por ser um título mais longo, o OGXPBZ 2022 sofreu descontos ainda maiores: 33,25\% de desconto em 4/4 (76.750) que se ampliou para 45,81\% em 18/4 (54.188). Mas o valor dos bonds da OGX não se sustentaria nos meses subsequentes. Em julho, ambos já haviam rompido a marca de descontos acima de $75 \%$.

Poucos dias depois da reclassificação da S\&P (em 11/4), o DB ${ }^{390}$ reduziu seu PA de R\$ 2,00 para $R \$ 0,80$, devido à nova redução nas premissas das taxas de recuperação. Os

alugados por 25 anos por US\$ $320 \mathrm{mil} / \mathrm{dia}$. Os contratos previam multas caso a OGX devolvesse os equipamentos antes do término do aluguel.

${ }^{389}$ Disponível em: https://www.valor.com.br/empresas/3067328/venda-de-mpx-so-traz-alivio-para-eike

390 SEQUEIRA \& FONSECA [2013h]. 
Analistas, que já não consideravam nenhum valor nos blocos da OGX no Brasil e na Colômbia, exceto por Campos (491 mboe), BS-4 (129 mboe) e Parnaíba (181 mboe), alertaram:

(...) nós destacamos que a probabilidade dos ativos da OGX valerem menos do que sua dívida bruta, próxima de US\$\$ 4,0 bilhões, não deva ser ignorada [SEQUEIRA \& FONSECA, 2013h, p. 1].

Em seu relatório, o DB foi incisivo: "a disciplina financeira da OGX tem sido pobre". E explicou com uma matemática simples:

O total de investimentos realizados na empresa somou US\$ 9,4 bilhões, da seguinte forma: (1) US\$ 1,3 bilhão do private placement, (2) US\$ 4,1 bilhões do IPO, (3) US\$ 3,7 bilhões dos Unsecured Notes e (4) $R \$ 600$ milhões de empréstimos bancários da Parnaíba. Destes, US\$ 5, 3 bilhões foram gastos na campanha exploratória. Nós estimamos que, até o final deste ano, a empresa ficará sem dinheiro (saldo de US\$ 1,7 bilhão em disponibilidades em 31/12/12). Embora significativamente desvantajosa para o seu controlador, a put da OGX de US\$ 1,0 bilhão a $R \$$ 6,30/ação terá que ser exercida, se a OGX não vender ativos (o farmout é improvável em nossa visão).

Bandeiras vermelhas iniciais sobre disciplina financeira

Em retrospetiva, houve vários sinais de indisciplina: (1) ofertas agressivas na 9a Rodada da ANP, (2) concentração de risco geológico e financeiro e (3) campanha de exploração agressiva na bacia de Campos. Isso resultou em que a OGX se tornou uma empresa altamente alavancada, especialmente considerando a fase inicial de suas operações [SEQUEIRA \& FONSECA, 2013h, p. 1].

Segundo O DB, a OGX concentrou seus esforços exploratórios em Campos, preponderantemente sem parceiros (o BM-C-37/38 foram as exceções, com 70\% OGX e $30 \%$ MAERSK), apesar do farm-out ser uma prática comum na indústria. Quando a OGX tentou fazê-lo, fontes não oficiais informavam que sua expectativa de valor era demasiadamente alta, desconsiderando o risco exploratório.

Além dos fluxos de TBAZ, os resultados da exploração de BM-C-37/38 se tornaram eventos cruciais. Resultados ruins poderiam levar a OGX a devolver os blocos e cancelar a contratação de OSX-4 e OSX-5.

8/04. O JVE relatou que a queda acentuada da $\operatorname{LLX}(-15 \%)$ e OGXP3 $(-13,4 \%)$, com rumores de problemas ambientais em $A c ̧ u$, mas as quedas se reverteram com a notícia que a Presidente Dilma considerava que a "quebra" do Grupo X não era de interesse do país e que iria ajudar a restaurar a credibilidade através de suporte via PETR em Açu. No dia seguinte (9/4), em teleconferência, Graça Foster confirmou que PETR estava negociando com LLX o uso de suas instalações em Açu. Moody's rebaixou OGX de B1 para B2. 
Poucos dias depois da teleconferência (19/4), a PETR descartou o interesse em participar de projetos da LLX.

Repercussões. Os Analistas da Amostra Própria não comentaram.

12/04. ANP divulgou que a produção média em fevereiro dos dois primeiros poços do TBAZ (OGX-26 e 68), os mais antigos em serviço foi de $4,247 \mathrm{kbpd}, 17 \%$ abaixo do pico de 5,129 em agosto de 2012 .

Repercussões. A produção do terceiro poço apresentou uma queda abrupta (de 4,594 em fevereiro para 2,483 kbpd em março) e o DB não conseguiu uma explicação da OGX para tal queda ${ }^{391}$ :

Poucos dias depois do DB (em 16/4), o CS reavaliou seu PA de $R \$ 2,00$ para $R \$ 1,00$ : além de toda incerteza em relação à posição de caixa, a viabilidade dos "tubarões", a produtividade decrescente em TBAZ, incidentes operacionais afetaram os três poços de TBAZ, cuja produção em março caiu $27 \%$ para cerca de $8,3 \mathrm{kbpd}$ (de $11,0 \mathrm{kbpd}$ em fevereiro). "Menos produção, menos caixa", resumiu. "Lei de Murphy" foi o título do relatório do $\mathrm{CS}^{392}$. Poderiam ser 421 mil barris perdidos (US\$ 42 milhões a menos de receitas) além de US\$ 24 milhões em investimentos não previstos. Lembrando que a Empresa havia começado o ano com US\$ 1,6 bilhão em caixa, mas tinha US\$ 1,3 bilhão em investimentos e US\$ 0,3 bilhão de despesas financeiras programados. Os Analistas do CS, IBBA e MS temiam que, com base neste incidente, o mercado começasse a questionar a habilidade operacional da OGX em desenvolver seu portfólio:

Especialistas da indústria, no entanto, argumentaram que a empresa poderia ignorar etapas importantes, definindo o sistema de produção e o equipamento sem dados suficientes dos reservatórios. Parece que eles podem ter tido pelo menos um certo grau de razão [KOVARSKY \& MENDES, 2013c, p. 1].

22 e 30/4. Segundo o JVE ${ }^{393}$, a OGXP3 abiu o pregão de 22/04 com alta de 19,2\% com rumores de socorro ao grupo $\mathrm{X}$ por investidor russo, Lukoil (3a maior petroleira russa após a Gazprom e Rosneft), em parceria com Petronas (assessorada pela MER) e a PETR.

Um investidor entrevistado relatou que "faltam referências na negociação com os papéis do grupo X". Não havia nenhum fato novo que justificasse o aumento de $18,38 \%$ da OGXP3. "De resto tudo é especulação e nenhuma precificação está fazendo sentido. $O$ próprio fato de uma empresa conservadora como a Petronas estar negociando há tanto tempo com Batista um ativo da OGX significa que encontrou algum valor na companhia, mas o mercado não parece capaz de enxergar onde está este valor."

\footnotetext{
391 SEQUEIRA \& FONSECA [2013i].

392 LEITE, CANHEU \& SOBREIRA [2013f].

393 Disponível em: https://www.valor.com.br/empresas/3096104/analise-faltam-referencias-nanegociacao-com-os-papeis-do-grupo-x
} 
Em 30/4, após a valorização de 34,56\% da OGXP3 na semana anterior, a Empresa publica desmentido sobre "rumores sobre oportunidades de negócios", sem especificá-los. Seria a suposta transação com a Lukoil?

6/05. Artigo na mídia relatou que o farm-out de TBMT com a malaia Petronas estava prestes a ser concluído: US\$ 850 milhões por $40 \%$ de participação (US\$ 7,5/boe) ) $^{394}$. 0 pagamento, em caixa, estaria condicionado à confirmação da performance do campo, que poderia ocorrer em meados de 2014.

Repercussões. Se o pagamento da Petronas estava condicionado do TBMT, a OGX precisaria exercer o put contra o AC antes disso. O IBBA estimou um múltiplo de EV de US\$ 7,5/boe para o farm-out, considerando 285 mboe (da Declaração de Comercialidade) e uma taxa de recuperação conservadora de $5 \mathrm{kbpd}$. Segundo os Analistas, o múltiplo representaria um desconto de $25 \%$ em relação ao que consideravam o "preço justo" de US\$ 10,0/boe. Os Analistas destacam que se o múltiplo de TBMT fosse aplicado ao restante do portfólio da OGX, o atual valor da OGXP3 na IBOV estaria superestimado. Para sustentar o valor atual, a OGX precisaria ter 400 a 500 mboe a mais do que estimava ter na época. O SAN, em um contraponto, argumentou que TBMT seria o melhor ativo da OGX, portanto, extrapolar o múltiplo para o portfólio da OGX "não faria sentido"395.

7/05. Produção de TBAZ em abril caiu ainda mais, de 8,3 (março) para $1,8 \mathrm{kbpd}$, por reflexos dos problemas técnicos com equipamentos ${ }^{396}$.

Repercussões. Além da notícia negativa sobre o TBAZ, a OGX também anunciou o segundo poço seco (OGX-106) no BM-C-37, agora no prospecto de Cancun (o primeiro tinha sido em Cozumel). No prospecto de Viedma (poço OGX-109), foram descobertos hidrocarbonetos, porém com um net pay de apenas 6 metros. Estas últimas duas notícias aumentavam as incertezas em relação aos outros tubarões (Areia, Gato e Tigre) e no bloco BM-C-37397.

Problemas operacionais não são incomuns, mas acreditamos que, neste caso, o processo foi agravado pela pressa para produzir petróleo, provavelmente ignorando etapas importantes no processo ou divulgando premissas excessivamente agressivas [KOVARSKY \& MENDES, 2013f, p. 1].

Ainda em $7 / 5$, outro farm-out foi anunciado em Polvo, apenas 8 quilômetros distante. A HRT estaria adquirindo $60 \%$ de Polvo da BP por US\$ 135 milhões (MAERSK continuaria

\footnotetext{
${ }^{394}$ Coluna de Lauro Jardim na revista Veja apud KOVARSKY \& MENDES [2013d]. Poucos dias depois (7/5), o JVE (apud KOVARSKY \& MENDES [2013f]) informou que haveria três pagamentos: US\$ 250 milhões no ato da assinatura do contrato; US\$ 500 milhões quando do primeiro óleo (1S14); e US\$ 100 milhões em função de metas da produtividade do campo.

395 AUDI \& FALANGA NETO, 2013e, p. 3.

396 Segundo KOVARSKY \& MENDES [2013f] o mercado esperava que os poços OGX-68 e o TBAZ-1 não produzissem em abril. O que não foi esperado pelo mercado foi que o primeiro poço, o OGX-26, ficou 14 dias parados por questões operacionais. Em julho, esperava-se que os três poços voltassem a produzir plenamente.

${ }^{397}$ SEQUEIRA \& FONSECA [2013k].
} 
com $40 \%$ de Polvo). A transação seria viabilizada por financiamentos à $H R T$, que se tornaria a operadora do campo. Considerando que haveria 24,3 mboe (de óleo pesado) remanescentes em Polvo, a HRT teria pago US\$ 9,26/boe, o que representaria um múltiplo máximo para TBMT, pois Polvo já estava operacional desde 2007 (atualmente com taxa de recuperação média de $1,4 \mathrm{kbpd} /$ poço) ${ }^{398}$.

O DB fez uma ponderação importante sobre o farm-out de Polvo. Primeiro, a BP teria vendido sua participação em Polvo por duas razões: seu tamanho relativamente pequeno; seu desempenho decepcionante, típico de acumulações albiana carbonadas na região de Campos $^{399}$. Então por que a HRT teria adquirido Polvo? Depois de resultados decepcionantes de GN na bacia do Solimões, dos altos investimentos na Namíbia e de sua declinante posição de caixa, Polvo agregaria cerca de US\$ 60 milhões por ano de fluxo de caixa à HRT até $2019^{400}$. Ou seja, a tese de investimento da HRT estava ficando cada vez mais difícil de sustentar, e Polvo poderia trazer uma nova perspectiva a esta junior oil.

8/05. Assinado o acordo de farm-out do TBMT com a Petronas, porém os termos dos pagamentos não foram revelados. Adicionalmente, a Petronas teria assinado com o AC um contrato de opção de compra de $5 \%$ da OGX por R\$ 6,30/ação, o mesmo preço de exercício da put. A call teria validade até abril de 2015.

Repercussões. Considerando uma estimativa de 212 mboe (2C) de fevereiro de 2012, efetuada pela D\&M para TBMT, o múltiplo do farm-out seria de US\$10,02/boe, considerado alto pelo $\mathrm{DB}^{401}$ e "decente" pelo IBBA ${ }^{402}$, que mencionou uma possível venda de participação a outro potencial sócio, a estatal russa Lukoil.

10/05. Em teleconferência, Executivos divulgaram detalhes do farm-out: US\$ 250 milhões a serem pagos no 4T2013; US\$ 500 milhões quando do primeiro óleo (1T2014); e US\$ 100 milhões em função de metas da produtividade do campo (US\$ 50 milhões ao atingir a produção média de $40 \mathrm{kbpd}$, mais US\$ 25 milhões para $50 \mathrm{kbpd}$, mais US\$ 25 milhões para $60 \mathrm{kbpd}$, respectivamente).

OGX anunciou também os resultados do 1T2013, que incluíam: vendas de 1,2 mboe; R\$ 1,2 bilhão em baixas de ativos (poços subcomerciais, dos quais $\mathrm{R} \$ 952$ milhões referiamse aos blocos devolvidos para a ANP); EBITDA negativo de $\mathrm{R} \$ 1,1$ bilhão; $R \$ 2,3$ bilhões em disponibilidades (US\$1,1 bilhão).

A OGX também confirmou a viabilidade comercial de TBTI, TBAR e TBGA.

Repercussões. Apesar do farm-out, os Analistas reiteravam a necessidade do exercício da put.

\footnotetext{
398 SEQUEIRA \& FONSECA [2013j].

${ }^{399}$ Em outubro de 2012, a produção de Polvo alcançou seu pico em 26,8 kbpd. A média dos últimos doze meses foi de 13,2 kbpd, com dez poços em produção.

$400 \mathrm{O}$ montante de fluxo de caixa anual foi estimado por KOVARSKY \& MENDES [2013e].

401 SEQUEIRA \& FONSECA [2013I].

402 KOVARSKY \& MENDES [2013g].
} 
A partir da análise da ata do COAD de 6/maio, o $\mathrm{DB}^{403}$ constatou que a OGX deu como garantias ao farm-out mais $40 \%$ de sua participação em TBMT $^{404}$ e $20 \%$ de participação no BS-4. Essas garantias indicavam o risco que a Petronas associava ao farm-out.

Para o MS, DB e o SAN, o montante de baixas nos ativos no 1 T2013 foi maior do que o esperado. O lançamento destas perdas teve impacto no valor de mercado dos bonds da OGX.

Apesar de confirmar a viabilidade comercial de TBTI, TBAR e TBGA, O PD só seria divulgado em junho com a chegada da OSX-2 em setembro e início da produção no 4 T2013.

14 e 15/05. OGX arrematou 13 blocos na 11a Rodada, por R\$ 376 milhões (US\$ 188 milhões) em BA e R\$ 698 milhões (US\$ 349 milhões) em PEM. Dos 13 blocos arrematados, 4 estavam na bacia do Paranaíba, 3 em Barreirinhas, 3 no Ceará, 2 na Potiguar e 1 na Foz do Amazonas.

Repercussões. A OGX foi "agressiva" 405 no número de blocos, BA e PEM. Nestas três dimensões, a OGX foi a segunda empresa com maior participação no leilão, perdendo apenas para a PETR (R\$ 535 milhões em BA) e distante do 30 colocado, a QGEP (R\$ 95 milhões em BA). Na maioria dos blocos, a OGX não teve parceiros, contrariando a expectativa do mercado. Em termos de comprometimento do caixa para pagar o BA, a OGX foi a mais agressiva: $16 \%$ contra $1 \%$ da PETR.

Nós havíamos estimado que o dinheiro da empresa se esgotaria até o 2T14-3T14, mas essa compra de blocos poderia acelerar o processo, implicando dois pontos significativos: (i) o PUT deve ser exercido em breve; e (ii) a empresa pode estar tentando contar uma nova história, em vez de se concentrar em seu atual portfólio de ativos [AUDI \& FALANGA NETO, 2013f, p. 2].

No início de junho (4), o Real sofreu uma forte desvalorização, o que deveria afetar negativamente a OGX, devido ao volume de sua dívida em dólares (US\$ 3,6 bilhões). Mesmo com suas receitas dolarizadas, o volume de vendas ainda era relativamente pequeno em relação à dívida.

11/06. Na divulgação da CVM 358 de maio, soube-se que o AC havia vendido o equivalente a $\mathrm{R} \$ 70,5$ milhões da OGXP3 (121,8 milhões de ações), reduzindo sua participação de $62,6 \%$ para $60,5 \%$.

Repercussões. Se o $A C$ estava vendendo suas ações por $\mathrm{R} \$ 1,73$, por que as compraria por $\mathrm{R} \$ 6,30^{406}$ ? Ao vender suas ações, o AC produziu um péssimo sinal ao mercado. $O$ valor do OGXPBZ2018 caiu de 57.625 (10/6) para 20.625 (1/7). O valor do OGXPBZ2022 caiu de $57.750(10 / 6)$ para $19.188(1 / 7)$. A OGXP3 caiu de $R \$ 1,29(10 / 6)$ para $R \$ 0,56$

\footnotetext{
${ }^{403}$ SEQUEIRA \& FONSECA, 2013m, p. 30.

404 LEITE, CANHEU \& SOBREIRA, 2013g, p. 2.

${ }^{405}$ AUDI \& FALANGA NETO [2013f].

${ }^{406}$ AUDI \& FALANGA NETO [2013g].
} 
(1/7). Finalmente, os bondholders perceberam algo que os acionistas minoritários já haviam percebido em abril de 2011: a OGX não tinha valor.

21/06. Resignação dos três membros independentes do COAD, Rodolpho Tourinho, Elen Gracie e Pedro Malan. Eles eram incumbidos de decidir sobre a validade do momento para exercício da put contra o AC.

Repercussões: No pregão (21/06), a OGXP3 se desvalorizou em 5,34\% (de $\mathrm{R} \$ 4,87$ para $R \$ 4,61)$. A perda no $E V$ foi de $R \$ 627,1$ milhões ou US\$ 301,7 milhões.

Artigo do JVE (24/6) ${ }^{407}$ relatou que a resignação dos três conselheiros independentes foi interpretada pelo mercado como reação a recusa do AC em conceder a put. Para poder exercer a put, a OGX precisaria atingir o nível mínimo de caixa de US\$ 100 milhões (em maio, a OGX teria US\$ 1,48 milhões em caixa, sem considerar os US\$ 250 milhões do farm-out para a Petronas).

No BTG, os sócios temiam que o risco X contaminasse o banco.

24/06. JVE ${ }^{408}$ relata que a OSX teria deixado de honrar obrigação com fornecedor (responsável pela construção da UCN, a empresa de engenharia espanhola Acciona no valor de $\mathrm{R} \$ 500 \mathrm{M})$, que não se pronunciou por questões de NDA.

1/07. OGX anunciou seu Plano de Negócios que incluía: (1) o pagamento imediato de US\$ 449 milhões à OSX para cobrir os custos de equipamentos encomendados, porém

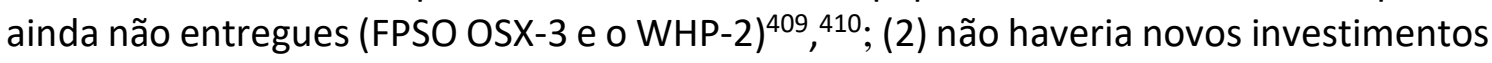
nos três poços de TBAZ, que deveriam parar de produzir até o fim do ano, porém o contrato de aluguel da FPSO OSX-1 continuaria a ser honrado (US\$ 263 mil por dia); (3) o desenvolvimento de TMTB seguiria o planejamento, mas os termos do contrato de aluguel da FPSO OSX-3 e WHP-2 seriam ajustados. O primeiro óleo era esperado para dezembro de 2013, o que implicaria no pagamento de US\$ 500 milhões da Petronas à OGX; (4) o desenvolvimento de TBTI, TBAR e TBGA seria cancelado e suas concessões devolvidas à ANP, pois os campos eram intensamente fragmentados; (5) em decorrência do estudo que apontou a falta de viabilidade econômica de TBTI, TBAR e TBGA, as encomendas da FPSOs OSX-4 e OSX-5, WHP-3/4 à OSX seriam suspensas.

Repercussões. A OGX também anunciou que honraria o contrato de aluguel da OSX-2, que se iniciaria em janeiro de 2014. Mas a OSX-2 seria vendida para a Petronas ou

407 Disponível em: https://www.valor.com.br/empresas/3171626/crise-do-grupo-ebx-piora-com-saidade-conselheiros.

408 Disponível em: https://www.valor.com.br/empresas/3171900/osx-nega-ter-deixado-de-honrarobrigacoes-com-empresa-espanhola.

409 LEITE, CANHEU \& SOBREIRA [2013g, p. 5] explicam que as WHPs são construídas de acordo com as especificidades de cada campo, portanto geralmente são vendidas como sucata após seu uso.

${ }^{410}$ Ainda em junho de 2013, o AC solicitou a anuência dos três conselheiros de alta visibilidade da OGX (Pedro Malan, Ellen Gracie e Rodolfo Tourinho) para compensar em US\$ 449 milhões à OSX pelo cancelamento de encomendas, em uma clássica situação de conflito de interesse [GASPAR, 2014, p. 449]. Na época, o AC detinha $57,18 \%$ das ações da OGX e 74,83\% na OSX. Não só os três conselheiros se recusaram a anuir, como renunciaram coletivamente em 21/6/2013. Mesmo assim, o pagamento foi feito. 
realocada, por exemplo, para o BS-4 ${ }^{411}$. Enquanto isso não ocorresse, a Empresa pagaria US\$ 360 mil por dia, a partir de janeiro de 2014.

É difícil questionar a lógica desta decisão [pagamentos à OSX], mas o resultado é negativo e aumenta o peso sobre a posição de caixa já pressionada da OGX. É sempre fácil olhar para trás e criticar uma decisão de negócios, mas talvez isso tinha de ter sido feito há muito tempo, quando os primeiros contratempos na produtividade de Waimea lançaram dúvidas sobre o potencial efetivo dos carbonatos de Campos. O pedido de muitas unidades produtoras nos estágios iniciais do desenvolvimento também contribuiu para a situação atual [KOVARSKY \& MENDES, 2013h, p. 1].

Em um único pregão, a OGXP3 caiu 29,1\%, (de R\$ 0,79 para 0,56), considerado o dia do "crash" da OGX. Os efeitos da queda da OGXP3 seriam sentidos por outras empresas abertas brasileiras e pelo IBOV, uma vez que a OGXP3 fazia parte do índice (que consolidava as ações mais negociadas, mesmo que fosse de uma empresa préoperacional como a OGX), que ficou conhecido como o "Efeito X".

Ainda no dia 1 de julho, a MER revisou seu PA de $\mathrm{R} \$ 1,0$ para $\mathrm{R} \$ \mathbf{0 , 1}$. No dia seguinte (27), o MS deixou de estimar um PA para a OGXP3 e recomendou aos seus clientes vende-la. Com apenas três ativos (Tubarão Martelo, Parnaíba e 40\% do BS-4, com 329 mboe recuperáveis), a OGX não teria recursos suficientes para pagar sua dívida ${ }^{412}$ : com US\$1,8 bilhão no caixa (já incluindo o farm-out da Petronas), a OGX teria de pagar US\$ 1,7 bilhão nos próximos 12 meses (US\$ 188 milhões de BA da 11a Rodada, US\$ 300 milhões em juros, U\$ 150 milhões em SG\&A, US\$ 380 milhões em investimentos e US\$ 449 milhões de pagamentos à OSX). O exercício da put só traria um alívio de curto prazo.

O DB reduziu seu PA de $\mathrm{R} \$ 0,7$ para $\mathrm{R} \$ 0,1$ e considerou que apesar da queda de $30 \%$ (2/7) na OGXP3, "o mercado ainda não havia precificado plenamente as notícias e suas consequências." ${ }^{413} \mathrm{O}$ único ativo operacional seria desativado e TBMT, muito próximo a Polvo, produziria seu primeiro óleo em 4T2013, se tudo desse certo. O CS também reduziu seu $\mathrm{PA}(2 / 7)$ de $\mathrm{R} \$ 1,0$ para $\mathrm{R} \$ 0,3$ e questionava: "resta algo para os acionistas [da OGX e OSX] neste novo panorama? Vale a pena o risco?" 414

US\$ 1,2 bilhão para TBMT, US\$ 500 milhões para Parnaíba e US\$ 270 milhões para BS-4 somam US\$ 2,0 bilhões. Isso não é um valor de ativos suficiente em comparação com uma dívida de US\$̦ 4,0 bilhões, o que

411 SEQUEIRA \& FONSECA [2013n] argumentam que a OSX-2 foi concebida para operar em águas rasas. Portanto, necessitaria passar por adaptações para operar nas águas profundas do BS-4 ou dos campos da Petronas. Ou seja, a resolução da OSX-2 levaria tempo.

412 MONTANARI \& BELLINETTI [2013c]. LEITE, CANHEU \& SOBREIRA [2013g, p. 3], por exemplo, estimaram o valor de liquidação da OGX. O valor de Tubarão Martelo foi estimado em US\$ 1,134 bilhão, Parnaíba em US\$ 0,448 bilhão, BS-4 em US\$ 0,270 milhão e os blocos da 11a Rodada pelo valor do BA (U\$S 183 milhões). Ou seja, um total de US\$2,036 bilhões de ativos para uma dívida líquida de US\$ 2,685 bilhões (US\$ 3,966 - 1,163-0,188).

413 SEQUEIRA \& FONSECA, 2013 n, p. 1.

${ }^{414}$ LEITE, CANHEU \& SOBREIRA, 2013g, p. 1. 
nos faz concluir que há pouco valor no patrimônio OGX em sua forma atual [LEITE, CANHEU \& SOBREIRA, 2013g, p. 1].

Ainda em 2/07, o IBBA anunciou que revisaria seu PA, mas já alertava que mesmo assumindo o exercício da put e valor para o BS-4 (US\$ 270 milhões): "nos esforçamos para encontrar algum valor para os acionistas existentes da OGX." 415 O IBBA alertava também que mesmo assumindo um pagamento à vista de US\$ 500 milhões pela Petronas, o caixa da OGX terminaria até o final do ano. Exercer a put traria algum alívio ao caixa por mais dois ou três trimestres.

Apenas a GS não recomendou a venda da OGXP3, ainda acreditando no potencial de TBMT, mas reduziu seu PA de $R \$ 2,0$ para $R \$ 0,7 / a c ̧ a ̃ 0^{416}$.

O valor de mercado dos bonds da OGX estava em US\$ 926 milhões, contra um principal de US\$3,966 bilhões. Em 9/07, o $\mathrm{CS}^{417}$ publicou um relatório discutindo cinco possíveis cenários de reestruturação do balanço patrimonial da OGX:

(1) Liquidação: "o menos provável", pois haveria muita destruição de ativos. A Petronas executaria as garantias e restaria apenas US\$1,0 bilhão de valor em TBMT e o BS-4. Os bondholders poderiam recuperar 33\% de seus créditos e os acionistas perderiam todo seu capital.

(2) Conversão dos bonds em ações: "o caminho mais lógico para corrigir a estrutura de capital", pois além de resolver o endividamento, cessa também o pagamento de US\$ 300 milhões por ano em juros. O aumento de capital gerado pela conversão implicaria que os credores deteriam $83 \%$ das ações da OGX. Os bondholders recuperariam $48 \%$ de seus créditos.

(3) Conversão dos bonds em ações mais o exercício da put: supondo que o AC aportasse US\$ 500 milhões, os bondholders recuperariam $60 \%$ de seus créditos.

(4) Pré-pagamento parcial dos bonds com put, e então a conversão: variação de (3), mas considerando que o exercício da put pagaria parte dos bonds com o restante do saldo sendo convertido.

(5) Pagamento parcial dos bonds, conversão, aporte de capital: uma mistura de todas as alternativas acima. Se US\$ 250 milhões fossem usados para pré-pagar os bondholders com os recursos da put, o restante da dívida convertida e os outros US\$ 250 milhões fossem injetados na OGX, a Empresa poderia obter uma taxa de recuperação de $60 \%$ de sua posição em capital.

415 KOVARSKY \& MENDES, 2013h, p. 1. Após este relatório, o IBBA nunca revisou seu PA ou sua recomendação aos clientes. A enigmática justificativa foi que: "Definir um valor justo objetivo para o OGX poderia criar uma referência de valor para negociar contra" [KOVARSKY \& MENDES, 2013j, p. 1].

${ }^{416}$ MATTAR et al. [2013b].

417 LEITE, CANHEU \& SOBREIRA [2013h]. Em 2 de setembro, o CS publicou outro relatório [LEITE, CANHEU \& SOBREIRA, 2013i] onde desconsiderou o exercício da put, o que reduziu o número de cenários para três, descartando (4) e (5), e modificando (3). No novo cenário (3), considerou que o Acionista Controlador venderia sua participação a valor de mercado, estimado em US\$ 300 milhões, para prépagar os bondholders. 
2/07. JVE ${ }^{418}$ reporta que o AC "admite fracasso na tentativa de salvar a OGX", após gastar US\$ 5,3 bilhões na campanha exploratória "mais cara de uma empresa privada no Brasil". As projeções anteriormente divulgadas "não devem mais ser consideradas válidas". "A put continua sendo uma opção viável a ser considerada pela companhia".

Um especialista entrevistado interpretou o anúncio como uma tentativa da OGX de "limpar seu passado" de promessas otimistas. O futuro desejado seria explorar os blocos da 11aㅡ Rodada, UTE Parnaíba (com MPX), Atlanta e Oliva (com QGEP) e o TMAT (com Petronas) em uma estrutura em que o AC seria minoritário. A CVM anunciou que abriu um processo para investigar a put do AC. Em 30/7, a OGX teria de entregar garantias a ANP da capacidade de executar o PEM de R\$ 700 milhões da 11a Rodada. Em 6/8, a OGX teria de comprovar o pagamento de $\mathrm{R} \$ 376$ milhões de BA da 11a Rodada.

4/07. JVE" reporta que "foi posto em marcha um plano para o completo desmembramento do Grupo X..." gerenciado pelo BTG, ao fim do qual, eventuais participações societárias do AC seriam diminutas, mas o AC ficaria sem dívidas e com um patrimônio de US\$ 1 a 2 bilhões. Pedir RJ não era aventado, mas talvez para a OSX a pedisse. O Grupo X estava "desacreditado" por investidores e financiadores. MMX (e sua "joia da coroa", o Porto Sudeste, e não suas minas "que são de baixa qualidade") e MPX seriam vendáveis. Ontem, teria sido acertado um aumento de capital na MPX de R\$ 800 $\mathrm{M}$ (antes era $\mathrm{R} \$ 1,2 \mathrm{~B}$ ) a $\mathrm{R} \$ 6,40 /$ ação, que deu a EON o controle da MPX. Ao AC restou $19 \%$ que seria vendido para pagar dívidas da EBX com o IBBA e BBD.

OSX e OGX estavam na "categoria de empresas sem compradores e candidatas a desaparecer". Os ativos da OGX (até US\$ 2 bilhões) valeriam menos do que a metade de suas dívidas (US\$ 4,5 bilhões). Mas, como os bonds estavam valendo cerca de $20 \%$ do valor de face, o equacionamento parecia possível. Se a dívida fosse convertida em ações, o AC seria diluído de $59 \%$ para $4 \%$.

OSX era o problema mais grave do Grupo e o plano era fechá-la. A UCN tinha algum valor (US\$ 200 milhões), mas lá foram investidos US\$ 2 bilhões e ainda havia, só com os bancos, uma dívida de US\$ 500 milhões, sem contar fornecedores e as dívidas atreladas às plataformas.

O destino do Porto de Açu não estava claro. Os principais credores eram BNDES e o FMM. Apenas $6 \%$ dos 70 milhões de $\mathrm{m}^{2}$ (4,16 milhões de $\left.\mathrm{m}^{2}\right)$ estavam ocupados por 7 empresas (NOV, Technip, Intermoor, Wärtsilä, V\&M, GE e OSX), $80 \%$ do mineroduto estava concluído e havia 80 MOUs assinados com interessados ${ }^{420}$.

8/08. Novos dados sobre TBAZ desapontaram mais uma vez. Outro problema técnico praticamente impediu a produção em julho, que ficou na média em 0,9 kbpd.

\footnotetext{
${ }^{418}$ Disponível em: https://www.valor.com.br/empresas/3181632/eike-admite-fracasso-na-tentativa-desalvar-ogx.

419 Disponível em: https://www.valor.com.br/empresas/3185564/apos-reestruturacao-eike-ficara-comus-1-bi.

420 Disponível em: https://www.valor.com.br/empresas/3185560/Ilx-tem-dificuldades-para-atrairparceiros.
} 
10/08. ANP divulgou a produção média do primeiro poço (OGX-26HP) em junho: 2,368 contra 4,665 kbpd em maio (11,037 kbpd em fevereiro). Em contraste, a produção média do segundo poço (OGX-68HP) aumentou em junho: 6,461 contra 4,065 kbpd em maio.

15/08. Anúncio dos resultados do $2 T 2013$ : um prejuízo de $R \$ 4,7$ bilhões, incluindo impairment de $\mathrm{R} \$ 3,665$ bilhões (referentes aos TBTI, TBAR e TBGA), R\$ 490,7 milhões em baixas de ativos (poços subcomerciais) e $\mathrm{R} \$ 956,8$ milhões em perdas devido a cancelamentos de contratos com a OSX. O prejuízo só não foi maior pois houve um ganho de capital de $\mathrm{R} \$ 1,035$ bilhão referente ao farm-out para Petronas. O EBITDA foi negativo em $R \$ 4,1$ bilhões. O saldo das disponibilidades em 30/6 era de apenas $R \$ 721$ milhões, insuficientes para as obrigações previstas no 3T2013, considerando que a OSX1 não produziria nada pelos próximos dois meses. $O$ auditor independente afirmava que a continuidade da OGX dependia de aporte de recursos do AC. A Empresa contratou o Blackstone Group como assessor financeiro na avaliação de sua estrutura de capital, o que indicava que a reestruturação da dívida era iminente ${ }^{421}$.

Repercussões. No pregão (15/08), a OGXP3 se desvalorizou em 5,34\% (de $\mathrm{R} \$ 4,87$ para $\mathrm{R} \$ 4,61)$. A perda no EV foi de $\mathrm{R} \$ 627,1$ milhões ou US\$ 301,7 milhões.

A OGX ainda possui a opção de US\$ 1,0 bilhão contra o controlador, mas com todas as dificuldades enfrentadas pelas outras empresas do grupo; acreditamos cada vez menos que essa opção será exercida [SEQUEIRA \& FONSECA, 2013o, p. 1].

27/08. OGX anunciou que devolveria à ANP 9 dos 13 blocos adquiridos na 11a Rodada em maio (BAR-M-213 / 251 / 389, CE-M-663, FZA-M-184, PN-T-113 / 114 / 153 / 168). A OGX justificou a devolução para evitar nova exposição ao risco exploratório em blocos onde não possuía parceiros. De fato, dos quatro blocos restantes, com $B A$ de $R \$ 96,0$ milhões, três eram em parceria com outras empresas.

Repercussões. Segundo o DB, essa provavelmente seria a primeira vez que uma empresa não honrou suas ofertas para a ANP422.

No momento do leilão, ficamos surpresos ao ver a OGX em busca dessas áreas por causa da concentração de riscos geológicos e financeiros. A estratégia de concentração de risco provou ser muito prejudicial para a empresa. (...)

Achamos difícil acreditar que a administração não tenha conhecimento desses riscos. Acreditamos que a atual falta de liquidez e a percepção de que seria difícil o farm-out desses blocos em termos favoráveis no curto prazo (dado o prêmio oferecido) foram os principais motivos por traz do anúncio [SEQUEIRA \& FONSECA, 2013p, p. 1].

421 SEQUEIRA \& FONSECA [2013o].

422 SEQUEIRA \& FONSECA [2013p]. A OGX pagaria uma multa de $\mathrm{R} \$ 3,4$ milhões à ANP, mas economizaria $\mathrm{R} \$ 280$ milhões em BAs. 
Notícias na mídia (JVE) relatavam que os pagamentos do farm-out com a Petronas estariam sujeitos à reestruturação do passivo da Empresa ${ }^{423}$. Como o primeiro pagamento de US\$ 250 milhões era a única fonte de recursos novos previstos no curto prazo, o DB estimou que a Empresa zeraria seu caixa ainda no 3T2013, se a put não fosse exercida ${ }^{424}$. A ANP e o CADE também não haviam aprovado a aquisição do BS-4 da PETR, o que também impedia a conclusão do farm-out com a Petronas ${ }^{425}$.

6/09. OGX exerceu o put contra o AC. Entretanto, do US\$1,0 bilhão a ser aportado, apenas $10 \%$ seriam desembolsados imediatamente.

Repercussões. Embora inevitável, o mercado recebeu com surpresa o exercício da put contra o AC. O desembolso de $10 \%$ daria um pouco mais de tempo para a OGX negociar com os bondholders e com a Petronas. O restante seria desembolsado de acordo com as necessidades da Empresa. "Mas o anúncio foi vago na capacidade do acionista controlador em honrar os US\$ 900 milhões restantes. ${ }^{426}$

Os Analistas entenderam o desembolso de US\$ 100 milhões como parte de uma estratégia negocial com os outros credores, pois o plano de reestruturação ainda não havia sido divulgado. O IBBA previa duas alternativas: a conversão dos bonds em capital; ou a recuperação judicial, "que poderia levar anos" e gerar perdas significativas aos acionistas ${ }^{427}$. O acordo de farm-out com a Petronas era crucial, pois caso fosse cancelado, o valor de TBMT seria questionado, o que tornaria a reestruturação ainda mais difícil. Mas o $\mathrm{MS}^{428}$ foi ainda mais pessimista em relação ao impacto da put e o comprometimento do AC:

Exercitar a opção de venda é mais uma necessidade (fiduciária) do que uma solução, nós pensamos. Isso não altera nossa visão de que é provável que haja pouco valor para os acionistas. A solução final para a OGX é um processo de reestruturação da dívida, nós pensamos, o que poderia causar uma grande diluição para os acionistas.

Depois de esperar provavelmente muito tempo, a OGX finalmente exerceu a opção de venda de US\$ 1,0 bilhão concedida pelo Sr. Eike Batista (...)

(...) mas ainda há incertezas sobre se o dinheiro entrará na empresa. Um artigo no jornal Folha de São Paulo sugere que o Sr. Batista talvez não esteja disposto a desembolsar US\$ 100 milhões, com base em apoio legal. Não nos surpreenderíamos com esse curso de ação. O Sr. Eike Batista vendeu 10,93\% de sua participação da OGX desde março, a um preço médio de $R \$ 0,80 / a c ̧ a ̃ o ~(R \$ 0,30-1,80)$ e o preço de exercício

\footnotetext{
${ }^{423}$ Relatado por SEQUEIRA \& FONSECA [2013p] e MCGANN \& VEGNER [2013a].

${ }^{424}$ SEQUEIRA \& FONSECA [2013p]. A OGX pagaria uma multa de R\$ 3,4 milhões à ANP, mas economizaria $\mathrm{R} \$ 280$ milhões em BAs.

425 KOVARSKY \& MENDES [2013i].

${ }^{426}$ LEITE, CANHEU \& SOBREIRA, 2013j, p. 1.

427 KOVARSKY \& MENDES [2013i].

${ }^{428}$ MONTANARI \& BELLINETTI [2013d].
} 


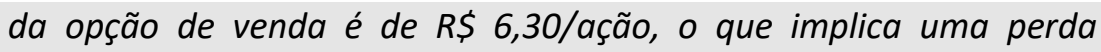
substancial na transação.

A put não altera o caso de investimento OGX; é apenas o início de uma reestruturação. Nossa visão é que é provável que haja pouco valor para os acionistas, mesmo com o pleno exercício da opção de venda, deixando uma reestruturação da dívida como a única alternativa para a empresa nesta fase. Exercitar os primeiros US\$ 100 milhões apenas deixa claro que a posição de caixa é muito apertada [MONTANARI \& BELLINETTI, 2013d, p. 1].

9/09. AC anunciou que contestaria o aporte de US\$ 100 milhões na câmara de arbitragem.

Repercussões. O IBBA ${ }^{429}$ e o $\mathrm{MS}^{430}$ também endossavam a tese do MS que a OGXP3 não teria mais valor, reforçada pela contestação do $\mathrm{AC}^{431}$ :

Após o mau desempenho de histórias de [empresas de] pura exploração no Brasil, cada vez que um analista se esforça para explicar uma grande queda no preço de uma ação, seja qual for seu setor, a piada é "Afinal, é um poço seco." Piadas a parte, isso reflete o quão histórias de pura exploração são desconsideradas neste momento. A orientação excessiva [over-guidance], envios de confusas mensagens sobre a probabilidade de sucesso geológico minimizando o risco real incorporado na exploração, causou perdas maciças aos investidores nos últimos dois anos.

Um executivo muito graduado de uma companhia de petróleo nos perguntou recentemente quem deveria ser culpado por este terrivel erro. Mas procurar por bodes expiatórios é uma receita para repetir um erro - ninguém comete um grande erro sozinho. Executivos renomados sobre-orientados [over-guided], mas também os analistas acreditavam facilmente nas histórias (no nosso caso particular, estávamos certos sobre a HRT desde o início, mas levamos muito tempo para desistir da OGX, pois achamos que a empresa teria algo em Campos depois de

${ }^{429}$ KOVARSKY \& MENDES [2013j].

${ }^{430}$ MONTANARI \& BELLINETTI, 2013d, p. 1.

431 "Em setembro de 2013 a Diretoria da Companhia exerceu opção em face a seu acionista controlador para que esse subscrevesse novas ações, a R\$ 6,30 por ação, no montante de US\$1,0 bilhão. Ainda em setembro de 2013, o acionista controlador apresentou "Notificação de Conflito" questionando as circunstâncias, validade e demais aspectos legais do pretendido exercício da opção" [OGX, DFP 2014, p. 95].

KOVARSKY \& MENDES [2013j] relatam que o contrato da put continha condições precedentes que davam margens para contestações. Por exemplo, a OGX teria de realizar o plano de negócios acordado na data da assinatura (outubro de 2012); a OGX só poderia exercer a put perante constatação da sua incapacidade de captar recursos financeiros através de outras formas, incluindo o perdão (waivers) de credores, venda de ativos, venda de participação para investidor estratégico. Além disso, o exercício da put deveria se aprovado por conselheiros independentes (Pedro Malan, Ellen Gracie e Rodolfo Tourinho) que já não fazem mais parte do Conselho de Administração. Segundo a cláusula de arbitragem, a OGX e o Acionista Controlador teriam 60 dias para negociar uma solução, mas o caixa da Empresa poderia não durar tanto. No "melhor cenário" do IBBA, é que nenhum recurso será aportado pelo Acionista Controlador após a arbitragem. 
tudo). Enquanto isso, as regras da Bovespa transformaram uma empresa pré-operacional como OGX em um blue chip.

(...) O melhor conselho possivel que podemos dar aos investidores é ficar longe de OGX. Mesmo supondo uma reestruturação societária bem-sucedida, nós vemos potenciais perdas para os acionistas [KOVARSKY \& MENDES, 2013j, p. 1].

Neste momento da história da OGX, o IBBA simulava seu potencial valor enquanto empresa detentora de prejuízos acumulados em $R \$ 6,9$ bilhões, que poderia valer $R \$ 2,3$ bilhões em abatimentos de IR\&CS, ou $R \$ 1,4$ bilhão a valor presente.

1/10. OGX deixou de pagar US\$ 44,1 milhões em juros do OGXPBZ de 2022.

Repercussões. A OGX explicou que a decisão estava relacionada: (1) às revisões, em andamento, do plano de negócios e estrutura de capital; (2) discussões entre seu assessor financeiro e as partes envolvidas, incluindo os bondholders; (3) à possibilidade da Empresa não pagar o juros por 30 dias sem implicar na aceleração da dívida ${ }^{432}$. Entretanto, notícias em vários jornais afirmavam que a RJ da OGX era iminente ${ }^{433}$.

3/10. OGX divulgou um relatório da D\&M para TMAT, que aumentou as dúvidas quanto à sua viabilidade: 87,9 mboe de reservas $2 \mathrm{P}, 108,5$ mboe de reservas $3 \mathrm{P}$ e zero mboe para reservas $1 \mathrm{P}$.

Repercussões. Zero mboe para reservas 1P para um campo de deveria começar a produzir até dezembro? A D\&M justificava o zero mboe para reservas $1 \mathrm{P}$ "devido à natureza não econômica do projeto" ${ }^{434}$.

Embora não fossem diretamente comparáveis, a estimativa de 87,9 mboe de reservas $2 \mathrm{P}$ ficava bem aquém da estimativa anterior de 147 mboe em reservas $2 C^{435}$ e dos 285 mboe da Declaração de Comercialidade. $\mathrm{A} \mathrm{MER}^{436}$ alertou para o risco de cancelamento do farm-out com a Petronas, que teria pagado um valor excessivo: US\$14,50/boe assumindo 147 mboe em reservas 2C; e US\$24,00/boe se consideramos $40 \%$ de 87,9 mboe de reservas $2 \mathrm{P}$ de um campo ainda sem produção. Além do potencial impacto negativo no farm-out, a incerteza do fluxo de caixa de Tubarão Martelo também afetaria a negociação da conversão da dívida para capital.

Qual seria o impacto na OGXP3? O MS resumiu bem: "as ações da OGX são transacionadas com base em aspectos técnicos e não fundamentalistas." 437

Após o relatório da D\&M sobre TBMT, a viabilidade de outros campos, como os de Atlanta e Oliva no BS-4, voltou à pauta. Entretanto, qualquer desenvolvimento no BS-4

\footnotetext{
432 Relatada por MATTAR et al. [2013c].

${ }^{433}$ Relatada por MATTAR et al. [2013c].

${ }^{434}$ MONTANARI \& BELLINETTI, 2013d, p. 1.

435 Subtraindo dos 212 mboe de Waikiki (reafirmado no acordo de farm-out com a Petronas em maio de 2013), 65 mboe de Ingá e Peró.

436 MCGANN \& VEGNER [2013b].

437 MONTANARI \& BELLINETTI, 2013d, p. 1.
} 
e nos quatro blocos da 11a Rodada exigiam tempo e investimentos: o início da produção era esperado para 2015. Havia também o prospecto de Piapara no pré-sal do BS-4, mas as perfurações começariam em 2014. Portanto, a produção de TBMT, esperada para o fim de 2013, começo de 2014, permanecia crucial para a reestruturação da Empresa.

Os Analistas da MER se esforçaram para encontrar valor, mesmo em cenários mais otimistas, tanto no aspecto operacional quanto na reestruturação financeira que implicaria em diluição dos atuais acionistas, uma vez que possivelmente envolveria aportes de capital:

Vemos a desvantagem das ações, mesmo sob pressupostos de alta. Nossa análise de cenários sugere que, mesmo com elevadas expectativas para os principais ativos do OGX, por exemplo Campos Atlanta/Oliva no BS-4, o valor patrimonial subjacente após uma reestruturação seria inferior ao preço atual das ações. O nível de valor patrimonial é altamente dependente de quatro fatores-chave: (1) fluxo de caixa de produção em Tubarão Martelo e BS-4; (2) quantidade e condições de qualquer dívida que seja reestruturada; (3) o preço da ação usado para o capital aportado por novos investidores ou de uma dívida reestruturada; e (4) quantidade de capital novo aportado na empresa [MCGANN \& VEGNER, 2013c, p. 1].

Outubro. Durante as negociações, a OGX teria proposto a conversão de um total de US\$ 2,73 bilhões em dívidas, incluindo US\$ 1,566 bilhão dos bonds e US\$ 1,64 bilhão das obrigações com fornecedores ${ }^{438}$.

Repercussões. Notícias nos jornais relatavam um potencial aporte de US\$ 200 milhões na OGX como parte do plano de reestruturação ${ }^{439}$. Os recursos seriam usados para viabilizar a produção de TBMT. A Empresa ainda precisaria vender suas ações na OGX Maranhão (estimada em US\$ 350 milhões), mas mesmo assim, a conversão da dívida em capital era vista como inevitável.

30/10. Com a recusa dos bondholders à adesão do plano de restruturação, e a recusa do AC em honrar a put, o inevitável aconteceu. Com dívida de US\$ 5,1 bilhões (US\$ 3,7 bilhões do bonds mais US\$2,6 bilhões com a OSX) e apenas $\mathrm{R} \$ 180$ milhões no caixa (31/9/13), a Empresa ajuizou o pedido de RJ (que foi deferido em 21/11/2013). Em seguida, a OGXP3 foi excluída de 10 diferentes índices incluindo o IBrX, a partir de 1/11. A RJ permitia que a Petronas abortasse o farm-out, que assim o fez.

Repercussões. No dia seguinte (31/10), a GS, ML encerraram suas coberturas. No dia $1 / 11$, laconicamente, o CS, IBBA também encerraram suas coberturas. Ainda em 30/10, o $D B$ divulgou um relatório atualizando seu $P A$ de $R \$ 0,10$ para $R \$ 0$.

A empresa afirma que, para que TBMT inicie a produção, é necessário um investimento de cerca de US\$100 milhões. No entanto, no $2 T 13$, a OGX pagou à empresa irmã OSX a maior parte dos US\$ 449 milhões devido a mudanças no contrato para OSX-3 e WHP-2, em um claro

\footnotetext{
${ }^{438}$ Relatado por SEQUEIRA [2013q].

${ }^{439}$ Relatado por MCGANN \& VEGNER [2013c].
} 
exemplo de má governança corporativa. O montante devido ao OSX pode atingir US\$ 2,6 bilhões. A OGX tem compromissos de trabalho com a ANP, se os compromissos não forem honrados, os contratos de concessão da OGX podem estar em risco [SEQUEIRA, 2013q, p. 1].

Todas as subsidiárias da OGX ${ }^{440}$ entraram na RJ, exceto a OGX Maranhão, cujo principal ativo era a participação de 66,67\% na Parnaíba Gás Natural S.A. ("PGN"), e estava sendo vendida para a Eneva e para o fundo de investimentos Cambuhy. A transação foi concluída em 19/02/2014, com um aporte de capital de R\$ 250 milhões na PGN. Após esses aumentos de capital, a OGX, anteriormente detentora de $66,67 \%$ da PGN, passou a deter de $36,36 \%$.

Segundo o DB, diante da desistência da Petronas, a OGX tentaria vender $100 \%$ de TBMT, cujo valor era estimado em US\$ 890 milhões. Poderia também vender o BS-4, cujo valor era estimado em US\$ 437 milhões.

De acordo com os contratos assinados com a ANP, a OGX poderia ter de devolver suas concessões se não conseguisse provar capacidade para executar os planos de desenvolvimento. Se este fosse o caso, a Empresa teria 90 dias para fazer o farm-out dos blocos antes de devolvê-los à ANP ${ }^{441}$.

Ainda em 2013, a OGX reconheceu perdas nos seus investimentos em Campos, Santos e ES, somando R\$ 8,66 bilhões. Em fevereiro de 2014 a OGX comunicou à ANP a devolução das referidas áreas exploratórias, o que não afetaria o seu plano de negócios, que consta do Plano de RJ, uma vez que o valor econômico destes projetos não tinha sido considerado em nenhuma das projeções da Empresa.

As baixas registradas no período findo em 31 de dezembro de 2013 estão associadas à:

\section{a) Impairment}

\section{Campo}

Tubarão Azul

Tubarão Tigre, Gato e Areia

Tubarão Martelo

Complexos Exploratórios Bacia de Campos (a)

Complexos Exploratórios Bacia de Santos (b)

Complexos Exploratórios Bacia do Espírito Santo (c)

(a) Inclui Viedma, Tulum, Vesuvio e Itacoatiara.
(b) Inclui Natal, Belém e Curitiba.
(c) Inclui Dendê e Caju.

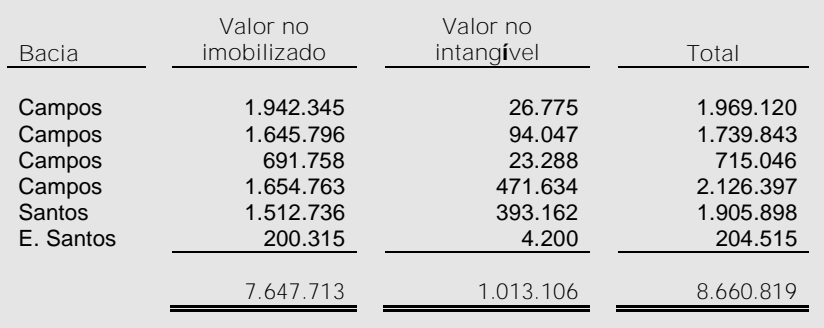

Mais informações na seção "Avaliação de indicativos de impairment", nessa Nota Explicativa de Imobilizado.

440 OGC Petróleo e Gas Participações S/A, OGX Petróleo e Gas S/A, OGX International GMBH and OGX Austria GMBH.

${ }^{441}$ Em novembro de 2013, a OGX firmou o farm-out de 35\% do bloco POT-M475 para a ExxonMobil. Em fevereiro de 2014, a ANP aprovou a transação. 
O prejuízo em 2013 seria de $R \$ 16,873$ bilhões, que acumulados com prejuízos de exercícios anteriores somavam $\mathrm{R} \$ 18,351$ bilhões.

As concessões na Colômbia foram canceladas pela Agencia Nacional de Hidrocarburos em 11/07/2014 e executou US\$ 24 milhões em cartas de crédito oferecidas como garantia do PEM/PEA. No 3T2013, a produção média em TBAZ foi de apenas 3,9 kbpd por poço. No 4T2013, não houve produção em TBAZ.

A OGX iniciou a produção em TBMT em $5 / 12 / 2013$, através de dois poços ligados à FPSO OSX-3. Em 3/03/2014, o campo alcançou a importante marca de 1 mboe produzidos, e em julho o terceiro poço foi conectado. Em 20 dias de operação em dezembro de 2013, TBMT produziu 256,5 kboe, gerando um EBITDA de $R \$ 19,5$ milhões (R\$ 76,13/boe, margem de $32,8 \%)$. 


\title{
Parte 2 - Processos, Atrasos e suas Repercussões
}

\section{Primeira Questão de Pesquisa}

\begin{abstract}
Verossímil. Que aparenta ser verdadeiro: uma descrição verossímil. Que é admissível ou realizável por não se opor à verdade; que não repugna à verdade; plausível: história verossímil.
\end{abstract}

https://www.dicio.com.br/verossimil/

Tudo começou com o momento do mercado e um empreendedor com precedentes favoráveis. Como descrito na seção 3.1, uma combinação de circunstâncias favoráveis no mercado mundial de $O \& G$ e no Brasil produziram Sentimentos de Mercado bullish. $O$ IPO foi na hora certa, no lugar certo, com as pessoas (aparentemente) certas. Os investidores compraram os Seis Pilares da Tese de Investimentos, dentre eles o bilionário sistema de remuneração dos Executivos e membros do COAD, o SOP OGX e o SOP AC. Nos 9 primeiros pregões após o IPO, o Valor de Mercado se apreciou em US\$ 5,65 bilhões, uma média que equivalia a US\$ 0,63 bilhão por pregão. Em duas primeiras semanas pós IPO, o Valor de Mercado chegou a US\$23,02 bilhões (R\$ 36,83 bilhões, em 25/6). Os Executivos, membros do COAD e o AC assistiram seus patrimônios crescerem muito e rapidamente. Mas durou pouco.

Como já descrito, em poucos meses, o Valor de Mercado chegou abaixo do valor de liquidação (6/11). Era preciso surpreender os investidores com uma campanha exploratória mais agressiva do que aquela descrita nos Seis Pilares. Combinando a reputação técnica dos Executivos com a sagacidade e eloquência do AC, o guidance foi rico em surpresas auspiciosas e metas agressivas: 100\% de taxa de sucesso nas perfurações de outubro de 2009 até julho de 2010 e $90 \%$ até dezembro de 2011; em menos de 2 anos de campanha exploratória, o aumento de 123,4\% nas estimativas de RPL em relação aquelas do IPO; o first oil no 1T2011; novas aquisições e farm-ins; acesso a equipamentos críticos, atendendo o requisito de conteúdo nacional, através da OSX/Hyundai; viabilização da UTE Parnaíba com a MPX; "vários interessados no farmout" de blocos de Campos, no momento que as IOCs estavam ávidas por ativos no Brasil; duas emissões de dívida sem garantia (junho de 2011 e março de 2012); descoberta de hidrocarbonetos nas águas rasas do pré-sal de Santos (1/02/2012). O guidance otimista que surtiu efeito e gerou o Rally (de 06/11/08 a 04/11/10), momentos de sobrevalorização entre 2009/10, e a 1a. Correção Apreciativa (de 08/08/11 a 24/02/12) conforme descrito nos capítulos 2 e 3 .

Por sua reputação com as transações de $M \& A$ da $M M X$, o $A C$ teve contribuição importante na percepção de credibilidade da Tese de Investimentos e do guidance. Um dos entrevistados o denominou de "Encantador de Serpentes" no sentido que o AC foi capaz de convencer até experientes investidores da validade da Tese de Investimentos e suas opções de crescimento. 
A intensa, dispersa e complexa campanha de E\&P produziu muitas oportunidades de negócios para fornecedores de equipamentos e capital, prestadores de serviços e Partes Relacionadas (OSX, LLX e MPX). Possivelmente, devido aos seus próprios sistemas de remuneração por metas, fornecedores, bancos, Analistas e outros envolvidos aumentaram suas disposições em assumir riscos e subscrever ao otimismo do guidance e endosso de investidores, financiadores e fornecedores já expostos ao Grupo X. E havia a valorização da OGXP3 para reforçar a percepção de valor do Grupo X.

Estes Processos Reforçadores podem explicar porque investidores sofisticados considerariam os Valores de Referência como proxy do Valor de Mercado, apesar de sua elevada incerteza. Explicam também porque bancos e gestores de fundos sofisticados, nacionais e internacionais, aceitaram financiar, direta e indiretamente, a OGX e suas Partes Relacionadas.

Para explorar estas oportunidades de negócios para o Grupo X, em particular a OSX e LLX, foram contraídos significativos empréstimos, que posteriormente pressionaram o AC e a própria OGX por capital. A demanda crescente por capital para capturar as opções de crescimento que o AC e os Executivos vislumbravam, em um primeiro momento, foi acolhida pelo mercado de capitais nacional e internacional. Mesmo em momentos difíceis para o mercado de capitais internacional, como ocorreu em agosto de 2011, a OGX conseguiu viabilizar os Notes.

\section{Figura 7 - Sistema Dinâmico da OGX no Período de Geração de Valor}

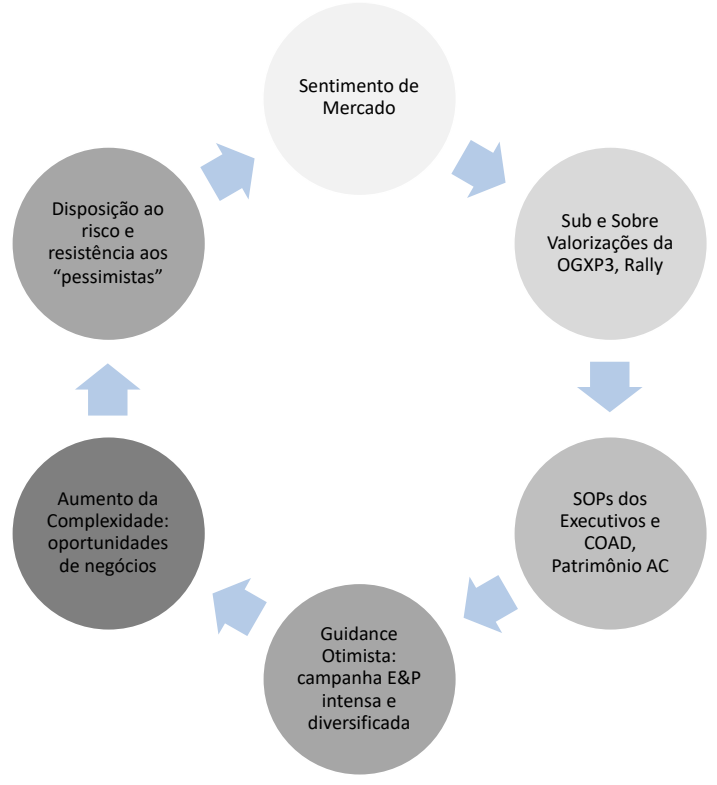

Fonte: elaborado pelo Autor.

As oportunidades de negócios que a OGX gerava direta e indiretamente, que combinada ao Sentimento do Mercado, produziu uma outra Conduta de Valor: aumentou a disposição ao risco e elevou o custo de análises contrárias, que alertassem para os riscos operacionais, geológicos e de governança corporativa da OGX. Os analistas, que incluíam não apenas sell, mas também buy side e de crédito de bancos e fornecedores 
que percebiam os crescentes riscos da OGX teriam de enfrentar as críticas de seus pares envolvidos em oportunidades de negócios com o AC e o Grupo X.

Para piorar a posição destes analistas, havia o argumento que outros importantes investidores, financiadores e fornecedores estavam alocando capital na OGX: "se o IBBA, a BlackRock, Mubadala e a GE têm negócios com o Grupo X, por que nós também não podemos ter? Eles entendem menos de riscos do que nós?" Além destes "endossos", havia também a possibilidade de capturar as externalidades positivas que 0 monitoramento que bancos, fundos e fornecedores contratados teoricamente faziam. A ausência de críticas dos gatekeepers externos e internos, em quantidade e qualidade, podem ter alimentado o Sentimento de Mercado favorável à OGX por anos. Esse conjunto de fatores pode explicar porque experientes Analistas pareciam não fazer o follow-up das descobertas com a diligência e disciplina necessárias. Pode explicar também porque o alicerce de valor do Grupo X era a OGX, o ativo de maior risco.

Em suma, neste sistema dinâmico, os Processos Reforçadores incluem o guidance otimista, as remunerações por metas (incluindo o SOP OGX e o SOP AC), o endosso dos Analistas e as estratégias de trading da OGXP3.

O presente capítulo descreve indicadores e possíveis respostas para Primeira Questão de Pesquisa, começando pelas circunstâncias que precederam o IPO e podem ter contribuído para sua viabilização e sobrevalorização. O Sentimento do Mercado na época do IPO da OGX foi muito favorável: preços do petróleo em altas históricas (4.1); descobertas significativamente promissoras no pré-sal da bacia de Santos e o novo marco regulatório (4.2); ambiente favorável no mercado de capitais (4.3). Mas não foram só aspectos exógenos à OGX que foram favoráveis. Houve elementos importantes da Tese de Investimentos que contribuíram para percepção de valor: a qualidade do portfólio da OGX (4.4); a reputação do $A C$ e as potenciais sinergias com Partes Relacionadas (4.5); e as "práticas diferenciadas de governança corporativa" da OGX, que incluía a participação societária relevante do AC, e os SOPs outorgados aos Executivos e membros do COAD (4.6). Adicionalmente, se combinaram a estes aspectos: as reações do mercado a evolução da OGX e OGXP3 (4.7); o endosso da mediana dos Analistas (4.8); e as externalidades na avaliação e monitoramento que podem ter sido geradas por renomados bancos e investidores (4.9).

Mas esta seção não pretende exaurir todos os possíveis precedentes, como a liquidez internacional, composição IBOV (de-tracking risk), momentum e noise trading, temas estes para futuras pesquisas. 
"No Mercado de petróleo não tem doutor". José Mendonça de Barros ${ }^{442}$

Em 4/01/2000, o Brent estava cotado a US\$23,95/barril. De 2003 em diante, começou uma apreciação que alcançou US\$ 97,01 em 2/1/2008, e posteriormente o recorde de US\$143,95 em 3/07/2008. No IPO da OGX, em 12 de junho, o preço do Brent estava em US\$132,11, portanto próximo do recorde histórico.

Gráfico 50 - Preço do Petróleo Bruto - Brent (FOB) - US\$/barril de 4/01/2000 a 12/06/2008

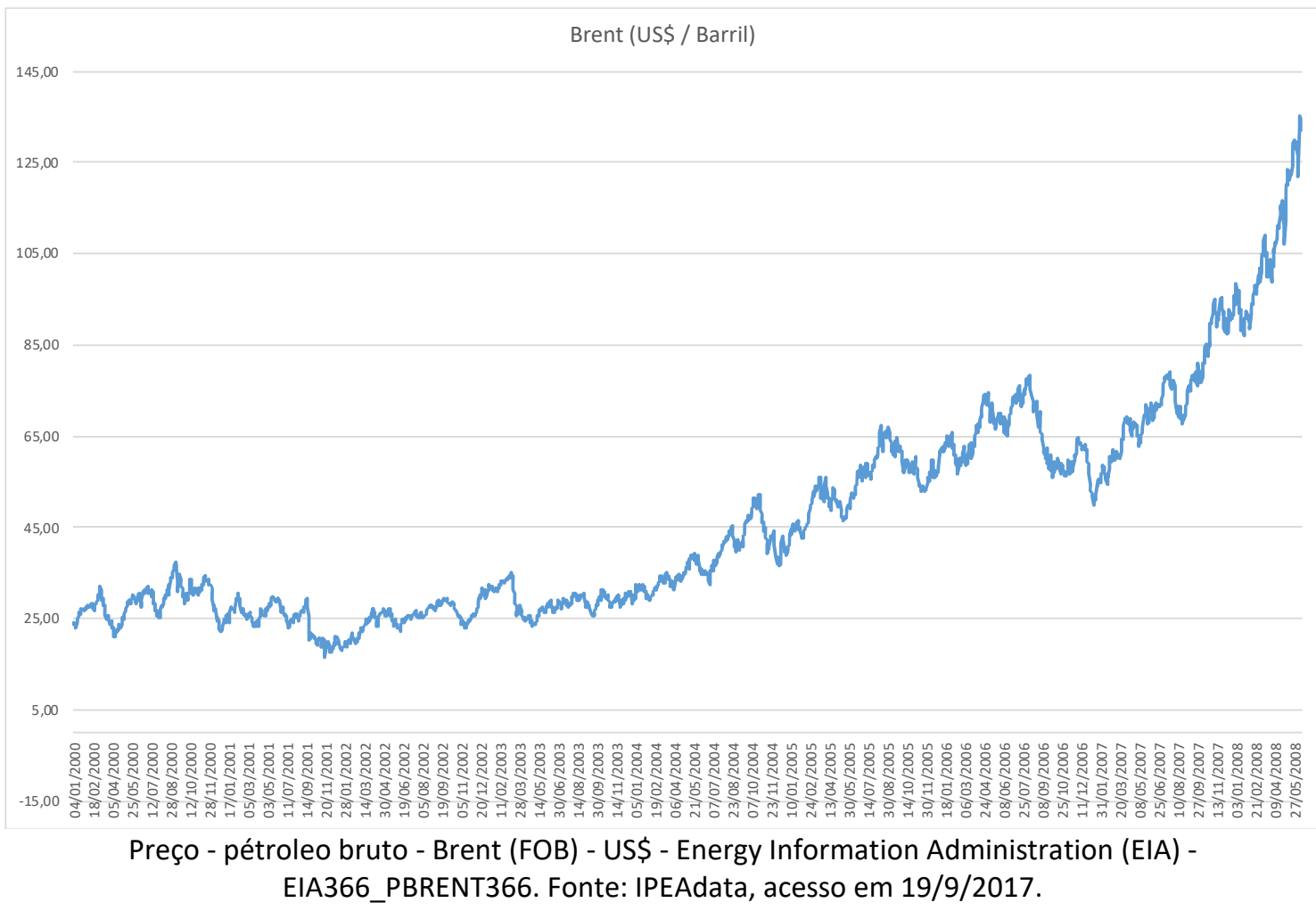

A apreciação de $335,7 \%$ do Brent entre 2/01/2003 e 12/06/2008 repercutiu no valor das ações das empresas abertas de O\&G e E\&P. O S\&P OGEP 600 se apreciou em 563,3\% no período mesmo. Mesmo o S\&P OGEP 1500, mais amplo, se apreciou em 423,2\% no período.

442 “No Mercado de petróleo não tem doutor”. OESP, p. B7, 27/01/2019. 
Gráfico 51 - Evolução do S\&P OGPE 600 e 1500 02/01/2000 a 12/06/2008

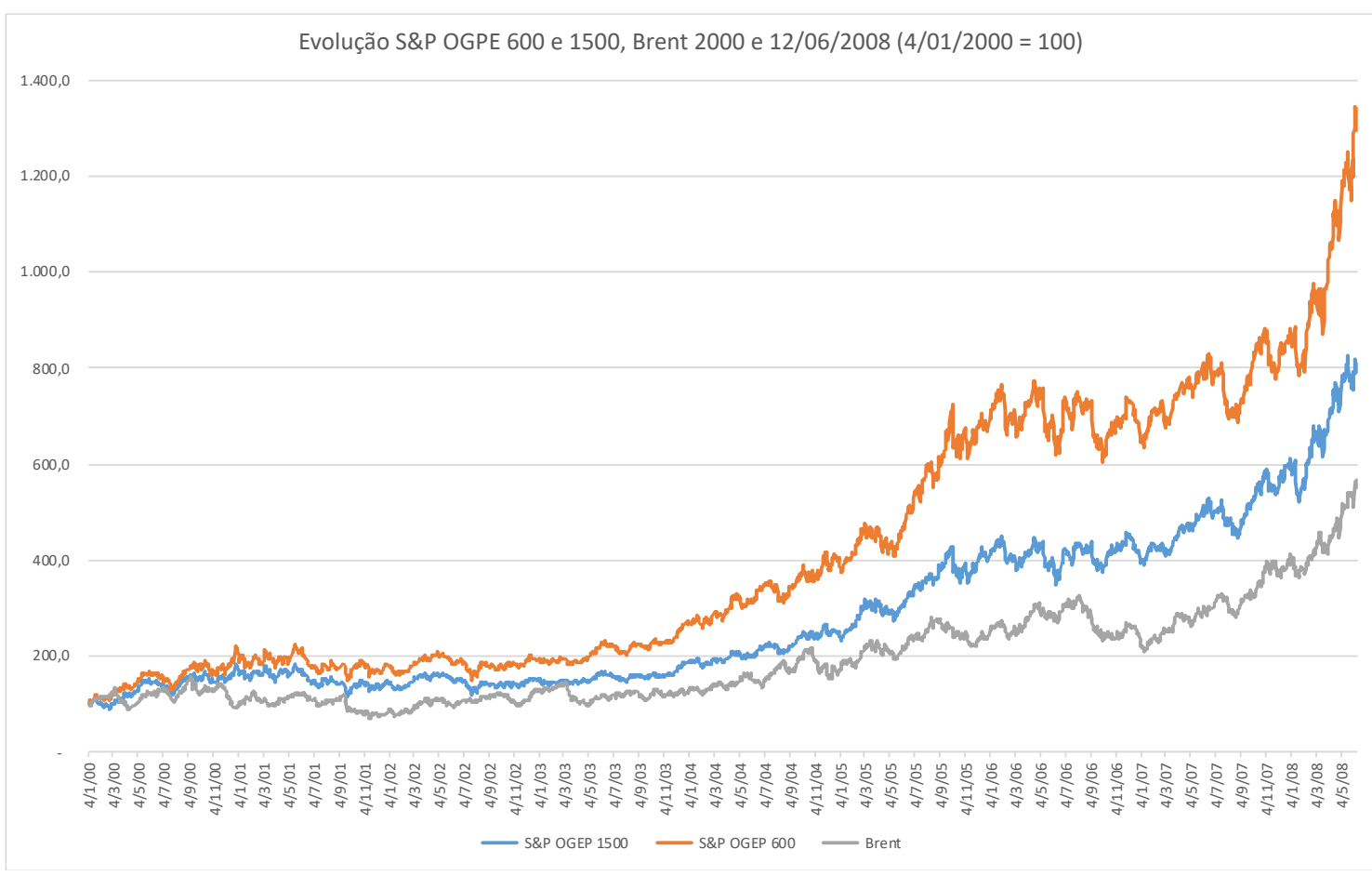

Fonte: S\&P Capital IQ, acesso em 7/02/2019.

A apreciação do preço do petróleo no começo de 2008, em particular, foi descrita e analisada como a "bolha do óleo do verão de 2008". Apenas em seis meses em 2008, entre 2 de janeiro e 3 de julho de 2008, o preço do Brent se apreciou em 48,38\% (de US\$ 97,01 para US\$143,95/barril), sem aparente respaldo dos fundamentos de mercado de petróleo. No entanto, no fim de 2008, o preço do Brent em US\$ $35,82 /$ barril $^{443}$.

443 KAHN [2009] investiga a "bolha do óleo do verão de 2008". Na ausência de um modelo para o preço de equilíbrio de longo prazo de petróleo, o autor cita como referências aquelas utilizadas por grandes produtores de US\$ 70 a 75/barril (como o Ministro do Petróleo da Arábia Saudita, Ali Al-Naimi) e pela Goldman Sachs de US\$ 90 a 100/barril. O overshoot e o undershoot do preço do petróleo poderia ter sido causado pela especulação no mercado futuro? O volume de óleo negociado em contratos futuros cresceu significativamente: em 2002, a média diária transacionada (em barris) era de 4,5 vezes a demanda mundial diária; em 2008 e 1S2009, essa média era de 15,0 vezes. Mas não é possível segregar nestes volumes posições de hedge e especulativas. Tampouco há evidências empíricas que indiquem relações de causalidade entre posições líquidas de contratos futuros (entretanto, sem diferenciar as posições longas e a descoberto) e preços spot em qualquer direção.

Em outra análise sobre o preço de equilíbrio, KAHN [2009] investigou a capitalização de mercado das principais empresas de petróleo (medido pelo S\&P 500 Integrated Oil and Gas Index): como o valor de empresas seria baseado no preço de equilíbrio de longo prazo, este deveria ser menos volátil que o preço do petróleo no mercado spot. Dados para 2007 e 2008 suportam a tese de que a volatilidade da capitalização de mercado das principais empresas de petróleo é menor do que a volatilidade dos preços do petróleo, em particular no 1S2008. 
Considerando apenas transações acima de US\$ 90 milhões, o número de IPOs de empresas de O\&G e E\&P no mundo aumentou significantemente. Somente entre 2006 e 2007, o número de IPOs (41) foi maior do que os seis anos anteriores somados (36).

\section{Gráfico 52 - Número de IPOs Concluídos de Empresas de O\&G e E\&P no Mundo entre Janeiro 2000 e Junho 2008}

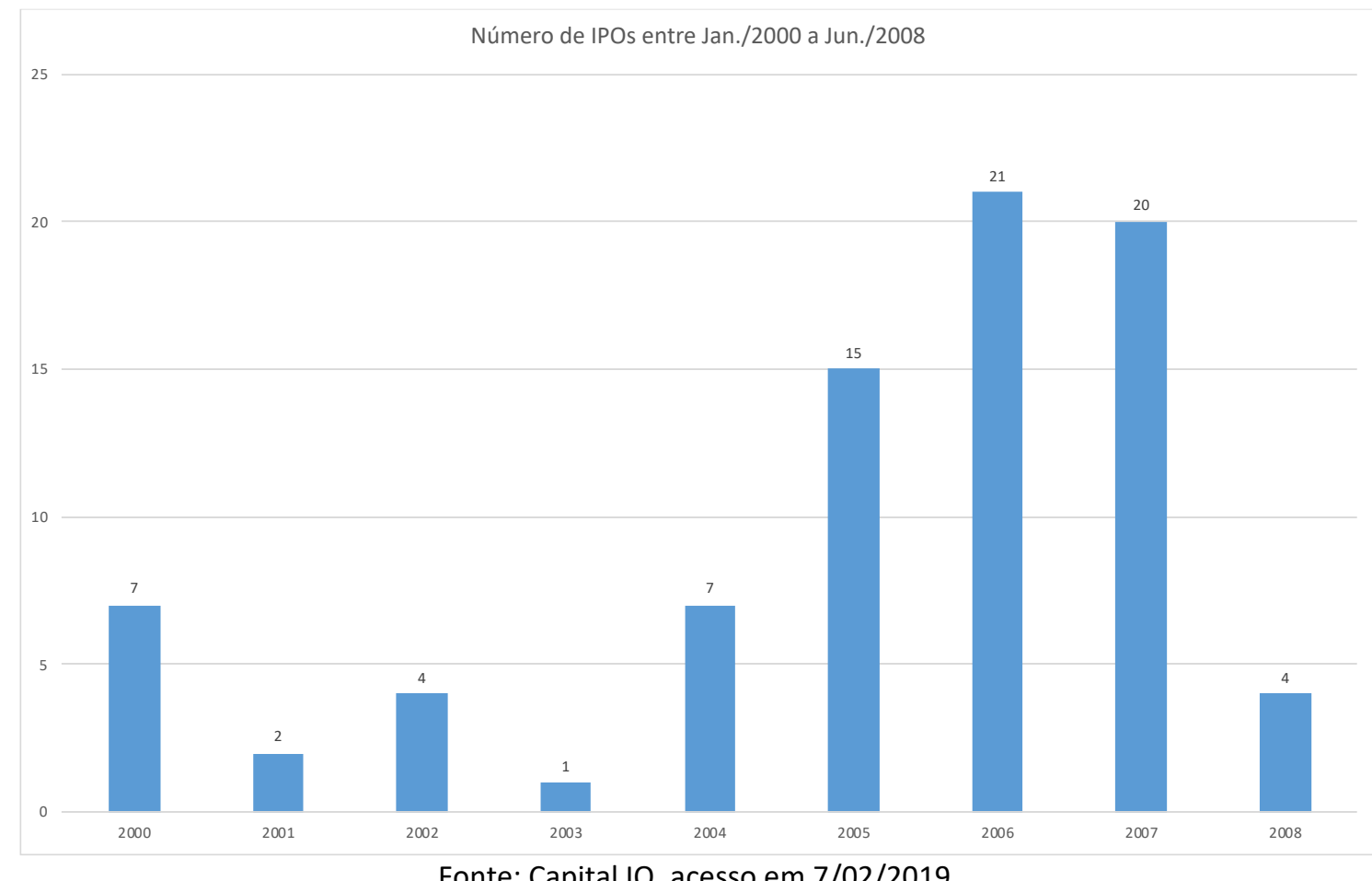

Fonte: Capital IQ, acesso em 7/02/2019.

Entre 2006 e 2007, o total dos valores dos IPOs (US\$ 30,97 bilhões) foi maior do que os seis anos anteriores somados (US\$23,93 bilhões). 
Gráfico 53 - Valor dos IPOs Concluídos de Empresas de O\&G e E\&P no Mundo entre Janeiro 2000 e Junho 2008 (em US\$ Milhões)

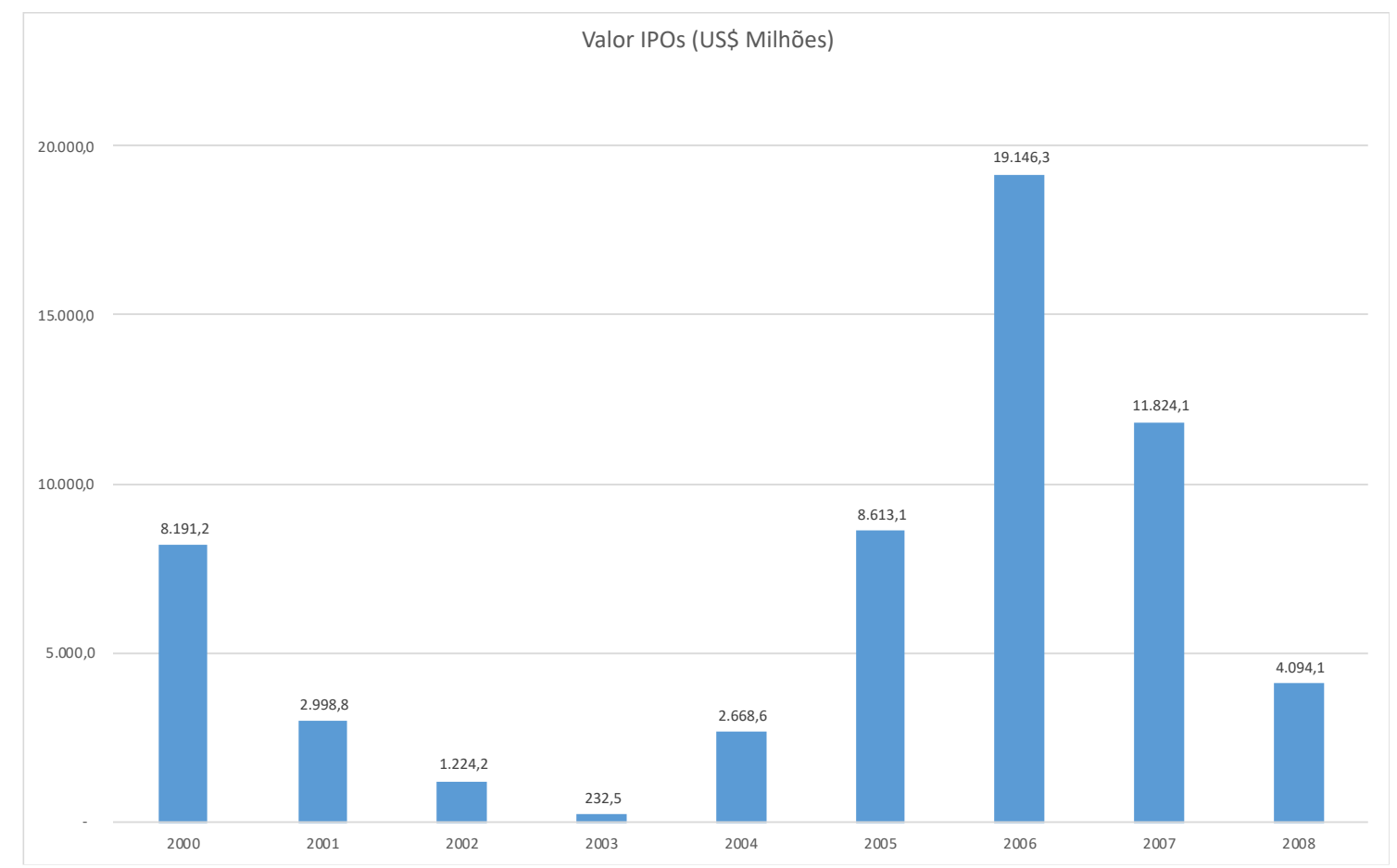

Entre julho e dezembro de 2008, não houve IPOs, provavelmente relacionados ao fim da Bolha de Verão e ao crash da Lehman Brothers.

Ou seja, o mercado internacional de capitais reunia indícios favoráveis para o IPO da OGX em junho de 2008. Estas circunstâncias favoráveis se somaram ao momento propício que o setor de O\&G no Brasil atravessava. 


\subsection{O\&G no Brasil}

"O offshore do Brasil tornou-se uma das regiões de desenvolvimento mais atraentes no negócio global de petróleo, rivalizando com a área offshore da África Ocidental, com a qual compartilha geologia semelhante. Como resultado, o país está preparado para desafiar a Venezuela e seu líder socialista Hugo Chávez, como o maior exportador de petróleo da América Latina."

WERTHEIM, 2008, p. 9

"Em um estudo sobre o impacto do E\&P do pré-sal na indústria de equipamentos e serviços, o banco UBS estima que, nos próximos 30 anos ou mais, serão necessários US $\$ 600$ bilhões para produzir 50 bboe em campos já descobertos na bacia de Santos.

Segundo dados da Bloomberg, a Petrobras é a quarta empresa mais valiosa do Hemisfério Ocidental, atrás da Exxon Mobil, da General Electric e da Microsoft."

WERTHEIM, 2008, p. 15

No Brasil, a exploração de petróleo avançava com o novo marco regulatório em $1997^{444}$. A produção nacional de petróleo mais que dobrou: de 307,1 mboe por ano em 1997 para 663,3 mboe por ano em 2008.

${ }^{444}$ A primeira iniciativa para a quebra do monopólio da Petrobras se deu com a Emenda Constitucional $n$. 9 de 10/11/1995, que alterou o 10 parágrafo do artigo 177, de modo a permitir que sociedades privadas ou estatais atuassem na E\&P de O\&G. A Lei 9.478, de 6 de agosto de 1997, ficou conhecida como Lei do Petróleo, instaurou o regime de concessão ou autorização para E\&P, que passou a ser regulado pela Agência Nacional do Petróleo (ANP), baseada nas políticas para o setor elaboradas no Conselho Nacional de Política Energética (CNPE). 
Gráfico 54 - Evolução da Produção Brasileira de Óleo (em mil barris ano), 1991 a 2008 antes e depois Novo Marco Regulatório

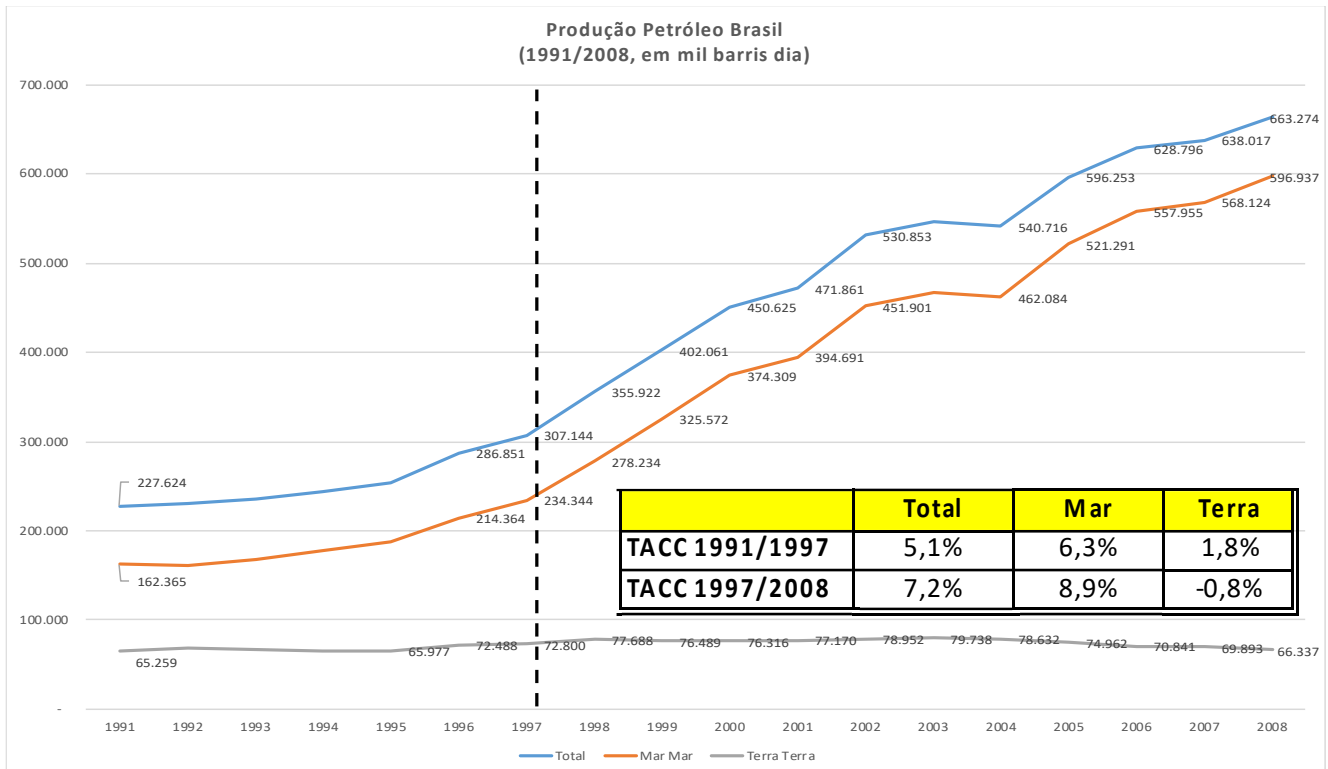

Fonte: 1991-1999, Anuário Estatístico Brasileiro do Petróleo e do Gás Natural 2001; 2000-2008: ANP, http://www.anp.gov.br/wwwanp/dados-estatisticos, Acesso: 25/08/2017.

$\mathrm{Na}$ época do IPO, a bacia de Campos, com $115 \mathrm{mil} \mathrm{km}$ 2, era considerada "a mais prolífica do Brasil":

Em 31 de dezembro de 2007, as reservas provadas da bacia de Campos eram estimadas em 10,5 bilhões de barris (89\% das reservas provadas brasileiras) e aproximadamente 157 milhões de $m^{3}$ de gás natural. Mais de 1.000 poços de petróleo e gás natural estão em operação na Bacia de Campos, com 43 estações de produção fixas e flutuantes e cerca de $4.200 \mathrm{~km}$ de dutos submarinos. A produção diária da bacia alcançou cerca de 1,5 mbpd e 20 milhões de $\mathrm{m}^{3}$ de gás natural, correspondendo, respectivamente, a $80 \%$ e $40 \%$ da produção total brasileira [OGX, 2008, p. 132].

Na bacia de Campos, 20 descobertas importantes ocorreram entre 2002 e 2008, sendo 14 feitas pela PETR (Jubarte, Cachalote, Baleia Azul, Baleia Franca, Baleia Anã, Catuá, Caxaréu, Pirambu e Mangagá, Papa-Terra, Maromba, Carataí, Carapicu e Xerelete), 4 pela Shell (Ostra, Nautilus, Abalone e Argonauta) e 2 pela Anadarko-Hydro e Devon (Peregrino e Polvo, respectivamente) ${ }^{445}$.

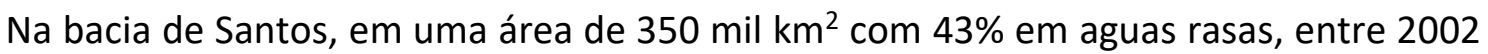
e 2007, foram perfurados 190 poços e descobertos 13 novos campos, sendo 10 pela PETR (Cavalo-Marinho, Mexilhão, Tambaú, Uruguá, Pirapitanga, Carapiá, Tambuatá, Tupi, Carioca e Júpiter), 2 pela Shell (Atlanta e Oliva) e uma pela El Paso (Lagosta). As

445 Entretanto, havia dúvidas sobre a capacidade ociosa da infraestrutura de dutos na bacia de Campos: "(...) há dois dutos para trazer petróleo para a terra, embora suas capacidades sejam relativamente limitadas" [Prospecto OGX, 2008, p. 136]. 
perspectivas para a bacia de Santos, na época, eram menos tangíveis que as de Campos, mas havia indícios de grande potencial.

Em fevereiro de 2008, em editorial, a revista The Economist ${ }^{446}$ relatou que as descobertas recentes no pré-sal poderiam mudar "drasticamente" a inserção do Brasil como exportador de óleo em 10 anos. As estimativas de reservas do Governo de 70 a 100 Bbo fossem confirmadas, o país estaria entre as 10 maiores reservas do mundo. Só o campo de Tupi em Santos, descoberto em novembro de 2007, com 5 a 7 Bbo conteria $35 \%$ das reservas comprovadas do Brasil na época (14 Bbo). $O$ consórcio que explorava Tupi pertencia à PETR (65\%), BG (25\%) e à portuguesa Galp (10\%), e em seus relatórios anuais tanto a BG quanto a Galp sugeriam que as estimativas de reservas possíveis para Tupi poderiam estar subestimadas.

Apesar da possível alta qualidade do óleo do pré-sal, os investimentos seriam elevados e arriscados. Os elevados investimentos para desenvolver Tupi foram estimados entre US\$ 70 a US\$ 120 bilhões, ou seja, uma média de US\$14,00 a US\$17,14 por barril ${ }^{447}$. Mas a The Economist previa que limites na oferta de óleo combinados com a forte demanda dos países emergentes manteriam os preços em elevados patamares de US\$ 73/barril em 2012. Uma publicação especializada [WERTHEIM, 2008, p. 8] estimava que o desenvolvimento de Tupi poderia custar entre US\$ 6,00 a US\$ 7,00 por barril.

No início de julho de 2008, um artigo na revista Offshore exaltava as descobertas no présal:

Nas profundezas do Oceano Atlântico, a Petrobras, controlada pelo governo brasileiro, fez o que poderia ser a maior descoberta de petróleo em 30 anos, e que impulsionaria o já próspero país para a grande liga de exportadores de petróleo.

O chefe da agência nacional de regulação de petróleo $e$ biocombustíveis (ANP), Haroldo Lima, disse em abril que a descoberta na área de exploração do Carioca pode conter 33 Bboe, o que o tornaria o quarto maior campo do mundo. Lima não disse se sua estimativa não oficial era de reservas recuperáveis ou de recursos in loco e a Petrobras não comentou.

O ministro das Minas e Energia do Brasil, Edison Lobão, teria dito no site do estado de São Paulo que não confirmaria nem negaria as declarações de Lima. No entanto, ele alertou que qualquer anúncio sobre a extensão dos campos de petróleo só deve ser feito uma vez que o governo esteja certo sobre os dados.

446 A big oil Discovery: Brazil could become a sizeable energy producer. 12/2/2008. Disponível em: https://www.economist.com/news/2008/02/12/a-big-oil-discovery. Acesso em 17/10/2018.

447 Posteriormente, em 2017, o custo médio de extração de óleo da PETR no pré-sal era de US\$ 8/barril. Fonte: ZAREMBA, H. Brazil's Pre-Salt Extraction Costs Fall To \$8 Per Barrel. Oilprice.com, 13/8/2017, Disponível em: https://oilprice.com/Energy/Crude-Oil/Brazils-Pre-Salt-Extraction-Costs-Fall-To-8-PerBarrel.html. Acesso em 18/10/2018. 
Por contexto, as atuais reservas provadas de petróleo bruto brasileiro estão em 14,4 Bbbl.

'Este é uma das descobertas de óleos mais impressionantes globalmente em termos de escala', diz David Riedel, da Riedel Research Inc., com sede em Nova York.

(...) Os possíveis $33 \mathrm{Bbbl}$ de petróleo de Carioca são suficientes para abastecer cada refinaria nos EUA por seis anos, tornando-se o quarto maior campo petrolifero já descoberto.

(...) Somente Ghawar da Arábia Saudita (83 Bbbl), Burgan do Kuwait (72 Bbbl) e Majnoon (50 Bbbl) descobertos pela Petrobras no Iraque em 1975 são maiores, diz Estrella ${ }^{448}$ [WERTHEIM, 2008, p. 1-2, 6-7].

Estudos prospectivos no pré-sal começaram na década de 1970 (GOMES et al. [2009]). Nos meses precedentes ao IPO da OGX, a PETR fez importantes descobertas no pré-sal, especialmente em Santos. Avanços tecnológicos recentes nas medições sísmicas 3D prometiam melhorar a capacidade de estimar o potencial das acumulações em águas rasas. Até então, a tecnologia de medição para águas profundas era mais avançada que para rasas e permitiu descobertas significativas, como Rocandor e Marlim, pela Petrobras ("PETR").

GOMES et al. [2009] destacaram que a estrutura formada por quatro blocos (BM-S-08, 09, 21, 22), ficou conhecida como "Sugar Loaf" depois do relatório divulgado pelo UBS Investment Research ao fim de 2007. O UBS Pactual foi o coordenador líder do IPO da OGX.

Naquela época, a PETR acreditava que a 300 quilômetros da costa, na Bacia de Santos, a mais de 6 mil metros de profundidade, sob uma espessa camada de sal, haveria uma reserva de petróleo extraordinária, um "mar de petróleo", que poderia conter 70 bboe, cujo valor poderia somar 8 vezes o PIB do país, suficiente para colocar o Brasil no nível de importância da Nigéria (69,3 bilhões boe) e se aproximar da Venezuela (107,4 bilhões boe) em reservas potenciais. Só Tupi elevaria as reservas do país em $60 \%$.

O World Energy Outlook da International Energy Association (IEA) de $2004^{449}$, antes das primeiras descobertas do pré-sal, estimava as reservas ainda não descobertas do Brasil em 50 bboe. Considerando o grande potencial inexplorado do pré-sal, calculava-se que o país teria entre 70 a 100 bboe de reservas de petróleo e $\mathrm{GN}^{450}$.

As descobertas da PETR no pré-sal geraram grandes expectativas na indústria mundial, apesar da Petrobras retirar blocos promissores da $9^{\text {a }}$ Rodada da ANP, onde a OGX havia adquirido 21 dos seus 22 blocos:

O emergente pré-sal, com as descobertas de Tupi, Carioca e Júpiter, colocaram o Brasil em destaque na indústria do petróleo. Apenas 4\%

\footnotetext{
${ }^{448}$ Guilherme Estrella, na época era diretor de E\&P da PETR. Geólogo, Estrella tinha sido chefe do CENPES, o centro de P\&D da PETR.

449 apud KOVARSKY \& MENDES, 2008a, p. 13.

450 Prospecto OGX, 2008, p. 128 e KOVARSKY \& MENDES, 2008a, p. 11.
} 
das [29] bacias sedimentares brasileiras haviam sido exploradas até então, e a OGX recebeu o benefício deste potencial inexplorado [LEITE, CANHEU \& CUSTODIO, 2008a, p. 1].

(...) As reservas provadas do país apresentaram a maior taxa de crescimento do mundo entre 1980 e 2006, de acordo com o BP Energy Review e estimativas da indústria; e as declarações da Petrobras pode ser tornar uma das 10 maiores reservas do mundo (...) [LEITE, CANHEU \& CUSTODIO, 2008a, p. 8].

Até 2006, a ANP havia promovido oito leilões de concessões ${ }^{451}$, envolvendo 409 mil km² e R\$ 3,54 bilhões em BA e R\$ 5,79 bilhões em Programa Exploratório Mínimo ("PEM") 452 . No total, as oito rodadas que haviam concedido 632 blocos, 345 dos quais ( $54,6 \%$ do total) foram integralmente ou parcialmente concedidos à PETR ${ }^{453}$.

Tabela 44 - Histórico de Leilões de Concessão (Rodadas) da ANP: Indicadores Seletos da 1a a 9a Rodadas

\begin{tabular}{|c|c|c|c|c|c|c|c|c|c|c|}
\hline & Data & $\begin{array}{l}\text { Empresas } \\
\text { Ofertantes }\end{array}$ & Vencedores & $\begin{array}{c}\text { Blocos } \\
\text { Oferecidos } \\
\text { (a) }\end{array}$ & $\begin{array}{c}\text { Blocos } \\
\text { Concedidos } \\
\text { (b) }\end{array}$ & $\begin{array}{l}\text { (a) } \\
/ \\
\text { (b) }\end{array}$ & $\begin{array}{l}\text { Concessões } \\
\text { PETR } \\
\text { (d) }\end{array}$ & $\begin{array}{c}\text { (b) } \\
/ \\
\text { (d) }\end{array}$ & $\begin{array}{c}\text { BA } \\
\text { (R\$ } \\
\text { milhões) }\end{array}$ & $\begin{array}{c}\text { PEM } \\
\text { (R\$ } \\
\text { milhões) }\end{array}$ \\
\hline 1 & $15 / 06 / 99$ & 14 & 11 & 27 & 12 & $44,4 \%$ & 5 & $41,7 \%$ & 21,7 & 357,7 \\
\hline 2 & 07/06/00 & 27 & 16 & 23 & 21 & $91,3 \%$ & 7 & $33,3 \%$ & 468,3 & 120,8 \\
\hline 3 & 19/06/01 & 26 & 22 & 53 & 34 & $64,2 \%$ & 15 & $44,1 \%$ & 594,9 & 212,1 \\
\hline 4 & 19/06/02 & 17 & 14 & 54 & 21 & $38,9 \%$ & 8 & $38,1 \%$ & 92,4 & 306,7 \\
\hline 5 & $19 / 08 / 03$ & 6 & 6 & 908 & 101 & $11,1 \%$ & 88 & $87,1 \%$ & 27,5 & 363,5 \\
\hline 6 & $17 / 08 / 04$ & 21 & 19 & 913 & 154 & $16,9 \%$ & 107 & $69,5 \%$ & 665,2 & $2.046,8$ \\
\hline 7 & $17 / 10 / 05$ & 32 & 30 & 1.134 & 251 & $22,1 \%$ & 95 & $37,8 \%$ & $1.085,8$ & $1.797,4$ \\
\hline \multirow[t]{2}{*}{8} & $28 / 11 / 06$ & 27 & 23 & 58 & 38 & $65,5 \%$ & 21 & $53,3 \%$ & 587,0 & 585,9 \\
\hline & Total & 170 & 141 & 3.170 & 632 & $19,9 \%$ & 346 & $54,7 \%$ & $3.542,7$ & $5.790,9$ \\
\hline
\end{tabular}

Fonte: ANP ${ }^{454}$.

${ }^{451}$ Parte da Oitava Rodada foi suspensa devido a liminares que alegavam que a imposição de restrições ao número de blocos arrematados pelos mesmos operadores, que tinha por objetivo estimular o processo concorrencial. Apesar da suspensão parcial, 58 dos 284 blocos ofertados foram licitados. Este resultado parcial superou as expectativas da ANP e "tudo apontava para uma das mais promissoras Rodadas de Licitação até então" [DA SILVA, 2003, p. 127].

452 O Programa Exploratório Mínimo consiste na proposta de trabalho de exploração apresentado à ANP e a ser executado em 3 a 6 anos. Incluem atividades exploratórias como sísmica 2D e 3D, métodos

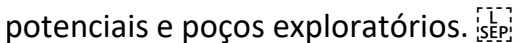

453 Posteriormente, 279 blocos foram devolvidos à ANP, o que representa 44,1\% do total concedido.

454 Disponível em: http://www.brasil-rounds.gov.br/portugues/RESUMO_geral_blocos.asp; http://www.brasil-rounds.gov.br/Resultado_Rodadas/resultados.asp. Para os dados de PEM das: Rodadas 1 a 4 - http://www.anp.gov.br/wwwanp/exploracao-e-producao-de-oleo-e-gas/gestao-decontratos-de-e-p/fase-de-exploracao/programa-exploratorio-minimo; $\begin{array}{lllll}\text { Rodadas } & 5 & \text { a } & 7 & -\end{array}$ http://www.brasil-rounds.gov.br/portugues/RESUMO_geral_blocos.asp; $\quad$ Rodada 8- 
Apesar de incertezas regulatórias (pré-sal e unitização), Analistas consideravam o Brasil um país "seguro para investir"455. Por exemplo, em vários países, como a China e a Rússia, os contratos de concessão incluíam cláusulas de "windfall", que previam limites aos ganhos inesperados dos investidores se o preço do petróleo subisse muito ${ }^{456}$.

Tabela 45 - Taxação sobre Receitas de Produção de Petróleo pelo Mundo

\begin{tabular}{|l|c|c|c|}
\hline & $@$ US\$ 50/bbl & $@$ US\$ 75/bbl & \\
\hline Angola & $75,7 \%$ & $79,6 \%$ & $3,9 \%$ \\
\hline Argentina & $50,7 \%$ & $51,0 \%$ & $0,3 \%$ \\
\hline Austrália & $51,0 \%$ & $52,1 \%$ & $1,0 \%$ \\
\hline Bolívia & $77,7 \%$ & $78,9 \%$ & $1,2 \%$ \\
\hline Brasil & $53,3 \%$ & $52,5 \%$ & $-0,7 \%$ \\
\hline Canadá & $43,7 \%$ & $44,4 \%$ & $0,7 \%$ \\
\hline China & $55,1 \%$ & $60,5 \%$ & $5,4 \%$ \\
\hline Colômbia & $53,2 \%$ & $54,0 \%$ & $0,8 \%$ \\
\hline Emirados Árabes Unidos & $98,0 \%$ & $98,0 \%$ & $-0,1 \%$ \\
\hline Estados Unidos & $44,1 \%$ & $44,2 \%$ & $0,1 \%$ \\
\hline Irã & $96,4 \%$ & $97,8 \%$ & $1,3 \%$ \\
\hline México & $90,6 \%$ & $92,2 \%$ & $1,6 \%$ \\
\hline Nigéria & $56,7 \%$ & $58,9 \%$ & $2,2 \%$ \\
\hline Noruega & $76,5 \%$ & $75,8 \%$ & $-0,6 \%$ \\
\hline Reino Unido & $55,6 \%$ & $54,9 \%$ & $-0,7 \%$ \\
\hline Rússia & $66,0 \%$ & $70,0 \%$ & $4,0 \%$ \\
\hline Venezuela & $64,2 \%$ & $68,8 \%$ & $4,7 \%$ \\
\hline
\end{tabular}

Fonte: KOVARSKY \& MENDES, 2008a, p. 17.

Havia uma crescente expectativa que o Governo brasileiro alterasse o marco regulatório com as descobertas do pré-sal. Um dos possíveis modelos em discussão envolvia Contratos de Partição de Produção (Production Sharing Contracts - PSC). No PSC, empresas privadas nacionais e internacionais teriam de partilhar a investimentos e produção com PETR e/ou uma estatal especialmente criada para isso. Esse modelo traria um fator de risco potencialmente importante: a unitização das reservas (reserves unitization).

http://www.anp.gov.br/wwwanp/noticias/2290-oitava-rodada-de-licitacoes-e-a-segunda-emarrecadacao.

455 Por exemplo, KOVARSKY \& MENDES, 2008a, p. 16; MCGANN \& KOYA, 2008a, p. 24; LEITE, CANHEU \& CUSTODIO, 2008b, p. 5.

${ }^{456}$ KOVARSKY \& MENDES [2008a, p. 16] relatam que na Rússia, o Governo se apropria de 65\% dos ganhos até US\$ 50 por barril, enquanto que no Brasil é $53 \%$. Acima deste preço, para cada US\$ 5 por barril a mais, o Governo aumenta sua participação em 100 pontos base (ou seja, 1,0\%). Na China, o Governo se apropria de $55 \%$ dos ganhos até US\$ 50 por barril. Entretanto, se o preço alcançar US\$ 75 por barril, o Governo aumenta captura $60 \%$ dos ganhos. No Brasil não há esta previsão. 
A unitização ocorre quando um reservatório é descoberto e sua área se estende além do perímetro já concedido no marco regulatório atual. Alguns analistas ${ }^{457}$ não classificavam esse risco como significativo, dado o elevado número de empresas privadas já operando no Brasil e ao marco regulatório atual que já royalties crescentes sobre a eventual produção extraordinária de novas descobertas.

Como mudanças no marco regulatório exigiriam alterações na Constituição, não havia expectativas de mudanças no curto prazo. Entretanto, esperava-se atrasos nas próximas rodadas de leilões da ANP, uma vez que o Governo claramente sinalizava que era necessário quantificar as dimensões do pré-sal antes de novas concessões e/ou alterações regulatórias. Essa incerteza, combinada com a questão da unitização das reservas, poderia comprometer futuros leilões de áreas do pré-sal, o que, em um primeiro momento, não afetariam a OGX, que como descrito adiante, já havia assegurado uma grande quantidade de blocos na 9a Rodada da ANP.

457 KOVARSKY \& MENDES, 2008a, p. 15. 


\subsection{Mercado de Capitais no Brasil}

Além do contexto favorável de O\&G no Brasil e no mundo, o mercado de capitais no Brasil estava em valorização. Entre 1994 e 2007, o IBOV, por exemplo, se valorizou em $1.368 \%$ em $\mathrm{R} \$$ e $602 \%$ em US\$ nominais.

\section{Gráfico 55 - Evolução do IBOV em R\$ e US\$ Nominais}

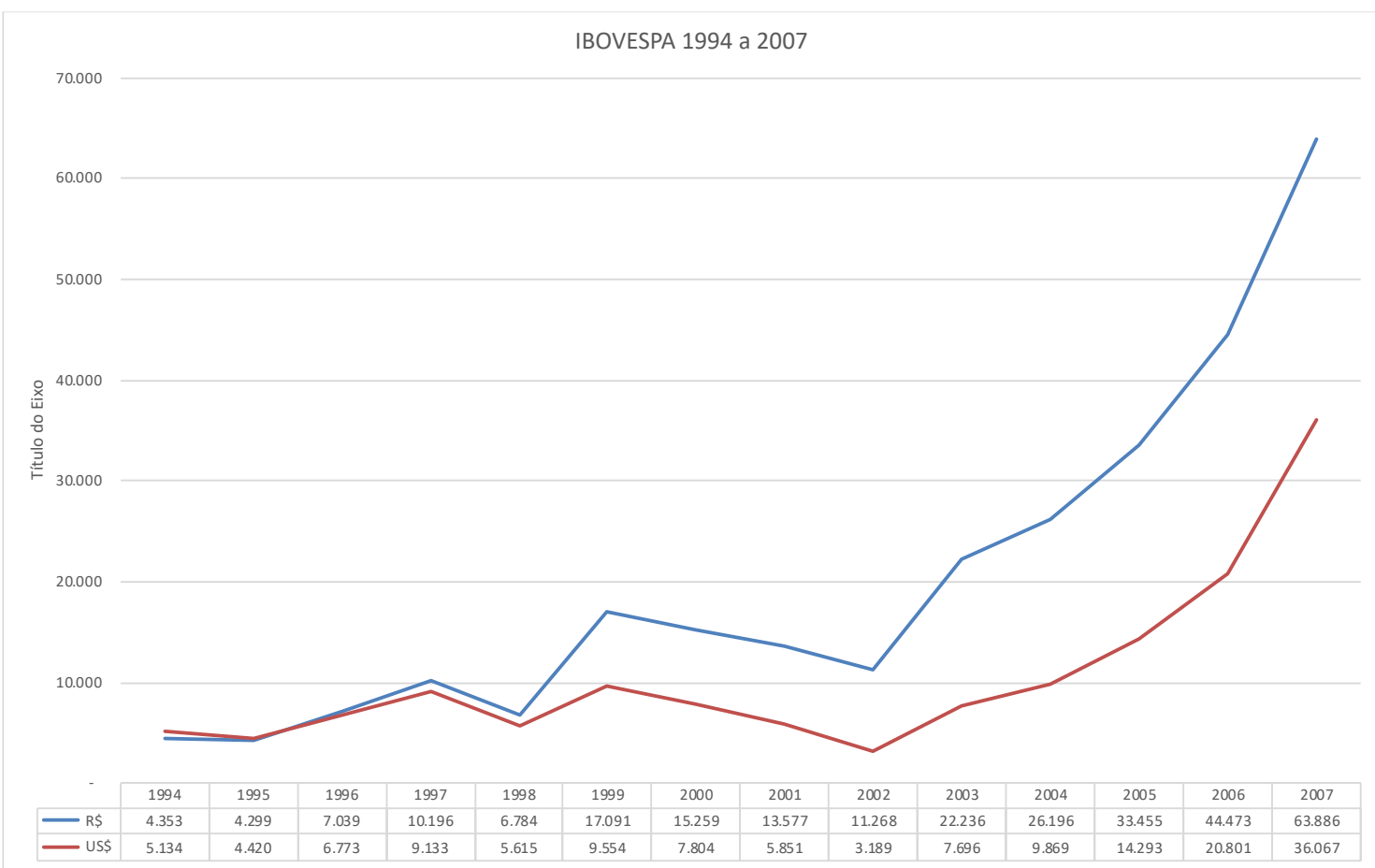

Fonte: Dados de Mercado - Outubro 2018 e Dezembro 2016, B3.

O VMD cresceu ainda mais no período de 1994 a 2007: 1.879\% em R\$ e 610\% em US\$. A composição dos investidores também mudou. Em 1994, 45,5\% do VMD era feito por instituições financeiras enquanto os estrangeiros (pessoas jurídicas e físicas) respondiam por $21,4 \%$, os institucionais por $16,4 \%$ e as pessoas físicas por $9,7 \%$. Em 2007 , a preponderância era dos estrangeiros $(34,5 \%)$ e institucionais $(29,8 \%)$ seguidos por pessoa físicas $(23,3 \%)$. 


\section{Gráfico 56 - Evolução do VMD na BOVESPA em Milhões de R\$̣ e US\$ Nominais}

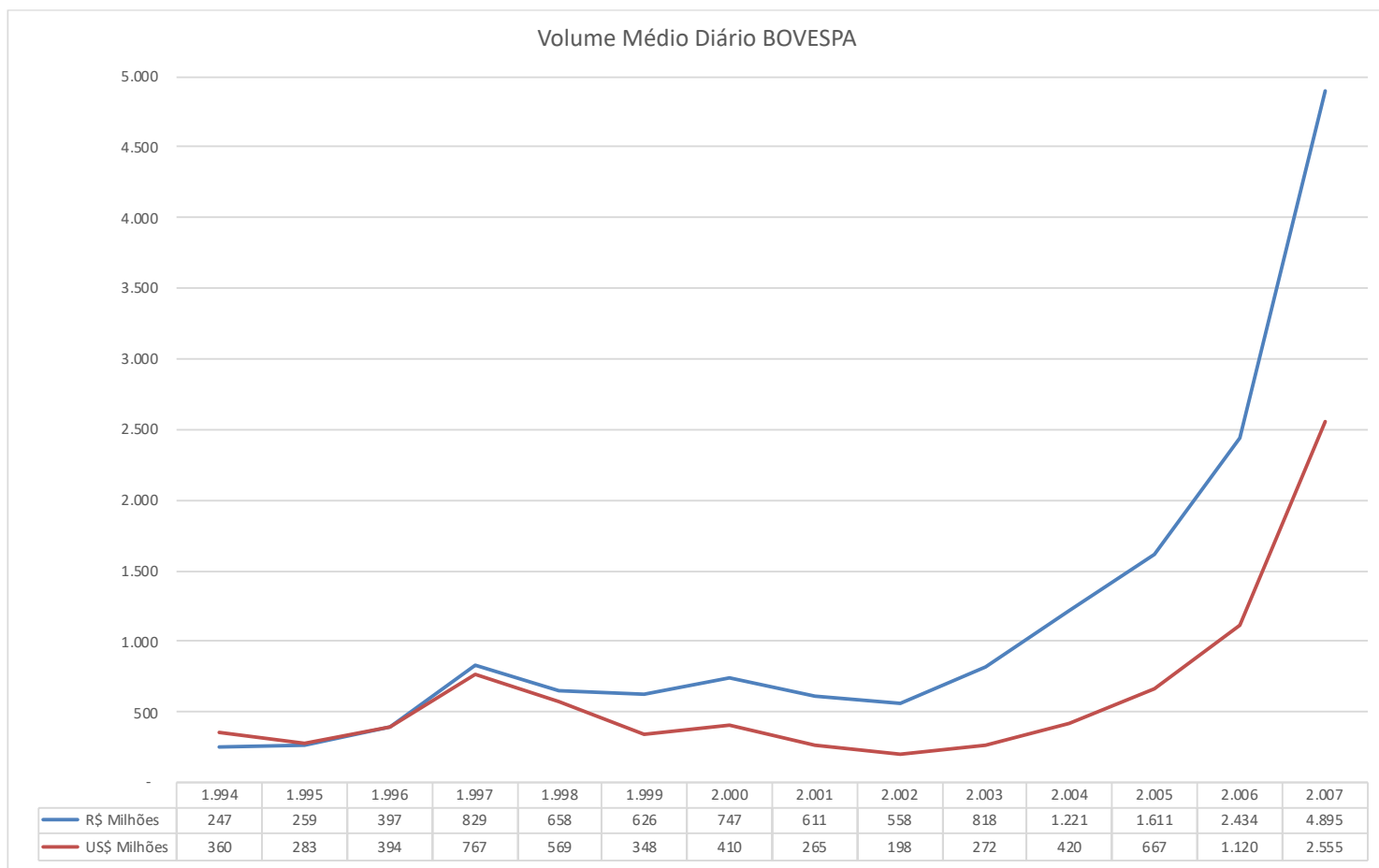

Fonte: Dados de Mercado - Outubro 2018 e Dezembro 2016, B3.

Em 30/04/2008, a Standard \& Poors elevou o risco país para grau de investimentos. Em 29/05/2008, a segunda agência classificadora, a Fitch, seguiu a elevação. O grau de investimento viabilizou a entrada de um novo tipo de investidor: investidores institucionais estrangeiros com visão de longo prazo.

\section{Gráfico 57 - Evolução do VMD na BOVESPA por Tipo de Investidor}

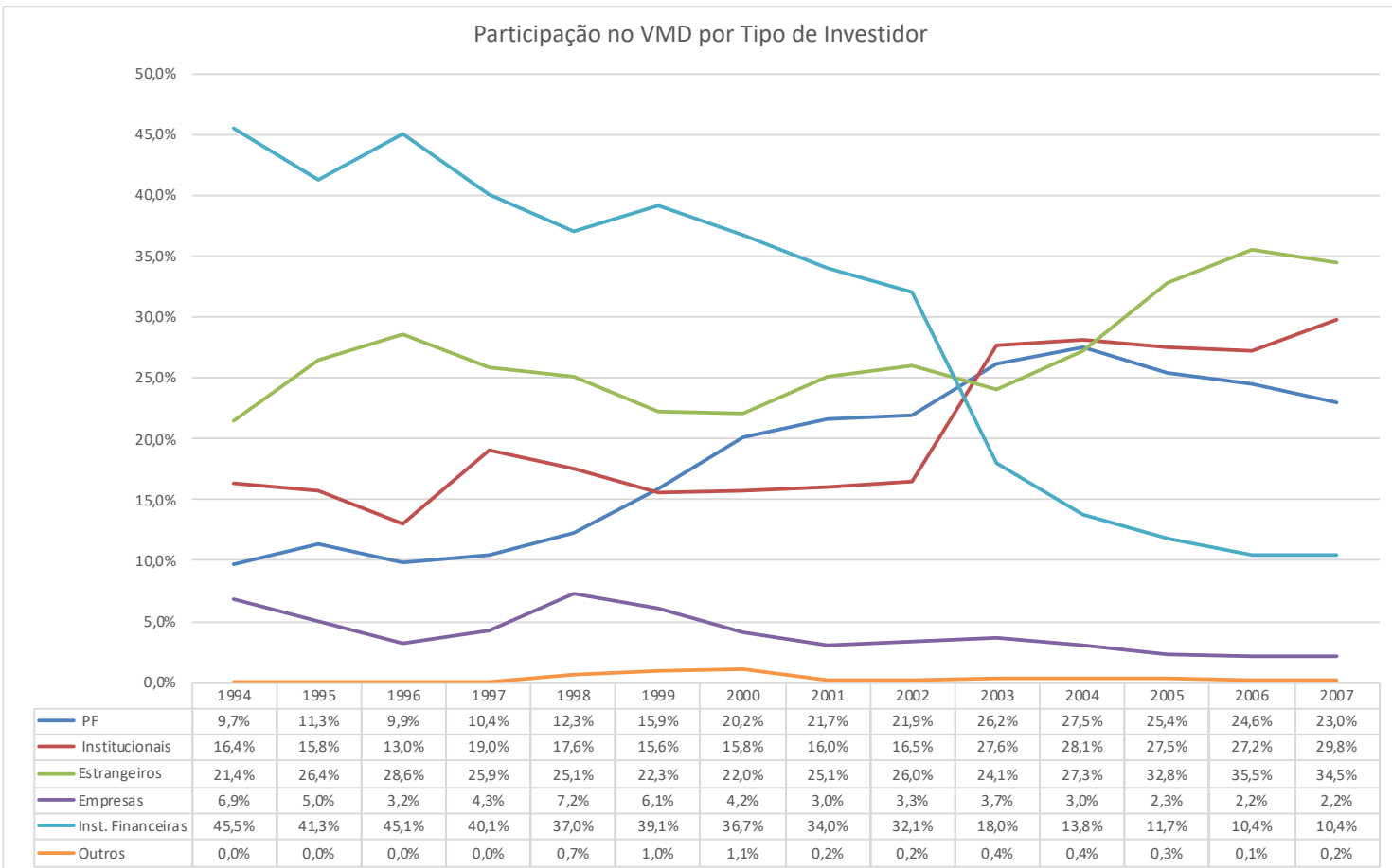

Fonte: Dados de Mercado - Outubro 2018 e Dezembro 2016, B3. 
Houve uma série de IPOs, ofertas subsequentes (follow-ons) e transações de M\&A sem precedentes no Brasil. A Fitch tinha concedido o segundo grau de investimento ao Brasil e 2007, em particular, foi o melhor para os IPOs na BOVESPA desde 2004, com 64 transações envolvendo $R \$ 55,65$ bilhões contra apenas $R \$ 4,49$ bilhões em 2004. $O$ número de investidores também foi recorde: 933,9 mil contra 32,8 em 2004. O número de IPOs de empresas relacionadas às commodities agrícolas e/ou minerais só foi significativo em 2007: 9 emissões no total de 64. Vale destacar que, entre 2004 a 2007, o volume de captações de IPOs (R\$ 81,0 bilhões) foi quase o dobro daquele captado por ofertas subsequentes ("follow-ons", somaram R\$ 42,3 bilhões), indicando a disposição dos investidores a empresas estreantes na BOVESPA ${ }^{458}$.

Tabela 46 - IPO e Follow-ons na BOVESPA entre 2004 a 2008, Excluindo OGX

\begin{tabular}{|l|c|c|c|c||}
\hline \multicolumn{1}{|c|}{ R\$ Milhões } & IPOs & Follow-ons & Total & \%IPOs \\
\hline 2004 & $4.487,1$ & $4.317,6$ & $8.804,6$ & $51,0 \%$ \\
\hline 2005 & $5.447,3$ & $8.488,9$ & $13.936,2$ & $39,1 \%$ \\
\hline 2006 & $15.373,6$ & $15.062,7$ & $30.436,3$ & $50,5 \%$ \\
\hline 2007 & $55.648,2$ & $14.464,7$ & $70.112,9$ & $79,4 \%$ \\
\hline Subtotal 04/07 & $\mathbf{8 0 . 9 5 6 , 2}$ & $\mathbf{4 2 . 3 3 3 , 9}$ & $\mathbf{1 2 3 . 2 9 0 , 1}$ & $\mathbf{6 5 , 7 \%}$ \\
\hline CAGR 04/07 & $\mathbf{1 3 1 , 5 \%}$ & $\mathbf{4 9 , 6 \%}$ & $\mathbf{9 9 , 7 \%}$ & \\
\hline 2008 & $\mathbf{7 8 2 , 9}$ & $\mathbf{2 6 . 7 6 0 , 5}$ & $\mathbf{2 7 . 5 4 3 , 5}$ & $2,8 \%$ \\
\hline Total 04/08 & $\mathbf{8 1 . 7 3 9 , 1}$ & $\mathbf{6 9 . 0 9 4 , 4}$ & $\mathbf{1 5 0 . 8 3 3 , 6}$ & $\mathbf{5 4 , 2 \%}$ \\
\hline
\end{tabular}

Fonte: BMFBovespa.

Dentre estes IPOs, cabe destacar cinco greenfields: no negócio de terras agrícolas, a Brasil Agro ${ }^{459}$ (IPO concluído em abril de 2006 com captação de R\$ 518,4 milhões); a MMX, em mineração de ferro (junho de 2006, R\$ 1,02 bilhão); Brasil Ecodiesel, na produção de ecodiesel (novembro de 2006, R\$ 378,9 milhões); Invest Tur, no setor hoteleiro (julho de 2007, R\$ 840,0 milhões); e a MPX, em geração de termoeletricidade (dezembro de 2007, $\mathrm{R} \$ 1,92$ bilhão).

Em termos de Fusões \& Aquisições, 2007 também foi um ano recorde com 722 transações compiladas pela PWC.

\footnotetext{
458 Note que "empresas estreantes no BOVESPA" não implica que estas empresas sejam greenfields.

${ }^{459} \mathrm{Na}$ época pertencente à argentina Cresud, Tarpon e ao empresário imobiliário Ely Horn.
} 
Tabela 47 - Transações de Fusões \& Aquisições entre 2004 a 2008

\begin{tabular}{|l|c|c|}
\hline \multicolumn{1}{|c|}{ M\&A } & $\begin{array}{c}\text { Número } \\
\text { Transações }\end{array}$ & Var.\% \\
\hline 2004 & 415 & \\
\hline 2005 & 389 & $-6,3 \%$ \\
\hline 2006 & 573 & $47,3 \%$ \\
\hline 2007 & 722 & $26,0 \%$ \\
\hline 2008 & 645 & $-10,7 \%$ \\
\hline CAGR 04/07 & $20,3 \%$ & \\
\hline
\end{tabular}

Fonte: PWC, outubro 2013. 


\subsection{Portfólio da OGX}

Apesar da elevada incerteza do portfólio, a percepção da qualidade e viabilidade pode ter sido compensada por quatro fatores: a qualidade dos Executivos e membros do COAD; os valores dos BAs pagos na 9a Rodada e seus investidores; e a proximidade de parte do portfólio com outros blocos já em desenvolvimento.

A equipe de Paulo Mendonça, Diretor de Exploração, era renomada, com "capacidade comprovada para execução de nosso plano de negócios," [cuja] "equipe de exploração, enquanto atuava na PETR ${ }^{460}$, obteve um índice médio de sucesso de $53 \%$ nos últimos 4 $\operatorname{anos}^{461 "}$. Soma-se à esta capacidade técnica e operacional, a reputação de membros do COAD, dentre eles ex-presidentes da PETR ou BR Distribuidora (Francisco Gros, Rodolpho Tourinho e Rodolfo Landim) e ex-ministros da Fazenda ou Minas e Energia (Pedro Malan, Eliezer Batista e Rodolpho Tourinho). Com a composição do COAD, o AC sinalizava aos investidores sua capacidade de articulação em várias esferas do governo, com empresas de O\&G (inclusive a PETR) e com o mercado de capitais.

Para viabilizar suas ofertas na 9a Rodada, que incluiu $\mathrm{R} \$ 1,48$ bilhão referentes aos $B A s$ e garantias para os $\mathrm{R} \$ 552,2$ milhões do PEM, a OGX executou transações significativas. O private placement de $\mathrm{R} \$ 2,35$ bilhões, com o apoio de um grande investidor institucional (OTT), hedge funds (Ziff Brothers), além de cartas de fiança para garantir o PEM emitidas por grandes bancos atuantes no Brasil ${ }^{462}$. Essas captações não apenas viabilizaram, mas endossaram a agressividade da OGX no leilão. O valor total dos BAs pagos pela OGX corresponderam a $75 \%$ da arrecadação total do leilão. Um único bloco (BM-S-59) foi arrecadado por R\$ 344 milhões, o maior lance da história da ANP até então ${ }^{463}$.

\footnotetext{
${ }^{460}$ A estratégia de fundar suas empresas contratando para sua liderança executivos de renome foi implementada na MMX também, com Ricardo Antunes, Joaquim Martino e Dalton Nosé (ficou conhecido como "Dr. Steel"), todos ex-funcionários da CVRD. Todos contratados com altos salários fixos mensais, bônus de contratação e pacotes de ações que variavam de 0,5\% a 5,0\% [GASPAR, 2014, p. 86 e 104].

461 Prospecto OGX, 2008, p. 15.

${ }^{462}$ Em 28/02/2008, o SAN emitiu 21 cartas de crédito, em caráter irrevogável, a favor da ANP, no valor total agregado de R\$535,8 milhões em prazos de 3,5 anos (blocos de Campos e Santos) e 4,5 anos (blocos do ES e PA-MA). Em 25/01/2008, o UBS Pactual emitiu duas cartas de crédito de R\$ 18,0 milhões para contra garantir obrigações assumidas pela OGX no contrato de farm-in do BM-S-29 (prazo de 787 dias).

${ }^{463}$ GASPAR, 2014, p. 136.
} 
Tabela 48 - Agressividade da OGX na 9ạ Rodada (US\$ Milhões)

\begin{tabular}{|l|c|c|c|c|c||}
\hline \multicolumn{1}{|c|}{ Blocos } & $\mathbf{\% O G X}$ & Maior Bid & $\mathbf{2}^{\circ}$ Maior Bid & Dif. & Empresa \\
\hline BM-C-39 & $100 \%$ & 237,24 & - & - & - \\
\hline BM-C-40 & $100 \%$ & 126,77 & - & - & - \\
\hline BM-C-41 & $100 \%$ & 237,24 & 112,45 & $111,0 \%$ & PETR/Galp/Ecopetrol \\
\hline BM-C-42 & $100 \%$ & 72,44 & 39,46 & $83,6 \%$ & PETR/Galp/Ecopetrol \\
\hline BM-C-43 & $100 \%$ & 108,66 & 67,50 & $61,0 \%$ & PETR/Galp/Ecopetrol \\
\hline BM-C-37 & $50 \%$ & 70,00 & 17,00 & $311,8 \%$ & Anadarko/Statoil \\
\hline BM-C-38 & $50 \%$ & 17,50 & 10,15 & $72,4 \%$ & PETR/Galp \\
\hline BM-S-56 & $100 \%$ & 90,55 & 9,79 & $824,9 \%$ & Starfish/PETR \\
\hline BM-S-57 & $100 \%$ & 144,88 & - & - & - \\
\hline BM-S-59 & $100 \%$ & 344,09 & - & - & - \\
\hline BM-S-58 & $100 \%$ & 19,92 & - & - & - \\
\hline BM-ES-37 & $50 \%$ & 40,20 & 5,20 & $673,1 \%$ & Anadarko \\
\hline BM-ES-38 & $50 \%$ & 40,20 & 13,50 & $197,8 \%$ & ONGC \\
\hline BM-ES-39 & $50 \%$ & 3,60 & - & - & - \\
\hline BM-ES-40 & $50 \%$ & 2,50 & - & - & - \\
\hline BM-ES-41 & $50 \%$ & 2,30 & - & - & - \\
\hline PAMA-13 & $100 \%$ & 1,45 & - & - & - \\
\hline PAMA-14 & $100 \%$ & 1,45 & - & - & - \\
\hline PAMA-15 & $100 \%$ & 1,45 & - & - & - \\
\hline PAMA-16 & $100 \%$ & 2,72 & - & - & - \\
\hline PAMA-17 & $100 \%$ & 2,72 & - & - & - \\
\hline Total BA OGX & & $1.479,72$ & & & \\
\hline \hline
\end{tabular}

Fonte: DB, 2013h, p. 10.

Na época, a agressividade da OGX no leilão levantou dúvidas sobre os valores ofertados, pois pouco antes da $9^{\text {a }}$ Rodada, a PETR convenceu o governo a retirar do leilão 41 dos 312 blocos que comporiam o leilão. Estes blocos do pré-sal eram considerados "de elevado potencial petrolífero", sendo 27 blocos em Santos, 13 em Campos e 2 no ES. Segundo a PETR, certamente haveria petróleo de alta qualidade e quantidade. Leiloá-las seria "um crime de lesa-pátria" 464.

464 DA SILVA [2013]. A resolução do CNPE 06/2007 de 08/11/07 foi publicada no DOU em 16/11/07 e ANP teve te acatá-la, poucos dias antes do leilão:

A decisão da retirada dos blocos foi bastante criticada, o que resultou no enfraquecimento da $9^{a}$ Rodada de Licitação, bem como na desistência de boa parte das grandes petrolíferas em participar do leilão. O que motivou a decisão do CNPE foi o anúncio estratégico, por parte da Petrobras, do megacampo de Tupi (...)

Munido dessas informações, o CNPE se viu na obrigação de propor medidas para preservar o interesse nacional. Dessa forma, a primeira providência foi determinar que a ANP excluísse da $9^{a}$ Rodada de Licitações os blocos situados nas bacias do Espírito Santo, de Campos e de Santos, relacionadas às possíveis acumulações próximas ao campo de Tupi [DA SILVA, 2013, p. 113]. 
Quando o governo anunciou o leilão sem as 41 áreas, a Shell, que seria uma das parceiras da OGX no leilão, desistiu de participar. Alguns Analistas ${ }^{465}$, entretanto, interpretaram a retirada das 41 áreas e a consequente desistência de algumas empresas estrangeiras como positivas para a OGX. Segundo eles, o foco do leilão para os desistentes era justamente as 41 áreas, mas havia outras áreas com alto potencial, próximas a poços já perfurados com sucesso, que haviam sido analisadas pela OGX em detalhe.

Outros Analistas consideraram que a OGX soube aproveitar o momento de saída de competidores estrangeiros ${ }^{466}$. Cinco blocos da OGX em Campos e Santos (BM-C-38, 39, 40, 41 e BM-S-59, coletivamente denominados doravante de "Blocos Seletos") estavam próximos a outros blocos de concorrentes com "Reservas Provadas e Prováveis", categorias estas com menor incerteza de acordo com a classificação da SPE-PRMS: Maromba (700 mboe/1P); Polvo e Peregrino (810 mboe/2P); e Papa-Terra (700 mboe/3P) ${ }^{467}$. Em Santos, os blocos da OGX estavam próximos ao campo de Mexilhão, onde a PETR estimava haver 1,4 bboe.

Tabela 49 - Proximidade dos Blocos da OGX com outros Blocos de Concorrentes com Reservas Provadas e Prováveis na Época do IPO

\begin{tabular}{|l|c|c|c|c|c|}
\hline \multicolumn{1}{|c|}{ Bacia } & $\begin{array}{c}\text { Blocos Seletos } \\
\text { da OGX }\end{array}$ & $\begin{array}{c}\text { BA (R\$ M) } \\
\text { \% Total }\end{array}$ & $\begin{array}{c}\text { Blocos } \\
\text { Próximos } \\
\text { Concorrentes }\end{array}$ & $\begin{array}{c}\text { Reservas } \\
\text { provadas e } \\
\text { prováveis } \\
\text { (bboe) }\end{array}$ & Operadores \\
\hline Campos & BM-C-39, 40 & $364,01(24,6 \%)$ & Polvo & 0,285 & Devon Energy \\
\hline & BM-C-40, 37, 41 & $364,01(24,6 \%)$ & Peregrino & 0,500 & Hydro Brasil \\
\hline & BM-C-38, 41 & $345,90(23,3 \%)$ & Maromba & 0,700 & PETR \\
\hline Santos & BM-S-59 & $344,09(23,3 \%)$ & Mexilhão & $1,400(G N)$ & PETR \\
\hline Subtotal & & $\mathbf{1 . 0 5 4 , 0 0 ~ ( 7 9 , 2 \% )}$ & & & \\
\hline
\end{tabular}

Fonte: Prospecto, 2008, p. 160, 164, 168.

O fato de os Blocos Seletos terem respondido por 79,2\% (ou R\$1,05 bilhão) do total de BAs, pode ter sinalizado aos investidores a elevada confiança dos Executivos no potencial destes blocos. Os Executivos teriam informações privilegiadas sobre os Blocos Seletos e o restante do portfólio? Esta foi uma questão levantada por alguns entrevistados no presente estudo. GASPAR [2014, p. 120] relata que na época, a PETR não exigia quarentena de funcionários com acesso a informações estratégicas, como era de costume em empresas privadas de O\&G. De fato, ex-post, houve descobertas importantes feitas pela PETR em outros blocos próximos a blocos da OGX. Foi o caso, por exemplo, do BM-S-29, que estava muito próximo do cluster de Tupi (BM-S-8 [Bemte-vi], 9 [Carioca], 10 [Parati] e BM-S-11 [Tupi]).

\footnotetext{
465 LEITE, CANHEU \& CUSTODIO, 2008a, p. 22.

${ }^{466}$ KOVARSKY \& MENDES, 2008a, p. 15.

${ }^{467}$ KOVARSKY \& MENDES, 2008a, p. 23.
} 
Explorar áreas próximas a descobertas por outrem é uma estratégia clássica na indústria de O\&G que data de 1901, com a descoberta de óleo em Spindletop no Texas ${ }^{468}$.

${ }^{468}$ Cf. YEARGIN, 2009, p. 66. 


\subsection{Reputação do AC e Sinergias com Partes Relacionadas}

“(...) Surpreendam sempre. A razão do nosso sucesso estrondoso é que a gente surpreende sempre. $O$ mercado cobra toda hora resultado. E transparência? Nós somos transparentes."

Entrevista do AC no Roda Viva, 30/8/2010 469

Entre 2006 e 2008, o AC havia construído uma reputação de empreendedorismo de sucesso com dois IPOs e transações comerciais ${ }^{470}$ e de M\&A significativas. $O$ primeiro IPO foi da mineradora de ferro $M M X$, com produção projetada de 15 milhões de toneladas por ano, equivalentes a um terço da produção de Carajás em 2000, a maior mina de ferro do país ${ }^{471}$. A MMX foi uma das primeiras empresas de porte deste tipo no BOVESPA $^{472}$ e estabeleceu um novo recorde de volume captado em IPO.

A MMX, que havia se tornado operacional às vésperas do IPO (IPO em 20/7/2006), era formada por três sistemas: MMX Corumbá (cujas operações haviam começado em dezembro de 2005, com receita operacional bruta de $\mathrm{R} \$$ 0,5 milhão no $1 \mathrm{T2005}$, e em fase de ramp-up), MMX Amapá (pré-operacional) e MMX Minas-Rio (pré-operacional). A tese de investimento também se baseava em "Seis Pilares": (1) portfólio de recursos mineiras de qualidade; (2) "administração com vasta experiência"; (3) baixo custo de produção e investimentos competitivos; (4) logística integrada e independente; (5) integração vertical com produtos de mais alto valor agregado; e (6) responsabilidade ambiental. O Prospecto ainda tinha mais um "ponto forte": o AC, com 20 anos de experiência técnica e em desenvolvimento de novos negócios, inclusive na TVX, umas das empresas líderes mundiais na mineração de ouro ${ }^{473}$. A MXX mencionava a logística ferroviária e portuária como diferenciais, que em parte daria origem ao Porto de Açu da LLX.

No ano seguinte, acontece o IPO da geradora de termoeletricidade, MPX, com projetos que somariam 9.647 MW de capacidade instalada, equivalentes a 9,2\% da capacidade instalada do SIN. No IPO da MPX, também um greenfield na geração de energia térmica e hidroelétrica, a tese de investimento também foi composta por "Seis Pilares": portfólio de ativos (pré-operacionais) diversificada em fontes e países (Brasil e América Latina), estrategicamente localizados, com escalabilidade; integração vertical com projetos de mineração de carvão (com minas na Austrália, Colômbia, Indonésia, África do Sul e Moçambique); comercialização diferenciada nos mercados regulado e livre; "administração com vasta experiência" e AC "com grande capacidade de execução,

\footnotetext{
${ }^{469}$ Disponível em: https://www.youtube.com/watch?v=6rDHBJHixTQ.

470 Por exemplo, GASPAR [2014, p. 109] cita o acordo de fornecimento de 6 milhões de toneladas anuais de ferro por 20 anos da MMX para o Gulf Investment Corporation (GIC), um consórcio de países árabes.

471 GASPAR, 2014, p. 88.

472 Segundo GASPAR [2014, p. 98], naquela época a CVM não tinha regras para um projeto greenfield, e teve de cria-las. Só poderiam comprar ações "investidores qualificados", como lotes mínimos de R\$ 300 mil por investidor. Só no Canadá, havia uma bolsa organizada para receber greenfields.

${ }^{473}$ Prospecto MMX, 2006, p. 21.
} 
conforme demonstrado na MMX"474; sinergias com empresas do Grupo X (minas e minerodutos da MMX, UTE em Porto de Açu da LLX).

Foram dois IPOs, envolvendo valores significativos de projetos greenfield com planos de negócio ambiciosos. A MMX captou R\$1,03 bilhão ou US\$ 510 milhões no IPO em 21/7/2006, e a MPX arrecadou R\$ 1,2 bilhão no IPO em 12/12/2007.

O IPO da MMX não foi fácil: a emissão foi concluída com um desconto de $18,5 \% \mathrm{em}$ relação ao preço mínimo sugerido ${ }^{475}$. O AC teve de contribuir com capital para o fechamento do livro. Entretanto, a evolução do valor das ações da MMX, após seu IPO foi impressionante: se considerarmos o período entre a data do IPO da MMX (21/7/2006 = 100) e um dia antes do IPO da OGX (11/6/2008), a MMXM3 se valorizou 469\% contra uma valorização de $88 \%$ do IBOVESPA e $82 \%$ do preço do minério de ferro ${ }^{476}$.

\section{Gráfico 58 - Evolução da MMX3 e IBOV (21/7/2006 = 100) entre o IPO da MMX (21/07/2006) e da OGX (12/6/2008)}

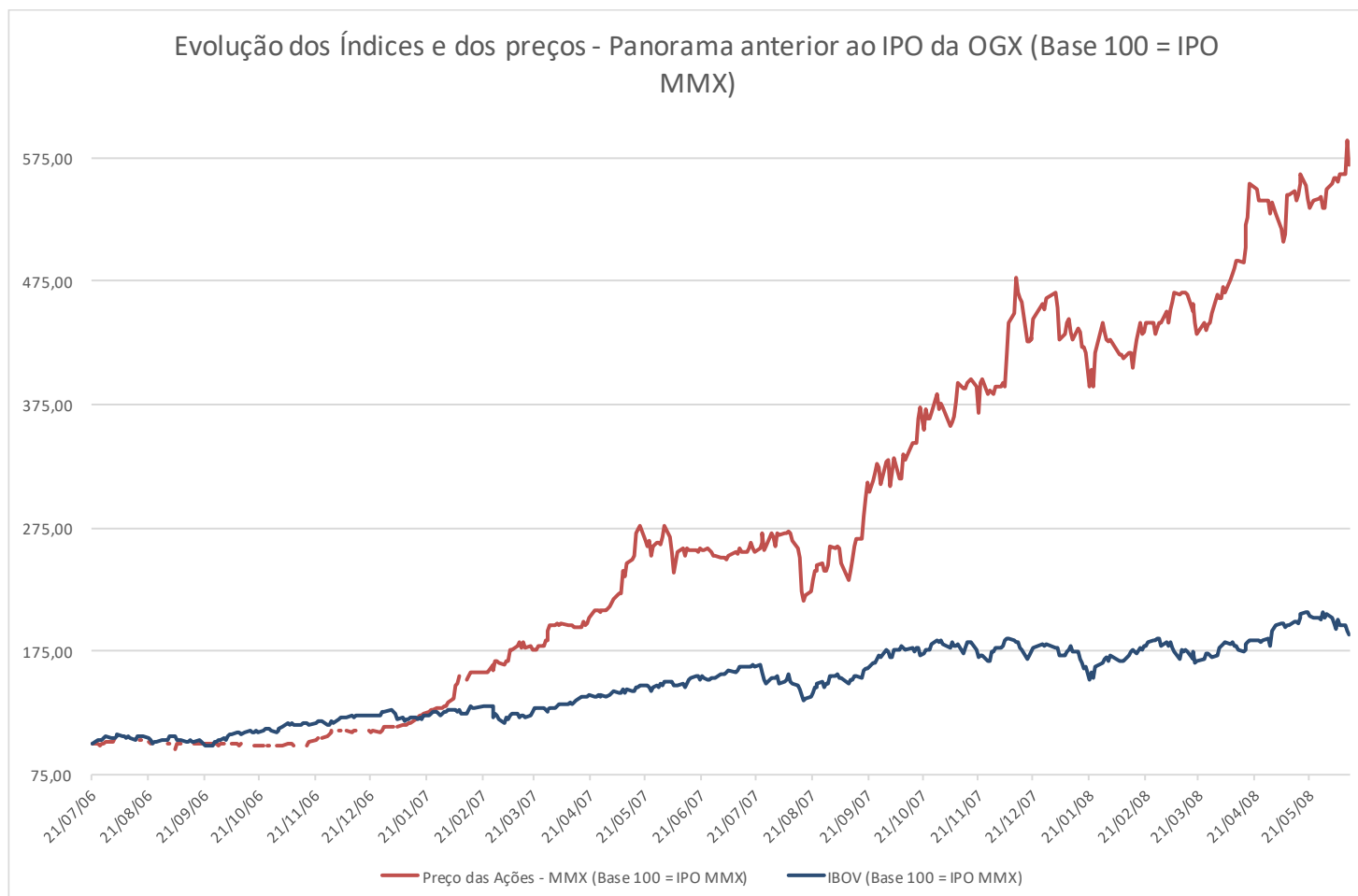

Segundo GASPAR [2014, p. 143], os recursos captados no IPO não seriam suficientes para desenvolver os projetos da MMX, com investimentos estimados em US\$ 3 bilhões. Além dos vultuosos investimentos, o plano de negócios projetava atingir, em dois anos, uma produção de 8 milhões de toneladas por ano, considerado "apertadíssimo". O

\footnotetext{
474 Prospecto MPX, 2007, p. 20.

475 Disponível em: https://www.valor.com.br/financas/3209858/mmx-buscou-credibilidade-no-canada

$476 \mathrm{O}$ cálculo da valorização do preço do minério de ferro foi medido com base no Iron Ore Fines $62 \%$ FE spot (CFR Tianjin port), em US\$ por ton. Fonte: FMI.
} 
Sistema Minas incluía ainda o maior mineroduto do mundo, ligando a mina no noroeste de Minas Gerais (Serra Azul) ao Porto de Açu da LLX, em São João da Barra, Rio de Janeiro, ambos a serem construídos.

Para viabilizar o conglomerado de minas da $\mathrm{MMX}$, o $\mathrm{AC}$ alienou participações societárias a mineradoras internacionais. Em setembro 2006, o AC vendeu 30\% do Sistema Amapá (Serra do Navio) para a mineradora norte-americana Cleveland-Cliffs por US\$ 837 milhões. Em 13/06/2007, quase um ano após o IPO, o AC vendeu $30 \%$ da LLX Minas-Rio por R\$1,32 bilhão para AA. Em janeiro de 2008 foi divulgada a venda do restante das ações do Complexo Minas-Rio para a AA por R\$ 5,4 bilhões ${ }^{477}$. As transações da $M M X / A A$, tornaria o $A C$ um dos homens mais ricos do Brasil e seus principais executivos foram "regiamente remunerados" 478 . Essas transações demonstraram ao mercado que os greenfields do AC poderiam realmente ter muito valor ${ }^{479}$.

Já o valor das ações da MPX, que no IPO fechou dentro do intervalo de preços estimado e tinha um risco menor, pois já possuía $\operatorname{CCVEs}^{480}$, não apresentou uma apreciação tão relevante quanto o da $\mathrm{MMX}$ no mesmo período, além de se mostrar muito volátil. Possíveis explicações para as diferenças entre a evolução dos preços das ações da MMX e MPX é que a primeira pode ter se beneficiado do superciclo de comodities e de possíveis transações de $M \& A$ (como posteriormente se confirmou). A segunda, além de ser dependente da disponibilidade de gás natural e de infraestrutura logística, estava sujeita a regulação do setor elétrico. Hoje, a MPX (atual Eneva) é a empresa remanescente do Grupo X com maior capitalização de mercado ( $R \$$ 4,3 bilhões, em 6/10/2017).

Houve também problemas na avaliação da MPX quando do IPO que levou o AC, em 19/02/2008, a transferir suas ações nos projetos da UTE Porto de Açu (1.400 MW) e UTE Castilla no Chile (350 MW) para a MPX sem custos para os acionistas minoritários.

477 A venda do Complexo Minas-Rio foi concluída juridicamente em 11/7/2008. A empresa IronX constituída com os ativos que foram vendidos a Anglo. O restante dos ativos permaneceria na MMX. Cinco anos depois, a AA reconheceria uma perda contábil de US\$ 4 bilhões no Complexo Minas-Rio.

${ }^{478}$ GASPAR [2014, p. 144] diz que US\$ 101 milhões foram pagos aos diretores da MMX.

${ }^{479}$ Alguns exemplos são: DARIPA \& SILVA, 2008a, p. 6; LEITE, CANHEU \& CUSTODIO [2008a]; MCGANN \& KOYA [2008a].

${ }^{480}$ Disponível em: https://www.valor.com.br/financas/3209858/mmx-buscou-credibilidade-no-canada. 


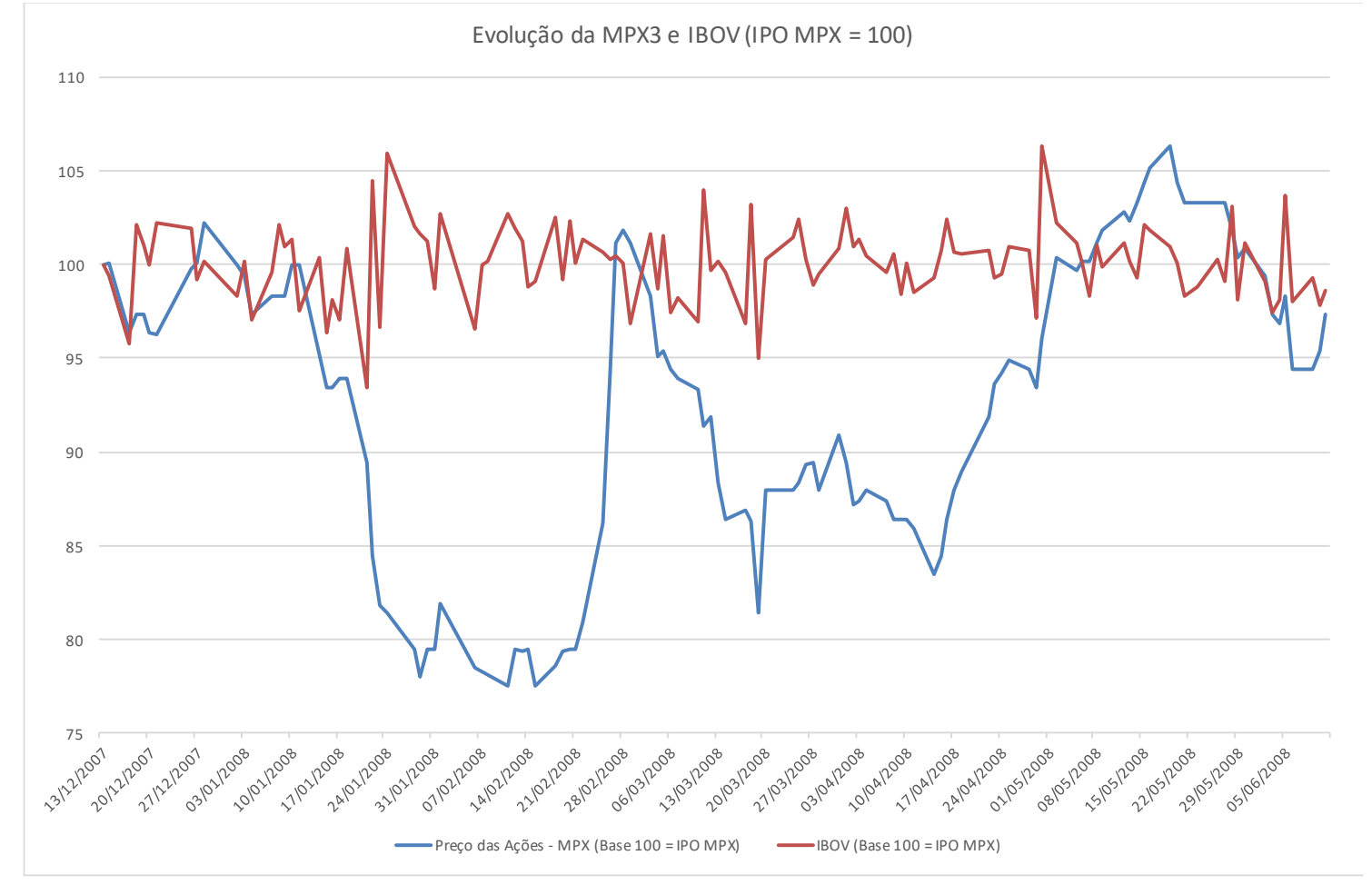

Somado a este histórico de empreendedorismo e geração de valor, o AC detinha uma participação societária significativa na OGX e outras empresa do Grupo X com as quais poderiam ser geradas sinergias. Como descrito no IPO, a complementariedade entre OGX e MPX era de particular importância para monetizar seu RPL de GN, que representava $26 \%$ do $\mathrm{RPL}$ total, e a PETR restringia o acesso de terceiros à sua rede de gasodutos no Brasil. A OGX teria de construir seus próprios gasodutos que alimentariam UTES da MPX.

De fato, o AC logo daria aos investidores evidências das sinergias com a MPX, que subsiste até hoje. Em 24/09/2009, no início da campanha de exploração, a OGX comprou 7 blocos com alto potencial de GN da Petra Energia, na bacia do Parnaíba (vide seção 3.2). O primeiro gás da OGX Maranhão foi em 26/11/2012 (seção 3.5).

Em 27/01/2010, quatro meses após anunciar a parceira com a MPX na OGX Maranhão, a OGX anunciou a encomenda de 48 equipamentos de produção até 2019 para a recémcriada OSX (vide seção 3.3) para viabilizar a conformidade com o requisito de conteúdo local e "ultrapassar o gargalo nos estaleiros brasileiros" ${ }^{481}$. No início de sua cobertura da OGX, em 23/10/2010, o SAN destacou a relação com a OSX como essencial para assegurar a viabilidade do ambicioso plano de produção da OGX.

As encomendas para a OSX refletiam a agressividade do plano de negócios da OGX. Para dimensionar o que 48 equipamentos significavam, entre 2012 a 2020, a PETR compraria

${ }^{481}$ DARIPA, 2010b, p. 1. 
43 FPSO, e 6 jackets e TLWP ${ }^{482}$. Na época, os Analistas pareciam estar cientes do risco de potencial conflito de interesse entre OSX e OGX, mas entendiam que pelo menos no curto e médio prazo, a associação reduziria a necessidade de capital da OGX ${ }^{483}$.

Quando a OSX anunciou que desistiria de construir seu estaleiro em SC e o construiria no Porto de Açu, o AC demonstrou mais uma vez a sinergias indiretas da OGX com a LLX, proprietária de Açu.

Além das sinergias operacionais, havia também sinergias "reputacionais" e políticas reconhecidas por alguns Analistas que, por exemplo, comparavam a alta capacidade de execução dos Executivos com às realizações da equipe da MMX:

Seu plano de negócios, embora envolva numerosos desafios, será executado por um time de gestores que enfrentaram desafios similares na MMX (por exemplo, Sr. Landim, atual CEO da OGX e ex-CEO da $M M X$ ), com resultados de sucessão, até então [LEITE, CANHEU \& CUSTODIO, 2008a, p. 10].

Até mesmo na obtenção das várias licenças ambientais, alguns Analistas consideravam o histórico de outras empresas do Grupo X:

(...) empresas do grupo EBX têm demonstrado um impressionante histórico de sucesso em obter licenças ambientais sem atrasos (MMX, LLX, MPX, por exemplo) [LEITE, CANHEU \& CUSTODIO, 2008a, p. 12].

482 SEQUEIRA \& FONSECA, 2010a, p. 33 e SEQUEIRA \& FONSECA, 2012a, p. 14.

${ }^{483}$ Segundo SEQUEIRA [2010a] estes equipamentos estavam avaliados em US\$ 30 bilhões. 


\subsection{Governança Corporativa}

"Pessoas essenciais. Nosso desempenho e sucesso dependem, em parte, de integrantes essenciais da nossa administração e da nossa equipe de exploração, e sua perda ou afastamento poderia ser prejudicial para nosso sucesso futuro."

Prospecto OGX, 2008, p. 77.

"Mr. Batista not only provided the capital base for the company's initial operations but also created compensation mechanisms out of its own pocket to attract some of the best talents in the Brazilian oil industry".

CREDIT SUISSE, 2008b, p. 16

Em teoria, para reduzir o risco moral há duas possíveis estratégias: (1) esquemas de incentivos baseados em performance; (2) monitoramento por um COAD, um grande acionista, potenciais acionistas (por exemplo, transações de $M \& A^{484}$ ) e/ou credores. $A$ governança corporativa da OGX era constituída destas estratégias.

Combinado a todas estas demonstrações de empreendedorismo e agressividade descritas na seção anterior, o AC detinha participações societárias expressivas em todas as empresas do Grupo X:

Tabela 50 - Participação do AC no Grupo X entre 2006 e 2012

\begin{tabular}{|l|l|c|}
\hline Empresa & \multicolumn{1}{|c|}{ Atividade } & $\begin{array}{c}\text { \% Capital } \\
\text { propriedade } \\
\text { AC }^{485}\end{array}$ \\
\hline MMX & Minério ferro & $65,8 \%$ \\
\hline MPX & Termoeletricidade & $76,9 \%$ \\
\hline OGX & E\&P de O\&G & $62,7 \%$ \\
\hline LLX & Logística portuária & $53,3 \%$ \\
\hline OSX & Construção naval & $79,9 \%$ \\
\hline CCX & Mineração carvão na Colômbia & $61,3 \%$ \\
\hline
\end{tabular}

O AC não apenas detinha uma participação significativa do capital social, mas também participava da gestão das empresas através do COAD e/ou como executivo.

\footnotetext{
${ }^{484}$ Há também a possibilidade de takeovers [JENSEN, 1988], menos frequentes no Brasil.

485 Controle exercido através da Centennial Asset Mining Fund LLC (“CAMF”), holding constituída em Nevada, EUA.
} 
Tabela 51 - Cargos Exercidos pelo AC nas Empresas de Capital Aberto do Grupo X

\begin{tabular}{|l|l||}
\hline Cargo no COAD & Cargo na Empresa \\
\hline OGX - Presidente (2008 a 2013) & OGX - Diretor Presidente (2009 a 2011) \\
\hline MMX - Presidente (2006 a 2015) & MMX - Diretor Presidente (2006 a 2008) \\
\hline CCX - Presidente (2012 a 2014) & CCX - Diretor VP (2015) \\
\hline OSX - Presidente (2008 a 2015) & \\
\hline LLX - Presidente (2008 a 2012) & \\
\hline MPX - Presidente (2007 a 2012) & \\
\hline
\end{tabular}

A princípio, a Estrutura de Governança tinha potencial para ser virtuosa. A participação societária significativa do AC e sua atuação, como principal, nos Conselhos de Administração e, por vezes, até em cargos executivos poderia reduzir assimetrias de informação com seus agentes, os executivos. Adicionalmente, a atuação do AC e seus principais executivos nos Conselhos de Administração poderia propiciar a identificação de sinergias estratégicas, operacionais e financeiras entre Partes Relacionadas. Os SOPs baseados em opções de compra de ações de empresas de capital aberto, à princípio, também poderiam ser poderosos elementos de alinhamentos entre principal e agentes. A elevada liquidez da OGXP3 poderia sinalizar rapidamente aos Gestores as percepções dos investidores minoritários sobre a eficácia da implementação operacional e financeira da campanha exploratória.

Em teoria, o uso do SOP para compensar executivos tem como objetivo alinhar os incentivos entre acionistas e gestores. Entretanto, dependendo dos termos, o SOP também pode criar incentivos aos gestores para focar em ações que aumentem a expectativa de investidores quanto à valorização das ações no curto prazo. A Enron chegou a ter $13 \%$ de suas ações ordinárias em SOP em 31/12/2000. Estas opções poderiam ser exercidas em até três anos e não havia menção a restrições a vendas subsequentes das ações após o exercício das opções ${ }^{486}$.

A estratégia do AC de fundar suas empresas contratando para sua liderança executivos de renome foi implementada na MMX também, com Ricardo Antunes, Joaquim Martino e Dalton Nosé (ficou conhecido como Dr. Steel), ex-Vale, e Rodolfo Landim da PETR (que posteriormente se tornou CEO da OGX). Todos contratados com altos salários fixos mensais, bônus de contratação e pacotes de ações que variavam de $0,5 \%$ a 5,0\% ${ }^{487}$.

No tema governança corporativa, no Prospecto do IPO, a OGX declarava possuir "práticas diferenciadas" ${ }^{488}$. O alinhamento de interesses entre o AC, COAD e Executivos teria sido reforçado pelo SOP OGX e o SOP AC que poderiam ser exercidos ao longo de 5 anos $^{489}$.

${ }^{486}$ HEALY \& PALEPU, 2003, p. 13.

487 GASPAR, 2014, p. 86 e 104.

488 Prospecto OGX, 2008, p. 216.

489 Prospecto OGX, 2008, p. 182, 187. O Programa foi aprovado em assembleia em 30/4/2008. A opção poderia ser exercida conforme preço a ser determinado pelo COAD, respeitado o preço mínimo de $80 \%$ (e o máximo de $100 \%$ ) do valor de mercado da OGXP3, calculado pela média simples do preço 
O programa de SOP OGX "poderia outorgar opções de compra aos membros do COAD, diretores, gerentes, consultores e empregados da OGX e de outras sociedades que estivessem ou viessem a estar sob o controle direto ou indireto da Empresa". O COAD não poderia, em nenhuma hipótese, estabelecer um vesting inferior a um ano. Simulações da própria Empresa no Prospecto, considerando parâmetros da época do IPO, o valor hipotético do SOP OGX poderia render aos outorgados $\mathrm{R} \$ 72,2$ milhões.

O SOP AC concedeu opções de compra de ações secundárias aos principais Executivos "e outros profissionais", para que os mesmos adquiram, globalmente, até $8 \%$ das ações de sua propriedade. Estas opções poderiam ser exercidas na proporção de $20 \%$ a cada um dos 5 primeiros aniversários do IPO. Simulações da própria Empresa no Prospecto, considerando parâmetros da época do IPO, o valor hipotético do SOP OGX poderia render aos outorgados $\mathrm{R} \$ 1.640,3$ milhão.

Somados, o SOP OGX, o SOP AC e o valor de R\$ 7,25 milhões de remuneração anual global "dos administradores, resultaria em uma remuneração anual global de nossos administradores de, aproximadamente, $R \$ 1.736,25$ milhão, para o exercício social de 2008" [p. 187]. Desta forma, 85,4\% da remuneração dos Executivos (diretoria estatutária) e 90,0\% do COAD era composta pelo SOP AC:

Tabela 52 - Proposta de Remuneração dos Administradores

\begin{tabular}{|l|c|c|c|c|}
\hline & $\begin{array}{c}\text { Remuneração } \\
\text { Fixa }\end{array}$ & \multicolumn{2}{|c|}{ SOP } & $\begin{array}{c}\text { Benefícios } \\
\text { Diretos e } \\
\text { Indiretos }\end{array}$ \\
\hline & & SOP AC & SOP OGX & \\
\hline COAD & $8,0 \%$ & $90,0 \%$ & $2,0 \%$ & - \\
\hline Diretoria & $14,3 \%$ & $85,4 \%$ & - & $0,3 \%$ \\
\hline
\end{tabular}

Fonte: Proposta da Administração da Companhia à Assembléia Geral Ordinária e Extraordinária a serem realizadas no dia 30/04/2010, Anexo IV, "Remuneração dos Administradores", p. 27.

O SOP AC seria interpretado como uma indicação adicional do comprometimento do AC com o sucesso da OGX ${ }^{490}$.

Ou seja, a presença e atuação do principal acionista, os SOPs, a listagem das empresas no Novo Mercado indicava, pelo menos em uma primeira leitura, uma elevada qualidade na governança corporativa. O Principal estava próximo dos seus Agentes.

das Ações nos 20 pregões da BOVESPA imediatamente anteriores à data de outorga das opções. $O$ preço ajustado seria atualizado pelo IPCA.

490 LEITE, CANHEU \& SOBREIRA, 2008, p. 5 e 16. 


\subsection{Sentimento Otimista do Mercado}

A princípio, considerando os aspectos das seções anteriores, os Analistas da Amostra Própria tinham argumentos para recomendarem a compra da OGXP3 no início da cobertura, conforme descrito na seção 3.1. Nos anos subsequentes, ex-ante, quando o guidance evidenciou a aceleração da campanha exploratória, os Analistas continuaram a reagir positivamente, conforme descrito nas seções 3.2 e 3.3. Se os principais objetivos dos renomados Executivos eram o de-risking e crescimento do portfólio, a evolução da Agenda de Catalisadores foi bem recebida pelos investidores e Analistas, pelo menos nos primeiros anos da execução da campanha de exploração (de agosto de 2009 a abril de 2011).

O processo de de-risking requer perfurar poços pioneiros e de avaliação que podem fornecer informações sobre volumes recuperáveis de O\&G, a migração do RPL para Recursos Contingentes e Reservas e o ramp-up da produção. Por ser um processo de elevado custo, farms-out e farm-ins são importantes estratégias de compartilhamento de recursos financeiros, expertises operacionais e riscos. Considerando a publicação do 3으 D\&M em 15/04/2011 como um ponto de inflexão na confiança dos investidores no guidance, podemos dividir a campanha de E\&P em dois grandes momentos: antes do 3 o D\&M e depois. Na primeira parte, entre 2/01/2009 e 30/12/2010, os investidores, que sustentavam o Rally, pareciam confiar no guidance dos renomados Executivos e AC, que até então era percebido como agressivo, mas não otimista. A comparação entre a evolução da OGXP3 e os principais eventos da campanha E\&P, que incluem descobertas, estimativas de O\&G recuperável, o 2ㅇ D\&M, farm-ins e farm-outs, e o início da produção de TBAZ, indica que os investidores, através da apreciação da ação, apoiavam a agressividade da implementação. 
Gráfico 60 - Evolução do Valor de Mercado entre 2/01/2009 e 15/04/2011

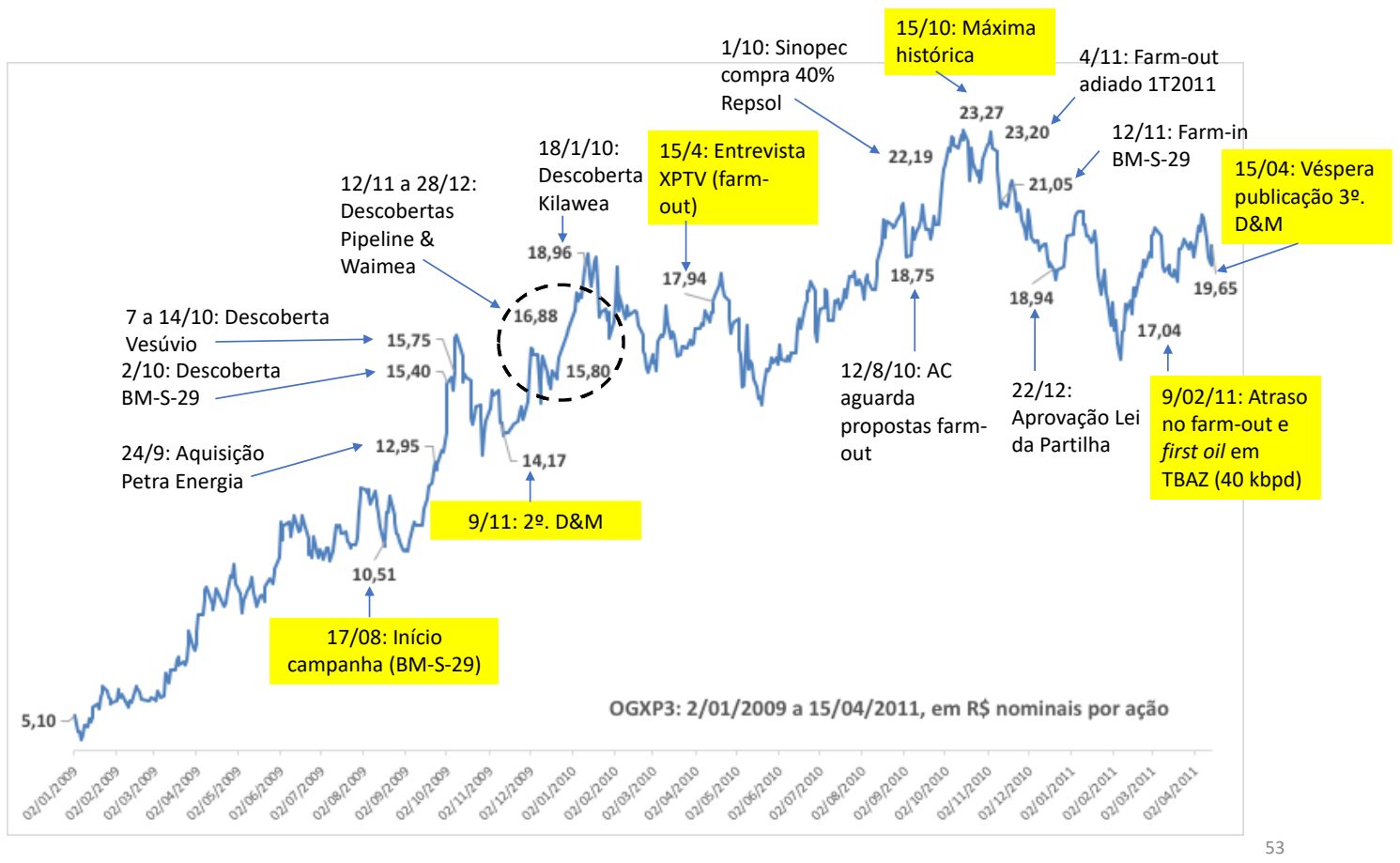

A valorização da OGXP3 em relação aos seus "peers" do S\&P OGEP 600 e 1500 é mais um indicador de high sentiments.

Gráfico 61 - S\&P OGEP 600 e 1500, Brent e OGXP3 de 2/01/2009 a 15/04/2011

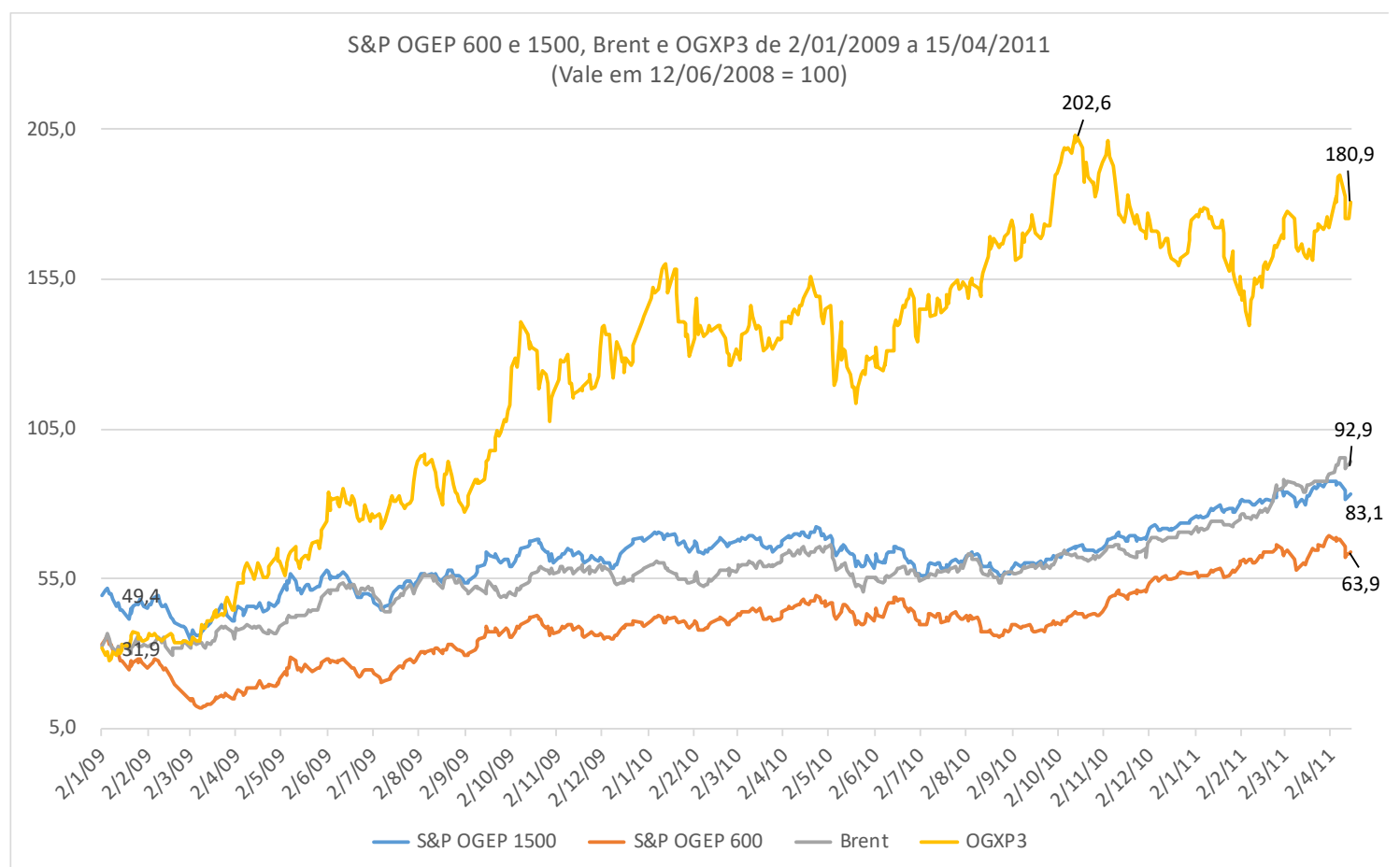

O período de 2009 a 15/04/2011 coincide com boa parte dos momentos de sobrevalorização da OGXP3 identificados na seção 2.3. 
Gráfico 62 - EV versus VPL do Cenários Médios D\&M: Indícios de Sobrevalorização da OGXP3

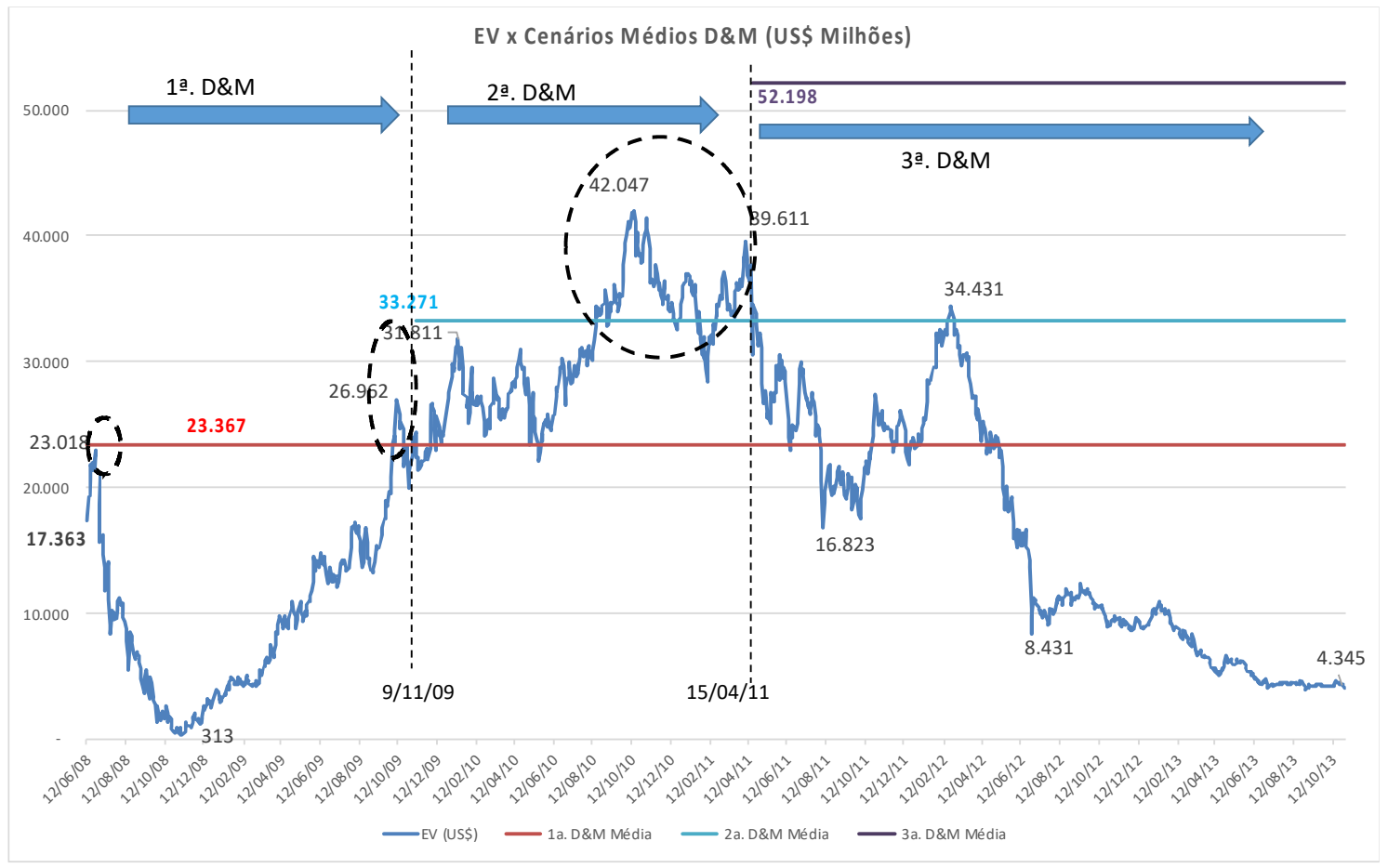




\subsection{Endosso dos Analistas}

Em geral, exceto por períodos críticos de 2008/09 e 2013, por longos períodos, a mediana do PA dos Analistas da Amostra TR estava acima do valor da OGXP3. A análise da mediana do PA da Amostra TR dividido pelo valor da OGXP3, mostra que, em geral, os Analistas mantiveram prêmios em relação às cotações de mercado até o início do 2T2013. Logo após os IPO, os Analistas da referida amostra se demonstraram, na mediana, empolgados com o futuro da OGX, mesmo durante a crise de 2008. Mas o ajuste mais conservador veio e permaneceu até o 4T2011, quando a mediana começou a se elevar até chegar a um pico de 2,72x em 8/11/11. Seguiu-se um ajuste quando os PAs, na mediana foram reduzidos até $23 / 2 / 12$, quando o otimismo parece ter voltado, provavelmente com as expectativas sobre o início da produção de TBAZ. Nota-se que o pessimismo só retorna no 1T2013, já precedendo o colapso financeiro da OGX.

\section{Gráfico 63 - Amostra TR: Evolução da Razão da Mediana dos PAs pelo Valor da OGXP3 na BOVESPA}

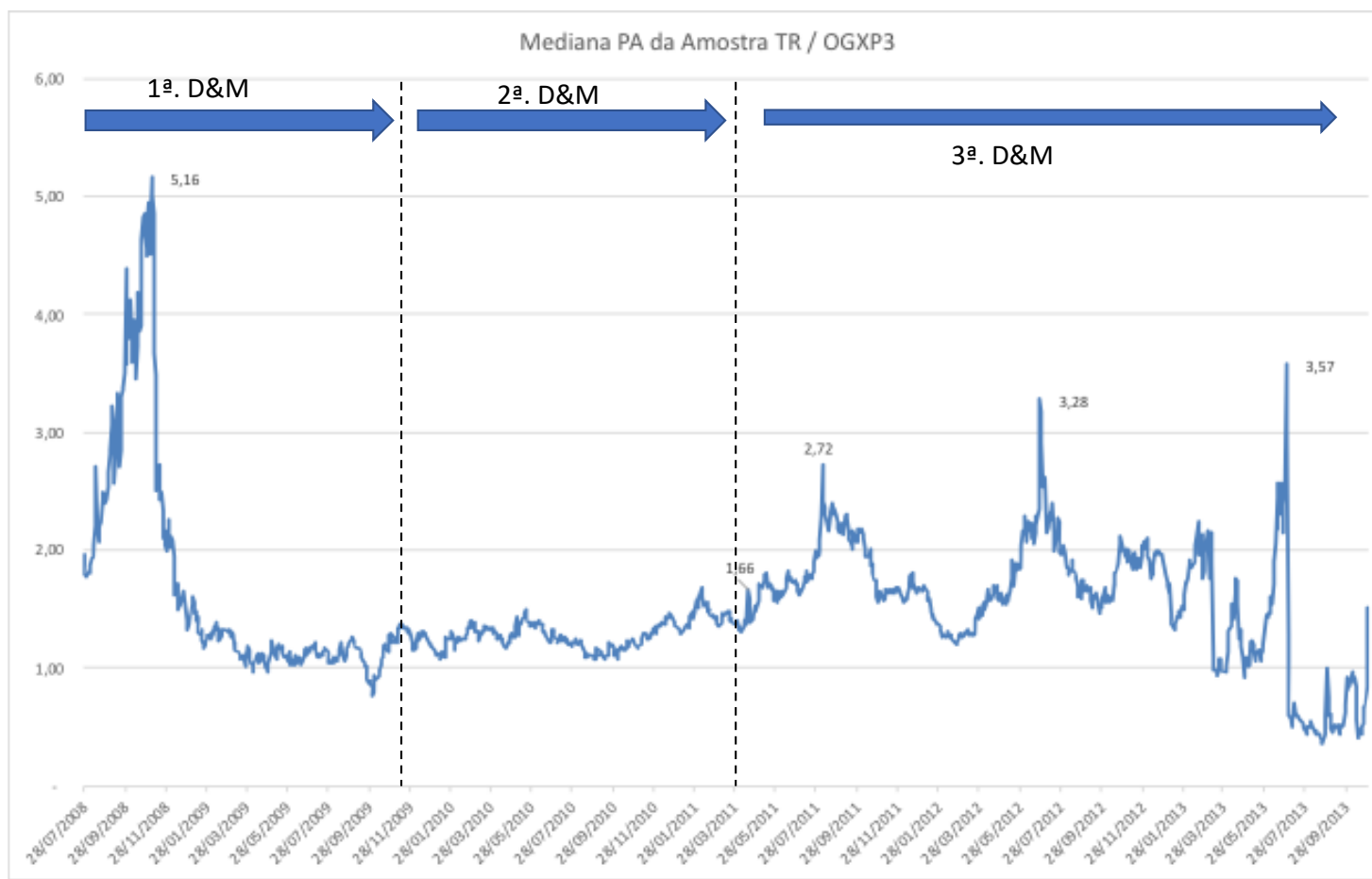

Mesmo com a confusão gerada pelo 3을 D a evolução do consenso dos Analistas e o mercado destoaram após 18/4/2010. A mediana da amostra de Analistas da Amostra TR manteve seu otimismo em relação à OGXP3 ${ }^{491}$ por muitos meses após 18/4/2010. Na mediana, possivelmente acreditando no guidance (2 e 3으 D\&s, múltiplos de M\&A que poderiam ser negociados no farm-out, ramp-up, e outros), os Analistas elevaram seus

491 Para comparar os PAs com as estimativas médias dos VPLs dos relatórios da D\&M, consideramos estimativas diárias para os saldos de disponibilidades, que só eram precisamente documentadas nos ITRs. 
prêmios relativos à OGXP3 entre 18/4/2010 e 21/06/2012 em relação o período do Rally do Valor de Mercado.

O período de 28/12/2009 a 21/06/2012 (617 pregões), o "Rally dos Analistas", a mediana da razão entre a mediana dos PAs e ao valor da OGXP3 foi de 1,41, acima daquela do "Rally do Mercado", 1,22, entre 06/11/2008 e 4/11/2010 (480 pregões). Estes dois momentos coincidiram por 198 dias (entre 28/12/2009 a 15/10/2010). O Rally do Mercado pode ter gerado a Sobrevalorização da OGXP3 por 140 pregões (de 17/08/2010 a 15/04/2011), mas esta foi além do Rally por 111 pregões (entre (4/11/2010 a 15/04/2011). O período Rally dos Analistas, por sua vez, começou durante o Rally de Mercado, mas perdurou por 418 pregões depois do fim do Rally (18/10/2010 a 21/06/2012) e 295 pregões depois da Sobrevalorização (15/4/2011 a 21/06/2012).

Gráfico 64 - Rally Mercado (6/11/2008 a (15/10/2010) versus Rally dos Analistas Amostra TR (28/12/2009 a 21/6/2012) versus Sobrevalorização (17/8/2010 a 15/4/2011)

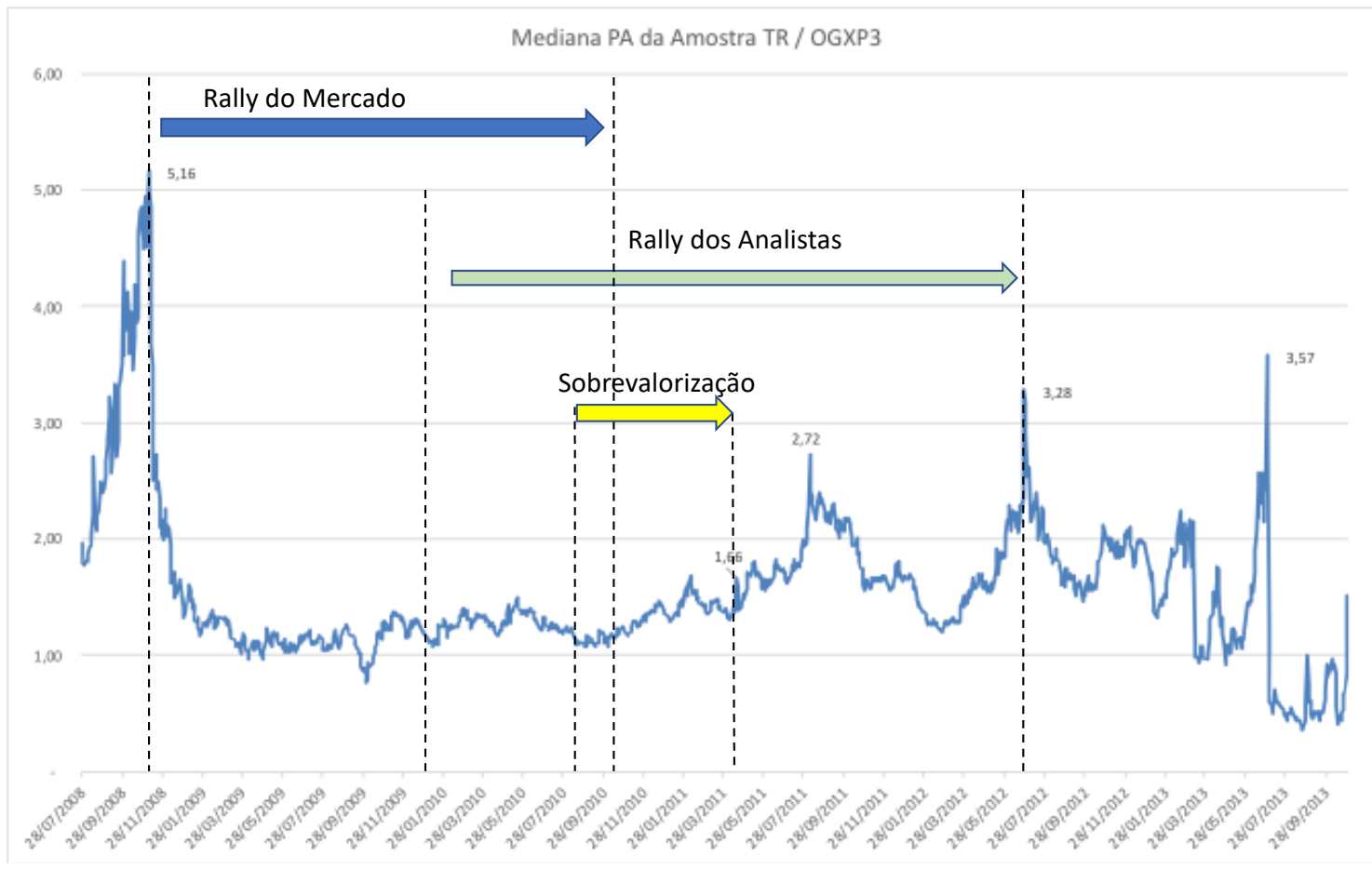

Apesar do otimismo que a relação entre o valor da OGXP 3 e a mediana dos PAs indica durante quase todo até a publicação do 3o D\&M (de 9/11/2009 a 15/04/2011), os Analistas aparentemente não acataram as estimativas médias do 20 D\&M. 


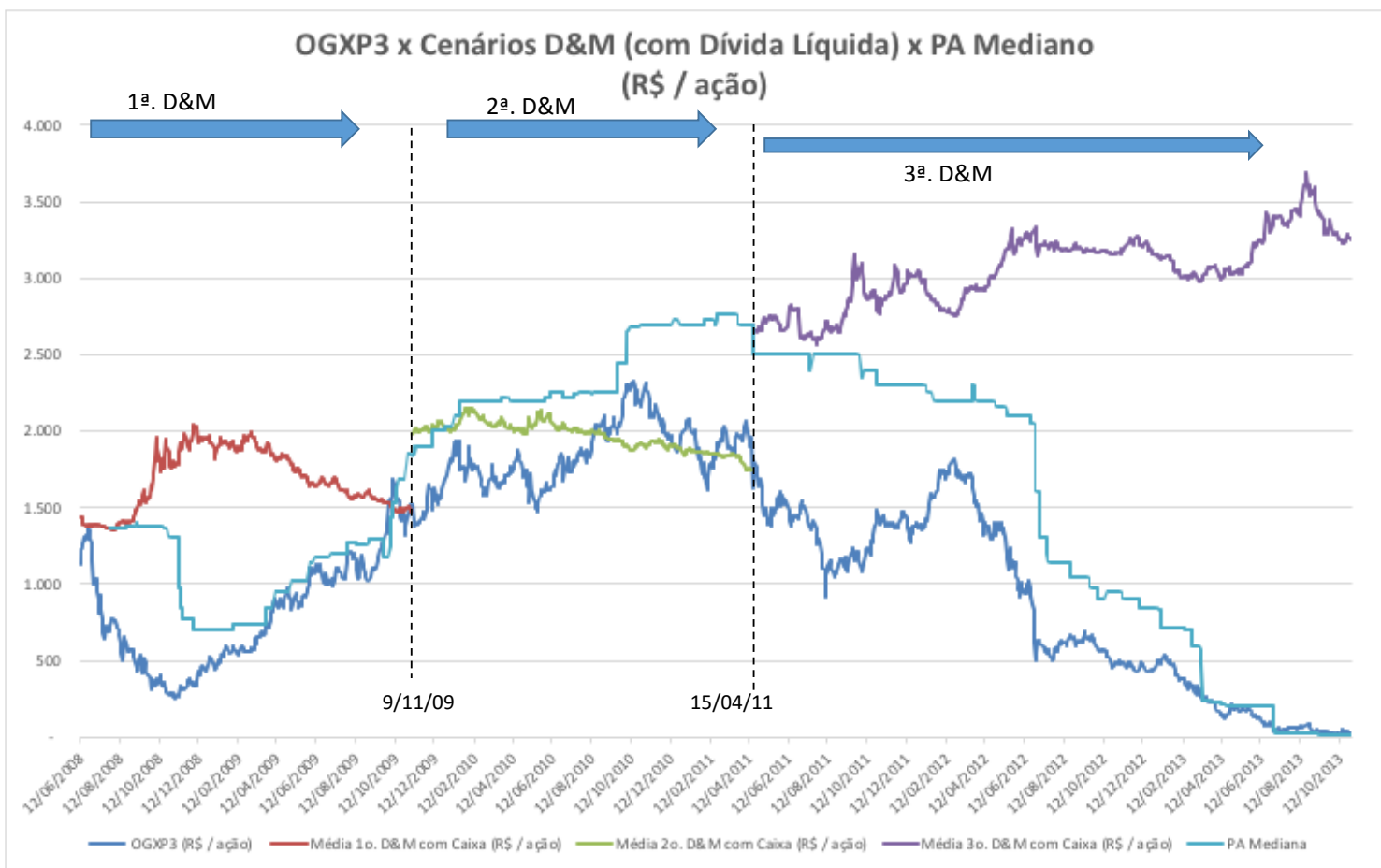

Em 26/06/2012, outro ponto de inflexão aconteceu: dados sobre a produção de TBAZ ficaram muito aquém do guidance, o que levou à substituição do CEO poucos dias depois (28/06). Aparentemente, a partir deste ponto, a confiança da mediana dos Analistas no guidance, que já estava abalada, foi comprometida. O gráfico a seguir indica que, após o 3 D\&M, mesmos os Analistas mais pessimistas entre 09/05/2011 até o fatídico 26/06/2012 mantiveram seu PA (PA Low) acima do valor da OGXP3. 


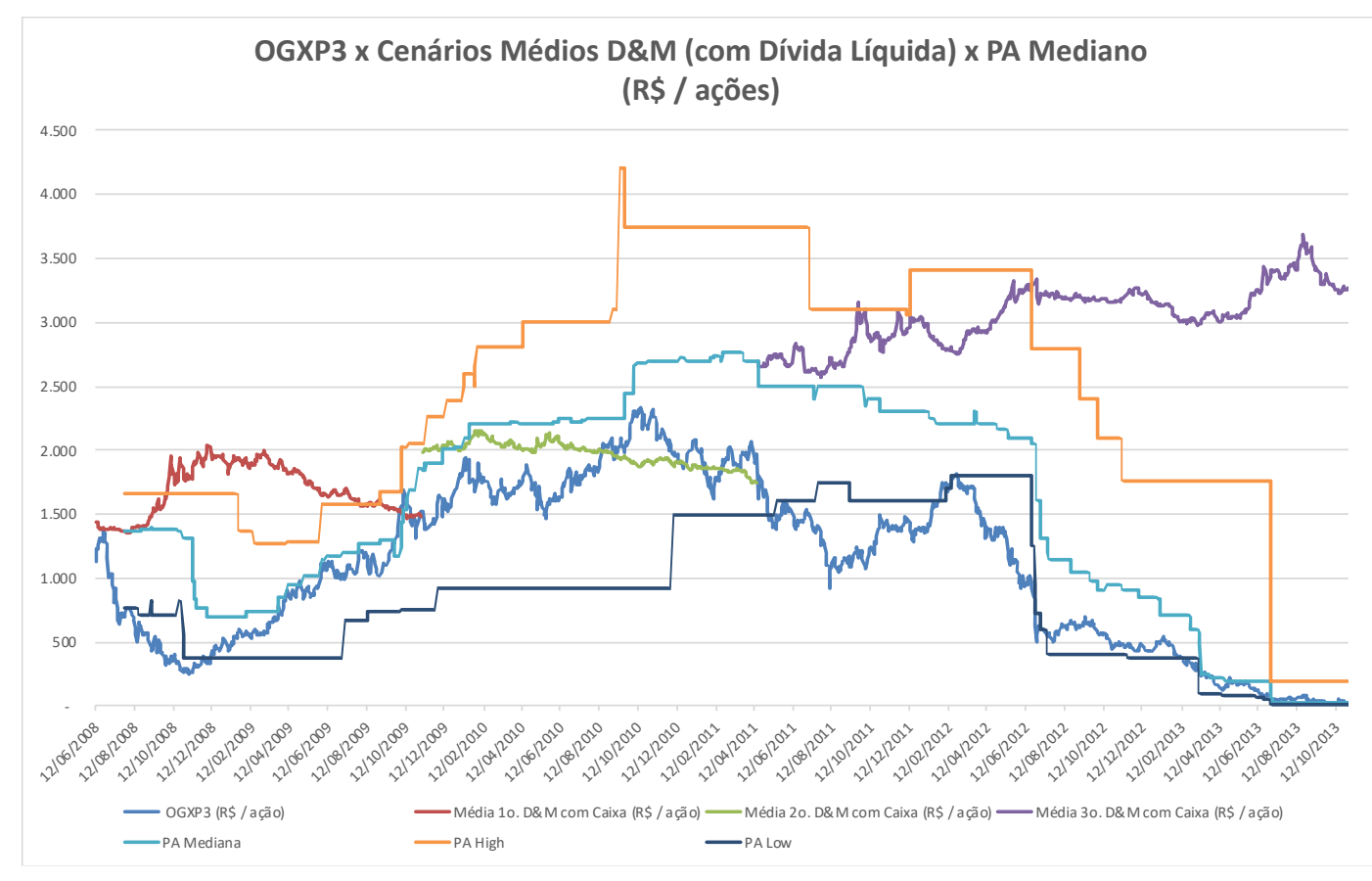

Há indícios que os Analistas, em geral, também corroboraram com a intensa e diversificada campanha exploratória, mantendo seus PAs relativamente altos em relação ao Valor de Mercado, mesmo após as primeiras evidências que comprometiam a credibilidade do guidance. Se a OGXP3 experimentou períodos de overshooting, parece que a mediana dos PAs também. Quer seja por pura boa fé, herding, influências do otimismo dos Executivos e AC e/ou por sucumbir aos conflitos de interesses das instituições financeiras onde trabalhavam, na mediana, os Analistas não apenas endossaram, mas sustentaram o guidance por meses após o fim do Rally. 


\subsection{Externalidade da Avaliação e Monitoramento de Investidores e Financiadores}

Apesar do inerente otimismo dos PAs e recomendações dos Analistas, a importância de seus questionamentos aos Executivos e $A C$ não pode ser menosprezada. Após cada teleconferência, cada encontro presencial com os Executivos e AC, os Analistas de grandes bancos e corretoras eram sabatinados por investidores sofisticados, cujo endosso era importante para a OGX e seus Gestores, especialmente em momentos de sinais divergentes sobre o sucesso da campanha de E\&P. Por sua vez, nas interações com os Analistas, os Executivos e o AC também coletavam sinais indiretos sobre as reações dos investidores ao guidance e a campanha E\&P e o Sentimento do Mercado.

Ou seja, os Analistas proporcionavam aos Executivos e o AC um diálogo indireto com o "mercado". Era uma valiosa troca de informações e sinais para ambos os lados: ofertantes e demandantes de informações.

A extraordinária estratégia de financiamento da OGX não se destacava apenas pelos montantes captados, mas também pela qualidade dos investidores e financiadores. Dentre eles havia dezenas de fundos de pensão nacionais e internacionais, fundos patrimoniais ("endowments"), fundos soberanos, fundos de investimento e hedge funds. Entre setembro de 2009 e setembro de 2013, com considerável oscilação, as atas das Assembleias Gerais Extraordinárias ("AGEs") registravam dentre os acionistas presentes, endowments, fundos de pensão corporativos, estaduais e municipais, como por exemplo: British Airways, British Telecom, British Petroleum, California State Public Employee (CalPERS), Ford Foundation, IBRD (Banco Mundial), Microsoft, OTPP, Rockfeller Foundation, IBM, HP, Cargill, Boeing, BellSouth, AT\&T, Shell, Professores do Estado do Texas e do Estado de Illinois, etc. Dentre os fundos soberanos presentes, destacavam-se o de Singapura (Cingapure Government Investment Corporation, ou CGIC) e de Abu Dhabi (Mubadala). Havia também vários renomados gestores de fundos de investimento internacionais, como o Vanguard, Fidelity, BlackRock, Morgan Stanley, Goldman Sachs, JP Morgan, dentre outros.

Embora a participação nas AGEs indique o interesse destes investidores institucionais, não se pode inferir sobre as dimensões de suas participações na composição do floating da OGX. Entretanto, é possível constatar que a medida que a mediana dos PAs indicava otimismo, a quantidade de investidores institucionais aumentava. A seguir, descreve-se, ano a ano, a evolução da mediana do PA e da quantidade de investidores institucionais.

\section{9}

Conforme descrito na seção 3.2, embora o mercado pareça ter recebido o 2 은 $\& M$ com cautela, os Analistas da Amostra TR também responderam com otimismo às descobertas e revisões de volumes recuperáveis, especialmente no quarto trimestre, com a descoberta de Vesúvio, Pipeline e Waimea. Cabe destacar que por um curto período, de 24/9 a 15/10, a OGXP3 foi transacionada acima da mediana dos PAs. Mas 
após 15/10, a OGXP3 se descolou, para menor, da mediana dos PAs, data esta que coincide com o inesperado e pouco usual anúncio dos volumes recuperáveis de Vesúvio (7 e 14/10) e Pipeline (12/11 a 22/12), que somados poderiam conter 1,5 a 3,5 bboe.

Gráfico 67 - Amostra da TR: Evolução da Mediana, Máximo e Mínimo do PA em 2009 (em R\$̧/ação, pré split)

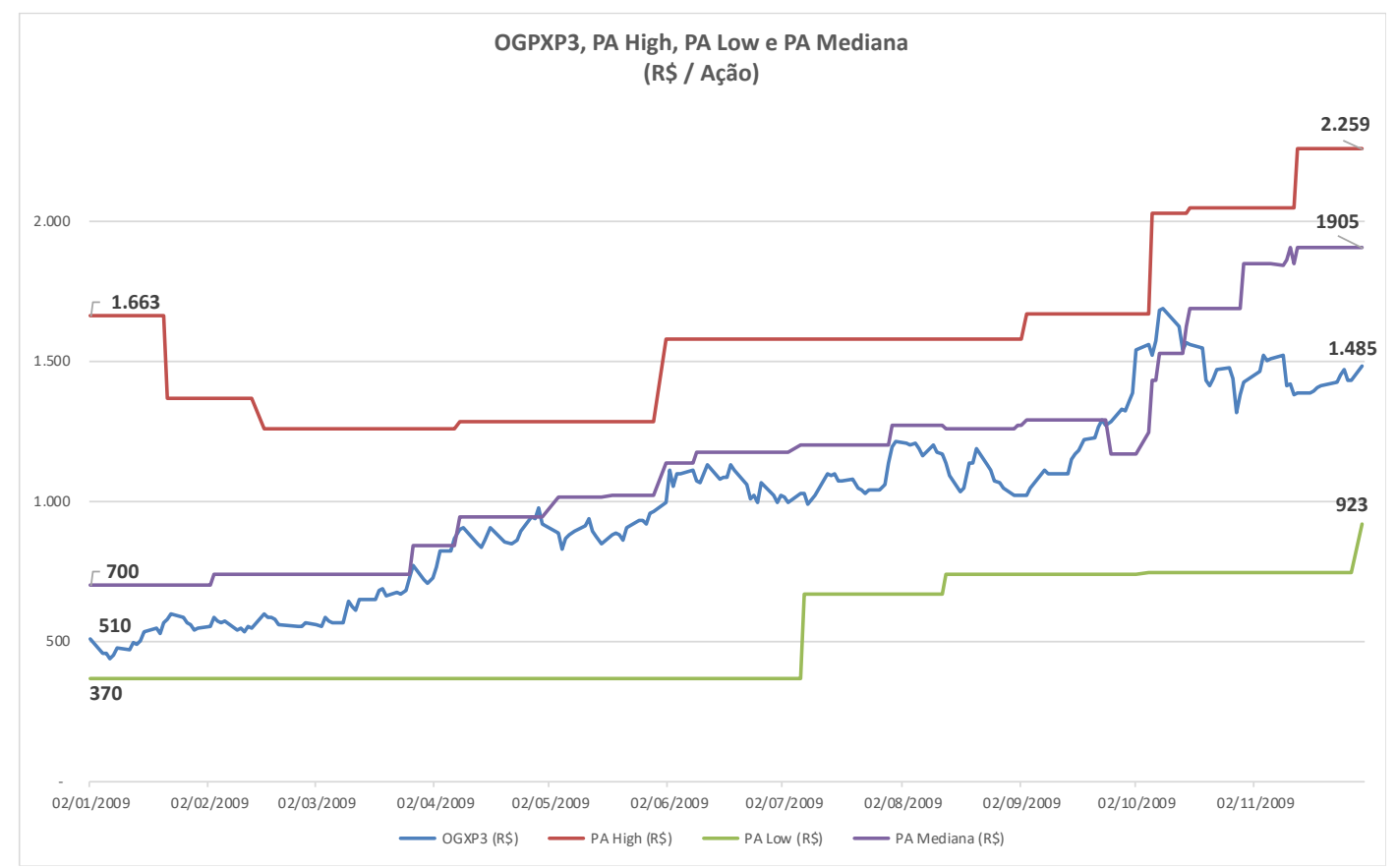

Esse entusiasmado apoio da mediana dos Analistas pode ter contribuído para a mudança da composição societária do floating. Tomando como base a presença nas AGEs de junho de 2008 e do ano de 2009, a composição dos acionistas minoritários também parece ter se modificado com a presença de fundos de pensão e fundos soberanos internacionais. 
Participação nas AGEs de 2008 e 2009

\begin{tabular}{|c|c|c|c|c|c|c|c|c|}
\hline \multirow{2}{*}{$\begin{array}{ll} & \mathbf{1 1 / 0 6 / 2 0 0 8} \\
\text { OTPP } & \\
\end{array}$} & \multicolumn{4}{|c|}{ 23/09/2009 } & \multicolumn{4}{|c|}{$18 / 12 / 2009$} \\
\hline & 1 & Abu Dahbi Pension Fund & 46 & OTPP & 1 & Abu Dahbi Pension Fund & 46 & ING Funds \\
\hline ZAM & 2 & Active Emerg. Mkts & 47 & Prudential & 2 & Active Emerg. Mkts & 47 & Ishares MSCl \\
\hline UBS Prestige & 3 & American Funds & 48 & Railway Pension & 3 & AGF & 48 & Jennison Natural Resources \\
\hline GIF Saturn & 4 & Artisan Em. Mkt Fund & 49 & Renaissance Devel. & 4 & American Funds & 49 & John Hancock Funds \\
\hline Tyticus Master & 5 & Barclays Global & 50 & Riversource & 5 & Artisan Emerging Mkt Fund & 50 & JPM Funds \\
\hline Gavião-P & 6 & Bell Atlantic & 51 & Rohm \& Haas & 6 & Ashmore Funds & 51 & Kansas Public Employee Ret. \\
\hline Gavião-M & 7 & Blackrock Funds & 52 & San Diego County & 7 & Asset Holder & 52 & Legg Mason Global Funds \\
\hline Opportunity Energia & 8 & Brazil MSCl & 53 & Scotia LA Growth & 8 & Barclays Global & 53 & Linconl Variable \\
\hline MS Uruguay & 9 & British Airways & 54 & Selected American & 9 & Barring Fund & 54 & Manulife Funds \\
\hline Jennison Natural Resources & 10 & Caisse Depot Quebec & 55 & Southern California & 10 & Batterymarch & 55 & Marsico Funds \\
\hline Natural Resources & 11 & California Endowment & 56 & State Street & 11 & Bell Atlantic & 56 & Marvin \& Palmer Funds \\
\hline Prudential Series & 12 & California State Teachers & 57 & Sumitomo & 12 & BGI Em. Mkts Insights & 57 & Mass Mutual \\
\hline Passaport Global & 13 & College Retirement & 58 & Teledyne Technol. & 13 & Blackrock Funds & 58 & Merril Lynch LA Inv. Trust \\
\hline IGXG Mgmt & 14 & Columbia Marsico Funds & 59 & Texas Education Agency & 14 & Brazil MSCl & 59 & MGI \\
\hline Perella Weinberg Xerion & 15 & Cook County Employee & 60 & Texas State Teachers & 15 & British Airways & 60 & Monks Inv. Trust \\
\hline \multirow[t]{7}{*}{ Libra Offshore } & 16 & Davis Funds & 61 & The Bar & 16 & CAAM Funds & 61 & New Jersey State \\
\hline & 17 & Discovery Fund & 62 & Thradneedle & 17 & Caisse Depot Quebec & 62 & North Carolina Retirement \\
\hline & 18 & Driehaus & 63 & Univ. Pittisburg Medical Center & 18 & California Endowment & 63 & Nothern Trust \\
\hline & 19 & Em. Mkts Funds & 64 & Vanguard Funds & 19 & California State Teachers & 64 & Ohio State Teacher Ret. \\
\hline & 20 & Europacific Fund & 65 & Wellington Trust & 20 & Canada Pension Board & 65 & Ontario Public Employee Ret. \\
\hline & 21 & Evangelical Lutheran Church & 66 & Wells Fargo & 21 & Canada Pension Plan Inv. Board & 66 & OTPP \\
\hline & 22 & Fidelity & & & 22 & Chinatrust Comm. Bank & 67 & Pennsylvania Public School \\
\hline
\end{tabular}




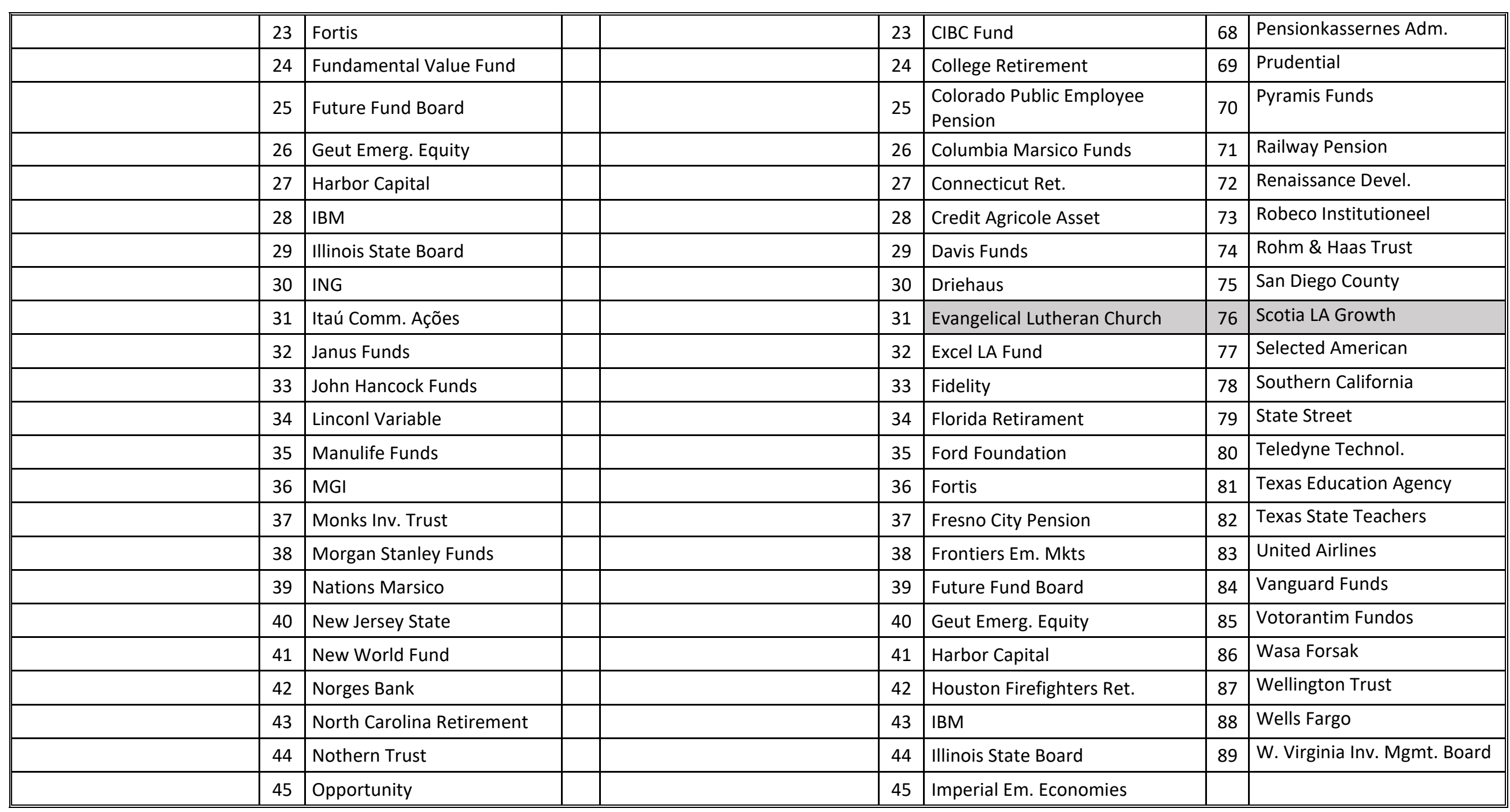


Conforme descrito em 3.3, em 2010, na mediana, os Analistas da Amostra TR endossaram o guidance otimista mantendo seus PAs acima do valor da OGXP3 ao longo do ano todo. Os Analistas mais otimistas se tornaram ainda mais otimistas aumentando seus PAs de $\mathrm{R} \$ 22,59$ no início do ano para $\mathrm{R} \$ 37,40$ no fim do ano. Até os Analistas mais pessimistas resistiram em rever seu PA por boa parte do ano, em dezembro ajustou de $\mathrm{R} \$ 9,23$ para $\mathrm{R} \$ 15,00$.

Gráfico 68 - Evolução da OGXP3, do PA Máximo, Mínimo e Mediano da Amostra TR em 2010 (em R\$̣/ação, pré split)

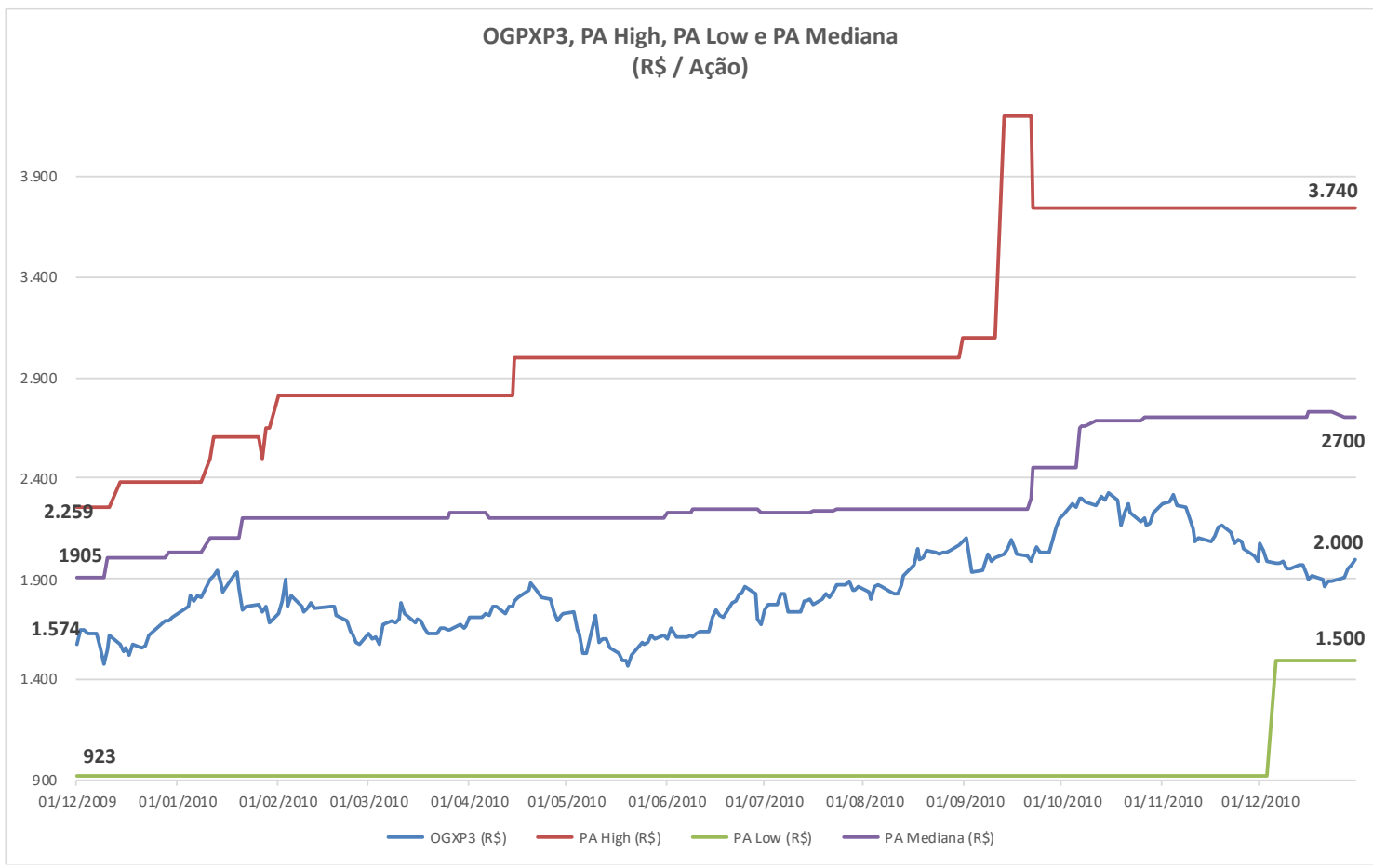

Ao longo de 2010, a quantidade e diversidade da presença de fundos de pensão internacionais nas AGEs da OGX aumentou. Alguns destes mantiveram suas presenças desde 2009, como o California Endownment Fund, Evangelical Lutheran Church e o Abu Dahbi Pension Fund, por exemplo. O endosso dos Analistas pode ter contribuído com esse aumento na quantidade e diversidade dos fundos de pensão internacionais com interesse na Empresa. 


\section{Fundos que Participaram das AGEs em 2010 e a Última AGE de 2008/09}

\begin{tabular}{|c|c|c|c|c|c|c|c|c|c|}
\hline \multicolumn{4}{|c|}{$18 / 12 / 2009$} & \multicolumn{3}{|c|}{$30 / 04 / 2010$} & \multicolumn{3}{|c|}{$28 / 09 / 2010$} \\
\hline 1 & $\begin{array}{l}\text { Abu Dahbi Pension } \\
\text { Fund }\end{array}$ & 66 & OTPP & $\begin{array}{l}\text { Abu Dahbi Pension } \\
\text { Fund }\end{array}$ & 66 & $\begin{array}{l}\text { Philadelphia City Public } \\
\text { Empl. Ret. }\end{array}$ & $\begin{array}{l}\text { Abu Dahbi Pension } \\
\text { Fund }\end{array}$ & 66 & $\begin{array}{l}\text { Minnesota Minning } \\
\text { Employee Ret. Fund }\end{array}$ \\
\hline 2 & Active Emerg. Mkts & 67 & $\begin{array}{l}\text { Pennsylvania Public } \\
\text { School }\end{array}$ & $\begin{array}{l}\text { Alberta Teachers Ret. } \\
\text { Fund }\end{array}$ & 67 & Prudential & Advanced Series Trust & 67 & $\begin{array}{l}\text { Molson Coors (UK) Pension } \\
\text { Plan }\end{array}$ \\
\hline 3 & AGF & 68 & $\begin{array}{l}\text { Pensionkassernes } \\
\text { Adm. }\end{array}$ & Anthem Insurance Co. & 68 & Pyramis Funds & Aegon Funds & 68 & $\begin{array}{l}\text { Monetary Authority of } \\
\text { Singapore }\end{array}$ \\
\hline 4 & American Funds & 69 & Prudential & AT\&T Trust & 69 & Railway Pension & AGF & 69 & Monks Inv. Trust \\
\hline 5 & Artisan Em. Mkt Fund & 70 & Pyramis Funds & $\begin{array}{l}\text { Australian Reward Inv. } \\
\text { Alliance }\end{array}$ & 70 & Raytheon Co. & Alaska Permanent Fund & 70 & Morgan Stanley Funds \\
\hline 6 & Ashmore Funds & 71 & Railway Pension & Baillie Gifford Funds & 71 & $\begin{array}{l}\text { Régime Rentes } \\
\text { Mouvement Caisse } \\
\text { Populaires } \\
\end{array}$ & $\begin{array}{l}\text { Alberta Teachers Ret. } \\
\text { Fund }\end{array}$ & 71 & $\begin{array}{l}\text { Municipal Employees Fund } \\
\text { Chicago }\end{array}$ \\
\hline 7 & Asset Holder & 72 & Renaissance Devel. & $\begin{array}{l}\text { Bank of Japan Funds \& } \\
\text { Trusts }\end{array}$ & 72 & Rockefeller Foundation & $\begin{array}{l}\text { American Legacy } \\
\text { Foundation }\end{array}$ & 72 & $\begin{array}{l}\text { National Council Social } \\
\text { Secutirity Council }\end{array}$ \\
\hline 8 & Barclays Global & 73 & $\begin{array}{l}\text { Robeco } \\
\text { Institutioneel } \\
\end{array}$ & Barring Fund & 73 & $\begin{array}{l}\text { Royal Bank of Scotland } \\
\text { Funds }\end{array}$ & Amundi Funds & 73 & National Pension Service \\
\hline 9 & Barring Fund & 74 & Rohm \& Haas Trust & Barthe Holdings & 74 & Russel Funds & Anthem Insurance Co. & 74 & Natixis Int'I Funds \\
\hline 10 & Batterymarch & 75 & San Diego County & BGI Em. Mkt. & 75 & San Diego County & $\begin{array}{l}\text { ARMY \& AIR FORCE RET } \\
\text { TR }\end{array}$ & 75 & $\begin{array}{l}\text { New Mexico Public Employee } \\
\text { Ret. }\end{array}$ \\
\hline 11 & Bell Atlantic & 76 & Scotia LA Growth & Blackrock Funds & 76 & Schwab Funds & Artha Master Fund & 76 & Norges Bank \\
\hline 12 & BGI Em. Mkts Insights & 77 & Selected American & British Airways & 77 & Scotia LA Growth & Ballie Gifford Funds & 77 & $\begin{array}{l}\text { North Dakota State Inv. } \\
\text { Board }\end{array}$ \\
\hline 13 & Blackrock Funds & 78 & Southern California & Caisse Depot Quebec & 78 & SCRI Robeco Institutioneel & $\begin{array}{l}\text { Bank of Japan Funds \& } \\
\text { Trusts }\end{array}$ & 78 & $\begin{array}{l}\text { Nothern Telecom Pension } \\
\text { Trust }\end{array}$ \\
\hline 14 & Brazil MSCl & 79 & State Street & $\begin{array}{l}\text { California State Public } \\
\text { Employee }\end{array}$ & 79 & State Farm Funds & $\begin{array}{l}\text { Brooklyn Union Gas } \\
\text { Employee Ret. }\end{array}$ & 79 & Nothern Trust \\
\hline 15 & British Airways & 80 & Teledyne Technol. & $\begin{array}{l}\text { California State } \\
\text { Teachers }\end{array}$ & 80 & Strathclyde Pension & Caisse Depot Quebec & 80 & Ohio State Teacher Ret. \\
\hline
\end{tabular}




\begin{tabular}{|c|c|c|c|c|c|c|c|c|c|}
\hline 16 & CAAM Funds & 81 & $\begin{array}{l}\text { Texas Education } \\
\text { Agency }\end{array}$ & $\begin{array}{l}\text { Canada Pension Plan } \\
\text { Inv. Board }\end{array}$ & 81 & Syracuse Univercity & California Endowment & 81 & Ontario Public Employee Ret. \\
\hline 17 & Caisse Depot Quebec & 82 & Texas State Teachers & $\begin{array}{l}\text { Catholic Helath } \\
\text { Initiatives } \\
\end{array}$ & 82 & Telecordia Technologies & $\begin{array}{l}\text { California State } \\
\text { Teachers }\end{array}$ & 82 & OTPP \\
\hline 18 & $\begin{array}{l}\text { California } \\
\text { Endowment } \\
\end{array}$ & 83 & United Airlines & $\begin{array}{l}\text { Colorado Public } \\
\text { Employee Pension }\end{array}$ & 83 & Texas State Employees & $\begin{array}{l}\text { California Wellness } \\
\text { Foundation }\end{array}$ & 83 & Panagora Group Trust \\
\hline 19 & $\begin{array}{l}\text { California State } \\
\text { Teachers } \\
\end{array}$ & 84 & Vanguard Funds & Constellation Fundos & 84 & Texas State Teachers & $\begin{array}{l}\text { Canada Pension Plan } \\
\text { Inv. Board }\end{array}$ & 84 & Pennsylvania Public School \\
\hline 20 & $\begin{array}{l}\text { Canada Pension } \\
\text { Board }\end{array}$ & 85 & Votorantim Fundos & Cox Entreprises & 85 & Texas State University & Cathay United Bank & 85 & $\begin{array}{l}\text { Philadelphia City Public Empl. } \\
\text { Ret. }\end{array}$ \\
\hline 21 & $\begin{array}{l}\text { Canada Pension Plan } \\
\text { Inv. Board }\end{array}$ & 86 & Wasa Forsak & Davis Funds & 86 & TRW Automotive Trust & $\begin{array}{l}\text { Catholic Helath } \\
\text { Initiatives }\end{array}$ & 86 & Prudential \\
\hline 22 & $\begin{array}{l}\text { Chinatrust Comm. } \\
\text { Bank }\end{array}$ & 87 & Wellington Trust & DGAN Em. Mkt Fund & 87 & United Airlines & $\begin{array}{l}\text { CEDARS-SINAI MEDICAL } \\
\text { CENTER }\end{array}$ & 87 & Railway Pension \\
\hline 23 & CIBC Fund & 88 & Wells Fargo & Driehaus Fund & 88 & Van Kampen Funds & CIBC Fund & 88 & Raytheon Co. \\
\hline 24 & College Retirement & 89 & $\begin{array}{l}\text { West Virginia Inv. } \\
\text { Mgmt. Board }\end{array}$ & Eaton Vance Fund & 89 & Vanguard Funds & Clough Global Funds & 89 & $\begin{array}{l}\text { Régime Rentes Mouvement } \\
\text { Caisse Populaires }\end{array}$ \\
\hline 25 & $\begin{array}{l}\text { Colorado Public } \\
\text { Employee Pension }\end{array}$ & 66 & OTPP & $\begin{array}{l}\text { Electricity Supply } \\
\text { Pension Fund }\end{array}$ & 90 & Votorantim Fundos & $\begin{array}{l}\text { Columbia Marsico } \\
\text { Funds }\end{array}$ & 90 & Rockefeller Foundation \\
\hline 26 & $\begin{array}{l}\text { Columbia Marsico } \\
\text { Funds }\end{array}$ & 67 & $\begin{array}{l}\text { Pennsylvania Public } \\
\text { School }\end{array}$ & Fidelity Funds & 91 & Wellington Trust & Cook County Employee & 91 & Rohm \& Haas Trust \\
\hline 27 & Connecticut Ret. & 68 & $\begin{array}{l}\text { Pensionkassernes } \\
\text { Adm. }\end{array}$ & Ford Foundation & 92 & $\begin{array}{l}\text { West Virginia Inv. Mgmt. } \\
\text { Board }\end{array}$ & Cox Entreprises & 92 & Royal Bank of Scotland Funds \\
\hline 28 & Credit Agricole Asset & 69 & Prudential & Fortis Funds & 93 & $\begin{array}{l}\text { William Blair Trusts \& } \\
\text { Funds }\end{array}$ & Credit Agricole Asset & 93 & Russel Funds \\
\hline 29 & Davis Funds & 70 & Pyramis Funds & Fresno City Pension & 94 & Winnipeg Foundation & Davis Funds & 94 & S\&P LA ETF \\
\hline 30 & Driehaus & 71 & Railway Pension & $\begin{array}{l}\text { General Conf. } \\
\text { Seventh-Day Adv. }\end{array}$ & 95 & $\begin{array}{l}\text { Xerox Canada Employee } \\
\text { Trust }\end{array}$ & DGAN Em. Mkt Fund & 95 & San Diego County \\
\hline 31 & $\begin{array}{l}\text { Evangelical Lutheran } \\
\text { Church }\end{array}$ & 72 & Renaissance Devel. & $\begin{array}{l}\text { Genesis Em. Mkt. For } \\
\text { Canada }\end{array}$ & 66 & $\begin{array}{l}\text { Philadelphia City Public } \\
\text { Empl. Ret. }\end{array}$ & Driehaus Fund & 96 & Schwab Funds \\
\hline 32 & Excel LA Fund & 73 & $\begin{array}{l}\text { Robeco } \\
\text { Institutioneel }\end{array}$ & Harbor Capital & 67 & Prudential & EDINBURGH COUNCIL & 97 & Shell Pension Trust \\
\hline
\end{tabular}




\begin{tabular}{|c|c|c|c|c|c|c|c|c|c|}
\hline 33 & Fidelity & 74 & Rohm \& Haas Trust & IBM & 68 & Pyramis Funds & $\begin{array}{l}\text { Evangelical Lutheran } \\
\text { Church }\end{array}$ & 98 & Southern CA Edison Nuclear \\
\hline 34 & Florida Retirament & 75 & San Diego County & $\begin{array}{l}\text { Idaho Public Employee } \\
\text { Ret. }\end{array}$ & 69 & Railway Pension & Fidelity Funds & 99 & Spectrum Trust \\
\hline 35 & Ford Foundation & 76 & Scotia LA Growth & $\begin{array}{l}\text { Illinois Municipal } \\
\text { Employees }\end{array}$ & 70 & Raytheon Co. & Frank Russell & 100 & Squadra Funds \\
\hline 36 & Fortis & 77 & Selected American & Illinois State Board & 71 & $\begin{array}{l}\text { Régime Rentes } \\
\text { Mouvement Caisse } \\
\text { Populaires }\end{array}$ & $\begin{array}{l}\text { Franklin Templeton Inv. } \\
\text { Funds }\end{array}$ & 101 & SSGA Funds \\
\hline 37 & Fresno City Pension & 78 & Southern California & ING Funds & 72 & Rockefeller Foundation & Fundação Eletrobrás & 102 & State Farm Funds \\
\hline 38 & Frontiers Em. Mkts & 79 & State Street & Ishares $\mathrm{MSCl}$ & 73 & $\begin{array}{l}\text { Royal Bank of Scotland } \\
\text { Funds }\end{array}$ & $\begin{array}{l}\text { Fundamental Value } \\
\text { Fund }\end{array}$ & 103 & State Street \\
\hline 39 & Future Fund Board & 80 & Teledyne Technol. & $\begin{array}{l}\text { Jennison Natural } \\
\text { Resources }\end{array}$ & 74 & Russel Funds & $\begin{array}{l}\text { General Motors of } \\
\text { Canada trust }\end{array}$ & 104 & Strathclyde Pension \\
\hline 40 & Geut Emerg. Equity & 81 & $\begin{array}{l}\text { Texas Education } \\
\text { Agency }\end{array}$ & $\begin{array}{l}\text { Jersey State Teachers } \\
\text { Fund }\end{array}$ & 75 & San Diego County & $\begin{array}{l}\text { Genesis Em. Mkt. For } \\
\text { Canada }\end{array}$ & 105 & Sumitomo \\
\hline 41 & Harbor Capital & 82 & Texas State Teachers & John Hancock Funds & 76 & Schwab Funds & Guidestone Funds & 106 & Syracuse Univercity \\
\hline 42 & \begin{tabular}{|l} 
Houston Firefighters \\
Ret. \\
\end{tabular} & 83 & United Airlines & JPM Funds & 77 & Scotia LA Growth & Harbor Capital & 107 & Taiwan Business Bank \\
\hline 43 & IBM & 84 & Vanguard Funds & $\begin{array}{l}\text { Kansas Public } \\
\text { Employee Ret. }\end{array}$ & 78 & SCRI Robeco Institutioneel & $\begin{array}{l}\text { Hewlett-Packard Co. } \\
\text { Trust }\end{array}$ & 108 & Telecordia Technologies \\
\hline 44 & Illinois State Board & 85 & Votorantim Fundos & Laudus Funds & 79 & State Farm Funds & $\begin{array}{l}\text { Houston Firefighters } \\
\text { Ret. }\end{array}$ & 109 & Tenaska Investment Fund \\
\hline 45 & $\begin{array}{l}\text { Imperial Em. } \\
\text { Economies } \\
\end{array}$ & 86 & Wasa Forsak & Loomy Sayles Fund & 80 & Strathclyde Pension & IBM & 110 & Texas Education Agency \\
\hline 46 & ING Funds & 87 & Wellington Trust & Manulife Funds & 81 & Syracuse Univercity & $\begin{array}{l}\text { Idaho Public Employee } \\
\text { Ret. }\end{array}$ & 111 & Texas State Employees \\
\hline 47 & Ishares $\mathrm{MSCl}$ & 88 & Wells Fargo & Marsico Funds & 82 & Telecordia Technologies & Illinois State Board & 112 & Texas State Teachers \\
\hline 48 & $\begin{array}{l}\text { Jennison Natural } \\
\text { Resources } \\
\end{array}$ & 89 & $\begin{array}{l}\text { West Virginia Inv. } \\
\text { Mgmt. Board }\end{array}$ & $\begin{array}{l}\text { Marvin \& Palmer } \\
\text { Funds }\end{array}$ & 83 & Texas State Employees & Illinois State Teachers & 113 & Texas State University \\
\hline 49 & John Hancock Funds & & & Mass Mutual & 84 & Texas State Teachers & Imperial Em. Economies & 114 & Threadneedle Funds \\
\hline
\end{tabular}




\begin{tabular}{|c|c|c|c|c|c|c|c|}
\hline 50 & JPM Funds & Mauá Fundos & 85 & Texas State University & ING Funds & 115 & TRW Automotive Trust \\
\hline 51 & $\begin{array}{l}\text { Kansas Public } \\
\text { Employee Ret. }\end{array}$ & $\begin{array}{l}\text { Microsoft Global } \\
\text { Finance }\end{array}$ & 86 & TRW Automotive Trust & Iowa Public Empl. Ret. & 116 & UBS Funds \\
\hline 52 & $\begin{array}{l}\text { Legg Mason Global } \\
\text { Funds }\end{array}$ & $\begin{array}{l}\text { Minnesota Employee } \\
\text { Ret. Fund }\end{array}$ & 87 & United Airlines & Ishares $\mathrm{MSCl}$ & 117 & United Airlines \\
\hline 53 & Linconl Variable & $\begin{array}{l}\text { Monetary Authority of } \\
\text { Singapore }\end{array}$ & 88 & Van Kampen Funds & John Hancock Funds & 118 & Van Kampen Funds \\
\hline 54 & Manulife Funds & Monks Inv. Trust & 89 & Vanguard Funds & JPM Funds & 119 & Vanguard Funds \\
\hline 55 & Marsico Funds & Morgan Stanley Funds & 90 & Votorantim Fundos & $\begin{array}{l}\text { Kansas Public Employee } \\
\text { Ret. }\end{array}$ & 120 & Washington State Inv. Board \\
\hline 56 & $\begin{array}{l}\text { Marvin \& Palmer } \\
\text { Funds }\end{array}$ & $\begin{array}{l}\text { Municipal Employees } \\
\text { Fund Chicago }\end{array}$ & 91 & Wellington Trust & Laudus Funds & 121 & Wellington Trust \\
\hline 57 & Mass Mutual & $\begin{array}{l}\text { National Railroad Ret. } \\
\text { Trust }\end{array}$ & 92 & $\begin{array}{l}\text { West Virginia Inv. Mgmt. } \\
\text { Board }\end{array}$ & Lifespan Corporation & 122 & $\begin{array}{l}\text { West Virginia Inv. Mgmt. } \\
\text { Board }\end{array}$ \\
\hline 58 & $\begin{array}{l}\text { Merril Lynch LA Inv. } \\
\text { Trust }\end{array}$ & New Jersey State & 93 & $\begin{array}{l}\text { William Blair Trusts \& } \\
\text { Funds }\end{array}$ & Loomy Sayles Fund & 123 & $\begin{array}{l}\text { Western Pennsylvania } \\
\text { Pension Fund }\end{array}$ \\
\hline 59 & MGI & $\begin{array}{l}\text { New Mexico } \\
\text { Educational Ret. }\end{array}$ & 94 & Winnipeg Foundation & $\begin{array}{l}\text { Los Angeles Fire \& } \\
\text { Police Pension }\end{array}$ & 124 & William Blair Funds \\
\hline 60 & Monks Inv. Trust & Norges Bank & 95 & $\begin{array}{l}\text { Xerox Canada Employee } \\
\text { Trust }\end{array}$ & $\begin{array}{l}\text { Louisiana State } \\
\text { Teachers }\end{array}$ & 125 & Wilmington International \\
\hline 61 & New Jersey State & $\begin{array}{l}\text { Nothern Telecom } \\
\text { Pension Trust }\end{array}$ & & & Manulife Funds & 126 & Winnipeg Foundation \\
\hline 62 & $\begin{array}{l}\text { North Carolina } \\
\text { Retirement }\end{array}$ & Nothern Trust & & & Marsico Funds & 127 & $\begin{array}{l}\text { Xerox Canada Employee } \\
\text { Trust }\end{array}$ \\
\hline 63 & Nothern Trust & $\begin{array}{l}\text { Pennsylvania Public } \\
\text { School }\end{array}$ & & & Marvin \& Palmer Funds & 128 & $\begin{array}{l}\text { UAW Retiree Medical } \\
\text { Benefits Trust }\end{array}$ \\
\hline 64 & $\begin{array}{l}\text { Ohio State Teacher } \\
\text { Ret. }\end{array}$ & $\begin{array}{l}\text { Pensionkassernes } \\
\text { Adm. }\end{array}$ & & & $\begin{array}{l}\text { Memorial Sloan } \\
\text { Kettering Cancer Center }\end{array}$ & & \\
\hline 65 & $\begin{array}{l}\text { Ontario Public } \\
\text { Employee Ret. }\end{array}$ & $\begin{array}{l}\text { PG\&E Coporation } \\
\text { Trusts }\end{array}$ & & & $\begin{array}{l}\text { Microsoft Global } \\
\text { Finance }\end{array}$ & & \\
\hline
\end{tabular}


Conforme descrito em 3.4, na Amostra da TR, ao longo de todo o ano de 2011, o mercado se tornou mais pessimista do que a mediana dos Analistas. A partir de 5/5, 0 mercado precificou a OGX abaixo do PA dos Analistas mais pessimistas. Os Analistas otimistas parecem ter ficado alienados do mercado e até mesmo da mediana de seus colegas. O que os Analistas estavam considerando que mercado parece ter questionado? Talvez a resposta esteja na credibilidade do guidance. De fato, alguns Analistas explicitamente relataram que "nos últimos meses, com a desvalorização das ações da OGX, a credibilidade do grupo [EBX] estava sendo cada vez mais questionada $(\ldots)^{\prime \prime 492}$.

\section{Gráfico 69 - Amostra da TR: Evolução da Mediana, Máximo e Mínimo do PA em 2011 (em R\$/ação, pré split)}

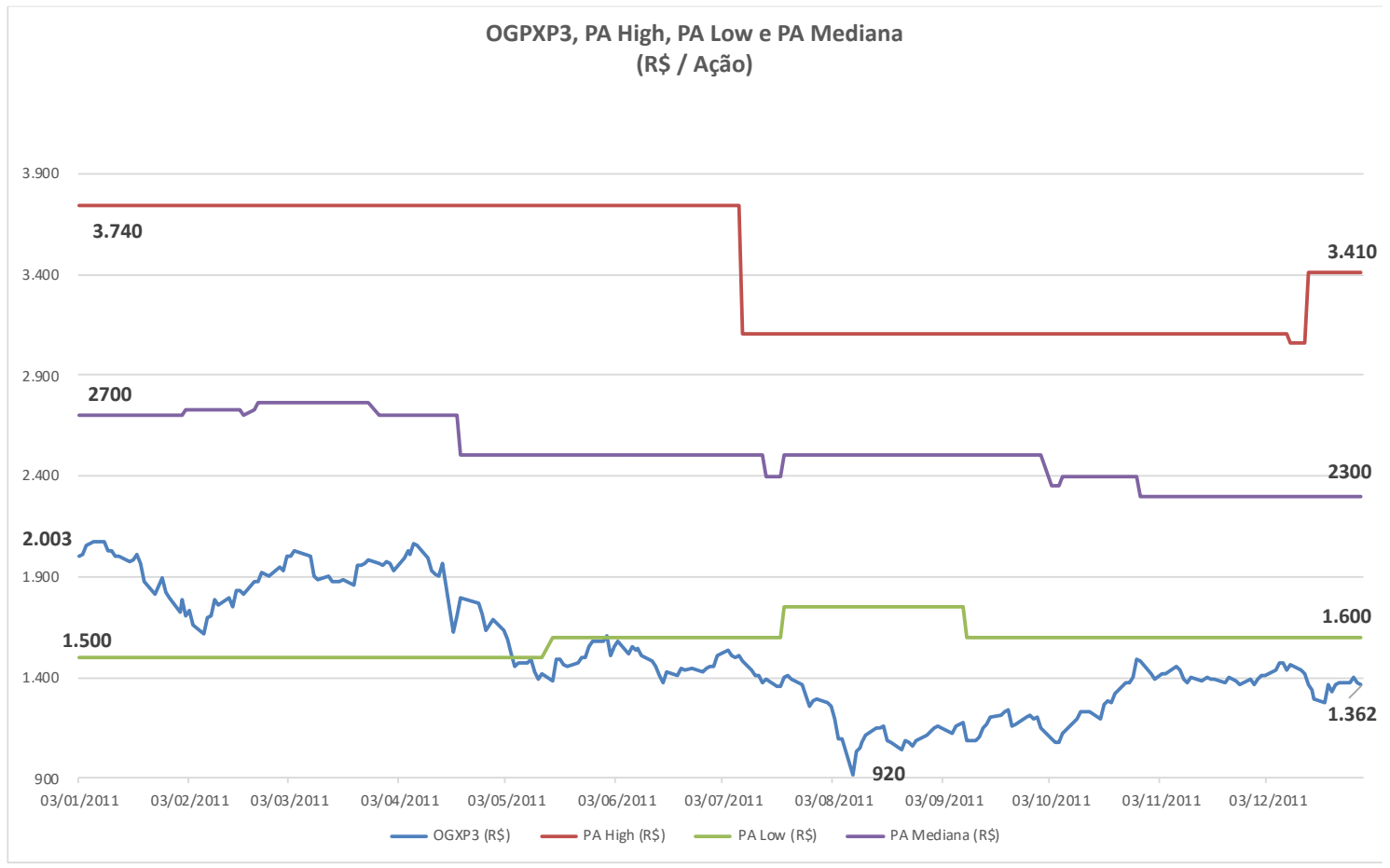

Apesar da reação do mercado ao 3 D\&M, a presença na AGE de fundos de pensão e soberanos aumentou em 2011 em relação a 2010. Aparentemente, investidores com horizonte de retorno de longo prazo, tanto em ações como nos Notes, divergiam das expectativas de mais curto prazo de outros investidores em ações que pressionavam o valor da OGXP3 ao longo de 2011.

492 AUDI \& FALANGA NETO, 2011a, p. 1. 


\section{Fundos que Participaram das AGEs em 2010 e a Última AGE de 2010}

\begin{tabular}{|c|c|c|c|c|c|c|c|}
\hline \multicolumn{4}{|c|}{$28 / 09 / 2010$} & \multicolumn{4}{|c|}{$01 / 12 / 2011$} \\
\hline 1 & Abu Dahbi Pension Fund & 70 & Morgan Stanley Funds & 1 & Abu Dahbi Pension Fund & 70 & Lifespan Corporation \\
\hline 2 & Advanced Series Trust & 71 & Municipal Employees Fund Chicago & 2 & Aegon Funds & 71 & Lockheed Martin Co Ret Trust \\
\hline 3 & Aegon Funds & 72 & $\begin{array}{l}\text { National Council Social Secutirity } \\
\text { Council }\end{array}$ & 3 & AGF & 72 & Louisiana State Teachers \\
\hline 4 & AGF & 73 & National Pension Service & 4 & Allianz & 73 & Lucent Technologies \\
\hline 5 & Alaska Permanent Fund & 74 & Natixis Int'I Funds & 5 & American Legacy Foundation & 74 & Manulife Funds \\
\hline 6 & Alberta Teachers Ret. Fund & 75 & New Mexico Public Employee Ret. & 6 & Amundi Funds & 75 & Marsico Funds \\
\hline 7 & $\begin{array}{l}\text { American Legacy } \\
\text { Foundation }\end{array}$ & 76 & Norges Bank & 7 & Anthem Insurance Co. & 76 & MELLON BANK Funds \\
\hline 8 & Amundi Funds & 77 & North Dakota State Inv. Board & 8 & ARMY \& AIR FORCE RET TR & 77 & $\begin{array}{l}\text { Memorial Sloan Kettering Cancer } \\
\text { Center }\end{array}$ \\
\hline 9 & Anthem Insurance Co. & 78 & Nothern Telecom Pension Trust & 9 & Ascetion Health & 78 & $\begin{array}{l}\text { Michigan State Municipal Emp } \\
\text { Ret Sys }\end{array}$ \\
\hline 10 & ARMY \& AIR FORCE RET TR & 79 & Nothern Trust & 10 & AT\&T Trust & 79 & Microsoft Global Finance \\
\hline 11 & Artha Master Fund & 80 & Ohio State Teacher Ret. & 11 & ATWILL & 80 & MISSOURI STATE EMP RET SYS \\
\hline 12 & Ballie Gifford Funds & 81 & Ontario Public Employee Ret. & 12 & AXA & 81 & Monetary Authority of Singapore \\
\hline 13 & $\begin{array}{l}\text { Bank of Japan Funds \& } \\
\text { Trusts }\end{array}$ & 82 & OTPP & 13 & Baillie Gifford Funds & 82 & Monks Inv. Trust \\
\hline 14 & $\begin{array}{l}\text { Brooklyn Union Gas } \\
\text { Employee Ret. }\end{array}$ & 83 & Panagora Group Trust & 14 & Baker Hughes Inc. Trust & 83 & Morgan Stanley Funds \\
\hline 15 & Caisse Depot Quebec & 84 & Pennsylvania Public School & 15 & $\begin{array}{l}\text { Baltimore Fire \& Police Empl } \\
\text { Ret Sys }\end{array}$ & 84 & $\begin{array}{l}\text { National Elevator Ind Pension } \\
\text { Plan }\end{array}$ \\
\hline 16 & California Endowment & 85 & Philadelphia City Public Empl. Ret. & 16 & Bank Of Korea & 85 & National Pension Service \\
\hline 17 & California State Teachers & 86 & Prudential & 17 & $\begin{array}{l}\text { Bank Of Ny Mellon Co Ret } \\
\text { Plans }\end{array}$ & 86 & National Social Secutirity Council \\
\hline
\end{tabular}




\begin{tabular}{|c|c|c|c|c|c|c|c|}
\hline 18 & $\begin{array}{l}\text { California Wellness } \\
\text { Foundation }\end{array}$ & 87 & Railway Pension & 18 & Baron Funds & 87 & $\begin{array}{l}\text { New Zealand Superannuation } \\
\text { Fund }\end{array}$ \\
\hline 19 & $\begin{array}{l}\text { Canada Pension Plan Inv. } \\
\text { Board }\end{array}$ & 88 & Raytheon Co. & 19 & Bayer Co. Trust & 88 & Norges Bank \\
\hline 20 & Cathay United Bank & 89 & $\begin{array}{l}\text { Régime Rentes Mouvement Caisse } \\
\text { Populaires }\end{array}$ & 20 & Bell Atlantic Trust & 89 & Nothern Trust \\
\hline 21 & Catholic Helath Initiatives & 90 & Rockefeller Foundation & 21 & Bellsouth Co. Trust & 90 & NY CITY DEF. COMP. PLAN \\
\hline 22 & $\begin{array}{l}\text { CEDARS-SINAI MEDICAL } \\
\text { CENTER }\end{array}$ & 91 & Rohm \& Haas Trust & 22 & Blackrock Funds & 91 & NY STATE TEACHER RET SYS \\
\hline 23 & CIBC Fund & 92 & Royal Bank of Scotland Funds & 23 & BOEING CO EMPLOYEE & 92 & OHIO PUBLIC EMP RET SYS \\
\hline 24 & Clough Global Funds & 93 & Russel Funds & 24 & British Airways & 93 & OHIO SCHOOL EMP RET SYS \\
\hline 25 & Columbia Marsico Funds & 94 & S\&P LA ETF & 25 & $\begin{array}{l}\text { BRITISH COLUMBIA INV. MGT } \\
\text { CO }\end{array}$ & 94 & Ohio State Teacher Ret. \\
\hline 26 & Cook County Employee & 95 & San Diego County & 26 & BRUNEI INVESTMENT AGENCY & 95 & Oregon State \\
\hline 27 & Cox Entreprises & 96 & Schwab Funds & 27 & BT PENSION SCHEME & 96 & OTPP \\
\hline 28 & Credit Agricole Asset & 97 & SHELL PENSION TRUST & 28 & Caisse Depot Quebec & 97 & Panagora Group Trust \\
\hline 29 & Davis Funds & 98 & Southern CA Edison Nuclear & 29 & California Endowment & 98 & Pennsylvania Public School \\
\hline 30 & DGAN Em. Mkt Fund & 99 & Spectrum Trust & 30 & $\begin{array}{l}\text { California State Public } \\
\text { Employee }\end{array}$ & 99 & $\begin{array}{l}\text { PENNSYLVANIA STATE EMP. RET } \\
\text { SYS }\end{array}$ \\
\hline 31 & Driehaus Fund & 100 & Squadra Funds & 31 & California State Teachers & 100 & Pensionkassernes Adm. \\
\hline 32 & EDINBURGH COUNCIL & 101 & SSGA Funds & 32 & $\begin{array}{l}\text { Canada Pension Plan Inv. } \\
\text { Board }\end{array}$ & 101 & PG\&E Coporation Trusts \\
\hline 33 & Evangelical Lutheran Church & 102 & State Farm Funds & 33 & $\begin{array}{l}\text { CANADIAN MASTER TRUST } \\
\text { FUND }\end{array}$ & 102 & $\begin{array}{l}\text { PHILADELPHIA CITY PUB EMPL. } \\
\text { RET SYS. }\end{array}$ \\
\hline 34 & Fidelity Funds & 103 & State Street & 34 & CARGILL INC Funds & 103 & Prudential \\
\hline 35 & Frank Russell & 104 & Strathclyde Pension & 35 & Catholic Helath Initiatives & 104 & $\begin{array}{l}\text { PUBLIC SECTOR PENSION INV } \\
\text { BOARD }\end{array}$ \\
\hline
\end{tabular}




\begin{tabular}{|c|c|c|c|c|c|c|c|}
\hline 36 & $\begin{array}{l}\text { FRANKLIN TEMPLETON INV. } \\
\text { FUNDS }\end{array}$ & 105 & Sumitomo & 36 & CIBC Fund & 105 & Pyramis Funds \\
\hline 37 & Fundação Eletrobrás & 106 & Syracuse Univercity & 37 & COLLEGE RET. EQUITIES FUND & 106 & Railway Pension \\
\hline 38 & Fundamental Value Fund & 107 & TAIWAN BUSINESS BANK & 38 & Cook County Employee & 107 & $\begin{array}{l}\text { Régime Rentes Mouvement } \\
\text { Caisse Populaires }\end{array}$ \\
\hline 39 & $\begin{array}{l}\text { General Motors of Canada } \\
\text { trust }\end{array}$ & 108 & Telecordia Technologies & 39 & Cox Entreprises & 108 & Robeco Funds \& Trusts \\
\hline 40 & $\begin{array}{l}\text { Genesis Em. Mkt. For } \\
\text { Canada }\end{array}$ & 109 & TENASKA INVESTMENT FUND & 40 & Davis Funds & 109 & ROTHSCHILD BANQUE \\
\hline 41 & Guidestone Funds & 110 & Texas Education Agency & 41 & Driehaus Fund & 110 & Royal Bank of Scotland Funds \\
\hline 42 & Harbor Capital & 111 & Texas State Employees & 42 & DTE FUNDS \& TRUSTS & 111 & Russel Funds \\
\hline 43 & Hewlett-Packard Co. Trust & 112 & Texas State Teachers & 43 & $\begin{array}{l}\text { EATON VANCE RET FUNDS \& } \\
\text { TRUSTS }\end{array}$ & 112 & S\&P LA ETF \\
\hline 44 & Houston Firefighters Ret. & 113 & Texas State University & 44 & Em. Mkts Funds & 113 & SAN DIEGO GAS \& ELEC CO \\
\hline 45 & IBM & 114 & Threadneedle Funds & 45 & Evangelical Lutheran Church & 114 & Schwab Funds \\
\hline 46 & Idaho Public Employee Ret. & 115 & TRW Automotive Trust & 46 & $\begin{array}{l}\text { FAMANDSFORENINGEN } \\
\text { PENSAM INVEST }\end{array}$ & 115 & SHELL PENSION TRUST \\
\hline 47 & Illinois State Board & 116 & UBS Funds & 47 & Fidelity Funds & 116 & Southern CA Edison Nuclear \\
\hline 48 & Illinois State Teachers & 117 & United Airlines & 48 & $\begin{array}{l}\text { FIREFIGHTERS RETIREMENT } \\
\text { SYS }\end{array}$ & 117 & SSGA Funds \\
\hline 49 & Imperial Em. Economies & 118 & Van Kampen Funds & 49 & $\begin{array}{l}\text { FLORIDA RET. SYS TRUST } \\
\text { FUND }\end{array}$ & 118 & State Farm Funds \\
\hline 50 & ING Funds & 119 & Vanguard Funds & 50 & Ford Motors Trusts & 119 & State Street \\
\hline 51 & Iowa Public Empl. Ret. & 120 & Washington State Inv. Board & 51 & $\begin{array}{l}\text { FRANKLIN TEMPLETON INV. } \\
\text { FUNDS }\end{array}$ & 120 & Telecordia Technologies \\
\hline 52 & Ishares $\mathrm{MSCl}$ & 121 & Wellington Trust & 52 & $\begin{array}{l}\text { General Conf. Seventh-Day } \\
\text { Adv. }\end{array}$ & 121 & TENASKA INVESTMENT FUND \\
\hline 53 & John Hancock Funds & 122 & West Virginia Inv. Mgmt. Board & 53 & Genesis Em. Mkt. For Canada & 122 & TENNESSEE VALLEY AUT RET SYS \\
\hline
\end{tabular}




\begin{tabular}{|c|c|c|c|c|c|c|c|}
\hline 54 & JPM Funds & 123 & $\begin{array}{l}\text { WESTERN PENNSYLVANIA PENSION } \\
\text { FUND }\end{array}$ & 54 & GMO FUNDS & 123 & Texas Education Agency \\
\hline 55 & Kansas Public Employee Ret. & 124 & William Blair Funds & 55 & Goldman Sachs Trusts & 124 & Texas State Employees \\
\hline 56 & Laudus Funds & 125 & WILMINGTON INTERNATIONAL & 56 & Harbor Trusts \& Funds & 125 & Texas State Teachers \\
\hline 57 & Lifespan Corporation & 126 & Winnipeg Foundation & 57 & Hewlett-Packard Co. Trust & 126 & Texas State University \\
\hline 58 & Loomy Sayles Fund & 127 & Xerox Canada Employee Trust & 58 & HSBC Funds & 127 & TIAA-CREF FUNDS \\
\hline 59 & $\begin{array}{l}\text { Los Angeles Fire \& Police } \\
\text { Pension }\end{array}$ & 128 & UAW Retiree Medical Benefits Trust & 59 & IBM & 128 & Unibanco Fundos \\
\hline 60 & Louisiana State Teachers & & & 60 & Idaho Public Employee Ret. & 129 & Univ. of Notre Dame Du Lac \\
\hline 61 & Manulife Funds & & & 61 & Illinois State Board & 130 & UPS GROUP TRUST \\
\hline 62 & Marsico Funds & & & 62 & ING Funds & 131 & $\begin{array}{l}\text { UAW Retiree Medical Benefits } \\
\text { Trust }\end{array}$ \\
\hline 63 & Marvin \& Palmer Funds & & & 63 & Ishares $\mathrm{MSCl}$ & 132 & Vanguard Funds \\
\hline 64 & $\begin{array}{l}\text { MEMORIAL SLOAN } \\
\text { KETTERING CANCER CENTER }\end{array}$ & & & 64 & Janus Funds & 133 & Votorantim Fundos \\
\hline 65 & Microsoft Global Finance & & & 65 & John Hancock Funds & 134 & Wellington Trust \\
\hline 66 & $\begin{array}{l}\text { Minnesota Minning } \\
\text { Employee Ret. Fund }\end{array}$ & & & 66 & JPM Funds & 135 & West Virginia Inv. Mgmt. Board \\
\hline 67 & $\begin{array}{l}\text { MOLSON COORS (UK) } \\
\text { PENSION PLAN }\end{array}$ & & & 67 & Kansas Public Employee Ret. & 136 & William Blair Funds \\
\hline 68 & $\begin{array}{l}\text { Monetary Authority of } \\
\text { Singapore }\end{array}$ & & & 68 & Laudus Funds & 137 & Wilmington International \\
\hline 69 & Monks Inv. Trust & & & 69 & Legg Mason Global Funds & 138 & Wyoming State Treasurer \\
\hline
\end{tabular}


Os indicadores da Amostra TR indicam que os Analistas pessimistas mantiveram suas apostas no valor da OGXP3 até junho, enquanto a mediana e os otimistas ajustaram seus PAs em junho, mas ainda os mantiveram acima do valor de mercado da OGXP3. O otimismo da mediana dos PAs no 1 S2012 pode ter ajudado a viabilizar a emissão do segundo Note da OGX no fim de março.

O write-off de R\$ 196 milhões do 4T2011, divulgado em 2012, poderia ter sido um sinal negativo para os financiadores, pois indicava que o valor contábil dos ativos poderia vir a sofrer novas revisões afetando o risco de crédito. Entretanto, conforme descrito na seção 3.5, o valor do OGXPBZ18 não foi afetado e a segunda emissão da OGX A captação, via OGX Áustria teve custo em linha com ao da anterior $(8,5 \%$, com vencimento em 2018) 493 . A segunda captação em menos de 12 meses atestava o "sólido acesso da Empresa ao mercado de financiamentos, que poderiam ser garantidos pelos seus ativos em Campos e pelo início de sua produção." 494

O interesse de investidores com visão de longo prazo não era apenas na OGX, mas no Grupo X. Entre março e maio de 2012, o fundo soberano de Abu Dhabi (Mubadala) e a GE adquiriam 5,63\% e 0,8\% das ações de empresa controladora da EBX (a Centennial Asset Brazil Equity Fund ou "CABEF") com uma avaliação entre US\$ 35,5 (R\$ 64,4) e 37,5 $(R \$ 76,4)$ bilhões, respectivamente. As participações societárias na OGX, OSX, MPX e LLX que a CABEF detinha foram estimadas na época em $\mathrm{R} \$ 24,8$ bilhões, o que representava um prêmio de $208 \%$ pago pela GE ${ }^{495}$. Na época, Jeff Immelt, CEO mundial da GEO, classificou a EBX como "um dos mais importantes e dinâmicos grupos do Brasil e do mundo." O acordo reforçaria e criaria oportunidades de expansão de negócios das duas empresas em todo o mundo ${ }^{496}$.

\footnotetext{
${ }^{493}$ AUDI \& FALANGA NETO [2012e].

${ }^{494}$ AUDI \& FALANGA NETO, 2012e, p. 1.

495 Estimativa do Jornal Valor Econômico (VALENTI, G. "Vale mais. Ainda Vale Mais", 28/5/2012, seção Empresas).

496 "GE compra fatia da EBX e confirma valor de US\$ 300 milhões", Jornal Valor Econômico, 24/05/2012, Disponível em: https://www.valor.com.br/u/2674528. Acesso em 4/12/2018.
} 
Gráfico 70 - Amostra da TR: Evolução da Mediana, Máximo e Mínimo do PA em 2012 (em R\$/ação, pré split)

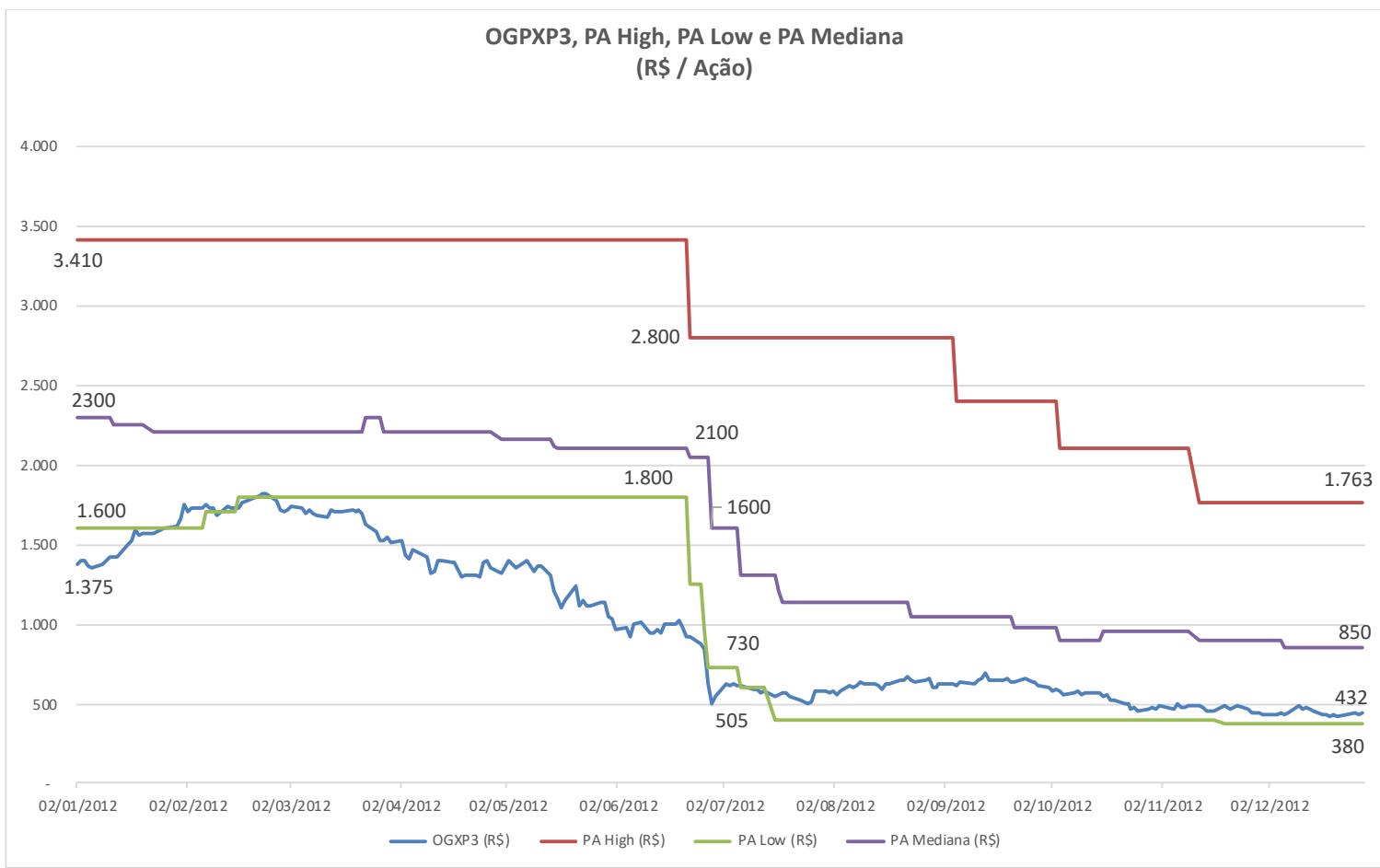

Entretanto, os fundos de pensão internacionais, cuja participação na AGE chegou a um pico em 26/4/2012, começou a se reduzir drasticamente. 


\section{Fundos que Participaram das AGEs em 2010 e a Última AGE de 2012}

\begin{tabular}{|c|c|c|c|c|c|c|c|c|c|}
\hline \multicolumn{4}{|c|}{$01 / 12 / 2011$} & \multicolumn{4}{|c|}{$26 / 04 / 2012$} & \multicolumn{2}{|r|}{$06 / 08 / 2012$} \\
\hline 1 & $\begin{array}{l}\text { Abu dahbi pension } \\
\text { fund }\end{array}$ & 71 & $\begin{array}{l}\text { Lockheed martin co } \\
\text { ret trust }\end{array}$ & 1 & $\begin{array}{l}\text { Abu dahbi pension } \\
\text { fund }\end{array}$ & 71 & J\&J P. F. & 1 & Abu dahbi pension fund \\
\hline 2 & Aegon funds & 72 & $\begin{array}{l}\text { Louisiana state } \\
\text { teachers }\end{array}$ & 2 & Advanced series trust & 72 & JPM Funds & 2 & Alaska permanent fund \\
\hline 3 & Agf & 73 & Lucent technologies & 3 & $\begin{array}{l}\text { Alaska permanent } \\
\text { fund }\end{array}$ & 73 & KODAK P.F. & 3 & Allianz \\
\hline 4 & Allianz & 74 & Manulife Funds & 4 & Allianz & 74 & Laudus Funds & 4 & Amundi Funds \\
\hline 5 & $\begin{array}{l}\text { American legacy } \\
\text { foundation }\end{array}$ & 75 & Marsico funds & 5 & Amundi funds & 75 & $\begin{array}{l}\text { Legg Mason Global } \\
\text { Funds }\end{array}$ & 5 & Ascetion health \\
\hline 6 & Amundi funds & 76 & Mellon bank funds & 6 & Anthem insurance co. & 76 & Lifespan Corporation & 6 & At\&t trust \\
\hline 7 & Anthem insurance co. & 77 & $\begin{array}{l}\text { Memorial sloan } \\
\text { kettering cancer } \\
\text { center }\end{array}$ & 7 & Ascetion health & 77 & $\begin{array}{l}\text { Louisiana State } \\
\text { Teachers }\end{array}$ & 7 & Axa \\
\hline 8 & Army \& air force ret tr & 78 & $\begin{array}{l}\text { Michigan state } \\
\text { municipal emp ret } \\
\text { sys }\end{array}$ & 8 & Ashmore funds & 78 & $\begin{array}{l}\text { LUCENT } \\
\text { TECHNOLOGIES }\end{array}$ & 8 & Baillie gifford funds \\
\hline 9 & Ascetion health & 79 & $\begin{array}{l}\text { Microsoft global } \\
\text { finance }\end{array}$ & 9 & At\&t trust & 79 & Manulife Funds & 9 & $\begin{array}{l}\text { Bank of japan funds \& } \\
\text { trusts }\end{array}$ \\
\hline 10 & At\&t trust & 80 & $\begin{array}{l}\text { Missouri state emp } \\
\text { ret sys }\end{array}$ & 10 & Atwill & 80 & $\begin{array}{l}\text { MARKS \& SPENCER } \\
\text { P. SCHEME }\end{array}$ & 10 & Bank of korea \\
\hline 11 & Atwill & 81 & $\begin{array}{l}\text { Monetary authority } \\
\text { of singapore }\end{array}$ & 11 & Axa & 81 & Marsico Funds & 11 & Barring fund \\
\hline 12 & Axa & 82 & Monks inv. Trust & 12 & Baillie gifford funds & 82 & MELLON BANK funds & 12 & Bayer co. Trust \\
\hline 13 & Baillie gifford funds & 83 & $\begin{array}{l}\text { Morgan stanley } \\
\text { funds }\end{array}$ & 13 & $\begin{array}{l}\text { Baltimore fire } \& \text { police } \\
\text { empl ret sys }\end{array}$ & 83 & $\begin{array}{l}\text { MEMORIAL SLOAN } \\
\text { KETTERING CANCER } \\
\text { CENTER }\end{array}$ & 13 & Bellsouth co. Trust \\
\hline 14 & Baker hughes inc. Trust & 84 & $\begin{array}{l}\text { National elevator } \\
\text { ind pension plan }\end{array}$ & 14 & $\begin{array}{l}\text { Bank of japan funds \& } \\
\text { trusts }\end{array}$ & 84 & $\begin{array}{l}\text { MICHIGAN STATE } \\
\text { MUNICIPAL EMP } \\
\text { RET SYS }\end{array}$ & 14 & Blackrock funds \\
\hline
\end{tabular}




\begin{tabular}{|c|c|c|c|c|c|c|c|c|c|}
\hline 15 & $\begin{array}{l}\text { Baltimore fire \& police } \\
\text { empl ret sys }\end{array}$ & 85 & $\begin{array}{l}\text { National pension } \\
\text { service }\end{array}$ & 15 & Bank of korea & 85 & $\begin{array}{l}\text { Microsoft Global } \\
\text { Finance } \\
\end{array}$ & 15 & British airways \\
\hline 16 & Bank of korea & 86 & $\begin{array}{l}\text { National social } \\
\text { secutirity council }\end{array}$ & 16 & $\begin{array}{l}\text { Bank of ny mellon co } \\
\text { ret plans }\end{array}$ & 86 & $\begin{array}{l}\text { MISSOURI STATE } \\
\text { EMP RET SYS } \\
\end{array}$ & 16 & $\begin{array}{l}\text { British coal staff } \\
\text { superannuation sc. }\end{array}$ \\
\hline 17 & $\begin{array}{l}\text { Bank of ny mellon co } \\
\text { ret plans }\end{array}$ & 87 & $\begin{array}{l}\text { New zealand } \\
\text { superannuation } \\
\text { fund }\end{array}$ & 17 & Barring fund & 87 & $\begin{array}{l}\text { MISSOURI STATE } \\
\text { PUBL EDUCATION } \\
\text { EMP RET SYS } \\
\end{array}$ & 17 & $\begin{array}{l}\text { British columbia inv. Mgt } \\
\text { co }\end{array}$ \\
\hline 18 & Baron funds & 88 & Norges bank & 18 & Bayer co. Trust & 88 & $\begin{array}{l}\text { MISSOURI STATE } \\
\text { PUBL SCHOOL EMP } \\
\text { RET SYS } \\
\end{array}$ & 18 & Brunei investment agency \\
\hline 19 & Bayer co. Trust & 89 & Nothern trust & 19 & Bell atlantic trust & 89 & $\begin{array}{l}\text { Monetary Authority } \\
\text { of Singapore }\end{array}$ & 19 & Bt pension scheme \\
\hline 20 & Bell atlantic trust & 90 & $\begin{array}{l}\text { Ny city def. Comp. } \\
\text { Plan }\end{array}$ & 20 & Bellsouth co. Trust & 90 & $\begin{array}{l}\text { Morgan Stanley } \\
\text { Funds }\end{array}$ & 20 & Caisse depot quebec \\
\hline 21 & Bellsouth co. Trust & 91 & $\begin{array}{l}\text { Ny state teacher ret } \\
\text { sys }\end{array}$ & 21 & Blackrock funds & 91 & $\begin{array}{l}\text { NATIONAL } \\
\text { ELEVATOR IND } \\
\text { PENSION PLAN } \\
\end{array}$ & 21 & California endowment \\
\hline 22 & Blackrock funds & 92 & $\begin{array}{l}\text { Ohio public emp ret } \\
\text { sys }\end{array}$ & 22 & Boeing co employee & 92 & $\begin{array}{l}\text { NATIONAL } \\
\text { WESTMINSTER } \\
\text { BANK Trusts \& } \\
\text { Funds } \\
\end{array}$ & 22 & $\begin{array}{l}\text { California state public } \\
\text { employee }\end{array}$ \\
\hline 23 & Boeing co employee & 93 & $\begin{array}{l}\text { Ohio school emp ret } \\
\text { sys }\end{array}$ & 23 & British airways & 93 & $\begin{array}{l}\text { NEW JERSEY STATE } \\
\text { PENSION FUND } \\
\end{array}$ & 23 & $\begin{array}{l}\text { Canada pension plan inv. } \\
\text { Board }\end{array}$ \\
\hline 24 & British airways & 94 & $\begin{array}{l}\text { Ohio state teacher } \\
\text { ret. }\end{array}$ & 24 & $\begin{array}{l}\text { Brunei investment } \\
\text { agency }\end{array}$ & 94 & $\begin{array}{l}\text { New Mexico Public } \\
\text { Emp. Ret. }\end{array}$ & 24 & $\begin{array}{l}\text { Canadian master trust } \\
\text { fund }\end{array}$ \\
\hline 25 & $\begin{array}{l}\text { British columbia inv. } \\
\text { Mgt co }\end{array}$ & 95 & Oregon state & 25 & Bt pension scheme & 95 & $\begin{array}{l}\text { New Mexico State } \\
\text { Educational Ret. } \\
\text { Board } \\
\end{array}$ & 25 & $\begin{array}{l}\text { Church commissioners for } \\
\text { england }\end{array}$ \\
\hline 26 & $\begin{array}{l}\text { Brunei investment } \\
\text { agency }\end{array}$ & 96 & Otpp & 26 & Cadbury pension trust & 96 & $\begin{array}{l}\text { NEW ZEALAND } \\
\text { SUPERANNUATION } \\
\text { FUND } \\
\end{array}$ & 26 & College ret. Equities fund \\
\hline 27 & Bt pension scheme & 97 & $\begin{array}{l}\text { Panagora group } \\
\text { trust }\end{array}$ & 27 & Caisse depot quebec & 97 & Norges Bank & 27 & Cook county employee \\
\hline
\end{tabular}




\begin{tabular}{|c|c|c|c|c|c|c|c|c|c|}
\hline 28 & Caisse depot quebec & 98 & $\begin{array}{l}\text { Pennsylvania public } \\
\text { school }\end{array}$ & 28 & California endowment & 98 & Nothern Trust & 28 & Davis funds \\
\hline 29 & California endowment & 99 & $\begin{array}{l}\text { Pennsylvania state } \\
\text { emp. Ret sys }\end{array}$ & 29 & $\begin{array}{l}\text { California state public } \\
\text { employee }\end{array}$ & 99 & $\begin{array}{l}\text { NY CITY DEF. COMP. } \\
\text { PLAN }\end{array}$ & 29 & Driehaus fund \\
\hline 30 & $\begin{array}{l}\text { California state public } \\
\text { employee }\end{array}$ & 100 & $\begin{array}{l}\text { Pensionkassernes } \\
\text { adm. }\end{array}$ & 30 & $\begin{array}{l}\text { Canada pension plan } \\
\text { inv. Board }\end{array}$ & 100 & $\begin{array}{l}\text { NY STATE TEACHER } \\
\text { RET SYS }\end{array}$ & 30 & $\begin{array}{l}\text { Eaton vance ret funds \& } \\
\text { trusts }\end{array}$ \\
\hline 31 & $\begin{array}{l}\text { California state } \\
\text { teachers }\end{array}$ & 101 & $\begin{array}{l}\text { Pg\&e coporation } \\
\text { trusts }\end{array}$ & 31 & $\begin{array}{l}\text { Canadian master trust } \\
\text { fund }\end{array}$ & 101 & $\begin{array}{l}\text { OHIO PUBLIC EMP } \\
\text { RET SYS }\end{array}$ & 31 & Em. Mkts funds \\
\hline 32 & $\begin{array}{l}\text { Canada pension plan } \\
\text { inv. Board }\end{array}$ & 102 & $\begin{array}{l}\text { Philadelphia city } \\
\text { pub empl. Ret sys. }\end{array}$ & 32 & Cargill inc funds & 102 & $\begin{array}{l}\text { Ohio State Teacher } \\
\text { Ret. }\end{array}$ & 32 & $\begin{array}{l}\text { Evangelical lutheran } \\
\text { church }\end{array}$ \\
\hline 33 & $\begin{array}{l}\text { Canadian master trust } \\
\text { fund }\end{array}$ & 103 & Prudential & 33 & $\begin{array}{l}\text { Catholic helath } \\
\text { initiatives }\end{array}$ & 103 & $\begin{array}{l}\text { Ontario Public } \\
\text { Employee Ret. }\end{array}$ & 33 & Fidelity funds \\
\hline 34 & Cargill inc funds & 104 & $\begin{array}{l}\text { Public sector } \\
\text { pension inv board }\end{array}$ & 34 & Cibc fund & 104 & OREGON STATE & 34 & Florida ret. Sys trust fund \\
\hline 35 & $\begin{array}{l}\text { Catholic helath } \\
\text { initiatives }\end{array}$ & 105 & Pyramis funds & 35 & $\begin{array}{l}\text { College ret. Equities } \\
\text { fund }\end{array}$ & 105 & OTPP & 35 & Ford motors trusts \\
\hline 36 & Cibc fund & 106 & Railway pension & 36 & $\begin{array}{l}\text { Connecticut state } r \text {. } \\
\text { Plans \& trust }\end{array}$ & 106 & $\begin{array}{l}\text { Panagora Group } \\
\text { Trust } \\
\end{array}$ & 36 & $\begin{array}{l}\text { Franklin templeton inv. } \\
\text { Funds }\end{array}$ \\
\hline 37 & $\begin{array}{l}\text { College ret. Equities } \\
\text { fund }\end{array}$ & 107 & $\begin{array}{l}\text { Régime rentes } \\
\text { mouvement caisse } \\
\text { populaires }\end{array}$ & 37 & $\begin{array}{l}\text { Cook county } \\
\text { employee }\end{array}$ & 107 & $\begin{array}{l}\text { PARKER HANNIFIN } \\
\text { TRUST }\end{array}$ & 37 & $\begin{array}{l}\text { Frontegra hexam em. } \\
\text { Mkts fund }\end{array}$ \\
\hline 38 & Cook county employee & 108 & $\begin{array}{l}\text { Robeco funds \& } \\
\text { trusts }\end{array}$ & 38 & Cox entreprises & 108 & $\begin{array}{l}\text { Pensionkassernes } \\
\text { Adm. }\end{array}$ & 38 & $\begin{array}{l}\text { Genesis em. Mkt. For } \\
\text { canada }\end{array}$ \\
\hline 39 & Cox entreprises & 109 & Rothschild banque & 39 & $\begin{array}{l}\text { Dallas city empl. Ret. } \\
\text { Fund }\end{array}$ & 109 & \begin{tabular}{|l|} 
PHILIPS \\
ELECTRONICS \\
NORTH AM CO R.T. \\
\end{tabular} & 39 & Goldman sachs trusts \\
\hline 40 & Davis funds & 110 & $\begin{array}{l}\text { Royal bank of } \\
\text { scotland funds }\end{array}$ & 40 & Davis funds & 110 & PICTET FUNDS & 40 & $\begin{array}{l}\text { Harmsworth pension } \\
\text { scheme }\end{array}$ \\
\hline 41 & Driehaus fund & 111 & Russel funds & 41 & Driehaus fund & 111 & Prudential & 41 & Hewlett-packard co. Trust \\
\hline 42 & Dte funds \& trusts & 112 & S\&p la etf & 42 & $\begin{array}{l}\text { Eaton vance ret funds } \\
\text { \& trusts }\end{array}$ & 112 & Pyramis Funds & 42 & Ibm \\
\hline 43 & $\begin{array}{l}\text { Eaton vance ret funds } \\
\& \text { trusts }\end{array}$ & 113 & $\begin{array}{l}\text { San diego gas \& elec } \\
\text { co }\end{array}$ & 43 & Em. Mkts funds & 113 & Railway Pension & 43 & Ibrd p.plan \\
\hline
\end{tabular}




\begin{tabular}{|c|c|c|c|c|c|c|c|c|c|}
\hline 44 & Em. Mkts funds & 114 & Schwab funds & 44 & Fidelity funds & 114 & $\begin{array}{l}\text { REGIME RENTES } \\
\text { MOUVEMENT } \\
\text { DESJARDINS } \\
\end{array}$ & 44 & $\begin{array}{l}\text { Idaho public employee } \\
\text { ret. }\end{array}$ \\
\hline 45 & $\begin{array}{l}\text { Evangelical lutheran } \\
\text { church }\end{array}$ & 115 & Shell pension trust & 45 & $\begin{array}{l}\text { Firefighters } \\
\text { retirement sys }\end{array}$ & 115 & $\begin{array}{l}\text { Robeco Funds \& } \\
\text { Trusts }\end{array}$ & 45 & Illinois state board \\
\hline 46 & $\begin{array}{l}\text { Famandsforeningen } \\
\text { pensam invest }\end{array}$ & 116 & $\begin{array}{l}\text { Southern ca edison } \\
\text { nuclear }\end{array}$ & 46 & $\begin{array}{l}\text { Florida ret. Sys trust } \\
\text { fund }\end{array}$ & 116 & $\begin{array}{l}\text { Rockefeller } \\
\text { Foundation }\end{array}$ & 46 & Ing funds \\
\hline 47 & Fidelity funds & 117 & Ssga funds & 47 & Ford motors trusts & 117 & $\begin{array}{l}\text { ROTHSCHILD } \\
\text { BANQUE \& FUND }\end{array}$ & 47 & Ishares msci \\
\hline 48 & $\begin{array}{l}\text { Firefighters retirement } \\
\text { sys }\end{array}$ & 118 & State farm funds & 48 & $\begin{array}{l}\text { Franklin templeton } \\
\text { inv. Funds }\end{array}$ & 118 & $\begin{array}{l}\text { Royal Bank of } \\
\text { Scotland Funds } \\
\end{array}$ & 48 & Janus funds \\
\hline 49 & $\begin{array}{l}\text { Florida ret. Sys trust } \\
\text { fund }\end{array}$ & 119 & State street & 49 & $\begin{array}{l}\text { Frontegra hexam em. } \\
\text { Mkts fund }\end{array}$ & 119 & S\&P LA ETF & 49 & John deere pension trust \\
\hline 50 & Ford motors trusts & 120 & $\begin{array}{l}\text { Telecordia } \\
\text { technologies }\end{array}$ & 50 & $\begin{array}{l}\text { General conf. } \\
\text { Seventh-day adv. }\end{array}$ & 120 & $\begin{array}{l}\text { SAN DIEGO GAS \& } \\
\text { ELEC CO }\end{array}$ & 50 & John hancock funds \\
\hline 51 & $\begin{array}{l}\text { Franklin templeton inv. } \\
\text { Funds }\end{array}$ & 121 & $\begin{array}{l}\text { Tenaska investment } \\
\text { fund }\end{array}$ & 51 & $\begin{array}{l}\text { Genesis em. Mkt. For } \\
\text { canada }\end{array}$ & 121 & Schwab Funds & 51 & Johnson \& johnson p. F. \\
\hline 52 & $\begin{array}{l}\text { General conf. Seventh- } \\
\text { day adv. }\end{array}$ & 122 & $\begin{array}{l}\text { Tennessee valley } \\
\text { aut ret sys }\end{array}$ & 52 & Gmo funds & 122 & & 52 & Jpm funds \\
\hline 53 & $\begin{array}{l}\text { Genesis em. Mkt. For } \\
\text { canada }\end{array}$ & 123 & $\begin{array}{l}\text { Texas education } \\
\text { agency }\end{array}$ & 53 & Goldman sachs trusts & 123 & $\begin{array}{l}\text { SHELL PENSION } \\
\text { TRUST } \\
\end{array}$ & 53 & $\begin{array}{l}\text { Kansas public employee } \\
\text { ret. }\end{array}$ \\
\hline 54 & Gmo funds & 124 & $\begin{array}{l}\text { Texas state } \\
\text { employees }\end{array}$ & 54 & Harbor trusts \& funds & 124 & $\begin{array}{l}\text { Southern CA Edison } \\
\text { Nuclear }\end{array}$ & 54 & Louisiana state teachers \\
\hline 55 & Goldman sachs trusts & 125 & Texas state teachers & 55 & $\begin{array}{l}\text { Harmsworth pension } \\
\text { scheme }\end{array}$ & 125 & SSGA Funds & 55 & Lucent technologies \\
\hline 56 & Harbor trusts \& funds & 126 & $\begin{array}{l}\text { Texas state } \\
\text { university }\end{array}$ & 56 & $\begin{array}{l}\text { Hewlett-packard co. } \\
\text { Trust }\end{array}$ & 126 & State Street & 56 & Manulife funds \\
\hline 57 & $\begin{array}{l}\text { Hewlett-packard co. } \\
\text { Trust }\end{array}$ & 127 & Tiaa-cref funds & 57 & Hsbc funds & 127 & STICHTING FUNDS & 57 & Mellon bank funds \\
\hline 58 & Hsbc funds & 128 & Unibanco fundos & 58 & Ibm & 128 & \begin{tabular}{|l} 
Telecordia \\
Technologies \\
\end{tabular} & 58 & Microsoft global finance \\
\hline 59 & Ibm & 129 & $\begin{array}{l}\text { Univ. Of notre dame } \\
\text { du lac }\end{array}$ & 59 & Ibrd p.plan & 129 & $\begin{array}{l}\text { TENASKA } \\
\text { INVESTMENT FUND }\end{array}$ & 59 & $\begin{array}{l}\text { Mineworkers' pension } \\
\text { scheme }\end{array}$ \\
\hline
\end{tabular}




\begin{tabular}{|c|c|c|c|c|c|c|c|c|c|}
\hline 60 & $\begin{array}{l}\text { Idaho public employee } \\
\text { ret. }\end{array}$ & 130 & Ups group trust & 60 & $\begin{array}{l}\text { Idaho public } \\
\text { employee ret. }\end{array}$ & 130 & $\begin{array}{l}\text { TENNESSEE VALLEY } \\
\text { AUT RET SYS }\end{array}$ & 60 & $\begin{array}{l}\text { Missouri state emp ret } \\
\text { sys }\end{array}$ \\
\hline 61 & Illinois state board & 131 & $\begin{array}{l}\text { Uaw retiree medical } \\
\text { benefits trust }\end{array}$ & 61 & Illinois state board & 131 & Texas State Teachers & 61 & $\begin{array}{l}\text { Missouri state publ } \\
\text { education emp ret sys }\end{array}$ \\
\hline 62 & Ing funds & 132 & Vanguard funds & 62 & Illinois state teachers & 132 & TIAA-CREF FUNDS & 62 & $\begin{array}{l}\text { Missouri state publ } \\
\text { school emp ret sys }\end{array}$ \\
\hline 63 & Ishares MSCl & 133 & Votorantim Fundos & 63 & $\begin{array}{l}\text { INDIANA STATE PUB. } \\
\text { EM. RET. FUND }\end{array}$ & 133 & $\begin{array}{l}\text { UAW RETIREE } \\
\text { MEDICAL BENEFITS } \\
\text { TRUST }\end{array}$ & 63 & $\begin{array}{l}\text { Monetary Authority of } \\
\text { Singapore }\end{array}$ \\
\hline 64 & Janus funds & 134 & Wellington trust & 64 & Ing funds & 134 & United Airlines & 64 & Morgan stanley funds \\
\hline 65 & John hancock funds & 135 & $\begin{array}{l}\text { West virginia inv. } \\
\text { Mgmt. Board }\end{array}$ & 65 & $\begin{array}{l}\text { Invesco developing } \\
\text { mkts fund }\end{array}$ & 135 & UNIV. OF MICHIGAN & 65 & $\begin{array}{l}\text { National elevator ind } \\
\text { pension plan }\end{array}$ \\
\hline 66 & Jpm funds & 136 & William blair funds & 66 & $\begin{array}{l}\text { lowa public emp ret } \\
\text { sys }\end{array}$ & 136 & $\begin{array}{l}\text { UNIV. OF MISSOURI } \\
\text { R. PL }\end{array}$ & 66 & National pension service \\
\hline 67 & $\begin{array}{l}\text { Kansas public } \\
\text { employee ret. }\end{array}$ & 137 & $\begin{array}{l}\text { Wilmington } \\
\text { international }\end{array}$ & 67 & Ishares msci & 137 & $\begin{array}{l}\text { UNIV. OF } \\
\text { PITTSBURGH } \\
\text { MEDICAL CENTER }\end{array}$ & 67 & $\begin{array}{l}\text { National social secutirity } \\
\text { council }\end{array}$ \\
\hline 68 & Laudus funds & 138 & $\begin{array}{l}\text { Wyoming state } \\
\text { treasurer }\end{array}$ & 68 & Janus funds & 138 & Vanguard Funds & 68 & $\begin{array}{l}\text { National westminster } \\
\text { bank trusts \& funds }\end{array}$ \\
\hline 69 & $\begin{array}{l}\text { Legg mason global } \\
\text { funds }\end{array}$ & & & 69 & $\begin{array}{l}\text { John deere pension } \\
\text { trust }\end{array}$ & 139 & $\begin{array}{l}\text { West Virginia Inv. } \\
\text { Mgmt. Board }\end{array}$ & 69 & $\begin{array}{l}\text { New jersey state pension } \\
\text { fund }\end{array}$ \\
\hline 70 & Lifespan corporation & & & 70 & John hancock funds & 140 & William Blair Funds & 70 & $\begin{array}{l}\text { New zealand } \\
\text { superannuation fund }\end{array}$ \\
\hline
\end{tabular}


Os investidores e a mediana dos Analistas da Amostra TR parecem não ter concedido muito crédito aos novos Executivos após a substituição do CEO em junho de 2012.

\section{Gráfico 71 - Amostra da TR: Evolução da Mediana e Mínimo do PA em 2013 (em R\$̣/ação,} pré split)

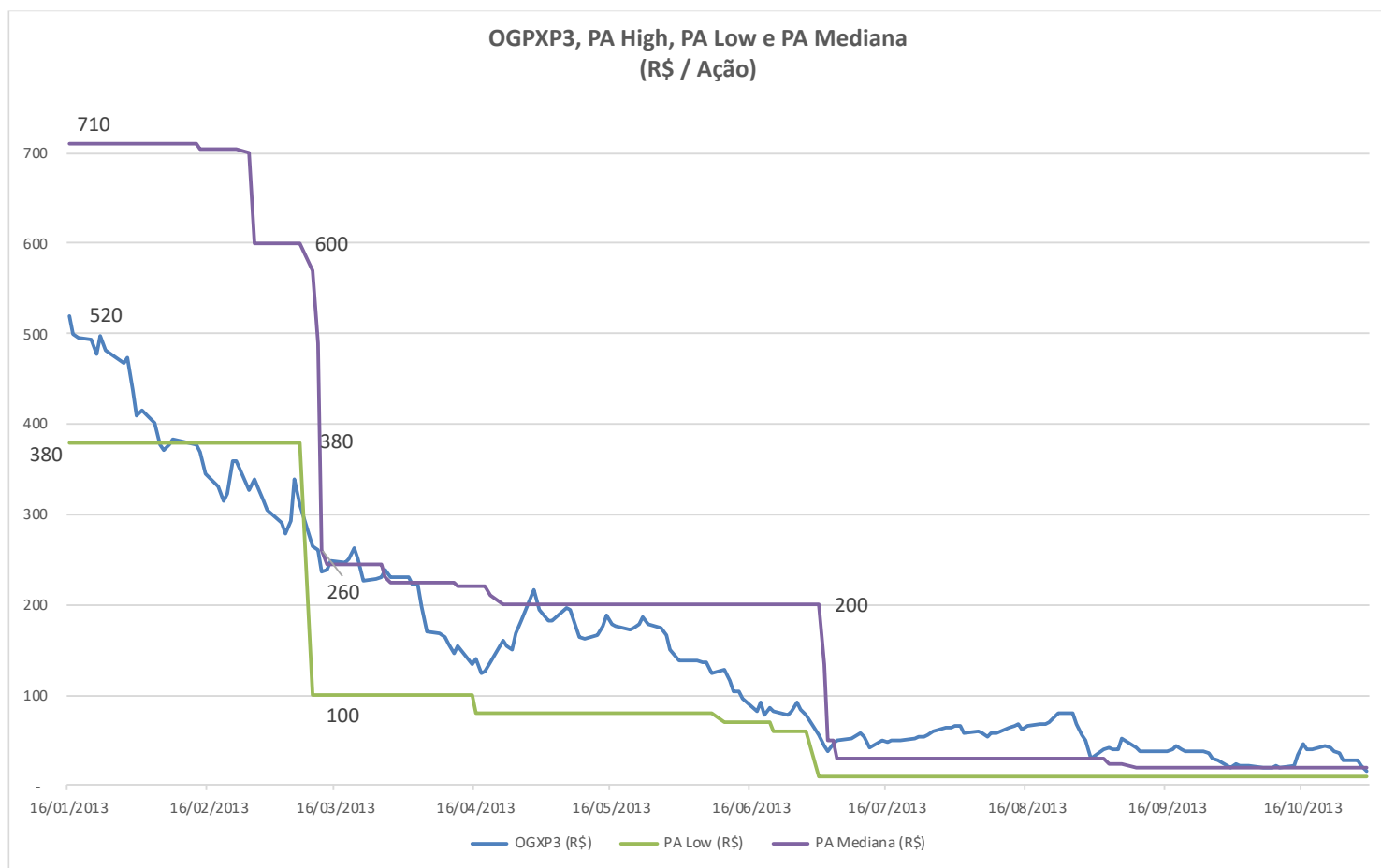

A participação de fundos de pensão nas AGEs se reduziu drasticamente em 2013. 


\section{Fundos que Participaram das AGEs em 2010 e a Última AGE de 2013}

\begin{tabular}{|c|c|c|c|c|c|c|c|}
\hline \multicolumn{4}{|c|}{$06 / 08 / 2012$} & \multicolumn{2}{|r|}{ 29/04/2013 } & \multicolumn{2}{|r|}{$12 / 09 / 2013$} \\
\hline 1 & Abu Dahbi Pension Fund & 53 & Kansas Public Employee Ret. & 1 & Abu Dahbi Pension Fund & 1 & Bank of Japan Funds \& Trusts \\
\hline 2 & Alaska Permanent Fund & 54 & Louisiana State Teachers & 2 & Advanced Series Trust & 2 & BELLSOUTH CO. TRUST \\
\hline 3 & Allianz & 55 & LUCENT TECHNOLOGIES & 3 & Alaska Permanent Fund & 3 & California State Public Employee \\
\hline 4 & Amundi Funds & 56 & Manulife Funds & 4 & AT\&T Trust & 4 & Canada Pension Plan Inv. Board \\
\hline 5 & Ascetion Health & 57 & MELLON BANK Funds & 5 & Bank of Japan Funds \& Trusts & 5 & COLLEGE RET. EQUITIES FUND \\
\hline 6 & AT\&T Trust & 58 & Microsoft Global Finance & 6 & BELLSOUTH CO. TRUST & 6 & Cook County Employee \\
\hline 7 & AXA & 59 & Mineworkers' Pension Scheme & 7 & Blackrock Funds & 7 & Em. Mkts Funds \\
\hline 8 & Baillie Gifford Funds & 60 & Missouri State Emp Ret Sys & 8 & British Airways & 8 & Evangelical Lutheran Church \\
\hline 9 & $\begin{array}{l}\text { Bank of Japan Funds \& } \\
\text { Trusts }\end{array}$ & 61 & $\begin{array}{l}\text { Missouri State Publ Education } \\
\text { Emp Ret Sys }\end{array}$ & 9 & Caisse Depot Quebec & 9 & Fidelity Funds \\
\hline 10 & BANK OF KOREA & 62 & $\begin{array}{l}\text { Missouri State Publ School Emp } \\
\text { Ret Sys }\end{array}$ & 10 & $\begin{array}{l}\text { California State Public } \\
\text { Employee }\end{array}$ & 10 & Ford Motors Trusts \\
\hline 11 & Barring Fund & 63 & $\begin{array}{l}\text { Monetary Authority Of } \\
\text { Singapore }\end{array}$ & 11 & Canada Pension Plan Inv. Board & 11 & Illinois State Board \\
\hline 12 & BAYER CO. TRUST & 64 & Morgan Stanley Funds & 12 & COLLEGE RET. EQUITIES FUND & 12 & Ishares $\mathrm{MSCl}$ \\
\hline 13 & BELLSOUTH CO. TRUST & 65 & $\begin{array}{l}\text { NATIONAL ELEVATOR IND } \\
\text { PENSION PLAN }\end{array}$ & 13 & Cook County Employee & 13 & Manulife Funds \\
\hline 14 & Blackrock Funds & 66 & National Pension Service & 14 & $\begin{array}{l}\text { EATON VANCE RET FUNDS \& } \\
\text { TRUSTS }\end{array}$ & 14 & MELLON BANK funds \\
\hline 15 & British Airways & 67 & $\begin{array}{l}\text { National Social Secutirity } \\
\text { Council }\end{array}$ & 15 & Em. Mkts Funds & 15 & National Pension Service \\
\hline 16 & $\begin{array}{l}\text { BRITISH COAL STAFF } \\
\text { SUPERANNUATION SC. }\end{array}$ & 68 & $\begin{array}{l}\text { NATIONAL WESTMINSTER } \\
\text { BANK Trusts \& Funds }\end{array}$ & 16 & Evangelical Lutheran Church & 16 & Norges Bank \\
\hline 17 & $\begin{array}{l}\text { BRITISH COLUMBIA INV. } \\
\text { MGT CO }\end{array}$ & 69 & $\begin{array}{l}\text { NEW JERSEY STATE PENSION } \\
\text { FUND }\end{array}$ & 17 & Fidelity Funds & 17 & NY STATE TEACHER RET SYS \\
\hline
\end{tabular}




\begin{tabular}{|c|c|c|c|c|c|c|c|}
\hline 18 & $\begin{array}{l}\text { BRUNEI INVESTMENT } \\
\text { AGENCY }\end{array}$ & 70 & $\begin{array}{l}\text { NEW ZEALAND } \\
\text { SUPERANNUATION FUND }\end{array}$ & 18 & Ford Motors Trusts & 18 & OHIO PUBLIC EMP RET SYS \\
\hline 19 & BT PENSION SCHEME & 71 & Norges Bank & 19 & IBM & 19 & Southern CA Edison Nuclear \\
\hline 20 & Caisse Depot Quebec & 72 & Nothern Trust & 20 & Idaho Public Employee Ret. & 20 & SSGA Funds \\
\hline 21 & California Endowment & 73 & NY CITY DEF. COMP. PLAN & 21 & Illinois State Board & 21 & State Street \\
\hline 22 & $\begin{array}{l}\text { California State Public } \\
\text { Employee }\end{array}$ & 74 & NY CITY GROUP TRUST & 22 & Ishares $\mathrm{MSCl}$ & 22 & Texas State Teachers \\
\hline 23 & $\begin{array}{l}\text { Canada Pension Plan Inv. } \\
\text { Board }\end{array}$ & 75 & OHIO PUBLIC EMP RET SYS & 23 & Janus Funds & 23 & UPS GROUP TRUST \\
\hline 24 & $\begin{array}{l}\text { CANADIAN MASTER } \\
\text { TRUST FUND } \\
\end{array}$ & 76 & Ohio State Teacher Ret. & 24 & John Hancock Funds & 24 & Vanguard Funds \\
\hline 25 & $\begin{array}{l}\text { CHURCH } \\
\text { COMMISSIONERS FOR } \\
\text { ENGLAND }\end{array}$ & 77 & Ontario Public Employee Ret. & 25 & Kansas Public Employee Ret. & 25 & Wells Fargo \\
\hline 26 & $\begin{array}{l}\text { COLLEGE RET. EQUITIES } \\
\text { FUND }\end{array}$ & 78 & OREGON STATE & 26 & Manulife Funds & & \\
\hline 27 & Cook County Employee & 79 & OTPP & 27 & Microsoft Global Finance & & \\
\hline 28 & Davis Funds & 80 & Panagora Group Trust & 28 & $\begin{array}{l}\text { Monetary Authority of } \\
\text { Singapore }\end{array}$ & & \\
\hline 29 & Driehaus Fund & 81 & Pensionkassernes Adm. & 29 & Morgan Stanley Funds & & \\
\hline 30 & $\begin{array}{l}\text { EATON VANCE RET } \\
\text { FUNDS \& TRUSTS }\end{array}$ & 82 & PICTET FUNDS & 30 & $\begin{array}{l}\text { Municipal Employees Fund } \\
\text { Chicago }\end{array}$ & & \\
\hline 31 & Em. Mkts Funds & 83 & Pyramis Funds & 31 & $\begin{array}{l}\text { National Social Secutirity } \\
\text { Council }\end{array}$ & & \\
\hline 32 & $\begin{array}{l}\text { Evangelical Lutheran } \\
\text { Church }\end{array}$ & 84 & $\begin{array}{l}\text { REGIME RENTES MOUVEMENT } \\
\text { DESJARDINS }\end{array}$ & 32 & New Mexico Public Emp. Ret. & & \\
\hline 33 & Fidelity Funds & 85 & ROTHSCHILD BANQUE \& FUND & 33 & New Mexico State Inv. Council & & \\
\hline 34 & $\begin{array}{l}\text { FLORIDA RET. SYS TRUST } \\
\text { FUND }\end{array}$ & 86 & Royal Bank Of Scotland Funds & 34 & $\begin{array}{l}\text { NEW ZEALAND } \\
\text { SUPERANNUATION FUND } \\
\end{array}$ & & \\
\hline
\end{tabular}




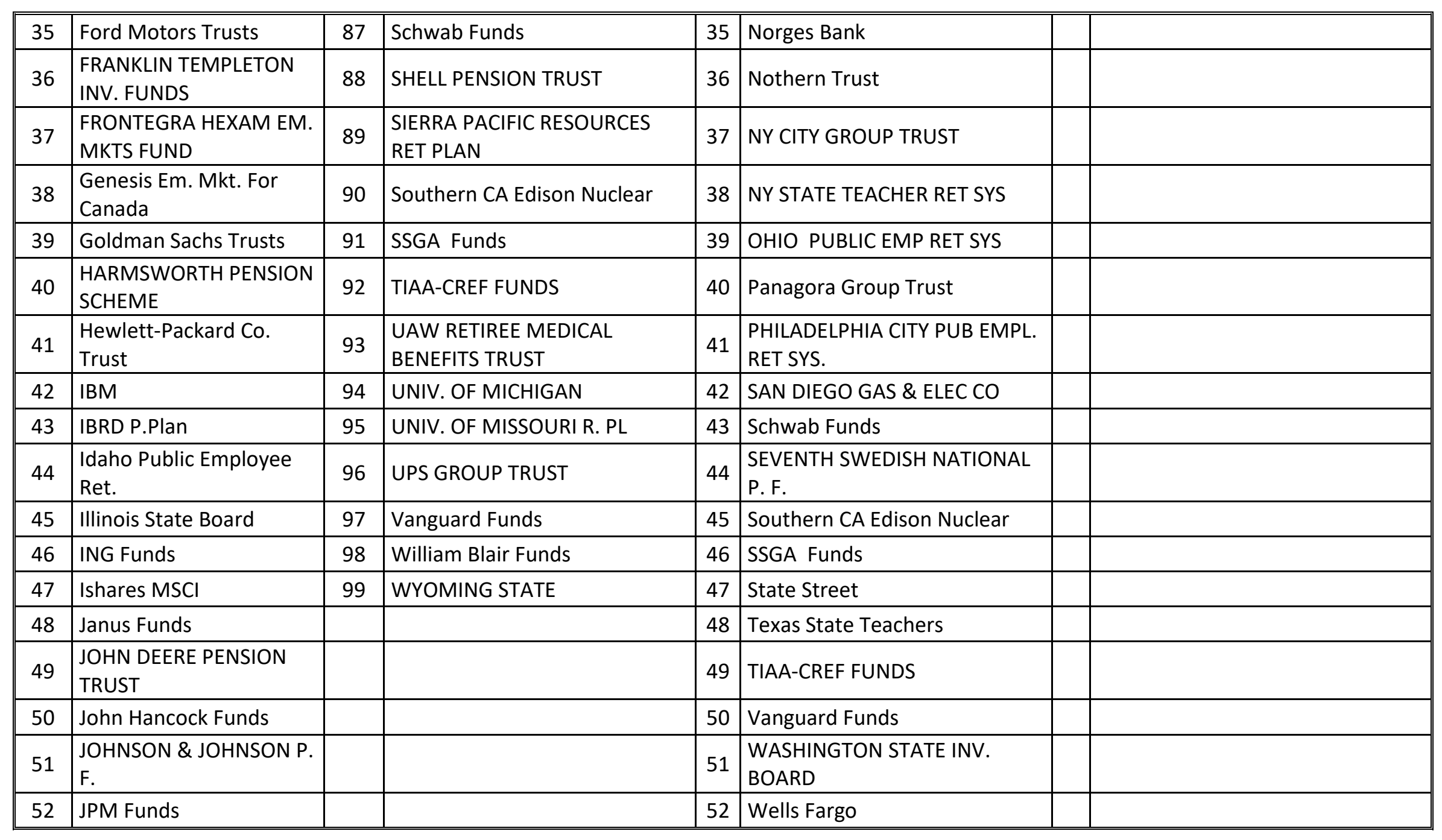




\title{
5. Segunda Questão de Pesquisa
}

\begin{abstract}
"Estruturas que não são percebidas nos aprisionam. Em contraste, aprender a enxergar a estrutura em que nós operamos é o começo do processo que pode nos libertar das forças que previamente não observávamos e que pode nos capacitar a trabalhar com elas para muda-las".
\end{abstract}

SENGE, 2006, p. 71.

O SOP OGX e SOP AC, que a princípio foi interpretado como virtuoso instrumento de alinhamento de interesses, provou ser um poderoso Processo de Reforço que contribuiu para comprometer o futuro da OGX e, por conseguinte, a OSX também.

A Heroína Gerencial gerada pelas sub e sobrevalorizações, combinadas com o SOPs, se manifestou publicamente através do guidance e da intensiva e dispersa campanha de E\&P com uma agressiva Agenda de Catalisadores. Foram 115 perfurações em 6 bacias diferentes com 51 blocos que consumiram $R \$ 13,8$ bilhões em investimentos. A crescente complexidade da campanha potencializou a assimetria informacional, que por sua vez promoveu comportamentos oportunistas para os Executivos. Manipulação e ocultação de informações, investimentos arriscados, uso de informação privilegiada e apropriações indevidas podem estar entre as Condutas de Valor que a Estrutura de Governança disfuncional da OGX promoveu.

Atrasos e percalços são característicos de todos sistemas complexos, entretanto, a Agenda de Catalisadores parecia ignorar este fato com metas arrojadas. Todavia, estas mesmas metas constituíram as bases de um Processo de Balanceamento que alertou os investidores mais atentos e racionais que o guidance era excessivamente otimista. 020 e o 3 D\&M, as tentativas de farm-out em 2010 e 2013 (com Petronas), as projeções para o ramp-up da produção, os write-offs, e a disponibilidade de caixa da OGX foram marcos deste Processo de Balanceamento.

Enquanto a OGX estava na fase exploratória, parte dos investidores e Analistas podem ter sido mais tolerantes com os atrasos da Agenda de Catalisadores. Afinal, "geologia é tudo menos uma ciência exata..." 497 Mas quando a Empresa entrou em fase operacional em março de 2012, os fluxos de produção do TBAZ indicavam que as metas para o rampup da produção, prometidas no IPO e incrementadas ao longo da campanha exploratória, se mostraram ser cada vez mais fisicamente inviáveis.

Do ponto de vista dos Analistas, o sucesso ou insucesso do de-risking era resumido quantitativamente em um único número: os PAs. Frente aos resultados muito aquém das metas que os próprios Executivos haviam definido para TBAZ, o Processo de Balanceamento funcionou como o freio de um carro em alta velocidade, no caso o Valor

${ }^{497}$ KOVARSKY, MENDES \& ARAUJO, 2009f, p. 1. 
de Mercado. Muitos Analistas, rapidamente, ajustaram seus PAs para patamares menores.

Simplesmente a OGX não demonstrava ter fluxos de produção, Recursos Contingentes ou Reservas suficientes para sustentar as metas do ramp-up. Os investidores reagiram e a desvalorização da OGXP3 combinada com sua crescente volatilidade aumentou a percepção e exposição ao risco da OGX e Partes Relacionadas. Não demorou para os primeiros Analistas alertarem que o caixa da OGX estava terminando ainda em 2012.

É importante ressaltar que as metas para o fluxo de TBAZ, estabelecidas pelos Executivos em fevereiro de 2011 ( $20 \mathrm{kbpd}$ ) poderiam ter sido muito mais conservadoras, e ainda seriam bem recebidas, pois haviam poucos campos no Brasil com produção acima de $10 \mathrm{kbpd} /$ poço.

Analisando somente a vazão, não consideramos os valores tão ruins, mas a discrepância entre as expectativas do management e a realidade observada é gritante, fato que tira a credibilidade da empresa no mercado [Analista da corretora XP Investimentos em relatório $]^{498}$.

Com a frustração com os fluxos de TBAZ, a percepção de risco de algum dos gatekeepers aumentou, e com elas vieram rebaixamento de PAs, os primeiros write-offs mais significativos, e no limite, a renúncia de membros do COAD.

\section{Figura 8 - Sistema Dinâmico da OGX no Período de Destruição de Valor}

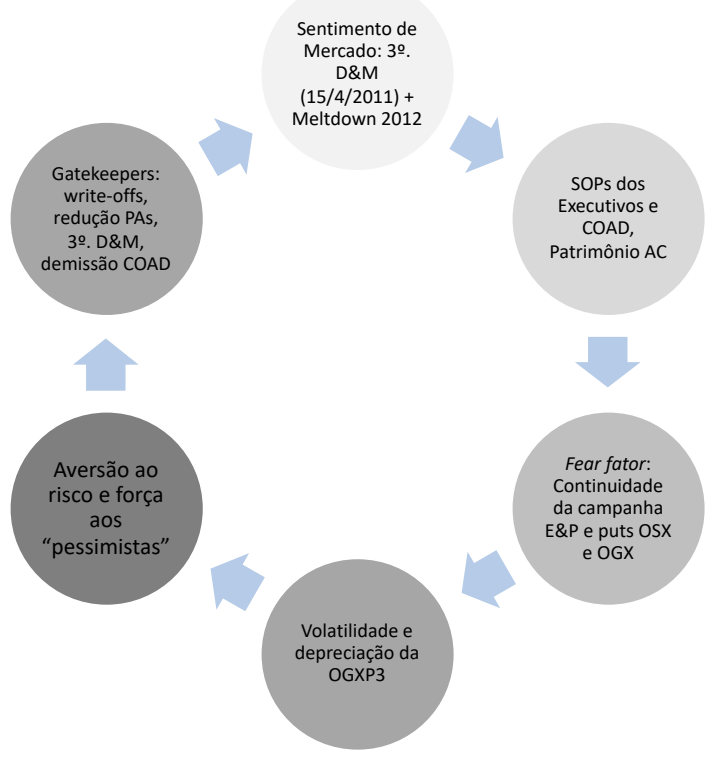

Fonte: elaborado pelo Autor.

A Estrutura de Governança mostrou ser tão disfuncional, que mesmo após a troca do CEO (28/06/2012) e com o caixa terminando, a Agenda de Catalisadores continuou a

${ }^{498}$ Disponível em: https://www.valor.com.br/u/2730190. 
crescer. Investidores, financiadores, fornecedores, e até alguns Executivos então buscaram liquidez ou demandaram garantias adicionais que acabaram por levar ao colapso da OGX e outras Partes Relacionadas.

Se por um lado, a desvalorização da OGXP3 e sua crescente volatilidade constituíram uma combinação letal para investidores mais conservadores, para outros pode ser um convite à especulação. A atuação de flippers, investidores que compraram ações só para vender em seguida e embolsar a valorização, aumentou consideravelmente no fim de 2012 e ao longo de 2013.

Gráfico 72 - Volume de Day-Trade da OGXP3 e PETR4 como Percentual do VMD entre 2012 e 2013

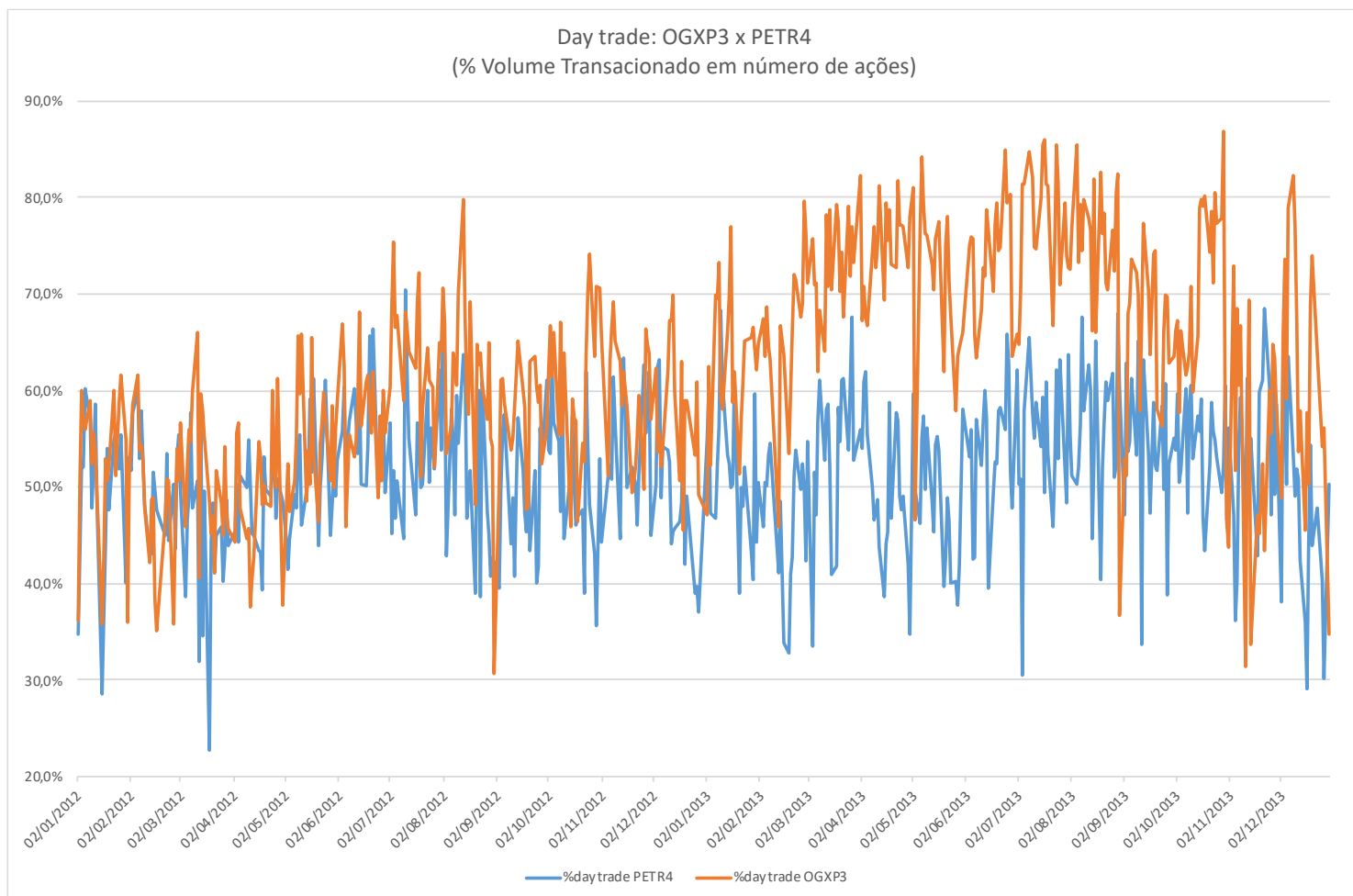

Somou-se à dinâmica da OGX outro sistema: o da OSX. Estas duas empresas estavam ligadas através de três relações: cliente-fornecedor, em termos operacionais e financeiros; societária indireta, uma vez compartilhavam o mesmo acionista controlador; gestão, uma vez que os executivos de ambas empresas participavam dos Conselhos de Administração. Por um lado, A Heroína Organizacional que se instalou na OGX repercutiu na OSX, através da relação cliente-fornecedor. O agressivo ramp-up da OGX dependia também da disponibilidade dos equipamentos que a OSX se comprometeu a entregar. Atrasos na OSX implicavam em atrasos no ramp-up da OGX.

Por outro lado, o AC comprometeu parte de seu patrimônio na viabilidade da OSX: OS empréstimos ponte para a construção de equipamentos e do estaleiro tiveram avais do 
AC, incluindo como colateral suas posições na OGXP3; e, no difícil IPO da OSX ${ }^{499}$, em 16/03/12, o AC outorgou uma put de US\$ 1 bilhão, que poderia ser exercida em parcelas a partir do 2S2012 até 2013. Na época, a put foi uma sinalização importante aos bancos que negociavam o financiamento de $\mathrm{R} \$ 3$ bilhões para a construção do estaleiro no Porto de Açu.

As dúvidas sobre o futuro da OGX que se agravaram a partir de 26/06/2012, refletidas nos valores de mercado da OGXP3 e dos Notes, afetaram a capacidade da OSX em captar financiamentos para as FPSOs. O Processo de Reforço da relação cliente-fornecedor se tornou um ciclo vicioso, potencializado pela relação societária indireta. Os aportes de capital que a put para a OSX exigia do AC antecedeu aqueles que o AC se comprometeu a fazer na OGX e não honrou. Para agravar o conflito de interesses, a OGX, já com severas limitações de caixa, honrou seus pagamentos à OSX, pois o Processo de Balanceamento da OSX era o cronograma de amortizações dos empréstimos ponte!

Ou seja, se por um lado, as encomendas superdimensionadas da OGX e seus cancelamentos impactaram a OSX, por outro lado, a estratégia de financiamento da OGX, composta por capital de risco e quase risco, foi comprometida pelo cronograma de amortizações dos financiamentos asset-baked da OSX.

A Heroína Organizacional da OGX afetou também investidores, financiadores, fornecedores e prestadores de serviços também. Como os maiores bancos nacionais e grandes fundos internacionais construíram exposições tão significativas ao Grupo X? Provavelmente, porque são instituições que também adotavam incentivos por metas e/ou SOPs.

Apesar do trânsito político do AC e dos membros do COAD, pode não ser coincidências que os grandes bancos estatais, BNDES, CEF e BB, que não tem SOPs, não assumiram exposição direta ao Grupo X. Um dos executivos entrevistados relatou que o BB, ao ser convidado a financiar alguma empresa do Grupo X, declinou rapidamente, alegando "não conheço o negócio O\&G".

\section{Sintomas de Governança Disfuncional}

Os indícios de Condutas de Valor na Governança Corporativa Disfuncional na OGX se manifestaram em:

- Estratégias de entrincheiramento como investimentos na perfuração, coleta de dados e interpretação de 51 blocos em 6 bacias diferentes, bem como investimentos em sinergias poucos transparentes com Partes Relacionadas, em destaque a OGX. Estratégias de entrincheiramento também incluem manipulações contábeis ou do valor de mercado para superestimar sua performance, que no caso da OGX pode ter

${ }^{499}$ Segundo reportagem do JVE, no IPO da OSX, o intervalo da oferta foi definido entre $\mathrm{R} \$ 1.000$ a $\mathrm{R} \$ 1.333$ por ação, mas fechou por $\mathrm{R} \$ 800 /$ ação. A oferta foi 44,4\% menor (de 5,511 para 3,063 milhões de ações) do que se esperava e o AC teve de participar com US\$300 M, que representou $21,8 \%$ do total de $\mathrm{R} \$$ 2.450,4 milhões (US\$ 1.373,2 milhões) captados (18/3/2010). Disponível em: https://www.valor.com.br/u/2570980. 
ocorrido através da emissão de FRs otimistas e adiamento de write-offs de poços. Tomar muito risco, especialmente quando a performance está aquém do esperado e os Executivos estão desesperados por "boas notícias" para os acionistas minoritários. Neste caso, os Executivos fazem arriscadas "apostas na ressurreição", como pode ter sido o caso do farm-in do BM-C-37/38, BS-4 e da participação da OGX na 11a Rodada da ANP.

Em relação às manipulações contábeis, algumas são legais, outras não, podendo requerer a cooperação de contadores, investidores, financiadores, empresas de rating e/ou parceiros comerciais. Manipulações servem para aumentar o valor das ações, o que aumenta o valor dos SOPs detidos pelos Executivos e membros do COAD.

- Investimentos ineficazes e/ou extravagantes. A perda do foco operacional parece também ter ocorrido na gestão direta da liquidez da Empresa. Por exemplo, a posição do caixa em 30/9/2012 (US\$ 2,5 milhões, ou R\$ 5,1 milhões) indicava que a Empresa poderia terminar 2013 com caixa próximo a zero (entre US\$ 400 a 500 milhões), segundo estimativas do SAN, BTG e IBBA. Em janeiro de 2013, a própria OGX viria a projetar que poderia terminar o ano de 2013 com US\$ 300 a 400 milhões em disponibilidades ${ }^{500}$.

- Falta de transparência. No artigo 18 da "Política de Divulgação e Uso de Informações para o Mercado" da OGX PETRÓLEO E GAS PARTICIPAÇÕES S.A., lia-se:

A OGX poderá divulgar previsões e/ou estimativas futuras de desempenho, apresentando, com clareza, as premissas que suportam tais projeções. Entretanto, caso haja alterações substanciais de mercado ou no plano de negócios da Companhia que justifiquem a revisão das previsões e/ou estimativas futuras, caberá ao Diretor de Relações com Investidores dar ampla e simultânea divulgação destas alterações ao Mercado na forma prevista no artigo 30 da Instrução CVM 358/2002 [Defesa de P. MALAN p. 190].

- Benefícios Privados e Self Dealings. Self-dealing legais incluem benefícios excessivos; escolha de seguidores (salas de eco) para posições executivas, ou ainda, isola executivos com posições divergentes; contratação de fornecedores caros por amizade ou reciprocidade pessoal. Self-dealing ilegais incluem uso de informação privilegiada, venda de ativos abaixo do valor de mercado para empresas relacionadas indiretamente aos executivos, roubos.

Estratégias de entrincheiramento e investimentos ineficazes são abordados na seção 5.1. Falta de transparência é abordada na seção 5.2. Benefícios privados e self-dealings são abordados na seção 5.3. A última seção, 5.4, discorre sobre potenciais conflitos de interesse entre o AC e a OGX através de Partes Relacionadas, em particular com a OSX.

${ }^{500}$ AUDI \& FALANGA NETO [2013a]. 


\subsection{Heroína Organizacional e Campanha Exploratória}

"[N]ós não queremos maximizar o valor das ações da Berkshire na Bolsa. Em vez disso, nós desejamos que elas sejam transacionadas em um estreito intervalo centrado no valor intrínseco do valor do negócio... Charlie Munger e eu nos incomodamos tanto com uma significativa sobrevalorização quanto com uma significativa subvalorização."

Warren Buffet, Berkshire Hathaway Annual Report, 1988, apud JENSEN, 2005, p. 5.

(...) [N]aquele tempo, Itaguaí, que como as demais vilas, arraiais e povoações da colônia, não dispunha de imprensa, tinha dois modos de divulgar uma notícia: ou por meio de cartazes manuscritos $e$ pregados na porta da câmara e da matriz; ou por meio da matraca. Eis que consistia este segundo uso. Contratava-se um homem, por um ou mais dias, para andar as ruas do povoado, com uma matraca na mão. De quando em quando tocava a matraca, reunia-se gente, e ele anunciava o que incumbiam, um remédio para sezões, umas terras lavradias, um soneto, um donativo eclesiástico, a melhor tesoura da via, o mais belo discurso do ano, etc. O sistema tinha inconvenientes para a paz pública, mas era conservado pela grande energia de divulgação que possuía. Por exemplo, um dos vereadores, - aquele justamente que se opusera à criação da Casa Verde ${ }^{501}$, - desfrutava a reputação de perfeito educador de cobras e macacos, e aliás nunca domesticara um só destes bichos; mas, tinha o cuidado de fazer trabalhar a matraca todos os meses. E dizem as crônicas que algumas pessoas afirmavam ter visto cascavéis dançando no peito do vereador; afirmação perfeitamente falsa, mas só devida a extrema confiança no sistema. Verdade, verdade; nem todas as instituições do antigo regime, mereciam o desprezo do nosso século."

ASSIS, M., O Alienista, p. 36.

Conforme discutido no Capítulo 1 (1.4), sobrevalorizações excessivas podem ter comprometido a gestão e a eficácia da governança corporativa da OGX através da Heroína Organizacional. As não menos nefastas subvalorizações, por sua vez, também podem ter, em um primeiro momento, alimentado a Heroína Organizacional, e em 2013 podem ter comprometido a financiabilidade da OGX, pois além das ações do AC que

${ }^{501}$ No conto de Machado de Assis, a Casa Verde era um manicômio, criada "por um certo médico, o Dr. Simão Bacamarte, filho da nobreza da terra e o maior dos médicos do Brasil, de Portugal e das Espanhas" [p. 19]. 
poderiam constituir garantias em empréstimos (caução de ações), o baixo valor da OGXP3 poderia ter inviabilizado novas captações (follow-ons).

No IPO e até 25/6/2008, Executivos e membros do COAD testemunharam os valores milionários de seus SOPs e o patrimônio bilionário do AC. Logo em seguida, na correção depreciativa de 26/6 a 6/11/2008, os Gestores assistiram os valores de seus patrimônios serem depreciados para níveis irrisórios, antes mesmo da campanha exploratória começar. Diante de uma subvalorização acentuada, com ápice em 6/11/2008, os Executivos e AC podem ter assumido elevados riscos ao divulgar estimativas excessivamente otimistas e prematuras, além de diversificar a campanha em novas regiões para reverter a percepção dos investidores, a ponto de promover até uma sobrevalorização entre 2009, 2010 e 2011. Durante o Rally, após 6/11/2008 até $15 / 10 / 2010$, os investidores endossaram esta implementação e o patrimônio dos Gestores não apenas se recuperou, mas se apreciou além do que parecia ser factível durante os momentos de sobrevalorização.

Mas à medida que surgiam indícios de excesso de otimismo, combinados com a falta de informações convincentes sobre o de-risking, a reação dos investidores reajustaria o Valor de Mercado significativamente, gerando bases para novas e longas subvalorizações. Era preciso expandir a Agenda de Catalisadores. Em 28/06/2012, após a decepção com os fluxos de TBAZ, quando o "otimista" Paulo Mendonça foi substituído pelo "conservador" Luiz Carneiro, o guidance mudou na forma, mas não na essência, uma vez que a estrutura de incentivos não havia sido alterada ${ }^{502}$. A Agenda de Catalisadores continuou a crescer e se diversificar geograficamente, incluindo o farm-in do BS-4 (26/11/2012) e a participação na 11a Rodada (14 e 15/05/2013), quando a Empresa já estava com caixa limitado. Entre julho de 2012 e março de 2013, a OGX, sob gestão de Luiz Carneiro investiu $R \$ 4,51$ bilhões (32,7\% do total), uma média de $R \$ 1,50$ bilhão por trimestre contra R\$ 755 milhões por trimestre de Paulo Mendonça (entre 3T2009 a 2T2012).

Uma vez instalada, seria difícil reverter a dinâmica da Heroína Organizacional que contribuiria para a crise de liquidez na OGX e em algumas Partes Relacionadas (OSX, LLX, MMX).

Como discutido no Capitulo 1, o de-risking do portfólio da OGX, como qualquer outra empresa de E\&P, era crucial para geração (ou destruição) de Valor de Mercado, pois: determina possível volume de produção, timing e viabilidade financeira (despesas operacionais ("OPEX") e investimentos ("CAPEX"). Acesso à infraestrutura e equipamentos de exploração e produção também são críticos no de-risking. Considerando os 51 poços planejados no IPO e os 115 efetivamente perfurados até 2013, a OGX e seus Executivos pareciam estar comprometidos no de-risking e na identificação de novos prospectos. A OGX concentrou a Campanha em Campos (onde os Executivos tinham maior experiência) e na Parnaíba (GN), onde investiu em JV com MPX e outros sócios.

502 Entre março de 2010 e junho de 2012, Luiz Carneiro, enquanto CEO da OSX, publicou apenas 5 FRs e 25 CMs, enquanto que Paulo Mendonça, CEO da OGX publicou 63 FRs e 46 CMs. Na gestão de Carneiro, a OGX publicou $21 \mathrm{FRs}$ e $28 \mathrm{CMs}$. 
Tabela 53 - Perfurações: Planejadas em 2008 x Realizadas até 2013

\begin{tabular}{|l|c|c|c|c||}
\hline & Plano & \%Plano & Real & \%Real \\
\hline Campos & 27 & $52,9 \%$ & 61 & $53,0 \%$ \\
\hline Santos & 14 & $27,5 \%$ & 16 & $13,9 \%$ \\
\hline Parnaíba & - & $0,0 \%$ & 24 & $20,9 \%$ \\
\hline ES & 6 & $11,8 \%$ & 5 & $4,3 \%$ \\
\hline PA-MA & 4 & $7,8 \%$ & 5 & $4,3 \%$ \\
\hline Total & $\mathbf{5 1}$ & $\mathbf{1 0 0 , 0 \%}$ & $\mathbf{1 1 5}$ & $\mathbf{1 0 0 , 0 \%}$ \\
\hline
\end{tabular}

As perfurações começaram em agosto de 2009, e já em 2010 extrapolava o número de perfuração planejadas. Em apenas dois anos, 2010 e 2011, a OGX perfurou 70 poços contra 38 planejados. Este esforço concentrado pode estar relacionado à necessidade de confirmar os 10,0 bboe que o AC afirmou existir na famosa entrevista de 15/04/2010. Essa confirmação era importante não apenas para viabilizar o farm-out e confirmar o de-risking do portfólio, mas também o futuro da credibilidade do guidance.

Gráfico 73 - Evolução das Perfurações e dos Relatórios D\&M: Planejado em 2008 x Realizado até 2013

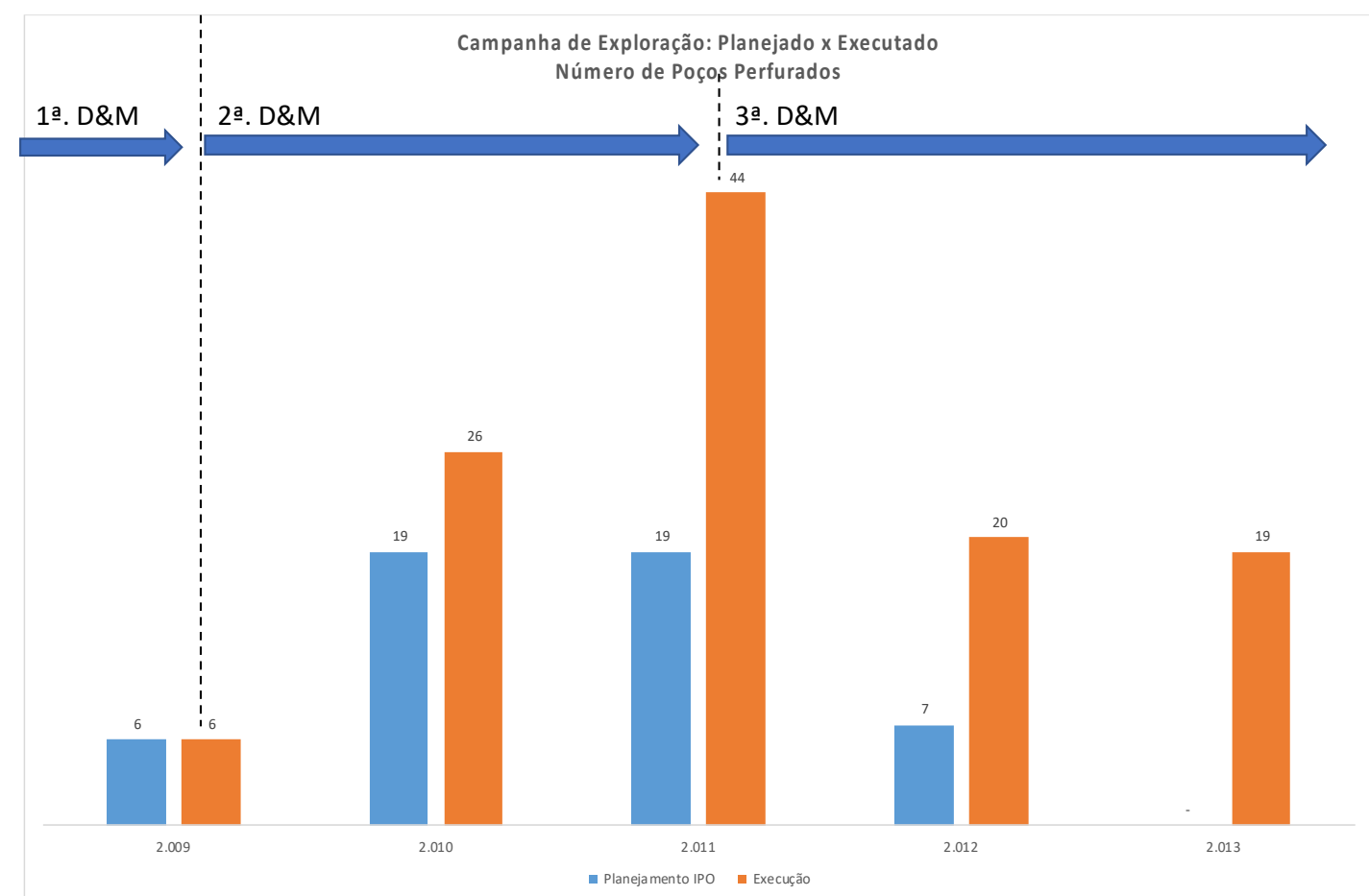

De fato, a intensa campanha exploratória da OGX gerou as informações para a publicação do 3을 em abril de 2011. Nos três relatórios, não houve recursos classificados como Reservas, mas houve sim, no 3을 $\& M$, a reclassificação de 3,1 bboe 
(sendo 3,0 bboe em Campos) para Recursos Contingentes, que poderiam ser interpretados como proxies para Reservas se o processo de exploração (perfurações e TLDs) continuasse a apresentar resultados promissores.

Tabela 54 - Resumo dos Três Relatórios de Avaliação da D\&M

\begin{tabular}{|c|c|c|c|c|c|c|c|c|c|}
\hline Relatórios & IPO 20 & $(3 / 2008)$ & & 20 D8 & $1(10 / 200$ & & & D\&M (4/2) & 011) \\
\hline Bacias & RPL & POS & RPL & POS & Var. IPO & Var.\% IPO & RPL & Var. IPO & Var.\% IPO \\
\hline Campos & 2,562 & $33,0 \%$ & 3,693 & $44,1 \%$ & 1,131 & $44,1 \%$ & 1,400 & $(1,162)$ & $-45,4 \%$ \\
\hline Santos & 1,569 & $25,0 \%$ & 1,688 & $27,0 \%$ & 0,119 & $7,6 \%$ & 1,800 & 0,231 & $14,7 \%$ \\
\hline ES & 0,27 & $18,0 \%$ & 0,817 & $32,6 \%$ & 0,547 & $202,6 \%$ & 0,800 & 0,530 & $196,3 \%$ \\
\hline PA-MA & 0,434 & $20,0 \%$ & 0,447 & $21,2 \%$ & 0,013 & $3,0 \%$ & 0,400 & $(0,034)$ & $-7,8 \%$ \\
\hline Parnaíba & 0 & $0,0 \%$ & 0,026 & $19,9 \%$ & 0,026 & & 1,000 & 1,000 & \\
\hline Colômbia & & & & & & & 0,100 & 0,100 & \\
\hline ST Prospectivo & 4,835 & $27,0 \%$ & 6,671 & $26,5 \%$ & 1,836 & $38,0 \%$ & 5,500 & 0,665 & $13,8 \%$ \\
\hline Delineados & - & - & & - & & - & 1,300 & - & \\
\hline Contingentes & - & - & 0,212 & - & 0,212 & - & 3,100 & - & \\
\hline Vol. Potencial & - & - & & - & & - & 1,000 & - & \\
\hline Total & 4,835 & & 6,883 & & 2,048 & $42,4 \%$ & 10,800 & 5,965 & $123,4 \%$ \\
\hline$\% G N$ & $26 \%$ & & $19 \%$ & & & & $21 \%$ & & \\
\hline
\end{tabular}

O fim do terceiro e último período de sobrevalorização (de 17/08/2010 a 15/04/2011) coincide com a publicação do 3으. D\&. A publicação indica o começo de um longo processo de deterioração do Valor de Mercado. Foi um Evento Crítico de Reputação, um ponto de inflexão na percepção do guidance pelo mercado, que não considerou nem sua estimativa mais conservadora (P90) de US\$43,61. No auge da secundária valorativa (de 08/08/2011 a 23/02/2012), quando alcançou US\$34,43 bilhões, o Valor de Mercado chegou próximo à média do 2ㅇ D\&M (US\$33,27 bilhões) e muito aquém do P90 do 3으 D\&M (US\$ 43.607 milhões). Foi como se o mercado ignorasse completamente as estimativas do 3은.

Uma possível explicação para o ponto de inflexão foi a falta de detalhes do 30 D\&M divulgado pela OGX. O nível de detalhes das premissas do 20 D\&M já foi menor do que o 1ㅇ D\&M, mas o 3으 D\&M gerou muita confusão entre os Analistas e investidores, como descrita na compilação dos relatórios dos Analistas da Amostra Própria na seção 3.4.

Curiosamente, se dividirmos o valor estimado no cenário da média dos três relatórios da D\&M (em US\$ milhões) pelo total volume recuperável (em bboe), independente da categoria do recurso (por exemplo, recursos contingentes versus recursos potenciais) obtemos o mesmo múltiplo até a quarta casa decimal: US\$ 4,8332. 
Tabela 55 - Evolução do Valor de Referência por bboe 2C nos Relatórios D\&M

\begin{tabular}{|l|c|c|c|c|c|c|}
\hline \hline & $\begin{array}{c}\text { Valor Presente } \\
\text { Cen. Médio } \\
\text { (US\$ Milhões) }\end{array}$ & \% 1o D\&M & $\begin{array}{c}\text { Volume } \\
\text { Recuperável } \\
\text { Total (kboe) }\end{array}$ & \% 19 D\&M & $\begin{array}{c}\text { VPL/boe } \\
\text { (US\$/boe) }\end{array}$ & \% 1o D\&M \\
\hline 10 D\&M & 23.367 & $100,000 \%$ & 4.834 .697 & $100,000 \%$ & 4,833188 & $100,000 \%$ \\
\hline 20 D\&M & 33.271 & $142,385 \%$ & 6.883 .853 & $142,384 \%$ & 4,833194 & $100,000 \%$ \\
\hline 30 D\&M & 52.198 & $223,383 \%$ & 10.800 .000 & $223,385 \%$ & 4,833148 & $99,999 \%$ \\
\hline
\end{tabular}

Ainda mais curioso é que cada nova versão dos relatórios da D\&M seria subsidiada com maiores e melhores informações sobre os prospectos coletados na campanha exploratória. De fato, cada nova versão dos relatórios da D\&M aumentou os volumes recuperáveis classificados em categorias teoricamente menos incertas. Aumentou-se o POS e a porcentagem de óleo versus GN. Apesar destes quatro aspectos, o múltiplo total diminui do 2 - para o 3 ㅇ D\&M, possivelmente devido ao impacto parcial do 1,0 bboe de recursos prospectivos na Colômbia.

Após a publicação do 3 D\&M, a campanha de E\&P continuou intensa em termos de número de poços perfurados. O esforço da OGX no de-risking de seu portfólio pode também ser ilustrado nos valores investidos. No IPO, os investimentos na exploração foram estimados em US\$1,61 a 1,69 bilhão ( $R \$ 2,64$ a $R \$ 2,77$ bilhões). A Empresa investiu em E\&P e outros ativos $R \$ 13,80$ bilhões (sendo que o PEM somava $R \$ 0,63$ bilhão). Mesmo em crise de reputação e financeira (2S2012 e 1T2013), a Empresa continuou a investir. Entretanto, é digno de nota que, apesar da intensa e custosa campanha, não houve um 4으 D\&M para o portfólio total da OGX503.

503 Na defesa de Pedro Malan [p. 9] no Processo n. 0000950-49.2014.02.5101 (22/4/2014), que foi membro do COAD da OGX de 2008 até 2013, foi notado que:

“37. Durante esses anos, principalmente entre 2009 e 2013, a OGX mobilizou um conjunto de dez sondas de perfuração, com operação em paralelo, o que possibilitou a condução de uma ampla campanha exploratória de larga escala, com perfuração de mais de 120 poços. Como produto dessa campanha, foi possível investigar áreas de exploração que não vinham sendo priorizadas no País, gerando como subproduto um importante acervo de informações geológicas para a gestão do setor pela Agência Nacional do Petróleo - ANP, que reconhece os relevantes serviços prestados pelo grupo OGX. Desde sua criação, a OGX investiu mais de R\$ 10 bilhões em suas atividades no Brasil, valor que a torna a empresa privada que mais investiu no país no seu segmento." 


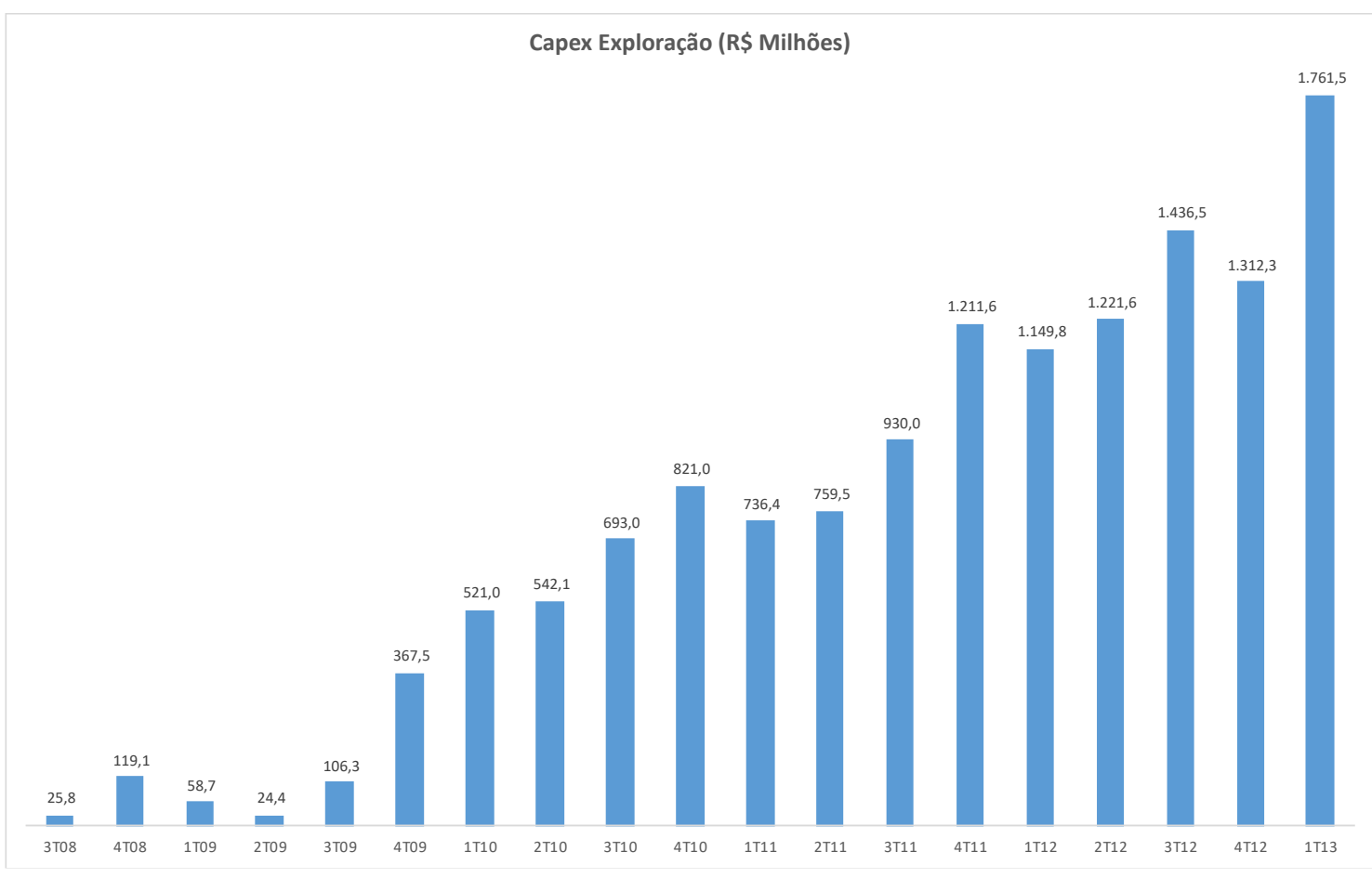

Do total de $\mathrm{R} \$ 13,80$ bilhões, 50,1\% (ou $R \$ 6,92$ bilhões) foram investidos até 2011 . Em 2012, quando começa o TLD de TBAZ, a OGX investiu o restante. Só em 2012 foram R\$ 5,12 bilhões, correspondendo a 37,1\% do total investido na campanha de E\&P. Ou seja, no auge da crise de credibilidade do guidance, 2012 foi o ano que a Empresa mais investiu, provavelmente em busca de novas evidências para o de-risking. No último trimestre de 2013, a OGX executou seu maior CAPEX (R\$ 1,76 bilhão). Mas a performance de TBAZ, embora razoável quando comparada a campos similares, ficou muito aquém dos elevados parâmetros do guidance, cuja credibilidade, medida pelo Valor de Mercado, havia sido comprometida irreversivelmente desde junho de 2012.

Em 2012, já com a credibilidade abalada, a OGX executou dois farm-ins: em 20/03 aumentou sua participação de $50 \%$ para $70 \%$ nos blocos BM-C-37 e BM-C38 (MAERSK permaneceu com 30\%); e em $26 / 11$, adquiriu $40 \%$ de participação do BS-4 pertencente à PETR por R\$ 575 milhões (US\$ 270 milhões).

Alguns Analistas reagiram com incredulidade. Por que a MAERSK venderia participação em um prospecto promissor ${ }^{504}$ ?

Desde o IPO, a OGX perfurou mais de 80 poços na bacia de Campos, principalmente em blocos $100 \%$ operados por ela, o que acreditamos ser suficiente para obter uma boa compreensão do potencial dos blocos. Ainda assim, a Empresa decidiu colocar as próximas unidades produtoras em áreas menos conhecidas, indicando potencialmente

${ }^{504}$ AUDI \& FALANGA NETO [2012d]. 
desapontamentos no resto, aparentemente muito mais difícil de produzir, da bacia de Campos [KOVARSKY \& MENDES, 2013a, p. 2].

O valor do farm-in do BS-4 representou um prêmio de $29 \%$ em relação ao valor pago pela QGEP em 24/08/2011 ${ }^{505}$. Alguns Analistas ${ }^{506}$ interpretaram a notícia da aquisição do BS-4 como negativa, pois levantava quatro questões:

(1) dado o discurso consistentemente positivo da Empresa sobre seu portfólio [em águas rasas] em Campos, por que se aventurar em uma produção mais cara em águas profundas? (2) o potencial do pré-sal do BS-4 é tão significativo assim para justificar a aquisição? (3) dado o balanço patrimonial da Empresa (com US\$ 5,1 bilhões em dívida líquida e crescendo), vale a pena a OGX comprometer mais capital? (4) qual é o significado da aquisição para o restante do portfólio da OGX (Santos, ES, PA-MA, Colômbia [e até certo ponto para Parnaíba])? (...) [SEQUEIRA \& FONSECA, 2012j, p. 1].

A aquisição do BS-4 também surpreendeu, pois a OGX pretendia participação na 11a Rodada (prevista para maio de 2013) justamente para buscar novas opções de crescimento mais baratas do que possíveis farm-ins de áreas já descobertas, e assim estaria preservando o caixa. Segundo os Analistas do IBBA, a aquisição do BS-4 provavelmente levaria a OGX a exercer a put contra o AC. No pregão (26/11), a OGXP3 se desvalorizou em 5,34\% (de $\mathrm{R} \$ 4,87$ para $\mathrm{R} \$ 4,61$ ). A perda no $\mathrm{EV}$ foi de $\mathrm{R} \$ 627,1$ milhões ou US\$ 301,7 milhões.

Em janeiro de 2013, dois anos depois de estimar seu potencial (0,5 a 1,5 bboe), a Empresa considerou Vesúvio como baixa prioridade, pois continha petróleo pesado em uma estrutura fragmentada. Ou seja, outras áreas menos conhecidas, incluindo as prospectivas não-perfuradas dos BM-C-37/38, agora, teriam prioridade sobre Vesúvio.

Em março (26/3), quando a OGX divulgou seu saldo de caixa em 31/12/2012 de US\$ 1,65 bilhão, alguns Analistas estimaram que este seria insuficiente para completar os gastos projetados em 2013 (US\$ 1,3 bilhão em investimentos e US\$ 0,3 bilhão de despesas financeiras) ${ }^{507}$. Em seu relatório, o DB foi incisivo: "a disciplina financeira da OGX tem sido pobre". E explicou com uma matemática simples:

\section{Bandeiras vermelhas iniciais sobre disciplina financeira}

Em retrospectiva, houve vários sinais de indisciplina: (1) ofertas agressivas na 9a Rodada da ANP, (2) concentração de risco geológico e financeiro e (3) campanha de exploração agressiva na bacia de Campos. Isso resultou em que a OGX se tornou uma empresa altamente alavancada, especialmente considerando a fase inicial de suas operações [SEQUEIRA \& FONSECA, 2013h, p. 1].

Segundo O DB, a OGX concentrou seus esforços exploratórios em Campos, preponderantemente sem parceiros (o BM-C-37/38 foram as exceções, com 70\% OGX e

\footnotetext{
${ }^{505}$ SEQUEIRA \& FONSECA [2012j].

${ }^{506}$ SEQUEIRA \& FONSECA [2012j].

507 LEITE, CANHEU \& SOBREIRA [2013f].
} 
30\% MAERSK), apesar do farm-out ser uma prática comum na indústria. Quando a OGX tentou fazê-lo, fontes não oficiais informavam que sua expectativa de valor era demasiadamente alta, desconsiderando o risco exploratório. De fato, o JVE ${ }^{508}$ relatou que na frustrada negociação com os chineses (CNOOC e Sinopec) em 2010, o lifting cost foi estimado em US\$ 8/barril, mas somente com logística de transporte seria de US\$ 7/barril. A agressiva estratégia de valorização dos prospectos pelos Executivos teria causado uma crise de confiança dos potenciais interessados no farm-out.

Tabela 56 - Processo de Reforço x Processo de Balanceamento: Disponibilidades, Investimentos e Abandonos

\begin{tabular}{|c|c|l||}
\hline $\begin{array}{c}\text { Início do } \\
\text { período }\end{array}$ & $\begin{array}{c}\text { Disponibilidades } \\
\text { (R\$ Bilhões) }\end{array}$ & \multicolumn{1}{|c|}{ Investimentos e Abandonos no Trimestre } \\
\hline $31 / 03 / 12$ & 6,61 & $\begin{array}{l}\text { Captação do 20 Note } \\
\text { 20/3/12: farm-in BM-C-37, BM-C-38 por valor não revelado }\end{array}$ \\
\hline $30 / 06 / 12$ & 5,94 & Desenvolvimento de TBAZ, TBMT \\
\hline $30 / 09 / 12$ & 5,06 & Desenvolvimento de TBAZ, TBMT \\
\hline $31 / 12 / 12$ & 3,38 & 26/11/12: farm-in BS-4 por R\$ 575 milhões \\
\hline $31 / 03 / 13$ & 2,31 & Desenvolvimento de TBAZ, TBMT \\
\hline $30 / 06 / 13$ & 0,72 & $\begin{array}{l}\text { 15/5: 11 } 1 \text { a Rodada por R\$ 376 milhões } \\
\text { 1/7: Pagamento de US\$ 449 milhões à OSX, cancelamento de } \\
\text { TBTI, TBAR e TBGA }\end{array}$ \\
\hline $30 / 09 / 13$ & 0,19 & \\
\hline
\end{tabular}

Ao longo do 1S2013, as causas das declinantes médias dos fluxos de TBAZ incluíam incidentes, atrasos, problemas com equipamentos.

Problemas operacionais não são incomuns, mas acreditamos que, neste caso, o processo foi agravado pela pressa para produzir petróleo, provavelmente ignorando etapas importantes no processo ou divulgando premissas excessivamente agressivas [KOVARSKY \& MENDES, 2013f, p.1].

Sinais contraditórios foram enviados aos investidores, numa aparente tentativa de recuperar a Agenda de Catalisadores. Em 13/3, a OGX declarou comercialidade de TBTI, TBGA (Pipeline, BM-C-41) e TBAR (Fuji/llimani, BM-C-41). Quatro meses depois, em $1 / 07$, cancelou o desenvolvimento de TBTI, TBAR e TBGA, cujas concessões seriam devolvidas à ANP.

Ainda em 13/3, a OGX pleiteou PADs para seis acumulações em Campos: Vesúvio, Veidma (BM-C-37), Tulum (BM-C-37), Itacoatiara (BM-C-39), Peró/Ingá (BM-C-40) e Tambora/Tupungato (BM-C-41). Em Santos, pleiteou PADs para três acumulações: Curitiba (BM-S-58), Belém (BM-S-56) e Natal (BM-S-59). Depois de tantos poços

508 Disponível em: https://www.valor.com.br/empresas/3017680/petronas-da-malasia-negocia-fatia-naogx. 
perfurados em Campos, a Empresa não era capaz de tomar decisões sobre a maior parte das acumulações descobertas ${ }^{509}$ ? A Empresa só era capaz de declarar a comercialidade em apenas três acumulações ${ }^{510}$ ? Em 31/12 do mesmo ano, a OGX reconheceria a perda (write-off) nestes blocos e nos "tubarões".

Em 15/05, a OGX arrematou 13 blocos na 11 a Rodada, por US\$ 188 milhões em BA, o segundo maior do leilão perdendo apenas para a PETR. Em 27/08, pouco mais que três meses após o leilão, a OGX anunciou que devolveria à ANP 9 dos 13 blocos adquiridos na 11a Rodada devido aos elevados investimentos e riscos exploratório.

No momento do leilão, ficamos surpresos ao ver a OGX em busca dessas áreas por causa da concentração de riscos geológicos e financeiros. A estratégia de concentração de risco provou ser muito prejudicial para a empresa. (...)

Achamos difícil acreditar que a administração não tenha conhecimento desses riscos. Acreditamos que a atual falta de liquidez e a percepção de que seria difícil o farm-out desses blocos em termos favoráveis no curto prazo (dado o prêmio oferecido) foram os principais motivos por traz do anúncio [SEQUEIRA \& FONSECA, 2013p, p. 1].

Por ironia do destino, ou efeito da dispersão da Heroína Organizacional, dos 44 blocos $^{511}$ da OGX o único que produziu óleo até hoje foi o BM-C-39 (Waikiki), onde se localiza o TBMT. O BM-C-39 foi o bloco que a OGX pagou o maior valor de BA $/ \mathrm{km}^{2}$ da 9a Rodada em novembro de 2007, o que já indicava o interesse da OGX. Foi um dos primeiros a serem perfurados e com descoberta anunciada no final de 2009 . Entretanto, a Declaração de Comercialidade do TBMT (OGX-25) com 285 mboe, foi feita (25/4/2012) mais de um ano antes da chegada programada da plataforma que garantiria o início da sua produção e o first oil só ocorreu em dezembro de 2013. Mais um indício da perda da capacidade de focar, de priorizar dos Executivos na campanha exploratória. Que por sua vez, aparentemente foi corroborada pelo AC e COAD.

Outra ironia do destino, ou efeito da dispersão da Heroína Organizacional, é que a UTE Parnaíba, outro projeto que sobrevive atualmente e talvez o mais bem-sucedido em termos de implementação, tinha pouco valor frente às dimensões do portfólio da OGX.

\footnotetext{
509 SEQUEIRA \& FONSECA [2013e].

${ }^{510}$ SEQUEIRA \& FONSECA [2013e]. Em entrevistas com alguns executivos de mercado, fomos informados que os executivos da OGX ganhavam bônus adicionais por poço perfurado.

511 O portfólio completo tinha 51 blocos, dos quais 7 eram de GN na bacia do Parnaíba.
} 
Tabela 57 - Histórico de Aquisições de Blocos Exploratórios e Anúncios de Descobertas e seus Desfechos

\begin{tabular}{|c|c|c|c|}
\hline $\begin{array}{c}\text { Data } \\
\text { Aquisição }\end{array}$ & Prospectos & Descoberta / Comentários & Desfecho \\
\hline $\begin{array}{l}\text { 9ạ } \\
\text { Rodada }\end{array}$ & BM-S-29 & $\begin{array}{l}\text { Descoberta em } 2 / 10 / 09 \\
\text { Farm-in de } 50 \% \text { no } 1 \text { T08, mais } 15 \% \text { em } 8 / 05 / 09 \text {, } \\
\text { mais } 35 \% \text { em } 9 / 11 / 10\end{array}$ & 8/11/2012: Write-off do BM-S-29 e devolução à ANP \\
\hline $\begin{array}{l}9 \underline{a} \\
\text { Rodada }\end{array}$ & $\begin{array}{l}\text { Vesúvio } \\
\text { (BM-C-43) }\end{array}$ & $\begin{array}{l}7 \text { e 14/10/09: Poderia ter de 0,5 a 1,5 bboe } \\
\text { 13/3/13: OGX pleiteou PADs para Vesúvio, } \\
\text { Veidma (BM-C-37), Tulum (BM-C-37), Itacoatiara } \\
\text { (BM-C-39), Peró/Ingá (BM-C-40) e } \\
\text { Tambora/Tupungato (BM-C-41). }\end{array}$ & $\begin{array}{l}\text { Janeiro/2013: a Empresa considerou Vesúvio baixa prioridade, } \\
\text { pois continha óleo pesado em estrutura fragmentada } \\
\text { 31/12/13: write-off de } R \$ 2,13 \text { bilhões (inclui Vesúvio, Tulum } \\
\text { (BM-C-37), Viedma (BM-C-38) e Itacoatiara (BM-C-39) } \\
\text { Fev./14: Devolução à ANP }\end{array}$ \\
\hline $\begin{array}{l}9 \underline{a} \\
\text { Rodada }\end{array}$ & $\begin{array}{l}\text { Pipeline, Fuji e llimani } \\
\text { (BM-C-41) }\end{array}$ & $\begin{array}{l}\text { De 12/11 a 22/12/09: Descobertas em Pipeline } \\
\text { (BM-C-41, OGX-2) com 1,0 a 2,0 bboe. } \\
\text { 24/3/10: Descoberta em Fuji } \\
\text { 13/3/13: OGX declara comercialidade de TBTI, } \\
\text { TBGA (Pipeline, BM-C-41) e TBAR (Fuji/llimani, } \\
\text { BM-C-41) }\end{array}$ & $\begin{array}{l}\text { 1/07/13: cancelamento do desenvolvimento de TBTI, TBAR e } \\
\text { TBGA } \\
\text { 31/12/13: write-off de R\$ 1,74 bilhões } \\
\text { Fev./14: Devolução à ANP }\end{array}$ \\
\hline $\begin{array}{l}9 \underline{a} \\
\text { Rodada }\end{array}$ & $\begin{array}{l}\text { Waikiki } \\
\text { (BM-C-39) NE Campos }\end{array}$ & $\begin{array}{l}\text { 8/12/10: descoberta. } \\
\text { 25/4/12: declaração de comercialidade de TBMT } \\
\text { (OGX-25) com } 285 \text { mboe } \\
\text { 12/12/12: OGX anuncia intenção de farm-out } \\
\text { TBMT. }\end{array}$ & $\begin{array}{l}\text { 5/12/13: first oil de TBMT. } \\
\text { 31/12/13: write-off de R\$ } 715 \text { milhões } \\
\text { Até hoje é o único poço produtor da Dommo. }\end{array}$ \\
\hline $\begin{array}{ll}9 \underline{a} \\
\text { Rodada }\end{array}$ & BM-S-57 & $\begin{array}{l}1 \text { e 16/1/12: Descoberta de óleo leve em Fortaleza } \\
\text { (OGX-63) }\end{array}$ & 13/3/13: Devolução do BM-S-57 à ANP \\
\hline
\end{tabular}




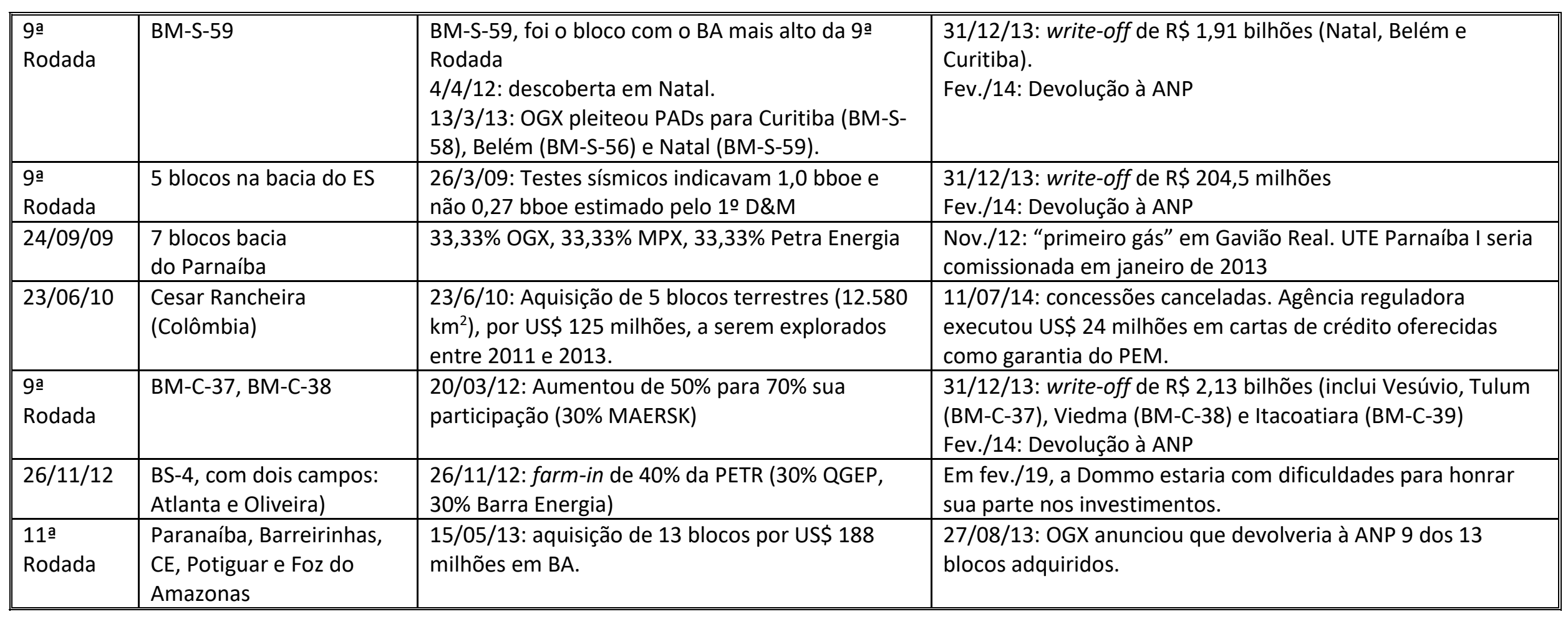




\subsection{Atrasos, Percalços e Ciclo Vicioso}

\begin{abstract}
"Se pudesse voltar atrás, não recorreria ao mercado". "O que deveria ter feito de diferente? Uma primeira questão (...) o modelo de financiamento. Hoje, se eu pudesse voltar atrás, não recorreria ao mercado de ações. Eu teria estruturado um private equity que me permitisse criar do zero $e$ desenvolver ao longo de pelo menos 10 anos a companhia (...) Nos projetos que concebi, o tempo se revelou fator de estresse vital para a reversão de expectativas sobre as companhias que ostentam resultados amplamente satisfatórios e possuem ativos valiosos." (...) Empreguei 30 mil pessoas (...) investi US\$ $4 B$ de recursos próprios nas empresas $X$ (...) Talvez tenha confiado demais em pessoas que não mereciam esta confiança, ainda que no final a responsabilidade seja toda minha."
\end{abstract}

Entrevista do AC ao JVE em 19/07/2013512.

Atrasos e percalços são naturais e esperados em uma campanha de E\&P da amplitude e complexidade que a OGX executou. Segundo o SPE-PRMS, o tempo razoável para uma reserva provada e não desenvolvida ("PUD") iniciar seu desenvolvimento é de até 5 anos, mas pode ser mais. No caso da OGX, a categoria de relativa menor incerteza do portfólio no 3‥ D\&M foi preponderantemente constituída de Recursos Contingentes, mais incertos do que PUD. Entretanto, possivelmente por receio dos efeitos depreciativos no Valor de Mercado, a reação dos Executivos e do AC aos atrasos e percalços foi mais otimismo com a produção de novos catalisadores e falta de transparência no follow-up na Agenda de Catalisadores.

$O$ desgaste da credibilidade dos Executivos e AC não ocorreu do dia para noite. Foi um longo processo que pode ter começado em 11/01/2010 quando a Empresa anunciou que, frente às descobertas em Campos (Vesúvio, Pipeline, Waimea e Kilawea), atualizou as metas do ramp-up para cima em $83 \%$. No auge da tensão com os resultados de TBAZ, em junho de 2012, e poucas semanas antes de sua substituição na presidência da Empresa, Paulo Mendonça declarou que não daria mais informações sobre a produção de Waimea até a declaração de comercialidade e a colocação de quatro poços produtores. Em sua opinião, a OGX enfrenta as "dores" de crescer sob o escrutínio do mercado financeiro. Desabafou:

Quando se expõe o patrimônio ao mercado e ele comprou uma parte, você está exposto a que ele julgue, compre, venda e faça o que é melhor. É um termômetro, mas nos castiga muito ${ }^{513}$.

512 BATISTA, E., "Se pudesse voltar atrás, não recorreria ao mercado". Disponível em: https://www.valor.com.br/empresas/3203332/se-pudesse-voltar-atras-nao-recorreria-ao-mercado

513 SCHÜFFNER, C., “OGX já produz, mas ainda apanha do mercado", in: JVE, 06/06/2012, versão online. Disponível em: https://www.valor.com.br/u/2693874. Acesso em 5/12/2018. 
Esta seção analisa os atrasos e percalços das metas operacionais e financeiras importantes ("Metas Estratégicas") que a própria Empresa definiu e não conseguiu realizar: o de-risking do portfólio através da reclassificação de Recursos Prospectivos para Recursos Contingentes; o farm-out de prospectos em Campos; ramp-up da produção; fluxos de Waimea; e a put do AC. Estes atrasos e percalços produziram três "Eventos Críticos de Reputação": pontos de inflexão na percepção de valor dos Analistas e do mercado, acarretando na perda de credibilidade dos Executivos e do AC. Foram eles:

i. 04/11/2010: anúncio do adiamento do farm-out;

ii. 15/04/2011: publicação do 3 D\&M;

iii. 26/06/2012: anúncio da vazão ideal de TBAZ;

Soma-se a estes três Eventos Críticos de Reputação um quarto constituído por decisões controversas do AC que foram interpretadas como indícios de conflitos de interesse com os acionistas minoritários:

iv. 11/06 a 9/09/2013: começou em 11/06/13 com a venda pequena parte (R\$ 70,5 milhões) das ações do AC na OGX, reforçado pela resignação dos três conselheiros independentes do $\operatorname{COAD}(21 / 06)$, pelo anúncio de indenizações (US\$ 449 milhões) à OSX geradas pela inviabilidade de TBAZ, TBTI, TBAR e TBGA (1/07) e culminou com a recusa a honrar $10 \%$ da put (9/09).

A seguir, a presente seção descreve sucintamente e analisa os precedentes e as reações às Metas Estratégicas e aos Eventos Críticos de Reputação. A descrição completa dos eventos está no capítulo 3.

\section{0: De-risking, Ramp-up, "Megamonetização"}

Logo no início de 2010, portanto menos de seis meses após o início de sua campanha exploratória, a OGX atualizou seu plano de negócios publicado no IPO, o que implicava na confirmação do de-risking do portfólio e novas captações de recursos. Ao fazê-lo, a OGX criou Metas Estratégicas que se tornariam focais no monitoramento da Agenda de Catalisadores.

Em 11/01/2010, quando a Empresa anunciou que, frente às descobertas no BM-S-29, em Vesúvio, Pipeline, Waimea e Kilawea poderia rever o ramp-up para cima. Um rampup poderia aumentar o PA de alguns Analistas em $10 \%{ }^{514}$. Duas semanas depois (27/01), a Empresa aumentou metas de produção para 2015 em 83\% (de 398 para 730 kboepd) e antecipou o first oil para o início de 2011 (20 kboed contra 5 kboed previstos anteriormente) em Waimea. Eram metas muito agressivas, considerando que o Brasil todo produziu 1,997 mboe em janeiro de 2010, que correspondia a uma média simples de 66,6 kboed. O aumento do fluxo projetado para Waimea de 5 para 20 kboed seria uma sinalização ao mercado que a OGX e os Executivos pagariam caro no 2T2012.

${ }^{514}$ KOVARSKY, MENDES \& ARAUJO [2010b]. 
O ramp-up implicaria na tentativa de farm-out para acelerar o desenvolvimento dos blocos em Campos ${ }^{515}$. Aos múltiplos da época, o farm-out poderia ocorrer a US\$ 10,0/boe, o que serviria como um importante "read-across" para o portfólio. A entrevista do AC em abril (15/04) potencializou as expectativas para o de-risking $(10,0$ bboe) e o farm-out, que poderia render US\$ 20 a 30 bilhões à OGX ("megamonetização"). Entre 8/01 a 15/04, a OGXP3 se valorizou em 26,9\% (de R\$ 18,05 em $8 / 01$ a $\mathrm{R} \$ 22,90$ em 18/10).

Vale notar que, em meio à expectativa do farm-out, o OTPP, que participou da origem e do private placement da OGX em 2007, já havia começado a reduzir gradualmente sua participação na OGX de 12,2\% (IPO) para 10,7\% em 23/09/09, 6,3\% em 30/06/10 até finalmente reduzir sua posição em $29 / 09 / 2010$ para níveis abaixo de $5 \%$, dias antes do pico histórico da OGXP3 em 15/10/10.

A expectativa quanto ao farm-out parecia ter desviado a atenção dos investidores para as descobertas de 2009, especialmente em Waimea, cujo início de produção (20 kbpd) foi adiado do 1T para o 2T2011.

Antes esperada para outubro, os Executivos, em 4/11, estimavam que ofarm-out estaria concluído no 1T2011. O atraso não era necessariamente era negativo, uma vez que é comum em transações deste tipo, especialmente se o objetivo for maximizar o valor da venda. Além disso, a Empresa detinha boa reserva de caixa e tinha tempo para negociar. Entretanto, como o mercado estava focado no farm-out, o atraso não seria bem recebido ${ }^{516}$. A OGXP3 sofreu desvalorização de 19,7\% em 33 pregões: de R\$ 23,20 em 4/11 para $\mathrm{R} \$ 18,63$ em 21/12. O adiamento pode ser considerado o primeiro Evento Crítico de Reputação.

\footnotetext{
515 LEITE \& CANHEU [2010a].

${ }^{516}$ SEQUEIRA [2010d] e KOVARSKY, MENDES \& ARAUJO [2010p].
} 


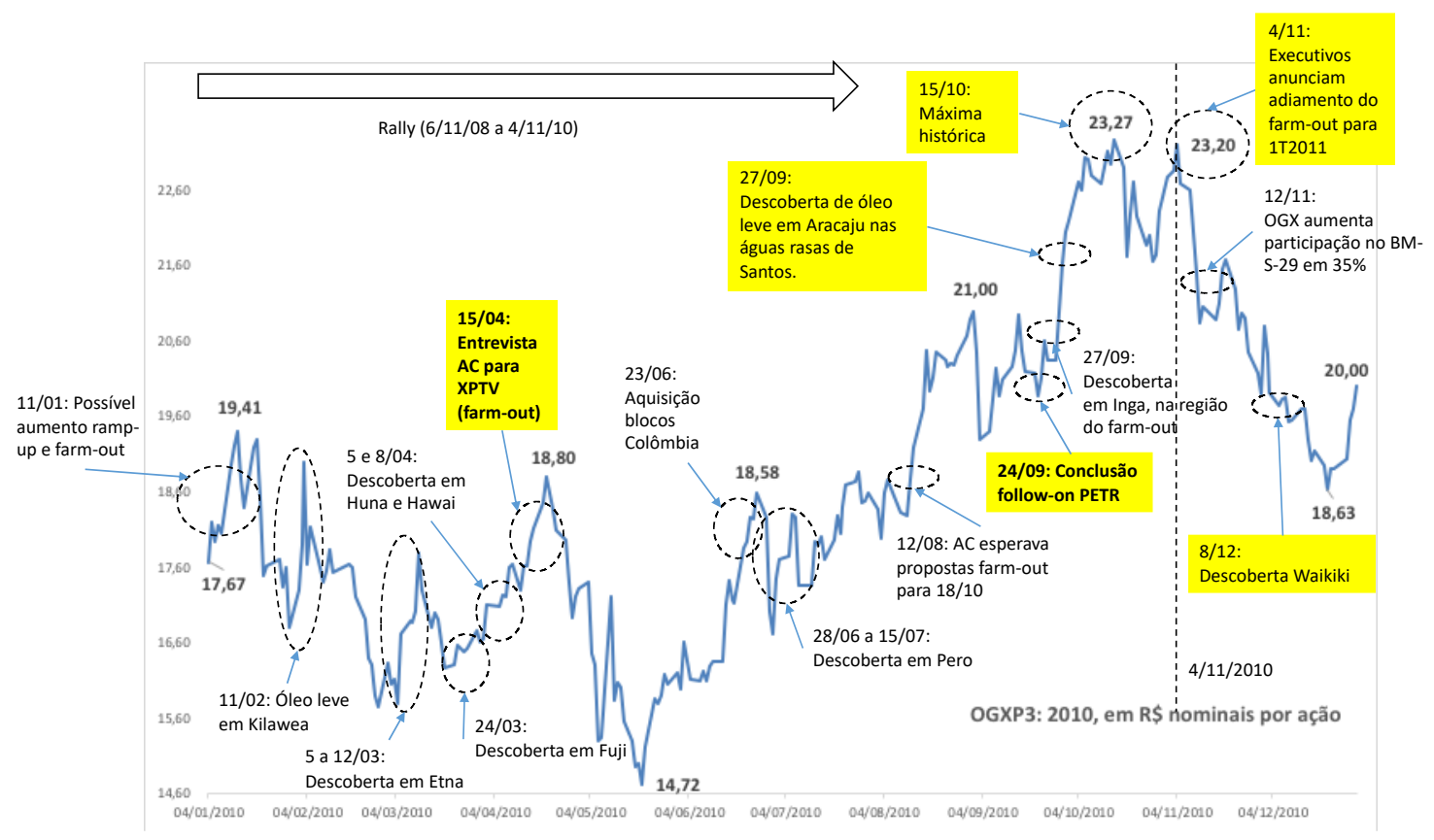

Ainda em 2010, enquanto o mercado aguardava a concretização do farm-out, começaram os sinais de desconforto dos Analistas e investidores com a falta de informações sobre os resultados da campanha exploratória. Foram externados também desconfortos com o "excesso de otimismo" do guidance. Após 8 descobertas anunciadas no ano (Kilawea, Etna, Fuji, Hawaii, Huna, Pero, Inga, em Campos, e Aracaju em Santos), alguns Analistas buscavam notícias sobre estimativas de volumes da campanha em andamento, especialmente em Waimea. Alguns Analistas consideraram os movimentos da OGXP3 como "injustificados", "ruídos" gerados pelas expectativas do farm-out, mas que os fundamentos da OGX eram sólidos e haveria um investidor chinês, "particularmente, faminto" pelo farm-out. Portanto, os investidores "não deveriam prestar atenção ao ruído..." ${ }^{517}$. Outro Analista, entretanto, ironizou: "falta de notícia é má notícia?" 518

Permanecemos positivos, mas nós amaríamos ter mais apoio na avaliação (...). Daqui para frente, nós acreditamos que um maior volume de revelações [disclosure] é necessário para apoiar a forte apreciação [rally]. Isso ou o farm out [GATTASS, G., FONSECA, R. \& VALENTE, 2010a, p. 1].

(...) Entretanto, com a ação tendo se valorizado significativamente, $\boldsymbol{e}$ o valor por barril descoberto ter ultrapassado o intervalo 6-8/boe, dentro do qual nos sentimos confortáveis, as ações da OGX parecem já estar precificando mais do que já se tornou público. [grifo nosso]

\footnotetext{
${ }^{517}$ AUDI \& FALANGA NETO, 2010b, p. 1.

518 SEQUEIRA [2010d].
} 
O que nos deixa com a questão... Qual será o vetor [driver] marginal? Um deslocamento para cima do valor de consenso por barril descoberto? Ou um aumento no número de barris encontrados? Talvez, ambos.

No presente, nós acreditamos que os investidores estão assumindo que a OGX já encontrou mais [barris]. Nós tendemos acreditar que isso seja verdade. A OGX tem, de fato, 6 poços que ainda não tiveram seus volumes revelados.

Mas no fundo, nós nos sentiríamos simplesmente mais confortáveis se estes volumes estivem sido relevados ao mercado. O histórico da OGX com os investidores é relativamente curto, e nós preferiríamos um ganho sólido no consenso de valor que reduzir o nível de confiança nos múltiplos [GATTASS, FONSECA \& VALENTE, 2010a, p. 2].

Outro Analista demonstrou preocupação com o comportamento do mercado que parecia esperar apenas pelo farm-out e desconsiderar outras conquistas na campanha exploratória:

(...) Embora a transação seja provavelmente um desenvolvimento positivo para a empresa, o farm-out não é o pilar da estória da OGX. Nós estamos preocupados que a performance da ação se torne função das notícias sobre o farm-out, em parte por causa do marketing intensivo dos executivos [da empresa] sobre este tema. $O$ mercado está ignorando um programa exploratório bem-sucedido até agora e o fato de não haver outros catalisadores para a ação no curto/médio prazo, e está focando apenas no processo de farm-out. [SEQUEIRA, 2010d, p.1].

Em 12/11, após atrasos e problemas técnicos que levaram os investidores a especularem que o BM-S-29 se tratava de um poço seco, a OGX comprou o restante da participação da MAERSK (35\%). O BM-S-29 se destacava no portfólio original do IPO: foi o único bloco não comprado a 9a Rodada; um dos primeiros blocos perfurados na campanha da OGX; e onde o 20 D\&M estimava ter 0,305 bboe. O valor pago no farm-in não foi revelado, mas provavelmente teria sido pelo valor do investimento restante necessário (capex carry agreement). Alguns Analistas questionaram a aquisição: "uma boa decisão estratégica ou jogo?"519 Afinal, por que a MAERSK venderia, de graça, sua participação em um bloco promissor?

A OGX encerraria o ano de $2010 \mathrm{com}$ a descoberta de Waikiki, no bloco BM-C-39, por quem foi pago o maior valor de $\mathrm{BA} / \mathrm{km}^{2}$ da 9a Rodada. Pela primeira vez, Analistas mencionam a possibilidade deste anúncio ser considerado uma notícia ruim, pois a Empresa estaria sendo criticada por "excesso de otimismo". Vale notar que, apesar desta menção, estes Analistas discordaram desta interpretação negativa e consideraram o anúncio positivo ${ }^{520}$. De fato, ao longo de 2010 foram 36 FRs publicados, quase todos

\footnotetext{
${ }^{519}$ AUDI \& FALANGA NETO, 2010c, p. 1.

520 KOVARSKY, MENDES \& ARAUJO [2010r].
} 
sobre novas descobertas de hidrocarbonetos. Posteriormente, foi em Waikiki que a OGX desenvolveu o prospecto de TBMT, produtivo até hoje.

A percepção de otimismo excessivo que pode ter motivado a 2a Correção Depreciativa e não era infundada. Além dos atrasos no farm-out, faltavam atualizações sobre outros catalisadores: o BM-S-29 e Waimea, cuja produção deveria começar no 1T2011 e só começaria em 2012. Estes atrasos podem ter gerado as primeiras fraturas na credibilidade do guidance da OGX.

No início de fevereiro de 2011 (9/2), o farm-out ainda não havia se concretizado, mas o primeiro poço de produção em Waimea gerou o "impressionante" fluxo de 40 kbpd/poço de óleo leve: "um marco na história da Companhia". A expectativa era manter a média de $20 \mathrm{kbpd}$, devido a limitações dos equipamentos. Alguns Analistas ${ }^{521}$ consideraram os resultados de Waimea especialmente interessantes, pois se tratava de uma descoberta na camada Albiana de Waimea, que geologicamente se comparava à Jabuti, o campo de produção mais elevada da PETR até então ( $28 \mathrm{kbpd}$ ). Jabuti teria sido uma surpresa tão significativa para a PETR que a fez retomar seu interesse em Campos. Da mesma maneira que Jabuti representava um caso de sucesso para PETR, Waimea poderia ter a mesma importância para a OGX.

Alguns Analistas explicitamente relataram que, "nos últimos meses, com a desvalorização das ações da OGX, a credibilidade do grupo [EBX] estava sendo cada vez mais questionada, e que isso poderia aumentar a probabilidade do anúncio do farmout ${ }^{\prime \prime 22}$. Se o farm-out não fosse efetivado, para manter o guidance otimista, a OGX precisaria substituí-lo por novos e poderosos catalisadores.

Outros Analistas ${ }^{523}$ deram pouca ênfase ao farm-out, pois consideravam como principal catalisador o 3을 DM, aguardado para o 1T2011. O relatório seria o principal vetor para a confiança dos investidores, que questionavam o real potencial das reservas da OGX.

Se nossas expectativas sobre o relatório da D\&M estiverem corretas, três anos após o IPO, quando o portfólio da OGX era estimado em 4,8 bboe em recursos prospectivos, a empresa apresentará ao mercado cerca de 4 bboe em recursos contingentes; uma conquista considerável [KOVARSKY \& MENDES, 2011b, p. 1]. (17/3)

Em suma:

\begin{abstract}
"o mercado deveria ser mais paciente com a OGX (...) as ações deveriam responder mais às notícias relacionadas com a produção. Enquanto isso, nós pensamos que os executivos da OGX precisam entender que o mercado não está tão receptivo à promessas como quanto estava no passado e muito menos tolerante quando estas promessas não são cumpridas, especialmente em uma empresa préoperacional [SEQUEIRA \& FONSECA, 2011a, p. 1].
\end{abstract}

\footnotetext{
${ }^{521}$ Por exemplo, GATTASS \& FONSECA [2011a]; DARIPA [2011a].

522 AUDI \& FALANGA NETO, 2011a, p. 1.

${ }^{523}$ Por exemplo, GATTASS \& FONSECA [2011a].
} 
Em 15/04, o segundo Evento Crítico de Reputação se materializou: o 3 D\&M se tornou público e desapontou. Foi um "choque de realidade" (reality check) ${ }^{524}$. Analistas questionaram quatro aspectos do 30 D\&M. Primeiro, a estimativa de Recursos Contingentes (2C) para Campos ficou em 0,7 bboe, bem abaixo da média de 4,0 bboe do intervalo esperado (entre 2,6 e 5,5 bboe), anunciados pela OGX ao longo de 2010. Em 1C, os Recursos Contingentes somariam 0,1 bboe. Essas estimativas comprometeriam a capacidade da OGX negociar termos favoráveis (ou seja, um EV/boe acima do CAPEX/boe) em um eventual farm-out ${ }^{525}$. A partir deste momento, o farm-out se tornou um catalisador secundário: "(...) o processo de farm-out foi para o banco de $\operatorname{traz}(\ldots)^{\prime \prime 526}$.

A segunda questão foi o significado de um conceito não previsto na taxonomia da SPEPRMS: "Recursos Delineados". Tratava-se de uma classificação intermediária entre Recursos Prospectivos e Contingentes ${ }^{527}$ e se referiam aos resultados de 15 poços adicionais perfurados desde $31 / 12 / 2010$. O novo conceito "trouxe mais confusão ao mercado do que o ajudou" 528 e o mercado não reagiu bem ${ }^{529}$. Questionados sobre o novo conceito, os Executivos orientaram Analistas a somar os Recursos Delineados (1,3 bboe) aos Recursos Contingentes (3C, de 3,0 bboe), totalizando 4,3 bboe.

Mesmo seguindo este guidance, a terceira questão era se esse volume (4,3 bboe) sustentaria as metas de produção. Além disso, os possíveis atrasos na entrega de embarcações necessárias (9 FPSOs e 8 WHPs) pela OSX reforçavam as dúvidas sobre a viabilidade da meta 2015. Até então, a OGX havia assegurado apenas 5 FPSOs e 2 WHPs $^{530}$ encomendadas a OSX. Mas a OGX insistiu na viabilidade da meta de produzir 730 kbpd em 2015.

A quarta questão foi por que a D\&M não detalhou as estimativas por poço/bloco, como fizera nos seus dois relatórios anteriores. Os Executivos também não forneceram mais informações e avisaram os Analistas que não poderiam questionar a D\&M diretamente, pois havia cláusula de confidencialidade entre a D\&M e a OGX. A Empresa também não elucidou as premissas para CAPEX e OPEX.

Na segunda-feira, 18/4, após a publicação do 3은 off. Entre 15/4 a 18/5, a Empresa perderia quase um terço de sua capitalização de mercado (de $R \$ 63,3$ bilhões em 15/4 para $R \$ 44,8$ bilhões em 18/5). Apesar da significativa desvalorização, alguns Analistas relutaram em reduzir suas estimativas de

\footnotetext{
524 KOVARSKY \& MENDES, 2011h, p. 1.

525 Por exemplo, AUDI \& FALANGA NETO [2011b].

526 DARIPA, 2011b, p. 1.

527 Por exemplo, KOVARSKY \& MENDES [2011c].

528 KOVARSKY \& MENDES, 2011g, p.1.

${ }^{529}$ KOVARSKY \& MENDES, 2011g, p.3.

${ }^{530}$ KOVARSKY \& MENDES, $2011 \mathrm{l}, \mathrm{p} .3$.
} 
PAs, considerando a desvalorização "exagerada"531, mas outros o fizeram ${ }^{532}$. Mesmos aqueles que relutaram em rever seus PAs acabaram por fazê-lo algumas semanas depois $^{533}$.

Apesar da nossa visão positiva sobre os recursos e a habilidade da OGX em capturar valor com estas descobertas, nós não acreditamos que o potencial se tornará visível nos relatórios [da D\&M] nos próximos 18 meses e nós tememos que a habilidade da OGX em orientar [os investidores] pode ter sido maculada [GATTASS \& FONSECA, 2011b, p. 3].

A Empresa precisaria converter mais Recursos Prospectivos em Contingentes. $O$ mercado precisava acreditar que seria factível obter 4,3 bboe em Recursos Contingentes. Os resultados de Waimea, Pipeline e Wakiki eram cruciais. Os Executivos teriam de reconquistar a confiança do mercado ${ }^{534}$ e para tanto precisariam:

(...) i) anunciar os resultados dos poços em Pipeline e Waikiki, que seriam cruciais para aumentar a taxa de recuperação por traz das estimativas 2C; ii) prover orientação ("guidance") transparente $e$ razoável para o plano de negócio de 4,1 bboe, incluindo capex, opex, a curva de produção; e o cronograma de entregas da OSX; e, iii) efetivamente iniciar a produção $0^{535}$ [KOVARSKY \& MENDES, 2011g, p. 1].

Em maio (9), Analistas já demonstravam preocupações com o caixa da Empresa frente aos investimentos previstos. Alguns Analistas ${ }^{536}$ estimavam que a OGX precisasse captar cerca de US\$2,0 bilhões para completar o plano de negócio do portfólio atual (excluindo novas aquisições). De fato, poucas semanas depois, a Empresa captou US\$2,56 bilhões em Senior Unsecured Notes com vencimento bullet em 7 anos. Após a captação, a OGX encerraria o 1S2011 com muito caixa ("plenty of cash" 537).

Ao longo de maio e junho, a Empresa ajustou suas premissas de OPEX, CAPEX e produção, mas reiterou a meta de $730 \mathrm{kbpd}$ em 2015, insistindo na premissa de 4,1 bboe em Campos (Contingentes 3C mais Delineados). Em julho, Analistas ${ }^{538}$ pontuaram que o alto índice de nacionalização exigido nos equipamentos utilizados no Brasil poderia atrasar a produção além de gerar custos mais elevados.

Apesar da desvalorização, a OGX tinha um EV de US\$ 26 bilhões, sem nenhuma produção ou reservas. Se comparada com outras empresas, já produtivas e com

\footnotetext{
531 KOVARSKY \& MENDES, 2011i, p.3.

532 Por exemplo, AUDI \& FALANGA NETO [2011b]; GATTASS \& FONSECA [2011b]; DARIPA [2011b]; SEQUEIRA \& FONSECA [2011d].

533 Por exemplo, KOVARSKY \& MENDES [2011h].

534 DARIPA, 2011c, p. 1.

535 AUDI \& FALANGA NETO [2011e] explicaram que o TLD em Waimea deveria começar em setembro/outubro de 2011 e a Declaração de Comercialidade deveria ser enviada à ANP até 1T12. A produção em 2012 seria, em média, 50-60 kbpd, com 3 poços. A OGX teria até, no máximo, o 1T13 para informar a ANP seus planos para desenvolver os blocos de Campos.

${ }^{536}$ AUDI \& FALANGA NETO [2011e].

537 GATTASS \& FONSECA, 2011d, p. 2.

538 SEQUEIRA \& FONSECA [2011f].
} 
reservas, e considerando a meta de produção da OGX para 2013 (165 kbpd), seu múltiplo seria de US\$157,0/kboe, contra US\$ 98,4/kboe da PETR ${ }^{539}$.

Em agosto (10), os Executivos revelaram mais e melhores informações sobre os resultados das perfurações (Waimea, Waikiki, Pipeline e outros) e os preparativos para o primeiro óleo (Waimea), o que causou boa impressão em alguns Analistas ${ }^{540}$. Curiosamente, em Vesúvio, onde a OGX estimou haver 0,5 a 1,5 bboe, não foram feitas novas perfurações ou testes. Um poço seco perfurado mais recentemente levantou dúvidas para alguns Analistas sobre a relevância de Vesúvio para os recursos $1 C, 2 C$ e $3 C$ da OGX541.

Em setembro (11), em aparente contraponto com outros Analistas, o MS reduziu seu PA em 30,4\% ${ }^{542}$. Em abril (18), após a divulgação do 3으 D\&M, o MS já havia reduzido seu PA de $\mathrm{R} \$ 27$ para $\mathrm{R} \$ 23$ e agora para $\mathrm{R} \$ 16$, uma redução de $40,7 \%$ em menos de 5 meses. A redução ocorreu "após revisar as informações disponíveis e checa-las com consultores especializados em O\&G ('consultores externos e geólogos de outras empresas, etc.')".

No início de outubro (3), o SAN, também reduziu seu PA para $\mathrm{R} \$ 21^{543}$. Em abril, antes do 3o D\&M, seu PA era de R\$33, ou seja, uma redução de 36,4\% em menos de 6 meses. Apesar da redução no PA, assim como o MS, o SAN recomendava seus clientes a manter suas ações da OGX, pois seu potencial era diferenciado em relação aos peers. Ainda no início de outubro o $A C$ anunciou que não perseguiria mais o farm-out no curto prazo. Se a intenção do AC foi "trocar" o farm-out pela captação pelo 10 Note, o mercado não gostou. Não era apenas menos dinheiro, mas o sinal para o de-risking.

\footnotetext{
539 GATTASS \& FONSECA, 2011c, p. 11.

540 GATTASS \& FONSECA [2011d].

${ }^{541}$ GATTASS \& FONSECA, 2011c, p. 23.

542 DARIPA [2011d].

${ }^{543}$ AUDI \& FALANGA NETO [2011i].
} 
OGXP3: 2011, em R\$ nominais por ação
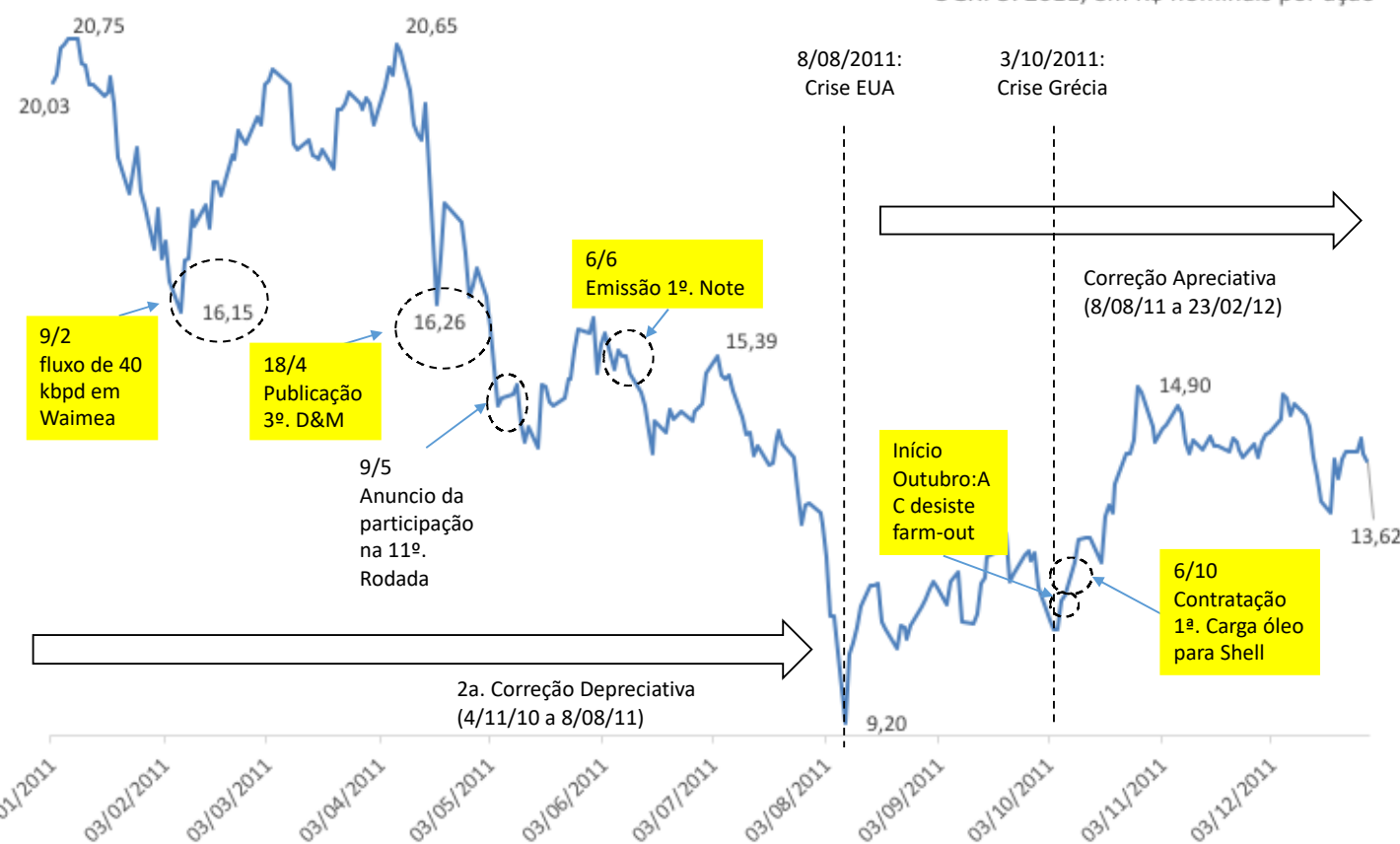

O tão esperado first oil de Waimea, anunciado originalmente para setembro sofreu atrasos por várias razões: condições climáticas, atrasos na entrega e/ou no licenciamento da FPSO. Em seu último Comunicado ao Mercado do Ano (14/12/2011), a OGX anunciou que a FPSO OSX-1 estaria preparada para iniciar a produção de Waimea (OGX-26HP) em 23/01/2012. Apesar dos atrasos em Waimea, alguns Analistas mantiveram sua recomendação de "outperform". Na Amostra da TR, ao longo de todo o ano de 2011, o mercado se tornou mais pessimista do que a mediana dos Analistas. A partir de 5/5, o mercado precificou a OGX abaixo do PA dos Analistas mais pessimistas. 
Gráfico 77 - Amostra da TR: Evolução da Mediana, Máximo e Mínimo do PA em 2011 (em R\$̦/ação, pré-split)

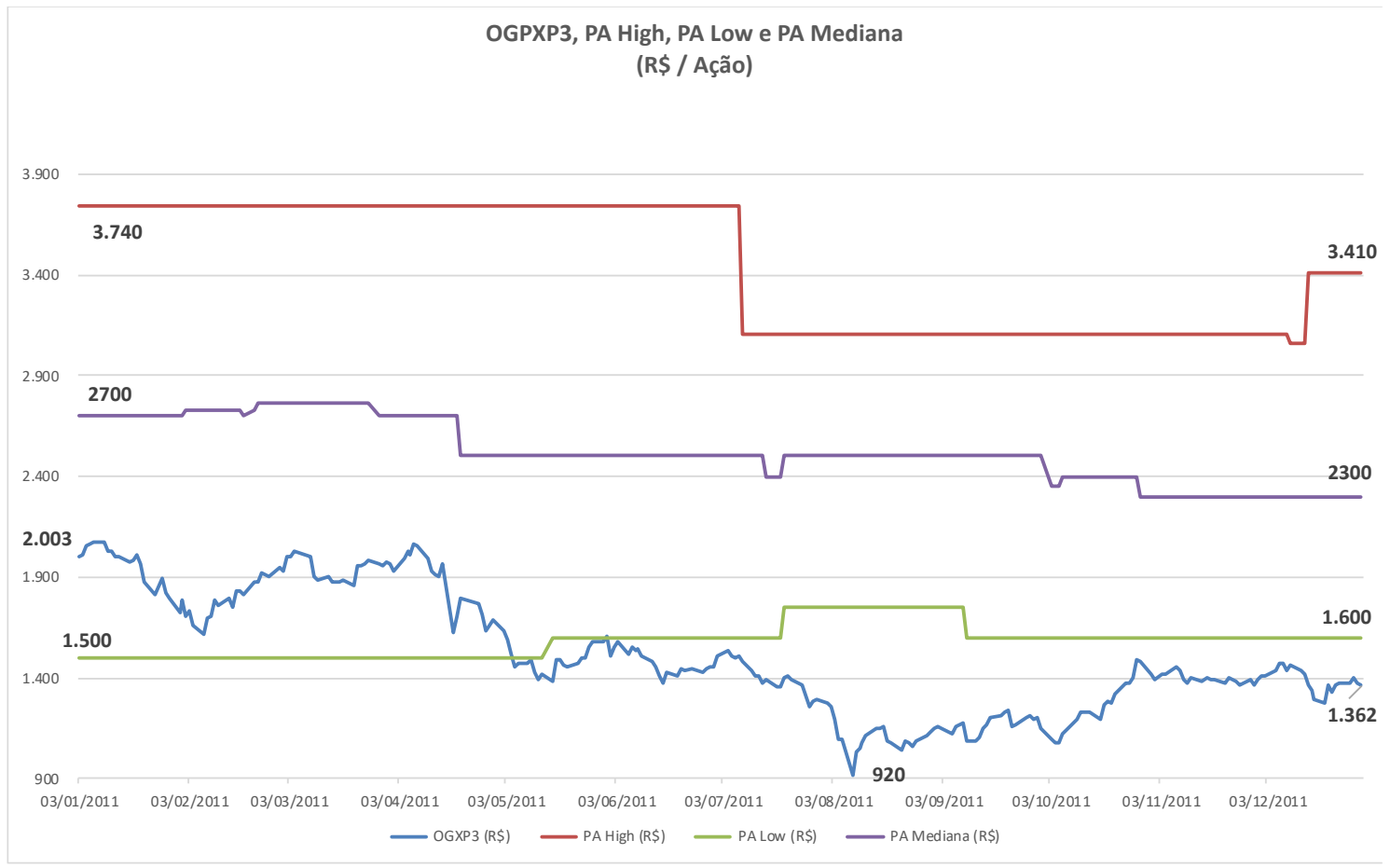

2012 e 2013: Write-offs, Decepção com TBAZ e a Busca pela Salvação

Em 30/01, a OGX se tornou operacional em apenas dois anos após as descobertas. Alguns Analistas projetavam que a Empresa poderia terminar o ano com lucro ${ }^{544}$. Curiosamente, o tão esperado "primeiro óleo" de TBAZ foi divulgado na forma de CM e não de FR.

Os anúncios de descobertas continuaram, em especial a de óleo leve em Fortaleza (OGX63), no pré-sal em Santos em 1/02, que poderia ser "game-changer". Mas, desta vez, alguns Analistas recomendaram aguardar as confirmações antes de alterar o PA ${ }^{545}$.

Em 7/3, a OGX, que não havia publicado o 4 D\&M, o fez, parcialmente, na apresentação a investidores interessados no bônus perpétuo da OSX. Na apresentação, os recursos de Waikiki (que seria explorado pela OSX-3) foram estimados em 212 mboe (2C), 50 mboe a menos do que o mercado estimava ${ }^{546}$. Entre 7/03 e 12/03, OGXP3 se desvalorizou em $2,6 \%$.

Em março (20), a OGX aumentou sua participação de $50 \%$ para $70 \%$ nos blocos BM-C-37 e BM-C38 devido "ao excelente potencial das águas rasas" de Campos. Em contraste com o farm-in do BM-S-29, executado de graça à OGX em 2009 e 2010, o farm-in do BM-

\footnotetext{
${ }^{544}$ KOVARSKY \& MENDES, 2012c, p. 1

545 KOVARSKY \& MENDES, 2012d, p. 1, e KOVARSKY \& MENDES, 2012g, p. 2. AUDI \& FALANGA NETO [2012b] também recomendaram cautela aos investidores.

${ }^{546}$ Disponível em: https://www.valor.com.br/u/2558246.
} 
C-37 e BM-C38 envolveria um pagamento à vista além da assunção do PEM. Valor este que seria um indicador "de mercado" para o de-risking dos blocos. Entretanto, a prometida divulgação do valor foi sendo protelada e acabou nunca acontecendo.

Ainda em março (23) o anúncio do primeiro write-off: $\mathrm{R} \$ 196$ milhões referentes a quatros poços (3 em Santos e 1 em Campos), três na Parnaíba e do total das despesas exploratórias no PA-MA.

Em abril (4), a média do primeiro poço do TBAZ em fevereiro foi de $11,0 \mathrm{kbpd}$. Poucos dias depois, o IBBA reduziu seu PA de $\mathrm{R} \$ 25,9$ para $\mathrm{R} \$ 21,2$ por não acreditar mais que as metas de produção da OGX eram factíveis ${ }^{547}$. A Empresa se aproximava do terceiro Evento Crítico de Reputação ao iniciar a produção após perfurar 78 poços desde o início de sua campanha exploratória, com a notável POS de 90\%. Enquanto a OGX insistia em $730 \mathrm{kbpd}$ em 2015, o IBBA que já havia reduzido sua projeção para $550 \mathrm{kbpd}$, agora considerava $345 \mathrm{kbpd}$ (12 kbpd/poço em Waimea). A estimativa considerava que apenas Campos estaria produzindo com 5 FPSOs.

Em maio (15), durante conferência com os Executivos, os Analistas voltaram a questionar a OGX sobre Vesúvio: "onde está Vesúvio"? A soma dos volumes de Waimea (110) e Waikiki (285) declarados à ANP ficava aquém dos 700 mboe $2 \mathrm{C}$ estimados pelo 3o D\&M, o que causou desconforto entre os Analistas. Em junho (21), o SAN, reduziu seu PA em 40,5\% em relação a sua última revisão de 8 meses atrás (de R\$ 21,0 em $3 / 10 / 2011$, para $\mathrm{R} \$ 12,5)^{548}$. O novo PA correspondia a $37,9 \%$ do valor do PA no início da cobertura ( $R \$ 33,0$ em 26/10/2010).

Em 26/06, o terceiro Evento Crítico de Reputação se materializou: os Executivos declararam que após o término de cinco meses de TLD, a vazão ideal de $5 \mathrm{kbpd}$ por poço para os dois primeiros poços, bem abaixo dos $20 \mathrm{kbpd}$ anunciado pela OGX em setembro de 2011. O valor da OGXP3 despencou 39,7\% em dois dias ( $R \$ 8,37$ em 26/6 para $R \$$ 5,05 em 28/6). Em relação ao seu último pico em 19/6/2012 (R\$ 10,20), sete pregões antes, a OGXP3 havia perdido 50,5\% de seu valor. "O otimismo dos executivos da OGX, mais uma vez, atuou contra a OGX"549. Em 28/06, já com o novo CEO, duas questões permaneciam:

(1) As reservas de caixa da OGX são suficientes para suportar as campanhas exploratórias e de desenvolvimento, ou a empresa precisará recorrer ao mercado de capitais? (2) Quão baixo o valor da OGXP3 pode chegar? [AUDI \& FALANGA NETO, 2012k, p. 1].

A crise de confiança estava instalada:

Os investidores não têm confiança alguma em nenhuma estimativa que a OGX fornece, negando a capacidade dos executivos em estimar

\footnotetext{
547 KOVARSKY \& MENDES [2012g].

548 AUDI \& FALANGA NETO [2012i] reduziram o volume de Campos de 3,7 para 2,3 bboe (0,5 bboe Waimea, 0,6 Waikiki, 0,7 Pipeline, 0,5 Vesúvio) e 0,65 bboe em Paranaíba. Nenhum volume foi considerado para PA-MA, ES e Colômbia. WACC real de 10,5\%

${ }^{549}$ SEQUEIRA \& FONSECA, 2012e, p. 1.
} 
e divulgar qualquer sucesso [GATTASS, CARVALHO \& VALDIZAN, 2012a, p. 7].

Quando OGXP3 chegou a $\mathrm{R} \$ 4,63$ (perda de 66,3\% em relação a 2/01), o AC outorgou à OGX uma put ao preço de exercício de $\mathrm{R} \$ 6,30$ e limite máximo de US\$ 1,0 bilhão. A put poderia ser exercida a qualquer momento até 30 de abril de 2014. O IBBA ${ }^{550}$ interpretou que a put serviria para reduzir as preocupações dos investidores em relação à liquidez financeira da Empresa, gerada pelas reduções consecutivas das suas metas de produção. $\mathrm{Na}$ época, os Analistas do IBBA e SAN ${ }^{551}$ se perguntavam por que a OGX ainda não havia encomendado a OSX-4.

Em novembro (8), ainda não havia notícias sobre as perfurações em Fortaleza e foram reconhecidas perdas de $\mathrm{R} \$ 213,0$ milhões no BM-S-29, cuja perfuração começou em agosto de 2009, portanto há 3 anos:

Não há maneira de minimizar a necessidade do auditor independente da Empresa fornecer um quadro mais detalhado sobre os ativos. Mais de US\$ 4 bilhões foram gastos desde dezembro de 2010 e nós ainda não sabemos o que foi encontrado! [GATTASS \& CARVALHO, 2012b, p. 2].

Gráfico 78 - Evolução do Valor de Mercado e Eventos Importantes no Guidance em 2012

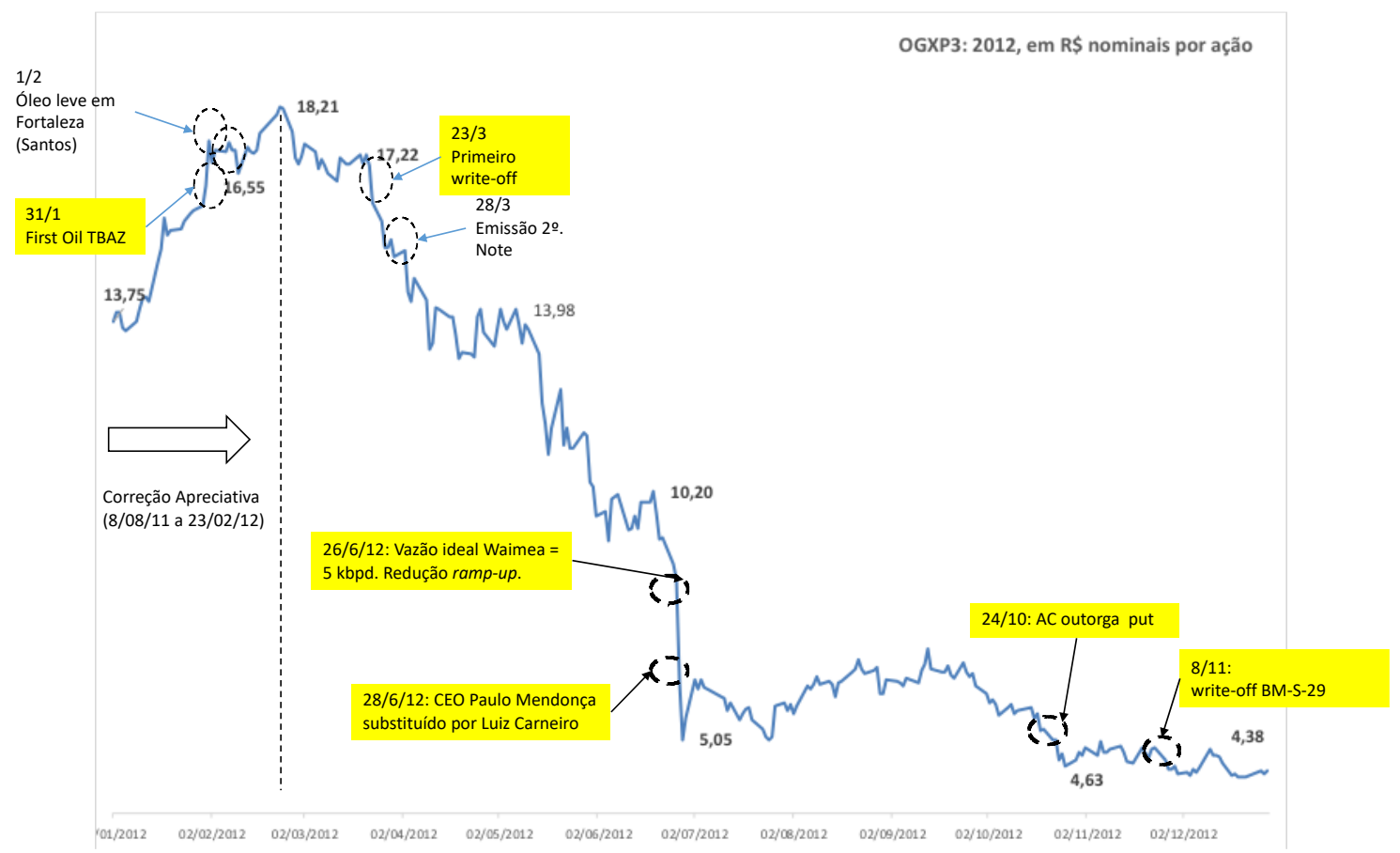

550 KOVARSKY \& MENDES [2012p].

551 KOVARSKY \& MENDES [2012p]. O covenant estipulava um limite de Dívida/EBITDA de 3,5x. Considerando o preço do Brent em US\$ 90/barril, uma produção de $90 \mathrm{kbpd}$, ao fim de 2014, a dívida total somaria US\$ 4 bilhões para um EBITDA de US\$ 0,7 bilhão. 
Logo no início de 2013 começou uma intensa busca pela salvação da OGX e outras empresas do Grupo X. Em fevereiro de 2013, o JVE relatou que a OGX negociava o farmout de TBMT com a Petronas. A OGXP3 se valorizou em $11,8 \%$ no pregão. No mês seguinte (6/3), a EBX e o BTG assinaram um contratado de "cooperação estratégica de negócios", que poderia resultar na venda da MPX, e por consequência da OGX Maranhão. O AC também apelou para a presidente da república (8/3) interceder junto à PETR para a apoiar a LLX no Porto de Açu.

Ao longo do 1S2013, as declinantes médias dos fluxos de TBAZ eram divulgadas pela ANP com dois meses de atraso em relação à data de anúncio, chegando a 1,8 kbpd em abril, muito aquém da média de 20 kbpd estimada inicialmente.

O acordo de farm-out do TBMT com a Petronas foi assinado em 8/5, porém os termos dos pagamentos só foram revelados em 12/5. Neste dia, a OGX anunciou também os resultados do 1T13, que incluíam: $\mathrm{R} \$ 1,2$ bilhão em baixas de ativos (poços subcomerciais, dos quais $\mathrm{R} \$ 952$ milhões referiam-se aos blocos devolvidos para a ANP); $\mathrm{R} \$ 2,3$ bilhões em disponibilidades (US\$ 1,1 bilhão). Para o MS, DB e o SAN, o montante de baixas no $1 \mathrm{~T} 13$ foi maior do que o esperado. O lançamento destas perdas teve impacto no valor de mercado dos bonds da OGX.

Em 11/06, na divulgação da CVM 358 de maio, soube-se que o AC havia vendido o equivalente a $\mathrm{R} \$ 70,5$ milhões da OGXP3, reduzindo sua participação de $62,6 \%$ para $60,5 \%$. Apesar do diminuto volume de ações, ao vendê-las, o AC produziu um péssimo sinal ao mercado constituindo o quarto Evento de Reputação. Em 21/06, a resignação dos três membros independentes do COAD foi interpretada pelo mercado como reação à recusa do $A C$ em conceder a put, que reforçaria o quarto Evento de Reputação. Em 24/06, a OSX teria deixado de honrar obrigação de $\mathrm{R} \$ 500$ milhões com um fornecedor responsável pela construção da UCN. Entre 10/6 e 1/7, os valores do OGXPBZ18 e OGXPBZ22 caíram $64,2 \%$ e $66,8 \%$, respectivamente, e a OGXP3 perdeu $56,6 \%$.

Em 1/07, com R\$ 722 milhões (US\$ 326 milhões) em caixa a OGX anunciou pagamentos controversos à OSX e a priorização da campanha de desenvolvimento no TBMT: (1) o pagamento imediato de US\$ 449 milhões à OSX para cobrir os custos de equipamentos

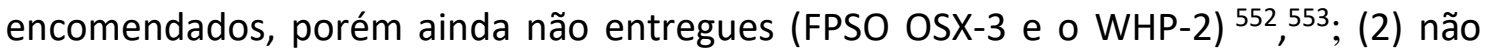
haveria novos investimentos nos três poços de TBAZ que deveriam parar de produzir até o fim do ano, porém o contrato de aluguel da FPSO OSX-1 continuaria a ser honrado (US\$ 263 mil por dia); (3) o desenvolvimento de TMTB seguiria o planejado, com o primeiro óleo esperado para dezembro de 2013, o que implicaria no pagamento de US\$ 500 milhões da Petronas à OGX; (4) cancelamento do desenvolvimento de TBTI, TBAR e

552 LEITE, CANHEU \& SOBREIRA, 2013g, p. 5, explicam que as WHPs são construídas de acordo com as especificidades de cada campo, portanto geralmente são vendidas como sucata após seu uso.

553 Ainda em junho de 2013, o AC solicitou a anuência dos três conselheiros de alta visibilidade da OGX (Pedro Malan, Ellen Gracie e Rodolfo Tourinho) para compensar em US\$ 449 milhões à OSX pelo cancelamento de encomendas, em uma clássica situação de conflito de interesse [GASPAR, 2014, p. 449]. Na época, o AC detinha $57,18 \%$ das ações da OGX e 74,83\% na OSX. Não só os três conselheiros se recusaram a anuir, como renunciaram coletivamente em 21/6/2013. Mesmo assim, o pagamento foi feito. 
TBGA, por serem campos intensamente fragmentados; (5) devido à (4), as encomendas da FPSOs OSX-4 e OSX-5, WHP-3/4 à OSX seriam suspensas.

É difícil questionar a lógica desta decisão [pagamentos à OSX], mas o resultado é negativo e aumenta o peso sobre a posição de caixa já pressionada da OGX. É sempre fácil olhar para trás e criticar uma decisão de negócios, mas talvez isso tinha de ter sido feito há muito tempo, quando os primeiros contratempos na produtividade de Waimea lançaram dúvidas sobre o potencial efetivo dos carbonatos de Campos. $O$ pedido de muitas unidades produtoras nos estágios iniciais do desenvolvimento também contribuiu para a situação atual [KOVARSKY \& MENDES, 2013h, p. 1].

Em um único pregão, a OGXP3 caiu 29,1\%, (de R\$ 0,79 para 0,56), considerado o dia do "crash" da OGX. O DB reduziu seu PA de R\$ 0,7 para R\$ 0,1 e considerou que apesar da queda de $30 \%$ (2/7) na OGXP3, "o mercado ainda não havia precificado plenamente as notícias e suas consequências." ${ }^{554}$ O CS também reduziu seu PA (2/7) de R\$ 1,0 para R\$ 0,3 e questionava: "resta algo para os acionistas [da OGX e OSX] neste novo panorama? Vale a pena o risco?" 555

US\$ 1,2 bilhão para TBMT, US\$ 500 milhões para Parnaíba e US\$ 270 milhões para BS-4 somam US\$ 2,0 bilhões. Isso não é um valor de ativos suficiente em comparação com uma dívida de US\$ 4,0 bilhões, o que nos faz concluir que há pouco valor no patrimônio OGX em sua forma atual [LEITE, CANHEU \& SOBREIRA, 2013g, p. 1].

Em 2/07, o JVE 556 reporta que o AC "admite fracasso na tentativa de salvar a OGX", após gastar US\$ 5,3 bilhões na campanha exploratória "mais cara de uma empresa privada no Brasil". As projeções anteriormente divulgadas "não devem mais ser consideradas válidas".

Em 15/08, a OGX anunciou os resultados do 2T13: um prejuízo de $\mathrm{R} \$ 4,7$ bilhões, incluindo impairment de $\mathrm{R} \$ 3,665$ bilhões (referentes aos TBTI, TBAR e TBGA), R\$ 490,7 milhões em baixas de ativos (poços subcomerciais) e $\mathrm{R} \$ 956,8$ milhões em perdas devido a cancelamentos de contratos com a OSX.

Em 27/08, notícias na mídia relatavam que o primeiro pagamento de US\$ 250 milhões do farm-out com a Petronas estaria sujeito à reestruturação do passivo da Empresa ${ }^{557}$. Como o primeiro pagamento era a única fonte de recursos novos previstos no curto prazo, o DB estimou que a Empresa zeraria seu caixa ainda no 3T13, se a put não fosse exercida ${ }^{558}$. Poucos dias depois (6/09), a OGX exerceu o put contra o AC, mas apenas

\footnotetext{
554 SEQUEIRA \& FONSECA, 2013n, p. 1.

555 LEITE, CANHEU \& SOBREIRA, 2013g, p. 1.

556 Disponível em: https://www.valor.com.br/empresas/3181632/eike-admite-fracasso-na-tentativa-desalvar-ogx.

557 Relatado por SEQUEIRA \& FONSECA, 2013p e MCGANN \& VEGNER, 2013a.

558 SEQUEIRA \& FONSECA [2013p]. A OGX pagaria uma multa de R\$ 3,4 milhões à ANP, mas economizaria $\mathrm{R} \$ 280$ milhões em BAs.
} 
US\$ 100 milhões seriam desembolsados imediatamente. Poucos dias depois (9/09), o AC anunciou que contestaria o aporte de US\$ 100 milhões na câmara de arbitragem.

\section{Gráfico 79 - Evolução do Valor de Mercado e Eventos Importantes no Guidance em 2013}

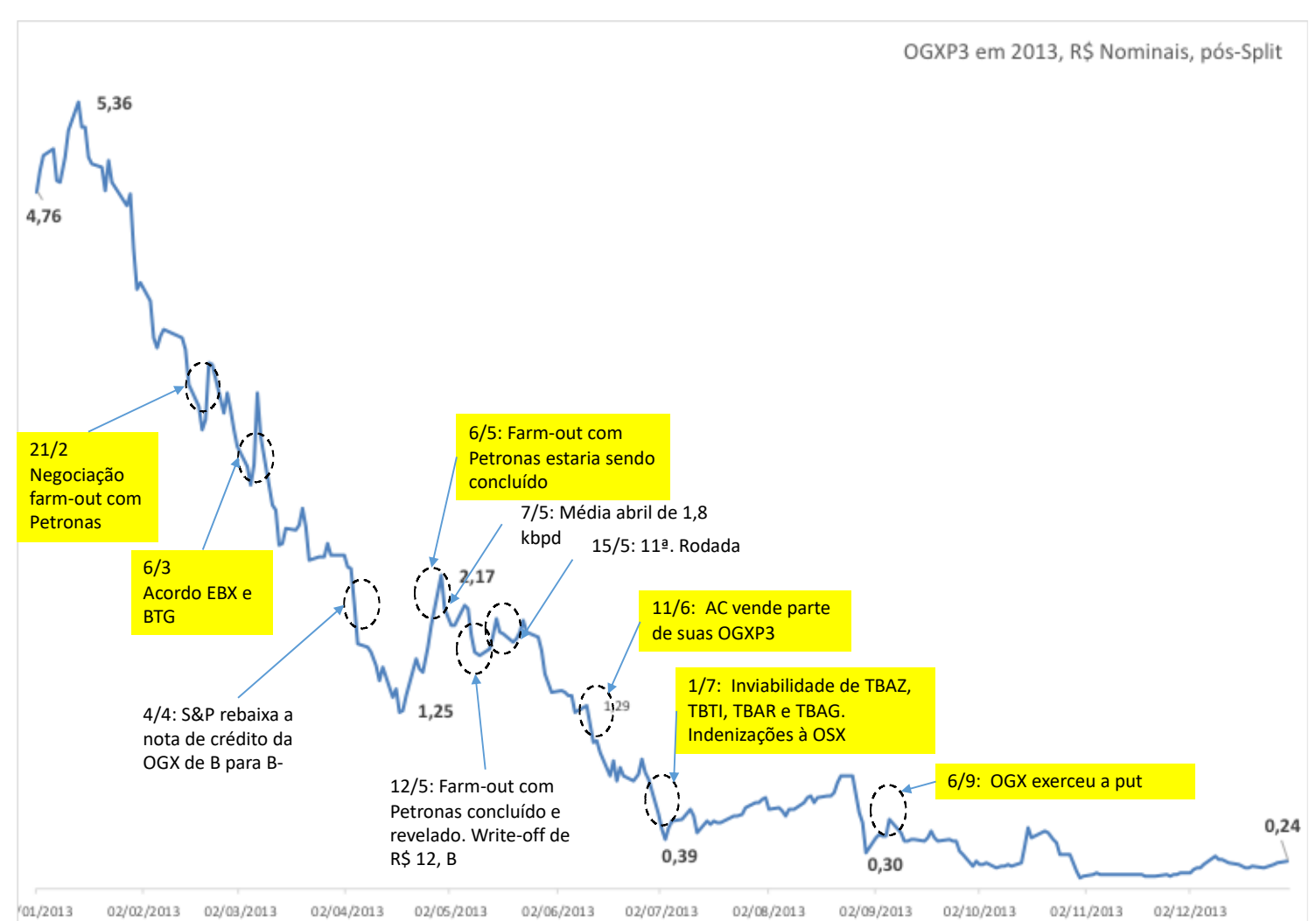

Para o IBBA ${ }^{559}$ e o $\mathrm{MS}^{560}$ a OGXP3 não teria mais valor, reforçada pela contestação do $A C^{561}$ :

559 KOVARSKY \& MENDES, 2013j.

560 MONTANARI \& BELLINETTI, 2013d, p. 1.

561 "Em setembro de 2013 a Diretoria da Companhia exerceu opção em face a seu acionista controlador para que esse subscrevesse novas ações, a $R \$ 6,30$ por ação, no montante de US\$ 1,0 bilhão. Ainda em setembro de 2013, o acionista controlador apresentou, "Notificação de Conflito" questionando as circunstâncias, validade e demais aspectos legais do pretendido exercício da opção" [OGX-DFP 2014, p. 95].

KOVARSKY \& MENDES [2013j] relatam que o contrato da put continha condições precedentes que davam margens para contestações. Por exemplo, a OGX teria de realizar o plano de negócios acordado na data da assinatura (outubro de 2012); a OGX só poderia exercer a put perante constatação da sua incapacidade de captar recursos financeiros através de outras formas, incluindo o perdão (waivers) de credores, venda de ativos, venda de participação para investidor estratégico. Além disso, o exercício da put deveria se aprovado por conselheiros independentes (Pedro Malan, Ellen Gracie e Rodolfo Tourinho) que já não fazem mais parte do Conselho de Administração. Segundo a cláusula de arbitragem, a OGX e o Acionista Controlador teriam 60 dias para negociar uma solução, mas o caixa da Empresa poderia não durar tanto. No "melhor cenário" do IBBA, é que nenhum recurso será aportado pelo Acionista Controlador após a arbitragem. 
A orientação excessiva [over-guidance], envios de confusas mensagens sobre a probabilidade de sucesso geológico minimizando o risco real incorporado na exploração, causou perdas maciças aos investidores nos últimos dois anos.

Um executivo muito graduado de uma companhia de petróleo nos perguntou recentemente quem deveria ser culpado por este terrível erro. Mas procurar por bodes expiatórios é uma receita para repetir um erro - ninguém comete um grande erro sozinho. Executivos renomados sobre-orientados [over-guided], mas também os analistas acreditavam facilmente nas histórias (no nosso caso particular, estávamos certos sobre a HRT desde o início, mas levamos muito tempo para desistir da OGX, pois achamos que a empresa teria algo em Campos depois de tudo). Enquanto isso, as regras da Bovespa transformaram uma empresa pré-operacional como OGX em um blue chip.

(...) O melhor conselho possivel que podemos dar aos investidores é ficar longe de OGX. Mesmo supondo uma reestruturação societária bem-sucedida, nós vemos potenciais perdas para os acionistas. [KOVARSKY \& MENDES, 2013j, p. 1]. 


\subsection{SOPs e Benefícios Privados}

"A gorda remuneração dos planos de opções também passou a ser um peso negativo na percepção geral. A avaliação é que, no lugar de alinhado com o risco do investidor, o administrador das empresas " $X$ " é incentivado a sustentar e até potencializar o otimismo de Eike.

Em 2010, as cinco empresas do grupo (OGX, MMX, MPX, LLX e OSX) pagaram RS 243,8 milhões aos executivos, dos quais $R \$ 222,5$ milhões eram em opções de ações, ou 91\%. Em 2011, com a primeira queda no valor dos papéis, o total diminuiu, mas a agressividade não. Dos $R \$ 164,6$ milhões pagos aos administradores, $R \$ 131,7$ milhões, ou $80 \%$, eram dos planos baseados em ações.

O pagamento elevado com ações era uma forma do grupo atrair e reter talentos para os projetos. Mas agora muitos investidores veem nesse modelo um caminho para os executivos superdimensionarem os prognósticos, pegando uma carona na credibilidade de Eike. Por isso, há quem de fato acredite que o empresário não sabia que alguns resultados seriam mais fracos do que o esperado.

Outra queixa é o discurso coletivo de Eike, que fala sempre como grupo. Como as companhias são abertas individualmente, o investidor não quer correr riscos que não sejam do negócio no qual escolheu investir."

Reportagem do Jornal Valor Econômico que relatou conversas com investidores do Grupo $\mathrm{X}^{562}$.

"Meu corpo técnico me reafirmava, dia após dia, a mesma coisa [a OGX possuiria recursos aproximados de 10,8 bilhões de barris de petróleo]. Minhas empresas eram auditadas por três das maiores agências de risco do mundo e nunca uma delas veio a mim ou a público alertar que não era bem assim."

GASPAR, 2014, p. 462.

"O essencial é invisível aos olhos."

SAINT-EXUPÉRY, 2004, p. 72.

562 VALENTI, G. e TORRES, F.. "Eike precisa retomar maior ativo: confiança.". Jornal Valor Econômico de 10/07/2012. Disponível em: https://www.valor.com.br/empresas/2743716/eike-precisa-retomarmaior-ativo-confianca. Acesso em 6/12/2018. 
Os Executivos, em particular na gestão de Paulo Mendonça (de junho de 2008 até junho de 2012), podem ter sido sistematicamente "otimistas" e superestimaram a performance da Empresa ou subestimaram seus riscos. HEATON [2002] explica que parte da literatura acredita que este comportamento pode ocorrer quando os executivos estão muito comprometidos com o sucesso da empresa, seja por questões patrimoniais e/ou de reputação profissional. Tal comportamento pode implicar em ações "irracionais" quando comparado com o paradigma tradicional de Finanças Corporativas, ou seja, os executivos como agentes que buscam maximizar o valor da empresa para seus acionistas, especialmente quando os resultados do plano de investimentos demoram para se materializar, como é o caso de exploração e produção de O\&G. Nestas circunstâncias, aprender com a experiência é menos provável. Fluxo livre de caixa também pode incentivar executivos irracionais.

A literatura não conseguiu esclarecer se mecanismos de incentivo internos das empresas ou a "cultura corporativa" são capazes de eliminar executivos irracionais Pode haver circunstâncias onde o principal, no caso o AC, tenha incentivado os Executivos a comportamentos irracionais.

O fato é que a maior parte da remuneração dos Executivos e membros do COAD da OGX era baseada em SOPs.

Tabela 58 - Proporção de cada elemento na remuneração total

\begin{tabular}{|lccc|}
\hline & $\begin{array}{c}\text { Remuneração } \\
\text { Fixa }\end{array}$ & Remuneração Baseada em Ações \\
\cline { 2 - 4 } & & $\begin{array}{c}\text { Plano do } \\
\text { Controlador }\end{array}$ & Plano da Companhia \\
\cline { 3 - 4 } Conselho de Administração & $87 \%$ & - & $13 \%$ \\
Diretoria & $20 \%$ & $80 \%$ & - \\
\hline \hline
\end{tabular}

Nota: ${ }^{1} \mathrm{O}$ Plano do Controlador não é diluitivo aos demais acionistas.

Fonte: AGO 27/4/2011, p. 40.

Poder exercer $20 \%$ ao ano do SOP OGX e do SOP AC, portanto antes de completar a campanha de E\&P, é um exemplo contundente de "relação tênue entre performance e compensação". Há relatos ${ }^{563}$ que mesmo o período de vesting foi antecipado ou encurtado pelo próprio AC:

"Eike foi vítima da decisão de acreditar em uma pessoa e outro erro gravíssimo foi dar muitos incentivos antes que os executivos entregassem os projetos. Ele criou um incentivo negativo." Os Executivos podiam receber em 4 anos e, em alguns casos 2, já que ele [AC] abriu exceções para permitir a retirada parcial em metade do tempo. O farm-out foi sugerido para testar se os compradores

563 Disponível em: https://www.valor.com.br/empresas/3183354/como-atuava-o-dream-team-de-eikena-ogx 
confirmavam a "tese" do dream team sobre a qualidade e quantidade de reservas. Depois do fracasso do farm-out veio a corrida para acelerar o início da produção. "Tirou-se petróleo em tempo recorde sem se preocupar se a companhia iria ganhar dinheiro", disse uma fonte do JVE.

GASPAR [2014], também relata que existia conflito de interesses na estrutura organizacional interna da Empresa. A autora relata um trecho de conversa entre o AC e Luiz Eduardo Carneiro, na época, diretor de operações da recém-criada OSX e que em junho de 2012 se tornaria CEO da OGX. Não há data do diálogo, mas pelo fluxo da narrativa, pode ter ocorrido no começo de 2010. A conversa versava sobre a Área de Reservatórios, que analisa a viabilidade econômica de uma descoberta, e era subordinada à área de perfuração:

O geólogo sempre vai querer perfurar mais, mas a decisão de fazer isso só é tomada se o engenheiro de reservatório concordar. É como se a exploração e a engenharia de reservatórios tivessem um conflito de interesses (...) Por isso ninguém coloca um subordinado ao outro. A coisa é tão sensivel que tem empresa que põe a área de reservatórios diretamente ligada ao dono. (...) Na Petrobrás era uma verdadeira guerra, com os técnicos debatendo por horas os melhores métodos, os riscos, os benefícios. (...) Aqui não tem nada disso. A área de exploração está subordinada à exploração e o Paulo Mendonça não consulta ninguém para nada! Só ele e o Paulo Ricardo (dos Santos, exPETR que assessorava diretamente o Dr. Oil) sabem exatamente o que acontece naqueles poços [GASPAR, 2014, p. 238-239].

Em 2010, dados coletados pela CVM sobre a remuneração de diretores estatutários e conselheiros das empresas brasileiras de capital aberto indicavam que os executivos da OSX (média de R\$ 8,39 milhões por diretor ${ }^{564}$ ), OGX (R\$ 7,15 milhões), MPX (R\$ 6,45 milhões) e LLX (R\$ 5,81 milhões) estavam entre os 10 mais bem remunerados ${ }^{565}$. No auge da crise em 2012, a OGX pagou bônus de R\$ 15 milhões aos executivos para "reter talentos".

O mercado respondeu positivamente ao início da campanha exploratória no 2S2009 e as primeiras descobertas anunciadas entre outubro e dezembro (Vesúvio, Pipeline Waimea) com 2,0 a 4,3 bboe de volumes recuperáveis estimados.

\footnotetext{
564 Inclui contribuição patronal ao INSS.

565 TORRES, F. "Remuneração da chefia sobe 14\% em 2011, mas desacelera”, Jornal Valor Econômico, 31/05/2012, versão online. Disponível em: https://www.valor.com.br/u/2684364. Acesso em $5 / 12 / 2018$.
} 
Gráfico 80 - Evolução da OGXP3 em 2009 (R\$̦ nominais por ação, pré-split)

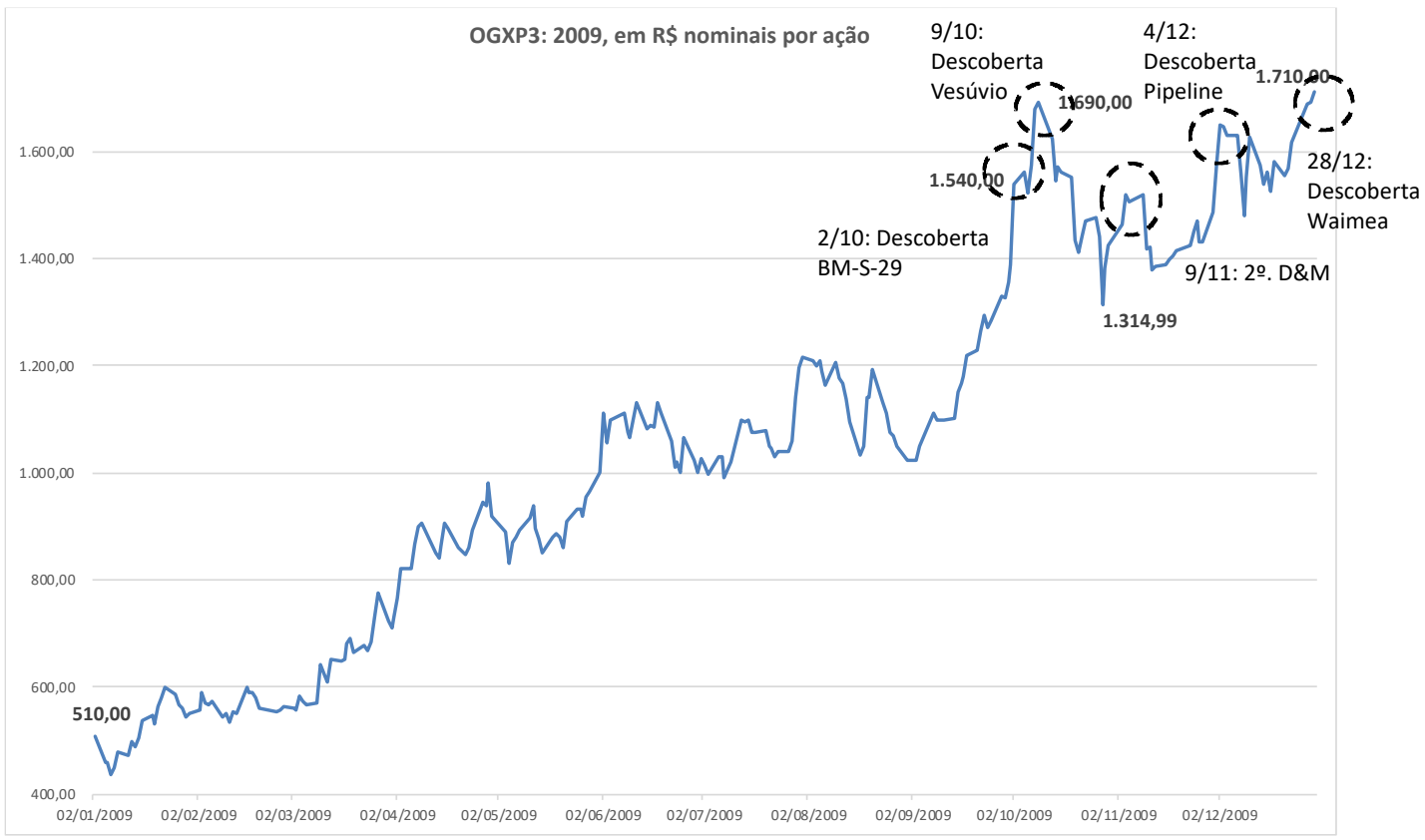

Em dezembro de 2009, Paulo Mendonça (Diretor de Exploração e Produção de 2007 a 22/4/09; Diretor Geral e Diretor de Exploração de 22/4/09 a 27/4/12; Diretor Presidente de 27/4/12 a 28/6/12) e Marcelo Faber Torres (Diretor RI desde 12/6/08 a 27/4/12) venderam $\mathrm{R} \$ 30,90$ milhões em ações da OGX. Dados da CVM 358 revelaram a movimentação ao público, mas não identificavam seus autores que só vieram a ser conhecidos anos depois através de processos judiciais.

Tabela 59 - Venda de Ações pelo DRI e DEX em 2009 (Instrução CVM 358)

\begin{tabular}{|l|c|c|c|c|c||}
\hline $\begin{array}{c}\text { Quantidade } \\
\text { OGXP3 } \\
\text { vendidas } \\
\text { pelo DRI }\end{array}$ & Datas & $\begin{array}{c}\text { Valor } \\
\text { R\$ Milhões }\end{array}$ & $\begin{array}{c}\text { Quantidade } \\
\text { OGXP3 } \\
\text { vendidas } \\
\text { pelo DEX }\end{array}$ & Datas & $\begin{array}{c}\text { Valor } \\
\text { R\$ } \\
\text { Milhões }\end{array}$ \\
\hline 3.000 & $7 / 12 / 09$ & 4,92 & 3.000 & $7 / 12 / 09$ & 4,92 \\
\hline 700 & $8 / 12 / 09$ & 1,12 & 700 & $8 / 12 / 09$ & 1,12 \\
\hline 3.900 & $9 / 12 / 09$ & 5,83 & 3.900 & $9 / 12 / 09$ & 5,83 \\
\hline 2.400 & $10 / 12 / 09$ & 3,58 & 2.400 & $10 / 12 / 09$ & 3,58 \\
\hline Total & & 15,45 & & & 15,45 \\
\hline
\end{tabular}

Fonte: Denúncia do MPF (Ref. Notícia de Fato n. 1.34.001.002738/2014-71), p. 14

Segundo a Instrução 480 da CVM, art. 45, o diretor de RI ("DRI") é responsável pela prestação de todas as informações exigidas, mas o dever desse executivo não diminui o dos demais administradores (art. 46). A comunicação com o mercado é responsabilidade 
direta do Presidente da empresa e do DRI. Cabia a Paulo Mendonça (CEO de 4/09 a 6/12) e Marcelo Torres (DRI até 4/12) a tarefa de frear e filtrar os arroubos otimistas do AC. A OGX, de 2008 a 2013, divulgou 114 FRs. Desde fevereiro de 2003, quando a CVM implementou o sistema eletrônico, a Ambev, a maior empresa da bolsa brasileira, emitiu 41 FR e a PETR um total de 155.

A dinâmica só mudou quando as notícias começaram a não ser tão boas, quando a Empresa passou a publicar mais Comunicados do que FRs. "Contar boas novas com festa e minimizar notícias ruins tende a ser prática corriqueira das companhias abertas. $O$ limite desse comportamento não está nada claro e a expectativa é que a questão seja avaliada agora pela CVM." 566

Em junho de 2011, o Diretor de Exploração, o DRI e agora o Diretor Jurídico da OGX José (Roberto Favaret, Diretor Jurídico, "DJUR", de 6/8/08 a 15/10/13) venderam R\$ 16,47 milhões de ações da OGXP3:

Tabela 60 - Venda de Ações pelo DRI, DEX e DJUR em 2011 (Instrução CVM 358)

\begin{tabular}{|l|c|c|r||}
\hline \hline Diretor & Data & Quantidade & $\begin{array}{c}\text { Valor total } \\
\text { (R\$) }\end{array}$ \\
\hline DRI & $09 / 06 / 2011$ & 71.500 & $1.106 .170,96$ \\
\hline DRI & $10 / 06 / 2011$ & 192.300 & $2.913 .190,51$ \\
\hline DRI & $13 / 06 / 2011$ & 5.200 & $78.655,34$ \\
\hline DRI & $14 / 06 / 2011$ & 66.200 & $988.860,85$ \\
\hline DRI & $15 / 06 / 2011$ & 222.300 & $3.198 .634,89$ \\
\hline DRI & $16 / 06 / 2011$ & 122.700 & $1.743 .310,92$ \\
\hline DEX & $09 / 06 / 2011$ & 33.700 & $521.370,12$ \\
\hline DEX & $10 / 06 / 2011$ & 90.800 & $1.375 .547,05$ \\
\hline DEX & $13 / 06 / 2011$ & 2.500 & $37.815,09$ \\
\hline DEX & $14 / 06 / 2011$ & 31.300 & $467.542,97$ \\
\hline DEX & $15 / 06 / 2011$ & 105.000 & $1.510 .826,19$ \\
\hline DEX & $16 / 06 / 2011$ & 57.900 & $822.638,13$ \\
\hline DJUR & $09 / 06 / 2011$ & 12.200 & $188.745,24$ \\
\hline DJUR & $10 / 06 / 2011$ & 32.700 & $495.378,7$ \\
\hline DJUR & $13 / 06 / 2011$ & 900 & $13.613,42$ \\
\hline DJUR & $14 / 06 / 2011$ & 11.300 & $168.793,47$ \\
\hline DJUR & $15 / 06 / 2011$ & 37.700 & $542.458,56$ \\
\hline DJUR & $16 / 06 / 2011$ & 20.900 & $296.945,38$ \\
\hline \hline
\end{tabular}

Segundo a Instrução 480, artigos 14 e 15: "o emissor deve divulgar informações verdadeiras, completas, consistentes e que não induzam o investidor ao erro." CVM estaria revisando as Instruções 358 e 480, em parte motivada pelo Grupo X, incluindo a comunicação da empresa via outras plataformas como o Twitter. "Não há, até o

${ }^{566}$ Disponível em: https://www.valor.com.br/u/3202056 
momento, suspeitas de comportamentos mais graves, como fraude (...) nada substitui a diligência dos investidores e acionistas." 567

A venda de ações por parte de membros do COAD e Executivos continuou em 2012, no auge da crise de confiança gerada pelos fluxos de TBAZ. Mas nenhum Analista por nós revisado comentou este fato público em seus relatórios. Em 2013 foi a vez do AC vender suas ações. Executivos e membros do COAD não reportaram transações de venda na Instrução CVM 358.

Tabela 61 - Venda de Ações de Pessoas Relacionadas entre 2009 e 2013 (Instrução CVM 358) em R\$ Milhões

\begin{tabular}{||l|c|c|c||}
\hline & COAD & Diretoria & AC \\
\hline 7 a $10 / 12 / 09$ & & 31,33 & \\
\hline 9 a $16 / 6 / 11$ & & 16,47 & \\
\hline $15 / 8 / 11$ a $1 / 2 / 12$ & 2,66 & & \\
\hline $29 / 5$ a $10 / 9 / 12$ & & 2,14 & \\
\hline $13 / 2$ a 20/12/12 & 13,16 & & \\
\hline $26 / 3$ a 3/9/13 & & & 324,14 \\
\hline Total & $\mathbf{1 5 , 8 2}$ & $\mathbf{4 9 , 9 4}$ & $\mathbf{3 2 4 , 1 4}$ \\
\hline
\end{tabular}

Na época, a Instrução CVM 358 (3/1/2002) regulava a divulgação de informações relevantes, inclusive a compra e venda, direta ou indireta (derivativos) de valores mobiliários da companhia por acionistas, diretores, membros do conselho de administração e pessoas ligadas. Originalmente, a divulgação deveria ocorrer em até 10 dias após o término do mês em que se verificou a negociação (artigo 11, parágrafo 5).

Pelas regras da CVM 358 somente o primeiro escalão de uma empresa de capital aberto eram obrigados a divulgar transações acionárias, mas o segundo escalão não.

Aparentemente, não foi apenas o exercício de opções dos SOPs que indicam a busca por benefícios privados. A própria Empresa divulgou evidências de apropriações indevidas quando, em 10/5/2012, publicou seu “Código de Conduta". Na página 8 lê-se:

Seguem abaixo exemplos de situações de mau uso com as quais nos deparamos:

- Uso das instalações das empresas do Grupo EBX para ganho pessoal;

- Uso excessivo de ligações telefônicas ou fax interurbanos para propósitos pessoais;

- Retirada de material de escritório ou equipamento para consumo ou uso pessoal, fora da empresa;

567 Disponível em: https://www.valor.com.br/u/3202056 
- Cópias não autorizadas de programas de software para computadores;

- Acesso à internet em sites de conteúdo não relacionado com atividade desenvolvida pelo colaborador;

- Uso do cartão de crédito da empresa para compras pessoais.

GASPAR [p. 91] relata que a Montana Dakota Utility (MDU), sócia do AC na Termo Ceará "queixava-se do descontrole nos gastos e viviam reclamando com os sócios do abuso do cartão de crédito corporativo para pagar despesas pessoais do AC, com empregados ou viagens em família."

Se a OGX não conseguia controlar os gastos com o cartão crédito corporativo de seus Executivos e o uso indevido de seus ativos, como conseguiria controlar os dispêndios de uma campanha de E\&P de R\$13,8 bilhões em 51 blocos e 6 bacias sedimentares? 


\subsection{AC e Partes Relacionadas}

Ao longo da história do Grupo X, o AC mostrou evidências de seu comprometimento com o futuro de suas empresas. Mas há evidências de conflitos de interesse também. A ironia é que os acionistas minoritários da OGX foram alertados para esta possibilidade já no Prospecto do IPO:

Poderemos estar sujeitos a conflitos de interesses em transações futuras com partes relacionadas. Esperamos nos beneficiar das sinergias com outras empresas do Grupo EBX durante a exploração, desenvolvimento e produção dos nossos projetos (...) Nesse sentido, podem surgir conflitos de interesse em função do nosso relacionamento com outras empresas do Grupo EBX e com nosso Acionista Controlador (...) Nosso Acionista Controlador poderá favorecer outras empresas em detrimento de nosso negócio, e neste caso, nossa situação financeira e os resultados das nossas operações poderão ser afetados de modo adverso e significativo [Prospecto OGX, 2008, p. 78].

O Sr. Eike Batista, nosso Acionista Controlador, poderá tomar determinadas decisões relativas ao nosso negócio sem a participação de todos os nossos acionistas que poderão conflitar com os interesses dos nossos acionistas. O Sr. Eike Batista detinha aproximadamente, por meio da Centennial Asset, 55,45\% do nosso capital votante antes de efetivar esta oferta, sem considerar o exercício do bônus de subscrição pela Centennial Asset, e deterá cerca de 62,71\% do nosso capital votante após a consumação desta Oferta, considerando o exercício do bônus de subscrição e sem considerar o exercício da Opção de Ações Suplementares e considerando as Ações Adicionais. (...) Dessa forma, o Grupo EBX, controlado pelo nosso Acionista Controlador, detém poder de voto suficiente para unilateralmente: nomear a maioria dos membros do nosso Conselho de Administração; dar o voto decisivo relativo a uma alteração em nosso controle, ainda que esta não vise o melhor interesse dos nossos acionistas; dar o voto decisivo relativo a uma fusão estratégica com outra empresa que poderia acarretar benefícios consideráveis para as empresas que participarem da fusão; restringir a oportunidade dos nossos outros acionistas receberem a diferença entre o valor contábil e o valor pago por suas ações em qualquer reestruturação societária, inclusive uma incorporação, fusão ou cisão; e influenciar nossa política de dividendos [Prospecto OGX, 2008, pg. 82].

Elementos cruciais das governanças corporativas das empresas do Grupo $\mathrm{X}$ eram parecidas com a Estrutura de Governança: capital aberto no Novo Mercado; significativos SOPs para seus executivos e membros do Conselhos de Administração; participação societária significativa do AC; participações cruzadas de executivos nos Conselhos de Administração das empresas irmãs. Portanto, a princípio, as duas empresas do Grupo X com significativas relações comerciais com a OGX poderiam estar expostas ao "risco de contágio" com sua a Heroína Organizacional. Esse contágio parece 
ter acometido a OSX, mas não a MPX, possivelmente devido à participação de sócios minoritários importantes como a E.ON e o BNDESPar. A OSX tinha como sócio a Hyundai (10\%), mas sua participação era mais focada no apoio técnico e transferência de tecnologia.

A OGX e OSX estavam ligadas através de três relações: cliente-fornecedor, em termos operacionais; societária indireta, uma vez que compartilhavam o mesmo acionista controlador; gestão, uma vez que os executivos de ambas empresas participavam dos Conselhos de Administração.

A relação cliente-fornecedor teria sido motivada pela política de conteúdo nacional nos equipamentos de E\&P de $O \& G^{568}$ e pelo aumento nas projeções do ramp-up da produção da OGX anunciado em 11/01/2010, que demandaria 48 equipamentos de produção até 2019 (19 FPSOs, 5 TLWPs e 24 WHPs). A OSX viabilizaria a conformidade com o requisito de conteúdo local e "ultrapassar o gargalo nos estaleiros brasileiros" 569. Mas era uma encomenda substancial comparada com a PETR, que entre 2012 a 2020, compraria 43 plataformas submersíveis e FPSOs, e 6 jackets e TLWP570.

Ainda em 2010 (22/09), alguns Analistas questionaram o AC sobre a capacidade da OSX em servir a OGX, pois o licenciamento ambiental em Santa Catarina estava atrasando a construção do estaleiro ${ }^{571}$.

Em novembro de 2011, se discutia os possíveis impactos das novas exigências de conteúdo local, com foco em três preocupações sobre a nova regulação: (1) sua efetividade, dada a limitada capacidade da ANP de monitorar sua implementação; (2) sua possível relação com o aumento de transações de $M \& A$ envolvendo IOCs que deixaram o país; (3) os desafios para desenvolver a indústria local para atender o rápido e significativo aumento do E\&P no Brasil, especialmente no pré-sal. A PETR planejava investir US\$ 53 bilhões entre 2011-15 no pré-sal para conseguir produzir 0,5 bbpd até 2015. "A Petrobras estava desenvolvendo o pré-sal em uma notável velocidade: desde a primeira descoberta em 2006 até o primeiro óleo no campo de Lula demorou cerca de três anos. ${ }^{\prime 572} \mathrm{E}$ a indústria de O\&G crescia mesmo sem novas rodadas de leilões da ANP desde $2008^{573}$.

${ }^{568}$ Até a 4a Rodada dos leilões ANP, não havia exigência de conteúdo local. Na 5a e 6a Rodadas, começou a se exigir um percentual mínimo de conteúdo local que variava de acordo com a localização e características de cada bloco (ex. blocos terrestre tinham um percentual maior dos que os marítimos). $\mathrm{Na} 7$ ạ Rodada começou a exigência de um percentual mínimo por item específico.

Segundo relato de SEQUEIRA \& FONSECA, 2011g, dos R\$ 17 bilhões investidos em exploração na 7ạ Rodada, $R \$ 12$ bilhões foram declarados como sendo de conteúdo local, entretanto, apenas $20 \%$ (R\$ 3,4 bilhões) eram certificados por alguma das 20 companhias independentes de certificação. Se as empresas não fossem capazes de provar a origem destes serviços e equipamentos, elas teriam de pagar uma multa de $60 \%$ do montante não certificado.

569 DARIPA, 2010b, p. 1.

570 SEQUEIRA \& FONSECA, 2010a, p. 33 e SEQUEIRA \& FONSECA, 2012a, p. 14.

${ }^{571}$ SEQUEIRA [2010b].

572 SEQUEIRA \& FONSECA, 2012a, p. 3.

${ }^{573}$ A 9a Rodada havia sido a última com blocos offshore. A 10a Rodada somente ofertou blocos terrestres. Segundo SEQUEIRA \& FONSECA [2012a] a interrupção dos leilões estaria relacionada com a indefinição da distribuição das receitas tributárias entre Estados produtores, não produtores e municipalidades. 
Neste contexto, a princípio, a constituição de um estaleiro próprio para apoiar a produção da OGX parecia fazer sentido. O AC afirmava que fabricar no Brasil seria, "no mínimo", 20\% mais barato, do que "qualquer outro estaleiro" 574.

Também, a princípio, para alinhar interesses, os Executivos participavam do Conselho de Administração da OSX e vice-versa. E como membros do Conselho de Administração, é possível que os Executivos participassem também do SOP da OSX.

Tabela 62 - Executivos que Participavam no CA do Grupo X

\begin{tabular}{|c|c|c|c|c|c|c|}
\hline \multirow{2}{*}{ Nome } & \multicolumn{3}{|c|}{ Conselho } & \multicolumn{3}{|c|}{ Diretoria } \\
\hline & Empresa & Cargo & Ano & Empresa & Cargo & Ano \\
\hline \multirow[t]{3}{*}{$\begin{array}{l}\text { Eduardo } \\
\text { Karrer }\end{array}$} & OGX & Conselheiro & $2010 / 2012$ & MPX & $\begin{array}{l}\text { Diretor Presidente e } \\
\text { RI }\end{array}$ & $2007 / 2013$ \\
\hline & CCX & Conselheiro & 2012 & & & \\
\hline & OSX & Conselheiro & 2012 & & & \\
\hline \multirow{6}{*}{$\begin{array}{l}\text { Eike } \\
\text { Batista }\end{array}$} & OGX & Presidente & $2008 / 2013$ & OGX & Diretor Presidente & $2009 / 2011$ \\
\hline & MMX & Presidente & $2006 / 2015$ & MMX & Diretor Presidente & $2006 / 2008$ \\
\hline & CCX & Presidente & $2012 / 2014$ & CCX & Diretor VP & \\
\hline & OSX & Presidente & $2008 / 2015$ & & & \\
\hline & LLX & Presidente & $2008 / 2012$ & & & \\
\hline & MPX & Presidente & $2007 / 2012$ & & & \\
\hline \multirow[t]{3}{*}{$\begin{array}{l}\text { Luiz E. G. } \\
\text { Carneiro }\end{array}$} & OGX & Conselheiro & $\begin{array}{l}2010 / 2011 \\
2013\end{array}$ & OSX & Diretor Presidente & $2009 / 2011$ \\
\hline & OSX & Conselheiro & 2012 & OGX & Diretor Presidente & 2012 \\
\hline & MPX & Conselheiro & 2012 & & & \\
\hline \multirow{4}{*}{$\begin{array}{l}\text { Luiz R. } \\
\text { Landim }\end{array}$} & OGX & Conselheiro & $2008 / 2009$ & OGX & Diretor Presidente & 2008 \\
\hline & MMX & Conselheiro & $2007 / 2009$ & MMX & Diretor Geral e RI & 2006 \\
\hline & MPX & Conselheiro & $2007 / 2009$ & OSX & Diretor Presidente & 2008 \\
\hline & LLX & Conselheiro & $2008 / 2009$ & & & \\
\hline \multirow[t]{2}{*}{$\begin{array}{l}\text { Paulo M. } \\
\text { Mendonça }\end{array}$} & MPX & Conselheiro & $2010 / 2011$ & OGX & \begin{tabular}{|l|} 
Diretor Geral e de \\
Exploração
\end{tabular} & $2008 / 2011$ \\
\hline & OSX & Conselheiro & 2009/2011 & & & \\
\hline
\end{tabular}

Em 2011, um Relatório do BTG, estimava a produção das plataformas da OSX para as metas de produção da OGX (versão de 2011):

Provavelmente, a implicação seria aumentar os royalties e impostos especiais. A expectativa era que a 11aㅡ rodada não incluiria blocos offshore em Campos, Santos e ES com potencial de pré-sal.

574 “OGX vai encomendar mais quatro plataformas este ano, diz Eike", JVE, Disponível em: https://www.valor.com.br/empresas/1039608/ogx-vai-encomendar-mais-quatro-plataformas-esteano-diz-eike. 
Tabela 63 - Metas para o Ramp-up x FPSOs da OSX

\begin{tabular}{||l|c|c|c|c||}
\hline & $\mathbf{2 0 1 1}$ & $\mathbf{2 0 1 2}$ & $\mathbf{2 0 1 3}$ & $\mathbf{2 0 1 5}$ \\
\hline Metas Produção OGX (kboed) & 20 & 50 & 150 & 730 \\
\hline Produção por FPSO da OSX & $\mathbf{4}$ & $\mathbf{4 0}$ & $\mathbf{1 0 0}$ & $\mathbf{2 6 3}$ \\
\hline OSX-1 (Keppel) & 4 & 40 & 60 & 43 \\
\hline OSX-2 (SBM Offshore) & & & 20 & 90 \\
\hline OSX-3 (Jurong) & & & 20 & 90 \\
\hline OSX-4 & & & & 20 \\
\hline OSX-5 & & & & 20 \\
\hline \% FPSOs / Produção Total & $\mathbf{2 0 , 0 \%}$ & $\mathbf{8 0 , 0 \%}$ & $\mathbf{6 6 , 7 \%}$ & $\mathbf{3 6 , 0}$ \\
\hline
\end{tabular}

Fonte: GATTASS \& FONSECA, 2011c, p. 14.

As projeções indicavam não apenas a significativa contribuição das FPSOs da OSX, mas também a importância do cronograma de entrega e comissionamento (incluindo as devidas licenças ambientais) destes equipamentos para o ramp-up da OGX. As três primeiras FPSOs seriam construídas em estaleiros no exterior, mas as outras seriam construídas na Unidade de Construção Naval ("UCN") no Complexo Industrial de Açu.

A UCN teria capacidade para processar 180 mil toneladas de aço por ano, podendo chegar a 400 mil. A empresa pretendia entregar 10 FPSO e 11 WHPs (plataformas fixas para águas rasas) até 2015 para a OGX. Deste total, 7 FPSOs e 9 WHPs seriam construídas em Açu. A encomenda da OGX era de 48 unidades offshore para a OSX nos próximos 10 anos.

A OGX não era o único cliente da OSX. Entre 2011 e 2012, a OSX acumulou 23 encomendas somando US\$ 7,0 bilhões. Deste backlog, 7 equipamentos eram da OGX, cujas compras previstas somavam um total de 48 equipamentos. 
Tabela 64 - Backlog OSX em 31/10/2012

\begin{tabular}{|l|l|l|c|c|c|}
\hline \multicolumn{1}{|c|}{ Cliente } & \multicolumn{1}{|c|}{$\begin{array}{c}\text { Data } \\
\text { Anúncio } \\
\text { Contratação }\end{array}$} & \multicolumn{1}{|c|}{ Objeto } & $\begin{array}{c}\text { Valor } \\
\text { (US\$ } \\
\text { milhões) }\end{array}$ & $\begin{array}{c}\text { Entrega } \\
\text { Prevista }\end{array}$ & $\begin{array}{c}\text { Financiamento } \\
\text { (US\$ milhões) }\end{array}$ \\
\hline OGX & FPSO OSX-1 & 775 & n.d. & R\$ 780,5 \\
\hline OGX & Out./2011 & FPSO OSX-2 & n.d. & n.d. & $428^{575}$ \\
\hline OGX & FPSO OSX-3 & 800 & $3 T 13$ & $500^{576}$ \\
\hline $\begin{array}{l}\text { Sapura } \\
\text { Navegação } \\
\text { Marítima }\end{array}$ & Fev./2012 & $\begin{array}{l}1 \text { navio } \\
\text { lançador de } \\
\text { linha (PLSV) }\end{array}$ & 263 & n.d. & n.d. \\
\hline Kingfish & Mar./2012 & $\begin{array}{l}10 \text { navios } \\
\text { tanque }\end{array}$ & 732 & 2017 & n.d. \\
\hline Sete Brasil & Mar./2012 & 2 sondas & 1.600 & n.d. & n.d. \\
\hline OGX & Abr./2012 & WHP-1 & n.d. & 1 T14 & n.d. \\
\hline OGX & Abr./2012 & WHP-2 & n.d. & $4 T 13$ & n.d. \\
\hline OGX & Mai./2012 & FPSO OSX-4 & 850 a 900 & $2 T 14$ & n.d. \\
\hline OGX & Mai./2012 & FPSO OSX-5 & 850 a 900 & 2 T14 & n.d. \\
\hline $\begin{array}{l}\text { PETR, BP, } \\
\text { Petrogal }\end{array}$ & Ago./2012 & P-67(*) & 900 & n.d. & n.d. \\
\hline $\begin{array}{l}\text { PETR, BP, } \\
\text { Petrogal }\end{array}$ & Ago./2012 & P-70(*) & 900 & n.d. & n.d. \\
\hline Total Backlog & & $\mathbf{2 3}$ & $\mathbf{7 . 0 0 0}$ & & \\
\hline
\end{tabular}

Nota: parceria OSX (49\%) e Mendes Junior Trading e Engenharia (51\%).

A OSX concorria com outros estaleiros brasileiros que estavam sendo construídos para capturar a demanda do O\&G brasileiro, como por exemplo, o Estaleiro Atlântico Sul (Queiroz Galvão, Camargo Corrêa e Samsung), Obebrecht O\&G, Sete Brasil (onde o BTG detinha 30\%, EIG Global Energy Partners).

Ou seja, o backlog indicava que a OSX era competitiva e sua dependência com a OGX era significativa, porém não absoluta. Mas a dependência de recursos do AC para a viabilidade da OSX era significativa e já havia começado no IPO em março de 2010. O IPO da OSX foi difícil ${ }^{577}$ : a oferta teve de ser reduzida em $40 \%$ e o AC teve de comprar $16 \%$ das ações e ainda outorgar uma put de US\$1,0 bilhão que poderia ser exercida até 2013.

575 Em 26/10/11, a OSX anunciou que obteve US\$ 850 milhões de financiamento, equivalente a $80 \%$ do capex do OSX-2, com juros de Libor $+4,41 \%$ ao ano com 12 anos para amortizar (líderes: ING, IBBA e Santander. Demais membros do sindicato: HSBC, Citibank, ABN-Amro, BB e NIBC). A OSX-2 seria afretada pela OGX por 20 anos para Waimea. Mas, em 4/05/2012, a OSX recebeu apenas US\$ 428 milhões. O Citibank e IBBA assinaram empréstimos pontes no valor de US\$25 M e US\$ $80 \mathrm{M}$ respectivamente.

576 Em 23/03/12, a OSX obteve financiamento com juros de juros de 9,25\% ao ano (pagamentos trimestrais), vencimento em 2015. Coordenadores: Pareto Securities e DNB Markets.

577 O intervalo do book building era de $\mathrm{R} \$ 1.000$ a $\mathrm{R} \$ 1.333$, mas fechou por $\mathrm{R} \$$ 800/ação, a oferta foi 44,4\% menor (de 5,511 para 3,063 milhões de ações) e o AC teve de participar com US\$ 300 milhões, que representaram $21,8 \%$ do um total de $\mathrm{R} \$ 2.450,4$ milhões ou US\$1.373,2 milhões. Disponível em: https://www.valor.com.br/u/2570980 
A estratégia de financiamento da OSX era composta por três elementos: a put do AC; financiamentos em US\$ do tipo "asset-backed" para cada grande equipamento encomendado; financiamento específico e subsidiado para a UCN.

Inicialmente, a UCN seria construída em Santa Catarina e foi orçada em R\$ 3,0 bilhões, dos quais $R \$ 2,7$ bilhões seriam financiados Fundo da Marinha Mercante ("FMM") e o restante através de aportes de capital do AC. Metade do financiamento do FMM seria estruturado através de repasses do BNDES e CEF, com prazo de 4+20 anos e juros de US\$ + 3,38\% ao ano. Devido a dificuldades no licenciamento ambiental, em 2011, a UCN acabou sendo construída no Porto de Açu, pertencente à LLX.

Em 10/01/2012, a OSX obteve US\$ 227,9 milhões de empréstimo ponte do BNDES para a UCN (18 meses, juros de 5,40\% ao ano). As obras tiveram início em julho de $2011 \mathrm{com}$ start das atividades de corte de chapas previsto para 1T2013. Em março (16), o AC anunciou que o aporte de US\$ 1 bilhão seria em quatro parcelas, cujos desembolsos começariam em novembro 2012 e terminariam em 2013. Anunciou também que o IBBA ofereceu propostas firmes de $\mathrm{R} \$ 1,8$ bilhão para empréstimos ponte com prazo de 2 anos.

Em outubro (17), o custo das obras da UCN somava $\mathrm{R} \$ 4,8$ bilhões, $40 \%$ a mais do que o estaleiro originalmente previsto em Santa Catarina ( $R \$ 3,4$ bilhões). Até o fim do mês (31), o repasse de $R \$ 2,7$ bilhões do FMM (CEF e BNDES) ainda não havia acontecido, mas a OSX continuava a investir. Ao todo, em 2012, a OSX investiu R\$ 4,4 bilhões só em 2012: OSX2, 3, 4 e 5, WHP 1 e 2; e R\$ 1,36 bilhões na UCN. Terminou o ano com R\$1,7 bilhão no caixa, graças ao 10 desembolso do FMM de R\$ 627 milhões via CEF e os US\$ 250 milhões do put. A dívida líquida somava $R \$ 5,5$ bilhões, parte dela em empréstimos ponte com vencimento em 2013. O CEO anunciou que a captação de US\$ 250 milhões em financiamentos para a OSX-3 estava avançando. A operação de financiamento para a WHP2 teria sido enquadrada no BNDES em fevereiro de 2013.

Porém, ao longo de 2012 começaram a surgir indícios que as encomendas da OGX poderiam estar superdimensionadas para suas necessidades. Por exemplo, em 13/03/2013, quando a Empresa declarou a comercialidade de TBTI, TBGA e TBAR, com um volume recuperável estimado em 0,206 bboe, que somados às declarações de TBAZ $(0,110)$ e TBMT $(0,285)$ não alcançaria o volume contingente $2 C$ de 0,700 bboe estimado pelo 3 D\&M, que, na época, a OGX considerou conservador. Esse volume estimado não justificaria mais do que três FPSOs ${ }^{578}$, mas a OGX havia encomendado cinco. Provavelmente não haveria uso para a OSX-4 e OSX-5 na OGX.

Em 26/3/2013, OGX divulgou seu saldo de caixa em 31/12/2012: US\$ 1,65 bilhão, que segundos alguns Analistas estaria aquém dos investimentos projetados e a questão do exercício da put, que o AC outorgou em outubro (24/10) se tornou crucial.

As ações da OSX que, um mês antes, já tinham se desvalorizado a um patamar equivalente ao seu valor de liquidação $(R \$ 7,00)$, em $25 / 3$, estavam ainda valendo

578 OSX-1, OSX-2 e OSX-3. A OSX-3 deveria chegar ao Brasil no 3T13 e começar a produzir no 4T13 [AUDI \& FALANGA NETO, 2013c]. 
menos (R\$ 4,21). "Mas o mercado não se importava mais com valor", interpretava os analistas do CS:

Além das preocupações com a situação financeira do grupo EBX, números de produção pobres da empresa irmã OGX e a "falha" recente da OSX para captar US \$ 265 milhões para o FPSO OSX-3, as ações caíram cerca de $40 \%$ e agora estão em $R \$$ 4,2/ação. As ações da OSX estão claramente precificando que a OGX nem poderá cumprir suas obrigações mínimas. [LEITE, CANHEU \& SOBREIRA, 2013e, p. 1].

O DFP do $1 T 2013$ da OSX foi divulgado em $15 / 5$, relatou uma dívida bruta de $R \$ 5,5$ bilhões. A OSX reavaliaria seu plano de negócios com prioridade para projetos geradores de caixa e redução no ritmo das obras da UCN devido à falta de confirmações de encomendas. Os atrasos nos desembolsos do BNDES e CEF podem estar relacionados aos aportes e garantias do AC, cujas incertezas aumentaram com a perda de Valor de Mercado da OGX. As perdas acumuladas na OSX3 no mês de maio (até o dia 20) foi de $76,53 \%$ e OGXP3 de 60,73\%. O mercado teria começado a precificar o "calote" da OGX nos contratos atuais ${ }^{579}$

Gráfico 81 - OGXP3 e OSX3 entre Abril/2011 e Outubro/2013 (15/04/2011 = 100)

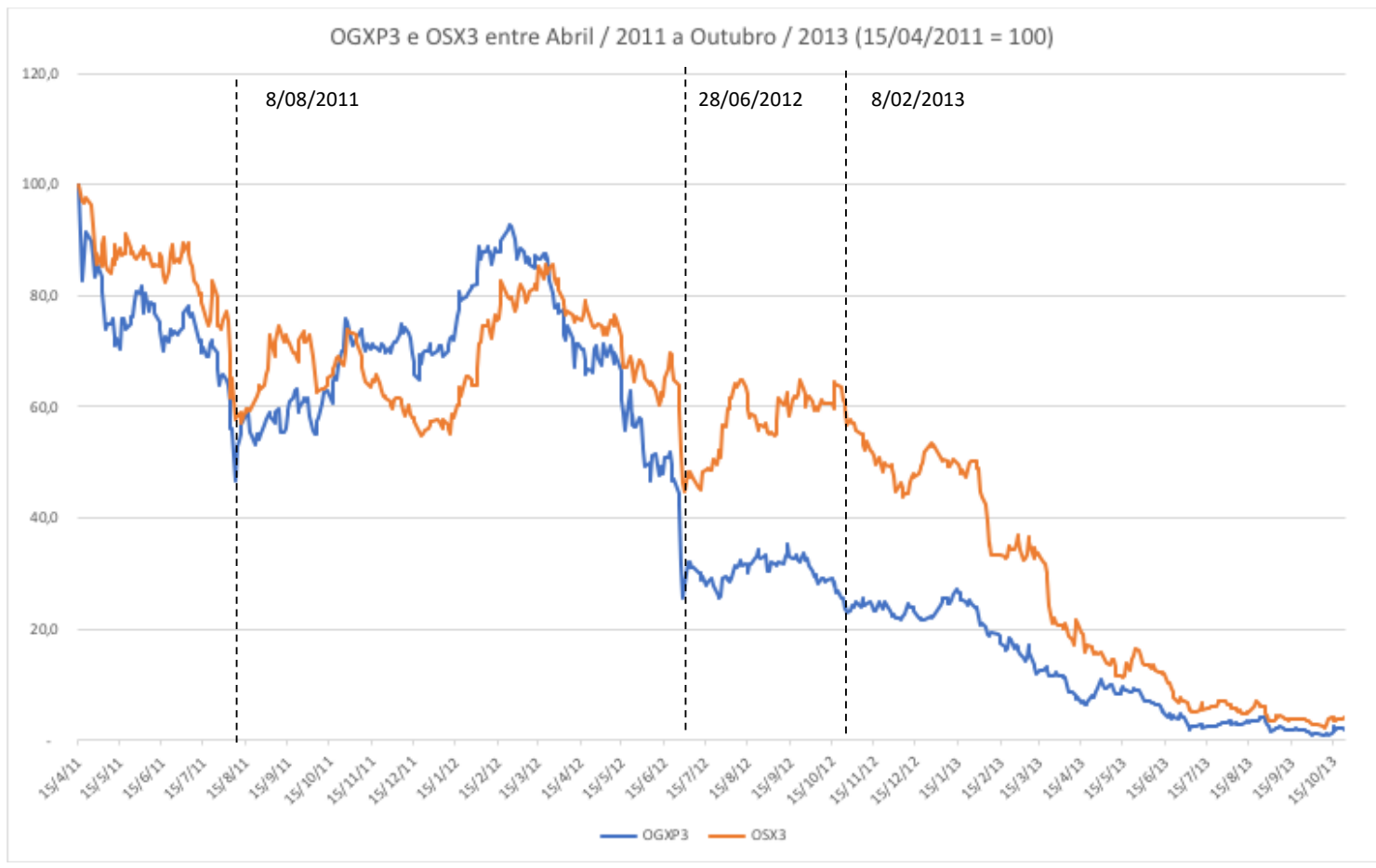

${ }^{579}$ Disponível em: https://www.valor.com.br/financas/3133268/revisao-estrategica-traz-fortevolatilidade-para-osx. 
Com disponibilidades limitadas, o CS estimava que a OSX teria de exercer a put de US\$ 0,5 bilhão contra o $\mathrm{AC}$, caso contrário, seu caixa se esgotaria em novembro ${ }^{580}$.

Em meados de 2013, a situação financeira da OSX, possivelmente a da OGX também, começou a comprometer a confiança dos clientes na entrega de seus pedidos. Em junho (19), a Kingfish cancelou sua encomenda de 11 navios-tanque (US\$ 732 milhões).

Em 17/5, OSX anunciou o exercício de US\$ 120 milhões ( $R \$ 243$ milhões) da put contra o $A C$ por R\$ 40,14/ação quando a OSX3 estava precificada a $\mathrm{R} \$ 2,40$. Ainda em junho (19), a OSX anunciou a paralisação das obras da UCN para focar em afretamento (OSX1). Contratou a Alvarez \& Marsal para reestruturar seu passivo. No curto prazo, havia os vencimentos de dois empréstimos ponte: o IBBA com $\mathrm{R} \$ 523,14$ milhões (venceria em 21/6) e o BNDES com $\mathrm{R} \$ 492,12$ milhões (15/8).

Mas não era apenas a OSX que estava pressionada com vencimentos de financiamentos:

- Com dívida de $\mathrm{R} \$ 3,1$ bilhões (sendo $\mathrm{R} \$ 1,2$ bilhão no $\mathrm{CP}$ e caixa de $\mathrm{R} \$ 1,2$ bilhão em 30/3/13), a MMX estaria negociando venda de participação para a Glencore Xstrata, a trading holandesa Trafigura e outros. O AC detinha 59,3\% da MMX e poderia vender só o Porto Sudeste cujo start-up estava programado para o fim de 2013. O projeto Serra Azul tinha sido adiado para além de $2015^{581}$.

- A LLX estaria renegociando prazos com BNDES (R\$ 527 milhões que venceria em 15/9) e BBD (R\$ 356,8 milhões em 19/2/14). A LLX já tinha investido R\$ 3,8 bilhões em Açu em parceria com a $A A$, mas ainda faltaria investir $R \$ 1,2$ bilhão (o caixa era de R\$ 764 milhões em 30/6/13). A LLX, ainda pré-operacional, estava em estágio mais embrionário: ainda não tinha algumas LAls e precisava investir para completar as obras em 2014, mas não possuía o financiamento para tal.

- Em 31/12/12, a MPX tinha dívida líquida de $R \$ 5,4$ bilhões dos quais $R \$ 1,9$ bilhão venceriam ainda em 2013, mas a empresa já era operacional, mas em 2012, gerou um EBITDA negativo de R\$ 374 milhões $^{582}$. O AC estava negociando a venda da MPX para a E.ON ${ }^{583}$.

${ }^{580}$ SEQUEIRA \& FONSECA, 2013h, p. 7, relata que os FPSOs OSX-1, 2 e 3 estavam alugados pela OGX por 20 anos por US\$ $263 \mathrm{mil} / \mathrm{dia}$ (OSX-1) e US\$ $360 \mathrm{mil} / \mathrm{dia}$ (OSX2 e 3), enquanto os dois WHPs estavam alugados por 25 anos por US\$ $320 \mathrm{mil} / \mathrm{dia}$. Os contratos previam multas caso a OGX devolvesse os equipamentos antes do término do aluguel.

${ }^{581} O$ programa de investimentos da MMX em Serra Azul, MG, era orçado em $R \$ 4,8$ bilhões. $A M M X$, onde o AC já havia aportado de R\$1,37 bilhão, possuía capacidade para produzir 8 milhões de toneladas de minério de ferro, e o projeto de Serra Azul acrescentaria mais 29 milhões à capacidade. A previsão do start da mina era para o 2S2015. Para viabilizar Serra Azul, a MMX negociava financiamentos de R\$ 3,2 bilhões com o BNDES, que em março de 2013, ainda não havia sido aprovado. O AC teria "suportado praticamente sozinho" o aumento de capital de R\$1,37 bilhão, pois não foi acompanhado pelos seus dois maiores sócios, a chinesa Wisco e a sul-coreana SK Networks (Disponível em: https://www.valor.com.br/empresas/3027582/ebx-se-apoia-no-bndes-para-tocar-seus-projetos; https://www.valor.com.br/empresas/3035024/esteves-levara-fundos-soberanos-eike).

${ }^{582} \mathrm{Na}$ época, a MPX tinha cinco usinas com 1,25 GW de capacidade instalada (4 térmicas, sendo 2 a carvão, $1 \mathrm{GN}$ e 1 a óleo diesel, e mais uma solar) o que garantiria uma receita bruta anual de R\$ 1 bilhão, e mais duas usinas (Pecem II e Parnaíba I e II) estavam próximas do start-up ainda em 2013 (2,814 GW), podendo chegar a 9,647 GW até 2018.

${ }^{583} \mathrm{Na}$ época a E.ON tinha 58,2 GW de capacidade instalada, receita líquida de $€ 132 \mathrm{~B}$, LL de $€ 2,64 \mathrm{~B}, \mathrm{DL}$ de $€ 14,65$ B. 
- Em 31/12/12, a dívida líquida consolidada do Grupo X somava $\mathrm{R} \$ 15,8$ bilhões ( $\mathrm{R} \$$ 10 bilhões dos quais seriam repasses do BNDES), sendo $R \$ 8,3$ bilhões em caixa. $O$ JVE relatou que investidores temiam que o $A C$ teria contraído empréstimos como pessoa física em bancos privados e dado ações em garantia. Diante da queda acumulada da OGX, que só em 2012 foi de 67,84\%, o AC teria renegociado as garantias, mas estaria com dificuldades de obter novas linhas. Procurado pelo VJE, o AC não se manifestou. A EBX informou que estava capitalizada e com os recursos (funding) "equacionados" para os próximos anos. O BNDES disse que o AC tinha ativos para vender e pagar seus empréstimos, o que já teria começado a fazer ${ }^{584}$. 0 mercado não tinha informações sobre a EBX que era capital fechado.

Em 31/12/12, a dívida bruta total do Grupo X somaria $R \$ 24,8$ bilhões, sendo que a $E B X$ tinha R\$ 1,44 bilhão em vencimentos até junho. Credores: R\$ 6 bilhões BNDES; R\$ 2,16 bilhões com CEF; IBBA com R\$ 1,76 bilhão; BBD com R\$1,53 bilhão. Essas informações, entretanto, não revelam o cenário completo. O BBD e IBBA podem ter exposição de RS 5 bilhões cada na EBX e o BTG teria R\$ 1,6 bilhão a receber, sem contar com a linha de crédito de US\$ 1 bilhão disponibilizada recentemente.

584 "Projetos de Eike dependem cada vez mais do BNDES", JVE, 1/3/13. Disponível em: https://www.valor.com.br/empresas/3027668/projetos-de-eike-dependem-cada-vez-mais-dobndes. Acesso em 7/12/18. 
Tabela 65 - Dívida Bruta do Grupo X em 31/12/12- Principais Credores (em R\$̣ Milhões)

\begin{tabular}{|l|c|c|c|c|c|c|c||}
\hline & OSX & MPX & MMX* & LLX & OGX & Total & $\%$ \\
\hline Bonds & 1.024 & - & - & - & 7.399 & 8.423 & $33,9 \%$ \\
\hline BNDES & 492 & 3.537 & 1.471 & 512 & - & 6.012 & $24,2 \%$ \\
\hline CEF & 1.053 & 347 & - & 757 & - & 2.156 & $8,7 \%$ \\
\hline IBBA** & 740 & 282 & 530 & - & 208 & 1.760 & $7,1 \%$ \\
\hline BBD** & - & 64 & 552 & 912 & - & 1.528 & $6,1 \%$ \\
\hline SAN & 330 & 104 & 38 & - & 208 & 680 & $2,7 \%$ \\
\hline BTG** & 82 & 410 & - & - & - & 493 & $2,0 \%$ \\
\hline Citi & 134 & 306 & - & - & - & 440 & $1,8 \%$ \\
\hline BNB & - & 435 & - & - & - & 435 & $1,8 \%$ \\
\hline HSBC & 217 & 135 & - & - & - & 352 & $1,4 \%$ \\
\hline MS & - & 100 & - & - & 230 & 331 & $1,3 \%$ \\
\hline BID & - & 307 & - & - & - & 307 & $1,2 \%$ \\
\hline ABN & 248 & - & - & - & - & 248 & $1,0 \%$ \\
\hline ING & 248 & - & - & - & - & 248 & $1,0 \%$ \\
\hline CS & 192 & 39 & - & - & - & 232 & $0,9 \%$ \\
\hline BBD & 134 & - & - & - & - & 134 & $0,5 \%$ \\
\hline NIBC & 134 & - & - & - & - & 134 & $0,5 \%$ \\
\hline DVB & 114 & - & - & - & - & 114 & $0,5 \%$ \\
\hline Ekspotfinans & 114 & - & - & - & - & 114 & $0,5 \%$ \\
\hline Credit Agricole & 114 & - & - & - & - & 114 & $0,5 \%$ \\
\hline ABC & 107 & - & - & - & - & 107 & $0,4 \%$ \\
\hline BofA & 82 & - & - & - & - & 82 & $0,3 \%$ \\
\hline Desconhecidos & - & - & 519 & - & - & 519 & $2,1 \%$ \\
\hline Custos não alocados & $(115)$ & - & - & - & - & $(115)$ & $-0,5 \%$ \\
\hline Total & 5.446 & 6.067 & $\mathbf{3 . 1 1 0}$ & $\mathbf{2 . 1 8 1}$ & $\mathbf{8 . 0 4 5}$ & $\mathbf{2 4 . 8 4 9}$ & $100,0 \%$ \\
\hline \%Total & $21,9 \%$ & $24,4 \%$ & $12,5 \%$ & $8,8 \%$ & $32,4 \%$ & $100,0 \%$ & \\
\hline
\end{tabular}

$\left({ }^{*}\right)$ Dados Estimados, pois MMX parou de divulgar esses dados em 2012.

$(* *)$ Estimativas incompletas.

Fonte: JVE 585

- O JVE relatou que até junho venceriam $R \$ 629$ milhões em dívidas na OSX (R\$ 106 milhões do $A B C$ e R\$ 523 milhões do IBBA). A dívida da LLX de R\$ 575 milhões com o $B B D$ venceria em ainda em abril. A MPX teria de quitar ou rolar até o fim de junho $\mathrm{R} \$ 64$ milhões com o BBD e R\$ 174 milhões com o IBBA. Entretanto, a EBX afirmou

\footnotetext{
585 Disponível em: https://www.valor.com.br/empresas/3078554/ebx-tem-r-144-bilhao-em-
} vencimentos-ate-junho 
que "não há qualquer pressão dos bancos credores para execução de garantias de suas companhias" 586 .

Em junho (25), o JVE ${ }^{587}$ apurou que a OSX já não pagava centenas de pequenos fornecedores e prestadores de serviços desde abril. A Acciona teria já demitido 600 dos 1.600 funcionários que trabalhavam na UCN como terceirizados.

Em 1/07, OGX anunciou: (1) o pagamento imediato de US\$ 449 milhões à OSX para cobrir os custos de equipamentos encomendados, porém ainda não entregues (FPSO OSX-3 e o WHP-2) ${ }^{588}$; (2) apesar de programar o fechamento do TBAZ até o fim do ano, o contrato de aluguel da FPSO OSX-1 continuaria a ser honrado (US\$ 263 mil por dia); (3) o desenvolvimento de TMTB seguiria o planejamento, portanto a FPSO OSX-3 estava confirmada; (4) as encomendas da FPSOs OSX-4 e OSX-5, WHP-3/4 à OSX seriam suspensas. No mesmo dia, a OSX iniciou tratativas com financiadores e fornecedores para "readequação aos cancelamentos da OGX"589.

A OSX tinha financiamentos com bancos importantes para a EBX e o Grupo X: BNDES, CEF, IBBA e BBD. O JVE ${ }^{590}$ relatou que o pagamento de US\$ 449 milhões indica que a OSX era o problema mais urgente do Grupo, pois concentra os vencimentos de CP. MER relatou que a dívida seria de $R \$ 2,151$ bilhões sendo $R \$ 1,037$ bilhão com $C E F, R \$ 515,1$ $M$ com IBBA, R\$491,3 milhões com BNDES e R\$106,8 milhões com ABC (este pagos em maio). Ainda havia uma fiança com o banco Votorantim. Havia também US\$ 1,2 bilhão em leasings. Como a OSX dependia da LLX e OGX, não tendo projetos próprios, o temor é que um eventual pedido de RJ poderia resultar na decretação da falência.

Neste cenário crítico do Grupo X, em 6/09, quando foi a vez da OGX exercer parte da put contra o AC (US\$ 100 milhões), este recusou-se a honrá-la. Sem recursos, a OGX protocola o pedido de RJ em 30/10. A OSX faz o mesmo em 8/11.

Afinal, quem quebrou quem: OGX ou OSX? OSX era um projeto ambicioso, difícil. Como uma empresa industrial, seu financiamento foi baseado em ativos (asset-backed financing), enquanto a OGX era equity e reserve-backed financing. Isoladamente, as estratégias de financiamentos da OGX e OSX eram adequadas, mas não como um todo. Afinal, a OSX chegou a ter uma carteira com 23 contratos, dos quais 9 eram com a OGX.

586 “EBX tem R\$̦ 1,44 bilhão em vencimentos até junho”. JVE, 9/4/2013. Disponível em: https://www.valor.com.br/empresas/3078554/ebx-tem-r-144-bilhao-em-vencimentos-ate-junho. Acesso em 7/12/18.

587 Disponível em: https://www.valor.com.br/empresas/3173256/osx-nao-paga-fornecedores-desdeabril.

${ }^{588} \mathrm{Em}$ esclarecimentos à CVM, a OGX explicou que o pagamento de US\$ $449 \mathrm{M}$ era para compensar a OSX por US\$ $383 \mathrm{M}$ desembolsos em caixa que teriam sido feitos na construção das unidades canceladas e a diferença era para compensar a renegociação dos contratos com desconto de $30 \%$ em favor da OGX. Esse pagamento seria compensado pelos pagamentos que a Petronas faria à OGX pelo farm-in. Disponível em: https://www.valor.com.br/empresas/3184064/negocio-com-petronas-garanterecursos-para-honrar-obrigacoes-diz-ogx.

589 Disponível em: https://www.valor.com.br/empresas/3180452/osx-conversa-com-credores-efornecedores-para-readequar-empresa.

590 Disponível em: https://www.valor.com.br/empresas/3183358/recursos-da-petroleira-evidenciamurgencia-para-osx. 
A dinâmica da Heroína Organizacional que capturou os Executivos e o AC na OGX pode ter repercutido indiretamente em várias das outras empresas do Grupo X via seu protagonista: o AC. Por serem empresas pré-operacionais e/ou no início das suas curvas de ramp-up de receitas, a MMX, MPX, LLX e a OSX dependiam de aportes de capital ou avais do AC em seus financiamentos. Todas estas empresas estavam implementando investimentos complexos, ao mesmo tempo, sujeitos a atrasos e reveses e, sobretudo, demandantes de capital. Nesta "família", a OGX era a irmã rica, mas a mais arriscada.

O AC, por um lado, atuava simultaneamente como Principal e Agente na OGX (no COAD de 2008 a 2013, e como Presidente, de 2009 a 2011), o que poderia reduzir custos de agência com Executivos. Por outro lado, o AC era o principal investidor de um portfólio de diversos e complexos ativos intensivos em capital, cuja viabilidade estava em parte influenciada pela reputação do AC e o sucesso da OGX. No consolidado, como o AC tinha participações muito relevantes, era como se a estratégia de financiamento da OGX fosse, indiretamente, baseada em dívidas não apenas da OSX mas de todo o Grupo X. O AC pode ter se tornado refém de sua própria "hubris" e/ou da complexidade de seus projetos. Não podia assumir erros na campanha exploratória (revisão do PRL), pois sabia que o mercado seria impiedoso com a OGX e o Grupo. 


\section{Parte 3 - Considerações Finais}

\section{Terceira Questão de Pesquisa: Possíveis Lições}

\begin{abstract}
"Outra pedra no sapato foi o que aconteceu com as chamadas empresas $X$, criadas pelo empresário Eike Batista. Várias emitiram ações na fase préoperacional e não apresentaram, posteriormente, o desempenho que propagaram após os IPOs. As ações acabaram sofrendo forte desvalorização. 'Um problema que passou por debaixo dos nossos narizes', lamenta Maria Helena [presidente da CVM entre 2007/12]. Eike e executivos do grupo X foram, mais tarde, alvo de investigações e processos, ainda em curso na CVM, sob acusação de terem prejudicado sócios minoritários".
\end{abstract}

VIDOR, 2016, p. 121-122.

O presente estudo identificou possíveis respostas à Primeira Questão de Pesquisa: momentos favoráveis nos mercados de O\&G internacional e brasileiro; a Tese de Investimentos; o endosso dos Analistas; e as possíveis externalidades geradas a partir da avaliação e monitoramento de grandes investidores e financiadores. Para a Segunda Questão de Pesquisa, o presente estudo identificou que as possíveis respostas que envolvem os reflexos das dinâmicas da Heroína Organizacional, dos atrasos e percalços que, em uma Estrutura de Governança, geraram condutas disfuncionais (Condutas de Valor).

Quais aprendizagens se pode extrair do caso OGX que poderiam contribuir para viabilizar outros greenfields?

Na essência, as possíveis aprendizagens apontam para um mesmo lugar: as estruturas de incentivos dos Stakeholders em momentos de sub e sobrevalorizações na capitalização de mercado da OGX. Identificar sub e sobrevalorizações não é trivial, e propor ações regulatórias pode fazer mais mal que bem. Restam as estruturas de incentivos.

Alinhar incentivos remete ao tema da governança corporativa, que é um desafio mundial e já é objeto de regulação há décadas. Nos anos 1990, por exemplo, o Reino Unido constituiu o Comitê de Cadbury \& Greenbury. Na França, o Comitê Viénot. Nos EUA, a CalPERs para investidores institucionais. ERTURK et al. [2004] ressaltam a importância histórica do Cadbury Report de 1992, como o primeiro documento oficial importante a abordar o tema de governança corporativa. Ao fim da década de 1990, relatórios do FMI e Banco Mundial sugeriram que o mundo poderia ser um lugar melhor se adotasse regras de governança corporativa anglo-americanas. Entretanto, no começo 
do século XXI, na Grã-Bretanha e nos EUA, a governança corporativa anglo-americanas geraram muito desapontamento.

As gestões fraudulentas com significativos impactos financeiros, como a ABB, Vivendi, Swissair (Europa), Enron, WorldCom, Global Crossing (EUA), suscitaram intenso debate sobre governança e ética corporativas e o papel dos intermediários e analistas de informações nos mercados de capitais. Intermediários estes que incluem bancos, fundos de investimentos, Analistas de informações que incluem agências de classificação de riscos, auditores independentes, analistas financeiros, e agentes da governança interna, como os Conselhos de Administração. Todos estes regulados por agências governamentais, como bancos centrais, agências reguladoras dos mercados de capitais e agências setoriais.

Tais gestões fraudulentas baseadas em modelos de negócios questionáveis promoveram, temporariamente, crescimentos exponenciais nos valores das ações de conglomerados, seguidas de colapso que causou significativa destruição de valor a investidores, financiadores, fornecedores, funcionários, além da queda na arrecadação tributária. As ações da Enron, por exemplo, chegaram a valer US\$ 83,13, equivalente a um múltiplo de 70 vezes seu lucro e 6 vezes seu valor patrimonial em 31 de dezembro de 2001, gerando uma capitalização de mercado de US\$ 60 bilhões. A Enron foi premiada pela Fortune como a empresa mais inovadora dos EUA, em sua pesquisa "Empresas mais Admiradas". Um ano depois, em 2 de dezembro de 2001, as ações valiam US\$ $0,26^{591}$.

Casos de alto impacto financeiro que contribuíram para identificar fragilidades na regulação dos mercados de capitais. Leis e novas instituições normatizadoras (por exemplo, o FASB/IFRS, a Sarbanes-Oxcley Act) foram criadas a partir destes escândalos para restaurar a confiança de investidores e financiadores nas empresas, inclusive no Brasil. Mas todos estes avanços não foram suficientes para evitar a destruição de valor da OGX.

Neste contexto mundial e nacional, dentre os vários temas para pesquisa e reflexão três se destacam:

- Por que é tão difícil elaborar e implementar políticas e processos de governança corporativa eficazes?

- Como diferenciar a gestão fraudulenta da gestão incompetente, porém de boa fé ex ante?

- Por que o mercado de capitais parece ter ignorado "red flags" associados à performance extraordinária destas empresas e suas estruturas corporativas potencialmente disfuncionais, provendo capital, a custos significativamente baixos, para suportar suas estratégias de expansão ${ }^{592}$ ?

\footnotetext{
${ }^{591}$ Citada em HEALY \& PALEPU [2003], p. 3 e 12.

${ }^{592}$ Foi, por exemplo, o caso da Enron, citado em HEALY \& PALEPU [2003], p. 12.
} 
O presente capítulo não pretende responder estas complexas questões, mas se propõe a identificar algumas possíveis respostas que o caso OGX proporciona, mas que demandam o devido aprofundamento em futuras pesquisas. Seis grandes temas são discutidos: o risco diferenciado de greenfields (6.1); fatos relevantes (6.2); partes relacionadas em conglomerados (6.3); atuação de auditores em conglomerados (6.4); isenção dos Analistas (6.5); Right to Trust nos Conselhos de Administração (6.6). 


\subsection{Risco Diferenciado de Greenfields}

Em projetos greenfield, o risco de execução é crucial. Devido à intensidade de capital e o elevado risco geológico, execuções rápidas e/ou dispersas em portfólio de O\&G, sem parcerias (farm-out), são sinais de alerta aos investidores.

Em prol da transparência, a avaliação da execução de projetos greenfield deve contar com o monitoramento detalhado e periódico das metas. Mas o caso OGX ensina que excesso de otimismo na definição das metas é um erro fatal.

SENGE [2006] explica que, na presença de metas, quando há atrasos, ações agressivas para compensá-los produzem o efeito oposto: mais instabilidade e oscilação. A OGX tinha uma meta audaciosa de produção para 2015. Entretanto, o de-risking do portfólio e o TLD de TBAZ foi marcado por atrasos e percalços. A reação da Empresa foi perfurar mais poços nos "tigres", reduzir a transparência no fluxo de informação aos investidores e comprar mais blocos. Estas ações não apenas não melhoraram os fluxos de TBAZ, mas depreciaram a OGXP3 e consumiram o restante do caixa da Empresa. Em 31/12/2013, a OGX reconheceu perdas contábeis de R\$ 4,42 bilhões em TBAZ, TBMT, TBTI, TBAR e TBGA, ou seja $32 \%$ do total investido na campanha de E\&P (R\$ 13,8 bilhões). Só em TBAZ foram $\mathrm{R} \$ 1,97$ bilhão.

Portanto, conservadorismo na definição de metas, considerando que atrasos e percalços são inerentes a processos complexos, foco e transparência na comunicação com investidores são lições importantes do caso OGX.

Aqui a importância do DRI e do guidance dos executivos e acionistas majoritários é crucial não só para prover informações, mas também consistência na política de comunicação. No caso da OGX, quando ocorreu a demissão de Paulo Mendonça, a mudança significativa na política de comunicação com o mercado foi traumática: antes havia excesso de informação, depois, escassez relativa. O erro foi o excesso de informação inicial, mas a mudança não ajudou a apaziguar os investidores.

Os eventos da Agenda de Catalisadores, a definição de metas, se bem definidos e monitorados, podem servir de parâmetros para financiamentos híbridos, tipo mezanino, e/ou eventos de diluição, como aqueles previstos no Contingent Value Rights ("CVR").

Outra lição importante do caso OGX foi o prematuro e significativo desdobramento das ações de 1 para 100. Segundo Carlos Rebello, ex-CVM e na época diretor de regulação da BM\&F Bovespa, para endereçar o risco diferenciado de greenfields, desde a Brasil Agro (IPO em 2006) adotou-se a prática de só permitir investidores qualificados nestes IPOs. "Nestes casos são negociados apenas lotes superiores a $R \$ 100$ mil durante 18 meses. A lógica é que, após um período sendo negociada no pregão, a companhia já 
teria divulgado uma quantidade razoável de informações financeiras para puder ser analisada por vários especialistas" ${ }^{\prime \prime 93}$.

No caso de O\&G, 18 meses de lockup é muito pouco. No caso de Waimea, as perfurações exploratórias começaram no 4T2009 e o TLD de TBAZ em 31/12/2012. A precocidade do desdobramento e sua magnitude podem ter atraído investidores com horizonte de curto prazo e com eles a volatilidade que investidores de longo prazo não gostam. Em O\&G, e talvez outros recursos minerários, o lockup poderia se estender até 18 meses do início da produção.

Os executivos de greenfields também não deveriam ter SOPs, muito menos com vestings inferiores às datas de completion dos projetos. SOPs podem fazer sentido após a fase pré-operacional. Durante a fase pré-operacional, a renda variável dos executivos pode estar atrelada às metas de execução do plano de negócio.

Pelas mesmas razões, membros de Conselhos de Administração não deveriam ter SOPs, ou pelo menos em magnitudes muito menores daquelas observadas na OGX.

Por fim, a venda de ações por pessoas relacionadas deveria ser divulgada em prazos mais curtos tanto para greenfields como para brownfields ${ }^{594}$. Se os nomes das pessoas relacionadas devem ser mantidos confidenciais por questões de segurança, que a CVM então monitore as transações que possam se indicar oportunismo ou conflitos de interesse. No caso da OGX, a venda de ações do DRI e do Diretor de Exploração no início da campanha exploratória (2009) com a publicação tantos FRs otimistas deveria ter sido investigada e coibida em tempo hábil para coibir o guidance otimista.

593 BRUNA, L. "Quanto vale uma ideia?", JVE, 20/8/2012. Disponível em: https://www.valor.com.br/financas/2794646/quanto-vale-uma-ideia. Acesso em 6/12/2018.

${ }^{594}$ A Instrução CVM 358 (3/1/2002) regula a divulgação de informações relevantes, inclusive a compra e venda, direta ou indireta (derivativos) de valores mobiliários da companhia por acionistas, diretores, membros do conselho de administração e pessoas ligadas. Originalmente, a divulgação deveria ocorrer em até 10 dias após o término do mês em que se verificou a negociação (artigo 11, parágrafo 5). Posteriormente, a Instrução CVM 590 (11/11/2017) alterou o prazo da divulgação para 5 dias após a realização da negociação. 


\subsection{Fatos Relevantes}

A Instrução 358 (3/1/2002) regula a divulgação e uso de informações de empresas abertas. Informações relevantes são definidas como decisões deliberadas pelo acionista controlador, Conselho de Administração e outros órgãos da administração da empresa que possam afetar o valor de suas ações e a decisão do investidor de comprar, vender ou manter os títulos mobiliários emitidos pela empresa. A Instrução lista vários exemplos de fatos relevantes, dentre eles, "descoberta, mudança ou desenvolvimento de tecnologia ou de recursos da companhia" e "modificação de projeções divulgadas pela companhia" (artigo 2, parágrafo único, itens XX e XXI, respectivamente).

Neste contexto, os FRs deveriam seguir critérios mínimos e customizados à especificidade de cada setor. Por exemplo, em O\&G, a CVM deveria definir parâmetros de divulgação para descobertas e estimativas de volumes recuperáveis. As regras de contabilização de reservas também podem ser aprimoradas. Em O\&G, os Analistas deveriam poder exigir o acesso à integra de Relatórios de Avaliação (como não aconteceu com o 3으이).

A Lei 6.404/76, no seu artigo 157, parágrafo 5ำ, define que a imediata divulgação de fatos relevantes ao mercado só não deve ocorrer se "sua revelação porá em risco interesse legítimo da companhia". Esta provisão é assegurada pelo artigo 60 Da Resolução CVM 358. No caso da OGX, essa provisão pode ter sido levada ao extremo para ocultar poços secos e/ou reservatórios compartimentalizados, por exemplo. De fato, a defesa de Pedro Malan [p. 17 e 20] cita como exemplo os fluxos de TBAZ que não foram divulgados pois "sua revelação porá em risco interesse legítimo da companhia".

Neste contexto, os DRIs, como responsáveis pela divulgação dos FRs, não deveriam ter SOPs, ou se os tiverem que pelo menos sejam em magnitudes muito menores do que aquelas da OGX. 


\subsection{Partes Relacionadas em Conglomerados}

O caso OGX nos remete aos desafios das sinergias positivas e negativas, operacionais e financeiras entre partes relacionadas. A começar pela holding. As participações societárias do AC com as empresas de capital aberto e algumas de capital fechado do Grupo $X^{595}$ eram congregadas em uma holding de capital fechado, a EBX, que por sua vez era controlada por offshores, a CAMF e a Centennial Asset Brazil Equity Fund ("CABEF"). Ou seja, os acionistas minoritários não tinham informações sobre os avais e as dívidas do AC na EBX e na CAMF, mas elas eram significativas.

Em 2012, duas transações de M\&A pareciam emitir sinais positivos sobre a EBX aos investidores. Em 26/3/12, o AC vendeu 5,63\% da CABEF para o Mubadala por US\$ 2 bilhões, o que implica em uma avaliação de US\$ 35,5 bilhões para $100 \%$ das ações. Dois meses depois (24/5) a GE comprou 0,8\% da EBX por US\$ 300 milhões, o que implica em uma avaliação de US\$ 37,5 bilhões para $100 \%$ das ações. Jeff Immelt, CEO mundial da GEO, classificou a EBX como "um dos mais importantes e dinâmicos grupos do Brasil e do mundo" 596 . O acordo reforçaria e criaria oportunidades de expansão de negócios das duas empresas em todo o mundo. Mas a transação não reverteu a queda na OGXP3, OSX, MPX e MMX.

Entretanto, a história demonstrou que apesar dos sinais auspiciosos destas duas transações, a EBX estava demasiadamente endividada, e os acionistas minoritários não tinham acesso direto e completo a esta informação. $O$ acesso era indireto e parcial através dos dados públicos da MMX, LLX, MPX, CCX, OGX e OSX.

\footnotetext{
${ }^{595}$ A EBX teria participações em 14 empresas, dentre elas, a OGX, OSX, MMX, LLX, MPX, AUX, REX e IMX. ${ }^{596}$ Disponível em: https://www.valor.com.br/u/2674528.
} 


\title{
6.4 Atuação de auditores em Conglomerados
}

\author{
"The fear of bad news often leads to bad \\ accounting."
}

Jacob Soll apud BROEDEL, A. [2017].

"Não há maneira de minimizar a necessidade do auditor independente da Empresa fornecer um quadro mais detalhado sobre os ativos. Mais de US\$ 4 bilhões foram gastos desde dezembro de 2010 e nós ainda não sabemos o que foi encontrado!

Mas, essas são as incógnitas identificadas que, em
nossa opinião, são indicadores que os investidores
deveriam estar observando nos resultados, buscando
sinais de fraqueza que poderiam mudar nossa visão
sobre os valores que simplesmente não estavam lá."

GATTASS \& CARVALHO, 2012b, p. 2.

Segundo HEALY \& PALEPU [2003] relatam os problemas contábeis da Enron aumentaram quando a empresa reconheceu contabilmente, através da perda por desvalorização ${ }^{597}$ (write-offs), a má performance de certos ativos e empresas adquiridas. Em outubro de 2001, por exemplo, a empresa reconheceu perdas que somaram US\$1,0 bilhão, equivalente a $22 \%$ dos investimentos totais entre 1998 e 2000 . Estes write-offs indicavam que "jogos contábeis permitiram que a empresa escondesse essa realidade por muitos anos" [HEALY \& PALEPU, 2003, p. 12].

Além da apreciação do valor das ações, manipulações também evitam a demissão de executivos, a interferência dos acionistas na gestão, evitam a quebra de convenants de financiamentos e possibilitam a captação continuada de recursos junto a financiadores e/ou acionistas.

No Grupo X, a KPMG, que auditou o primeiro greenfield a abrir capital no Brasil, a Brasil Agro, teve função predominante como auditor de todas as empresas do Grupo X entre 2006 e 2011, e nos anos seguintes. Ao analisarmos a importância da KPMG para a OGX, notamos que esta se estende às outras empresas do grupo: por quatro anos seguidos (2008 a 2012) a KPMG auditou todas as principais empresas do grupo. Em 2012, a E\&Y assumiu este papel predominante, mas por períodos mais curtos, especialmente na OGX e MPX, onde foi o auditor apenas por 2012.

597 CPC01. 
Tabela 66 - Auditores Independentes das Empresas de Capital Aberto do Grupo X: 2006 a 2016

\begin{tabular}{|l|c|c|c|c|c|c|c|c|c|c|}
\hline & MMX & Sócio & MPX & Sócio & OGX & Sócio & LLX & Sócio & OSX & Sócio \\
\hline IPO & KPMG & MFRS & KPMG & MFRS & KPMG & MFRS & KPMG598 & MFRS & KPMG & MFRS \\
\hline 2006 & KPMG & MFRS & KPMG & MFRS & KPMG & MFRS & & & & \\
\hline 2007 & KPMG & MFRS & KPMG & MFRS & KPMG & MFRS & & & & \\
\hline 2008 & KPMG & MFRS & KPMG & MFRS & KPMG & MFRS & KPMG & MFRS & ACAL & GJA \\
\hline 2009 & KPMG & MFRS & KPMG & MFRS & KPMG & VAS & KPMG & MFRS & KPMG & MFRS \\
\hline 2010 & KPMG & VAS & KPMG & MFRS & KPMG & VAS & KPMG & MFRS & KPMG & MFRS \\
\hline 2011 & KPMG & UMDM & KPMG & VAS & KPMG & MFRS & KPMG & MFRS & KPMG & MFRS \\
\hline 2012 & E\&Y & WJOM \& PJM & E\&Y & RCAS & E\&Y & PJM & E\&Y & WJOM \& PJM & KPMG & MFRS \\
\hline 2013 & E\&Y & LAD & PWC & GNV & CHB & GBS & E\&Y & WJOM \& PJM & E\&Y & PJM \& DAP \\
\hline 2014 & E\&Y & LAD e DAP & PWC & GNV & PWC & MDP & E\&Y & WJOM & E\&Y & PJM \& DAP \\
\hline 2015 & E\&Y & RXM & PWC & GNV & KPMG & ACVD & KPMG & LCFA & E\&Y & PJM \\
\hline 2016 & BDO & FPRJ & PWC & GNV & KPMG & ACVD & KPMG & LCFA & BDO & JC \\
\hline
\end{tabular}

A KPMG (sócio MFRS) e a E\&Y (sócios WJOM, PJM) acumularam a auditoria de empresas do Grupo X, ao mesmo tempo. Neste panorama, destaca-se o fato que entre 2011/15, a OGX trocou de auditor cinco vezes, incluindo KPMG que retoma sua função de auditor em 2015.

\begin{tabular}{|l|c|c||}
\hline & OGX & Sócio \\
\hline IPO & KPMG & MFRS \\
\hline DFP 2006 & KPMG & MFRS \\
\hline DFP 2007 & KPMG & MFRS \\
\hline DFP 2008 & KPMG & MFRS \\
\hline DFP 2009 & KPMG & VAS \\
\hline DFP 2010 & KPMG & VAS \\
\hline DFP 2011 & KPMG & MFRS \\
\hline DFP 2012 & E\&Y & PJM \\
\hline DFP 2013 & CHB & GBS \\
\hline DFP 2014 & PWC & MDP \\
\hline DFP 2015 & KPMG & ACVD \\
\hline DFP 2016 & KPMG & ACVD \\
\hline
\end{tabular}

A OGX, ao longo de 2011 a 2013 teve parte de suas contas reclassificadas por três auditores independentes: E\&Y (que auditou a OGX até o 3T13, inclusive), Crowe Horwath Bendoraytes ("CHB", cujo primeiro demonstrativo auditado foi o anual de 2013) e PWC. As reclassificações mais relevantes ocorreram no 4T13, quando a E\&Y deixou de auditar a OGX e a CHB auditou o DFP do ano. A CHB reclassificou saldos auditados pela E\&Y em 31/12/2012:

598 Não houve IPO e sim spin-off. 
- Disponibilidades e aplicações foi revisado em R\$ 525 milhões a menor;

- Redução da produção em 794 mil barris no ano (de 2.393 para 1.599 mil barris), que teve impacto relativamente pequeno ( $\mathrm{R} \$ 28$ milhões) na Receita Operacional Líquida ("ROL").

- Redução do Ativo Imobilizado em $\mathrm{R}$ 1,056 bilhão, parte por baixas devidos à poços secos (R\$ 0,665 bilhão), o que reduziu o saldo do Patrimônio Líquido.

Em 31/12/2013, o saldo do Ativo Imobilizado sofreria outro ajuste ainda mais significativo: uma redução de $R \$ 8,638$ bilhões devido a testes de impairment. Foi registrado também despesas de $R \$ 4,853$ bilhões.

A postergação do impairment afetou a financiabilidade da OGX, pois quando se baixa ativos ou se faz o impairment se produz dois sinais: 1) fluxos de caixa futuros estão comprometidos; 2) ativos tangíveis (barris de petróleo ou GN) e intangíveis (BAs), que atualmente são usados como garantia e/ou podem ser usados como colateral em novos financiamentos, perderam valor. Talvez seja por isso que a OGX parou de divulgar a produção de TBAZ.

No 3T12, auditado pela E\&Y, OGX estimou um EBITDA pro forma incluindo os embarques do $4 \mathrm{~T} 12$ e excluindo as perdas ativas (write-offs) que implicaria em uma margem de $35 \%$, o que segundo alguns Analistas não corroborava com a visão dos Executivos da Empresa que a consideravam uma produtora de baixo custo ("low cost producer") $)^{599}$. Portanto, indicadores críticos, como margem bruta, EBITDA, saldo de disponibilidades, ativo imobilizado eram alguns dos números que sustentavam o valor da OGXP3 e dos Notes.

${ }^{599}$ SEQUEIRA \& FONSECA [2012i]. 


\subsection{Isenção dos Analistas}

\begin{abstract}
"O papel do 'forecaster' no mundo real é bastante diferente do vidente mítico. A vidência está preocupada com a certeza futura; já a projeção [forecast] analisa a forma como as tendências ocultas no presente podem mudar de direção para empresas, sociedades ou o mundo em geral. Assim, o principal objetivo da projeção é identificar toda a gama de possibilidades, e não um conjunto limitado de certezas ilusórias. Se uma projeção especifica realmente se revela precisa é apenas parte do cenário - mesmo um relógio quebrado está certo duas vezes por dia. Acima de tudo, a tarefa do 'forecaster' é mapear a incerteza, pois em um mundo onde nossas ações no presente influenciam o futuro, a incerteza é oportunidade.
\end{abstract}

Ao contrário de uma vidência, uma projeção deve ter uma lógica. Isso é o que levanta a projeção do domínio sombrio da superstição. $O$ 'forecaster' deve poder articular e defender essa lógica. Além disso, o consumidor da projeção deve entender o suficiente do processo de projeção e da lógica para fazer uma avaliação independente de sua qualidade e para responder corretamente as oportunidades e riscos que apresenta. $O$ consumidor sábio de uma projeção não é um espectador confiante, mas um participante e, acima de tudo, um crítico".

SAFFO, 2007, p. 1-2.

SAFFO [2007] lista seis regras das boas projeções de analistas (sell, buy, crédito e risco), dentre elas, destacam-se quatro:

1) Mapear as incertezas construir o "Cone da Incerteza" ("cone of uncertainty"), com bordas são compostas por eventos possíveis, porém pouco prováveis (outliers), cuja definição não é trivial. O cone deve ser refinado e suas bordas redefinidas em processos interativos. A essência do problema é que a natureza humana abomina a incerteza. É um erro focar nas bordas, pois pode-se ignorar eventos com alta probabilidade. Entretanto, é preciso revisar frequentemente os outliers que podem se deslocar em direção ao centro do cone. O cone não é estático - se expande e se contrai a medida que o futuro se torna presente e novas possibilidades emergem e outras desaparecem.

2) Considerar eventos que destoam do senso comum ("embrace the things that don't fit").

3) Questionar opiniões consolidadas ("hold strong opinions weakly"). Boas projeções se constroem ao longo de um processo de frequentes revisões, quando o Analista deveria ser o primeiro a provar estar errado. Ter opiniões consolidadas permite ao 
Analista, diante de novos fatos, chegar a conclusões rapidamente. Entretanto, desconfiar destas opiniões, também permite descarta-las diante de evidências conflitantes.

4) Considerar o passado duas vezes mais distante ao se considerar o futuro ("look back twice as far as you look forward"). Eventos passados podem ser usados para "ligar os pontos" com o presente e produzir um mapa para uma futura trajetória, desde que se analise o passado distante o suficiente. $O$ passado recente raramente é um indicador confiável do futuro.

Aparentemente, os Analistas não foram diligentes o suficiente em suas avaliações da OGX, ou no mínimo endossaram o otimismo do guidance por um longo período pós IPO (de outubro de 2009 até junho de 2012), ou ainda se deixaram influenciar por pressões internas das instituições financeiras em que trabalhavam que por sua vez tinham relações com o Grupo X.

\section{Gráfico 82 - Evolução da OGXP3 e da Mediana do PA da Amostra TR}

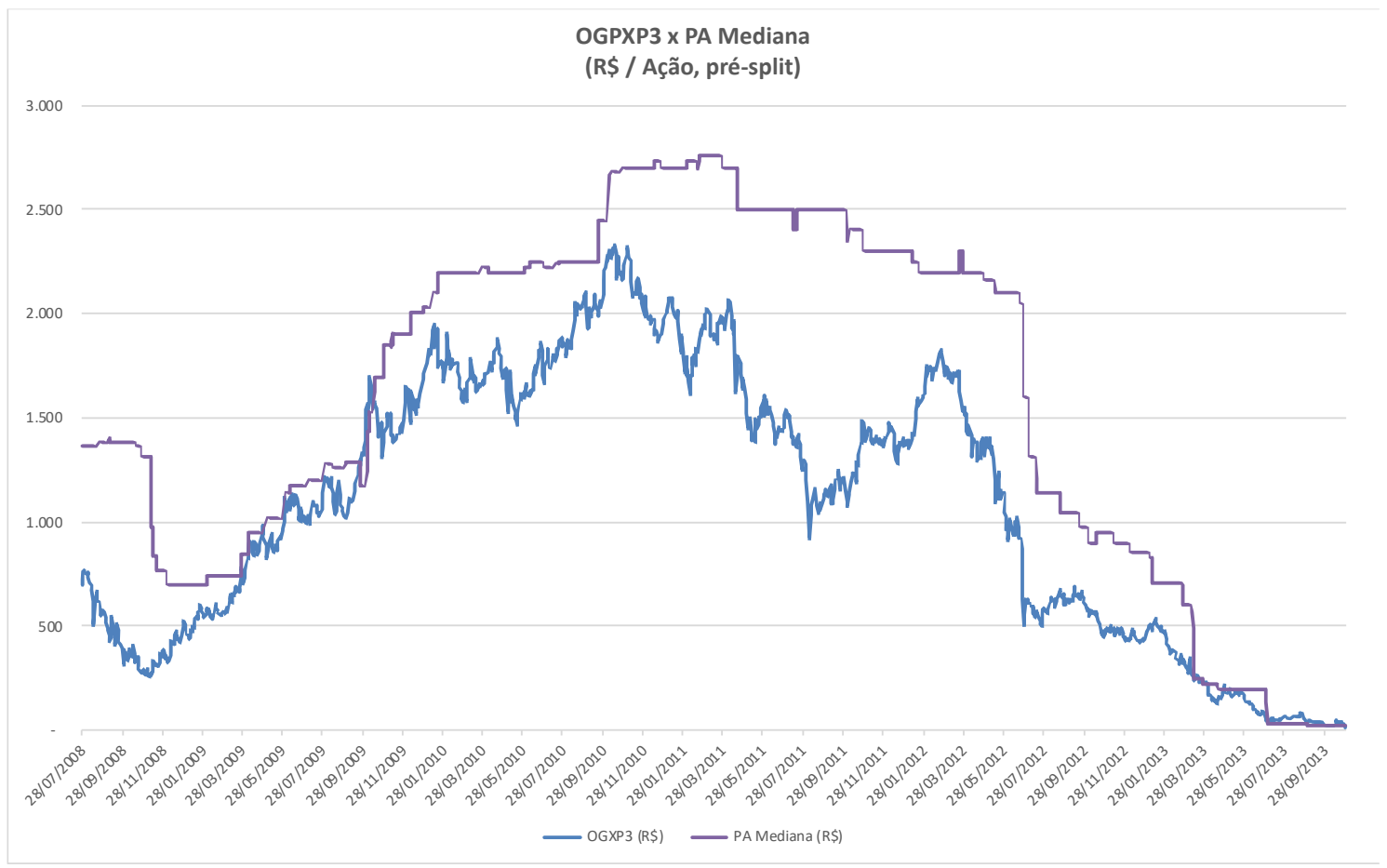

Durante o Rally (6/11/2008 a 4/11/2010) os Analistas revisaram seus PAs frequentemente. O IBBA, por exemplo, atualizou seu PA quatorze vezes no período. 
Tabela 67 - Frequência de Atualizações Positivas no PAs durante o Rally

\begin{tabular}{||l|c|c|c|c|}
\hline \hline & $\begin{array}{c}\text { PA Início } \\
\mathbf{6 / 1 1 / 0 8} \text { ou } \\
\text { primeiro dado* }\end{array}$ & $\begin{array}{c}\text { PA Fim } \\
\mathbf{( 4 / 1 1 / 1 0 )}\end{array}$ & $\begin{array}{c}\text { Variação } \\
\mathbf{\%}\end{array}$ & $\begin{array}{c}\text { Revisões } \\
\text { Positivas }\end{array}$ \\
\hline $\begin{array}{c}\text { Mediana Amostra } \\
\text { TR }\end{array}$ & $\mathbf{1 3 , 1 1}$ & $\mathbf{2 7 , 0 0}$ & $\mathbf{1 0 5 , 9 \%}$ & $\mathbf{3 6}$ \\
\hline BTG & $12,63(22 / 1 / 09)^{* *}$ & 27,63 & $118,8 \%$ & n.d. \\
\hline IBBA & 13,67 & 31,00 & $126,8 \%$ & 14 \\
\hline JPM & 5,50 & 20,30 & $269,1 \%$ & 3 \\
\hline MS & 8,40 & 27,00 & $221,4 \%$ & 3 \\
\hline GS & $19,00(6 / 12 / 09)$ & 27,00 & $42,1 \%$ & 5 \\
\hline UBS & $12,63(22 / 1 / 09)^{* *}$ & 29,50 & $133,6 \%$ & n.d. \\
\hline DB & $28,00(16 / 8 / 10)$ & 28,00 & $0,0 \%$ & - \\
\hline SAN & $33,00(26 / 10 / 10)$ & 33,00 & $0,0 \%$ & - \\
\hline
\end{tabular}

Nota: $\left({ }^{*}\right)$ como a Amostra Própria não possui todos os Relatórios dos Analistas, em alguns deles foi apontado a data do primeiro PA disponível durante o Rally. (**) O Analista do UBS era o mesmo no BTG na época do IPO. Por isso, replicamos seu PA no início do período.

Não é possível identificar se os Analistas, na definição de seus PAs, sofreram pressões internas das instituições financeiras em que trabalhavam que por sua vez tinham relações com o Grupo X. Entretanto, vale destacar os montantes de remunerações pagas pelo Grupo X a alguns destes bancos.

Para começar, vale destacar as remunerações dos bancos de investimentos que executaram o IPO de dois greenfields que precederam o da OGX:

Tabela 68 - IPOs Greenfields: Comissões pagas aos Bancos

\begin{tabular}{|l|c|c|c|c|c|c|}
\hline & Data IPO & $\begin{array}{c}\text { Captação IPO } \\
\text { (R\$ Milhões) }\end{array}$ & $\begin{array}{c}\text { Comissões } \\
(*)\end{array}$ & $\%$ & Bancos & $\begin{array}{c}\text { Auditor } \\
\text { IPO }\end{array}$ \\
\hline Brasil Agro & $27 / 04 / 2006$ & 518,4 & 21,8 & $4,2 \%$ & CS & KPMG \\
\hline Brasil Ecodiesel & $09 / 11 / 2006$ & 378,9 & 22,7 & $6,0 \%$ & Fator Citi & Deloitte \\
\hline Invest Turr & $16 / 07 / 2007$ & 840,0 & n.d. & - & n.d. & n.d. \\
\hline Total / Média & & 897,3 & 44,5 & $5,0 \%$ & & \\
\hline
\end{tabular}

Nota: $(*)$ Inclui somente comissões ao Coordenador, Garantia Firme e Colocação.

A MMX pagou a maior taxa relativa entre os greenfields: 6,22\%. Nos IPOs do Grupo X, as comissões somaram 438,4 milhões, com uma comissão média de 3,9\%. 
Tabela 69 - IPOs Greenfields da OGX: Comissões pagas aos Bancos

\begin{tabular}{|l|c|c|c|c|c|c|c|}
\hline \hline & $\begin{array}{c}\text { Data } \\
\text { IPO }\end{array}$ & $\begin{array}{c}\text { Volume } \\
\text { Captação IPO } \\
\text { (R\$ Milhões) }\end{array}$ & $\begin{array}{c}\text { Comissões } \\
(*)\end{array}$ & $\%$ & Banco Líder & $\begin{array}{c}\text { Joint- } \\
\text { Coordenadores }\end{array}$ & $\begin{array}{c}\text { Auditor } \\
\text { IPO }\end{array}$ \\
\hline MMX & $20 / 07 / 2006$ & $1.029,0$ & 64,0 & $6,2 \%$ & UBS Pactual & CS, IBBA, UBB & KPMG \\
\hline MPX & $12 / 12 / 2007$ & $1.916,4$ & 79,8 & $4,2 \%$ & UBS Pactual & MER, IBBA, SAN & KPMG \\
\hline OGX & $12 / 06 / 2008$ & $5.872,7$ & 234,9 & $4,0 \%$ & CS & UBS, IBBA & KPMG \\
\hline OSX & $18 / 03 / 2010$ & $2.450,4$ & 59,8 & $2,4 \%$ & CS & IBBA, BBD, BTG, MS & KPMG \\
\hline Total OGX & & $\mathbf{1 1 . 2 6 8 , 5}$ & $\mathbf{4 3 8 , 4}$ & $\mathbf{3 , 9 \%}$ & & & \\
\hline
\end{tabular}

Nota: $(*)$ Inclui somente comissões ao Coordenador, Garantia Firme e Colocação.

Entre junho 2011 e março de 2012 a OGX emitiria duas Notes somando US\$ 3,7 bilhões, que renderam mais honorários significativos:

Tabela 70 - Honorários por Assessoria (Advisory) dos Bancos de investimentos envolvidos na Emissão dos OGXPBZ18 e OGXPBZ22 (em US\$ Milhões)

\begin{tabular}{||l|c|c|c||}
\hline \multicolumn{1}{|c|}{ US\$ Milhões } & $\mathbf{2 0 1 1}$ & $\mathbf{2 0 1 2}$ & Total 2011/12 \\
\hline CS & 2,6 & 1,1 & 3,6 \\
\hline BTG & 2,6 & 1,1 & 3,6 \\
\hline IBBA & 2,6 & 1,1 & 3,6 \\
\hline HSBC & 2,6 & 1,1 & 3,6 \\
\hline JPM & 2,6 & 1,1 & 3,6 \\
\hline BBI & & 1,1 & 1,1 \\
\hline MS & & 1,1 & 1,1 \\
\hline Total Comissões & $\mathbf{1 2 , 8}$ & $\mathbf{7 , 4}$ & $\mathbf{2 0 , 3}$ \\
\hline Total Captações & $\mathbf{2 . 5 6 3 , 0}$ & $\mathbf{1 . 0 6 3 , 0}$ & $\mathbf{3 . 6 2 6 , 0}$ \\
\hline \% Comissões & $\mathbf{0 , 5 \%}$ & $\mathbf{0 , 7} \%$ & $\mathbf{0 , 6 \%}$ \\
\hline
\end{tabular}

Os bancos de investimentos envolvidos na emissão do OGXPBZ18 foram o CS, IBBA, HSBC e JPM. Destes, apenas o CS interrompeu a emissão de relatórios de Analistas com PA, por se considerar "restrito". Na nossa amostra, não possuímos relatórios dos Analistas do HSBC. O IBBA e JPM continuaram publicando relatórios e PAs ao longo de 2011.

É importante notar que as receitas com comissões descritas acima não incluem outras ganhas em transações de Bis, como $M \& A$, estruturação de financiamentos. Ou seja, o 
Grupo X pagou milhões em comissões a vários bancos, inclusive aqueles para os quais os Analistas trabalhavam.

Em suma, o caso OGX indica a importância de reforçar a isenção dos Analistas e sua responsabilidade nas recomendações. Nos Estados Unidos, a legislação pós-Enron sobre este tema pode fornecer insights preciosos. 


\subsection{Right to Trust nos Conselhos de Administração}

O último possível aprendizado com o caso OGX talvez seja o que mais requeira pesquisa. Um aspecto, porém, é possível identificar: os conselheiros independentes e o right to trust. Em sua defesa, acusado de negligência por acionistas minoritários, um dos renomados conselheiros independentes do COAD conclamou o right to trust:

174. O Corporate Director's Guidebook, elaborado pela American Bar Association, textualmente dispõe a respeito do direito do administrador de "confiar nos outros" "the right to rely on others") nos seguintes termos:

A director is entitled to rely on reports, opinions, information and statements, including financial statements and other data, presented by (...) (ii) legal counsel, public accountants or other persons as to matters that the director reasonably believes to be within the person's professional or expert competence or as to which the person merits confidence. [p. 53]

183. De qualquer forma, o ordenamento jurídico brasileiro reconhece aos administradores o direito de confiar nas informações e avaliações elaboradas pelos especialistas por eles contratados para realizar as aludidas avaliações, especialmente em se tratando de empresas renomadas e de notória reputação no mercado, como é o caso da DeGolyer and MacNaughton. [p. 55]

189. Da diligência ordinária decorre que o administrador pode confiar em seus colaboradores e outros órgãos, sob pena de exigir-se dele diligência extraordinária. Afinal, a condição de expert não é pressuposto para a eleição de administrador, bastando a reputação ilibada. E, no caso da OGX, como é público e notório, o corpo técnico da Companhia era formado pelas maiores autoridades da indústria de óleo e gás do País, contando ainda com assessoria externa das maiores consultorias do mundo na área - o que, aliás, torna pueril a alegação de culpa in eligendo, na medida, repita-se, em que o melhor corpo técnico existente no mercado foi reunido na OGX, como é fato público e notório. Portanto, não seria de se exigir do réu, economista de carreira, que ele se insurgisse, isoladamente, contra as avaliações (técnicas) do quadro técnico da Companhia e de empresas especializadas, especialmente diante da absoluta inexistência de sinais de alerta (red flags). [p. 56]

Não pretendo aqui ignorar o art. 142, III da Lei das S.A., que impõe o dever de fiscalização das atividades dos diretores pelo 
conselho. Mas no presente caso, para fins especificos de responsabilização administrativa, me parece que a deteç̧ão dessas irregularidades pelos membros do conselho seria demasiado difícil, até pela especificidade e diversidade das mesmas, e que, somente quando somadas, vieram a apresentar impactos significativos no patrimônio da companhia. [Contestação Malan, p. 63] (grifos nossos).

Por que membros do COAD não contrataram geólogos independentes para reduzir assimetrias de conhecimentos específicos com os Executivos? Não haviam "red flags" suficientes?

TIROLE, 2006, nos convoca a uma reflexão importante: membros dos Conselhos de Administração ("CAs") são cães de guarda ou cães de colo? Um conselheiro é dito independente se não acumular cargo executivo na empresa, não prestar serviços à empresa, ou seja, não tiver conflitos de interesse na sua função como monitor. Mas, detectar este conflito é difícil, pois o conselheiro pode ter sido escolhido por sua amizade com o CEO, ou pertencer a mesma rede social, ou ainda estar suscetível à "subornos" (bribes), do tipo ser contratado para fazer uma consultoria.

TIROLE, 2006, identifica outro comportamento que pode limitar a eficácia dos conselheiros: a atenção insuficiente. Nos EUA, é frequente ocorrer que conselheiros acumulem cargos de CEOs em outras empresas. Portanto, além de ter uma jornada intensa em suas empresas também exercem a função de conselheiros. Ou seja, quão preparados podem estar estes executivos para participarem das reuniões dos conselhos? Esse despreparo pode levar estes conselheiros a dependerem excessivamente nas informações e análises dos gestores a quem deveriam monitorar.

No caso da OGX, os três CEOs da OGX, Luiz Carneiro, Paulo Mendonça e Rodolfo Landim ocuparam cargos nos CAs de várias empresas do Grupo X, inclusive a própria OGX: 
Tabela 71 - Executivos que Participavam no CA do Grupo X

\begin{tabular}{|c|c|c|c|c|c|c|}
\hline \multirow{2}{*}{ Nome } & \multicolumn{3}{|c|}{ CA } & \multicolumn{3}{|c|}{ Diretoria } \\
\hline & Empresa & Cargo & Ano & Empresa & Cargo & Ano \\
\hline \multirow{3}{*}{ Luiz Carneiro } & OGX & Conselheiro & $\begin{array}{c}2010 / 2011 \\
2013\end{array}$ & OGX & \begin{tabular}{|l|} 
Diretor \\
Presidente \\
\end{tabular} & 2012 \\
\hline & OSX & Conselheiro & 2012 & OSX & \begin{tabular}{|l|} 
Diretor \\
Presidente \\
\end{tabular} & $2009 / 2011$ \\
\hline & MPX & Conselheiro & 2012 & & & \\
\hline \multirow{4}{*}{ Rodolfo Landim } & OGX & Conselheiro & $2008 / 2009$ & OGX & \begin{tabular}{|l|} 
Diretor \\
Presidente \\
\end{tabular} & 2008 \\
\hline & MMX & Conselheiro & $2007 / 2009$ & MMX & \begin{tabular}{|l|} 
Diretor \\
Geral e DRI \\
\end{tabular} & 2006 \\
\hline & MPX & Conselheiro & $2007 / 2009$ & OSX & \begin{tabular}{|l|} 
Diretor \\
Presidente \\
\end{tabular} & 2008 \\
\hline & LLX & Conselheiro & $2008 / 2009$ & & & \\
\hline \multirow[t]{2}{*}{ Paulo Mendonça } & MPX & Conselheiro & $2010 / 2011$ & OGX & \begin{tabular}{|l|} 
Diretor \\
Geral e DEX
\end{tabular} & $2008 / 2011$ \\
\hline & os $x$ & Conselheiro & $2009 / 2011$ & & & \\
\hline
\end{tabular}

Fonte: Elaborado pelo Autor com base nas informações disponíveis nos IANs das empresas.

Há outros temas de pesquisa sobre COAD e os CAs das outras empresas do Grupo X devido às suas inter-relações. Por exemplo, enquanto a CVM recomenda conselhos formados por 5 a 9 membros, o COAD nasceu, em 2008, com 14 membros. CAs numerosos também se verificaram em outras empresas $X$ : LLX tinha 13 membros em 2008; MPX (15); MMX (15); OSX (13 membros em 2010).

Outro exemplo é o fato do AC ter acumulado os cargos de presidente do COAD e Diretor Presidente da OGX (de 2009 a 2011), o que também vai contra a recomendação da CVM. Em 2008, Rodolfo Landim também acumulou os cargos de presidência do Conselho e Diretor Presidente da OGX. O AC também acumulou cargos de presidente do CA e Presidente na MMX (de 2006 a 2008). Outros presidentes de empresas $X$ também acumularam o cargo de presidente ou vice-presidentes com o cargo de presidente ou vice-presidente dos seus CAs:

Tabela 72 - Acumulo de Cargos na Presidência dos CA e Presidência da mesma Empresa

\begin{tabular}{|l|l|l|}
\hline Nome & \multicolumn{1}{|c|}{ Cargo no Conselho } & \multicolumn{1}{c|}{ Cargo na Empresa } \\
\hline \multirow{4}{*}{ AC } & OGX - Presidente (2008 a 2013) & $\begin{array}{l}\text { OGX - Diretor Presidente (2009 a } \\
\text { 2011) }\end{array}$ \\
\cline { 2 - 4 } & MMX - Presidente (2006 a 2015) & $\begin{array}{l}\text { MMX - Diretor Presidente (2006 } \\
\text { a 2008) }\end{array}$ \\
\cline { 2 - 3 } & CCX - Presidente (2012 a 2014) & CCX - Diretor VP (2015) \\
\hline
\end{tabular}

Fonte: Elaborado pelo Autor com base nas informações disponíveis nos IANs das empresas. 


\subsection{Considerações Finais}

Analisar a evolução da OGXP3 é como montar um quebra-cabeças já sabendo de antemão que haverá peças faltando. Um quebra-cabeças fascinante que comporta múltiplas abordagens: condutas destruidoras de valor e governança corporativa (risco moral e seleção adversa); função dos gatekeepers externos (analistas, auditores e consultores); eficácia de Conselhos de Administração; economia comportamental dos investidores de curto e longo prazo; momentum trading e a evolução do valor da OGXP3 e dos unsecured bonds; avaliação de greenfields em IPOs e RJs; planejamento e implementação de grandes projetos de infraestrutura; sinergias positivas e negativas em conglomerados; economia política da regulação dos mercados de capitais; organização e regulação da indústria de E\&P de O\&G no Brasil; ética empresarial; bolhas especulativas; política de fomento à indústria naval; e outros.

O presente estudo é um apenas começo, uma tentativa de identificar os principais temas deste quebra-cabeças de milhares de peças. Além de economia, há muitas oportunidades de pesquisas multidisciplinares envolvendo temas contábeis, direito, psicologia, gestão de pessoas, planejamento e implementação de projetos, comunicação com investidores, geologia e engenharia do O\&G.

Quem ganhou e quem perdeu com a saga da OGX provavelmente são as questões mais difíceis de mensurar. $O$ fato é que o Brasil é um país rico em projetos greenfield em infraestrutura, não apenas em ativos minerários, mas também logística, energia, agricultura, indústria, mobilidade urbana e infraestrutura social (saneamento básico, saúde, educação e segurança pública), dentre outros. $O$ país precisa atrair capital e financiamentos de longo prazo e a derrocada da OGX pode não ter contribuído para a percepção destes investidores em relação ao nosso mercado de capitais.

Embora não seja possível, ainda, mensurar o possível custo da derrocada da OGX sobre a reputação e atratividade do mercado de capitais brasileiro, podemos refletir sobre o cenário oposto: que oportunidades poderiam ter sido geradas ao Grupo X e ao Brasil se a OGX tivesse sido bem-sucedida? Se este tivesse sido o caso, apenas contemplando o Grupo $X$, a OSX provavelmente também teria sido bem-sucedida, com impactos positivos para a LLX e MPX no Porto de Açu. Outros empregos, diretos e indiretos, teriam sido gerados e possivelmente os IPOs de outras junior oils de capital nacional poderiam ter sido viabilizadas.

Análises objetivas do caso OGX e suas repercussões podem produzir insights e políticas de valor para a viabilidade de investimentos em infraestrutura, não apenas no Brasil, mas também em outros países emergentes. Fica aqui o convite aos pesquisadores. 


\section{Anexos Valor de Empresas de E\&P em O\&G}

A OGX foi a primeira e-company de capital aberto deste tipo no Brasil ${ }^{600}$. A PETR, em contraste, era uma empresa integrada, pois possui o upstream, midstream (oleodutos, gasodutos e comercialização) e downstream (refinarias e petroquímicos).

Os direitos de exploração da OGX foram adquiridos em leilões (9a Rodada em 2007 e 11 a Rodada em 2012) e farm-ins. Como greenfield, a história da OGX, desde seu IPO até seu pedido de recuperação judicial, foi marcada por uma questão: qual a capacidade de produção de petróleo que a Empresa realmente poderia executar com margens rentáveis? Esta questão envolvia discussões técnicas comuns ao setor de E\&P. Alguns conceitos são fundamentais para entender a evolução da narrativa da OGX ao mercado, e parte das reações do mercado. Em parte, são conceitos relacionados a geologia, geofísica, probabilidade, ao mercado de petróleo e sua regulação no Brasil.

Este anexo está organizado em três seções A seção A.1 descreve alguns elementos básicos da indústria de O\&G e do processo de E\&P. O objetivo é, de forma resumida, apresentar conceitos e nomenclaturas que compõe o valor de uma empresa de E\&P. Muitos destes termos foram utilizados extensivamente no guidance dos Executivos e nos relatórios dos Analistas. Como o foco é a OGX, esta seção se restringe a conceitos e nomenclaturas aplicados no upstream da indústria de O\&G.

A seção A.2 descreve metodologias de avaliação de empresas de $O \& G$, dentre a análise de múltiplos, FDC e o NAV. Estas duas seções abordam elementos cruciais para a discussão sobre o Valor Ótimo da OGX. Na sequência, a seção A.3 discute evidências empíricas sobre o comportamento dos preços das ações de empresas de O\&G, ou seja, as possíveis variáveis de afetam a capitalização de mercado destas empresas. Dentre as variáveis específicas à indústria de $O \& G$, destaca-se o preço de $O \& G$ e as estimativas de reservas.

${ }^{600}$ A HRT e a QGEP executaram seus IPOs em 25 de outubro de 2010 e fevereiro de 2011, respectivamente. A HRT Participações em Petróleo (hoje, PetroRio S.A.), uma greenfield formada por ex-funcionários da PETR, captou R\$2,624 B em no seu IPO junto à investidores qualificados, com 2,1 bboe em recursos prospectivos, nas bacias dos Solimões, AM, e na Namíbia, segundo a D\&M. O líder no IPO foi o CS, junto com Citi e GS. 


\section{A.1 Elementos Básicos de O\&G e do Processo de E\&P}

Antes dos leilões de concessões no Brasil, a ANP disponibiliza aos interessados um pacote com todos os dados relevantes das áreas em licitação, contendo informações técnicas e sumários geológicos. Com base nestes dados, os investidores fazem extrapolações sobre o volume potencial de "Recursos Prospectivos" nos blocos.

"Recursos Prospectivos" são estimativas puramente estatísticas para volumes de O\&G baseado em acumulações ainda não descobertas, mas potencialmente recuperáveis, tendo como base analogias, extrapolações de resultados de poços vizinhos. Estimar recursos prospectivos é, "no melhor dos casos, uma tarefa subjetiva"601.

Após a assinatura do contrato de concessão e o pagamento do Bônus de Assinatura ("BA"), inicia-se a campanha de exploração, que começa com testes sísmicos, perfurações (sondagens), perfilagem ${ }^{602}$, em áreas menores, denominadas prospectos $^{603}$. As perfurações produzem informações preliminares sobre a presença ou não de hidrocarbonetos. Se forem descobertos hidrocarbonetos, então as perfurações continuam em busca de identificar as composições químicas dos hidrocarbonetos (por exemplo, óleo e GN), possíveis dimensões e características dos reservatórios, em particular a altura da coluna de óleo e/ou gás e a camada produtora ("net pay") 604.

Ainda na fase de exploração, temos os testes de formação e testes de longa duração ("TLD"). Estes testes indicarão a capacidade de produção do reservatório e seu risco. Portanto, quando uma empresa resolve devolver um bloco concedido à ANP, pode ser motivada por três possíveis causas: os testes podem não ter sido conclusivos; os testes foram conclusivos, porém os investimentos necessários para seu desenvolvimento e a perspectiva para o preço do petróleo não torna o campo economicamente viável; ou porque o campo é viável economicamente, mas a empresa não possui capacidade financeira de executar seu desenvolvimento.

601 KOVARSKY \& MENDES, 2011o, p. 2.

602 Perfilagem: método utilizado para verificar/avaliar as características físicas e químicas das camadas geológicas e dos fluidos nelas contidos. Por meio de sensores e amostradores apropriados, estas características são medidas e as respostas são transmitidas para computadores na superfície onde os dados são processados. Características dos fluidos e das rochas são identificadas e quantificadas através deste método.

${ }^{603}$ Prospecto é uma feição geológica mapeada como resultado de estudos e interpretações geofísica e geológica que justificam a perfuração de poços exploratórios para a localização de petróleo e/ou gás natural. Existem dados suficientes para identificar e quantificar as incertezas e a probabilidade de sucesso e estimar-se recursos potenciais e economicidade.

${ }^{604}$ Coluna de Óleo/Gás é uma seção vertical contínua de rochas saturadas por óleo e/ou GN, englobando rochas reservatório e não reservatório. O net pay é a parte da coluna de óleo, englobando somente o intervalo ou intervalos de rochas reservatório saturados por petróleo e/ou GN. É definido por critérios como porosidade, permeabilidade e saturação mínima de hidrocarbonetos. 


\section{Figura 9 - Fluxo de Atividades da Fase de Exploração em Poços Offshore}

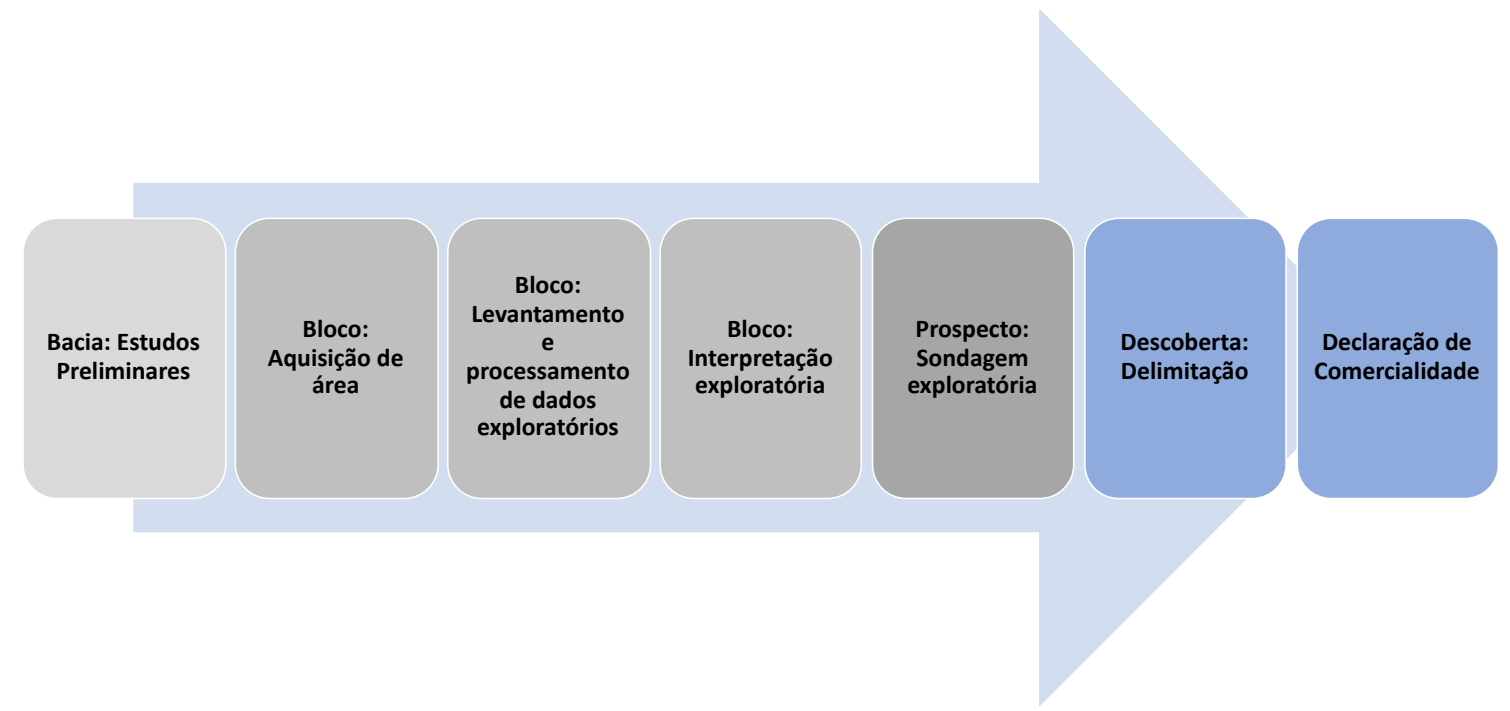

O objetivo do processo de exploração é identificar a viabilidade geológica e financeira dos Recursos Prospectivos de maneira a reclassificá-los para categorias de recursos com menor incerteza, culminando na "Declaração de Comercialidade" ou na devolução do bloco à ANP. A seguir, uma suscinta descrição o sistema de classificação de recursos mais adotado, o SPE-PRMS.

\section{Classificação de Reservas Provadas e Não Provadas}

Petróleo é definido como a ocorrência natural de uma mistura de hidrocarbonetos em estado gasoso, liquido e sólido. Em projetos pré-operacionais de E\&P de O\&G, a primeira grande incógnita é a geologia dos blocos: que tipo de hidrocarboneto pode existir em seu subsolo (óleo ou GN, em que porcentagem, e qual o tipo de óleo ${ }^{605}$ ), em qual seção ${ }^{606}$, qual o tamanho das reservas (medidas em boe). Ao mesmo tempo em que a

605 A escala $\mathrm{API}^{\circ}$ é uma forma de representar a densidade relativa do petróleo. Quanto mais denso (pesado), menor o API. Quanto maior o API, mais leve (ou doce) é o petróleo. A PETROBRAS [2010, p. 13] classifica petróleos com grau API superior a 31 como leves; entre 22 e 31 são intermediários; igual ou abaixo de 22, como pesados.

${ }^{606}$ A nomenclatura das seções (albiana, cretáceo superior, etc.) refere-se às idades da formação geológica das diferentes acumulações. Por exemplo, a seção Albiana foi formada há 99,6 a 112,0 milhões de anos. A seção Barremiana foi formada há 125,0 a 130,0 milhões de anos. Estas seções podem ser associadas à qualidade do óleo lá encontrada, medida pelo API․

Exemplos de Associações entre Seções Geológicas e Campos em Produção

\begin{tabular}{||l|c|l||}
\hline \multicolumn{1}{|c|}{ Seções / Objetivos } & \multicolumn{1}{|c||}{ API $^{\mathbf{0}}$} & \multicolumn{1}{c|}{ Campos de Petróleo Análogos } \\
\hline Terciário & $14-20$ & Maromba, Enchova, Complexo Marlim \\
\hline Cretáceo Superior & $18-23$ & Maromba, Papa-Terra, Espadarte e Jubarte \\
\hline Albiano & $18-25$ & Polvo, Pampo Bicudo \\
\hline Aptiano-Barremiamo Pré-Sal & $28-38$ & Maromba, Linguado, Tupi \\
\hline
\end{tabular}

Fonte: Prospecto, 2008, p. 161. 
geologia é uma ciência, há muita subjetividade. De acordo com MISUND \& OSMUNDSEN [2017], as quantidades e valores das reservas são fonte de confusão entre investidores de empresas de O\&G. O caso da OGX não foi exceção.

Os esforços de padronização das definições de reservas começaram na década de 1930, inicialmente com foco em "reservas provadas". O contínuo desenvolvimento tecnológico exige revisões periódicas das definições de reservas, que envolvem aspectos técnicos e comerciais.

SCHOLTENS \& WAGENAAR [2011] relatam que desde a década de 1980, experts em O\&G se preocupam com a qualidade da informação contida nas estimativas das reservas. Empresas e governos podem usar diferentes critérios, metodologias e pode haver incentivos para superestimá-las.

\section{Sistema de Classificações do SPE-PRMS}

O termo "recursos" se refere a todas as quantidades de petróleo na crosta da Terra, descobertas e não descobertas (recuperáveis e não recuperáveis). Inclui todos os tipos de petróleo convencional e não convencional ${ }^{607}$. A figura a seguir ilustra as classificações dos recursos segundo o grau de incerteza e comercialidade segundo a SPE-PRMS:

Além da qualidade do petróleo, o tipo de seção pode estar associado com as taxas de recuperação do óleo. Descobertas em seções Albiana também poderiam ter taxas mais elevadas de fluxo (até 45 kboed/poço), o que resultaria em maior taxa de recuperação [DARIPA \& SILVA, 2009d].

${ }^{607}$ Areia betuminosa, gás de xisto são exemplos de petróleo não convencional, que pode ser extraído com o uso de tecnologias diferenciadas. 


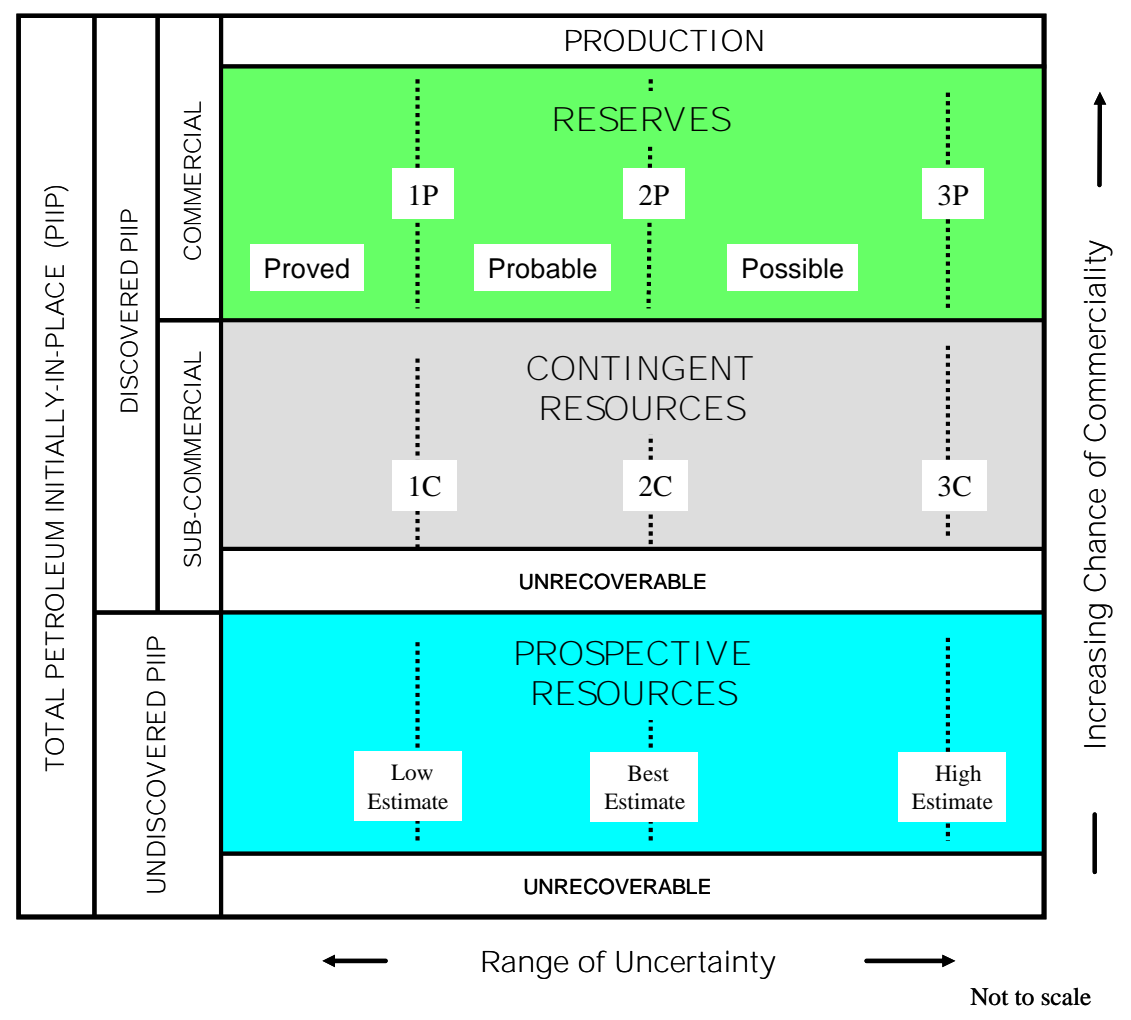

Fonte: SPE-PRMS, 2008, p. 2.

Portanto, o termo "recursos" é o mais genérico. Recursos Prospectivos ("untapped resources", ou ainda, "recursos potenciais") são identificados através de testes sísmicos, porém ainda não foram submetidas à perfuração. Essa definição implica que não há certeza que alguma parte dos recursos prospectivos seja descoberta e, se a for, não há certeza que sua produção seja viável economicamente.

"Recursos Contingentes" são quantidades de petróleo, de acumulações conhecidas, que podem ser potencialmente recuperáveis, entretanto ainda não são consideradas maduras o suficiente para desenvolvimento comercial devido a uma ou mais contingências, em uma determinada data. Recursos contingentes podem incluir projetos que ainda não têm mercado, ou que requerem uma tecnologia ainda em desenvolvimento, ou que a avaliação ainda não é suficiente para estimar a viabilidade comercial.

Ou seja, recursos contingentes podem ser interpretados como estimativas das reservas. O conceito de "recursos contingentes", no caso do Brasil, se distingue do conceito de "reserva", pois esta última requer a "Declaração de Comercialidade". A "Declaração de Comercialidade" de uma reserva marca o fim do período de exploração e o início do período contratual da concessão de produção. Por isso, as empresas, geralmente, adiam a Declaração de Comercialidade até o momento que a produção efetivamente começará. Por vezes, quando o período de concessão está por terminar, empresas podem antecipar a Declaração de Comercialidade para não perder a possibilidade de desenvolver da área. Entretanto, após a entrega da Declaração de Comercialidade, a 
empresa tem prazos para apresentar e implementar o Plano de Desenvolvimento (“PD").

Os "Recursos Não Descobertos do PIIP" são quantidades de petróleo estimadas, em uma determinada data, que podem estar contidas em acumulações que ainda não foram descobertas. Os "Recursos Prospectivos" são quantidades de petróleo estimadas, em uma determinada data, que podem ser potencialmente recuperáveis em acumulações que ainda não foram descobertas. Recursos Prospectivos possuem uma probabilidade de descoberta e uma probabilidade de desenvolvimento.

Já as "Reservas" são quantidades de petróleo que podem ser comercialmente recuperáveis dentro de certas premissas técnicas e comerciais, em uma determinada data. Há reservas provadas e não provadas. Como descrito adiante, uma das grandes fontes de confusão nas estimativas de valor da OGX foi o significado das classificações utilizadas pela Empresa, pela D\&M e por outras referências (peers) utilizadas pelos Analistas.

Segundo HOWARD \& HART [2009], com base no SPE-PRMS, as reservas provadas podem ser classificadas em três tipos:

1. Provadas, Desenvolvidas e Produzindo (PDP). São reservas que estão abertas e produzindo no momento da estimativa e geram fluxo de caixa. É o tipo menos arriscado e, portanto, mais valioso de reservas.

2. Provadas, Desenvolvidas e Não-Produzindo (PDNP). São reservas que estão fechadas e, portanto, sem produção no momento da estimativa, mas podem ter produzido anteriormente. Como tal, não geram fluxo de caixa. Podem requerer investimentos adicionais para produzir.

3. Provadas e Não Desenvolvidas (PUD). São reservas de recursos que podem ser recuperados com: (i) novos poços em áreas ainda não perfuradas ou (ii) poços já perfurados, mas que irão requerer investimentos significativos para produzir.

Geralmente, PUDs não são consideradas ou contabilizadas até que esteja claro o poço ou a viabilidade do investimento estejam completados no futuro próximo. [p. 2]

Entretanto, as PUDs de hoje podem ser as PDPs do futuro:

Investir em E\&P é essencialmente apostar em commodities. Os preços do mercado [das ações] estão altamente correlacionados com as expectativas de preços das commodities que vendem. A análise, portanto, baseia-se fortemente na vida de reserva e na capacidade de substituir a produção [de reservas decadentes]. As PUDs são as reservas que irão, no futuro, substituir as reservas em decadência. [p. 6]

Segundo o SPE-PRMS, o tempo razoável para uma PUD iniciar seu desenvolvimento é de até 5 anos. Caso este período seja mais longo, o SPE-PRMS recomenda que essa demora seja explicitamente justificada para manter os recursos classificados como PUD.

Reservas não provadas podem ser classificadas 
4. Reservas Prováveis $\mathbf{2 P}$, quando agregadas com reservas provadas, tem $50 \%$ de chance que a quantidade efetiva seja superior à estimada e $50 \%$ de chance de ser inferior, de acordo com a definição do American Petroleum Institute - API.

5. Reservas Possíveis 3P, quando agregadas com reservas prováveis e provadas, tem $10 \%$ de chance que a quantidade efetiva seja superior à estimada e $90 \%$ de chance de ser inferior. "Esta categoria de reservas não provadas é altamente especulativa e, como tal, têm geralmente pouco peso". [p. 3]

Em suma, o fator decisivo para a classificação entre "recursos prospectivos", "recursos contingentes" e "reservas" é o nível de incerteza, calculado com base em análises qualitativas, mas que podem ser associados com os conceitos probabilísticos de P90, $\mathrm{P} 50$ e $\mathrm{P} 10^{608}$ :

Tabela 73 - Conceitos de Níveis de Incerteza no Sistema de Classificação de Recursos

\begin{tabular}{|c|c|c|}
\hline Recursos Prospectivos & Recursos Contingentes & Reservas \\
\hline Baixo (P90) & 1C (P90) & 1P (P90) - Provada \\
\hline Melhor (P50) & 2C (P50) & 2P (P50) - Provável \\
\hline Alto (P10) & 3C (P10) & 3P (P10) - Possível \\
\hline
\end{tabular}

Fonte: KOVARSKY \& MENDES, 2011a.

A SPE recomenda que a incerteza das estimativas dos recursos recuperáveis seja divulgada em intervalos de possíveis resultados. Caso seja necessário um único resultado, então recomenda-se o uso da "melhor" estimativa (P50). Entretanto, segundo a SPE, para considerar um recurso prospectivo como reserva, deve haver uma probabilidade de $90 \%$ que a reserva é maior ou igual ao seu volume estimado.

As classificações de incerteza dos recursos prospectivos utilizam simulações de Monte Carlo considerando funções de distribuição de probabilidades para vários aspectos físicos químicos (porosidade, saturação do óleo, taxas de recuperação, densidade do fluído, etc.) e econômicos (preço do petróleo, custo de extração, etc).

A proximidade dos prospectos com outras reservas já comprovadas é um diferencial, pois permite o read-across.

\section{Processo de Avaliação de Recursos}

O Processo de Avaliação de Recursos consiste em identificar um projeto recuperável, associado a uma acumulação de petróleo, estimando o PIIP e posteriormente a porção do PIIP que pode ser recuperável, e classificando os projetos com base no seu estágio

608 P90, por exemplo, significa que há, pelo menos, 90\% de probabilidade que a quantidade de óleo efetivamente recuperada seja igual ou maior do que a menor estimativa. 
de maturidade ou probabilidade de comercialização. Esse é o processo de de-risking do portfólio de projetos.

Figura 11 - Fontes de Informações para Avaliação dos Recursos

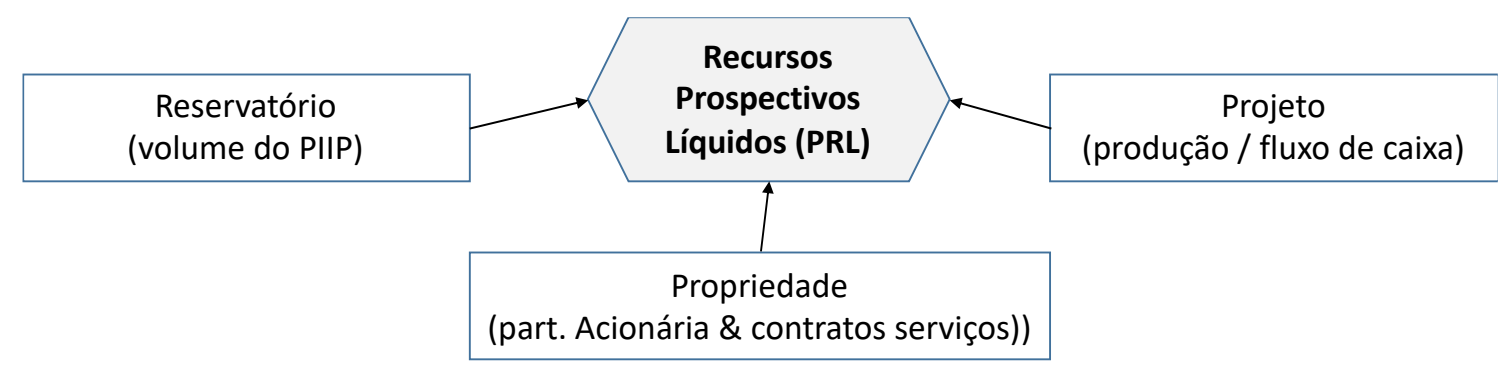

Fonte: SPE-PRMS, 2008, p. 4.

O reservatório (ou acumulação) inclui os tipos e volumes de PIIP, as propriedades do fluído e da rocha que podem afetar a recuperação do petróleo. Cada prospecto se aplica ao desenvolvimento de um reservatório específico que gerará uma determinada produção e fluxo de caixa. O projeto pode incluir um ou mais poços. Um projeto pode desenvolver muitos reservatórios, ou vários projetos podem se aplicar a apenas um reservatório. Portanto, um reservatório pode ter volumes de recursos em várias classificações, ao mesmo tempo.

Cada propriedade (alugada (leased) ou concedida) pode estar associada a direitos e obrigações contratuais únicos, incluindo termos tributários, divisão dos investimentos, despesas e receitas. Uma propriedade pode ter mais de um reservatório e um reservatório pode se estender por várias propriedades. Cada propriedade pode conter acumulações descobertas e não descobertas.

Neste contexto, o projeto é o elemento primário da classificação de recursos, e os "Recursos Recuperáveis Líquidos" são os volumes incrementais derivados de cada projeto. $O$ projeto representa o elo entre a acumulação do petróleo e o processo decisório sobre prosseguir ou não com os investimentos necessários para a extração do petróleo. $O$ projeto deve ter um intervalo estimativa para seus volumes recuperáveis.

Para definir recursos como recuperáveis, em qualquer classe, é preciso um plano de desenvolvimento de um ou mais projetos Mesmo para Recursos Prospectivos, as estimativas de volumes recuperáveis precisam ser mensuradas assumindo um programa de desenvolvimento, incluindo premissas para a descoberta e desenvolvimento comercial. As estimativas para as quantidades de recursos, na maioria dos casos, são feitas com base em projetos análogos. O volume PIIP de um projeto viável que não puder ser definido usando a tecnologia disponível deve ser classificado como "Irrecuperável". 
Nem todos os planos de desenvolvimento factíveis serão comerciais, por questões financeiras, legais, ambientais, logísticas, tributárias, etc...

\section{Processo de Classificação}

1. Descoberta de uma acumulação, através de uma ou várias perfurações, estabelece que há uma quantidade "significativa" de hidrocarbonetos que podem ser recuperáveis economicamente.

A probabilidade de uma potencial acumulação resultar em uma descoberta de petróleo é denominada de "probabilidade de descoberta".

2. Volumes estimados recuperáveis em acumulações identificadas (conhecidas) serão classificados como Recursos Contingentes.

Se os hidrocarbonetos descobertos não forem considerados recuperáveis, devem ser classificados como "Descobertas Irrecuperáveis". Uma parte destas Descobertas Irrecuperáveis podem se tornar recuperável no futuro, se as condições comerciais mudarem ou houver avanços tecnológicos.

3. Projetos com chances suficientes de viabilidade comercial, podem ser classificados, em parte ou no todo, como reservas.

A probabilidade de uma acumulação identificada ser comercialmente viável é denominada de "probabilidade de desenvolvimento".

4. Para determinar a comercialidade de uma reserva, a empresa deve ter evidências para sustentar: um razoável cronograma de desenvolvimento; uma estimativa razoável dos resultados econômicos dos projetos, incluindo que haverá demanda para o volume a ser produzido; a disponibilidade da infraestrutura de produção e transporte; que há condições legais, regulatórias, contratuais e ambientais que permitirão a implementação dos projetos em avaliação.

Se a probabilidade de descoberta de uma acumulação identificada for de $100 \%$, então a "probabilidade de comercialidade" se torna equivalente a "probabilidade de desenvolvimento".

Para os Recursos Contingentes serem classificados como Reservas é preciso ter uma alta confiança na capacidade do reservatório produzir comercialmente, consubstanciada por testes de formação ou pela produção efetiva. Sem novas informações técnicas, não deve haver mudanças na distribuição e categorização dos recursos recuperáveis.

O tempo para iniciar o desenvolvimento de um projeto varia de acordo com seu escopo e com as circunstâncias. Apesar de recomendar benchmark de 5 anos, o SPE-PRMS reconhece que o período pode ser mais longo, se o produtor tiver esta opção. Nestes casos, o produtor pode aguardar condições de mercado mais favoráveis ou critérios estratégicos para iniciar o desenvolvimento do projeto. Entretanto, o SPE-PRMS 
recomenda que, nestes casos, as justificativas para a classificação das reservas sejam claramente documentadas.

A soma das Reservas, Recursos Contingentes e Recursos Prospectivos é denominada "Recursos Recuperáveis Remanescentes" (Remaining Recoverable Resources). A "Estimativa de Recuperação Final" (EUR) não é uma categoria de recursos, mas um termo que pode ser aplicado a uma ou mais acumulações, descobertas ou não, para definir as quantidades de petróleo estimadas, em uma data, para serem potencialmente recuperáveis sob condições técnicas e comerciais definidas, mais as quantidades já produzidas. Geralmente, o intervalo estimado de EUR tende a decrescer com a maior disponibilidade de informações, mas pode não ser o caso.

\section{Estimativas de Volume Recuperável}

O SPE-PRMS descreve três procedimentos analíticos para estimar volumes recuperáveis:

a) Analogias. Dados sobre campos ou projetos análogos são tipicamente utilizados em estimativas pré-descoberta, quando informações sobre medições diretas são escassas. Analogias também são usadas em pós-descobertas.

Os parâmetros que identificam acumulações análogas são muitos, dentre eles: profundidade estimada; pressão; temperatura; porosidade; permeabilidade; plano de desenvolvimento. Embora a proximidade geográfica entre os projetos e a similaridade das idades geralmente podem gerar melhores análogos, a proximidade não pode ser a consideração primária.

b) Estimativas Volumétricas. Este processo se baseia nas propriedades da rocha e do fluído para estimar os volumes recuperáveis. As principais incertezas que podem afetar os volumes são: geometria do reservatório; porosidade e permeabilidade das rochas; elevação dos fluídos contatados. Estimativas volumétricas também consideram a possível eficiência dos mecanismos de recuperação do projeto. Testes sísmicos podem aprimorar as estimativas do reservatório e sua produtividade.

c) Estimativas Baseadas em Performance, dentre elas, Balanço Material (Material Balance), Declínio da Produção (Production Decline) e outros. Somente pode ser aplicado após o início da produção.

Métodos de Balanço Material, que incluem modelos computacionais para simulação do reservatório, envolvem a análise dos fluídos extraídos e do comportamento da pressão do reservatório. Esses métodos podem gerar resultados pouco precisos e até errôneos em situações complexas, como quando há compartimentalização do reservatório, ou multicamadas, influxo de água e baixa permeabilidade.

Métodos de Declínio da Produção analisam as variações das taxas de produção ao longo do tempo para estimar taxas de declínio (depletion rate). Indicadores de performance, como a razão gás/óleo, água/óleo, são extrapolados para estimar as 
reservas. Estimativas confiáveis dependem de dados sobre períodos de produção suficientemente longos.

\section{Etapas de Maturidade do Projeto}

Uma forma complementar de apresentar a classificação dos recursos é incluir uma coordenada com a etapa de maturidade do projeto. São etapas qualitativas associadas com probabilidades de sucesso (quantitativas).

Figura 12 - Fases de Maturidade de um Projeto

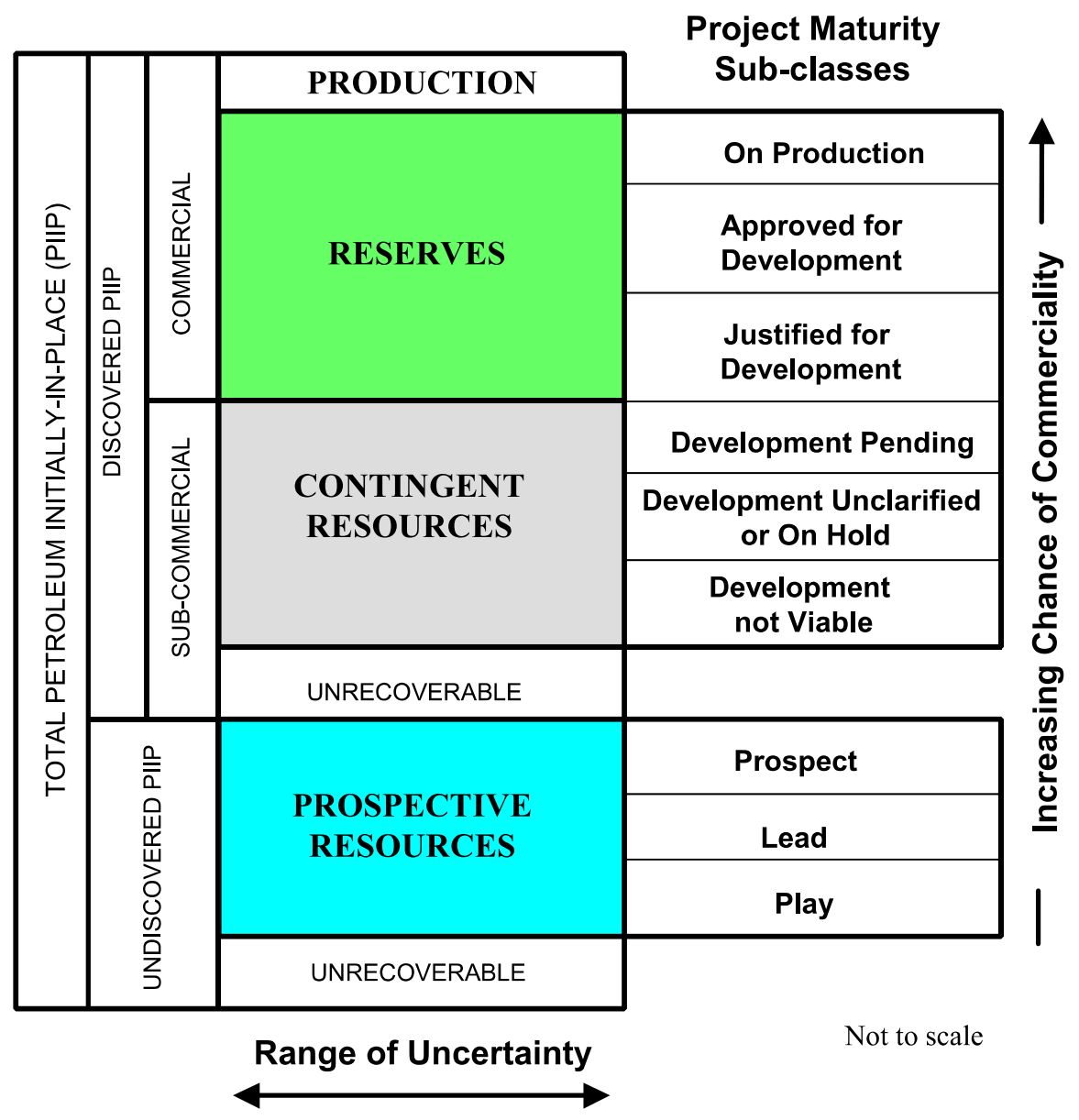

Figure 2-1: Sub-classes based on Project Maturity.

Fonte: SPE-PRMS, 2008, p. 7.

A fronteira entre cada etapa da maturidade do projeto é chamada de "portões de decisão" (decision gates). Prospecto é então uma fase de maturidade de um projeto que pode se tornar um recurso contingente. A cada portão de decisão, a coleta de dados e análise de suporte devem focar na viabilidade técnica e comercial que poderá justificar 
os investimentos para prosseguir para a próxima etapa. A direção é sempre em aumentar a probabilidade de comercialidade do projeto.

Para as Reservas Contingentes, a análise de suporte deve focar na coleta de dados para clarificar ou mitigar as condições críticas, ou contingências, que podem inviabilizar o desenvolvimento comercial do projeto.

Os projetos também podem ser classificados de acordo com seu "Status Econômico":

- Recursos Contingentes Marginais: recursos associados a projetos tecnicamente viáveis e que são, ou podem vir a ser comercialmente viáveis, em condições futuras razoáveis, entretanto não iniciaram seu desenvolvimento devido a uma ou mais contingências.

- Recursos Contingentes Sub-Marginais: recursos associados a projetos tecnicamente viáveis e que não são, ou não podem vir a ser comercialmente viáveis, em condições futuras razoáveis. 


\section{A.2 Avaliação Econômico Financeira de Empresas de Exploração de O\&G}

Existem empresas de consultoria internacionais (appraisers) que são especializadas em avaliar e classificar as reservas provadas e não provadas de empresas de O\&G, elaborando os relatórios de avaliação (appraisal reports), como por exemplo, a Wood Mackenzie. A OGX contratou a consultoria D\&M.

As estimativas de recursos destes relatórios podem ser usadas para: (i) fins contábeis e exigências das agências reguladoras dos mercados de capitais; (ii) bancos e outras fontes de financiamento; (iii) transações de M\&A. Nestes relatórios deve estar claro se foram ou não considerados volumes de PUDs, reservas possíveis 3P.

A D\&M, como outras consultorias, conduz seus trabalhos com base nas informações disponibilizadas pelos seus próprios clientes, o que implica em dois desafios. Primeiro, que as informações disponibilizadas sejam de qualidade e verídicas. Nos EUA, o Pension Protection Act de 2006 define multas para os avaliadores que aceitarem informações de seus clientes sem uma adequada auditoria (due diligence).

O segundo desafio dos relatórios de avaliação é que, dada a diversidade de técnicas exploratórias, as reservas $2 \mathrm{P}$ de uma empresa, por exemplo, podem não ser diretamente comparáveis às reservas $2 \mathrm{P}$ de outras empresas.

\section{Estimativa da Viabilidade Comercial - Base Empresas Análogas e NAV}

Para identificar empresas de capital aberto comparáveis de E\&P ("guideline companies"), HOWARD \& HART [2009] recomendam atentar para as seguintes diferenças: (i) tamanho da capitalização de mercado ou volume de reservas; (ii) mix GN e óleo nas reservas ou na produção; (iii) vida útil das reservas, mensurado pela razão entre Reservas Provadas e a produção anual (conhecida como razão "r/p"); (iv) a razão entre PUD e o total de PDP, que indica quanto do total de reservas está atualmente gerando EBITDAX (Earnings Before Interest, Taxes, Depreciation, Depletion, Amortization and Exploration Expenses); (v) razão entre áreas/bacias em operação, como por exemplo, a produção entre blocos terrestres versus marítimos.

Na revisão dos Relatórios de Avaliação, HOWARD \& HART [2009] recomendam atenção a certas premissas:

a. Price deck.

b. Projeção de volumes futuros comparado com históricos.

c. Volumes de PUDs e Reservas Possíveis 3P. Premissas de investimentos em perfurações.

d. Grau de concentração da produção por poço. Quanto mais concentrada a produção for, maior o risco do fluxo de caixa projetado.

e. Premissas para os custos de abandono. Pelo GAAP, estes custos são considerados passivos. 
Os principais múltiplos de EV são:

- EV/volume de Reservas Provadas

- EV/produção diária

- EV/EBITDAX

A análise de múltiplos é complexa porque além de encontrar empresas com perfil operacional parecido, o volume de reservas pode variar com frequência devido às aquisições e/ou vendas. Empresas pequenas e pouco diversificadas (junior oils), com Reservas Provadas porém não desenvolvidas, necessitam de altos investimentos para converter reservas em ativos capazes de gerar fluxo de caixa. Entretanto, são empresas com alto potencial de crescimento e geralmente pouco endividadas. Se a razão $\mathrm{r} / \mathrm{p}$ for alta, isto pode implicar que seus atuais níveis de produção podem ser mantidos por um período mais longo do que outras empresas de referência. Segundo HOWARD \& HART [2009], baixo endividamento e alto $\mathrm{r} / \mathrm{p}$ podem implicar em um binômio favorável de risco e crescimento.

Alguns autores argumentam que o FDC não funciona bem para empresas de O\&G, por duas razões: elevados investimentos iniciais com fluxos de caixa declinantes no futuro devido a exaustão das reservas; o uso do valor terminal do tipo Gordon, especialmente com taxas de crescimento, embora tenham um impacto significativo, podem não ter significado prático, dado que o volume de reservas é finito e declinante. O método alternativo é o NAV - Net Asset Value, especialmente para empresas de E\&P.

\section{Estimativa da Viabilidade Comercial - Base Parâmetros Históricos}

A SPE-PRMS recomenda que os relatórios de avaliação descrevam suas premissas comerciais de forma clara. A avaliação da viabilidade comercial dos recursos pode ser baseada em preços e custos históricos de desenvolvimento, recuperação e produção da própria empresa nos projetos ou parâmetros de empresas comparáveis, na ausência de histórico.

Quando a empresa em avaliação possui histórico operacional, a SPE recomenda que as projeções devam ter como base variações em relação às médias históricas dos últimos 12 meses de preços e custos. São considerados também os tributos, pagamentos de royalties e outras deduções. A vida útil da reserva pode ser projetada de acordo com o prazo contratual de propriedade, ou "qualquer outra estimativa razoável" ${ }^{609}$. A taxa de desconto utilizada deve refletir o WACC ou a TMA do projeto. As projeções devem ser em moeda constante e cenários econômicos alternativos devem ser considerados. Geralmente, um projeto pode ser considerado economicamente viável se seu Valor Presente Líquido ("VPL") for positivo usando "melhores estimativas" (P50) de volumes recuperáveis ${ }^{610}$.

\footnotetext{
${ }^{609}$ SPE-PRMS, 2008, p. 14.

${ }^{610}$ SPE-PRMS, 2008, p. 14.
} 
Nos EUA, a SEC exige relatórios de avaliação de reservas, elaborados por consultorias especializadas, com premissas de preços constantes para o longo prazo (conhecidos como "price decks"), descontados por um custo de capital, em moeda constante, de $10 \%$ (conhecido como "SEC 10") ) $^{611}$.

A SPE não requer que a avaliação dos recursos inclua o financiamento do projeto (project finance). Geralmente, financiamentos externos exigem que a avaliação utilize somente volumes em reservas provadas.

Desde o final da década de 1970, a SEC obrigava a divulgação de Reservas Provadas (1P) aos investidores das empresas de O\&G listadas nos EUA. Porém, entre 2008/10, possivelmente por causa da "revolução" do gás de xisto, a SEC e o FASB atualizaram as regras permitindo a divulgação, facultativa, de Reservas Prováveis $(2 \mathrm{P})^{612}$, compatíveis com as classificações da SPE (permaneceu a obrigação de divulgar Reservas Provadas [1P]). Apesar desta atualização, MISUND \& OSMUNDSEN [2017] constataram que poucas empresas de O\&G dos EUA divulgam suas Reservas Prováveis, o que pode subestimar sistematicamente o potencial de crescimento destas empresas.

No Canadá, as empresas de O\&G são obrigadas a divulgar suas Reservas Provadas e Não Provadas e podem divulgar também Recursos Contingentes, o que permite a análise do impacto dos diferentes tipos de reservas no valor de mercado das empresas ${ }^{613}$. Segundo os autores, há poucos estudos que focam na importância das outras classificações de reservas, porém há evidências circunstâncias que demonstram sua importância. Citam, por exemplo, em 2004, quando a Royal Dutch Shell reclassificou 28\% de suas reservas de $O \& G$ de provadas para prováveis, suas ações se depreciaram significativamente. Essa reclassificação também ilustrou a incerteza inerente ao conceito de reservas provadas.

${ }^{611}$ A taxa de desconto de $10 \%$ se tornou uma referência da indústria internacional de O\&G.

${ }^{612}$ Cf. Financial Accounting Standards Board [1982, 2009, 2010] e Securities and Exchange Commission. [1978, 1979, 1981, 2008].

${ }^{613} \mathrm{Cf}$. Canadian Securities Administrators [2002a e 2002b]. 


\section{A.3 Capitalização de Mercado de Empresas de O\&G: Evidências da Literatura Empírica}

Embora não seja objeto do presente estudo a análise econométrica das variáveis explicativas dos preços das ações da OGX, a revisão da literatura empírica sobre as ações de empresas de $O \& G$ fornece indícios importantes.

\section{Preços de Petróleo e Reservas Estimadas}

Segundo a revisão da literatura empírica de MISUND \& OSMUNDSEN [2017, p. 5], os preços das ações de empresas de O\&G podem ser afetados por múltiplos fatores, incluindo rentabilidade (preços de $O \& G$ e variações nas estimativas das reservas) e fatores de risco sistemático.

SCHOLTENS \& WAGENAAR [2011] analisaram a assimetria do impacto de variações nos preços do petróleo e as ações de O\&G e constataram que aumentos em preços têm impacto maior do que quedas. A literatura sugere duas explicações para tal assimetria: o que importa são preços relativos; e que há um valor na opção associado com esperar para investir ${ }^{614}$.

SCHOLTENS \& WAGENAAR [2011] também analisaram o impacto no preço das ações de empresas de O\&G que revisaram suas estimativas de reservas provadas, com pelo menos 90\% de confiança (P90 ou 1P), entre 2000-2010, em 17 países $^{615}$. Utilizando um modelo "market and risk adjusted" concluíram que as revisões geraram impactos significativos e diretamente correlacionados nos preços das ações ${ }^{616}$. Os autores constataram que o impacto de revisões em reservas para menor tem um impacto proporcionalmente maior do que revisões para maior ${ }^{617}$. Ou seja, más notícias no mercado de energia têm impacto maior do que boas notícias, o que já havia sido constatado em outros estudos ${ }^{618}$.

${ }^{614}$ Cf. BALKE et al. [2002] e JONES et al. [2004].

${ }^{615}$ A amostra considerou 100 revisões de estimativas de reservas $1 \mathrm{P}$, sendo 72 revisões para cima e 28 para baixo. Destas 100 revisões, $40 \%$ ocorreram no período 2000/05 e 60\% entre 2006/10. A maior parte da amostra (70) considerava os efeitos de revisões em empresas do Canadá (19), EUA (18), GrãBretanha (16), Austrália (10) e Rússia (7). A amostra ainda incluía 2 revisões da PETR (16/1/04 e 7/2/08) e uma da OGX (2/9/09).

616 Os autores usaram a metodologia de eventos utilizadas por: MACKINLAY [1997]; BROWN \& WARNER [1980; 1985], HILLIER et al. [2008].

${ }^{617}$ Uma revisão para cima resulta em um aumento médio de 1,60\% na capitalização de mercado no dia do evento e $0,68 \%$ de aumento no período de até 6 dias do evento. Uma revisão para baixo resulta em uma redução média de $1,53 \%$ na capitalização de mercado no dia do evento, e $-4,79 \%$ de redução no período de até 6 dias do evento. Os efeitos da divulgação da redução duram cerca de uma semana.

${ }^{618}$ Adicionalmente, os autores constataram que a magnitude destes impactos foi menor na Austrália, Canadá, EUA e Grã-Bretanha do que em outros países, que podem estar relacionados às diferenças no sistema legal (common law protege mais os investidores, portanto, quanto mais informação, menor a incerteza e portanto, menor a resposta) e desenvolvimento do mercado. O impacto também foi maior 
Entretanto, MISUND \& OSMUNDSEN [2017] ponderam que o valor contábil das reservas provadas sofre de várias fraquezas, pois suas estimativas dependem de: (1) preço médio do O\&G no ano (o FASB - SFAS \#69 de 1982 usa os preços médios do ano fiscal); (2) termos contratuais (por exemplo, concessões, PSC) ${ }^{619}$; (3) informações limitadas quanto ao potencial de crescimento futuro da empresa, pois o conceito de reservas provadas exclui as reservas maduras.

\section{Reservas Não Provadas e Outras Categorias de Recursos}

Em uma extensa revisão da literatura empírica, MISUND \& OSMUNDSEN [2017] não constataram relação robusta entre variações de reservas e a capitalização de mercado das empresas. Talvez, por problemas nas especificações do modelo (por exemplo, viés de variáveis omitidas). Talvez, porque a ênfase da SEC nas reservas provadas e a falta de divulgação de informações, poucos estudos empíricos analisaram o impacto de outros tipos de reserva.

Para tentar capturar o impacto dos outros tipos de reserva, MISUND \& OSMUNDSEN [2017] analisaram uma amostra de 94 empresas de O\&G não americanas entre 19932013. Dados sobre reservas possíveis (3P) não estavam disponíveis. Portanto os autores utilizaram três conceitos de reservas: provadas e desenvolvidas (onde já existem poços); provadas e não desenvolvidas (PUD, onde há novos poços em áreas ainda não perfuradas ou poços existentes aonde investimentos significativos são necessários para completa-los [completion]); e reservas prováveis (2P).

Concluíram que existia uma relação positiva e significante entre as variações em Reservas Provadas e Desenvolvidas de óleo com o retorno das empresas. Entretanto, não encontraram evidências convincentes para a relação com as variações de reservas menos maduras de óleo, o que sugere que os investidores consideram este tipo de reservas como muito incertas, o que os incapacita de precificar estes ativos ${ }^{620}$. Como tal, os investidores podem considerar informações sobre Reservas Prováveis como pouco relevantes. Os autores concluíram que as agências reguladoras de mercados de capitais, incluindo a SEC, deveriam tornar mandatória a divulgação de dados sobre Reservas Prováveis, pois estas podem ser a base para a geração futura de caixa das empresas de O\&G.

No caso da OGX, nenhum dos três Relatórios de Avaliação identificaram Reservas Prováveis ou Reservas Provadas. Como apontado anteriormente, a D\&M identificou

no subperíodo 2000/05 do que 2006/10. O período de 2006/10 foi caracterizado por maior turbulência (turmoil).

Cf. TVERSKY \& KAHNEMAN [1974]; LEE K et al. [1995], FERDERER [1996], SADORSKY [1999, 2008].

${ }^{619}$ Cf. BINDEMANN [1999]; KRETZSCHMAR et al [2007]

${ }^{620}$ Os autores encontraram evidências convincentes da relação positiva e significante entre as variações de reservas menos maduras de óleo de xisto com o retorno das ações destas empresas. Começou com gás não convencional e posteriormente para óleo (óleo de xisto ou shale oil). Preços do GN despencaram, enquanto preços do óleo aumentaram. A tecnologia do gás de xisto permite o desenvolvimento mais rápido das reservas do que o GN convencional, portanto as empresas com xisto geravam FOC antes de outras com GN. Ex. Devon Energy 
Recursos Contingentes no 20 D\&M (0,212 bboe) e no 3은 (3,034 bboe em 3C). Na discussão sobre o 3o D\&M, os Executivos da OGX argumentaram que, devido às idiossincrasias da regulação do setor de O\&G no Brasil, Recursos Contingentes seriam uma proxy para Reservas. 


\section{Referências}

AGENCIA NACIONAL DE PETROLEO (ANP). Glossário. Disponível em:

<http://www.anp.gov.br/glossario>. Acesso em: 08 nov. 2017.

AGHION, P., STEIN, J.C. Growth vs. Margins: Destabilizing Consequences of Giving the Stock Market What it Wants. NBER Working Paper Series n. 10999. Cambridge, MA, dez. 2004.

AISSIA, D.B. Home and foreign investor sentiment and the stock returns. The Quarterly Review of Economics and Finance, v. 59, issue C, p. 71-77, 2016.

ALMEIDA, M.S., CARVALHO, P.L.C. e BRITO, M.J., Hermenêutica como forma de análise dos relatórios da OGX petróleo e gás participações S.A., in: Acta Scientiarum, Maringá, v. 37, n. 1, p. 1-12, Jan.-Jun., 2015.

ASSOCIAÇÃO DOS ANALISTAS E PROFISSIONAIS DE INVESTIMENTO DO MERCADO DE CAPITAIS (APIMEC). Código de Conduta da Apimec para o Analista de Valores Mobiliários. Disponível em:

<http://www.apimec.com.br/Apimec/show.aspx?id_canal=3760\&id_materia=29368>. Acesso em: 21 fev. 2018.

AUDI, C. \& FALANGA NETO, V.. OGX - The Most Complete Upstream Play in Brazil: Catalyst-Rich and Set to Start a Promising New Chapter, Santander Latin American Equity Research, 26 de outubro de 2010a.

. OGX - Attractive Buying Opportunity Given Recent Unwarrented

Performance, Santander Latin American Equity Research, 11 de novembro de 2010b. . OGX Gets Acreage for Free: Good Strategic Call or Gamble, Santander Latin American Equity Research, 15 de novembro de 2010c. . OGX: Eike Batista Addresses Key Concerns, Santander Latin American Equity Research, 9 de fevereiro de 2011a. . OGX: How will the Stock React to the D\&M Report? Scenario Analysis and

More..., Santander Latin American Equity Research, 24 de março de 2011b. . OGX - Downgrading to Hold: Disappointing D\&M Report and Lack of ShortTerm Catalysts, Santander Latin American Equity Research, 18 de abril de 2011c. OGX - A Difference of Opnion, Santander Latin American Equity Research, 4 de maio de 2011d. OGX - Roadshow with CFP Prductive, but Key Issues Remain, Santander Latin American Equity Research, 10 de maio de 2011e. 
. OGX - Positive Stock Reaction Overdone?, Santander Latin American Equity

Research, 17 de maio de 2011f.

. OGX - Cost Increase is Key Takeaway from New Strategic Plan, Santander

Latin American Equity Research, 7 de junho de 2011g.

Switching Out of OGX into Petrobrás: Na Attractive Trade?, Santander Latin

American Equity Research, 27 de julho de 2011h.

OGX - Lack of Short-Term Catalysts: Not Yet Ready to get Back in; Introducing

YE2012 Target Price, Santander Latin American Equity Research, 3 de outubro de 2011 i.

. OGX - Antecipated Contract Signed - Limited Impact, Santander Latin

American Equity Research, 6 de outubro de 2011j.

. OGX - Implications of Perenco-Sinochem Transaction, Santander Latin

American Equity Research, 9 de janeiro de 2012a.

. OGX - Large Discovery in the Santos Basin, Positive for Stock, Santander Latin

American Equity Research, 17 de janeiro de 2012b.

. OGX - Discovery of Pre-Salt in the Santos Basin, Santander Latin American

Equity Research, 1 de fevereiro de 2012c.

OGX - Participation Increased to 70\% in Blocks BM-C-37 and BM-C38,

Santander Latin American Equity Research, 20 de março de 2012d.

OGX - Issues US\$ 1 billion in Senior Unsecured Notes, Santander Latin

American Equity Research, 28 de março de 2012e.

OGX - Productive Roadshow with CEO Yields New Key Takeaways; Atractive

Buying Opportunity, Santander Latin American Equity Research, 5 de abril de $2012 f$.

OGX - Declaration of Commerciality of Portion of Waimea, Potential Pressure

on Stock, Santander Latin American Equity Research, 15 de maio de 2012g.

OGX - CEO Comments on Well Productivity - Careful Monitoring Needed,

Santander Latin American Equity Research, 30 de maio de 2012h.

. OGX - More Conservative Stance Needed: Downgrading to Hold; Introducing

YE2013 Target Price, Santander Latin American Equity Research, 21 de junho de $2012 \mathrm{i}$.

OGX - Weaker Productivity Supports our Recent Downgrade; Reducing our YE2013 Target Price, Santander Latin American Equity Research, 26 de junho de $2012 \mathrm{j}$. 
. OGX - CEO Departs; Downgrade Maintained - Financing Capability + How Low is Too Low?, Santander Latin American Equity Research, 28 de junho de 2012k.

. OGX - Mixed Expectations on Fortaleza Pressure Stock; Sensitivity Analysis Helps Measure Downside, Santander Latin American Equity Research, 24 de outubro de 2012 l.

. OGX - WEAK 3Q12: Write-Off of Wells, Blocks Returned to the ANP and More..., Santander Latin American Equity Research, 8 de novembro de 2012m.

. Brazil Oil \& Gas: BS-4 M\&A Transaction Has Key Implications for Petrobras, OGX AND Queiroz Galvao, Santander Latin American Equity Research, 27 de novembro de $2012 \mathrm{n}$.

. OGX: Management Comments During Investor Day, Santander Latin American Equity Research, 11 de dezembro de 20120.

. OGX-Upside/Downside Asymmetry in Place, But is it Attractive? YE13 TP Increased to $\mathrm{R} \$ 5.70$, Santander Latin American Equity Research, 23 de janeiro de $2013 a$.

. OGX-Downgrading on Very Weak Operating Update and Potentially Negative Catalysts Ahead, Santander Latin American Equity Research, 12 de março de 2013b. OGX: Underperform Reiterated on the Back of Declaration of Commerciality Announcement, Santander Latin American Equity Research, 13 de março de 2013c. . OGX: Weak 4Q12, with 2013 Capex Guidance Revised Upward, Santander Latin American Equity Research, 26 de março de 2013d.

OGX-Farm-Out of Tubarão Martelo to be Announced Today, Santander Latin American Equity Research, 7 de maio de 2013e.

. Brazil Oil, Gas \& Petrochemicals-Implications of Successful 11th Auction of Blocks for Petrobras, OGX, QGEP and HRT, Santander Latin American Equity Research, 14 de maio de $2013 f$.

. OGX-Eike Batista Sells Shares at Average Price of $\mathrm{R} \$ 1.73$, Negative for Stock, Santander Latin American Equity Research, 11 de junho de 2013g.

BALKE N.S.; BROWN S.P.A.; YUCEL M.K. Oil price shocks and the US economy: where does the asymmetry originate? Energy Journal; 23:27e52, 2002.

BAKER, M., WURGLER, J.. Investor Sentiment and the Cross-Section of Stock Returns. The Journal of Finance, v. LXI, n. 4, p. 1645-1680, ago. 2006.

Investor Sentiment in the Stock Market. Journal of Economic Perspectives, v. 21, n. 2, p. 129-151, abr. 2007. 
BARBERIS, N., SHLEIFER, A., VISHNY, R.. A model of investor. Journal of Financial Economics, v. 49, n. 3, p. 307-343, 1998.

BARROS, L.A.B.C., DA SILVEIRA, A.D.M., Excesso de Confiança, Otimismo Gerencial e so Determinantes da Estrutura de Capital. Revista Brasileira de Finanças, vol. 6, no. 3, o. 293-335, 2008.

BATISTA, E.. O X da Questão, Rio de Janeiro: Sextante, 2011. 160p.

BERNSTEIN, P.L., Capital Ideas: The Improbable Origins of Modern Wall Street. Hoboken, NJ: John Wiley \& Sons, Inc., 2005.

BIKHCHANDANI, S., SHARMA, S.. Herd Behavior in Financial Markets: A Review. IMF Working Paper, WP/00/08. IMF Institute, mar. 2000.

BINDEMANN, K.. Production-sharing agreements: An economic analysis. WPM 25. Oxford: Oxford Institute for Energy Studies, 1999.

BODIE, Z., KANES, A., MARCUS, A.J., Investimentos. Porto Alegre: AMGH, 2010, $8^{\mathrm{a}}$. edição.

BRASIL AGRO, Prospecto Definitivo IPO, 27 de abril de 2006. URL: http://www.brasilagro.com/brasilagro2011/web/conteudo_pt.asp?idioma=0\&conta=28\&tipo=36826, acesso em 4/12/2018.

BRASIL ECODIESEL, Prospecto Definitivo IPO, 9 de novembro de 2006. URL: https://www.google.com.br/url?sa=t\&rct=j\&q=\&esrc=s\&source=web\&cd=2\&cad=rja\& uact=8\&ved=2ahUKEwiXos_TrlbfAhXEW5AKHbggAZQQFjABegQICBAC\&url=http\%3A\%2 F\%2Fsiteempresas.bovespa.com.br\%2Fconsbov\%2FArquivosExibe.asp\%3Fsite\%3DC\%2 6protocolo\%3D103492\&usg=AOvVaw3rlYual08OAIXXz_V_sGH9, acesso em $4 / 12 / 2018$.

BREEDEN, R.C.. Restoring Trust: Report to the Honorable Jed S. Rakoff, The United States District Court for the Southern District of New York on Corporate Governance for the Future of $\mathbf{M C l}$, Inc.. Ago. 2003, Disponível em:

<http://sites.fas.harvard.edu/ ec970dr/Paper2/02cv4963_082603.pdf>, Acesso em:

BROCHET, F.. Information Content of Insider Trades before and after the SarbanesOxley Act. The Accounting Review, v. 85, n. 2, p. 419-446, mar. 2010.

BROEDEL, A.. Disciplina financeira nos setores públicos e privados. Valor Econômico, São Paulo, 29 ago. 2017, p. A10.

BROWN S. J., WARNER J.B. Measuring security price performance. Journal of Financial Economics; 8:205e58, 1980. Using daily stockreturns. Journal of Financial Economics; 14:3e31, 1985.

BUSTISTA. The Economist, v. 409 (8860), p. 68, 2013. 
BUTLER, K.C., LANG, L.H. The forecast accuracy of individual analysts: Evidence of systematic optimism and pessimism. J. Account. Res. p. 150-156, 1991.

CALDAS, S.. Partilha ou Consessão?. O Estado de São Paulo, São Paulo, 30 set. 2017, p. B2.

CANADIAN SECURITIES ADMINISTRATORS. National instrument 51-101: Standards of disclosure for oil and gas activities. Alberta: CSA, 2002a.

Companion policy 51-101: Standards of disclosure for oil and gas activities. Alberta: CSA, 2002b.

COLLINS, J. Como os Gigantes Caem. São Paulo: Elsevier, 2010. 216p.

COOPER, R., DAY, T., \& LEWIS, C. Following the leader: A study of individual analysts' earnings forecasts. Journal of Financial Economics, v. 61, p. 383-416, 2001.

CVM - COMISSÃO DE VALORES MOBILIÁRIOS. Recomendações da CVM sobre Governança Corporativa. 2002.

Instrução n. 400, com as alterações introduzidas pelas Instruções CVM No. 429/06, 442/06, 472/08 e 482/10. 29 dez. 2003.

Extrato da sessão de julgamento do processo administrativo sancionador CVM No. RJ2013/7916, 18 mar. 2015. Disponível em:

<http://www.cvm.gov.br/export/sites/cvm/sancionadores/sancionador/anexos/2015/ 20150318_PAS_RJ20137916.pdf>. Acesso em: 17 mai. 2018.

CAMPBELL, J.. O Poder do Mito. São Paulo: Palas Athena, 2004, 22a․ Ed., 250p.

DAMODARAN, A.. Avaliação de Empresas. São Paulo: Pearson Prentice Hall, 2007, 2ª . ed., $264 p$.

Narrative and Numbers: The Value of Stories in Business. Nova York: Columbia Business School Publishing, 2017. 296p.

DA SILVA, J.F.F.. Análise Crítica das Devoluções dos Blocos do Pré-Sal Concedidos nas Rodadas de Licitação da ANP. 2013. Dissertação (Mestrado em Engenharia do Petróleo) - Escola Politécnica, Universidade Federal do Rio de Janeiro, Rio de Janeiro, 2013.

DANIEL, K., HIRSHLEIFER, D., SUBRAHMANYAM, A. Investor psychology and security market under- and overreactions. J. Finance, v. 53, p. 1839-1885, 1998.

DARIPA, S. \& SILVA, A. OGX: Compelling Investment Long Term; Better Entry Mid-2009, Morgan Stanley Research Latin America, 10 de novembro de 2008.

. OGX: Quick Comment: Stay Cautious in the Short-Term, Morgan Stanley

Research Latin America, 29 de abril de 2009a. 
. OGX: Catalysts Ahead - Overwight, Morgan Stanley Research Latin America, 1 de junho de 2009b.

. OGX: Research Tactical Idea, Morgan Stanley Research Latin America, 19 de agosto de 2009c.

. OGX - Quick Comment: Discussion with Mgmt. Confirms Positive Read-Across

of BM-C-36, Morgan Stanley Research Latin America, 21 de agosto de 2009d.

DARIPA, S.. OGX: Even Better than the Real Thing, Morgan Stanley Research Latin America, 10 de novembro de 2009e.

. OGX - Story Shifting from Exploration to Production: Raising Price Target,

Morgan Stanley Research Latin America, 21 de janeiro de 2010a.

. OGX - Quick Comment: Roadmap Becomes Clearer, Morgan Stanley Research

Latin America, 27 de janeiro de 2010b.

. OGX - Quick Comment: Takeaways from 2Q10 Conference Call, Morgan

Stanley Research Latin America, 12 de agosto de 2010c.

OGX - Quick Comment: Repsol Deal Viewed as a Positive for Brazil O\&G,

Morgan Stanley Research Latin America, 1 de outubro de 2010d.

. OGX - Increased Confidence in Bull Case; Raising Price Target, Morgan Stanley

Research Latin America, 8 de outubro de 2010e.

. OGX - Buying Opportunity as Stock Pricing in Volume Well Below Our

Forecast, Morgan Stanley Research Latin America, 15 de fevereiro de 2011a.

. OGX - Correction: Investment Case Remains Unchanged; Cutting PT to R\$23,

Morgan Stanley Research Latin America, 18 de abril de 2011b.

. OGX - In Bear Case Territory, Morgan Stanley Research Latin America, 19 de abril de 2011c.

. OGX - Lowering PT on Lower and Riked Resources; Remain Overweight,

Morgan Stanley Research Latin America, 11 de setembro de 2011d.

DE LONG, J. B., SHLEIFER, A., SUMMERS, L. H., \& WALDMANN, R. J.. The economic consequences of noise traders. NBER Working Paper, n. 2395, p. 1-47, out. 1987.

. Noise trader risk in financial markets. Journal of Political Economy, v. 98, n. 4, p. 703-738, ago. 1990.

DECHOW, P., HUTTON, A., SLOAN, R.. The relation between analysts' forecasts of longterm earnings growth and stock price performance following equity offerings.

Contemporary Accounting Research, v. 17, n. 1, p. 1-32, abr. 2010. 
DUGAR, A., NATHAN, S. The effect of investment banking relationships on financial analysts' earnings forecasts and investment recommendations. Contemp. Account. Res. V. 12 (1), p. 131-160, 1995.

EDWARDS, R.D. \& MAGEE, J.. Technical Analysis of Stock Trends, 6th ed.. Nova York: New York Institute of Finance, 1992. 500p.

EDWARDS, W.. Conservatism in human information processing. In: KLEINMUTZ, B. (Ed.). Formal Representation of Human Judgment. Nova York: John Wiley and Sons, 1968, p. 17-52.

ERTURK, I., FROUD, F., JOHAL, S., WILLIAMS, K.. Corporate Governance and Disappointment. Review of International Political Economy, v. 11, n. 4, p. 677-713, out. 2004.

ESTADOS UNIDOS. Congresso. Public Law 107-204: Sarbanes-Oxley Act of 2002. Corporate responsibility, 30 de julho de 2002.

FERDERER J. Oil price volatility and the macroeconomy. Journal of Macroeconomics; 18:1e26, 1996.

FINANCIAL ACCOUNTING STANDARDS BOARD. Statement of financial accounting standards No. 69: Disclosures about oil and gas producing activities. Stamford, CT: FASB, 1982.

Financial accounting codification topic 932: Extractive activities - oil and gas. Stamford, CT: FASB, 2009.

Financial accounting series. accounting standards update. Extractive activities - oil and gas (Topic 932): Oil and gas reserves estimation and disclosures. An amendment of the FAB accounting standards codification. Stamford, CT: FASB, 2010.

FINNERTY, J.D.. Project Finance: Engenharia Financeira Baseada em Ativos, Rio de Janeiro: Qualitymark, 1999, p. 354.

FRIESEN, G., WELLER, P. Quantifying cognitive biases in analyst earnings forecasts. J. Financ. Mark., v. 9, p. 333-365, 2006.

GATTASS, G., FONSECA, R., VALENTE, P.. OGX - 3Q10 Review: Looking at what matters. BTG Pactual Equity Research Latin America, 11 de novembro de 2010.

GATTASS, G. \& FONSECA, R.. OGX - Albian Punch. BTG Pactual Equity Research Latin America, 10 de fevereiro de 2011a. OGX - The Measure of Success. Downgrading to Neutral, BTG Pactual Equity Research Latin America, 18 de março de 2011b. 
. OGX - Relevant Developments. Up to Buy Again. BTG Pactual Equity Research Latin America, 2 de agosto de 2011c.

. OGX - Constructive Approach. BTG Pactual Equity Research Latin America, 11

de agosto de 2011 d.

GATTASS, G., CARVALHO, L.F., VALDIZAN, R.. OGX - Tectonic (or is it Teutonic) Shifts, BTG Pactual Equity Research Latin America, 5 de julho de 2012a.

GATTASS, G., CARVALHO, L.F.. OGX - Officially operational. BTG Pactual Equity Research Latin America, 9 de novembro de 2012b.

GOMES, P. O., KILSDONK, B., MINKEN, J., GROW, T., BARRAGAN, R.. The Outer High of the Santos Basin, Southern São Paulo Plateau, Brazil: Pre-Salt Exploration Outbreak, Paleogeographic Setting, and Evolution of the Syn-Rift Structures. Search and Discovery Article \#10193 (2009). Posted July 2, 2009. Adapted from oral presentation at AAPG International Conference and Exhibition, Cape Town, South Africa, October 26-29, 2008.

GREENBURY, R.. Directors' Remuneration: Report of a Study Group Chaired by Sir Richard Greenbury. Disponível em:

<http://www.ecgi.org/codes/documents/greenbury_less_recommendations.pdf>. Acesso em: 17 out 2017.

GRIFFIN, D., TVERSKY, A.. The weighing of evidence and the determinants of confidence. Cognitive Psychology, v. 24, n.3, p. 411-435, jul. 1992.

GROYSBERG, B., HEALY, P.M., MABER, D.A.. What Drives Sell-Side Analyst Compensation at High-Status Investment Banks?. Journal of Accounting Research, $v$. 49, n. 4, p. 969-1000, set. 2011.

HARIS, L.,\& GUREL, E.. Price and Volume Efects Asociated with Changes in the S\&P 50: New Evidence for the Existence of Price Presure. Journal of Finance, v. 41, p. 851-60, 1986.

HART, O., MOORE, R.. Property rights and the nature of the firm. Journal of Political Economy, v. 98, n. 6, p. 1119-1158, dez. 1990.

HEALY, P., PALEPU, K.. The Fall of Enron. The Journal of Economic Perspectives, v. 17, n. 2, p. 3-26, 2003.

HEATON, J. B.. Managerial Optimism and Corporate Finance. Financial Management, v. 31, n. 2, p. 33-45, 2002.

HILLIER D, GRINBLATT M, TITMAN S. Financial markets and corporate strategy. Maidenhead: McGraw-Hill, 2008. 
HOWARD, A. W., HARP, A.B.. Oil and Gas Company Valutions. Business Valuation Review, v. 28, n. 1, p. 30-35, 2009.

IRVINE, P. Do Analysts Generate Trade for Their Firms? Evidence from the Toronto Stock Exchange. Journal of Accounting \& Economics, v. 30, p. 209-26, 2000.

Analysts' Forecasts and Brokerage-Firm Trading. The Accounting Review, v. 79, p. 125-49, 2004.

JENSEN, M.C.. Agency Costs of Free Cash Flow, Corporate Finance, and Takeovers. The American Economic Review, v. 76, n. 2, p.323-329, mai. 1986 19, 2005.

Agency Costs of Overvalued Equity. Financial Management, v. 34, n. 1, p. 5-

JENSEN, M.C., MURPHY, K.J., WRUCK, E.G.. Remuneration: Where We've Been, How We Got to Here, What are the Problems, and How to Fix Them. Harvard NOM Working Paper No. 04-28; ECGI - Finance Working Paper No. 44/2004, jul. 2004

JOOS, P., PIOTROSKIB, J.D., SRINIVASAN, S.. Can analysts assess fundamental risk and valuation uncertainty? An empirical analysis of scenario-based value estimates. Journal of Financial Economics, v. 121, n. 3, p. 645-663, set. 2016.

JONES DW, LEIBY PN, PAIK IK. Oil price shocks and the macroeconomy: what has been learned since 1986. Energy Journal; 25:1e32, 2004.

JUERGENS, J.; L. LINDSEY. Getting Out Early: An Analysis of Market Making Activity at the Recommending Analyst's Firm. Journal of Finance, v. 64, p. 2327-59, 2009.

KADIYALA, P., RAU, R.. Investor Reaction to Corporate Event Announcements: Underreaction or Overreaction?. The Journal of Business, v. 77, n. 2, p. 357-386, abr. 2004.

KAHN, M.. The 2008 Oil Price "Bubble". Peterson Institute ofr International Economics, No. PB09-19, ago.2009. Disponível em: http://citeseerx.ist.psu.edu/viewdoc/download?doi=10.1.1.175.3338\&rep=rep1\&type =pdf. Acesso em: 23 jul. 2018.

KAPLANSKI, G., LEVY, H.. Analysts and sentiment: A causality study. The Quarterly Review of Economics and Finance, v. 63, p. 315-327, fev. 2017.

KEYNES, J. M. The General Theory of Employment, Interest and Money. London: Macmillan, 1936.

KOC, C., ROSS, T., SZCZPANSKI, J.M.. Beneath the Surface: Valuing Oil and Gas Assets in Litigation. International Law News, v. 44, n. 3, 2015. 
KOVARSKY, P. \& MENDES, D.. OGX: The UpXtream Option, Itaú BBA, 28 de julho de 2008a.

. OGX: Upgrading to Outperform, Itaú BBA, 13 de fevereiro de 2009a.

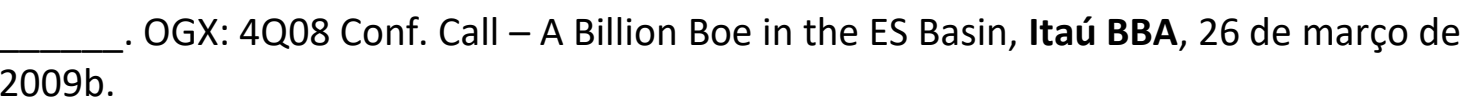
de 2011a.

OGX: Reading into the EBX Call and Waimea Results, Itaú BBA, 9 de fevereiro . OGX: Guide to Reading the D\&M Report, Itaú BBA, 17 de março de 2011b. . OGX: Hydrocarbon finds at OGX-36D - Delimiting Well for Pipeline, Itaú BBA, 22 de março de 2011c.

. OGX: Hydrocarbon Presence in the Wikiki Delimiting Well, Itaú BBA, 24 de março de 2011d.

. OGX: 4Q10 Conference Call Highlights, Itaú BBA, 28 de março de 2011e.

. OGX: The D\&M Report: Not a Surprise, Itaú BBA, 17 de abril de $2011 \mathrm{f}$. abril de 2011g.

OGX Announces Finds Around the Pipeline and Waikiki Welss, Itaú BBA, 20 de . OGX: Updating Valuation after D\&M, Itaú BBA, 5 de maio de $2011 \mathrm{~h}$. . OGX: 1Q11 Conference Call Highlights, Itaú BBA, 9 de maio de 2011i. $2011 \mathrm{j}$. OGX: Announces New Discovery in Santos Basin, Itaú BBA, 12 de maio de . OGX: Declaration of Commerciality for Two Gas Field in the Parnaíba Basin, Itaú BBA, 17 de maio de 2011k.

. OGX: Bond Issuance, Itaú BBA, 17 de maio de 2011 . de $2011 \mathrm{~m}$.

OGX: Business Plan Update: No Game-Changing News, Itaú BBA, 7 de junho . OGX: Waikiki Horizontal Well - Good Prospects for Production, Itaú BBA, 20 de junho de $2011 \mathrm{n}$. . Brazil - Oil \& Gas: Where's the Bottom for Brazilian Junior E\&Os?, Itaú BBA, 7 de agosto de 20110. 2011p. . OGX: OGX Sells 1.2-Million-Barrel Cargo to Shell, Itaú BBA, 6 de outubro de OGX: Dry Well in Espirito Santo Basin, Itaú BBA, 6 de janeiro de 2012a. 
. OGX: Another Discovery in the Santos Basin, Likely Gas, Itaú BBA, 16 de janeiro de 2012b.

. OGX: Production Startup, Itaú BBA, 30 de janeiro de 2012c.

. OGX Confirms Pre-Salt in Santos, Itaú BBA, 1 de fevereiro de 2012d.

. Increasing Stake in the BM-C-37 and -38 Blocks to 70\% from 50\%, Itaú BBA, 20

de março de 2012e.

. 4Q11 - All Eyes on Flow Rates, Itaú BBA, 23 de março de $2012 f$.

. Reducing FV to BRL 21,2/OGXP3, Itaú BBA, 16 de abril de 2012g.

. Waikiki Declaration of Commerciality, Itaú BBA, 25 de abril de 2012h.

. Waimea Declaration of Commerciality, Itaú BBA, 15 de maio de 2012i.

. Whay a Campos Basin Update Now, Itaú BBA, 22 de maio de 2012j.

. Struggling with Flow Rates, Itaú BBA, 30 de maio de 2012k.

. Oil (Not Gas!) Find the Campos Basin Pre-Salt (OGX78-Honolulu), Itaú BBA, 13 de junho de 2012 .

. Struggling (Further!) with Flow Rates, Itaú BBA, 26 de junho de 2012m.

. Another Reality Check - Cutting FV to BRL 14.8/OGXP3, Itaú BBA, 28 de junho de $2012 n$.

. Fine-Tuning (Down) Production and FV, Itaú BBA, 17 de julho de 20120.

OGX - Controlling Shareholder Grants USD 1 Billion Put, Itaú BBA, 24 de outubro de 2012p.

Oil \& Gas: OGX Acquires a 40\% Stake in BS-4 for USD 270 MM, Itaú BBA, 27 de novembro de 2012q.

. OGX - Reducing the Campos Basin Potential, Itaú BBA, 7 de janeiro de 2013a.

. OGX - Production Numbers - Bad News, Itaú BBA, 11 de março de 2013b.

. OGX - Bad News on Production- Bad News, Itaú BBA, 16 de abril de 2013c.

. OGX: Tubarao Martelo Deal Apparently Nearing Conclusion, Itaú BBA, 6 de maio de 2013d.

. HRT: Acquisition of $60 \%$ Stake in Polvo Field, in: LatAm Daily, Itaú BBA, 7 de maio de 2013e.

OGX - April Production - Negative, Itaú BBA, 7 de maio de $2013 f$. 
. OGX - Tubarao Martelo 40\% Stake Sold for USD 850 Million, Itaú BBA, 8 de maio de 2013g. $\frac{}{2013 \mathrm{~h} .}$. OGX - Fair Value and Recommendation Under Review, Itaú BBA, 2 de julho de

OGX - Put Option Against Controlling Shareholder Exercised, Itaú BBA, 6 de setembro de 2013i.

. OGX - It's a Dry Well After All..., Itaú BBA, 12 de setembro de 2013j.

KOVARSKY, P., MENDES, D., ARAUJO, G.. OGX: Reiterating Outperform at New FV of R\$ 1,210 / Share, Itaú BBA, 4 de maio de 2009c.

. OGX Increases Its Stake in BM-S-29 by 15\%, Itaú BBA, 11 de maio de 2009d.

. OGX: Lower Ke Boosting the Fair Value, Itaú BBA, 1 de junho de 2009e.

. OGX: Corcovado-2 is Dry, Itaú BBA, 24 de agosto de $2009 f$.

. OGX: Introducing YE10 Fair Value, Itaú BBA, 26 de agosto de 2009g.

. OGX - Acquisition of Gas Prone Blocks: Almost a Free Option, Itaú BBA, 24 de setembro de $2009 \mathrm{~h}$.

. OGX Finds Hydrocarbons in BM-S-29!, Itaú BBA, 2 de outubro de 2009i.

. OGX: What's Next?, Itaú BBA, 2 de outubro de 2009k.

. OGX: Confirming ou Bullish Expectations, Itaú BBA, 9 de novembro de 2009I.

. OGX: Raising FV on D\&M Report, Itaú BBA, 10 de novembro de 2009m.

. OGX: Another Hydrocrabons Presence in the BMC41, Itaú BBA, 30 de

novembro de $2009 n$.

. OGX - Pipeline: 1-2 Billion Boe, Itaú BBA, 22 de dezembro de 2009o. $\frac{}{2010 a .}$. OGX - Hydrocarbon Find in the Kilawea Well, Itaú BBA, 11 de janeiro de

. OGX - Production Ahead of Schedule, Itaú BBA, 27 de janeiro de 2010b.

_. OGX - Waymea Estimate: 500 - 900 Million boe, Itaú BBA, 3 de fevereiro de 2010c.

OGX - No Big News on BM-S-29, Itaú BBA, 2 de março de 2010d.

. OGX - Hydrocarbon Find in the Etna Well, Itaú BBA, 3 de março de 2010e. 
$2010 f$.

OGX - 4Q09 Results: Conference Call Highlights, Itaú BBA, 12 de março de $\frac{}{2010 \mathrm{~g} .}$. OGX - Hydrocarbon Find in the Fuji Well (OGX8), Itaú BBA, 24 de março de . OGX - A Good Time to Buy!, Itaú BBA, 29 de março de 2010 h.

. OGX - 1Q10 Conference Call Highlights, Itaú BBA, 17 de maio de 2010i.

. OGX Acquires Exploration Blocks in Colombia, Itaú BBA, 23 de junho de 2010j. de $2010 k$. OGX Hydrocarbon Find in the Nothern Campos Basin, Itaú BBA, 28 de junho . OGX While Waiting for the Farm-out..., Itaú BBA, 13 de julho de 2010 l. . OGX - 15 Tcf Recoverable Gas in the Parnaiba Onshoe Basin, Itaú BBA, 16 de agosto de $2010 \mathrm{~m}$.

. OGX18: 27o API, Great Surprise in Santonian Sandstone, Itaú BBA, 27 de setembro de 2010 .

. OGX: Finds in Santos \& News on the Farm-out, Itaú BBA, 30 de setembro de 20100. . OGX: 3Q10 Conference Call Highlights, Itaú BBA, 11 de novembro de 2010p. . OGX Acquires Remaining BM-S-29 Stake, Itaú BBA, 12 de novembro de 2010q. 2010r. .OGX: 116 Meter Net Pay in North Campos Basin, Itaú BBA, 8 de dezembro de KRAMER, L.A., LIAO, C.M.. The Spillover effects of management overconfidence on analyst forecasts. Journal of Behavioral and Experimental Finance, v. 12, p. 79-92, 2016.

KRETZSCHMAR, G. L., MISUND, B., \& HATHERLY, D. Market risks and oil field ownership - Refining oil and gas disclosures. Energy Policy, v. 35 (11), p. 5909-5917, 2007.

KRIGMAN, L.; W. SHAW; AND K. WOMACK. Why Do Firms Switch Underwriters? Journal of Financial Economics, v. 60, p. 245-84, 2001.

LEE K.; NI S., RATTI R.A. Oil shocks and the macroeconomy: the role of price variability. Energy Journal, v. 1995(16):39e56, 1995

LEITE, E., CANHEU, V. \& CUSTODIO, F., OGX: The Quest for Brazilian Oil, Credit Suisse Equity Research, 28 de julho de 2008a. 
OGX: Business Plan Moving at Steady Pace, Credit Suisse Equity Research, 6 de outubro de $2008 \mathrm{~b}$.

LEITE, E., CANHEU, V.. OGX: Setting the stage for a busy 2010, Credit Suisse Equity Research, 11 de janeiro de 2010a.

LEITE, E., CANHEU, V. \& SOBREIRA, A.. OGXP3: What do you believe in? Reinstate coverage, Credit Suisse Equity Research, 16 de janeiro de 2013x. . OGXP3: The third well: don't fight the carbonates, Credit Suisse Equity Research, 4 de fevereiro de 2013a. . OGX \& OSX - What has changed and what has not, Credit Suisse Equity Research, 11 de março de 2013b. . OGX - "In Situ", Credit Suisse Equity Research, 13 de março de 2013c. 2013d. OGXP3: Four Sentences, Credit Suisse Equity Research, 26 de março de . OSX: "Liquidation" Revisited and More, Credit Suisse Equity Research, 31 de março de 2013e.

OSX: Murphy's Law, Credit Suisse Equity Research, 16 de abril de $2013 f$. . OGX and OSX - What is left for the shareholder?, Credit Suisse Equity Research, 2 de julho de 2013g. . OGX: Ways Out, Credit Suisse Equity Research, 9 de julho de $2013 \mathrm{~h}$. $2013 i$. . OGX: Food for Thought, Credit Suisse Equity Research, 2 de setembro de OGX: \$100m Now, \$900m Later, Credit Suisse Equity Research, 6 de setembro de 2013j.

LIN, H., MCNICHOLS, M.F. Underwriting relationships, analysts' earnings forecasts and investment recommendations. J. Account. Econ., v. 25, p. 101-127, 1998.

LUSTOSA, M.C.J.. Meio ambiente, inovação e competitividade na indústria brasileira: A cadeia produtiva do petróleo. 2002. Tese (Doutorado em Economia) - Instituto de Economia, Universidade Federal do Rio de Janeiro, Rio de Janeiro, 2002.

MACKINLAY A. C. Event studies in economics and finance. Journal of Economic Literature; 35:13e39, 1997.

MARCH, J.G., SHAPIRA, Z., Managerial perspectives on risk and risk taking. Management Science, 33 (11): 1404-18, 1987. 
MASSAINI, S.A., OLIVA, F.L.. Evidências da divulgação dos riscos empresariais nos prospectos de distribuição pública de ações: o caso OGX e Petrobrás. XXXIX Encontro ANPAD, Belo Horizonte - MG, 2015.

MATTAR, F., CONTI, S. \& PASCON, B.. OGX - Reduce 12-month Target on Lower Productivity and Higher Risks/CoE, Goldman Sachs Equity Research, 14 de março de 2013a.

OGX - Reduce Target Price to R\$ 0,7 Following Update to Business Plan, Goldman Sachs Equity Research, 2 de julho de 2013b.

Analyzing the Legal Recovery Law in Brazil and Alternatives for OGX, Goldman Sachs Equity Research, 10 de outubro de 2013c.

MATTAR, F., CONTI, S., PASCON, B. \& GAETA, A.. OGX - EBITDA in Line, More Negative EPS on Lower FX Gains, Goldman Sachs Equity Research, 15 de maio de 2012a.

MCGANN, F. \& KOYA, S.. OGX: Initiating with a Buy Rating, Bank of America Merril Lynch, 28 de julho de 2008a.

MCGANN, F. \& KOYA, S.. OGX: Donsgrading to Underperfom, Bank of America Merril Lynch, 28 de outubro de 2008 b.

MCGANN, F. \& VEGNER, C.. OGX - Pressure Rises: $11^{\text {th }}$ Rd Blocks Relinquished; Filed Sale Doubts, Bank of America Merril Lynch, 27 de agosto de 2013a. OGX - New D\&M Report Increases Concern for Tubarão Martelo, Bank of America Merril Lynch, 3 de outubro de 2013b. OGX - Dilution Risk Significant in Possible Re-Structuring, Bank of America Merril Lynch, 17 de outubro de 2013c.

MCLEAN, B., ELKIND, P., The Smartest Guys in the Room: the amazing rise and scandalous fall of Enron. Nova lorque: Penguin Group, 2004.

MICHAELY, R., WOMACK, K. Conflict of interest and credibility of underwriter analyst recommendations. Rev. Financ. Stud., v. 12, p. 653-686, 1999.

MILGRAM, S., Behavioral study of obedience. Journal of Abnormal and Social Psychology, 67, p. 317-378, 1963.

MILLER, D.T., ROSS, M., Self-serving biases in attribution of casuality: fact or fiction? Psycological Bulletin, 82 (2): 213-25, 1975...

MILLER, M., WELLER, P., ZHANG, L.. Moral Hazard and the US Stock Market: Analysing the 'Greenspan Put'. The Economic Journal, v. 112, n. 478, p. C171-C186, mar. 2002.

MISHRA, C., DRTINA, R.. Accounting Manipulations and Business Failures: The Case for Effective Financial Disclosure. The Journal of Private Equity, v. 7, n. 4, p. 27-35, 2004. 
MISUND, B., OSMUNDSEN, P.. Valuation of Proved vs. Probable Oil and Gas Reserves, Cogent Economics \& Finance, v. 5, n. 1, Article 1385442, 2017.

MONTANARI, B. \& BELLINETTI, G.. OGX: Flow Rates Much Lower Than Rebased Guidance; Cutting Estimates and Target, Morgan Stanley Research Latin America, 13 de março de 2013a.

. OGX: Relatively In-Line 4Q12 Results; Waiting for Liquidity Enhancement

Events, Morgan Stanley Research Latin America, 27 de março de 2013b.

. OGX: Limited Options to Generate Value for Equity Holders; Downgrade to UW, from EW, Morgan Stanley Research Latin America, 1 de julho de 2013c.

. OGX: Put Option Exercised, But Will the Cash Come In? Stay UW as Thesis is

Unchanged, Morgan Stanley Research Latin America, 8 de setembro de 2013d.

OGX: Disappointing 2P Reserves for T. Martelo; Remain UW, Morgan Stanley Research Latin America, 3 de outubro de 2013e.

MOORE, D., KURTZBERG, T., FOX, C., BAZERMAN, M. Positive illusions and forecasting errors in mutual fund investment decisions. Organizational Behaviour Human

Decision Process. v. 79, p. 95-114, 1999.

NISBETT, R.E., ROSS, L., Human Inference: Strategies and Shortcomings of Social Judgement. Prentice-Hall, New Jersey, 1980.

NUNES, F. \& LUNA, D.. Pré-Sal já compete com Oriente Médio. O Estado de São Paulo, São Paulo, 22 de out. 2017, p. B8.

OGX. Prospecto Definitivo de Distribuição Pública Primária de Ações Ordinárias de Emissão da OGX, 2008.

Demonstrativos Financeiros Padronizados (DFPs), ITRs, Atas e Editais de AGEs, Assembleias Gerais Ordinárias (AGOs), RCAs, Comunicados ao Mercado, Apresentações Corporativas, Fatos Relevantes, Politicas Corporativas, Avisos aos Acionistas, e outros documentos. Disponível em:

$<$ http://ri.ogpar.com.br/conteudo_pt.asp?tipo=50328\&id=0\&idioma=0\&conta=28\&su bmenu=0\&img $=0$ \&ano=2009>.

Política de divulgação e uso de informações para o mercado da OGX

Petróleo e Gás Participações S.A., Junho de 2009. Disponível em: < http://ri.ogpar.com.br/download_arquivos.asp?id_arquivo=5396DCD6-3B4F-41B3AC31-1E861487A365>. Acesso em: 17 mai. 2018.

PEREIRA, M.A., SECURATO, J.R., SOUSA, A.F.. Effect of investments on fundamentals and market reaction on pre-operational and operational Brazilian companies for the period 2006-2012. Revista de Administração, São Paulo, v. 51, n. 1, p. 56-71, jan./mar. 2016.

PETROBRÁS. Relatório de atividades, 2010. 
PIRES, A.. Nova chance (perdida) para o gás natural. O Estado de São Paulo, São Paulo, 21 out. 2017 , p. B2.

PWC. Fusões \& Aquisições no Brasil - Dezembro de 2013. Disponível em: < https://www.pwc.com.br/pt/estudos/servicos/assessoria-tributaria-societaria/fusoesaquisicoes.html>. Acesso em: 12 jun. 2018.

QUINTAS, H.. Concessão vs. Partilha: Breves Considerações sobre a Competitividade de cada Modelo. Ciclo de Debates sobre Petróleo e Economia. Disponível em: <https://www.ibp.org.br/personalizado/uploads/2016/11/4-HUMBERTOQUINTAS_BP_Ciclo-de-Debates_Partilha-e-Concessão_04_11_2016_.pdf >. Acesso em: 24 out 2017.

RAMALHO, A., "Leilões de áreas de óleo e gás já atraíram quase 30 empresas". Jornal Valor Econômico, São Paulo, 14 jun. 2018, p. B1.

RAMALHO, A. et al., "Ciclo de seis leilões rendeu R\$ 28 bi em bônus". Jornal Valor Econômico, São Paulo, 29 e 30 set. e 1 out. 2018, p. B1.

RAMNATH, S., ROCK, S., SHANE, P.. The financial analyst forecasting literature: A taxonomy with suggestions for further research. International Journal of Forecasting, v. 24, p. 34-75, 2008.

RIO DE JANEIRO. Justiça Federal. Seção Judiciária do Rio de Janeiro. Processo no 0000950-49.2014.02.5101. Disponível em:

<https://www.brasil247.com/attachment/403/Contestacao\%20Pedro\%20Malan.pdf>. Acesso em: 10 mai. 2018.

ROZENBAUM, A. \& VARELLA, B., Bradesco Relatório OGX: Uma Estrela em Ascenção, Bradesco Corretora, 7 de abril de 2009a.

. Bradesco Relatório OGX: Recente "Rally" foi apenas o Começo, Bradesco Corretora, 5 de outubro de 2009b.

. Bradesco Relatório OGX: Estimativa dos Reservatórios acima das Expectativas, Bradesco Corretora, 15 de outubro de 2009c.

. Bradesco Relatório OGX: Maciço Aumento dos recursos Potenciais, Bradesco Corretora, 13 de novembro de 2009d.

Bradesco Relatório OGX: OGX Anuncia a Presença de Hidrocarbonetos na Seção Aptiano do OGX-2A, Bradesco Corretora, 3 de dezembro de 2009e.

SADORSKY P. Oil price shocks and stock market activity. Energy Economics; 21:449e69, 1999

Assessing the impact of oil prices on firms of different sizes: its tough being in the middle. Energy Policy; 36:3854e61, 2008. 
SAFFO, P.. Six Rules for Effective Forecasting. Harvard Business Review. jul/ago. 2007. Disponível em: <https://hbr.org/2007/07/six-rules-for-effective-forecasting >. Acesso em: 5 mar 2018.

SANVINCENTE, A.Z.. Price-Volume relationship in the Brazilian Market, Stock Lending and Technical Analysis. Revista Brasileira de Finança, v. 13, n. 4, p. 643-662, 2015.

SÃO PAULO. Ministério Público Federal. Denúncia do MPF (Ref. Notícia de Fato $\mathrm{n}$. 1.34.001.002738/2014-71, DEN no. 71866/14). Disponível em:

$<$ http://www.mpf.mp.br/sp/sala-de-imprensa/sala-de-

imprensa/noticias_prsp/DENUNCIA\%200GX\%20DIR\%20INSIDER.pdf>. Acesso em: 10 mai. 2018.

SCHEINKMAN, J.; WEI XIONG. Overconfidence and Speculative Bubbles. Journal of Political Economy, v. 111(6), p. 1183-1219, 2003.

SCHOLTENS, B., WAGENAAR, R. Revisions of international Firms' Energy Reserves and the Reaction of the Stock Market. Energy, v. 36, n. 5, p. 3541-3546, mai. 2011.

SECURITIES AND EXCHANGE COMMISSION. Accounting series release no. 253. Washington, DC: SEC, 1978.

Accounting series release no. 269: Oil and gas producers - supplemental disclosures on the basis of reserve recognition accounting. Washington, DC: SEC, 1979.

Accounting series release no. 289. Washington, DC: SEC, 1981.

Modernization of oil and gas reporting requirements: The final rule. Washington: SEC, 2008.

SENGE, P.. The Fifth Discipline: The Art and Practice of the Learning Organization, Nova Iorque: Currency (Random House), 2006, 445p..

SEQUEIRA, M. OGX: The Thrill of the Drill, Deutsche Bank Global Emerging Markets, 16 de agosto de 2010a.

. OGX: Positive view reiterated during GEMs conference, Deutsche Bank Global Emerging Markets, 22 de setembro de 2010b.

Repsol Brasil Deal: Implications for OGX, Deutsche Bank Global Emerging Markets, 1 de outubro de 2010c.

OGX : No equity value left, Deutsche Bank Global Emerging Markets, 30 de outubro de $2013 q$.

SEQUEIRA, M. \& FONSECA, L.. OGX - Conference Call Highlights: Is No News Bad News?, Deutsche Bank Global Emerging Markets, 11 de novembro de 2010d. 
. OGX - Update: farm out, Vesuvio, D\&M Report, Deutsche Bank Global

Emerging Markets, 6 de dezembro de 2010e.

. OGX - Conference Call: Good Initiative but Little New Information, Deutsche

Bank Global Emerging Markets, 10 de fevereiro de 2011a.

. Brazilian Oils: Highlighs from DB's Brazil Oil Day, Deutsche Bank Global

Emerging Markets, 27 de março de 2011b.

. OGX: Lower 4Q10 Results. Focus on D\&M Report and Production, Deutsche

Bank Global Emerging Markets, 27 de março de 2011c.

. OGX: Lowering Rating and PT on More Conservative Approach, Deutsche Bank

Global Emerging Markets, 18 de abril de 2011d.

. OGX: Stronger Balance Sheet for Existing and New Oppontunities, Deutsche

Bank Global Emerging Markets, 18 de abril de 2011e.

. Latin American Oils Trip: Significant Opportunities in the Latam Oil and Gas

Industry, Deutsche Bank Global Emerging Markets, 4 de julho de 2011f.

. Industry Alert: Oil \& Gas, Deutsche Bank Global Emerging Markets, 11 de novembro de 2011g.

. Latam Energy - Key Themes and Stocks for 2012, Deutsche Bank Global

Emerging Markets, 23 de janeiro de 2012a.

. Industry Update: Exploration News Flow Playing Out on QGEP and OGX,

Deutsche Bank Global Emerging Markets, 1 de fevereiro de 2012b.

. OGX: 4Q11 Review - Strong Pick up in Exploration Income, Deutsche Bank

Global Emerging Markets, 1 de fevereiro de 2012c.

. OGX: 1Q12 Results, New Declaration of Commerciality, Deutsche Bank Global

Emerging Markets, 15 de maio de 2012d.

. OGX: Flow Rates at Tubarão Azul set at Lower Levels, Deutsche Bank Global

Emerging Markets, 26 de junho de 2012e.

. OGX: Hoping for the Best, but Turning more Bearish. Sell and PT of R\$ 4,

Deutsche Bank Global Emerging Markets, 16 de julho de $2012 f$.

. Latin America Energy: Looking Ahead - Main Themes and Stocks to Own,

Deutsche Bank Global Emerging Markets, 9 de setembro de 2012g.

. OGX Alert : Controller's Put Option a Positive but not a Game Changer,

Deutsche Bank Global Emerging Markets, 24 de outubro de 2012h.

. OGX Alert : 3Q12: Exploration Expenses Pressure Results, Deutsche Bank

Global Emerging Markets, 9 de novembro de 2012i. 
. Brazil Oil and Gas : HRT farms out; OGX farms in, Deutsche Bank Global Emerging Markets, 26 de novembro de 2012j.

. OGX Alert : Too early to call R\$4 the floor. Reiterate Sell, Deutsche Bank

Global Emerging Markets, 31 de janeiro de 2013a.

. OGX Alert : January production figures disappoint, Deutsche Bank Global

Emerging Markets, 4 de fevereiro de 2013b.

. OGX : Lowering our PT to R\$2.00/share; reiterating Sell, Deutsche Bank Global

Emerging Markets, 3 de março de 2013c.

. OGX : Lowering our PT to R\$2.00/share; reiterating Sell, Deutsche Bank Global

Emerging Markets, 11 de março de 2013d.

. OGX Alert : Three commercial accumulations and extension for six areas,

Deutsche Bank Global Emerging Markets, 13 de março de 2013e.

OGX Alert : ANP data provides a twist on the third well saga, Deutsche Bank

Global Emerging Markets, 14 de março de 2013f.

OGX Alert : 4Q12 conference call preview: questions for management,

Deutsche Bank Global Emerging Markets, 26 de março de 2013g.

. OGX : Price Target lowered to $\mathrm{R} \$ 0.80 /$ share. Sell reiterated, Deutsche Bank

Global Emerging Markets, 11 de abril de 2013h.

. OGX Alert : Main takeaways from ANP February per well production data,

Deutsche Bank Global Emerging Markets, 12 de abril de 2013i.

. Oil \& Gas Alert - Polvo: implications for HRT and OGX, Deutsche Bank Global

Emerging Markets, 7 de maio de 2013j.

. OGX Alert : Sharp drop in oil production; OGX-106 well (Cancun) is dry,

Deutsche Bank Global Emerging Markets, 7 de maio de 2013k.

. OGX Alert : OGX sells 40\% stake of BM-C-39 and BM-C-40, Deutsche Bank

Global Emerging Markets, 8 de maio de 2013I.

. Brazilian Energy View is still Cautious but we see Opportunities, Deutsche

Bank Global Emerging Markets, 2 de julho de 2013m.

OGX Alert: Coming Undone, Deutsche Bank Global Emerging Markets, 2 de

julho de 2013n.

OGX Alert : 2Q13 results very weak; resizing and restructuring, Deutsche Bank

Global Emerging Markets, 15 de agosto de 20130.

OGX Alert : Re-sizing the exploratory portfólio, Deutsche Bank Global

Emerging Markets, 27 de agosto de 2013p. 
SCHUTTE, G.R.. Brazil: New Developmentalism and the Management of Offshore Oil Wealth. European Review of Latin American and Caribbean Studies / Revista Europea de Estudios Latinoamericanos y del Caribe, n. 95, p. 49-70, out. 2013.

SHEFRIN, H., BELOTTI, M.L.. Behavioral Finance: Biases, Mean-Variance Returns, and Risk Premiums. CFA Institute Conference Proceedings Quarterly, v. 24, n. 2, p. 4-12, jun. 2007.

SHILLER, R.J.. Conversation, Information, and Herd Behavior. The American Economic Review, v. 85, n. 2, Papers and Proceedings of the Hundredth and Seventh Annual Meeting of the American Economic Association Washington, DC, p. 181-185, jan. 1995.

SHLEIFER, A., Do Demand Curves for Stocks Slope Down?. Journal of Finance, v. 41, p. 579- 90, 1986.

SHLEIFER, A., SUMMERS, L. H.. The noise trader approach to finance. Journal of Economic Perspectives, v. 4, p. 19-33, 1990.

SPE-PRMS - Society of Petroleum Engineers. Petroleum Resources Management Systems, 2008. Disponível em:

<http://www.spe.org/industry/docs/Petroleum_Resources_Management_System_200 7.pdf>. Acesso em: 23 fev. 2018.

STICKEL, S. The Anatomy of the Performance of Buy and Sell Recommendations. Financial Analysts Journal, v. 51, p. 25-39, 1995.

TEBECHRANI, F.. Corporate Research: OGX, Banco Pine, 16 de agosto de 2013.

TWEDT, B. \& REES, L.. Reading between the lines: An empirical examination of qualitative attributes of financial analysts' reports. Journal of Accounting and Public Policy, v. 31, p. 1-21, 2012.

TIROLE, J.. The Theory of Corporate Finance, Nova Jersey: Princeton University Press, 2006. 656p.

TVERSKY A., KAHNEMAN D.. Judgment under Uncertainty: Heuristics and Biases. Science, v. 185, n. 4157, p. 1124-31, 1974.

VIDOR, G.. 40 Anos de CVM - A História da CVM pelo Olhar de seus ex-presidentes. Rio de Janeiro: ANBIMA e BM\&FBOVESPA, 2016, 160p.

WERTHEIM, P.H. Pre-salt discoveries continues in Brazil: Potential for super-giant fields remains to be confirmed in ultra deepwater. Offsphore, 1 de Julho de 2008. URL: https://www.offshore-mag.com/articles/print/volume-68/issue-7/brazil/pre-saltdiscoveries-continue-in-brazil.html, acesso: 15/10/2018.

WOMACK, K. Do Brokerage Analysts' Recommendations Have Investment Value?. The Journal of Finance, v. 51, p. 137-67, 1996.

THE GREAT X-IT. The Economist, v. 410 (8875), p. 57, 2014. 
YERGIN, D.. The Prize: The epic quest for oil, money \& power. Nova York: Free- Press, 2009, 908p.

YERGIN, D.. The Quest: energy, security, and the remaking of the modern world. Nova York: The Penguin Press, 2011, 804p.

ZMIJESWSKI, M.E.. Comments on 'Earnings forecasting research: its implications for capital markets research' by L. Brown. International Journal of Forecasting, v. 9, p. 337-342, 1993.

ZUCKOFF, M.. Ponzi's Scheme: The True Story of a Financial Legend. Nova York: Random House Trade Paperback, 2005. 416p. 